LUIZ FELIPE PELLEGRINI

ANÁLISE E OTIMIZAÇÃO TERMO-ECONÔMICA-AMBIENTAL APLICADA À PRODUÇÃ̃O COMBINADA DE AÇÚCAR, ÁLCOOL E ELETRICIDADE 
LUIZ FELIPE PELLEGRINI

ANÁLISE E OTIMIZAÇÃO TERMO-ECONÔMICA-AMBIENTAL APLICADA À PRODUÇÃ̃O COMBINADA DE AÇÚCAR, ÁLCOOL E ELETRICIDADE

Tese apresentada à Escola Politécnica da Universidade de São Paulo para obtenção do título de Doutor em Engenharia Mecânica 


\section{ANÁLISE E OTIMIZAÇÃO TERMO-ECONÔMICA-AMBIENTAL APLICADA À PRODUÇÃ̃O COMBINADA DE AÇÚCAR, ÁLCOOL E ELETRICIDADE}

Tese apresentada à Escola Politécnica da Universidade de São Paulo para obtenção do título de Doutor em Engenharia Mecânica

Área de Concentração:

Energia e Fluidos

Orientador: Prof. Dr. Silvio de Oliveira Jr. 
Este exemplar foi revisado e alterado em relação à versão original, sob responsabilidade única do autor e com a anuência de seu orientador.

São Paulo, de janeiro de 2009.

Assinatura do autor

Assinatura do orientador

FICHA CATALOGRÁFICA

Pellegrini, Luiz Felipe

Análise e otimização termo-econômica-ambiental aplicada à produção combinada de açúcar, álcool e eletricidade / L.F.

Pellegrini. -- ed.rev. -- São Paulo, 2009.

$350 \mathrm{p}$.

Tese (Doutorado) - Escola Politécnica da Universidade de São Paulo. Departamento de Engenharia Mecânica.

1.Indústria alcooleira 2.Entropia (Termodinâmica) 3.Cogeração de energia elétrica 4.Sustentabilidade 5.Processo (Otimização) I.Universidade de São Paulo. Escola Politécnica.

Departamento de Engenharia Mecânica II.t. 
Dedico este trabalho a meus professores. 


\section{AGRADECIMENTOS}

Ao Prof. Dr. Silvio de Oliveira Jr, pela confiança depositada em mim nos últimos cinco anos para desenvolvimento desse trabalho. Pela orientação segura, pelas discussões, oportunidades de expor as minhas idéias, almoços no Clube, enfim, pelo comprometimento e amizade ao longo dos anos.

À Kerli Saori Ueda, minha namorada, pelo seu apoio incondicional, compreensão e carinho, um porto seguro nos momentos difíceis.

À minha mãe, Rosa Maria Pescarin Pellegrini, pelo suporte e carinho durante toda a minha vida, um exemplo para mim. Esta conquista também é dela. Ao meu irmão, Luiz Fernando Pellegrini, pela amizade e companheirismo desde sempre.

Ao amigo Celso Yukio Nakashima, que no início deste trabalho mostrou alguns "atalhos" da vida acadêmica.

A los compañeros del laboratorio, Héctor Iván Velásquez Arredondo, Juan Carlos Burbano Jaramillo y Carlos Humberto Mora Bejarano, por las muchas risas y discusiones en los últimos cinco años.

Aos amigos da pós-graduação, Amaury, Giancarlo, Christian, Rocha, Kleiber e Cyro pelos cafés das quatro da tarde.

Aos alunos da graduação, Alessandro Aparecido Zanetti, Ricardo Strambi e Daniel Bacellar, com quem tive a oportunidade de trabalhar em diversos assuntos e também aprendi a delegar tarefas e orientar para obter os resultados adequados.

Aos amigos da análise exergética em aviões, Ricardo Gandolfi, Guilherme A. L. da Silva, Cesare Tona e Paolo Raviolo. 
Ao amigo Moisés Teles dos Santos e suas dúvidas sobre exergia que levantaram inúmeras discussões sobre essa ferramenta.

Aos Professores e Funcionários do PME.

À Profa. Dra. Silvia Azucena Nebra, primeiro por me ajudar no meu primeiro ECOS, e pelas valiosas discussões sobre os diferentes aspectos do uso da exergia como ferramenta de análise em usinas. Aos seus orientados, Adriano Viana Ensinas e Juan Harold Sosa-Arnao, pelas trocas de informações e resultados.

Ao amigo Prof. Dr. Marcelo Modesto pelas várias discussões no MSN.

Aos técnicos e engenheiros da Usina Iracema do Grupo São Martinho que muito me ensinaram sobre usinas. Em especial, a Bernardo Hendler.

Às meninas da Fonoaudiologia USP turma 26 pela amizade e incentivo ao longo dos anos.

Aos meus veteranos que em 1999 me ajudaram a dar os primeiros passos na Poli.

À FAPESP pelo apoio financeiro e oportunidade de participação em eventos dentro e fora do País para a divulgação do meu trabalho.

À Emilio Rietmann e Paulo de Tarso Vasconcellos Neto por me mostrarem o lado do negócio por trás das avaliações em usinas.

Enfim, a todos os amigos e familiares que me apoiaram e/ou contribuíram para a realização deste trabalho. 


\section{RESUMO}

O presente trabalho objetiva a obtenção de configurações ótimas para geração conjunta de energia eletromecânica e calor em usinas sucroalcooleiras, avaliando o impacto destas nos custos de produção de açúcar, álcool e eletricidade. Desta maneira, uma proposta para a avaliação do uso racional da energia em usinas é desenvolvida, utilizando as análises exergética e termoeconômica como ferramentas de avaliação das alternativas propostas sob o ponto de vista da termodinâmica, da análise econômico-financeira e da perspectiva ambiental. Após a apresentação dos principais processos de conversão de energia de uma usina sucroalcooleira, uma análise exergética é desenvolvida a fim de identificar os principais mecanismos de geração de entropia e propor alternativas para melhorar o desempenho termoeconômico-ambiental da usina. O sistema de cogeração é identificado como o principal destruidor de exergia e diversas configurações são propostas para esse sistema, incluindo outras modificações relacionadas aos processos de produção de açúcar e álcool. As propostas incluem a elevação dos parâmetros de geração de vapor nas caldeiras, maior integração térmica dos processos, eletrificação dos acionamentos mecânicos e uso de sistemas avançados de cogeração, considerando sistemas com vapor supercrítico e ciclos combinados com gaseificação de biomassa. Para avaliar o impacto dessas alterações no desempenho termodinâmico da usina, propõe-se o uso do custo em base exergética dos produtos da usina. Mostra-se que o aumento da geração de eletricidade excedente está diretamente relacionado ao melhor desempenho dos processos de produção de açúcar e álcool. Os sistemas avançados de cogeração são capazes de gerar muito mais eletricidade excedente quando comparados aos sistemas convencionais. Essa situação implica um aumento da rentabilidade da eletricidade frente aos demais produtos, mostrando a importância desse produto para o lucro da usina. As análises de viabilidade econômico-financeiras indicaram que para os sistemas convencionais o par 67 bar e $480^{\circ} \mathrm{C}$ apresenta o melhor benefício financeiro atualmente; ainda a eletrificação das moendas só se justifica em casos de ampliação da capacidade de moagem ou substituição das turbinas por esgotamento da vida útil. O sistema supercrítico é mais atrativo economicamente frente aos ciclos combinados com gaseificação atmosférica. Finalmente, é proposta uma discussão sobre a renovabilidade dos processos baseada em um índice exergético de renovabilidade, trazendo uma nova visão sobre a renovabilidade das usinas como produtoras de fontes de energia renovável.

Palavras-chave: Usinas sucroalcooleiras. Otimização. Exergia. Termoeconomia. Renovabilidade. Poligeração. 


\begin{abstract}
This thesis aims at obtaining optimal configurations of cogeneration systems for sugarcane mills, analyzing its impacts on the production of sugar, ethanol and electricity. In this sense, it is proposed the assessment of the rational use of energy inside the mill, using exergy and thermoeconomic analysis as evaluation tools of each alternative based on different criteria: thermodynamics, economics and finance, and environmental impacts. After a brief discussion regarding the different energy conversion processes used in sugarcane mill, an exergy analysis is developed in order to identify the main sources of irreversibilities, and also to propose alternatives to improve the thermo-economic-environmental performance of the mill. The cogeneration system is shown to be the process which generates more entropy among all; hence different configurations are developed, including changes in the sugar and ethanol production processes. These modifications include: higher steam temperature and pressure in the boiler, better thermal integration among the processes, electrification of the milling system, and the use of more advanced cogeneration systems, considering supercritical steam systems and biomass integrated gasification combined cycles. For the evaluation the impact of these configurations on the thermodynamic performance of the mill, it is used the exergybased cost. It is shown that the higher the generation of excess electricity is, the better is the thermodynamic performance of the mill. Advanced cogeneration systems are able to generate much more electricity than conventional ones. This means a better profitability of those, increasing the importance of electricity for the profit of the mill. Economical feasibility analyses show that the best option for power generation in conventional cogeneration systems is with steam temperature of $480^{\circ} \mathrm{C}$ and pressure of $67 \mathrm{bar}$, while electrification of mills are only interesting if there is a need of replacement the turbines due to increasing capacities or end of lifetime. Supercritical steam system is more economic attractive than combined cycles based on atmospheric gasification. Finally, a discussion on the renewability of processes is made based on an exergy index of renewability.
\end{abstract}

Key-words: Sugarcane mills. Optimization. Exergy. Thermoeconomics. Renewability. Polygeneration. 


\section{LISTA DE FIGURAS}

Figura 1.1 - Oferta mundial de energia primária em 2004. (Adaptado de Goldemberg, 2007). 2

Figura 1.2 - Oferta interna de energia (OIE) no Brasil (MME, 2007). 4

Figura 4.1 - Conversão de energia solar em carboidratos em uma folha (TAIZ; ZEIGER, 2004).

Figura 4.2 - Volumes de controle do processamento industrial da cana-de-açúcar. ................25

Figura 5.1 - Volume de controle indeformável com uma entrada e uma saída....................... 41

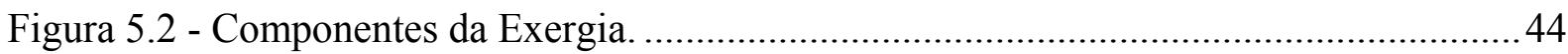

Figura 5.3 - Representação das Exergia Físicas e Químicas, para uma mistura de 2 componentes (Adaptado de: NEBRA; FERNÁNDEZ-PARRA, 2005).

Figura 5.4 - Representação do cálculo da exergia das soluções de água-sacarose (Adaptado

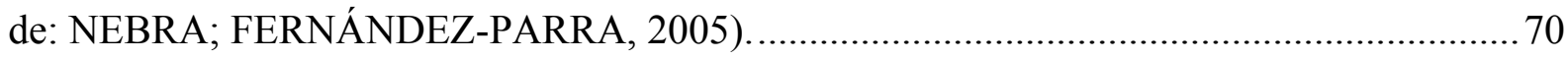

Figura 6.1 - Distribuição da Exergia Destruída na Usina...................................................... 82

Figura 6.2 - Diagrama Temperatura vs. $\Delta \mathrm{H}$ para o sistema de aquecimento de caldo.............85

Figura 6.3- Diagrama Fator de $\operatorname{Carnot}(\theta)$ vs. $\Delta H$ para o sistema de aquecimento de caldo. .. 86

Figura 7.1 - Sistema de Cogeração com Turbina de Contrapressão....................................... 103

Figura 7.2 - Sistema de Cogeração com Turbinas de Contrapressão e de Condensação....... 103

Figura 7.3 - Sistema de Cogeração com Turbina de Extração-Condensação.......................... 104

Figura 7.4 - Produção de eletricidade e vapor de sistemas de cogeração com queima de bagaço (OGDEN; HOCHGREB; HYLTON, 1990). ............................................................. 109

Figura 7.5 - Sistema de Cogeração com Vapor Supercrítico. ............................................... 111

Figura 7.6 - Passagem da Água/Vapor em Caldeiras de Tambor e de Passe Único. ............. 113

Figura 7.7 - Configurações Existentes para Caldeiras Supercríticas: a) em forma de U e b)

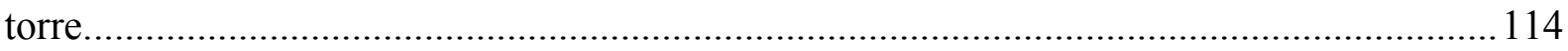

Figura 7.8 - (a) Conjunto de uma turbina da classe 600-1000 MW. (b) Turbina de alta pressão do tipo barril (HP). (c) Turbina de media pressão (IP). (d) Turbina de baixa pressão (LP)

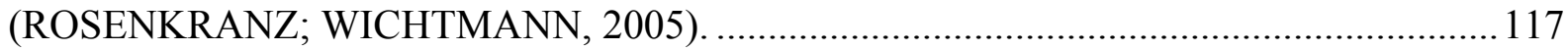

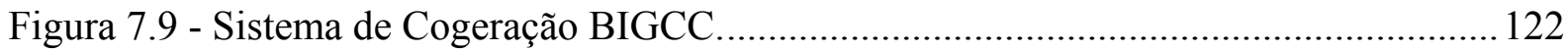

Figura 7.10 - Esquema das etapas do processo de gaseificação (Fonte: www.btgworld.com).

Figura 7.11 - Influência do consumo de vapor e dos parâmetros de geração de vapor na geração de eletricidade excedente em sistemas de contrapressão. 
Figura 7.12 - Influência do consumo de vapor e dos parâmetros de geração de vapor no excedente de bagaço.

Figura 7.13- Influência do consumo de vapor e dos parâmetros de geração de vapor na geração de eletricidade excedente em sistemas de contrapressão com condensação do vapor excedente.

Figura 7.14 - Variações da Geração de Vapor e Eletricidade Excedente em função da quantidade de bagaço enviada para o gaseificador.

Figura 8.1 - Sistema a vapor com turbinas de contrapressão.

Figura 8.2- Variação da eficiência exergética da caldeira em função da pressão e temperatura de geração do vapor.

Figura 8.3 - Variação da eletricidade excedente gerada, as irreversibilidades e a exergia perdida devido à não utilização do bagaço excedente. 142

Figura 8.4 - Variação dos Custos em Base Exergética do Açúcar, Álcool e Eletricidade. .... 143 Figura 8.5 - Diagrama esquemático da rede trocadores de calor do tratamento de caldo...... 146 Figura 8.6 - Diagrama Temperatura vs. $\Delta \mathrm{H}$ para o sistema de aquecimento de caldo utilizando vapores extraídos do evaporador de múltiplos-efeitos.

Figura 8.7 - Diagrama Fator de $\operatorname{Carnot}(\theta)$ vs. $\Delta \mathrm{H}$ para o sistema de aquecimento de caldo. 148 Figura 8.8 - Variação da eletricidade excedente gerada, as irreversibilidades e a exergia perdida devido à não utilização do bagaço excedente. 150

Figura 8.9 - Variação dos Custos em Base Exergética do Açúcar, Álcool e Eletricidade. .... 151

Figura 8.10 - Sistema a vapor com turbinas de condensação. 152

Figura 8.11 - Variação da eletricidade excedente gerada, as irreversibilidades e a exergia perdida devido a não utilização do bagaço excedente. 153

Figura 8.12 - Variação dos Custos em Base Exergética do Açúcar, Álcool e Eletricidade. .. 154 Figura 8.13 - Diagrama esquemático da rede trocadores de calor do tratamento de caldo.... 158 Figura 8.14 - Diagrama Temperatura vs. $\Delta \mathrm{H}$ para o sistema de aquecimento de caldo. 159

Figura 8.15 - Diagrama Fator de $\operatorname{Carnot}(\theta)$ vs. $\Delta H$ para o sistema de aquecimento de caldo. 160

Figura 8.16 - Sistema Supercrítico. 162

Figura 8.17 - Diagrama Temperatura-Entropia do Sistema Supercrítico proposto. 162

Figura 8.18 - Sistema com gaseificação atmosférica e geração de vapor em 42 bar e $400^{\circ} \mathrm{C}$. 
Figura 8.19 - Sistema com gaseificação atmosférica e geração de vapor em 80 bar e $510^{\circ} \mathrm{C}$..

Figura 8.20 - Sistema com gaseificação pressurizada e geração de vapor em 80 bar e $510^{\circ} \mathrm{C}$.

Figura 8.21 - Custo em base exergética do açucar e do álcool, para as configurações avaliadas.

Figura 8.22 - Custo em base exergética da eletricidade em função da geração de eletricidade excedente, para as diferentes configurações analisadas.

Figura 8.23 - Variação do Potencial de Melhoria em função da tecnolgia de cogeração. ...... 172 Figura 9.1- Volumes de Controle para Avaliação da Margem de Contribuição dos Produtos.

Figura 9.2 - Margem de Contribuição Total 185

Figura 9.3 - Margem de Contribuição Unitária dos Produtos para as diversas Configurações.

Figura 10.1 - Fluxo de Caixa considerado.

Figura 10.2 - Variação do VPL e da TIR para diferentes pressões e temperaturas de geração de vapor.

Figura 10.3 - Variação do VPL em função do aumento do investimento no $\mathrm{kW}_{\text {inst }}$ devido à mudança de material da tubulação e da espessura dos tubos.

Figura 10.4 - Variação do VPL e da TIR para diferentes pressões e temperaturas de geração de vapor, considerando a aletrificação das moendas.

Figura 10.5 - Análise de Sensibilidade do VPL.

Figura 10.6 - Análise de Sensibilidade da TIR.

Figura 10.7 - Variação do VPL e da TIR para diferentes pressões e temperaturas de geração de vapor.

Figura 10.8 - Variação do VPL e da TIR para diferentes pressões e temperaturas de geração de vapor. 203

Figura 10.9 - Variação do VPL e da TIR para diferentes Custos de $\mathrm{kW}_{\text {inst. }}$.... 205

Figura 10.10 - Variação do VPL e da TIR para diferentes Custos de $\mathrm{kW}_{\text {ins }} \mathrm{t}$ - Sistema com gaseificação atmosférica e geração de vapor em 42 bar e $400^{\circ} \mathrm{C}$. 208 Figura 10.11 - Variação do VPL e da TIR para diferentes Custos de $\mathrm{kW}_{\text {inst }}$ - Sistema com gaseificação atmosférica e geração de vapor em 80 bar e $510^{\circ} \mathrm{C}$ 208

Figura 10.12 - Variação do VPL e da TIR para diferentes Custos de $\mathrm{kW}_{\text {inst }}$ - Sistema com gaseificação pressurizada e geração de vapor em 80 bar e $510^{\circ} \mathrm{C}$. 
Figura 10.13 - Variação do VPL para as diversas alternativas avaliadas. 211

Figura 10.14 - Variação do VPL para as diversas alternativas avaliadas. 212

Figura 11.1 - Os fluxos de matéria e energia na Terra são dirigidos pelo contraste enre o Sol e o Espaço (WALL, 1977). 216

Figura 11.2 - Processo Econômico considerando as idéias de Georgescu-Roegen (elaboração do autor) 221

Figura 11.3 - Volumes de controle considerados para a determinação do índice exergético de renovabilidade 224

Figura 11.4 - Índice exergético de renovabilidade para a usina em função do índice do sistema de cogeração. 225

Figura 11.5 - Variação de $\lambda$ em função da eficiência exergética. 227

Figura A.1 - Fluxograma simplificado do sistema de extração.

Figura A.2 - Esquema do Tratamento de Caldo...................................................................

Figura A.3 - Esquema de Produção de Açúcar.......................................................................... 10

Figura A.4 - Esquema de Produção de Álcool. ..................................................................... 17

Figura A.5 - Diagrama simplificado do sistema de cogeração de uma usina tradicional.........20

Figura B.1 - Sistema fechado heterogêneo...........................................................................2

Figura B.2 - Resultados do Modelo de Equilíbrio Químico.................................................... 11

Figura B.3 - Representação esquemática do modelo modificado II (LI et al., 2004).............. 15

Figura C.1 - Diagrama Esquemático de uma Turbina a Gás. ................................................... 6

Figura C.2 - Diagrama Esquemático de uma Caldeira de Recuperação................................... 11

Figura C.3 - Diagrama T vs. $\Delta \mathrm{H}$ para a Caldeira de Recuperação.......................................... 12 


\section{LISTA DE TABELAS}

Tabela 4.1 - Composição Média da Cana-de-Açúcar (COPERSUCAR, 2007). 22

Tabela 4.2 - Quantidade de açúcar e álcool produzidas, para 1 tonelada de cana (FINGUERUT, 2004)

Tabela 6.1 - Composição da Cana.

Tabela 6.2 - Composição da fibra.

Tabela 6.3 - Resultados da Simulação de uma Usina Sucroalcooleira Tradicional 81

Tabela 6.4 - Valores de referência para propriedades de alguns fluxos da usina. 82

Tabela 6.5 - Parâmetros de Desempenho do Sistema de Evaporação. .88

Tabela 6.6 - Parâmetros de Desempenho do Sistema de Cozimento. 90

Tabela 6.7 - Custo em base exergética de diferentes fluxos de exergia na usina. 100

Tabela 7.1 - Evolução da tecnologia das caldeiras no setor sucroalcooleiro. 105

Tabela 7.2 - Parâmetros de Diferentes Tipos de Caldeira. 107

Tabela 7.3 - Comparativo entre sistemas simples e combinados. 108

Tabela 7.4 - Plantas Supercríticas " $600^{\circ} \mathrm{C} "$ 112

Tabela 7.5 - Número típico de regeneradores em função da capacidade de geração.

Tabela 7.6 - Ganhos relativos na eficiência do sistema (os parâmetros são apenas indicativos).

Tabela 7.7 - Comparativo entre as diferentes configurações do sistema BIGCC. 126

Tabela 7.8 - Comparação entre os diferentes teores de material particulado e alcatrão para diferentes tipos de gaseificador. 127

Tabela 7.9 - Considerações para avaliação da integração térmica de sistemas BIGCC. 134

Tabela 7.10 - Composição das pontas e folhas em comparação com o bagaço. 136

Tabela 7.11 - Avaliação da recuperação das pontas e folhas com a colheita mecanizada..... 137

Tabela 8.1 - Parâmetros Técnicos Utilizados na Simulação. 140

Tabela 8.2 - Índices Exergéticos para o par 67 bar $/ 515^{\circ} \mathrm{C}$, sem e com eletrificação das moendas. 144

Tabela 8.3 - Parâmetros utilizados para a nova rede de trocadores de calor. 146

Tabela 8.4 - Parâmetros de desempenho da nova configuração do sistema de evaporação... 148 Tabela 8.5 - Índices exergéticos para o par $67 \mathrm{bar} / 515^{\circ} \mathrm{C}$, sem e com eletrificação das moendas. 
Tabela 8.6 - Índices exergéticos para o par 67 bar $/ 515^{\circ} \mathrm{C}$, com geração de eletricidade ao longo do ano todo 156

Tabela 8.7 - Parâmetros de desempenho da nova configuração do sistema de evaporação... 160

Tabela 8.8 - Índices exergéticos para o Sistema Supercrítico. 163

Tabela 8.9 - Características técnicas dos sistemas de gaseificação. 166

Tabela 8.10 - Parâmetros utilizados para as simulações dos Sistemas com Gaseificação e Ciclos Combinados.

Tabela 8.11 - Índices exergéticos para os Sistemas com Gaseificação e Ciclos Combinados 168

Tabela 9.1 - Preços, sem impostos, utilizados nas análises das margens de contribuição dos produtos. 176

Tabela 9.2 - Custo de produção e margens de contribuição dos produtos. 176

Tabela 9.3 - Custo de Produção e Margens de Contribuição dos Produtos 177

Tabela 9.4 - Custo de Produção e Margens de Contribuição dos Produtos 179

Tabela 9.5 - Custo de Produção e Margens de Contribuição dos Produtos 180

Tabela 9.6 - Custo de Produção e Margens de Contribuição dos Produtos 181

Tabela 9.7 - Custo de Produção e Margens de Contribuição dos Produtos 182

Tabela 9.8 - Custo de Produção e Margens de Contribuição dos Produtos............................. 183

Tabela 10.1 - Parâmetros Econômicos. ..................................................................................... 188

Tabela 10.2 - Demonstração de Resultados do Exercício 189

Tabela 10.3 - Investimento necessário para Geração de Eletricidade por Termelétricas a Biomassa (adaptado de: EPE, 2008).

Tabela 10.4 - Custos envolvidos na redução do consumo de vapor.

Tabela 10.5 - Aumento máximo do valor do $\mathrm{kW}_{\text {inst }}$ para manter a rentabilidade obtida com a geração em 67 bar e $480^{\circ} \mathrm{C}$. 195

Tabela 10.6 - Aumentos máximos no investimento para sistemas de contrapressão. 213

Tabela 10.7 - Aumentos máximos no investimento para sistemas de condensação. 213

Tabela A.1 - Pressões de operação de cada corpo do múltiplo-efeito e dos tachos de cozimento.

Tabela A.2 - Considerações para a modelagem da extração

Tabela B.1 - Valores das constantes para a eq.(B.19), entalpias de formação e entropia no estado padrão para as substâncias modeladas como gases ideais............................................ 8

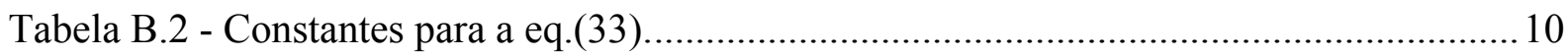

Tabela B.3 - Parâmetros operacionais dos testes com chips de eucalipto. 
Tabela B.4 - Resultados para o Teste 1 (Modelo de Puro Equilíbrio)..................................... 12

Tabela B.5 - Resultados para o Teste 2 (Modelo de Puro Equilíbrio)...................................... 12

Tabela B.6 - Resultados para o Teste 3 (Modelo de Puro Equilíbrio)...................................... 12

Tabela B.7 - Resultados para o Teste 1 (Modelo Modificado I)............................................ 14

Tabela B.8 - Resultados para o Teste 2 (Modelo Modificado I)............................................ 14

Tabela B.9 - Resultados para o Teste 3 (Modelo Modificado I)............................................ 14

Tabela B.10 - Resultados para o Teste 1 (Modelo Modificado II) .......................................... 16

Tabela B.11 - Parâmetros operacionais dos testes apresentados em Li et al. (2004).............. 16

Tabela B.12 - Resultados para o Teste 14 (Modelo Modificado II)........................................ 17

Tabela B.13 - Resultados para o Teste 15 (Modelo Modificado II)....................................... 17

Tabela B.14 - Parâmetros operacionais dos testes apresentados em Baptista, 1986............... 17

Tabela B.15 - Resultados para o Teste 9 (Modelo Modificado II) .......................................... 18

Tabela B.16 - Resultados para o Teste 15 (Modelo Modificado II)........................................ 18

Tabela B.17 - Resultados para o Teste 17 (Modelo Modificado II)........................................ 18 
LISTA DE ABREVIATURAS E SIGLAS

$\mathrm{ACV}$

ANEEL

ANFAVEA

ASTM

BEN

BIGCC

CETESB

CONAB

DOE

DRE

DTI

EPE

MIT

MME

OIE

$\mathrm{ONU}$

$\mathrm{PCH}$

PIB

PROINFA

TIR

UNICA

UTE

VPL
Análise de Ciclo de Vida

Agência Nacional de Energia Elétrica

Associação Nacional dos Fabricantes de Veículos Automotores

American Society of Testing Materials

Balanço Energético Nacional

Biomass Integrated Gasification Combined Cycle

Companhia de Tecnologia de Saneamento Ambiental

Companhia Nacional de Abastecimento

Department of Energy (EUA)

Demonstração de Resultados do Exercício

Department of Trade and Industry (Reino Unido)

Empresa de Pesquisas Energéticas

Massachusetts Institute of Technology

Ministério das Minas e Energia

Oferta Interna de Energia

Organização das Nações Unidas

Pequena Central Hidrelétrica

Produto Interno Bruto

Programa de Incentivo às Fontes Alternativas de Energia Elétrica

Taxa Interna de Retorno

União da Indústria de Cana-de-Açúcar

Unidade Termelétrica

Valor Presente Líquido 


\section{LISTA DE SÍMBOLOS}

\section{Símbolos Latinos}

a

A

ART

b

$\dot{\mathrm{B}}$

$\mathrm{c}_{\mathrm{p}}$

$\mathrm{c}$

C

$\mathrm{CF}$

$\mathrm{CV}$

$\dot{\mathrm{C}}$

DV

$\mathrm{f}$

G

$\mathrm{h}$

$\mathrm{H}$

I

$\mathrm{m}$

MM

$\dot{\mathrm{m}}$

$\mathrm{MC}$

$\mathrm{MCU}$

$\mathrm{n}$

$\mathrm{N}$

$\mathrm{p}$

PCI

PCS

PD

PM

PQ

PT

$\mathrm{Pz}$

q

Q

$\dot{\mathrm{Q}}$

$\mathrm{R}$
Número de átomos da espécie $\mathrm{k}$ na molécula de $\mathrm{j}$

Número total de átomos da espécie $\mathrm{k}$

Açúcares Redutores Totais

Exergia específica $(\mathrm{kJ} / \mathrm{kg})$ ou $(\mathrm{kJ} / \mathrm{kmol})$

Fluxo de exergia $(\mathrm{kW})$

Calor específico (kJ/kg.K) ou (kJ/kmol.K)

Custo em base exergética $(\mathrm{kJ} / \mathrm{kJ})$

Custo

Custo Fixo

Custo Variável

Fluxo de custos

Despesa de Venda

Função- objetivo, fugacidade

Energia livre de Gibbs ( $\mathrm{kJ} / \mathrm{kg})$ ou $(\mathrm{kJ} / \mathrm{kmol})$

Entalpia específica $(\mathrm{kJ} / \mathrm{kg})$ ou $(\mathrm{kJ} / \mathrm{kmol})$

Entalpia (kJ)

Taxa de irreversibilidades $(\mathrm{kW})$

Massa $(\mathrm{kg})$

Massa molar $(\mathrm{kg} / \mathrm{kmol})$

Fluxo de massa (kg/s)

Margem de Contribuição

Margem de Contribuição Unitária

Número de mols

Número total de moléculas, de variáveis de decisão

Pressão (bar)

Poder calorífico inferior $(\mathrm{kJ} / \mathrm{kg})$

Poder calorífico superior $(\mathrm{kJ} / \mathrm{kg})$

Processo dissipativo

Potencial de Melhoria (kW)

Processo químico

Processo térmico

Coeficiente de pureza

Calor por unidade de massa/mol ( $\mathrm{kJ} / \mathrm{kg}$ ou $\mathrm{kmol})$

Calor (kJ) / quantidade

Taxa de transferência de calor $(\mathrm{kW})$

Constante universal dos gases $(\mathrm{kJ} / \mathrm{kmol} . \mathrm{K})$ / número de reações químicas 


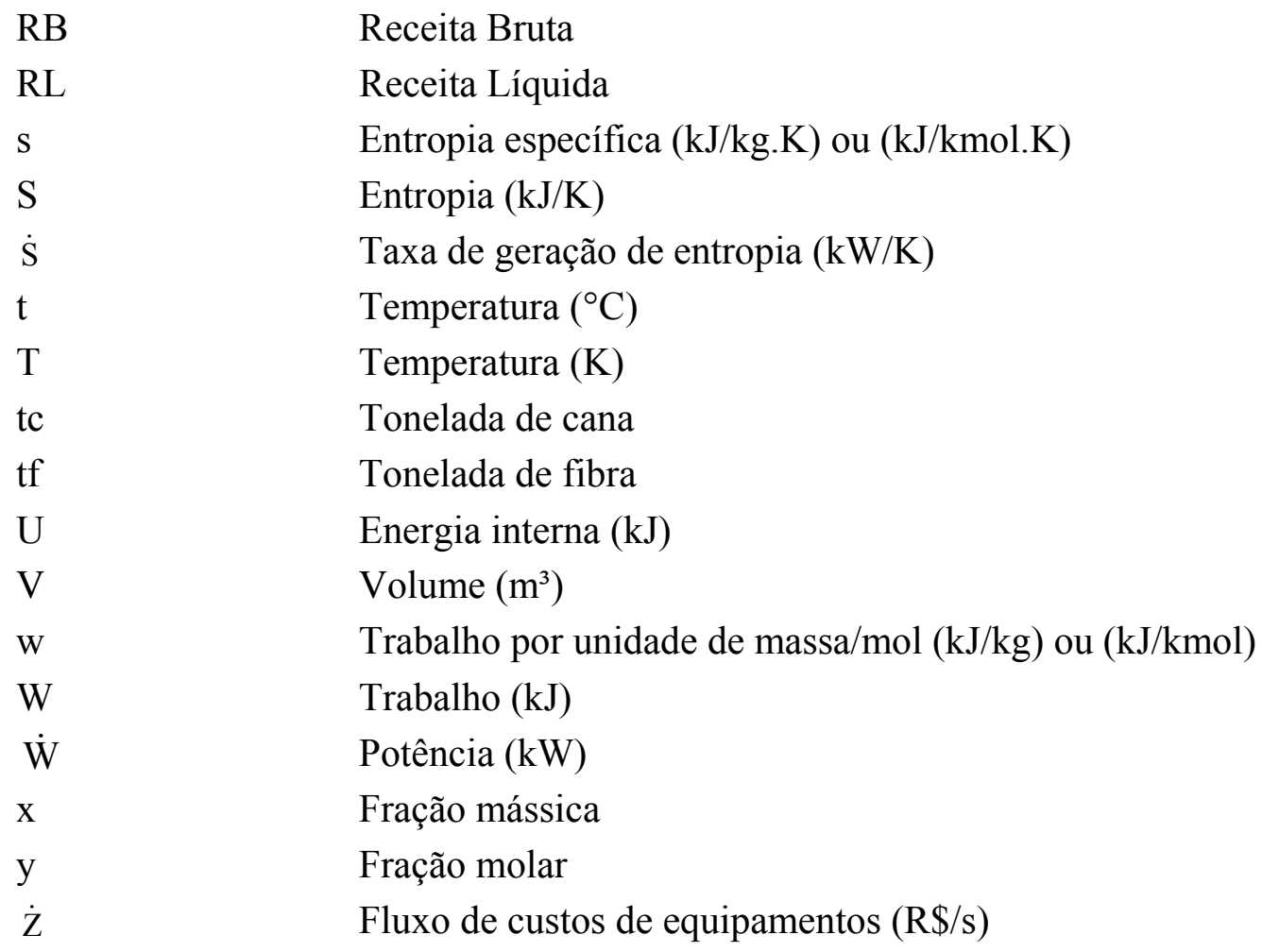

\section{Símbolos Gregos}

$\begin{array}{ll}\gamma & \text { Coeficiente de atividade } \\ \rho & \text { Densidade } \\ \eta & \text { Eficiência } \\ \nu & \text { Volume específico } \\ \Phi & \text { Razão de equivalência } \\ \beta & \text { Coeficiente para cálculo da exergia química, correlação } \\ \lambda & \text { para fatores cinéticos } \\ \xi & \text { Índice exergético de renovabilidade / multiplicador de } \\ \nu & \text { Lagrange } \\ \mu & \text { Extensão da reação } \\ & \text { Coeficiente estequiométrico } \\ & \text { Potencial químico }\end{array}$

\section{Subscritos}

$\begin{array}{ll}0 & \text { Estado de referência } \\ \mathrm{ex} & \text { Exergético } \\ \mathrm{f} & \text { Formação } \\ \mathrm{fis} & \text { Físico } \\ \mathrm{i} & \text { Índice de componentes } \\ \text { inst } & \text { Instalado } \\ \mathrm{j} & \text { Índice de componentes } \\ \mathrm{k} & \text { Índice de átomos }\end{array}$


liq

lv

$\mathrm{m}$

qui

sac

sat

sol

\section{Sobrescritos}

0

00

gi

Q

$\mathrm{t}$

W
Líquido

Vaporização / Condensação

Número de restrições

Químico

Sacarose

Saturação

Solução / solubilidade

\section{Estado termodinâmico de referência}

Estado de referência para a exergia química

Gás ideal

Calor

Fração mássica

Trabalho 


\section{GLOSSÁRIO DE TERMOS DA AGROINDÚSTRIA CANAVIEIRA}

Conforme destaca Fernandes (2003), a terminologia adotada pela indústria canavieira nem sempre é a mesma em todas as empresas e regiões do país. Ainda, uma série de fluxos materiais recebe nomes não usuais na literatura acadêmica, porém sem similar adequada. Portanto, a seguir serão listados os termos utilizados nessa tese para nomear alguns dos fluxos materiais relacionados a usinas.

Açúcares Redutores Totais: representam todos os açúcares da cana na forma de açúcares invertidos (mistura eqüimolar de glucose e frutose, obtida pela hidrólise da sacarose)

Água de Embebição: água utilizada na moenda para facilitar a extração dos açúcares da cana.

Bagaço: resíduo fibroso resultante da moagem da cana de açúcar, constituído de fibra mais caldo residual. À saída da moenda, sua umidade é aproximadamente 50\%.

Bagacilho: a fração de partículas muito finas separada do bagaço e utilizada como auxiliar de filtração do lodo dos decantadores para separação do caldo filtrado.

Brix: expressa a porcentagem em peso de sólidos solúveis contidos em uma solução.

Caldo: solução de água, açúcares e outros sólidos solúveis.

Caldo Bruto: caldo obtido após a passagem da cana pelas moendas.

Caldo Clarificado: caldo resultante do processo de clarificação (após o tratamento).

Caldo Filtrado: caldo recuperado do lodo decantado.

Caldo Misto: mistura do caldo bruto com o caldo filtrado.

Flegma: corrente hidroalcoólica extraída da coluna de epuração do vinho.

Fibra: é a matéria insolúvel em água contida na cana.

Leite de Cal: suspensão inorgânica que consiste de hidróxido de cálcio e água.

Leite de Levedura: suspensão de células de levedura obtida pela centrifugação do vinho.

Lodo: material insolúvel sedimentado no processo de decantação da purificação do caldo de cana antes da entrada nos evaporadores ou sistemas de fermentação.

Magma: solução de sacarose com alta pureza, resultante da centrifugação da massa cozida do Mel A, re-utilizada junto com o cozimento do xarope.

Massa Cozida: mistura sólido-líquida resultante da concentração da solução saturada de sacarose. 
Mel A: solução de sacarose obtida da centrifugação da massa cozida para a obtenção do açúcar.

Mel Final (melaço): solução de sacarose com baixa pureza, resultante da centrifugação da massa cozida do Mel A.

Mosto: mistura de Mel Final e Caldo Clarificado enviada para fermentação.

Pol: porcentagem aparente de sacarose contida em uma solução de açúcares.

Pureza: porcentagem de sacarose contida nos sólidos solúveis.

Torta de Filtro: material insolúvel obtido após a filtração do lodo.

Vapor Vegetal: vapor de água obtido por evaporação da água do caldo de cana.

Vinhaça: efluente da fabricação de etanol resultante da destilação do vinho.

Vinho: mosto fermentado após o término da fermentação.

Xarope: solução de sacarose próxima da saturação e alta viscosidade obtida no evaporador de múltiplos-efeitos. 


\section{SUMÁRIO}

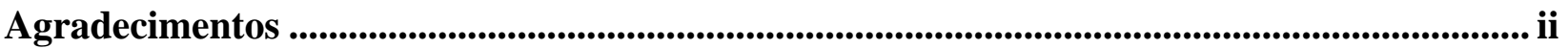

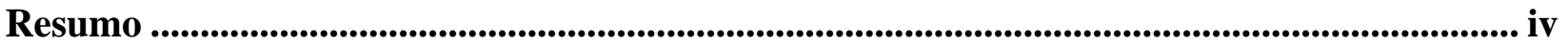

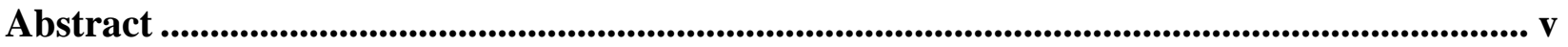

Lista de Figuras ................................................................................................................................................ vi

Lista de Tabelas .............................................................................................................................................. $x$

Lista de Abreviaturas e Siglas ...................................................................................................................... xiii

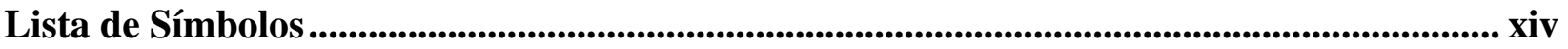

Glossário de Termos da AgroIndústria Canavieira ................................................................ xvii

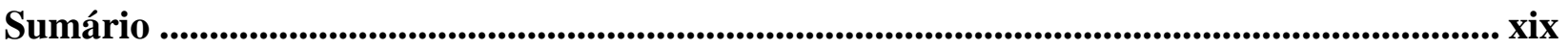

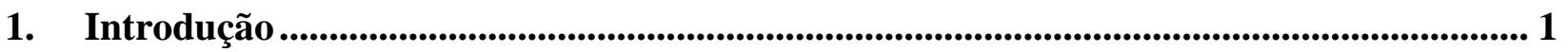

1.1. Energia e Desenvolvimento Sustentável .............................................................

1.2. Matriz Energética Brasileira ...............................................................................

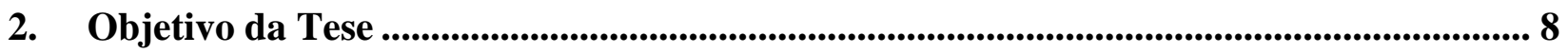

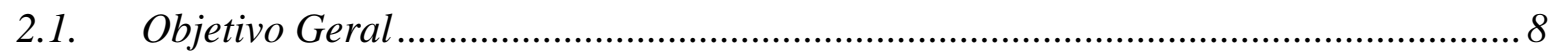

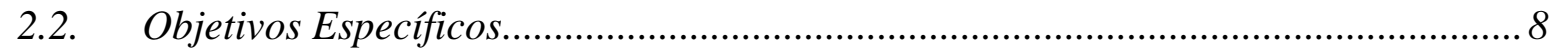

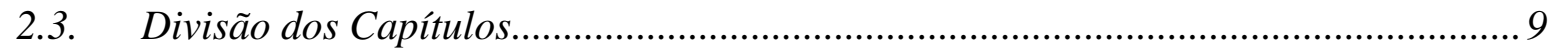

3. A Agroindústria Canavieira ............................................................................................................ 11

4. Processos de Conversão de Energia na Agroindústria Canavieira................................. 20

4.1. A Conversão de Energia na Parte Agrícola ............................................................20

4.2. A Conversão de Energia na Parte Industrial .........................................................24

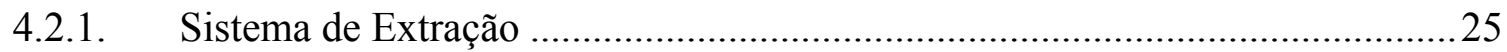


4.2.2. Planta de Tratamento de Caldo.........................................................................28

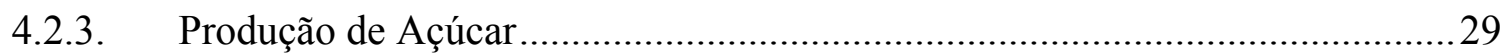

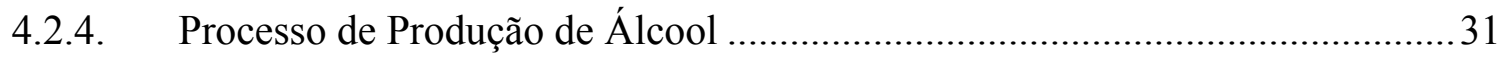

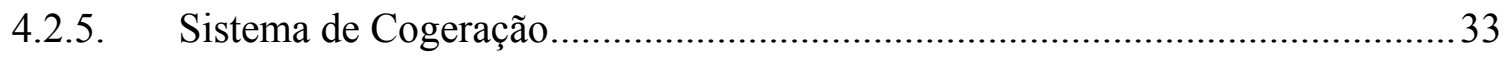

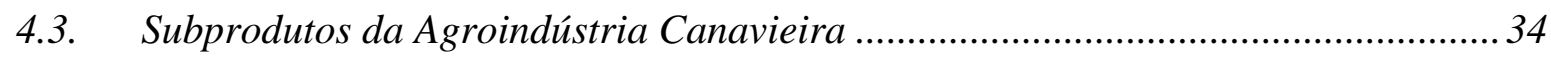

4.4. Impactos Ambientais Relacionados à Agroindústria Canavieira ............................36

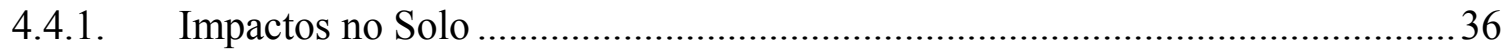

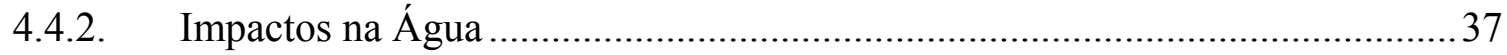

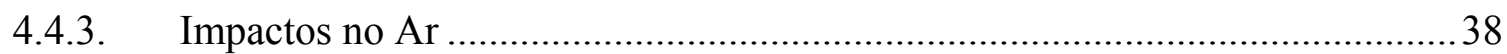

5. Análise Exergética e Termoeconômica na Agroindústria Canavieira.............................. 40

5.1. Análise Exergética e Termoeconômica de Processos de Conversão de Energia..... 40

5.1.1. Exergia e Balanço Exergético....................................................................... 41

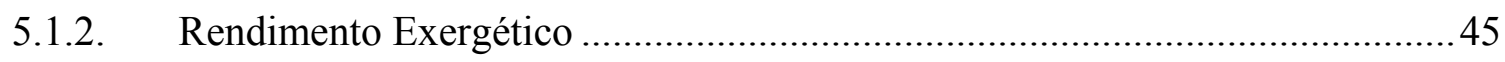

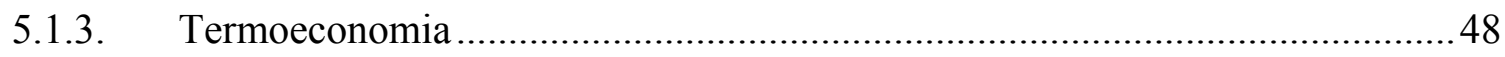

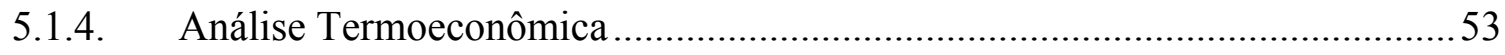

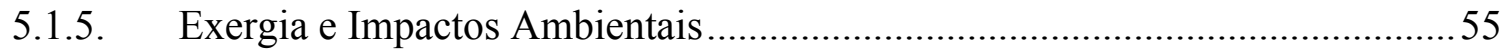

5.2. Análise Exergética e Termoeconômica de Alternativas de Uso Racional de Energia

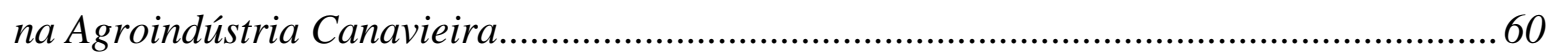

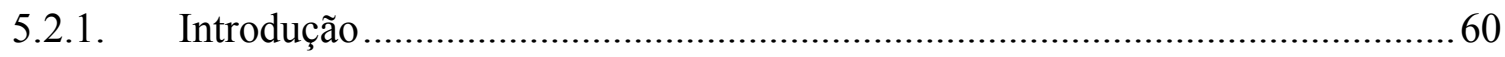

5.2.2. A exergia como Ferramenta de Análise em Usinas.........................................61

5.3. Cálculo da Exergia Específica dos Fluxos Materiais na Agroindústria Canavieira 65

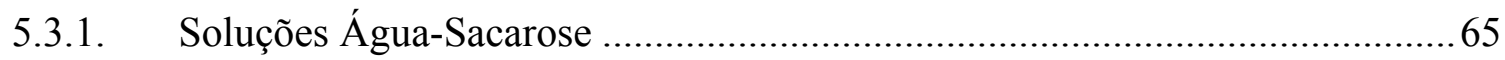

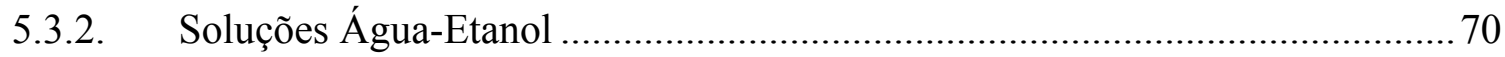

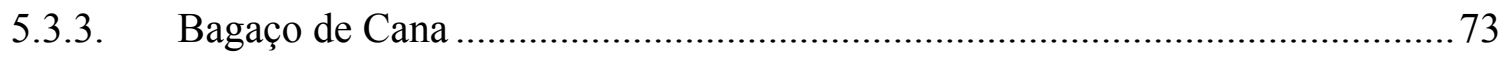

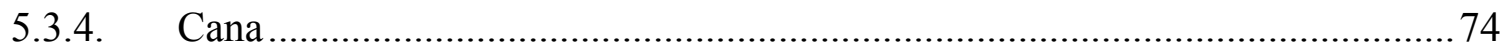

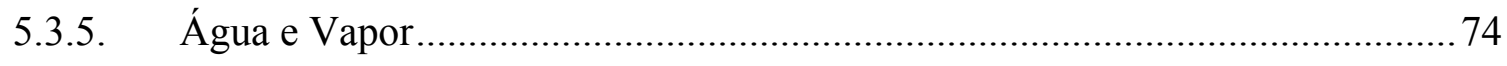

5.3.6. Ar, Gases de Combustão e Gás Proveniente da Gaseificação ........................... 75

6. Análise Exergética de uma Usina Sucroalcooleira Tradicional ................................... 76

6.1. Modelagem dos Processos de Conversão de Energia em Usinas Sucroalcooleiras 76

6.1.1. Sistema de Extração 


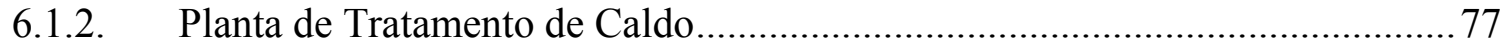

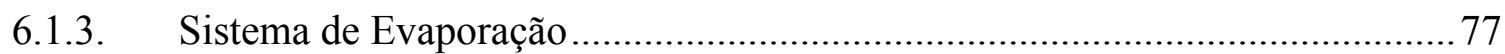

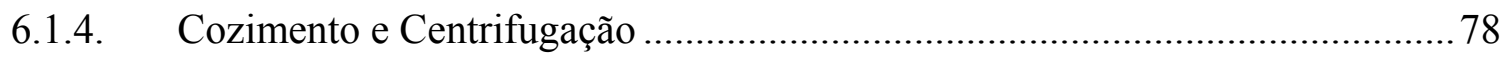

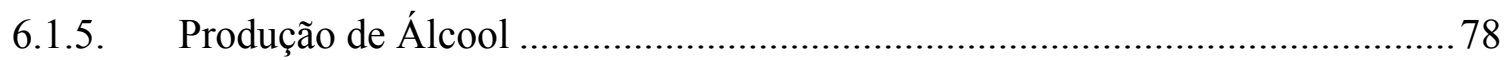

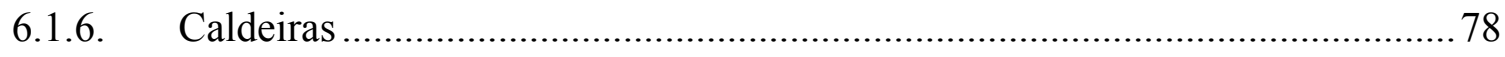

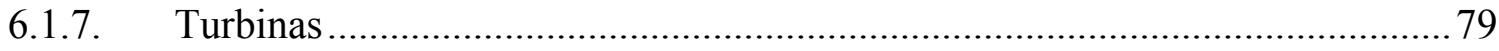

6.2. Simulação dos processos de conversão de energia em usinas sucroalcooleiras..... 79

6.3. Análise Exergética de Uma Usina Sucroalcooleira Tradicional .............................80

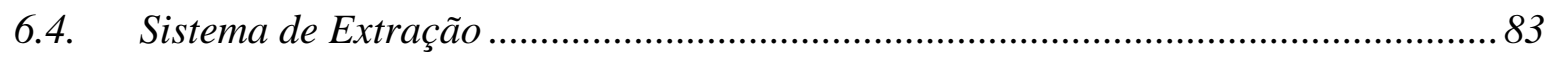

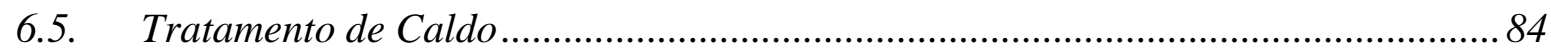

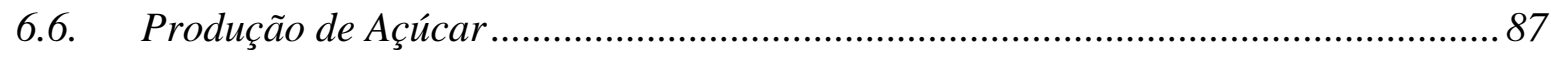

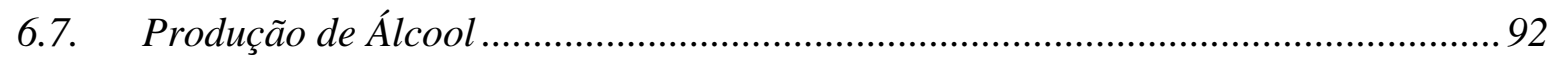

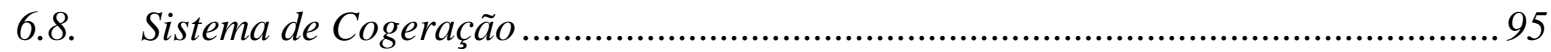

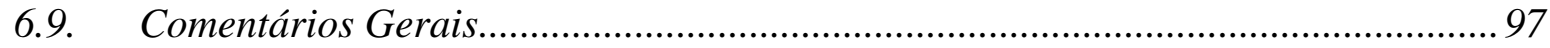

7. Tecnologias de Cogeração Aplicáveis a Plantas de Utilidades ...................................... 102

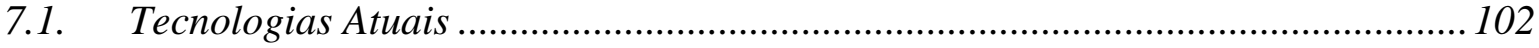

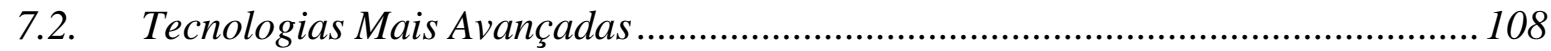

7.2.1. Plantas Supercríticas de Potência .................................................................... 110

7.2.2. Ciclos Combinados com Gaseificação de Biomassa..................................... 121

7.3. Integração Térmica entre as Tecnologias e as Demandas Termo-Mecânicas de uma

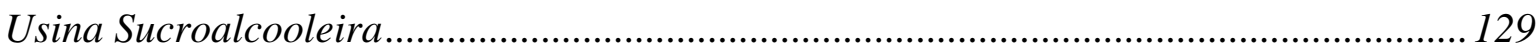

8. Avaliação do Custo em base Exergética das Opções de Configurações para a Produção Combinada de Açúcar, Álcool e Eletricidade.......................................................... 138

8.1. Sistemas a Vapor com Turbinas de Contrapressão, sem modificações nos processos 139

8.2. Sistemas a Vapor com Turbinas de Contrapressão, com modificações nos processos 145

8.3. Sistemas a Vapor com Turbinas de Condensação.

8.4. Redução do Consumo de Vapor de Processo para Integração dos Sistemas

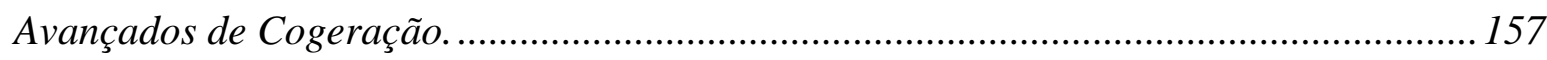

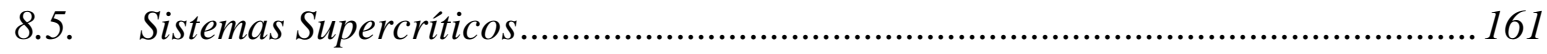


8.6. Sistemas com Gaseificação de Biomassa e Ciclos Combinados ............................... 164

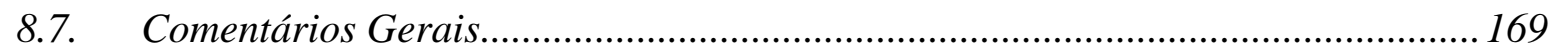

9. Avaliação da Margem de Contribuição dos Produtos por meio da Análise

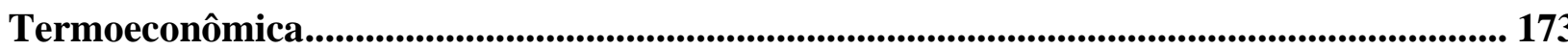

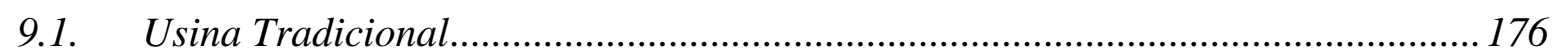

9.2. Sistemas a Vapor com Turbinas de Contrapressão, sem modificações nos processos 178

9.3. Sistemas a Vapor com Turbinas de Contrapressão, com modificações nos processos 179

9.4. Sistemas a Vapor com Turbinas de Condensação.................................................180

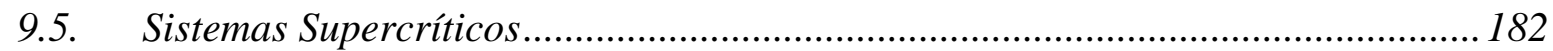

9.6. Sistemas com Gaseificação de Biomassa e Ciclos Combinados ............................. 182

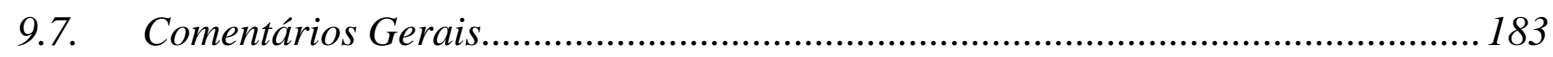

10. Avaliação Econômica das Opções de Configurações para a Produção Combinada de Açúcar, Álcool e Eletricidade.

10.1. Sistemas a Vapor com Turbinas de Contrapressão, sem modificações nos processos 192

10.1.1. Aumento da Pressão e Temperatura de Geração do Vapor .............................. 192

10.1.2. Eletrificação das Moendas.............................................................................. 195

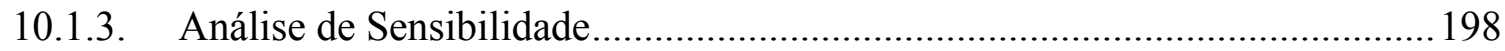

10.2. Sistemas a Vapor com Turbinas de Condensação, com modificações nos processos 201

10.2.1. Geração de Vapor apenas na Safra ...............................................................201

10.2.2. Geração ao Longo do Ano Todo ....................................................................2202

10.2.3. Mudança de Materiais e Eletrificação das Moendas .......................................2204

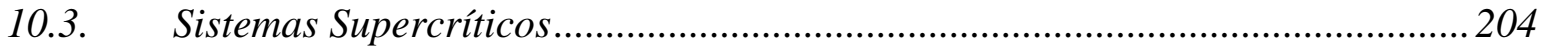

10.4. Sistemas com Gaseificação de Biomassa e Ciclos Combinados.........................206

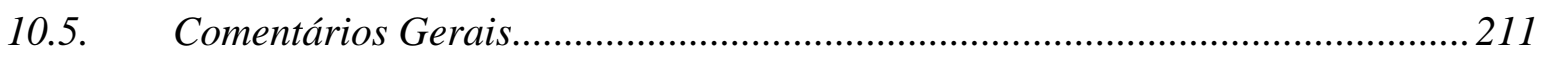

11. Discussão Exergo-ambiental a respeito da Renovabilidade das Configurações para a Produção Combinada de Açúcar, Álcool e Eletricidade....................................................... 215 


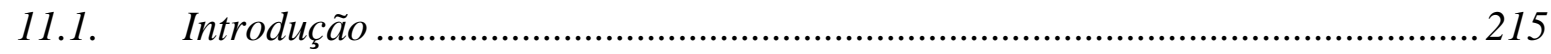

11.2. Indicador Exergético de Renovabilidade ......................................................... 222

11.3. Aplicação do Índice Exergético de Renovabilidade às Configurações para a

Produção Combinada de Açúcar, Álcool e Eletricidade ....................................................224

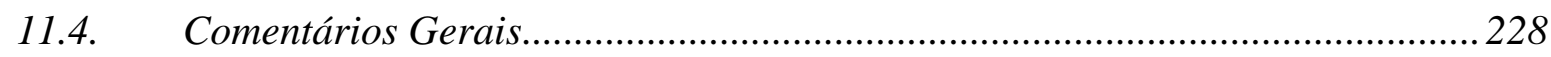

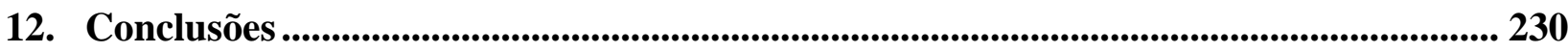

12.1. Sugestão para Trabalhos Futuros .......................................................... 236

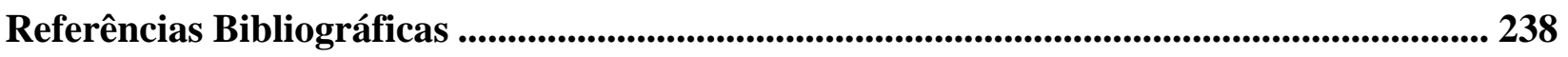

Apêndice A. Modelagem dos Processos de Conversão de Energia em Usinas ........................A.1

A.1. Sistema de Extração............................................................................................. A.1

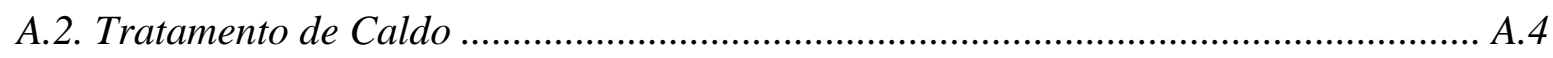

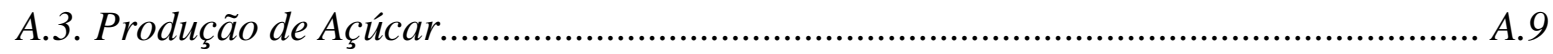

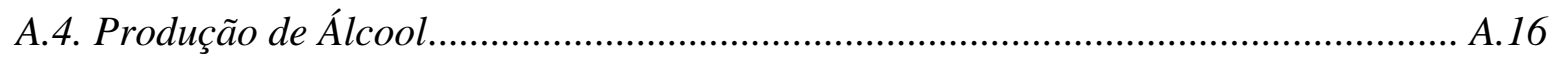

A.5. Sistema de Cogeração.......................................................................................... A.20

A.6. Equações Acoplamento ...................................................................................... A.25

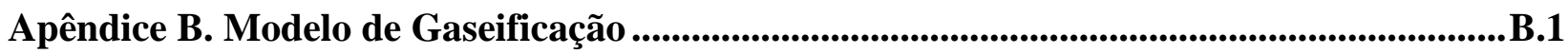

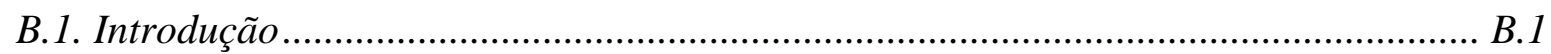

B.2. Definição do Estado de Equilíbrio...................................................................... B.2

B.3. Determinação do Estado de Equilíbrio................................................................... B.5

B.3.1. Abordagem Estequiométrica..................................................................... B. 5

B.3.1. Abordagem não-Estequiométrica.................................................................. B.6

B.4. Construção do Modelo de Gaseificação de Biomassa................................................... B.7

B.4.1. Modelo para Determinação das Propriedades Termodinâmicas.......................... B.7

B.4.2. Modelo para a determinação do Potencial Químico $\left(\mu_{\mathrm{i}}\right)$.................................... B.9

B.4.3. Balanço de energia .................................................................................... B. 10

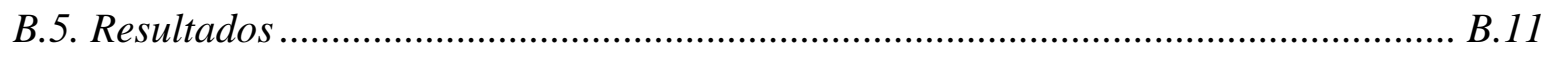

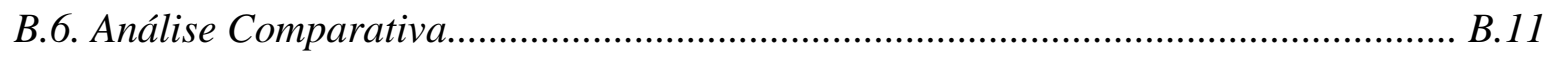

B.7. Comentários Gerais sobre as Comparações ........................................................... B.19 


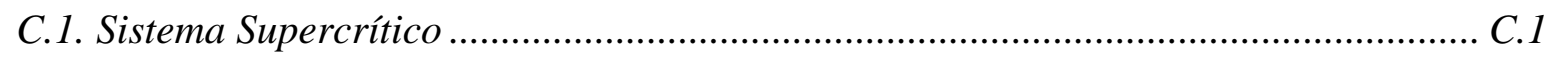

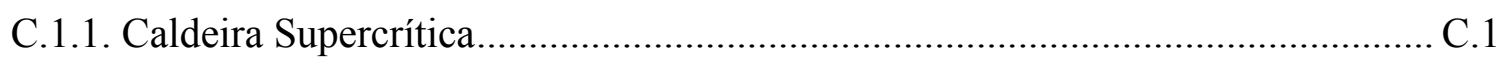

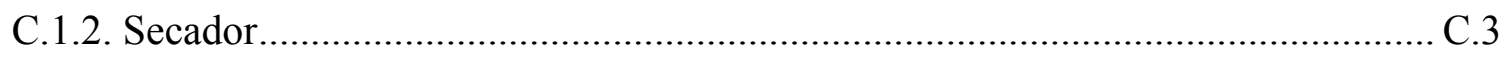

C.1.3. Turbinas, Bombas e demais Equipamentos ………………………………..... C.4

C.1.4. Trocadores de Calor Regenerativos................................................................. C.4

C.2. Ciclo Combinado com Gaseificação de Biomassa ................................................... C.6

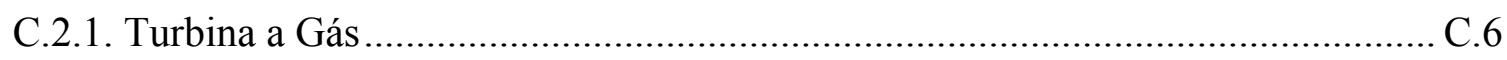

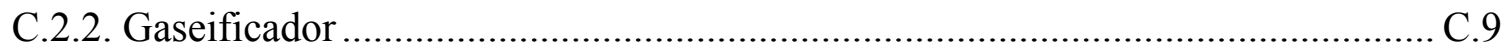

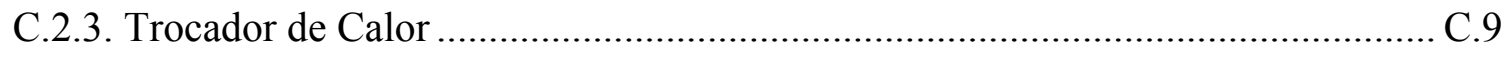

C.2.4. Sistema de Limpeza de Gases....................................................................... C.10

C.2.5. Caldeira de Recuperação ............................................................................. C.11

C.2.6. Compressores de Ar e Gás Produzido …………………………………….... C.13

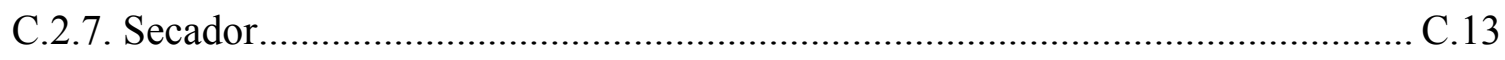

C.2.8. Turbinas, Bombas e demais Equipamentos ....................................................... C.13 


\section{INTRODUÇÃO}

\subsection{ENERGIA E DESENVOLVIMENTO SUSTENTÁVEL}

A questão posta em todas as esferas da sociedade é como se poderá manter o ritmo atual de desenvolvimento da humanidade de maneira a não comprometer ainda mais o meio ambiente. Esta idéia está intimamente ligada ao que, em 1987, a Comissão Mundial sobre Meio Ambiente e Desenvolvimento da Organização das Nações Unidas (ONU) definiu como Desenvolvimento Sustentável: uma forma de desenvolvimento ou progresso que satisfaça as necessidades do presente sem comprometer a capacidade de as futuras gerações satisfazerem as suas próprias necessidades (SCMIDHEINY, 1992).

Desde então, estratégias e políticas, inovações tecnológicas, iniciativas científicas e educacionais e novas legislações que promovam o desenvolvimento sustentável vêm sendo buscadas e desenvolvidas. Essas medidas visam alavancar técnicas de produção e meios de consumo menos prejudiciais ao meio ambiente. $\mathrm{O}$ conceito de desenvolvimento sustentável agora influencia governos, negócios e atividades econômicas nos mais diferentes níveis, além de afetar as escolhas individuais de cada um (AZAPAGIC; PERDAN; CLIFT, 2004).

De uma maneira geral, o princípio fundamental do desenvolvimento sustentável é melhorar o bem-estar dos seres humanos e manter essas melhorias ao longo do tempo. Para tanto, é necessário uma diminuição dos níveis excessivos de produção e consumo (padrões não sustentáveis de produção e consumo), limitando a utilização de energia e recursos naturais na economia através do uso mais racional dos mesmos; e tratando o desafio de erradicação da pobreza através de ações concretas que lidem com as suas causas e garantam que os recursos disponíveis sejam usados para o benefício de todos (AZAPAGIC; PERDAN; CLIFT, 2004).

Durante toda a história da humanidade, o homem utilizou várias formas de energia que o auxiliaram nas suas tarefas diárias. Como exemplo dessas, pode-se citar: energia hidráulica, energia eólica, energia proveniente da queima de combustíveis renováveis e não-renováveis, energia química, energia solar, energia nuclear, energia elétrica, dentre outras. Conforme destaca Sachs (2007), a história da humanidade pode ser resumida como a história da 
produção e alocação do excedente econômico, ritmada por revoluções energéticas, decorridas da descoberta de uma nova fonte de energia com qualidades superiores e custos inferiores.

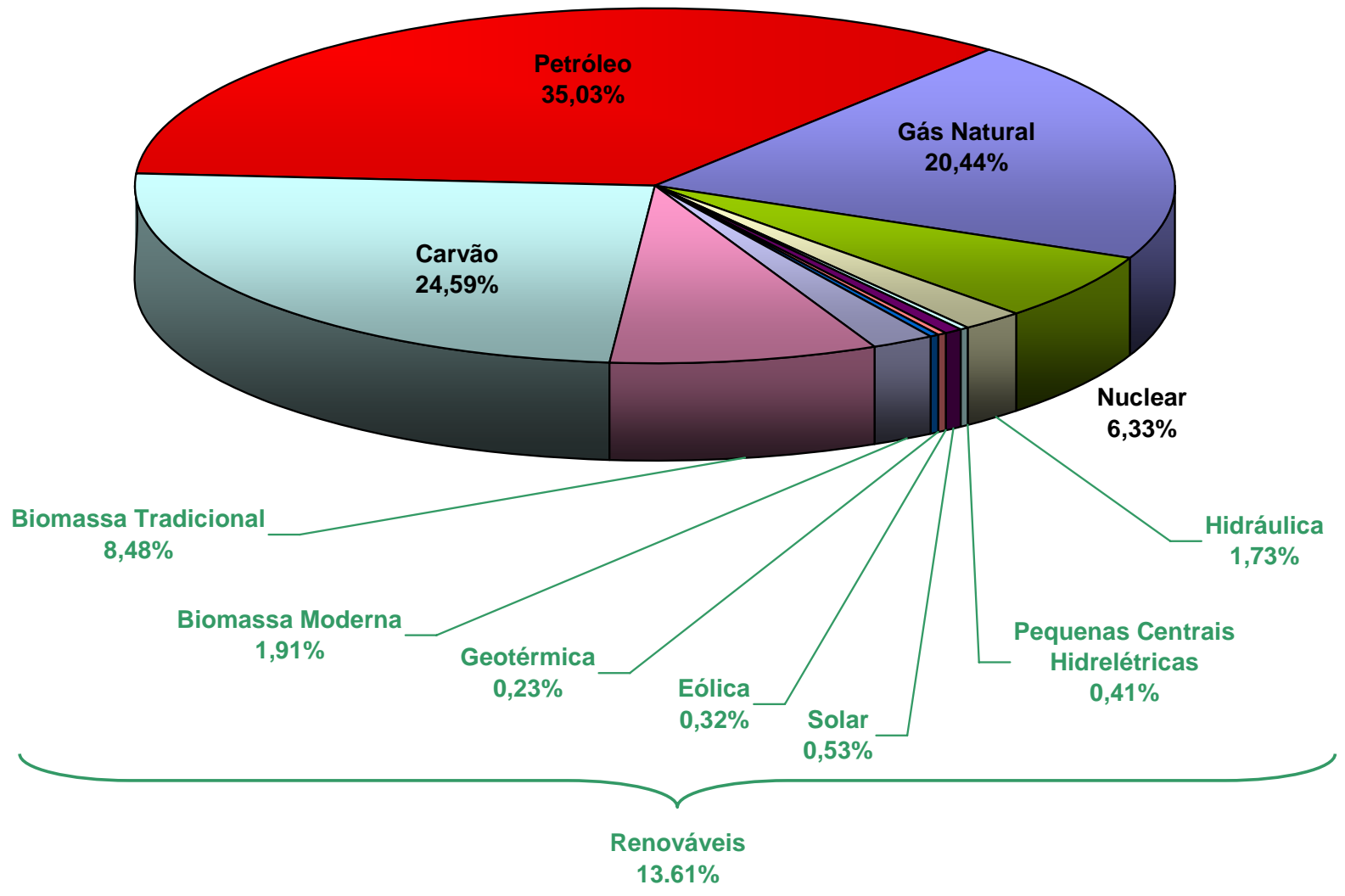

Figura 1.1 - Oferta mundial de energia primária em 2004. (Adaptado de Goldemberg, 2007).

Atualmente, os combustíveis fósseis (não-renováveis) são os mais utilizados (Fig. 1.1) principalmente devido à disponibilidade na natureza e aos custos relativamente baixos. Entretanto, este tipo de combustível, como dito, não é renovável e, assim, já são feitas previsões quanto a sua futura utilização. As reservas atualmente conhecidas de petróleo irão durar mais 41 anos, as de gás natural 64 anos e as de carvão 155 anos, dado que o consumo se mantenha nos níveis atuais e não ocorram novas descobertas (BP, 2007). Contudo, o que efetivamente irá ocorrer será o encarecimento dessas fontes, viabilizando o uso de outras, tanto fósseis (óleos pesados e transformação do carvão em combustíveis líquidos e gasosos) como renováveis. Estas previsões, associadas à crescente preocupação com relação ao meioambiente (impactos devido a emissões, disposição de resíduos), vêm despertando o interesse mundial pela busca de fontes de energia limpas e renováveis. 
Um futuro sustentável para geração de energia depende do aumento da participação de energias renováveis na matriz energética mundial, especialmente nos países em desenvolvimento. Tal aumento da participação iria ajudar no prolongamento das reservas de combustível fóssil (base das matrizes energéticas dos países desenvolvidos), no processo de redução da emissão de gases de efeito estufa, além de possibilitar uma melhor segurança energética numa escala global ${ }^{1}$. Contudo, a maior barreira para a adoção dessas fontes continua sendo o seu elevado custo (GOLDEMBERG, 2007).

Vários países desenvolvidos vêm promovendo estratégias de inserção de fontes renováveis. Porém, conforme argumenta Sachs (2007), as estratégias encontradas até o momento, principalmente relacionadas ao debate sobre mudanças climáticas, têm uma ênfase excessiva em soluções de mercado e na incorporação nos preços dos custos ambientais.

Uma argumentação nesse sentido se refere ao uso ineficiente de combustíveis renováveis, já que seu uso de maneira mais eficiente/racional implicaria uma maior diminuição do consumo de seus correspondentes fósseis. A questão que se põe, então, é a definição de quais rotas de conversão são mais interessantes sob o ponto de vista do desenvolvimento sustentável. Assim, como mostrado na Fig. 1.1, é interessante classificar as fontes provenientes de biomassa em duas categorias: a biomassa tradicional a qual é utilizada de forma ineficiente (p.ex., a lenha utilizada para o cozimento de alimentos) e normalmente causa desflorestamentos; e a biomassa moderna, produzida de forma sustentável e utilizada para geração de eletricidade, calor e produção de combustíveis líquidos para transporte (GOLDEMBERG, 2007).

Deste modo, o estudo de otimização energética de processos industriais (o qual objetiva identificar as ineficiências, que conseqüentemente causam perdas, utilizando modelos matemáticos para otimização e propondo, assim, alterações no ciclo que possibilitem a redução dessas ineficiências) é fundamental no desenvolvimento de soluções para formas de aproveitamento racional da energia. O conceito de ineficiência está diretamente relacionado ao termo irreversibilidade que é característico de todos os processos reais que ocorrem na natureza. A irreversibilidade de um processo pode ser associada diretamente à exergia

\footnotetext{
${ }^{1}$ É importante observar que as maiores reservas de petróleo encontram-se em regiões muito instáveis politicamente.
} 
destruída, a qual é obtida através de uma análise exergética que é a aplicação da Segunda Lei da Termodinâmica em conjunto com a Primeira Lei da Termodinâmica.

Numa visão mais ampla, o presente trabalho visa atacar a questão do uso racional da energia e recursos naturais dentro do contexto da busca de alternativas aos combustíveis fósseis para geração sustentável de energia. Cabe aqui definir o termo "energia sustentável" como a energia gerada e utilizada de maneira a suportar o desenvolvimento humano no longo prazo em todas as dimensões sociais, econômicas e ambientais (JOHANSSON; GOLDEMBERG, 2004).

\subsection{MATRIZ ENERGÉTICA BRASILEIRA}

Comparando a matriz energética mundial com a brasileira (Fig. 1.2), pode-se ver que o Brasil está em uma posição privilegiada com mais de $40 \%$ de sua matriz com recursos renováveis.

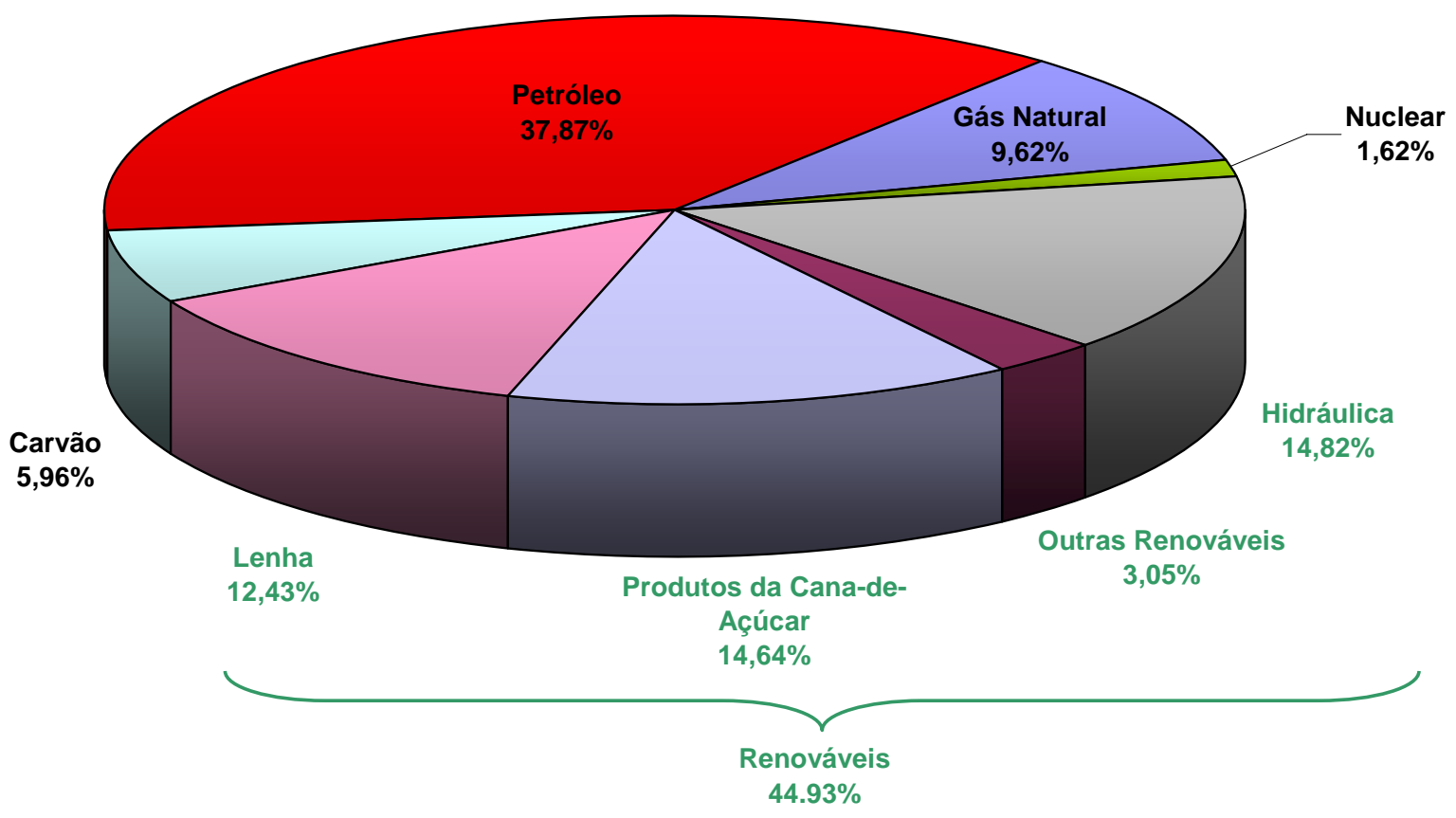

Figura 1.2 - Oferta interna de energia (OIE) no Brasil (MME, 2007).

Entre as energias renováveis, destacam-se principalmente a hidráulica, responsável por 75\% da eletricidade gerada no Brasil, e os produtos da cana-de-açúcar, sobretudo o etanol utilizado como combustível em motores de veículos. 
Essa situação é conseqüência da estratégia adotada pelo país para diminuir a dependência nacional por petróleo a partir da década 70, devido aos choques de 1973 e 1979. As políticas desenvolvimentistas iniciadas no governo Kubitschek, impulsionaram o uso do petróleo, tornando-o o principal insumo energético do país em 1969. Neste panorama, os dois choques do petróleo, responsáveis pela elevação do seu preço em $800 \%$, forçaram o Brasil a adotar medidas de forma a diminuir essa dependência, a fim de melhorar o saldo da sua balança comercial. Dentre essas medidas destacam-se:

Prospecção e extração de petróleo em águas profundas;

Acordo com a Alemanha para o uso da energia nuclear;

Aumento da exploração do carvão mineral;

Lançamento do Programa Brasileiro do Álcool (Proálcool);

Aumento do parque gerador hidrelétrico (construção de Itaipu);

Incentivo ao setor de transportes para utilização de energéticos não-derivados do petróleo.

Assim, os derivados da cana-de-açúcar começaram a ter um papel de grande importância na matriz energética brasileira, passando de 5\% em 1970 para 15\% em 1985 (Fig. 1.2), valor no qual se encontra até hoje.

Além da alta participação de fontes renováveis, os esforços iniciados naquela época viabilizaram a obtenção da sempre desejada auto-suficiência na produção de petróleo. Porém, conforme destacam Goldemberg e Lucon (2007), a auto-suficiência não é garantida no longo prazo, além de ser apenas física, já que o nosso petróleo não é de boa qualidade, sendo necessárias importações para o refino de outros produtos (p.ex., óleo diesel). Isso leva a um déficit na conta-petróleo por conta das altas ocorridas nos últimos tempos.

Nos últimos anos, a evolução da OIE acompanhou de perto a evolução do PIB, porém o consumo de eletricidade tem aumentado mais rapidamente, o que resultou no "apagão" ocorrido em 2001. O racionamento de energia elétrica pode ser analisado, basicamente, por dois fatores (BAER, 2003):

Estiagem ocorrida nos três anos precedentes ao "apagão", diminuindo os níveis dos reservatórios (em 2000, 83\% da geração de eletricidade era de base hidráulica); 
$>$ Falta de planejamento por parte do governo. Entre 1980 e 2000 o consumo de eletricidade aumentou $5 \%$, enquanto a capacidade instalada cresceu $4 \%$.

Houve uma redução compulsória de quase 7.000 MW médios no consumo durante o racionamento. Entretanto, ao final deste, grande parte do consumo não voltou aos níveis anteriores, pois os consumidores se tornaram mais eficientes (substituindo equipamentos, racionalizando os processos de produção etc.). Desta maneira, o país passou muito rapidamente de uma situação de escassez para uma de "folga", não havendo a necessidade de investir em nova capacidade.

Contudo, o risco de um novo racionamento ainda existe, mesmo com o governo garantindo uma situação tranqüila até 2016, segundo o Plano Decenal 2007-2016 (EPE, 2007), dada a falta de investimentos na geração, o atraso na liberação de licenças ambientais para construção de usinas hidrelétricas, questões relacionados ao abastecimento do gás natural, entre outras. Todavia, é importante ressaltar que a expansão da oferta de energia elétrica (dos atuais $100 \mathrm{GW}$ para $155 \mathrm{GW}$ ) está baseada no aumento da participação do uso de combustíveis fósseis na matriz elétrica, passando dos atuais $12 \%(12 \mathrm{GW})$ para $17 \%$ (26 $\mathrm{GW}$ ), quase triplicando a emissão de $\mathrm{CO}_{2}$ da matriz elétrica brasileira. Haverá também um aumento da geração a partir de biomassa, porém inferior ao dos combustíveis fósseis.

O $1^{\text {o }}$ Leilão de Energia de Fontes Alternativas, ocorrido no dia 18 de junho de 2007, foi considerado um fracasso por muitos, haja visto que estava prevista a contratação de 1.165 MW, porém apenas $639 \mathrm{MW}$ foram efetivamente contratados, sendo $512 \mathrm{MW}$ provenientes de biomassa (bagaço de cana-de-açúcar). A grande razão para o desempenho ruim do leilão foi o preço oferecido pela energia. No caso da energia eólica, o valor médio oferecido no leilão R\$ 137,32 por MWh é muito inferior ao valor que viabiliza essa geração. Além disso, o preço oferecido pela energia não foi considerado atraente pelas usinas sucroalcooleiras e pelas PCH's, as quais estão optando pelo mercado livre. Segundo a Empresa de Pesquisas Energéticas (EPE, 2008), o $1^{\circ}$ Leilão de Energia de Reserva, ocorrido em agosto de 2008, contratou quase $2.500 \mathrm{MW}$ de sistemas movidos a biomassa, que iniciarão a geração a partir de 2011. Todavia, esse valor é bastante inferior ao volume cadastrado, 7.200 MW, o qual representaria 7\% da capacidade total instalada no Brasil (MME, 2008). A justificativa, mais uma vez, dada pelo baixo volume contratado foi o preço-teto estabelecido no leilão (R\$ 157,00/MWh), considerado baixo pelos donos de usinas. 
De uma maneira geral, a questão da geração de energia está fortemente atrelada ao ritmo de crescimento e desenvolvimento do país, além do tipo de desenvolvimento, principalmente nas economias emergentes. O Brasil, diferentemente da maioria dos países em desenvolvimento, é capaz de calcar boa parte de seu crescimento no consumo de recursos renováveis, principalmente em PCH's e UTE's movidas a biomassa, além do uso de combustíveis renováveis (etanol e biodiesel) para transporte.

Essa condição justifica, em parte, o estudo do uso racional de energia em usinas sucroalcooleiras, a fim de maximizar a eficiência de conversão nos processos de produção. Ainda, um enfoque especial para a geração de eletricidade excedente é justificável frente à possibilidade de um novo racionamento a partir de 2011. 


\section{OBJETIVO DA TESE}

\subsection{OBJETIVO GERAL}

O presente trabalho objetiva a obtenção de configurações ótimas para geração conjunta de energia eletromecânica e calor em usinas sucroalcooleiras, avaliando o impacto destas nos custos de produção de açúcar, álcool e eletricidade, e no desempenho ambiental da usina.

\subsection{OBJETIVOS ESPECÍFICOS}

As configurações propostas são produto de uma metodologia para a otimização paramétrica de índices termodinâmicos, econômicos e ambientais, os quais avaliarão o potencial de utilização das mesmas em usinas sucroalcooleiras para a geração sustentável de energia. A metodologia foi baseada nas análises exergética, termoeconômica e exergoambiental de plantas de conversão de energia. Assim, os seguintes objetivos específicos são propostos:

$\checkmark$ Avaliar o potencial de geração de energia elétrica em usinas sucroalcooleiras frente à demanda brasileira;

$\checkmark$ Discutir os principais processos responsáveis por transformar a cana-de-açúcar em açúcar, álcool e eletricidade;

$\checkmark$ Desenvolver um modelo termodinâmico para simulação dos processos de conversão de energia em usinas sucroalcooleiras;

$\checkmark$ Fazer uma análise exergética dos principais processos de conversão de energia, avaliando alternativas para minimizar a geração de entropia nos mesmos;

$\checkmark$ Mostrar aspectos tecnológicos das alternativas estudadas para o sistema de cogeração, bem como a integração térmica dessas com a produção de açúcar e álcool;

$\checkmark$ Avaliar como as modificações nos processos de conversão de energia alteram o processo de formação de custo dos produtos, identificando e quantificando as vantagens e/ou desvantagens dessas alterações;

$\checkmark$ Estudar a rentabilidade dos produtos da usina em função das alterações propostas;

$\checkmark$ Discutir a viabilidade econômico-financeira das modificações analisadas; 
$\checkmark$ Avaliar o desempenho ambiental das alternativas a partir de um índice exergético de renovabilidade, proposto pelo autor em Velásquez, Pellegrini e Oliveira Jr. (2008).

Este trabalho fez parte do Projeto Temático FAPESP USP/UNICAMP "Análise Técnica, Econômica e Ambiental do Uso da Cana de Açúcar para Geração Sustentável de Energia Elétrica", sob coordenação do Prof. Dr. José Goldemberg (USP), o qual visava a obtenção de parâmetros técnicos econômicos que auxiliassem na elaboração de políticas específicas, de medidas regulatórias e, também, na decisão sobre investimentos para utilização eficiente do potencial de geração de energia elétrica a partir de sub-produtos da cana de açúcar (bagaço e de pontas e folhas).

\subsection{DIVISÃO DOS CAPÍTULOS}

A tese ora apresentada está dividida em doze capítulos e três apêndices.

O Cap. 1 apresenta uma discussão sobre a relação existente entre a energia e o conceito de desenvolvimento sustentável, além de mostrar um breve panorama da situação energética brasileira.

O Cap. 2 expressa de maneira clara o objetivo da presente tese.

O Cap. 3 discute a evolução do setor sucroalcooleiro desde a chegada da cana-de-açúcar no Brasil no século XV até os dias de hoje.

O Cap. 4 mostra os principais processos de conversão de energia envolvidos na produção combinada de açúcar, álcool e eletricidade a partir da cana, com uma breve discussão sobre o impacto ambiental da agroindústria canavieira.

O Cap. 5 descreve os conceitos envolvidos na análise exergética e termoeconômica, seguida de uma revisão dos trabalhos publicados na área para usinas sucroalcooleiras. Ainda, os modelos matemáticos para cálculo das propriedades termodinâmicas são apresentados. 
O Cap. 6 traz a aplicação da análise exergética a uma usina sucroalcooleira tradicional, identificando os principais mecanismos de geração de entropia dos processos de conversão de energia, propondo alterações que visem minimizar a exergia destruída nos processos.

O Cap. 7 apresenta as tecnologias de cogeração estudadas na tese, mostrando aspectos tecnológicos destas e sua integração em usinas sucroalcooleiras.

O Cap. 8 mostra os resultados das análises feitas para as diversas configurações estudadas para melhorar o desempenho termodinâmico da usina. São apresentados os custos em base exergética para os produtos da usina e a sua relação com a redução da geração de entropia nos processos de conversão de energia.

O Cap. 9 traz uma análise da margem de contribuição dos produtos da usina, utilizando a Termoeconomia como base para a determinação dos custos de produção, identificando a rentabilidade dos produtos em função da configuração avaliada.

O Cap. 10 apresenta uma avaliação de viabilidade econômica das configurações apresentadas no Cap. 8, identificando aquelas com maior retorno financeiro. Para essa análise, utilizou-se como figura de mérito a taxa interna de retorno e o valor presente líquido do investimento.

O Cap. 11 discute a questão da renovabilidade dos processos de conversão de energia, introduzindo um índice em base exergética para a avaliação dessa questão, proposto pelo autor em conjunto com membros do Laboratório de Engenharia Térmica e Ambiental do Departamento de Engenharia Mecânica da Escola Politécnica da USP.

Finalmente, o Cap. 12 apresenta as conclusões do trabalho, assim como uma lista de sugestões para trabalhos futuros.

Os Apêndices A e C mostram os principais equacionamentos utilizados para a elaboração dos modelos computacionais para a produção combinada de açúcar, álcool e eletricidade desenvolvidos para a obtenção dos resultados. O Apêndice B mostra o modelo computacional desenvolvido para avaliar o processo de gaseificação de biomassa, utilizado na avaliação dos sistemas de ciclo combinado com gaseificação integrada. 


\section{A AGROINDÚSTRIA CANAVIEIRA}

Analisando a agroindústria canavieira sob uma perspectiva histórica é possível mostrar que a sua dinâmica é marcada por crises recorrentes e uma forte intervenção estatal, apesar de ineficiente, durante a maior parte do século XX. A intervenção do Estado era necessária devido à incapacidade do setor de se auto-organizar. Historicamente, o setor é marcado por disputas entre os produtores, usineiros, comerciantes e refinadores, para a definição de preços. Segundo Vian (2003), há uma tendência dos agentes ligados ao setor de cooperar apenas em épocas de crise e de abusar do oportunismo nas fases de expansão. Ainda segundo esse autor, outro aspecto recorrente do setor é a utilização do álcool combustível como regulador do mercado de açúcar em momentos de superprodução e a integração vertical para trás ${ }^{2}$. Este autor divide a evolução da produção canavieira em quatro fases, baseada na relação entre produtores e o governo:

$\checkmark$ Etapa I: a coroa portuguesa era sócia dos produtores na fundação dos engenhos, cedendo as sesmarias, dando proteção e obrigando a comercialização do açúcar com Portugal;

$\checkmark$ Etapa II: Portugal incentivou a produção de açúcar, mas impôs limitações e taxou os lucros da atividade;

$\checkmark$ Etapa III: após a Independência, o Estado adotou medidas liberais, permitindo a iniciativa privada determinar a implementação e comercialização do produto. Na fase republicana, essa postura foi reafirmada, através de incentivos para criação de Engenhos Centrais;

$\checkmark$ Etapa IV: após os anos 30, o Estado voltou a ter um posicionamento intervencionista, adotando medidas para planejamento e controle da produção de açúcar.

Com a desregulamentação do setor durante a década de 1990, pode-se dizer que a indústria canavieira iniciou uma nova etapa, marcada pela entrada de novos agentes no mercado, profissionalização e a busca por melhores alternativas de produção para redução de custos.

\footnotetext{
${ }^{2}$ A firma passa a produzir as matérias-primas de que necessita em vez de comprá-las (produção e processamento da cana).
} 
A cana-de-açúcar foi a primeira lavoura instalada no Brasil, sendo ligada às primeiras tentativas de colonização do território logo após a chegada dos portugueses em 1500. Oficialmente, foi Martim Affonso de Souza que em 1532 trouxe a primeira muda de cana para o Brasil, iniciando a sua produção na Capitania de São Vicente, na região do atual Estado de São Paulo. O açúcar teve participação relativamente importante no desenvolvimento da economia brasileira colonial como mercadoria destinada prioritariamente à exportação ${ }^{3}$, com a produção predominantemente nordestina, devido a suas condições edafoclimáticas e proximidade com o principal centro consumidor, a Europa. A produção era baseada no baixo custo da mão-de-obra escrava em grandes latifúndios para exportação de uma única mercadoria (o conhecido sistema plantation de produção), o que estimulava uma atitude conservadora com relação a inovações tecnológicas e/ou novas técnicas de produção. As moendas eram acionadas por tração humana ${ }^{4}$, animal ou por rodas d'água, sendo o caldo fervido em tachos que utilizavam lenha para o fornecimento de calor (CARVALHO, 2000).

Esta atividade deu ao Brasil o monopólio do açúcar por quase dois séculos, sendo a principal atividade econômica da colônia até a descoberta do ouro no final do século XVIII. Durante o período colonial, a intervenção estatal era intensa, sendo deixada de lado apenas durante o Império e os primeiros anos da República, sendo retomada a partir da Grande Depressão de 1929 (SZMRECSÁNYI, 1979). O Estado português estabelecia as regras de comercialização, doava as terras, controlava o tráfico negreiro, mantinha a escravidão, além de proibir a concorrência de outras atividades.

Enquanto isso, nas Antilhas, a produção de açúcar, introduzida pelos holandeses expulsos do Nordeste no século XVII, sofria um processo de modernização com a introdução de novas variedades vegetais, maquinário, métodos de produção, aproveitamento do bagaço como insumo energético e diversificação da produção. Este processo aliado à resistência dos produtores brasileiros a mudanças tecnológicas fez com que a produção brasileira fosse suplantada pela caribenha

\footnotetext{
${ }^{3} \mathrm{O}$ engenho era o maior e mais complexo empreendimento econômico no mundo e o açúcar o produto de maior valor no comércio mundial.

${ }^{4}$ Não se tem certeza se no Brasil existiram moendas acionadas por tração humana.
} 
No início do século XIX, sob o domínio do Imperador Francês Napoleão I, a produção de açúcar a partir da beterraba foi iniciada na Europa. Ainda, durante a Revolução Industrial, o uso de máquinas a vapor para o acionamento das moendas de aço (John Steward - 1770), evaporadores de múlitplos-efeitos (Norbert Rillieux - 1845), processo de cozimento a vácuo (Edward Charles Howard - 1813) e centrífugas para promover a separação dos cristais de açúcar do melaço (Penzoldt - 1837) permitiu à indústria açucareira, tanto a canavieira como a de beterraba, atingir novos níveis de eficiência, muito maiores que aqueles normalmente encontrados na produção brasileira da época. Além disso, a abolição da escravatura em 1888 marcou o fim do sistema de produção de açúcar utilizado no Brasil por quase quatro séculos. Ao mesmo tempo, o cultivo da cana-de-açúcar voltou a ter importância econômica, principalmente em São Paulo, onde migrou das terras costeiras para a terra roxa mais fértil do interior.

Enquanto surgiam novas regiões produtoras mais modernas e eficientes ao redor do mundo, a produção brasileira ia perdendo cada vez mais o seu espaço no mercado internacional. Segundo Vian (2003), a não-modernização do setor representaria a estagnação e até a retração da produção, provocando a desativação de unidades e a reconversão da terra para outros cultivos. Finalmente, a agroindústria canavieira passou por um choque de modernização a partir de 1870, surgindo os primeiros engenhos a vapor e o melhor aproveitamento do bagaço como combustível (SANT'ANA, 1970; JAMBEIRO; 1973; CARVALHO, 2000). Nesta época surgem as primeiras aplicações de cogeração no setor, sendo o vapor gerado nas caldeiras expandido até a pressão de processo em turbinas centrífugas utilizadas no acionamento das moendas.

O surgimento dos Engenhos Centrais nessa época é a marca dessa modernização. A idéia do uso dessas plantas era a desintegração vertical do setor, ou seja, separar as atividades de cultivo e processamento, permitindo aos senhores de engenho investir mais na fase agrícola e os investimentos para melhorias na fase industrial seriam responsabilidade de outros grupos econômicos. A instalação de Engenhos Centrais, com investimento estrangeiro, não foi bem recebida pelos senhores de engenho, os quais alegavam a perda de poder sobre o processo produtivo (base do seu poder político na época) e, portanto, continuaram a operar seus engenhos, principalmente em momentos de preços baixos da cana. Por fim, a partir de 1890, os senhores-de-engenho aceitaram a modernização. Mas o fizeram sob duas condições: 
i. Os Engenhos Centrais ficariam sob seu domínio, ou seja, manter-se-ia a integração vertical para trás.

ii. A aquisição de equipamentos a partir de financiamentos subsidiados dos governos estaduais e federal.

Essas novas unidades fabris receberam o nome de Usinas, assim denominadas até hoje (VIAN, 2003). No entanto, este processo aconteceu de forma desordenada e confusa, já que as concessões eram feitas de forma indiscriminada, expandindo as produções sem um planejamento das ações.

Porém, esses esforços não foram suficientes, com a contínua queda das exportações de açúcar e as crises de superprodução, o setor requisitou a intervenção estatal, a fim de minimizar os efeitos da crise.

A eclosão da Primeira Guerra Mundial trouxe um novo ânimo para o setor, com a exportação dos excedentes de produção, já que a indústria européia do açúcar de beterraba estava devastada e os preços deste produto no mercado internacional estavam em alta. Contudo, na década de 20, as crises ressurgiram e, com elas, veio a intervenção estatal para regular a oferta de açúcar. Ao fim desta década, as crises entre produtores, usineiros, comerciantes e refinadores se agravaram ainda mais devido à Grande Depressão, a qual derrubou os preços do açúcar e fez o Brasil entrar numa época de recessão. Além disso, a crise do café fez com que os cafeicultores paulistas optassem pela cana para diminuir os prejuízos com a crise externa, iniciando-se um período de forte expansão da produção paulista (SZMRECSÁNYI, 1979).

Assim, em 1933, foi criado o Instituto do Açúcar e do Álcool (IAA), o qual seria responsável pelo estabelecimento dos volumes de produção e processamento de cana em cada unidade fabril, além do controle sobre as expansões das unidades. Segundo Vian (2003), o principal objetivo deste órgão era regular o mercado de açúcar através do uso alternativo da matériaprima (cana-de-açúcar), sendo parte da produção destinada para a fabricação de álcool anidro. Nas palavras de Vian (2003), “os usineiros estavam acostumados a produzir açúcar e viam o álcool apenas como subproduto” (p. 75). 
O advento da Segunda Guerra Mundial teve impactos tanto na produção de açúcar com na de álcool. Neste último devido à escassez dos derivados do petróleo, com o governo passando a considerar a produção de álcool anidro como estratégica para a economia nacional. Assim, vários incentivos foram dados à produção deste combustível, além da fixação em $20 \%$ o teor mínimo de mistura a gasolina (SZMRECSÁNYI,1979; MORAES, 2000). A guerra trouxe dificuldades de abastecimento do açúcar nordestino para o mercado do Centro-Sul, criando condições favoráveis para que os produtores paulistas reivindicassem a expansão da produção. Szmrecsányi (1979) afirma que "a conseqüência principal e mais duradoura desse processo foi a transferência do eixo da agroindústria canavieira do Brasil, da região Nordeste para o Centro-Sul” (p. 204).

Nas décadas seguintes, a produção de açúcar foi marcada por disputas entre os produtores por maiores cotas de produção, oscilando entre períodos de grande prosperidade e outros de forte recessão. A produção de álcool era vista como um resíduo da fabricação de açúcar, ou seja, uma maneira de regular a oferta do mesmo. Muitas vezes os produtores optavam pela produção e exportação de melaço (SZMRECSÁNYI,1979; MORAES, 2000; CARVALHO, 2000; VIAN, 2003).

Por ocasião dos choques do petróleo na década de 1970, o mercado externo começou a dar sinais de enfraquecimento e era necessário dar continuidade ao processo de aumento da produção para amortizar os investimentos efetuados nos anos anteriores (VIAN, 2003). Ainda, segundo Leite (1997), as políticas desenvolvimentistas iniciadas no governo Kubitschek, impulsionaram o uso do petróleo, tornando-o o principal insumo energético do país em 1969, deixando o país muito vulnerável a crises externas. Neste período, 80\% do petróleo utilizado no país era importado, com a alta dos preços, a situação do comércio exterior brasileiro ficou bastante comprometida, com as despesas para compra do petróleo aumentando em mais de 500\%. De acordo com Shikida (1998), a crise do petróleo e a crise na agroindústria canavieira contribuíram para viabilizar o Programa Nacional do Álcool (PNA), conhecido como Proálcool. Muitos autores (WALTER, 1994; SHIKIDA, 1998; VIAN, 2003) analisam o programa em três fases. Shikida (1998) nomeia essas fases como:

de 1975 a 1979 - "Expansão Moderada", marcada pelo aumento da produção de álcool anidro, via capacidade ociosa existente (destilarias anexas), baixa adesão da 
indústria automobilística e alta concentração de recursos públicos para o financiamento do programa;

$\checkmark$ de 1980 a 1985 - "Expansão Acelerada", marcada pela expansão da produção de álcool hidratado a partir de destilarias autônomas e aumento substancial da produção/venda de carros à álcool;

$\checkmark$ de 1986 a 1995 - "Desaceleração e Crise", marcada pela recuperação dos preços do petróleo no mercado internacional, aumento da produção nacional de petróleo, fim dos incentivos estatais, crise de abastecimento e retração do mercado.

O programa trouxe um novo período de desenvolvimento tecnológico na agroindústria canavieira, cujo objetivo era a maior eficiência de conversão da sacarose e reduções no custo de produção, sobretudo a partir da safra 1981/82 (SHIKIDA; BACHA, 1998). Em 1983, ocorreu uma mudança na forma de pagamento pela cana (deixando de ser quantitativa baseada na tonelada de cana, passando a ser qualitativa baseada na quantidade de sacarose). Esta mudança obrigou também uma adequação tecnológica por parte dos produtores.

O Proálcool teve um grande impacto na produção de álcool no Brasil, a qual aumentou mais de 200\% entre 1970 e 1989. Em 1986, mais de 70\% da produção de veículos leves no Brasil era movida a álcool (ANFAVEA, 2007) e, entre os anos de 1986 e 1989, o consumo de álcool hidratado foi maior que o consumo de gasolina (MME, 2008).

Com a redução dos preços do petróleo no mercado internacional a partir de 1985, a competitividade do álcool foi sendo diminuída ${ }^{5}$. Além disso, houve um aumento expressivo da produção nacional de petróleo e a diminuição do investimento público no programa. Essa situação levou a um desequilíbrio entre a oferta, estagnada devido à falta de investimentos, e a demanda de álcool, já que a frota de carros a álcool nacional era muito grande (VIAN, 2003).

Ao fim da década de 80, apesar do sucesso do programa nas duas primeiras fases, com a elevação da produção de álcool em mais de 25 vezes a produção de 1975/76, o novo governo reconhecia a limitação deste combustível frente à gasolina e optou pela manutenção da

\footnotetext{
${ }^{5}$ Considerando um mistura de $25 \%$ de álcool anidro à gasolina, temos um combustível com um PCI de 28,9 $\mathrm{MJ} / \mathrm{L}$; o PCI do álcool hidratado é de aproximadamente 21,5 MJ/L. Para um mesmo volume de combustível consumido, o trabalho realizado (ou a distância percorrida) por um veículo a álcool pode ser até $25 \%$ menor que aquele realizado pelo veículo com a mistura gasolina-álcool, ou seja, o preço do álcool deve ser no máximo $75 \%$ do preço da gasolina.
} 
produção dentro da capacidade instalada. A existência de dois combustíveis competindo nos país evidenciava a necessidade de um novo modelo de intervenção estatal, onde o governo passaria a ser um mediador de conflitos (MORAES, 2000).

O início da década de 90 foi marcado por um processo de liberação da economia brasileira, conseqüência da crise fiscal do Estado e da passagem de um regime com fortes traços burocráticos e autoritários para um sistema mais democrático. Neste novo ambiente institucional, as funções antes exercidas pelo governo passaram a ser de responsabilidade dos diversos agentes envolvidos no setor (BARROS; MORAES, 2002). Assim, os preços e as cotas de produção não eram mais fixadas pelo governo e as empresas se viram dentro de um mercado liberado, onde as mais eficientes teriam lucros maiores que as demais. Todavia, essa transição foi turbulenta conforme registram Moraes (2000) e Vian (2003). A desregulamentação total veio em 1999 e mostrou as debilidades do setor em se autoorganizar, além da sua heterogeneidade produtiva. Durante esse período, a participação do álcool na matriz energética brasileira permaneceu praticamente constante.

Com o racionamento de energia elétrica ("o apagão") ocorrido em 2001, o governo iniciou um programa para incentivar o uso de fontes alternativas de geração de eletricidade (PROINFA), o qual estabelecia a geração de $3.300 \mathrm{MW}$ a partir da energia eólica, biomassa e pequenas centrais hidrelétricas numa primeira fase, elevando a participação dessas fontes na matriz elétrica nacional para $10 \%$. Porém, essa fase foi abandonada (GOLDEMBERG, LUCON, 2007).

O advento do carro flex-fuel em 2003 (atualmente, mais de 80\% dos veículos leves produzidos são flex), as fortes oscilações do preço do petróleo nos últimos dois anos (batendo quase US\$ 150,00 por barril) e a maior preocupação com o aquecimento global por parte da comunidade internacional re-aqueceu o interesse pela produção de álcool nacional. Neste novo ambiente, os usineiros vêm buscando novas estratégias competitivas a fim de diferenciarem seus produtos. A Cosan, maior empresa sucroalcooleira do mundo, foi a primeira a lançar ações na Bolsa de Valores de São Paulo (BOVESPA) no final de 2005. Além disso, novos agentes, capitalizados com recursos nacionais e internacionais, estão entrando no mercado adquirindo usinas e/ou construindo novas unidades, aumentando a competitividade dentro do setor. Entre esses agentes destacam-se: 
$\checkmark$ Abengoa, maior produtora européia de álcool, que comprou $100 \%$ do capital da Dedini Agro, com duas usinas de açúcar e álcool e capacidade de moagem de 6,5 milhões de toneladas de cana;

$\checkmark$ Adecoagro, empresa que tem como principal acionista o megainvestidor George Soros;

$\checkmark$ Brenco (Companhia Brasileira de Energia Renovável), empresa comandada pelo expresidente da Petrobrás Henri Philippe Reichstul que prevê a construção de 10 usinas com uma capacidade de moagem de 44 milhões de toneladas de cana;

$\checkmark$ Bunge, uma das principais empresas de agribusiness e alimentos do país, que anunciou a compra da usina Santa Juliana, esperando processar até 4 milhões de toneladas de cana em 2011. A empresa anunciou também a construção de uma usina no Tocantins com capacidade para 4,4 milhões de toneladas de cana.

$\checkmark$ Infinity Bioenergy, empresa com ações cotadas na Bolsa de Londres, tem seis usinas em operação com capacidade para 14,5 milhões de toneladas de cana, além de 2 projetos que deverão iniciar a operação em 2009 e 2010.

$\checkmark$ Grupo Louis Dreyfus, grupo francês dono de nove usinas no Brasil com capacidade de moagem de 15 milhões de toneladas de cana, pretendo chegar a 20 milhões na safra 2009/10. A empresa é uma três maiores comercializadoras de açúcar do mundo.

Conforme os dados da consultoria DATAGRO, a participação do capital estrangeiro no setor deverá passar dos atuais $12,4 \%$ na safra $2008 / 09$ para $14,4 \%$ na safra $2009 / 10$, sendo que no início da década o capital internacional respondia por pouco mais de $1 \%$ da produção nacional $^{6}$.

Segundo estimativas da Companhia Nacional de Abastecimento (CONAB), a safra 2008/09 deverá moer 571 milhões de toneladas, superior à safra passada em 14\%. A produção nacional de açúcar está estimada em 32 milhões de toneladas, quase 5\% superior à da safra 2006/07, enquanto a produção nacional de álcool será de 27 bilhões de litros, superior em 17\% à da safra anterior. A região Centro-Sul será responsável por $89 \%$ da produção nacional, com uma produtividade de 84 t/ha (CONAB, 2008).

\footnotetext{
${ }^{6}$ Cresce a participação de estrangeiros na moagem de cana, Valor Econômico, 22/12/2008.
} 
De acordo com informações da Agência Nacional de Energia Elétrica, a capacidade instalada no setor sucroalcooleiro é aproximadamente $3.400 \mathrm{MW}$, ainda quase $1.000 \mathrm{MW}$ em processo de construção ou outorga (ANEEL, 2008). A maior parte dessa capacidade, 2.800 MW, é utilizada para consumo interno e o restante é exportado. Todavia, esta situação tende a mudar nos próximos anos. Segundo a Empresa de Pesquisas Energéticas (EPE, 2008), o último leilão de energia de reserva ocorrido em agosto de 2008 contratou quase $2.500 \mathrm{MW}$ de sistemas movidos à biomassa, que iniciarão a geração a partir de 2011. Porém, este valor é bastante inferior o volume cadastrado, $7.200 \mathrm{MW}$, valor que representaria $7 \%$ da capacidade total instalada no Brasil (MME, 2008). A justificativa dada pelo baixo volume contratado foi o preço-teto estabelecido no leilão (R\$ 157,00/MWh), considerado baixo pelos donos de usinas.

Atualmente, a crise financeira mundial trouxe muitas incertezas para o mercado global, o que talvez postergue os investimentos para a ampliação dos sistemas de cogeração em usinas sucroalcooleiras devido à escassez de crédito e diminuição da margem de lucro dos produtos, porém o potencial do setor é grande como será mostrado nos próximos capítulos.

De uma maneira geral, é possível concluir que a Agroindústria Canavieira Brasileira evoluiu de uma indústria de um único produto no século XVI para uma indústria de poligeração, ou como os produtores preferem, uma indústria de energia (sucroenergética) no século XXI. 


\section{PROCESSOS DE CONVERSÃO DE ENERGIA NA AGROINDÚSTRIA CANAVIEIRA}

A fim de desenvolver uma metodologia para avaliar o uso racional da energia na Agroindústria Canavieira, é muito importante conhecer quais são os processos de conversão de energia existentes.

Este capítulo tem por objetivo apresentar os principais processos de conversão de energia envolvidos na produção de açúcar, álcool e eletricidade, desde a produção agrícola da canade-açúcar até o seu processamento industrial. Ainda, uma discussão sobre os principais resíduos e/ou sub-produtos e os potenciais impactos ambientais dessa agroindústria serão brevemente discutidos.

Para uma descrição mais detalhada dos processos industriais, citam-se aqui os trabalhos de Hugot (1986), Payne (1989), Camargo (1990) e Rein (2007).

\subsection{A CONVERSÃO DE ENERGIA NA PARTE AGRÍCOLA}

A quantidade de matéria orgânica sintetizada anualmente através da fotossíntese é aproximadamente 190 bilhões de toneladas, equivalente a $3 \mathrm{ZT}\left(3 \times 10^{18} \mathrm{~kJ}\right)$ de energia armazenada. Considerando que a incidência de radiação solar na Terra é igual a 3 YJ $\left(3 \times 10^{21}\right.$ kJ), a eficiência energética média dessa conversão é $0,1 \%$. Valores para a eficiência de conversão fotossintética variam entre 1 a $5 \%$, considerando o ano todo - descontando-se, portanto, a taxa de respiração nos períodos noturnos - para plantações (BISIO; BISIO, 1998). Esses mesmos autores calculam que a eficiência exergética da fotossíntese de plantações em zonas temperadas varia entre $0,5 \%$ e $1,3 \%$ da radiação total, enquanto que em zonas tropicais pode chegar a 2,5\%. Em um trabalho mais recente, Petela (2008) desenvolveu a análise exergética do processo da fotossíntese, cujas perdas chegam a representar $97 \%$ da exergia total disponibilizada. 
Conforme mostrado na Fig. 4.1, a maior parte das perdas está na não-absorção de grande parte dos comprimentos de onda que chegam até a folha, sendo as demais relacionadas a perdas na forma de calor e a florescência (metabolismo) (TAIZ; ZEIGER, 2004).

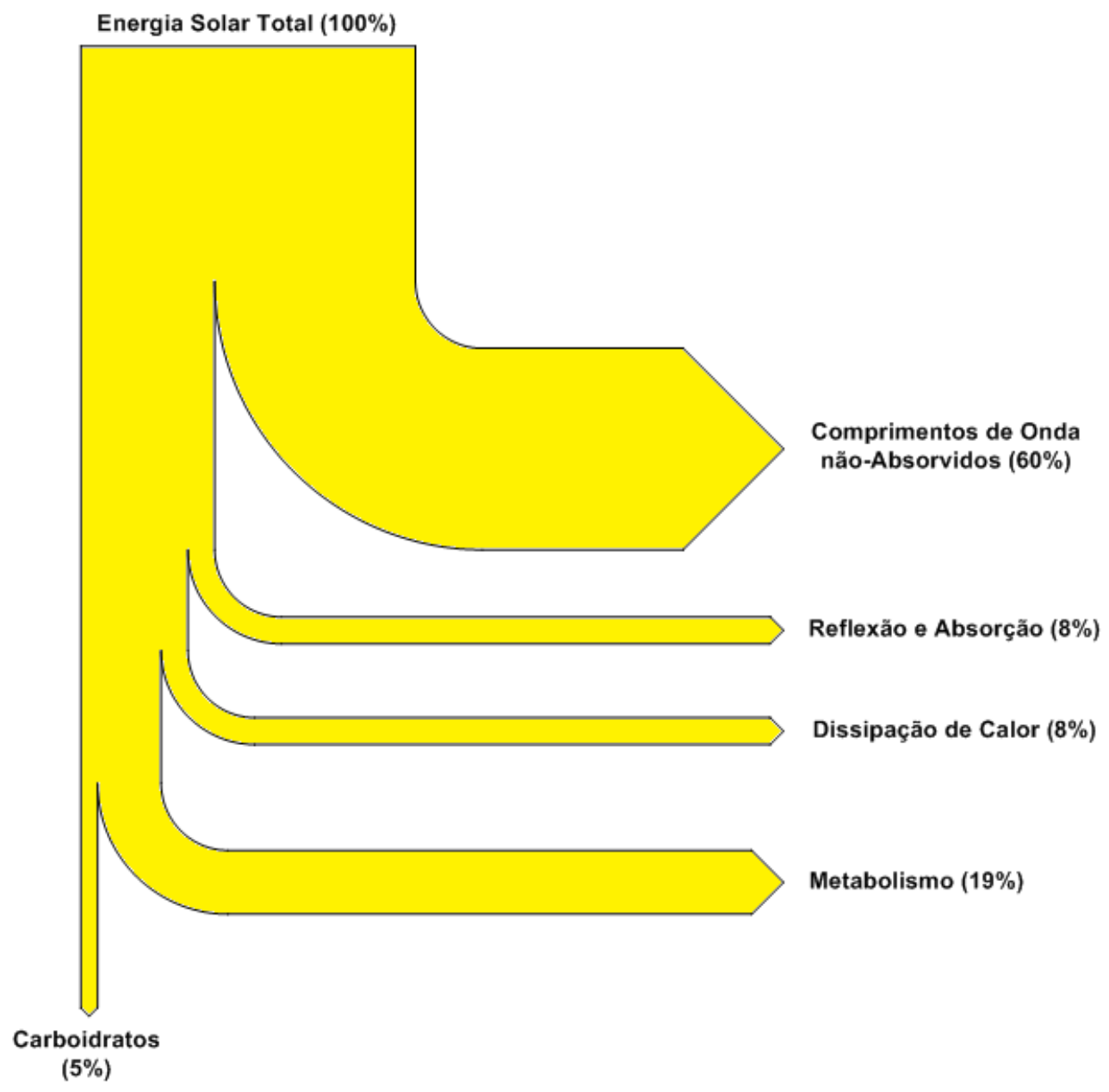

Figura 4.1 - Conversão de energia solar em carboidratos em uma folha (TAIZ; ZEIGER, 2004).

A cana-de-açúcar é uma das poucas plantas que armazenam seus carboidratos na forma de açúcares (sacarose) em vez de amido $^{7}$ (TAIZ; ZEIGER, 2004). Ainda, por se tratar de uma planta $\mathrm{C}_{4}{ }^{8}$, a cana-de-açúcar é um fotossintetizante muito eficiente, com uma eficiência energética de conversão da radiação solar de 4,8\% (ODUM, 1971), com uma alta produtividade no campo, entre 80 e 90 t/ha. Entretanto, esta alta atividade fotossintética, não se correlaciona diretamente com a elevada produtividade de biomassa. A grande capacidade

\footnotetext{
${ }^{7}$ Outro exemplo deste tipo de planta é a beterraba, utilizada na Europa para a produção de açúcar.

${ }^{8}$ Plantas C4 referem-se a plantas cujo primeiro composto estável formado durante as reações da fotossíntese contém 4 átomos de carbono.
} 
da cana-de-açúcar, para a produção de matéria orgânica, reside na alta taxa de fotossíntese por unidade de superfície de terreno, que é influenciado pelo Índice de Área Foliar (IAF). Além disso, o longo ciclo de crescimento da planta resulta em elevadas produções de matéria seca (RODRIGUES, 1995). Como base de comparação, o milho, também uma planta C4, tem uma eficiência energética de conversão da radiação solar de 3,2\% (ODUM, 1971), com uma produtividade de 8 a 9 t/ha nos EUA (SHAPOURI; DUFFIELD; WANG, 2006) e 3,7 t/ha no Brasil (CONAB, 2008).

A cana-de-açúcar é cultivada numa extensa área territorial, compreendida entre os paralelos $35^{\circ}$ de latitude Norte e Sul do Equador, apresentando melhor comportamento nas regiões quentes. O clima ideal é aquele que apresenta duas estações distintas, uma quente e úmida, para proporcionar a germinação, perfilhamento e desenvolvimento vegetativo, seguido de outra fria e seca, para promover a maturação e conseqüente acúmulo de sacarose nos colmos (AGROBYTE, 2007).

A produção brasileira de cana-de-açúcar é dividida em duas regiões com diferentes períodos de safra: a região Centro-Sul, moendo entre os meses de Abril e Novembro, e a região NorteNordeste, moendo entre os meses de Agosto e Março. Conforme discutido no capítulo anterior, o Centro-Sul é responsável por quase toda produção de álcool (90\%) e açúcar (85\%).

A Tab. 4.1 a seguir mostra a composição média da cana-de-açúcar.

Tabela 4.1 - Composição Média da Cana-de-Açúcar (COPERSUCAR, 2007).

\begin{tabular}{cc}
\hline Componente & Fração Molar (\%) \\
\hline Água & $65-75$ \\
Sacarose & $11-18$ \\
Fibra & $8-14$ \\
Sólidos Solúveis & $12-23$ \\
\hline
\end{tabular}

O cultivo da cana-de-açúcar é baseado num sistema de cultura de soca, ou seja, depois do primeiro corte, a soqueira é mantida de maneira que a mesma planta é cortada várias vezes em base anual (normalmente, 4 vezes). Antes do plantio no primeiro ano, o solo é preparado intensamente por operações tais como subsolagem (descompactação do solo), aração, seguida de gradagem e aplicação de fertilizantes minerais. Em seguida, o solo é sulcado e fertilizantes 
ricos em fosfatos são aplicados. As sementes são distribuídas e os sulcos fechados, sendo fertilizantes e herbicidas utilizados mais uma vez. A plantação é sulcada e tratada com fertilizantes sintéticos ou com fertilizantes naturais (p.ex., torta de filtro) mais uma ou duas vezes durante o cultivo no primeiro ano. Após 12 a 18 meses, a cana está pronta para o primeiro corte (SMEETS et al., 2006).

Tanto a colheita manual quanto a colheita mecanizada são utilizadas atualmente no Brasil, no Centro-Sul essa última representou $37 \%$ da cana colhida (UNICA, 2006). Contudo, devido à queimada necessária para a colheita manual, esta vem sendo eliminada gradualmente nas últimas safras. A principal razão para a prevenção da queimada de cana é a questão ambiental, devido à emissão de poluentes e material particulado que causam impactos na saúde das pessoas e em construções próximas aos locais da colheita. Ainda, a queimada acarreta perdas de sacarose na cana por exudação.

Um Protocolo de Cooperação assinado em 2007 entre o governo do Estado de São Paulo e a UNICA prevê que os produtores que aderirem ao protocolo deverão antecipar o prazo final para a eliminação das queimadas da palha de cana-de-açúcar, de 2021 para 2014 e, em 2010, adiantar o percentual de cana não queimada, de $50 \%$, para $70 \%$; e, nos terrenos com declividade acima de $12 \%$, antecipar o prazo final para a eliminação da queima de cana, de 2031 para 2017, adiantando o percentual da cana não queimada, em 2010 , de $10 \%$ para $30 \%$.

$\mathrm{Na}$ colheita manual, a queimada é utilizada para eliminar a palhada e matar animais perigosos no campo; após a queimada, a colheita dos colmos de cana-de-açúcar é feita pelo simples corte manual. A capacidade de colheita manual varia entre 4 e 7 t/homem/dia com custo entre US\$ 3 a 4 por tonelada. A principal vantagem deste método de colheita é a menor quantidade de terra transportada para a usina (BRAUNBECK et al., 1999).

A colheita mecanizada, atualmente, só é possível em terrenos cuja declividade é inferior a $12 \%$. Não há necessidade de queimada e as pontas e folhas podem ser deixadas no campo como adubos orgânicos, ou mesmo, podem ser enviadas para a usina para aumentar a capacidade de geração de eletricidade. Porém, conforme argumentam Braunbeck et al. (1999), a colheita mecânica ainda enfrenta barreiras técnicas e econômicas para a sua expansão. Informações sobre o maquinário e os diferentes métodos existentes para a colheita mecanizada podem ser obtidas em Hassuani, Leal e Macedo (2005). 
Após o corte, a cana-de-açúcar deve ser transportada o mais rápido possível ao setor industrial, por meio de caminhão ou carreta tracionada por trator, a fim de evitar perdas de sacarose. O combustível utilizado pelos caminhões e tratores é o óleo diesel; porém já existe uma movimentação no setor para a integração de plantas de biodiesel às usinas, de maneira a produzir o combustível necessário para abastecer o transporte da cana do campo até a usina.

\subsection{A CONVERSÃO DE ENERGIA NA PARTE INDUSTRIAL}

A etapa industrial do processamento da cana-açúcar pode ser dividida em cinco grandes volumes de controle: Sistema de Extração, Planta de Tratamento de Caldo, Produção de Açúcar, Produção de Álcool e Sistema de Cogeração (Fig. 4.2).

A Tab. 4.2 mostra as quantidades de açúcar e álcool possíveis de serem obtidas em função da estratégia de operação escolhida pela usina.

Tabela 4.2 - Quantidade de açúcar e álcool produzidas, para 1 tonelada de cana (FINGUERUT, 2004).

\begin{tabular}{ccc}
\hline Estratégia de Produção & Açúcar (kg) & Álcool (L) \\
\hline Só Açúcar & 120 & 7 (residual) \\
Açúcar e Álcool (50/50) & 60 & 42 \\
Só Álcool & - & 85 \\
\hline
\end{tabular}

Conforme pode ser visto na Fig. 4.2, há uma grande interação entre os diferentes processos, assim alterações em um desses influencia a operação dos demais e, portanto, nos custos de produção de açúcar, álcool e eletricidade. 


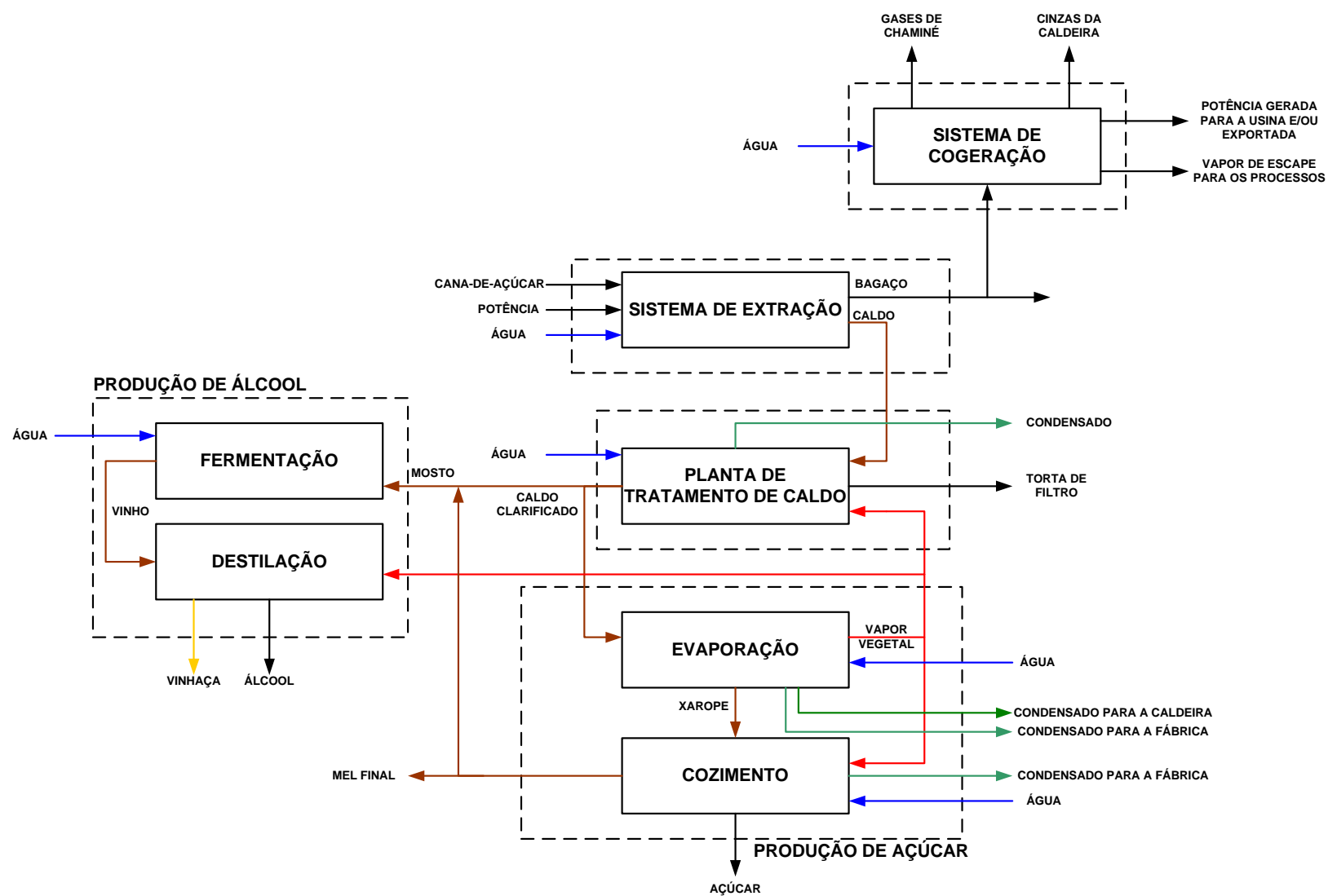

Figura 4.2 - Volumes de controle do processamento industrial da cana-de-açúcar.

A seguir, uma breve descrição das principais operações que acontecem nesses cinco volumes de controle será apresentada.

\subsubsection{Sistema de Extração}

A cana-de-açúcar, após o transporte até a usina, é descarregada na mesa alimentadora, normalmente de forma automatizada. Antes, todavia, os caminhões são pesados e amostras da cana são retiradas para análises laboratoriais. Os dados coletados nessa etapa servirão de base para o pagamento pelo teor de sacarose, além de fornecer parâmetros para avaliar o desempenho do processo de conversão da sacarose em açúcar e/ou álcool (CAMARGO, 1990).

Em seguida, a cana passa por um processo de lavagem a fim de eliminar as impurezas trazidas do campo (terra, pedras, pontas e folhas, entre outros). A água utilizada para essa lavagem pode ser re-circulada no processo, desde que a mesma passe por um processo de purificação. 
O consumo de água nessa etapa gira em torno de 5 m³/tc (CAMARGO, 1990). Em seguida, a cana é enviada para a etapa de moagem.

A extração é basicamente um exercício de separação de materiais (PAYNE, 1989). Conforme mostrado na Tab. 4.1 a cana-de-açúcar é composta de caldo (água + sólidos dissolvidos) e fibras. Assim, o objetivo da extração é recuperar a máxima quantidade de caldo possível, mas também produzir um bagaço com umidade admissível para ser queimado de maneira rápida nas caldeiras.

Antes da extração propriamente dita, a cana deve ser preparada, já que esta pode oferecer maior ou menor resistência à recuperação da sacarose. O principal objetivo do preparo é desintegrar a cana para facilitar a extração do caldo. Além disso, esta etapa serve para alimentar a moenda com uma massa homogênea e compacta. Conforme indica Payne (1989), um bom preparo significa a liberação de grande parte do caldo da estrutura celular da cana, sem reduzir o tamanho da fibra tal que a alimentação dos ternos da moenda seja comprometida. Para avaliar o grau de preparação da cana, um indicador foi definido: índice de preparação. Esse indicador é obtido a partir de um ensaio padronizado para a determinação do número de células abertas, sendo da ordem de 90\% para extração em moendas e $94 \%$ para extração por difusão (PAYNE, 1989). A operação de preparo é realizada utilizando-se facas rotativas seguidas de desfibradores, sendo seus acionamentos feitos ou por turbinas a vapor ou por motores elétricos. As facas têm o objetivo de nivelar e uniformizar a carga de cana, além de promoverem a redução do tamanho (picagem). Os desfibradores causam a destruição completa da estrutura da cana, dando um ganho significativo na extração. As turbinas a vapor normalmente são turbinas de simples estágio ou com 3 estágios, com rendimentos isoentrópicos inferiores a $60 \%$, ou seja, consumos específicos de $13-16 \mathrm{~kg} / \mathrm{kWh}$. O consumo de energia mecânica no preparo é da ordem de $5,2 \mathrm{kWh} / \mathrm{tc}$ para moenda e $6,5 \mathrm{kWh} / \mathrm{tc}$ para difusão, dado que o difusor necessita de índices de preparo superior à moenda (PROCKNOR, 2001).

A extração do caldo pode ser efetuada de duas maneiras: moagem e difusão. A primeira é a mais comum em usinas brasileiras.

Um tandem de moendas pode ser composto por 4 a 7 ternos de moenda, sendo um terno constituído de 3 rolos de esmagamento. Esses são dispostos em triângulos de maneira que a 
fibra seja espremida duas vezes, na entrada e na saída do terno. O controle da capacidade de moagem é feito em função da abertura entre o rolo de entrada (fixo) e o rolo superior, cuja posição é regulada por um regulador de pressão hidráulica entre o rolo superior e o rolo de saída. A quantidade de fibra que passa pela moenda na unidade de tempo é o parâmetro utilizado para a regulagem das aberturas.

No primeiro terno é alcançada uma extração na faixa de 50 a $70 \%$, sendo o bagaço enviado para os ternos seguintes para completar a extração. Para aumentar a extração de sacarose, é realizada a embebição do bagaço a fim de facilitar a recuperação do caldo presente neste. Os valores normalmente praticados na embebição variam entre 250 e $300 \mathrm{~kg} / \mathrm{tc}$. A embebição é tradicionalmente realizada a temperatura ambiente, porém há autores que sugerem a utilização de água quente $\left(80^{\circ} \mathrm{C}\right)$ na embebição (PAYNE, 1989). A eficiência máxima de recuperação de sacarose na moagem é aproximadamente 96\% (PAYNE, 1989; CAMARGO, 1990). A quantidade de energia mecânica necessária para o acionamento dos ternos é da ordem de 9,2 $\mathrm{kWh} / \mathrm{tc}$ (PROCKNOR, 2001), sendo que o acionamento pode ser feito ou com turbinas a vapor (como para o preparo) ou com motores elétricos. Portanto, o consumo total de energia mecânica no sistema de extração, considerando o uso de moendas, é igual a $14,4 \mathrm{kWh} / \mathrm{tc}$.

Na difusão, o caldo é deslocado da cana desintegrada por um fluxo contra-corrente de água. Esse processo ocorre de duas maneiras distintas: parte do caldo é extraída por meio de um processo de lavagem (lixiviação) e a outra parte é extraída através de um processo de troca físico-química causado por pressão osmótica e difusão celular. Após o difusor, o bagaço é enviado para uma prensa para o deságüe do mesmo, originando o caldo de retorno. Para difusão, a água de embebição e do caldo de retorno da prensa devem ser mantidos a $80^{\circ} \mathrm{C}$ a fim de evitar o desenvolvimento de microorganismos. A quantidade de água necessária na difusão pode ser a mesma que para a moagem, para a mesma eficiência de recuperação. Todavia, é possível atingir valores maiores de eficiência de recuperação (99\% máximo) na difusão para quantidades de água acima de $300 \mathrm{~kg} / \mathrm{tc}$. O consumo de energia mecânica nessa operação é de aproximadamente 1,5 kWh/tc (PROCKNOR, 2001), considerando o "rolo desaguador para retirada da água, esse consumo passa para 3,5 kWh/tc (NETO, 2008). Desta maneira, o consumo total de energia mecânica para o uso do difusor é igual a 9,9 kWh/tc, $32 \%$ inferior ao consumo da moenda. Entretanto, o difusor requer o uso de vapor para manter a temperatura da água de embebição e do caldo de retorno, o consumo estimado de vapor de baixa pressão para esse aquecimento é de 60 a $100 \mathrm{~kg} / \mathrm{tc}(36,7$ a 61,1 kWh/tc) (NETO, 2008). 
Em termos exergéticos, a moenda consome $14,4 \mathrm{kWh}_{\mathrm{ex}} / \mathrm{tc}$, enquanto o difusor consome entre 18,7 e 24,6 kWh $\mathrm{ex} / \mathrm{tc}$, porém obtém uma maior eficiência de extração. Ainda, o uso do vapor de baixa do difusor implica uma geração de eletricidade adicional em relação à moenda. Portanto, a decisão entre um ou outro sistema deve ser feita considerando o impacto do equipamento na usina com um todo (PROCKNOR, 2001; NETO, 2008).

\subsubsection{Planta de Tratamento de Caldo}

Essa etapa também é conhecida como Clarificação. Os principais objetivos do tratamento de caldo são: a elevação do pH a um nível onde as perdas por inversão de sacarose sejam mínimas durante os processos subseqüentes, e a remoção de material insolúvel e substâncias dissolvidas indesejáveis.

Inicialmente, o caldo misto é peneirado a fim de remover materiais em suspensão como areia, terra, pedaços de cana e bagacilhos.

Durante o processo de alcalinização, normalmente leite de cal é adicionado ao caldo misto proveniente do sistema de extração numa proporção que varia entre 0,5 a $0,8 \mathrm{~kg}$ de $\mathrm{CaO} / \mathrm{tc}$, equivalente a 6-9 $\mathrm{kg}$ de leite de cal por tc (HUGOT, 1986). Camargo (1990) calcula um consumo de $1,55 \mathrm{~kg}$ de leite de cal por tonelada de caldo. A reação mais importante do hidróxido de cálcio é com o fósforo, formando o fosfato de cálcio, o qual é insolúvel no caldo e se precipita. Outros compostos podem ser utilizados para a clarificação do caldo, a fim de facilitar o processo e/ou melhorar a qualidade do açúcar produzido (caso da sulfitação).

Na planta de tratamento de caldo também ocorre o aquecimento deste, cujos objetivos são: eliminar os microorganismos por esterilização, completar as reações químicas com o agente alcalinizante, flocular as impurezas insolúveis e remover os gases dissolvidos no caldo. Geralmente, esse aquecimento ocorre em duas etapas: até $70^{\circ} \mathrm{C}$, para a adição dos agentes alcalinizantes, e até $105^{\circ} \mathrm{C}$, antes de ser enviado para o "flasheamento", onde os gases dissolvidos são eliminados. Vapores provenientes dos diferentes efeitos do sistema de evaporação podem ser utilizados para o aquecimento do caldo. Nas usinas brasileiras, é comum utilizar vapores do $1^{\circ}$ e $2^{\circ}$ efeitos apenas, enquanto em usinas de beterraba vapores de praticamente todos os efeitos são utilizados. 
Após passar pelos tratamentos térmico e químico requeridos, o caldo deve ser enviado para a decantação, a fim de promover a separação do caldo clarificado do precipitado formado no corpo do caldo tratado. $\mathrm{O}$ equipamento utilizado para este fim é chamado Decantador.

O lodo decantado é enviado para a filtragem para a recuperação do caldo contido no mesmo. Para a separação são normalmente utilizados Filtros Rotativos a Vácuo. Devido à consistência gelatinosa do lodo, é prática comum adicionar bagacilho aumentando a porosidade do lodo.

O filtro é um tambor rotativo de telas perfuradas, onde a parte inferior está imersa no lodo. A seção do filtro imersa no lodo é conectada a um compartimento de baixo vácuo, de maneira que o líquido flui através da tela perfurada e a torta se forma na tela. Após a formação da torta, as fibras do bagacilho começam a impedir a passagem do material insolúvel e o líquido que passa através da tela torna-se relativamente mais claro. Conforme o tambor vai girando, a torta vai ficando mais espessa até emergir do cocho de lodo. Nesse momento, há um aumento do vácuo e água é aspergida na superfície da torta (lavagem). Assim, essa água passa pela torta recuperando o caldo remanescente. No topo do tambor, água é aplicada por gotejamento, mantendo a torta úmida até o ponto de retirada. O caldo filtrado é bombeado para o tanque de caldo misto. A torta produzida contém aproximadamente $2 \%$ de sacarose e $70 \%$ de umidade, sendo utilizado no campo como adubo orgânico. O consumo de água na lavagem do filtro é de $50 \mathrm{~m}^{3} / \mathrm{tc}$ (CETESB, 2002).

\subsubsection{Produção de Açúcar}

O caldo clarificado proveniente da planta de tratamento pós-moendas passa por um processo de concentração para eliminação da água e produção dos cristais de açúcar.

O processo de evaporação é o primeiro estágio de concentração de caldo clarificado. Sua principal função é a concentração de caldo com 14 a $17^{\circ}$ Brix até uma solução com concentração de 60 a $70^{\circ}$ Brix, conhecida como xarope (CAMARGO, 1990).

Nas usinas brasileiras, o sistema mais utilizado é o sistema de evaporação de múltiplos-efeitos em correntes paralelas, ou seja, tanto caldo como vapor são alimentados no $1^{\circ}$ efeito seguindo paralelos até o último efeito. O tipo de evaporador mais comum na indústria brasileira de 
açúcar e álcool é o de tubos verticais, de fluxo ascendente, construído em aço carbono. O corpo é formado por um cilindro vertical que se eleva sobre a calandra circular, através da qual se efetua a troca de calor. Este cilindro termina na parte superior em um separador de arrasto, cuja finalidade é separar as gotas líquidas que poderiam ser arrastadas com o vapor vegetal (HUGOT, 1986; CAMARGO, 1990). Estes evaporadores são conhecidos como do tipo Robert. Estes sistemas são menos eficientes que os evaporadores de filme descendente, contudo a aplicação no Brasil deste último é ainda restrita.

O primeiro efeito é alimentado com caldo a aproximadamente $115^{\circ} \mathrm{C}$ e $12-15^{\circ}$ Brix, e vapor de escape saturado a 2,5 bar (responsável pela energia necessária para concentrar o caldo neste efeito). O condensado do vapor de escape retorna para a planta de utilidades e caldo concentrado segue para a próxima caixa. $\mathrm{O}$ vapor "produzido" neste efeito segue para o $2^{\circ}$ efeito, para concentrar o caldo que sai do $1^{\circ}$ efeito e assim sucessivamente até o $5^{\circ}$ efeito (o caldo na saída do $5^{\circ}$ efeito é chamado xarope e tem aproximadamente $65-70^{\circ}$ Brix). Os condensados dos $2^{\circ}, 3^{\circ}$ e $4^{\circ}$ efeitos passam por um tanque de flash. $O$ condensado remanescente é tratado e, depois, utilizado na fábrica como água de lavagem e/ou enviado para a extração como água embebição. É possível fazer extrações em todos os corpos do evaporador, a fim de aproveitar os diferentes vapores produzidos durante o processo de concentração.

O processo de evaporação do caldo de cana é o principal consumidor de vapor de escape das turbinas de uma usina sucroalcooleira. Ainda, este processo é responsável pela "produção" do vapor vegetal utilizado nos mais diversos processos de aquecimento do processo produtivo (tratamento de caldo, cozimento, destilação, dentre outros). Assim, pode-se dizer que este processo é o responsável pela integração entre a planta de utilidades e o processo em uma usina. Este fato mostra que uma otimização, a qual vise maximizar o desempenho da planta de utilidades, deverá levar em consideração modificações neste sistema, de forma a reduzir o seu consumo de vapor de escape.

Devido à elevada viscosidade do xarope, não é possível mais concentrá-lo em evaporadores comuns. Assim, são utilizados equipamentos denominados cozedores, tachos, etc. ${ }^{9}$, semelhantes às caixas dos evaporadores, que trabalham individualmente sob vácuo e de forma

\footnotetext{
${ }^{9}$ De fato, tratam-se de "cristalizadores" de açúcar.
} 
descontínua ou contínua. A evaporação da água dá origem a uma mistura de cristais envolvidos em mel (solução açucarada) que recebe o nome de massa cozida. A massa cozida é enviada para as centrífugas, onde a força centrífuga separa os cristais de sacarose da solução. O processo é completado pela lavagem com água ou vapor ainda dentro do cesto. $\mathrm{O}$ mel removido é coletado em um tanque e retorna aos cozedores para recuperação do açúcar dissolvido ainda presente, até que se atinja um maior esgotamento do mesmo. A partir deste ponto, o mel passa a ser denominado mel final ou melaço e é enviado para a fabricação de álcool. No Brasil, é normalmente utilizado o sistema de duas massas (ver Apêndice A).

O açúcar extraído nas centrífugas tem um elevado grau de umidade, sendo enviado para os secadores antes de ser ensacado.

\subsubsection{Processo de Produção de Álcool}

O processo de tratamento de caldo para a produção de álcool é um pouco diferente relativamente ao açúcar, necessitando a adição de compostos químicos apenas para a correção do ph. Embora, os processos de aquecimento se mantenham os mesmos.

O processo de fermentação Melle-Boinot é comumente utilizado em usinas brasileiras. Parte do caldo clarificado é misturada com o mel final proveniente da fabricação de açúcar, formando o mosto, a qual é enviado para as dornas de fermentação. O Brix do caldo enviado às dornas varia entre $16^{\circ}$ Brix até $20^{\circ}$ Brix dependendo da origem do mosto (maior para mostos mais ricos em caldo e menor para mostos ricos em mel final).

No interior das dornas, os açúcares são transformados em etanol. Durante a reação, ocorre intensa liberação de dióxido de carbono (ou gás carbônico), a solução aquece-se e ocorre a formação de alguns produtos secundários como: álcoois superiores, glicerol, aldeídos, etc. É necessário manter a temperatura da dorna entre $32^{\circ} \mathrm{C}$ e $35^{\circ} \mathrm{C}$, assim no interior das dornas são instaladas serpentinas com circulação de água. Após a fermentação, o vinho é enviado às centrífugas para a recuperação do fermento. O concentrado do fermento recuperado, denominado leite de levedura, retorna às cubas para o tratamento. A fase leve da centrifugação, ou vinho "delevedurado", é enviada para as colunas de destilação. O teor alcoólico do vinho produzido é $9^{\circ} \mathrm{GL}$ e o rendimento estequiométrico da fermentação é aproximadamente $91 \%$ (FINGUERUT, 2004). 
O álcool diluído no vinho é recuperado através do processo de destilação, o qual utiliza os diferentes pontos de ebulição das diferentes substâncias voláteis para promover a separação. O vinho é enviado para a Coluna A, na qual a mistura água-etanol, chamada flegma (graduação alcoólica em tono de $50^{\circ} \mathrm{GL}$ ), é separada da vinhaça (produto de fundo) e do álcool de segunda (produto de topo). Essa coluna é separada em três partes: a coluna de epuração (onde o vinho é alimentado), responsável pela eliminação das impurezas; a coluna de concentração do álcool de segunda (considerado o produto de topo da Coluna A); e a coluna de esgotamento do vinho (parte inferior). A flegma segue para a Coluna B, chamada de Coluna de Retificação, onde a concentração da mistura atinge $96^{\circ} \mathrm{GL}$. Essa coluna ainda produz o óleo fúsel, composto de produtos secundários da fermentação.

A energia necessária para operação dessas colunas é fornecida por vapor de baixa pressão através da troca direta (borbotagem) ou indireta (uso de refervedor). As quantidades de vinhaça e flegmaça formada variam entre 9 e $15 \mathrm{~L} / \mathrm{L}$ de álcool (flegamaça + vinhaça), dependendo do tipo da troca com o vapor.

A fim de se obter álcool anidro, é ainda necessário desidratar o álcool hidratado, seja através de uma coluna operando com ciclohexano (destilação extrativa) ou em peneiras moleculares. A concentração final do álcool anidro atinge $99,7^{\circ} \mathrm{GL}$. Esses sistemas necessitam de vapor de baixa pressão (ciclohexano) ou vapor de média (peneira molecular).

O consumo de vapor na produção de álcool diminuiu sensivelmente desde o início da década de 80 até os dias atuais. No início do Proálcool, para produção de $1 \mathrm{~L}$ de álcool hidratado eram necessários $3,7 \mathrm{~kg}$ de vapor, para o álcool anidro esse consumo era de 4,5 kg/L. Atualmente, esses valores caíram para $2-3 \mathrm{~kg} / \mathrm{L}$ para o álcool hidratado e 2,7-4 kg/L para o álcool anidro. Tecnologias mais modernas chegam a 1,6 kg/L para o hidratado e 1,8 para o anidro, valendo-se da destilação em múltiplos-efeitos (SEEMANN, 2003; OLIVÉRIO, 2007) ou mesmo de sistemas de pervaporação (FRANÇA, 2008; VAPERMA, 2008; WHITEFOX, 2008) 


\subsubsection{Sistema de Cogeração}

Atualmente, todas as usinas brasileiras são auto-suficientes com relação à geração de energia eletromecânica e calor para os seus processos. O bagaço gerado no sistema de extração é enviado para planta de utilidades, onde é queimado nas caldeiras, sendo 5\% armazenado com reserva técnica para partidas do sistema. A visão do bagaço como um resíduo natural da produção de açúcar e álcool, levou os produtores a utilizarem processos que consumissem todo o bagaço, para evitar gastos desnecessários com o seu armazenamento e movimentação. Porém, a necessidade de redução de custos aliada a uma valorização dos subprodutos da cana $^{10,11}$, tornou a geração de bagaço excedente bastante interessante ao setor.

Os sistemas de cogeração utilizados na maioria das usinas são baseados em caldeiras de geração de vapor a 21 bar e turbinas de contrapressão (escape a 2,5 bar). Aproximadamente, $50 \%$ do vapor necessário no processo é expandido nas turbinas de acionamento das moendas, cuja eficiência isoentrópica é inferior a $60 \%$ (consumo específico entre $14-16 \mathrm{~kg} / \mathrm{kWh}$ ). A energia elétrica necessária é gerada em turbogeradores com eficiências isoentrópicas entre 60$65 \%$ (consumo específico de $12 \mathrm{~kg} / \mathrm{kWh}$ ). Ainda, as bombas de água de alimentação da caldeira e os turboexaustores também são acionados por turbinas de simples estágio, com baixas eficiências. Mesmo com a baixa eficiência das turbinas, dado o consumo de vapor elevado no processo (500 kg/tc usinas existentes, sem grande integração térmica), faz-se necessário o uso de válvulas de expansão.

Contudo, algumas usinas geram vapor com parâmetros mais elevados (42-66 bar), gerando um excedente de eletricidade, comercializado com as empresas próximas ou com a concessionária local. Uma discussão mais aprofundada das diferentes configurações para sistemas de cogeração em usinas será feita no Cap. 7.

\footnotetext{
${ }^{10} \mathrm{O}$ preço do bagaço passou de R \$ 4,5/t em 1992 (COELHO, 1992), para R \$ 7,5/t (preço sem impostos e frete) em 1999, com valores chegando ainda a R\$ 10/t (COELHO, 1999). Estes valores são utilizados na maioria dos trabalhos recentes (BARREDA DEL CAMPO, 1999, PRIETO, 2003).

${ }^{11}$ Fora das usinas, o bagaço é amplamente utilizado como combustível em indústrias localizadas próximas às mesmas (destacando-se as indústrias de alimentos, sobretudo as cítricas). Além de servir como combustível, o bagaço pode ser utilizado como ração animal e na produção de celulose, papel, aglomerados e chapas semelhantes à madeira (CAMARGO, 1990). Ainda, nos últimos anos tem-se desenvolvido a indústria de pellets, para serem utilizados como combustível em outras indústrias.
} 


\subsection{SUBPRODUTOS DA AGROINDÚSTRIA CANAVIEIRA}

Uma característica bastante interessante e peculiar da Agroindústria Canavieira é o aproveitamento de muitos (ou quase todos) de seus resíduos em atividades relacionadas à cadeia de produção da cana. Assim, esses resíduos podem ser vistos muito mais como subprodutos. Como discutido anteriormente, o bagaço, um subproduto do sistema de extração, é utilizado como fonte energética no sistema de cogeração, evitando a necessidade de se utilizar um combustível adicional no processo (fóssil ou não). Ainda, o mel final, subproduto da produção de açúcar, é utilizado na produção de álcool. Da mesma maneira, existem outros subprodutos que podem ser utilizados como matéria-prima em outras atividades agrícolas e industriais.

De acordo com Rosseto (2004), pesquisas científicas, em conjunto com avanços tecnológicos e conceitos ligados à sustentabilidade, tornaram a cultura da cana-de-açúcar uma atividade que preserva o solo, utiliza poucos defensivos químicos, gera poucas quantidades de resíduos que também são re-utilizados nos processos de produção.

Dentre esses subprodutos, é interessante citar:

Pontas e Folhas: após a colheita, as pontas são deixadas no campo como fertilizantes orgânicos, embora pudessem ser utilizadas como ração animal ou como fonte energética para geração de eletricidade. As folhas verdes, disponíveis com a colheita mecânica, poderiam ter os mesmos usos finais das pontas. Estima-se que para cada tonelada de cana colhida, há aproximadamente $140 \mathrm{~kg}$ de matéria seca proveniente de pontas e folhas. Há uma grande variação da umidade presente nessa matéria, desde $13,5 \%$ nas folhas secas até $82,3 \%$ nas pontas. A quantidade de matéria passível de ser recuperada varia entre $75 \%$ a $95 \%$, dependendo do sistema de recuperação escolhido. Porém, não há até o momento nenhum estudo conclusivo com relação à proporção de pontas e folhas que deverá ser deixada no campo (BRAUNBECK et al., 1999; HASSUANI; LEAL; MACEDO, 2005).

Torta de Filtro: produzida durante o processo de filtragem do lodo proveniente da planta de tratamento de caldo. Esse material contém uma grande quantidade de 
fosfatos e material orgânico, sendo muito útil como fertilizante, condicionador de solo ou para alimentação animal. Estima-se que para cada tonelada de cana processada, são produzidos $35 \mathrm{~kg}$ de torta.

Vinhaça e Flegmaça: subprodutos do processo de destilação do álcool (gradação alcoólica inferior a $0,03^{\circ} \mathrm{GL}$ ) com altos DBO (Demanda Bioquímica de Oxigênio) e DQO (Demanda Química de Oxigênio), sendo utilizadas principalmente como fertilizantes, dadas suas elevadas concentrações de potássio.

Cinzas das Caldeiras: produzidas durante a combustão do bagaço nas caldeiras, elas são utilizadas como fertilizantes devido à presença de potássio e outros inorgânicos. Para cada tonelada de cana, entre 5 e $6 \mathrm{~kg}$ de cinzas são geradas nas caldeiras.

Condensados: são os condensados do vapor vegetal utilizados como vetores de aquecimento na planta de tratamento de caldo, evaporadores, tachos de cozimento e destilaria. Podem ser re-utilizados como água de embebição no sistema de extração, para lavagem do açúcar nas centrífugas, nos filtros e na preparação de soluções químicas para a planta de tratamento de caldo.

Águas residuais: originárias dos processos de lavagem dos equipamentos, podendo ser utilizadas como fertilizantes no campo.

Água de lavagem da cana: a água utilizada na lavagem da cana na entrada da usina contém uma quantidade razoável de sacarose, terra e material vegetal. Normalmente, essa água opera em circuito fechado.

Como discutido acima, quase todos os subprodutos são utilizados como fertilizantes. Contudo, existem outras rotas de conversão mais comprometidas com o uso racional da energia e dos subprodutos dos processos. Por exemplo, a vinhaça e a flegmaça podem ser enviadas a biodigestores para produção de biogás para a geração de eletricidade em motores alternativos, ou podem ser concentradas para queima em caldeiras de geração de potência e calor. Os resíduos do biodigestor ou da queima nas caldeiras podem ser utilizados como fertilizante na lavoura. Ou mesmo, as pontas e folhas poderiam ser utilizadas como insumo 
energético para os sistemas de cogeração ou como matéria-prima para a produção de álcool, via hidrólise.

\subsection{IMPACTOS AMBIENTAIS RELACIONADOS À AGROINDÚSTRIA CANAVIEIRA}

A seguir uma breve discussão sobre os principais impactos ambientais relativos à cadeia de conversão de cana-de-açúcar em açúcar, álcool e eletricidade será feita. Serão abordados os impactos no solo, água e ar, baseado em diferentes trabalhos (ROSSETO, 2004; HASSUANI; LEAL; MACEDO, 2005; MACEDO, 2005; SMEETS et al., 2006).

\subsubsection{Impactos no Solo}

Erosão é a principal fonte de degradação de solos agricultáveis. O cultivo da cana-de-açúcar é conhecido por ser uma atividade na qual as perdas de solo são pequenas em comparação ao cultivo de milho ou soja (ROSSETO, 2004; MACEDO, 2005).

Em áreas onde os resíduos da colheita são queimados ou enterrados durante o preparo do solo, o solo desprotegido fica exposto ao impacto das gotas da chuva, as quais são o primeiro e mais importante estágio do processo erosivo por água. Assim, a introdução da colheita mecanizada, a qual permite deixar toda ou parte das pontas e folhas no campo, ajuda na proteção do solo contra erosão, além de permitir a reciclagem de diferentes macronutrientes (ROSSETO, 2004; HASSUANI; LEAL; MACEDO, 2005).

Quanto ao uso de fertilizantes, a cultura da cana-de-açúcar é única, devido à intensa utilização de resíduos (subprodutos) dos processos industriais como fertilizantes naturais, conforme discutido anteriormente. Um outro benefício, relacionado a essa prática, é evitar custos relacionados à disposição destes resíduos na natureza (LEME, 2005).

Uma questão que vem chamando muito a atenção nos últimos meses refere-se à expansão da fronteira canavieira e a segurança alimentar, além do impacto na biodiversidade. A cultura da cana-de-açúcar representa atualmente $0,6 \%$ da área total do Brasil, ou $10 \%$ de toda área agricultável (MACEDO, 2005). Contudo, não há um consenso entre as diferentes partes da 
sociedade sobre o risco da expansão da fronteira da cana ameaçar a produção de alimentos e/ou a biodiversidade do Brasil.

A expansão agrícola nos últimos quarenta anos deu-se principalmente sobre áreas de pastagens degradadas e "campos sujos", e não nas áreas de florestas. A expansão da cana-deaçúcar, nos últimos 25 anos, ocorreu essencialmente no Centro-Sul do Brasil, em áreas muito distantes dos biomas atuais da Floresta Amazônica, Mata Atlântica e Pantanal. Entre 1992 e 2003, no Centro-Sul, a expansão deu-se quase totalmente (94\%) nas unidades existentes; novas fronteiras agrícolas foram muito pouco envolvidas. Em São Paulo, o crescimento ocorreu com a substituição de outras culturas e pastagens. Para os próximos anos, o crescimento deverá ocorrer no Centro-Sul com ênfase no Oeste de São Paulo, nas regiões limítrofes com Mato Grosso e em algumas áreas no Estado de Goiás (MACEDO, 2005). Um estudo feito pela FAO em parceria com a Comissão Econômica para a América Latina e o Caribe (Cepal), mostra que o Brasil é o país que tem as melhores possibilidades no mundo para expandir a produção de agroenergia sem comprometer a segurança alimentar (FAO, 2007).

Porém, conforme discute o Plano de Expansão da Agroenergia formulado pela Embrapa e pelo estudo da FAO, há necessidade de um plano diretor para a expansão da indústria sucroalcooleira. Esse plano deve começar pelo zoneamento agrícola da cana, o qual deve subsidiar não apenas o planejamento da ocupação de novas áreas, como também o gerenciamento de políticas públicas para áreas tradicionais, eventualmente não recomendadas para o cultivo. É preocupante a situação do Estado de São Paulo, onde além de já ter aproximadamente metade de suas terras agricultáveis cobertas pela cana, constitui a maior fronteira de expansão do país, com mais de 25 projetos de implantação de novas unidades. Esse excesso de concentração, embora aparentemente irreversível naquele Estado, deve ser evitado nas novas áreas (FAO, 2007).

\subsubsection{Impactos na Água}

Na última década, um grande esforço foi feito para a diminuição do consumo de água fresca na agroindústria canavieira. Em 1997, o consumo líquido de água fresca era aproximadamente $5 \mathrm{~m}^{3} / \mathrm{tc}$. Atualmente, esse valor foi reduzido para $1,8 \mathrm{~m}^{3} / \mathrm{tc}$, devido ao grande reciclo de água no processo e o uso da vinhaça para irrigação. A disposição de efluentes em mananciais de 
água é praticamente nula. Parece ser possível atingir valores próximos a $1 \mathrm{~m}^{3} /$ tc (captação) e lançamento zero, com otimização da re-utilização e uso da água residual em fertirrigação (ROSSETO, 2004; MACEDO, 2005).

\subsubsection{Impactos no Ar}

Dois aspectos diferentes devem ser discutidos com relação ao impacto ambiental no ar relativo à agroindústria canavieira.

A queima da plantação antes da colheita manual emite uma grande quantidade de material particulado e aumenta o risco de acidentes relacionados à fumaça (p.ex., em rodovias próximas ao canavial). Além disso, a queima sem controle gera a emissão de metano, contribuindo para a emissão de gases de efeito estufa não re-absorvíveis na cadeia produtiva. A introdução da colheita mecanizada não necessita da queima antes da colheita, porém tem um efeito negativo no número de empregos, já que menos trabalhadores são necessários.

Por outro lado, o uso do álcool combustível melhorou a qualidade do ar nos centros urbanos, além de contribuir para a diminuição da emissão dos gases de efeito estufa. A geração de eletricidade excedente para venda na rede também contribui para esta redução. Leme (2005) discute o potencial de redução de gases de efeito estufa para diferentes opções de cogeração disponíveis atualmente para usinas sucroalcooleiras.

Este capítulo objetivou apresentar os principais processos de conversão de energia envolvidos na produção de açúcar, álcool e eletricidade, desde a produção agrícola da cana-de-açúcar até o seu processamento industrial, além de algumas características operacionais. Muitas das informações apresentadas foram utilizadas no desenvolvimento do modelo computacional utilizado neste trabalho para avaliação da produção de açúcar, álcool e eletricidade.

As questões referentes ao uso dos subprodutos e do impacto ambiental da cadeia de produção de cana foram levantadas e brevemente discutidas, de maneira a complementar as informações referentes aos processos de conversão. Uma discussão mais aprofundada dessas questões pode ser encontrada em Macedo (2005) e Smeets et al. (2006), entre outros citados anteriormente. 
O próximo capítulo irá apresentar uma revisão de trabalhos que lidaram com a questão do uso racional de energia em usinas, buscando alternativas para melhorar o desempenho dessas plantas. 


\section{ANÁLISE EXERGÉTICA E TERMOECONÔMICA NA AGROINDÚSTRIA CANAVIEIRA}

Este capítulo apresenta uma revisão bibliográfica da metodologia utilizada para a obtenção dos resultados apresentados no Cap. 8. A metodologia desenvolvida é baseada na análise exergética e termoeconômica de processos de conversão de energia.

A primeira parte do capítulo visa descrever a análise exergética e termoeconômica, seguida de uma revisão dos trabalhos publicados na área para usinas sucroalcooleiras. Finalmente, os modelos matemáticos para cálculo das propriedades termodinâmicas são apresentados.

\subsection{ANÁliSE EXERGÉTICA E TERMOECONÔMICA DE PROCESSOS DE CONVERSÃO DE ENERGIA}

A Termodinâmica Clássica fornece os conceitos de energia, transferência de energia nas formas de calor e trabalho, balanço de energia, entropia e balanço de entropia, bem como fórmulas matemáticas para o cálculo das propriedades termodinâmicas no equilíbrio. A Segunda Lei da Termodinâmica complementa e acrescenta a esses balanços a idéia de valor termodinâmico real de um fluxo energético, além dos conceitos de ineficiências e perdas termodinâmicas. (TSATSARONIS, 1993).

O conceito de valor termodinâmico real de um fluxo energético está diretamente relacionado à grandeza termodinâmica exergia, a qual representa a máxima quantidade de trabalho obtida quando uma massa é trazida até um estado de equilíbrio termodinâmico com os componentes comuns do meio ambiente, através de processos reversíveis, envolvendo interação apenas com os componentes do meio ambiente (SZARGUT; MORRIS; STEWARD, 1988). Segundo Gaggioli (1983), exergia é de fato o que a pessoa leiga considera energia, ou seja, a capacidade de se produzir um efeito útil. A análise exergética de plantas de conversão de energia permite caracterizar como a exergia disponibilizada (p.ex., devido à queima do combustível, empregado como insumo energético) é utilizada e destruída nos processos de conversão de energia existentes na planta. 
Segundo Erlach, Serra e Valero (1999), a Termoeconomia pode ser considerada uma nova ciência que, ao ligar a Termodinâmica e a Economia, fornece ferramentas para a solução de problemas em sistemas energéticos complexos, os quais, dificilmente, poderiam ser resolvidos usando uma análise energética convencional, baseada na Primeira Lei da Termodinâmica. Dentre estes problemas pode-se destacar, por exemplo, a atribuição racional de custos aos produtos de uma planta energética ou a otimização operacional de um sistema.

A seguir uma breve discussão será feita sobre o conceito de exergia, seu balanço e a aplicação dela como base para o desenvolvimento da termoeconomia.

\subsubsection{Exergia e Balanço Exergético}

O conceito de exergia tem suas origens na formulação proposta por Gouy e Stodola (RIVERO, 1993) que mostra que o máximo potencial de um sistema realizar trabalho é função de sua energia interna e das condições do meio ambiente (pressão, temperatura e composição).

A quantificação da grandeza exergia pode ser introduzida a partir do conceito de trabalho reversível, assim como se pode mostrar que o balanço de exergia pode ser escrito como uma combinação linear do balanço de energia com o balanço de entropia. Essa demonstração será feita a seguir para um caso simples de processos ocorrendo em um volume de controle (Fig. 5.1), com uma entrada e uma saída, em regime permanente, desprezando-se os termos de energia cinética e potencial, assim como eventuais efeitos elétricos e magnéticos (OLIVEIRA JR., 2006).

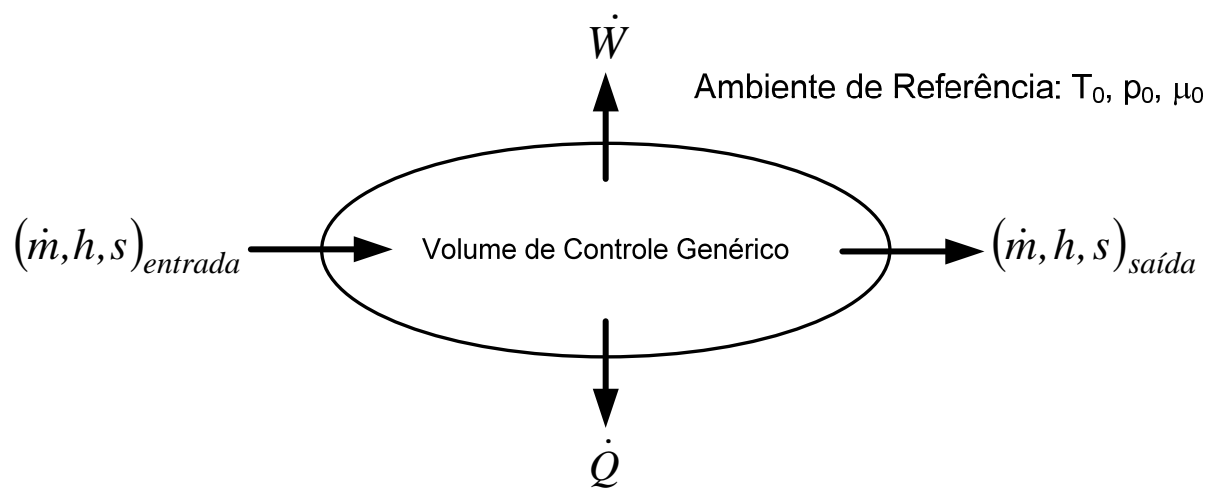

Figura 5.1 - Volume de controle indeformável com uma entrada e uma saída. 
Pelas Primeira e Segunda Leis da Termodinâmica tem-se ${ }^{12}$ :

$$
\begin{gathered}
(\dot{\mathrm{m}} \cdot \mathrm{h})_{\text {saida }}-(\dot{\mathrm{m}} \cdot \mathrm{h})_{\text {entrada }}=\dot{\mathrm{Q}}-\dot{\mathrm{W}} \Rightarrow \Delta \mathrm{h}=\mathrm{q}-\mathrm{w} \\
(\dot{\mathrm{m}} \cdot \mathrm{s})_{\text {saída }}-(\dot{\mathrm{m}} \cdot \mathrm{s})_{\text {entrada }}=\int \frac{\delta \dot{\mathrm{Q}}}{\mathrm{T}}+\dot{\mathrm{S}}_{\text {gerado }} \Rightarrow \Delta \mathrm{s}=\int \frac{\delta \mathrm{q}}{\mathrm{T}}+\mathrm{s}_{\text {gerado }}
\end{gathered}
$$

Dado que a exergia representa a máxima quantidade de trabalho, pode-se perguntar qual o máximo trabalho possível de ser obtido, mantendo-se os mesmos estados dos fluxos mássicos na entrada e na saída, além de w e q. Assim, o incremento de trabalho poderia ser obtido introduzindo-se um motor reversível entre $\mathrm{T}_{\mathrm{e}}$ e $\mathrm{T}_{\mathrm{s}}$ e $\mathrm{T}_{0}$. Para o motor reversível, pode-se escrever:

$$
\begin{gathered}
\mathrm{w}_{\mathrm{mr}}=\mathrm{q}-\mathrm{q}_{0} \\
\oint \frac{\delta \mathrm{q}}{\mathrm{T}}=\int_{\mathrm{T}_{\mathrm{e}}}^{\mathrm{T}_{\mathrm{s}}}\left(\frac{\delta \mathrm{q}}{\mathrm{T}}\right)-\frac{\mathrm{q}_{0}}{\mathrm{~T}_{0}}=0 \Rightarrow \mathrm{q}_{0}=\mathrm{T}_{0} \int_{\mathrm{T}_{\mathrm{e}}}^{\mathrm{T}_{\mathrm{s}}}\left(\frac{\delta \mathrm{q}}{\mathrm{T}}\right)
\end{gathered}
$$

Eliminando-se $\mathrm{q}_{0}$ entre (3) e (4):

$$
\mathrm{w}_{\mathrm{mr}}=\mathrm{q}-\mathrm{T}_{0} \int_{\mathrm{T}_{\mathrm{e}}}^{\mathrm{T}_{\mathrm{s}}}\left(\frac{\delta \mathrm{q}}{\mathrm{T}}\right)=\mathrm{q}\left(1-\frac{\mathrm{T}_{0}}{\mathrm{q}} \int_{\mathrm{T}_{\mathrm{e}}}^{\mathrm{T}_{\mathrm{s}}}\left(\frac{\delta \mathrm{q}}{\mathrm{T}}\right)\right)=\mathrm{q} \eta_{\mathrm{mr}}
$$

Aplicando-se a Primeira e Segunda Leis para o volume de controle englobando o motor térmico, tem-se

$$
\begin{gathered}
\Delta \mathrm{h}=\mathrm{q}_{0}-\mathrm{w}-\mathrm{w}_{\mathrm{mr}} \\
\Delta \mathrm{s}=\frac{\mathrm{q}_{0}}{\mathrm{~T}_{0}}+\mathrm{s}_{\text {ger }} \Rightarrow \mathrm{q}_{\mathrm{o}}=\mathrm{T}_{0} \Delta \mathrm{s}-\mathrm{T}_{0} \mathrm{~s}_{\text {ger }}
\end{gathered}
$$

Fazendo-se as substituições dos termos $\mathrm{q}_{0}$ da eq. (7) e $\mathrm{w}_{\mathrm{mr}}$ da eq. (5) na eq. (6), obtém-se:

\footnotetext{
${ }^{12}$ Convenção de sinais de trabalho e calor utilizada: q $>0$ quando o calor é recebido pelo sistema e w $>0$ quando o sistema realiza trabalho.
} 


$$
\Delta \mathrm{h}-\mathrm{T}_{0} \Delta \mathrm{s}=-\mathrm{T}_{0} \mathrm{~s}_{\text {ger }}-\mathrm{w}-\mathrm{q} \eta_{\mathrm{mr}}
$$

Observa-se que o termo $\Delta \mathrm{h}-\mathrm{T}_{0} \Delta \mathrm{s}$ caracteriza um potencial de realização de trabalho que, quando há processos irreversíveis, é atenuado pela existência de irreversibilidades $\left(\mathrm{T}_{0} \mathrm{~s}_{\mathrm{ger}}\right)$.

Se todos os processos no interior do volume de controle fossem reversíveis e o fluxo mássico na seção de saída estivesse em equilíbrio termodinâmico com o meio ambiente $\left(\mathrm{h}_{\mathrm{s}}=\mathrm{h}_{0}\right.$ e $\mathrm{s}_{\mathrm{s}}=$ $\mathrm{s}_{0}$ ), ter-se-ia a expressão do máximo trabalho reversível associado ao estado do fluxo mássico na seção de entrada do volume de controle:

$$
\left(\mathrm{h}-\mathrm{h}_{0}\right)-\mathrm{T}_{0}\left(\mathrm{~s}-\mathrm{s}_{0}\right)=\mathrm{w}+\mathrm{q}\left(1-\frac{\mathrm{T}_{0}}{\mathrm{q}} \int_{\mathrm{T}_{\mathrm{e}}}^{\mathrm{T}_{\mathrm{s}}}\left(\frac{\delta \mathrm{q}}{\mathrm{T}}\right)\right)=\mathrm{w}_{\text {máx }}
$$

A esse trabalho máximo é associada a exergia específica do fluxo mássico na entrada do volume de controle.

$$
\mathrm{b}=\left(\mathrm{h}-\mathrm{h}_{0}\right)-\mathrm{T}_{0} \cdot\left(\mathrm{s}-\mathrm{s}_{0}\right)
$$

Nota-se que a exergia específica é função de propriedades de dois estados termodinâmicos: aquele em que o fluxo mássico se encontra e aquele em que o fluxo mássico estaria em equilíbrio com o meio ambiente.

Para uma situação mais geral, em que há várias entradas e saídas, trocas de calor a diferentes temperaturas $\mathrm{T}_{\mathrm{i}, \mathrm{o}}$ balanço de exergia fica:

$$
\begin{gathered}
\sum(\dot{\mathrm{m}} \cdot \mathrm{b})_{\text {saída }}-\sum(\dot{\mathrm{m}} \cdot \mathrm{b})_{\text {entrada }}=-\sum \dot{\mathrm{Q}} \cdot\left(1-\frac{\mathrm{T}_{0}}{\mathrm{~T}}\right)-\sum \dot{\mathrm{W}}-\mathrm{T}_{0} \dot{\mathrm{S}}_{\text {gerado }} \\
\dot{\mathrm{B}}_{\text {saida }}-\dot{\mathrm{B}}_{\text {entrada }}=-\dot{\mathrm{B}}^{\mathrm{Q}}-\dot{\mathrm{B}}^{\mathrm{W}}-\dot{\mathrm{B}}_{\text {destruida }}
\end{gathered}
$$

A eq.(12) representa o balanço de exergia válido para um volume de controle qualquer, em regime permanente. Esta expressão mostra a variação da exergia entre os fluxos de entrada e 
saída, sendo esta o máximo trabalho que poderia ser obtido nessa transformação. Esta quantidade de trabalho é igual à somatória das seguintes parcelas - lado direito da equação:

Trabalho realizado por um motor térmico operando entre $\mathrm{T}$ e $\mathrm{T}_{0}$, consumindo $\dot{\mathrm{Q}} \mathrm{e}$ rejeitando calor para o meio a $\mathrm{T}_{0}$ (esta é exergia associada ao calor trocado);

Trabalho útil realizado (exergia pura);

Trabalho disponível destruído devido à presença de irreversibilidades no processo.

Assim, esta equação pode ser chamada de Lei da Degradação da Energia, uma vez que quantifica a redução da disponibilidade de realização de trabalho, devido à presença de irreversibilidades no processo. É interessante notar que, ao contrário da energia, a exergia associada a um fluxo (ou sistema) não se conserva, sendo sempre reduzida à medida que existam irreversibilidades inerentes ao processo de conversão de energia (variações de volume não quase-estáticas, perda de carga, mistura, troca de calor com $\Delta \mathrm{T}$ finito, reação química), caso este fluxo ou sistema troque calor e trabalho apenas com o meio ambiente.

Desconsiderando-se efeitos nucleares, magnéticos, elétricos e de tensão superficial, pode-se dividir a exergia em quatro componentes: exergia cinética, potencial, física e química, como mostrado na Fig. 5.2 (KOTAS, 1995).

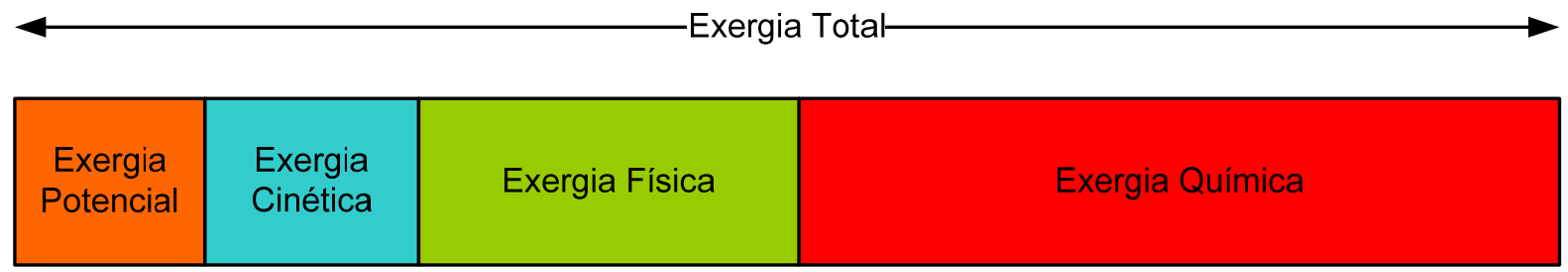

Figura 5.2 - Componentes da Exergia.

A exergia cinética e potencial equivalem, respectivamente, à energia cinética e potencial, pois teoricamente podem ser totalmente convertidas em trabalho, teoricamente. Na maior parte das análises de sistemas térmicos, os valores das exergias cinética e potencial podem ser desprezados. 
A exergia física equivale à máxima quantidade de trabalho possível de se obter quando um sistema ou fluxo de uma substância passa de um estado inicial ao estado de referência restrito, caracterizado pela existência de equilíbrio térmico e mecânico com o meio ambiente.

A exergia química é o máximo trabalho possível de se obter quando um sistema ou fluxo é levado do estado de referência restrito ao estado morto, caracterizado pela existência de equilíbrio térmico, mecânico e químico, interagindo reversivelmente com componentes do meio ambiente. Para a determinação da exergia química é necessário definir um modelo de meio ambiente padrão, como proposto por Szargut, Morris e Steward (1988).

A Fig. 5.3 ilustra a definição das exergias física e química.

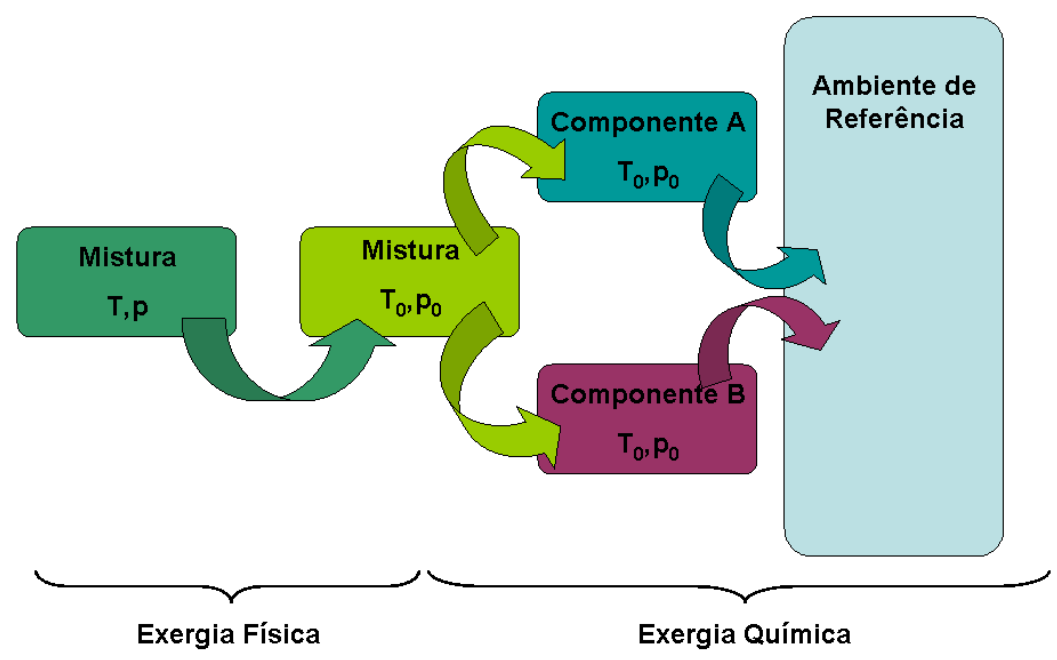

Figura 5.3 - Representação das Exergia Físicas e Químicas, para uma mistura de 2 componentes (Adaptado de: NEBRA; FERNÁNDEZ-PARRA, 2005).

\subsubsection{Rendimento Exergético}

O balanço exergético apresentado anteriormente permite avaliar e identificar os principais responsáveis pelas ineficiências de um sistema. Porém, para comparar sistemas de tipos e tamanhos diferentes é necessário determinar um índice que permita avaliar qualitativamente a diferença entre a operação real de um sistema e a operação máxima (ideal) possível de ser obtida de acordo com a $2^{\text {a }}$ Lei da Termodinâmica. Normalmente, é feita uma razão entre a operação real e a operação ideal (RIVERO, 1993). 
A literatura de análise exergética apresenta variações da expressão de rendimento exergético (KOTAS, 1985; SZARGUT; MORRIS; STEWARD, 1988; RIVERO, 1993; BRODYANSKY; SORIN; LE GOFF, 1994; BEJAN; TSATSARONIS; MORAN, 1996). São apresentadas a seguir, três formas de rendimento exergético adequadas para avaliar $o$ desempenho de processos de conversão de energia em processos químicos (PQ), máquinas térmicas e/ou processos térmicos (PT), e processos puramente dissipativos (PD).

A primeira expressão é denominada por Szargut, Morris e Steward (1988) de grau de perfeição e é útil para avaliar processos químicos:

$$
\eta_{\mathrm{PQ}}=\frac{\text { exergia dos produtos úteis }}{\text { exergia de a lim entação }}
$$

A segunda expressão é idêntica à definida anteriormente, sendo indicada para analisar processos térmicos:

$$
\eta_{\mathrm{PT}}=\frac{\text { exergia útil produzida }}{\text { consumo de exergia }}
$$

Cabe ao usuário de cada sistema identificar o que é a exergia útil produzida em cada equipamento e/ou sistema, bem como qual foi o gasto de exergia feito para a obtenção do produto.

A terceira expressão é indicada para avaliar processos em que há somente destruição de exergia, como expansão em uma válvula e rejeição de calor em um condensador, normalmente denominados processos puramente dissipativos:

$$
\eta_{\mathrm{PD}}=\frac{\sum(\text { exergia de saída })}{\sum(\text { exergia de entrada })}
$$

Considerando a otimização de sistemas de conversão de energia, uma técnica possível é identificar o impacto da eficiência de cada componente/equipamento na eficiência global do sistema (BRODYANSKY; SORIN; LE GOFF, 1994). Sorin e Brodyansky (1992) propõem uma metodologia para escrever a eficiência global em função das eficiências de cada 
componente/equipamento para qualquer estrutura/configuração da planta analisada e aplicamna para a otimização de uma planta de síntese de amônia.

É possível, ainda, encontrar na literatura outros índices para avaliar o desempenho de plantas de conversão de energia.

Beyer (1970) introduz relações entre a irreversibilidade local de cada equipamento com a irreversibilidade total do sistema, chamadas de coeficientes estruturais. Essa abordagem permite mostrar que a variação da irreversibilidade em um dado equipamento do sistema não implica na mesma variação da exergia total consumida, mas depende da posição (próximo ao início ou ao final da cadeia de conversão) e da "importância termodinâmica" (valor do coeficiente estrutural) do equipamento para o sistema. Conforme mostrado por Kotas (1995), uma redução da irreversibilidade de um equipamento localizado próximo ao final da cadeia de conversão leva a maiores ganhos se comparados à mesma redução em um equipamento próximo ao início da cadeia. Uma abordagem similar foi desenvolvida por Pellegrini et al. (2007) e Gandolfi et al. (2007) para avaliar comparativamente duas arquiteturas para aeronaves comerciais, identificando o impacto da variação da eficiência exergética dos diferentes equipamentos no consumo total de combustível.

Oliveira Jr. (1991) propõe o "Valor Técnico-Econômico" (VTE - Valeur TechnoEconomique) que leva em consideração o rendimento exergético, parâmetros de operação do sistema e custos, todos ponderados por expoentes cuja soma é igual à unidade. Esse parâmetro foi utilizado para avaliar diferentes configurações para bombas de calor e sistemas de refrigeração (OLIVEIRA JR., 1991; BRODYANSKY; SORIN; LE GOFF, 1994).

Rivero (1993 e 1997) discute a utilização de um índice que considere tanto aspectos qualitativos (eficiências) como quantitativos (irreversibilidades). Assim, este autor propõe o Potencial de Melhoria (PM), baseado no trabalho de Reistad (1970). A idéia deste índice é que em alguns componentes de um sistema térmico complexo, onde as irreversibilidades são tão proeminentes, mesmo um pequeno ganho de eficiência produziria grandes vantagens na operação; ao mesmo tempo, há componentes em que as irreversibilidades são tão pequenas que a sua redução não teria um ganho real no consumo de exergia pelo sistema. De acordo com a proposta, para a otimização de um sistema térmico é necessário atacar preferencialmente os blocos com maiores valores de PM. 
Conforme será discutido a seguir, uma maneira de se analisar e otimizar sistemas de conversão de energia é através da avaliação dos custos de produção dos produtos de uma planta considerando a eficiência dos processos de conversão, já que a maior ou menor eficiência tem um impacto direto no custo dos produtos. Vale ressaltar que a definição do rendimento exergético de um equipamento ou sistema, guarda forte relação com o sistema de atribuição de custos, já que o cálculo do rendimento exergético implica a determinação do produto (exergia útil) do equipamento/sistema.

\subsubsection{Termoeconomia}

A busca pelo processo de formação de custos é onde a Física melhor se conecta com a Economia (VALERO; SERRA; UCHE, 2006). A análise termoeconômica pode ser definida como sendo uma combinação entre a análise exergética e a análise econômica. Desta maneira, tal análise permite valorar (já que permite a atribuição de custos aos fluxos de exergia) a influência das ineficiências termodinâmicas (irreversibilidades) dos processos nos custos de produção. Como definido por Serra (1994), o objetivo fundamental da Termoeconomia é a determinação e cálculo de custos baseados em critérios físicos relacionados à Segunda Lei da Termodinâmica que leva em conta a degradação da qualidade da energia.

A determinação desses custos em plantas de conversão de energia apresenta desafios metodológicos importantes quando se devem distribuir os custos de produção para os produtos da planta. Diferentes abordagens vêm sendo propostas para reduzir as arbitrariedades nos critérios de partição de custos (GAGGIOLI; WEPFER, 1980; TSATSARONIS; WINHOLD, 1985; FRANGOPOULOS, 1987; LOZANO; VALERO, 1993; BRODYANSKY; SORIN; LE GOFF, 1994, VON SPAKVOSKY, 1994; ERLACH; SERRA; VALERO, 1999; ERLACH; TSATSARONIS; CZIESLA, 2001; SCIUBBA, 2001; ELSAYED, 2003; LAZZARETTO; TSATSARONIS, 2006), a fim de melhor caracterizar os processos de formação de custos de cada produto. Contudo, ainda não foi definida uma metodologia geral aplicável a qualquer processo de conversão de energia e que seja reconhecida mundialmente como única. Todas as metodologias partem do pressuposto que a exergia, e não a energia, é a única base racional para a atribuição de custos a fluxos energéticos e a "perdas" energéticas (exergia destruída e/ou perdida) (TSATSARONIS, 1993). 
As informações geradas pela análise termoeconômica são distintas daquelas obtidas pelos métodos tradicionais de avaliação econômica que determinam parâmetros como tempo de retorno de investimento, taxa interna de retorno, valor presente líquido e preços (FRATZSCHER, 1997).

Há um consenso que a primeira aplicação da exergia com critério de partição de custos foi realizada por Joseph Keenan em 1932. Segundo Gaggioli e El-Sayed (1987), mesmo sem aplicar o custeio exergético propriamente dito, Keenan fez menção explícita ao uso da exergia para atribuir custos para uma planta de cogeração. Esses mesmos autores também citam um método de George A. Goodenough, "Lost Kilowatts Method", desenvolvido baseado nas idéias de Keenan para a atribuição de custo ao vapor de escape da turbina. Ainda, Gaggioli e El-Sayed (1987) e Tsatsaronis (1993) mencionam uma palestra de M. Benedict que utilizou o custo das irreversibilidades para otimizar uma planta de separação de ar.

O desenvolvimento "moderno" da termoeconomia se iniciou na década de 60 do século passado. Na Europa, com os trabalhos de Wolfang Fratzscher, na Alemanha, Jan Szargut, na Polônia e Viktor Brodyansky, na antiga União Soviética, e nos Estados Unidos, com os trabalhos de Myron Tribus e Robert B. Evans, e E. F. Obert e Richard A. Gaggioli (TSATSARONIS, 1993; SCIUBBA, 2005).

Nos últimos 20 anos, as principais contribuições para o desenvolvimento da termoeconomia podem ser encontradas nos trabalhos de Antonio Valero e co-autores, Christos Frangopoulos, George Tsatsaronis e Michael Von Spakovsky, listados aqui em ordem alfabética e não em ordem de importância ou relevância. Cada um destes autores propôs uma formulação para resolver o problema da determinação das equações auxiliares necessárias para a solução dos balanços de custo em base exergética. A revista Energy, The International Journal, dedicou o número 3 do seu volume 19 do ano 1994 inteiramente a uma tentativa de comparar essas metodologias, aplicando-as a um mesmo sistema de cogeração, conhecido como CGAM (nome proveniente das iniciais dos nomes de cada autor de cada metodologia - Christos, George, Antonio e Michael) (TSATSARONIS, 1994). Nenhuma conclusão foi tirada com relação a qual abordagem deveria ser tomada como a mais geral. 
Cerqueira (1999) revisou esses métodos e mais uma vez aplicou-os ao problema CGAM, considerando ainda a incorporação de custos devido a irreversibilidades externas, originada pela liberação de uma corrente portadora de exergia para o ambiente. O trabalho é bastante didático sobre a aplicação das diferentes metodologias, porém não apresenta uma conclusão clara com relação a qual deveria ser utilizada de maneira geral. A questão da redistribuição das irreversibilidades externas, ainda, ficou em aberto.

De uma maneira geral, as metodologias termoeconômicas podem ser divididas em dois grupos (GAGGIOLI; EL-SAYED, 1987; LAZZARETTO; TSATSARONIS, 2006): Métodos de Custeio em Base Exergética, calculando-se custos médios, e Métodos de Otimização (baseados nos multiplicadores de Lagrange, p.ex.), onde se calculam os custos marginais dos produtos.

Dentre os Métodos de Custeio em Base Exergética ("Accounting Methods"), cujo objetivo é atribuir custos aos produtos e subprodutos do processo, avaliar equipamentos e sistemas, e promover a otimização iterativa dos sistemas energéticos, citam-se:

Métodos de Partição (GAGGIOLI; WEPFER, 1980), baseada em métodos de atribuição de custos utilizados na área econômica: Método da igualdade: todos os produtos têm o mesmo custo médio por unidade de exergia; Método da extração: os custos dos equipamentos do volume de controle são descarregados num único fluxo e o Método do Subproduto: define-se um custo para um dos produtos. A aplicação destes métodos implica resultados diferentes, assim a opção por um deles fica a critério do analista, pois envolve a definição da importância de cada produto do volume de controle.

Teoria do Custo Exergético (LOZANO; VALERO, 1993), a qual desenvolveu um formalismo matemático para a aplicação dos critérios de participação, através do uso de matrizes. O desenvolvimento dessas matrizes é feito através da aplicação de 4 proposições: Proposição 1 - os custos exergético e exergoeconômico são quantidades conservativas, portanto, pode-se escrever uma equação de balanço para cada unidade do sistema. Nas equações de balanço de custo exergético, o lado direito será igualado a zero, e na determinação do custo exergoeconômico, igualado aos outros custos associados ao sistema, com sinal negativo; Proposição 2 - na ausência de informações 
externas, o custo exergético de um insumo suprido externamente ao sistema é igual à sua exergia e o custo exergoeconômico é o custo de aquisição do insumo; Proposição 3 - todos os custos gerados no processo produtivo devem ser incluídos no custo final do produto, o que se traduz na atribuição de custo zero a todas as perdas; Proposição $4 a$ - se uma parcela ou todo o insumo de uma unidade é a variação da exergia de um fluxo que a atravessa, então o custo exergético unitário do fluxo é constante através da unidade; Proposição $4 b$ - se o produto de uma unidade é composto por mais de um fluxo, então são iguais os custos exergéticos unitários de cada um destes fluxos. É possível notar que o método proposto por Lozano e Valero (1993) constitui a aplicação dos métodos da igualdade e extração de acordo com a função do equipamento, definida pelas proposições acima. Esse método deu origem à Teoria Estrutural da Termoeconomia (VALERO; SERRA; LOZANO, 1993; SERRA, 1994; ERLACH; SERRA; VALERO, 1999). Esta teoria introduz um formalismo matemático, o qual permite a obtenção de um conjunto de equações características que representa $o$ comportamento de cada componente, de onde as equações de custo são obtidas. Assim, uma estrutura produtiva do sistema, que não necessariamente reproduz a estrutura física, a qual representa a distribuição insumo/produto por toda a planta, deve ser definida e os custos de cada fluxo de exergia podem ser calculados pela regra da cadeia de derivadas matemáticas. A neguentropia ${ }^{13}$ é utilizada para redistribuir os custos das irreversibilidades de unidades cuja função não é suprir exergia, ou seja, para re-dividir o custo dessas irreversibilidades externas entre os componentes do sistema e não atribuí-lo exclusivamente ao último componente da planta. Ainda, a desagregação da exergia nos seus diversos componentes (devido à variação de pressão $-\Delta \mathrm{P}$, variação de temperatura $-\Delta \mathrm{T}$ e química) foi aplicada (SERRA, 1994)

Custeio Específico ("LIFO - Last in, first out e SPECO - Specific Exergy Costing") (TSATSARONIS; WINHOLD, 1985; TSATSARONIS, 1993; LAZZARETTO; TSATSARONIS, 2006), baseados em considerações contábeis, os insumos, os produtos e custos são definidos a partir de um registro sistemático das adições de

\footnotetext{
${ }^{13}$ Os equipamentos dissipativos (condensadores, chaminés, etc) rejeitam uma quantidade de entropia (gerada pelos outros equipamentos da planta) para o meio-ambiente, diminuindo a entropia dos fluxos que atravessam esses equipamentos. Ou seja, esses sistemas são responsáveis por disponibilizar para a planta de processo um fluxo negativo de entropia (neguentropia) (FRANGOPOULOS, 1987).
} 
exergia e custos e das remoções de exergia e custos de cada fluxo material e energético. A idéia é que o custo por unidade de exergia removido do fluxo energético é igual ao custo médio a que a quantidade de exergia removida foi fornecida por componentes anteriores. Ainda, esse método propõe a desagregação da exergia em diferentes componentes de modo a melhorar a definição dos insumos e produtos (adições e remoções de exergia). Contudo, os autores afirmam que os ganhos obtidos com a desagregação da exergia são, na maior parte dos casos, muito pequenos. Com relação às irreversibilidades externas, é possível atribuir um custo a essas e redistribuílo entre os demais fluxos internos do sistema, baseados nos seus conteúdos exergéticos.

Outras propostas: Sorin, Brodyansky e Valero (1993) e Brodyansky, Sorin e Le Goff (1994) discutem o uso do conceito de exergia em trânsito (quantidade de exergia que não se altera durante um determinado processo - "transit exergy") para distribuição de custos. Erlach, Tsatsaronis e Cziesla (2001) propõem um método para atribuição de custos em sistemas de cogeração.

Já os Métodos de Otimização, baseados nos multiplicadores de Lagrange, cuja meta é otimizar o sistema energético e o cálculo do custo marginal dos produtos, foram baseados no trabalhos de Tribus, El-Sayed e Evans, no início da década de 70 do século passado, que introduz métodos de cálculo para a otimização na termoeconomia, baseado no uso de multiplicadores de Lagrange. Os autores introduzem o conceito de isolamento termodinâmico de sistemas térmicos, permitindo a otimização do sistema completo pela otimização de suas unidades. Nessa abordagem, não há a necessidade de se definir explicitamente as equações auxiliares, e os multiplicadores de Lagrange representam os custos marginais dos produtos. Os principais métodos derivados do formalismo de El-Sayed e Evans (1970) são:

Análise Funcional Termoeconômica (FRANGOPOULOS, 1987), a qual introduz a idéia que um sistema térmico consiste em uma série de unidades inter-relacionadas, sendo que cada unidade tem a sua particular (única) função (produto ou propósito). A análise funcional é a determinação formal e documentada da função do sistema como um todo e de cada um dos seus componentes. A representação gráfica do sistema, seguindo as idéias da Análise Funcional, é chamada de "diagrama funcional", a qual representa a estrutura produtiva do sistema. Uma característica dessa metodologia é a 
utilização da neguentropia para redistribuir as irreversibilidades associadas a equipamentos dissipativos para os outros componentes da planta e a divisão da exergia dos fluxos em duas parcelas: uma associada à variação de pressão e outra à variação de temperatura. A metodologia utiliza ainda unidades de distribuição através das quais se acaba trabalhando com custos diferentes da exergia associada à pressão e à temperatura.

Análise Funcional de Engenharia (VON SPAKOVSKY, 1994), cuja maior contribuição é o estudo mais detalhado das condições de isolamento termodinâmico (CERQUEIRA, 1999). Mais recentemente, essa análise vem sendo desenvolvida e utilizada para a otimização de sistemas de aeronaves comerciais e militares (MUÑOZ, 2000; RANCRUEL, 2002).

Valero, Serra e Uche (2006) destacam ainda o trabalho de Beyer, que desenvolveu um método de otimização baseado nos chamados coeficientes estruturais (KOTAS, 1995), muito similares a custos marginais sob uma ótica matemática; e o trabalho de Szargut (2005) que desenvolveu o conceito de consumo acumulativo de exergia, o qual guarda similaridades com as idéias do custeio exergético.

\subsubsection{Análise Termoeconômica}

Do ponto de vista da análise e otimização de sistemas de conversão de energia, a análise termoeconômica agrega, basicamente, dois conjuntos de equações aos balanços de massa, energia e exergia: os balanços de custo para cada equipamento/processo e os critérios de partição de custos para os equipamentos/processos em que há mais de um produto.

Segundo Tsatsaronis (1993), a análise termoeconômica completa compreende as seguintes etapas:

Análise exergética detalhada do sistema;

Análise econômica detalhada dos equipamentos;

Custeio exergético; e 
Avaliação exergoeconômica de cada equipamento do sistema.

Quanto mais individualizada for feita a análise termoeconômica, mais detalhado será o resultado do processo de formação de custo dos produtos da planta.

Na termoeconomia, um custo é atribuído a cada fluxo material/energético no sistema sendo estudado; este valor representa o custo total necessário para a obtenção deste fluxo. Considerando a Fig. 5.1, pode-se escrever o seguinte balanço de custos:

$$
\dot{\mathrm{C}}_{\text {entrada }}+\dot{\mathrm{Z}}=\dot{\mathrm{C}}_{\text {saída }}+\dot{\mathrm{C}}^{\mathrm{W}}+\dot{\mathrm{C}}^{\mathrm{Q}}
$$

Rearranjando os termos desta equação, tem-se:

$$
\dot{\mathrm{C}}_{\text {saída }}-\dot{\mathrm{C}}_{\text {entrada }}=-\dot{\mathrm{C}}^{\mathrm{Q}}-\dot{\mathrm{C}}^{\mathrm{W}}+\dot{\mathrm{Z}}
$$

Comparando esta equação com a Eq. (12), obtém-se o custo médio por unidade de exergia da seguinte forma:

$$
\mathrm{c}_{\text {saída }} \cdot \dot{\mathrm{B}}_{\text {saida }}-\mathrm{c}_{\text {entrada }} \cdot \dot{\mathrm{B}}_{\text {entrada }}=-\mathrm{c}^{\mathrm{Q}} \cdot \dot{\mathrm{B}}^{\mathrm{Q}}-\mathrm{c}^{\mathrm{W}} \cdot \dot{\mathrm{B}}^{\mathrm{W}}+\dot{\mathrm{Z}}
$$

Ou seja, o custo médio por unidade de exergia de um fluxo material/energético qualquer $\left(\mathrm{c}_{\mathrm{i}}\right)$ é definido por:

$$
\mathrm{c}_{\mathrm{i}}=\dot{\mathrm{C}}_{\mathrm{i}} / \dot{\mathrm{B}}_{\mathrm{i}}
$$

Os balanços representados pelas eqs. (17) e (18) podem ser aplicados para todos os componentes do sistema. Assim, no sistema de equações formado, as incógnitas são os custos médios por unidade de exergia de cada fluxo. Contudo, o número de equações é menor que o número de incógnitas, caso um dos equipamentos apresente mais de um fluxo de saída. Portanto, é necessária a introdução de equações auxiliares para a determinação das incógnitas. A diferença entre as metodologias existentes para a aplicação da termoeconomia está 
exatamente na determinação das equações auxiliares para solução dos balanços de custo. Pellegrini, Pacheco e Oliveira Jr. (2004) apresentam um estudo de caso didático de uma aplicação da análise termoeconômica em uma planta de cogeração.

\subsubsection{Exergia e Impactos Ambientais}

Índices termodinâmicos, mais especificamente índices exergéticos, também podem representar formas de avaliação de impacto ambiental (BEJARANO, 2004). De acordo com Rosen e Dincer (1997), dado que a exergia pode ser definida como um potencial de se causar uma mudança, esta grandeza parece ser uma medida também do potencial impacto que uma substância pode causar no meio ambiente. Segundo Santarelli (1998) o conceito de exergia está relacionado a:

$\checkmark$ A destruição de exergia devido a um funcionamento deficiente do sistema energético, quando evitável, está ligada à causa de poluição; de tal modo que ao minimizar a exergia destruída, intervém-se na emissão de poluentes, de forma a preveni-la.

$\checkmark$ A exergia representa um índice de desequilíbrio com respeito ao meio-ambiente padrão, portanto é possível tratá-la como um valor conceitual de medida de poluição. Por meio da exergia residual, associada com as substâncias contidas nos gases de combustão, por exemplo, pode-se efetuar uma valoração da poluição, tal que ao minimizá-la interfere no efeito poluidor da atividade do sistema.

Neste contexto, é possível identificar quatro alternativas na literatura, para a introdução da exergia na avaliação de impactos/benefícios ambientais:

Incorparação de custos ambientais na análise termoeconômica

Aplicação direta dos índices exergéticos para avaliação do impacto;

Determinação de "taxas exergéticas" para impactos ambientais;

Análise Exergética do Ciclo de Vida.

Considerando a incorparação desses custos, dois são os principais pontos de debate a respeito dos métodos de avaliação dos impactos/benefícios ambientais de sistemas energéticos (MASCOLLEL; WHINSTON; GREEN, 1995; FRANGOPOULOS; CARALIS， 1997; SANTARELLI, 1998): 
$\checkmark$ Como estimar os custos externos devidos à atividade de transformação energética?

- A externalidade existe sempre que o bem-estar de um consumidor ou as possibilidades de produção de uma firma forem diretamente afetadas pela ação de outros agentes da economia

$\checkmark$ Como internalizar estes custos na avaliação econômica de um sistema energético?

- Como avaliar essas ações (externalidades) dentro de um sistema produtivo

Atualmente, a introdução de taxas ambientais é a opção mais comum para incorporação dos aspectos ambientais na análise de sistemas energéticos ou de políticas energéticas. Contudo, essa abordagem requer a atribuição de um valor econômico para essas externalidades (SANTARELLI, 1998). É importante notar que devido às diferentes metodologias adotadas, os custos dessas externalidades são bastante diversos, o que torna o uso destes procedimentos bastante limitado para a criação de políticas ambientais (SCHLEISNER, 2000; SUNDQVIST, 2003). Dentre as metodologias existentes, destaca-se o trabalho desenvolvido pela Comissão Européia ("EC - European Commission") ao longo dos últimos 15 anos para a avaliação dos custos das externalidades de sistemas energéticos. O projeto, conhecido como ExternE ("Externalities of Energy"), desenvolveu uma metodologia que permite traduzir impactos ambientais medidos a partir de diferentes métodos para uma unidade comum, um valor monetário (BICKEL; FRIEDRICH, 2005). Essa metodologia foi utilizada por Prado (2007) para avaliação das externalidades do ciclo produtivo da cana-de-açúcar, enfatizando a geração de energia elétrica.

A fim de evitar distorções relativas à atribuição direta de um valor econômico a um dano ambiental, Gaivao e Jaumotte (1984) propuseram um método inspirado na análise exergética para avaliar custos devido a emissões industriais. O método é dividido em três etapas: i) quantificação da agressão a partir de um fator de desequilíbrio derivado do conceito da exergia; ii) determinação de um coeficiente de nocividade relativo ao impacto ecológico da emissão, definido como uma razão com relação a um valor de referência que fixa um valor máximo para a emissão; e iii) cálculo do custo marginal de redução, definido como o custo incremental de um equipamento de despoluição dividido pelo redução da emissão correspondente. Os autores aplicaram o método a uma planta de potência a carvão. Rosen e Dincer (1999) comparam duas metodologias para a determinação do custo de emissões 
atmosféricas: uma baseada no custo de remoção do poluente, utilizando como referência a sua exergia, e outra utilizando custos determinados a partir de avaliações quantitativas e qualitativas dos custos incorridos pela sociedade devido às emissões. Os resultados indicaram que a análise exergética contribui para a avaliação de impactos ambientais, porém maiores desenvolvimentos são necessários.

O termo "environomics" foi apresentado pela primeira vez em 1992 para nomear um novo método para levar em consideração custos ambientais dentro da análise termoeconômica (FRANGOPOULOS, 1992). O método guarda similaridades com a proposta de Gaivao e Jaumotte (1984), porém depende de uma metodologia para a determinação do custo da poluição emitida. Esse método foi aplicado por diversos autores para avaliar o impacto de custos relacionados a impactos ambientais nos custos ótimos de operação de diversos sistemas energéticos (FRANGOPOULOS; CALLARIS, 1997; VON SPAKOVSKY, 1997; AGAZZANI; MASSARDO; FRANGOPOULOS, 1998; CURTI; VON SPAKOVSKY; FAVRAT, 2000; PELSTER; FAVRAT; VON SPAKOVSKY, 2001).

A fim de estabelecer uma abordagem que unisse princípios da análise termoeconômica e da otimização termoeconômica considerando aspectos relativos a impactos ambientais, Santarelli (1998) propôs uma metodologia, na qual a função-objetivo do problema de otimização termoeconômica (e environômica) é modificada, integrando parcelas referentes à exergia destruída e à exergia perdida. Estes termos invocam custos relacionados a estes fluxos, permitindo a internalização de aspectos (eficiência das transformações energéticas e emissões de poluentes) antes "escondidos" no termo referente ao consumo de combustível. Em trabalhos posteriores (BORCHIELLINI; MASSARDO; SANTARELLI, 2000 e 2002; MASSARDO; SANTARELLI; BORCHIELLINI, 2003; TRAVERSO et al., 2003; SANTARELLI, 2004), uma metodologia, derivada da abordagem descrita, foi estabelecida para a determinação de uma taxa exergética de carbono ("Carbon Exergy Tax"), a qual pode ser aplicada como um instrumento de política energética para redução das emissões de $\mathrm{CO}_{2}$. Contudo, nenhum desses trabalhos abordou questões referentes a outros poluentes.

O consumo total da exergia dos recursos naturais utilizados para a fabricação de um determinado produto, desde o início da cadeia de produção passando pelos produtos semiterminados até o produto final, é chamado de consumo cumulativo de exergia ("Cumulative Exergy Consumption" - CexC) (SZARGUT; MORRIS; STEWARD, 1988). Utilizando esse 
conceito, Szargut, Ziebik e Stanek (2002) propõem uma metodologia para a determinação do custo termo-ecológico de um determinado produto ("Thermo-Ecological Cost"), baseado no consumo cumulativo de exergia não-renovável dos recursos naturais, em valores monetários relativos à nocividade das emissões e no produto interno bruto. Szargut (2005) define o índice de sustentabilidade como a razão entre o custo termo-ecológico e a exergia do produto final, caracterizando a fração de exergia não-renovável utilizada na produção do produto final.

Outra abordagem referente à análise e otimização de sistemas energéticos considerando aspectos ambientais é a otimização multi-objetivo, na qual duas ou mais funções-objetivo são definidas e o resultado da otimização é um conjunto de soluções ótimas que mostram a relação de "trade-off" entre os objetivos propostos. Esta abordagem não requer necessariamente o uso de valores monetários para avaliar o impacto das emissões de um sistema, assim índices que diretamente explicitam um determinado impacto podem ser utilizados (TOFFOLO; LAZZARETTO, 2002 e 2004; BURER et al., 2003; LI et al., 2006).

Rosen e Dincer (1997) apresentaram três relações entre exergia e impacto ambiental e ilustraram esses conceitos utilizando dados de uma planta de potência a base de carvão mineral:

Destruição da Ordem/Criação do Caos, relacionado à geração de entropia como uma forma de dano ambiental;

$>$ Degradação dos recursos naturais, relacionado à busca de rotas de conversão de energia mais eficientes, reduzindo o impacto ambiental; e

Emissões da exergia dos rejeitos, relacionado ao desequilíbrio entre as emissões e as condições de referência do meio ambiente, ou seja, ao consumo de exergia necessário para trazer essa emissão para uma condição de equilíbrio com o meio.

A produção de gás combustível e eletricidade a partir do carvão foi estudada por Makarytchev (1998) a partir de três indicadores ambientais (taxa de recursos; a eficiência ambiental e a taxa de poluição total). Estes indicadores baseiam-se na evolução do ciclo de vida da exergia contida em cada um dos fluxos. Bejarano (2004) definiu a eficiência exergética ambiental de processos de conversão de energia como a razão da exergia final pela exergia total consumida dos recursos humanos e naturais. O autor aplicou esse índice em conjunto com a taxa de 
poluição global para avaliar o desempenho exergo-ambiental de plantas de tratamento de esgoto (BEJARANO; OLIVEIRA Jr., 2005).

Cornelissen (1997) propõe a Análise Exergética de Ciclo de Vida (Exergetic Life Cycle Analysis - ELCA) a qual contabiliza toda destruição de exergia ao longo do ciclo de vida de um produto, servindo como ferramenta de melhoria do desempenho ambiental pela busca da minimização das irreversibilidades (destruição de exergia) do mesmo. Cornelissen e Hirs (2002) aplicaram esse método para avaliar o desempenho ambiental de rotas para o uso de rejeito de madeireiras. Ayres, Ayres e Martinás (1998) citam três grandes vantagens do uso de exergia no contexto da ACV:

i. Fornece uma medida comum para entradas e saídas do processo, permitindo o cálculo de eficiências exergéticas que revelam o potencial de melhorias nos sistemas.

ii. Permite comparar materiais de natureza diferente em relação ao desempenho ambiental.

iii. Combinado com balanços materiais e energéticos da ACV, facilita a divulgação e acompanhamento de índices de desempenho de empresas e nações ao longo do tempo, permitindo identificar os reais ganhos/perdas de desempenho e comparar diferentes emissões.

Wall e Gong (2001) discutiram a aplicação da exergia como um indicador ambiental, tratando esta grandeza como uma medida física de diferenças e as emissões como diferenças no ambiente. No trabalho seguinte (GONG; WALL; 2001), analisaram a exergia a partir da definição de indicador ecológico ${ }^{14}$, em um estudo de caso partindo do trabalho de Cornelissen (1997). Os resultados indicaram que a exergia é a melhor medida do dano em relação ao parâmetro usado como referência (Eco-indicador 95) e um bom indicador ecológico.

Uma revisão de outros índices exergéticos de impacto ambiental pode ser encontrada em Latouf (2003) e Bejarano (2004).

\footnotetext{
${ }^{14}$ Indicador ecológico é um parâmetro, ou valor derivado de parâmetros, que fornece informações, descreve o estado do fenômeno, ambiente ou área, com uma importância maior que o valor associado ao parâmetro (BEJARANO, 2004)
} 
No Cap. 11 será discutido um índice em base exergética para a avaliação da renovabilidade de processos de conversão de energia.

\subsection{ANÁLISE EXERGÉTICA E TERMOECONÔMICA DE ALTERNATIVAS DE USO RACIONAL DE ENERGIA NA AGROINDÚSTRIA CANAVIEIRA}

\subsubsection{Introdução}

Durante a rápida expansão na instalação de novas unidades produtoras de álcool no Estado de São Paulo, ocorrida após a segunda crise do petróleo, a preocupação com a adoção de tecnologias mais eficientes nas unidades produtivas ficou relegada a um segundo plano (SINÍCIO; BAJAY, 1992). Assim, quando se fala em uso racional da energia em usinas sucroalcooleiras, discute-se uma série de medidas que reduzem o consumo específico global de energia da planta, através de alterações no processo ou em equipamentos e sistemas, evitando, muitas vezes, perdas (CAMARGO, 1990). As perdas citadas são referentes ao consumo excessivo de algum insumo energético (p. ex., bagaço ou vapor), para a obtenção de um efeito útil, o qual poderia ser obtido com um menor consumo, dada uma maior eficiência dos processos e/ou equipamentos. Esta maior eficiência dos processos levaria a uma economia desses insumos, os quais poderiam ser utilizados na produção de eletricidade excedente, p.ex. A recuperação das pontas e folhas significaria um aporte adicional de biomassa na usina, de forma que estes resíduos poderiam, também, ser utilizados na produção de eletricidade.

Assim, em usinas sucroalcooleiras, os conceitos de uso racional de energia e de geração de energia elétrica excedente estão intimamente ligados a:

1. Geração de excedente de bagaço;

2. Redução do consumo de vapor nos processos;

3. Aproveitamento de pontas e folhas.

O primeiro caso pode ser descrito da seguinte forma: o bagaço é um resíduo natural da produção de açúcar e álcool, assim a visão inicial do setor era eliminá-lo para evitar gastos desnecessários com o seu armazenamento e movimentação. Inicialmente, as unidades geradoras de vapor utilizadas no setor tinham (algumas ainda têm) uma concepção antiga e de baixa eficiência, operando como "incineradores" de bagaço. Porém, a necessidade de redução 
de custos aliada a uma valorização dos subprodutos da cana, tornou a geração de bagaço excedente bastante interessante ao setor. Desta forma, a busca de formas mais eficientes de aproveitamento do bagaço vem sendo considerada nos últimos anos, tanto para geração de eletricidade (WALTER, 1994; LARSON, WILLIAMS; LEAL, 2001; PRIETO, 2003; PELLEGRINI; OLIVEIRA JR., 2007a e 2007b; PELLEGRINI; BURBANO; OLIVEIRA JR., 2007) quanto para a produção de etanol (NEBRA, 2007; CORDONA; SANCHEZ, 2007).

O segundo caso, visando uso racional da energia nas usinas, aborda mecanismos para redução do consumo de vapor nos processos. Uma série de recomendações visando esta redução pode ser encontrada em diversos trabalhos (CAMARGO, 1990; OGDEN; HOCHGREB; HYLTON, 1990; HIGA; BANNWART, 2001; AVRAM; MORGENROTH; SEEMANN, 2004; PELLEGRINI; OLIVEIRA JR., 2006b; MODESTO; ZEMP; NEBRA, 2006b; ENSINAS, 2008). Christodoulou (1996) faz uma revisão sobre a economia de energia em usinas de açúcar de beterraba nos últimos 50 anos, mostrando que esta indústria consumia 700 $\mathrm{kg}$ de vapor/tonelada de beterraba em 1930, e hoje consome $150 \mathrm{~kg}$. Segundo Hassuani, Leal e Macedo (2005) muitas das alternativas aplicadas a usinas de beterraba poderiam ser aplicadas a usinas sucroalcooleiras.

Finalmente, o aproveitamento de pontas e folhas deve ser considerado como forma de aproveitamento energético, atualmente desperdiçado devido às queimadas pré-colheita (MACEDO; LEAL; HASSUANI, 2001; HASSUANI; LEAL; MACEDO, 2005). Esse aproveitamento pode ser tanto pela geração de eletricidade adicional como pela produção de etanol a partir da hidrólise ácida ou enzimática.

\subsubsection{A exergia como Ferramenta de Análise em Usinas}

Manuais de engenharia relacionados à indústria açucareira mostram diferentes metodologias de análise de sistemas relacionados à produção de açúcar e álcool (SCHNEIDER, 1968; HUGOT, 1986; CAMARGO, 1990; BALOH; WITTWER, 1995). Estas metodologias permitem uma avaliação energética de instalações existentes e até como projetar um sistema, dadas as condições de entrada e saída. Contudo, a análise exergética só é citada por Baloh (1968) e Baloh e Wittwer (1995) e mesmo assim sua aplicação não fica clara, já que não são mostradas as relações utilizadas para a determinação do cálculo da exergia dos diferentes 
fluxos. A seguir, uma revisão será feita sobre trabalhos desenvolvidos objetivando levantar o estado da arte da utilização das análises exergética e termoeconômica em usinas.

Os primeiros trabalhos relacionados à aplicação da exergia para avaliação do processo de produção de açúcar datam da década de 60 do século passado, sendo os estudos realizados para usinas de beterraba (BALOH, 1981). Ao longo dos anos, diversos trabalhos foram publicados considerando o uso da exergia para avaliação do desempenho das usinas de beterraba. Goutte (1987) desenvolveu a análise exergética do processo de fabricação de açúcar e álcool a partir de beterraba, baseando o estudo em dados obtidos de duas plantas reais; ainda, são apresentadas diversas correlações para determinação da exergia específica das soluções água-sacarose e água-etanol. Guallar e Valero (1989a, 1989b, 1989c) utilizam a Teoria do Custo Exergético para determinação dos custos exergéticos dos diferentes fluxos existentes na produção de açúcar de beterraba. Christodoulou (1996) discute a utilização das diversas ferramentas de análise disponíveis para a fabricação de açúcar e a evolução do consumo de vapor em fábricas de açúcar de beterraba. Tekin e Bayramoğlu (1998 e 2001) aplicam a análise exergética à produção de açúcar, propondo alternativas para melhorar o desempenho da planta, baseadas na análise dos coeficientes estruturais propostos por Beyer (1970). Bayrak, Midilli e Nurveren (2003) também realizaram análises energética e exergética dos estágios de produção de açúcar a partir de beterraba. Outros trabalhos (TWAITE; DAVENPORT; MACDONALD， 1986; URBANIEC; ZALEWSKI; ZHU, 2000; RAM; BANERJEE, 2003) utilizam a análise de "pinch point" para determinação de novos arranjos para as trocas térmicas em usinas de beterraba.

González (1990) apresenta a aplicação da análise exergética à indústria canavieira cubana. A metodologia para determinação da exergia química dos diferentes fluxos envolvidos se baseia em admitir o valor zero para a exergia da cana na temperatura de referência. A mesma metodologia foi utilizada por Benítez (2002) para avaliar diferentes opções para geração de eletricidade excedente em uma usina cubana, fazendo uso da análise exergoecônomica (TSATSARONIS, 1993).

$\mathrm{Na}$ indústria canavieira argentina, a análise exergética foi utilizada para avaliar o desepenho de sistemas caldeira-secador de bagaço (CÁRDENAS; PAZ; WITTWER, 1994), além de diferentes opções de integração térmica entre o sistemas de tratamento, evaporação e cozimento do caldo (PAZ; CÁRDENAS, 1997). 
Velásquez (2002) e Velásquez, Chejne e Agudelo (2004) aplicaram a análise exergética a diferentes configurações de plantas de produção de rapadura na Colômbia, discutindo a aplicação de índices de desempenho em base exergética. Velásquez, Gutiérrez e Oliveira Jr. (2006) utilizaram a Teoria do Custo Exergético (LOZANO; VALERO, 1993) para avaliar a operação de uma moderna planta de produção de rapadura. Velásquez, Pellegrini e Oliveira Jr (2008) utilizaram a análise exergética como ferramenta para avaliar o desempenho ambiental de uma usina sucroalcooleira colombiana.

Talvez a primeira aplicação da análise exergética à indústria canavieira brasileira, tenha sido realizada por Castier e Rajagopal (1988). Os autores desenvolveram a análise para uma destilaria autônoma e os resultados do trabalho permitem hierarquizar as etapas de maior destruição de exergia: utilidades (56\%), fermentação (31\%), destilação (7\%) e sistema de extração (4\%).

Vertiola e Oliveira Jr. (1995), em um trabalho pioneiro, aplicaram a análise termoeconômica à planta de utilidades de uma usina brasileira. Este trabalho foi baseado em dados (pressão, temperatura e vazão) levantados na usina durante parte da safra de 1992/93, considerando os métodos de partição (GAGGIOLI; WEPFER, 1980) para distribuição dos custos entre os produtos da planta. Utilizando a mesma metodologia, Coelho, Oliveira Jr. e Zylbersztajn (1997) avaliaram sistemas com turbinas de extração-condensação, em destilarias autônomas. As opções para modificação da planta de utilidades foram baseadas na aquisição de equipamentos novos para a planta de utilidades e eletrificação parcial e total dos acionamentos mecânicos.

A Teoria do Custo Exergético (LOZANO; VALERO, 1993) foi aplicada nos estudos de Barreda del Campo, Cerqueira e Nebra (1998), Prieto e Nebra (2002 e 2004) para determinação dos custos exergéticos e termoeconômicos da planta de utilidades de usinas cubanas e brasileiras. Fernández-Parra e Nebra (2001) estudaram o desempenho da etapa de evaporação em duas configurações distintas (sem e com termocompressão) mediante a análise dos custos exergéticos das opções. Neste estudo, uma metodologia para o cálculo da parcela química da exergia do caldo (considerado uma solução binária de água e sacarose) foi proposta. Esta proposta foi modificada em Nebra e Fernández-Parra (2005) e utilizada nos desenvolvimentos dos modelos desta tese. Arrieta, Lora e Nebra (2000) utilizaram a teoria do 
custo exergético para avaliação de um ciclo combinado com gaseificação de biomassa em usinas sucroalcooleiras. Mais recentemente, Modesto, Zemp e Nebra (2006a e 2006b) estudaram, utilizando a mesma metodologia, algumas alternativas para melhorar o desempenho de destilarias autônomas, considerando tanto uma melhor integração térmica dos processos, como o uso de novas tecnologias de cogeração. Esses autores propuseram uma metodologia para o cálculo da exergia de misturas água-etanol (MODESTO; NEBRA; ZEMP, 2006). Já Ensinas et al. (2006, 2007a, 2007b e 2008) desenvolveram uma metodologia termoeconômica para melhorar a integração entre a etapa de evaporação e as etapas de tratamento e cozimento do caldo, considerando ainda a integração da fabricação de álcool. Ensinas (2008) apresentou uma metodologia de integração térmica utilizando a termoeconomia e análise de "pinch point" para melhorar o desempenho de plantas para a produção de açúcar e álcool.

Pellegrini e Oliveira Jr (2006a e 2006b) propõem um modelo para avaliar o desempenho exergético de evaporadores múltiplos-efeitos em usinas, considerando diversas configurações para as extrações, buscando minimizar o consumo de vapor de escape no primeiro efeito. Em outro trabalho, os mesmos autores desenvolvem uma primeira abordagem para a otimização exergética de usinas sucroalcooleiras, analisando o impacto nos custos de produção em base exergética do açúcar, álcool e eletricidade devido a variações na planta de utilidades (PELLEGRINI; OLIVEIRA JR., 2007b). Sistemas mais avançados de cogeração em usinas, como sistemas com gaseificação de biomassa (PELLEGRINI, 2003; PELLEGRINI; OLIVEIRA JR, 2005a e 2007a; ZANETTI, PELLEGRINI; OLIVEIRA JR., 2007) e sistemas supercríticos de vapor (PELLEGRINI; BURBANO; OLIVEIRA JR., 2007 e 2008) também foram avaliados segundo a mesma metodologia. Pellegrini et al (2008) mostram uma avaliação exergética e de viabilidade econômica para algumas configurações para destilarias autônomas, considerando o uso de destilarias de múltiplos-efeitoss. Os resultados apresentados nessa tese são uma compilação dos resultados dos trabalhos citados.

De uma forma geral, o tema exergia vem sendo desenvolvido há mais de 20 anos na área açucareira, sobretudo nas indústrias de açúcar de beterraba. As aplicações variam desde análise de sistemas convencionais em plantas existentes até avaliação do impacto de novas tecnologias nos custos de produção de açúcar, álcool e eletricidade. 


\subsection{Cálculo da Exergia Específica dos Fluxos Materiais na Agroindústria Canavieira}

A seguir são apresentadas as equações utilizadas para a determinação da exergia específica dos fluxos pertinentes a usinas sucroalcooleiras. As metodologias para a determinação da exergia das misturas água-sacarose e água-etanol foram baseadas nas propostas de Nebra e Fernández-Parra (2005) e Modesto, Nebra e Zemp (2006), respectivamente.

\subsubsection{Soluções Água-Sacarose}

\subsubsection{Solubilidade}

De acordo com Peacock (1995), a solubilidade máxima de uma solução de sacarose $\left(\mathrm{x}_{\text {sol }}\right)$ pode ser calculada por:

$$
x_{\text {sol }}=63,753+0,13542 \cdot t+8,869 \cdot 10^{-4} \cdot \mathrm{t}^{2}-2,222 \cdot 10^{-6} \cdot \mathrm{t}^{3}
$$

Quando a solução estiver acima deste valor, duas fases coexistirão: solução de água-sacarose e cristais de açúcar. A partir da solubilidade máxima é possível calcular a fração molar de saturação da sacarose na solução:

$$
\mathrm{y}_{\mathrm{sac}, \mathrm{sat}}=\frac{\mathrm{x}_{\mathrm{sol}} / \mathrm{MM}_{\mathrm{sac}}}{\mathrm{x}_{\mathrm{sol}} / \mathrm{MM}_{\mathrm{sac}}+\left(1-\mathrm{x}_{\mathrm{sol}}\right) / \mathrm{MM}_{\text {água }}}
$$

Em uma mistura, na qual duas fases estão presentes (mistura água-sacarore e cristais de cristais de açúcar/sacarose pura), ou seja, acima do ponto de máxima solubilidade, a quantidade da mistura água-sacarose (z) presente é determinada por (NEBRA; FERNÁNDEZ-PARRA, 2005):

$$
z=\frac{1-x}{1-x_{\text {sol }}}
$$


De maneira que qualquer propriedade $\mathrm{k}$ de uma mistura de duas fases pode ser calculada pela soma ponderada das propriedades da mistura água-sacarose e dos cristais de açúcar:

$$
\mathrm{k}_{\text {mist }}=\mathrm{z} \cdot \mathrm{k}_{\mathrm{sol}}+(1-\mathrm{z}) \cdot \mathrm{k}_{\mathrm{sac}}
$$

\subsubsection{Calor Específico}

Como discutido por Nebra e Fernández-Parra (2005), a melhor correlação existente para determinação do calor específico de uma solução água-sacarose (em kJ/kg.K) é dada por:

$$
\mathrm{c}_{\mathrm{p}}=4,1868-0,0297 \cdot \mathrm{x}+4,6 \cdot 10^{-5} \cdot \mathrm{x} \cdot \mathrm{Pz}+7,5 \cdot 10^{-5} \cdot \mathrm{x} \cdot \mathrm{t}
$$

A principal vantagem desta correlação é que leva em consideração tanto o efeito da temperatura como o efeito da pureza da solução (a pureza está relacionada à quantidade de sacarose existente no total de componentes sólidos da solução). Para o caso da sacarose pura, o calor específico (em kJ/kg.K) é calculado pela seguinte equação (NEBRA; FERNÁNDEZPARRA, 2005):

$$
\mathrm{c}_{\mathrm{p}_{\mathrm{sac}}}=1,244+4,819 \times 10^{-3} \cdot(\mathrm{t}-25)+6,238 \times 10^{-6} \cdot(\mathrm{t}-25)^{2}
$$

Ainda, o calor específico de uma mistura bifásica é calculada a partir da média ponderada das fases, conforme a eq.(23).

\subsubsection{Entalpia e Entropia Específicas}

A entalpia $(\mathrm{kJ} / \mathrm{kg})$ e a entropia (kJ/kg.K) específicas de uma substância e/ou mistura de substâncias pode ser obtida a partir de uma equação de estado para a substância em questão e uma correlação para determinação do calor específico. Para tanto, basta integrar as seguintes equações (ABBOT; SMITH; VAN NESS, 2001):

$$
d h=c_{p} \cdot d T+\left[v-T \cdot\left(\frac{\partial v}{\partial T}\right)_{p}\right] \cdot d p
$$




$$
\mathrm{ds}=\mathrm{c}_{\mathrm{p}} \cdot \frac{\mathrm{dT}}{\mathrm{T}}+\left(\frac{\partial \mathrm{v}}{\partial \mathrm{T}}\right)_{\mathrm{p}} \cdot \mathrm{dp}
$$

$\mathrm{O}$ estado de referência adotado para a integração foi: entalpia e entropia nula a $0^{\circ} \mathrm{C}$ (de acordo com a função STEAM_IAPWS do software EES ${ }^{\circledR}$ (KLEIN, 2008), usada para determinar as propriedades da água no modelo). Assim, utilizando a eq.(24) e desprezando o efeito da pressão $^{15}$, as eqs.(26) e (27) podem ser integradas, resultando em (NEBRA; FERNÁNDEZPARRA, 2005):

$$
\begin{gathered}
\mathrm{h}_{\mathrm{sol}}=\left(4,1868-0,0297 \cdot \mathrm{x}+4,6 \cdot 10^{-5} \cdot \mathrm{x} \cdot \mathrm{Pz}\right) \cdot \mathrm{t}+3,75 \cdot 10^{-5} \cdot \mathrm{x} \cdot \mathrm{t}^{2} \\
\mathrm{~s}_{\mathrm{sol}}=\left(4,1868-0,05018265 \cdot \mathrm{x}+4,6 \cdot 10^{-5} \cdot \mathrm{x} \cdot \mathrm{Pz}\right) \cdot \ln \left(\frac{\mathrm{T}}{\mathrm{T}_{\mathrm{ref}}}\right)+7,5 \cdot 10^{-5} \cdot \mathrm{x} \cdot\left(\mathrm{T}-\mathrm{T}_{\mathrm{ref}}\right)
\end{gathered}
$$

Na segunda integração é importante chamar a atenção ao fato que houve uma mudança da escala de temperatura, de Celsius para Kelvin.

Para entalpia e entropia específicas da sacarose pura, o mesmo procedimento anterior foi utilizado considerando a eq.(25) (NEBRA; FERNÁNDEZ-PARRA, 2005).

$$
\begin{gathered}
\mathrm{h}_{\mathrm{sac}}=1,244+2,4095 \times 10^{-3} \cdot(\mathrm{t}-25)+2,0793 \times 10^{-6} \cdot(\mathrm{t}-25)^{3} \\
\mathrm{~s}_{\mathrm{sac}}=0,361732319 \cdot \ln \left(\frac{\mathrm{T}}{\mathrm{T}_{\mathrm{ref}}}\right)+1,0992806 \cdot\left(\mathrm{T}-\mathrm{T}_{\mathrm{ref}}\right)+3,119 \times 10^{-6} \cdot\left(\mathrm{T}-\mathrm{T}_{\mathrm{ref}}\right)^{2}
\end{gathered}
$$

\footnotetext{
${ }^{15}$ Para soluções líquidas, o efeito da variação da pressão sobre a variação da entalpia e da entropia é muito inferior ao da variação da temperatura. Portando, o segundo termo das eqs.(26) e (27) foram desconsiderados na integração.
} 


\subsubsection{Coeficiente de Atividade}

Starzak e Peacock (1997) propuseram a seguinte equação para a determinação do coeficiente de atividade da água em soluções água-sacarose:

$$
\ln \gamma_{\text {água }}=\frac{-2121,4052}{\mathrm{~T}} \cdot \mathrm{y}_{\mathrm{sac}}^{2} \cdot\left(1+\mathrm{a} \cdot \mathrm{y}_{\mathrm{sac}}+\mathrm{b} \cdot \mathrm{y}_{\mathrm{sac}}{ }^{2}\right)
$$

onde os coeficientes são: $a=-1,0038$

$$
\mathrm{b}=-0,24653
$$

Utilizando a relação de Gibbs-Duhem (ABBOT; SMITH; VAN NESS, 2001), é possível calcular o coeficiente de atividade da sacarose na solução:

$$
\sum_{\mathrm{i}} \mathrm{y}_{\mathrm{i}} \cdot \mathrm{d} \ln \gamma_{\mathrm{i}}=0 \Rightarrow \int \mathrm{d} \ln \gamma_{\text {suc }}=-\int \frac{\mathrm{y}_{\text {água }}}{\mathrm{y}_{\text {sac }}} \cdot \mathrm{d} \ln \gamma_{\text {água }}
$$

Integrando essa equação entre um estado genérico e o estado de solução saturada, é possível obter o valor do coeficiente de atividade. Contudo, o estado de saturação corresponde ao estado onde a solução está em equilíbrio com a sacarose pura. Assim, o valor de referência do coeficiente de atividade da sacarose corresponde ao coeficiente da sacarose pura:

$$
\gamma_{\mathrm{sac}, \mathrm{sat}}=\frac{1}{\mathrm{y}_{\mathrm{sac}, \mathrm{sat}}}
$$

Utlilizando as Eqs. (32) e (34) na Eq. (33), obtém-se:

$$
\left.\ln \left(\frac{\gamma_{\mathrm{sac}, \mathrm{sat}}}{\gamma_{\mathrm{sac}}}\right)=\frac{2121,4052}{\mathrm{~T}} \cdot\left[2 \cdot \mathrm{y}_{\mathrm{sac}}+\frac{(3 \cdot \mathrm{a}-2)}{2} \cdot \mathrm{y}_{\mathrm{sac}}{ }^{2}+\frac{(4 \cdot \mathrm{b}-3 \cdot \mathrm{a})}{3} \cdot \mathrm{y}_{\mathrm{sac}}{ }^{3}-\mathrm{b} \cdot \mathrm{y}_{\mathrm{sac}} 4\right]_{\text {estado }}^{\text {sat }}\right]_{\text {genico }}^{\text {sat }}
$$

\subsubsection{Equilíbrio Líquido-Vapor}

O cálculo do equilíbrio líquido-vapor da água da solução água-sacarose pode ser obtida pela Lei de Raoult Modificada: 


$$
\mathrm{p}_{\text {vapor }}=\gamma_{\text {água }} \cdot \mathrm{y}_{\text {água }} \cdot \mathrm{p}_{\text {sat }}\left(\mathrm{T}_{\text {sol }}\right)
$$

A eq.(36) implica a hipótese de apenas água estar presente na fase vapor. Essa equação é utilizada para determinar a Elevação do Ponto de Ebulição (EPE) da solução:

$$
\Delta \mathrm{T}_{\mathrm{EPE}}=\mathrm{T}_{\mathrm{sol}}-\mathrm{T}_{\text {sat }}\left(\mathrm{p}_{\text {vapor }}\right)
$$

\subsubsection{Exergia Específica}

Dado o ambiente de referência, a exergia da solução água-sacarose pode ser calculada de acordo com as equações a seguir (SZARGUT; MORRIS; STEWARD, 1988):

\section{Parcela Física $(\mathrm{kJ} / \mathrm{kg})$ :}

$$
\mathrm{b}_{\text {fis }}=\mathrm{h}_{\text {sol }}(\mathrm{T}, \mathrm{p})-\mathrm{h}_{\text {sol }}\left(\mathrm{T}_{0}, \mathrm{p}_{0}\right)-\mathrm{T}_{0} \cdot\left(\mathrm{s}_{\text {sol }}(\mathrm{T}, \mathrm{p})-\mathrm{s}_{\text {sol }}\left(\mathrm{T}_{0}, \mathrm{p}_{0}\right)\right)
$$

\section{Parcela Química $(\mathrm{kJ} / \mathrm{kg})$ :}

$$
\begin{aligned}
& \mathrm{b}_{\text {qui }}=\frac{1}{\mathrm{MM}_{\text {sol }}} \cdot\left[\left(\mathrm{y}_{\text {água }} \cdot \mathrm{b}_{\text {qui,água }}^{00}+\mathrm{y}_{\text {sac }} \cdot \mathrm{b}_{\text {qui,sac }}^{00}\right)+\right. \\
& \left.\mathrm{R} \cdot \mathrm{T}_{0} \cdot\left(\mathrm{y}_{\text {água }} \cdot \ln \left(\mathrm{y}_{\text {água }} \cdot \gamma_{\text {água }}\right)+\mathrm{y}_{\mathrm{sac}} \cdot \ln \left(\mathrm{y}_{\mathrm{sac}} \cdot \gamma_{\mathrm{sac}}\right)\right)\right]
\end{aligned}
$$

Este procedimento de cálculo pode ser visto na Fig. 5.4. 


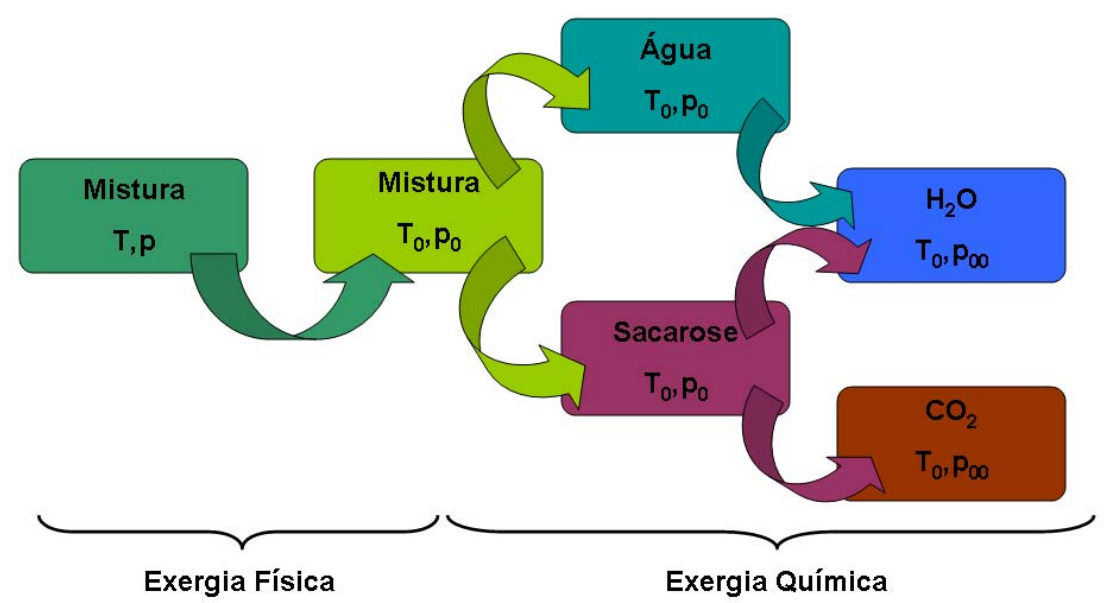

Figura 5.4 - Representação do cálculo da exergia das soluções de água-sacarose (Adaptado de: NEBRA; FERNÁNDEZ-PARRA, 2005).

\subsubsection{Soluções Água-Etanol ${ }^{16}$}

\subsubsection{Entalpia Específica}

A entalpia específica de uma solução pode ser calculada através da soma ponderada das entalpias específicas de cada substância (entalpia de uma solução ideal) mais um termo de mistura, chamado de entalpia de excesso (ABBOT; SMITH; VAN NESS, 2001). Assim, para uma solução água-etanol:

$$
\mathrm{h}_{\text {sol }}=\mathrm{y}_{\text {água }} \cdot \mathrm{h}_{\text {água }}+\mathrm{y}_{\text {etan ol }} \cdot \mathrm{h}_{\mathrm{etan} \mathrm{ol}}+\mathrm{h}^{\mathrm{E}}
$$

As entalpias específicas da água e do etanol podem ser obtidas diretamente de uma biblioteca de propriedades termodinâmicas. Assim, foi utilizado o EES $^{\circledR}$ para a determinação desses valores.

Larkin (1974) propõe a seguinte expressão para a determinação da entalpia de excesso (em $\mathrm{kJ} / \mathrm{kmol})$ :

$$
\mathrm{h}^{\mathrm{E}}=\mathrm{y}_{\mathrm{etanol}} \cdot\left(1-\mathrm{y}_{\mathrm{etanol}}\right) \cdot\left(\mathrm{a}_{0}+\mathrm{a}_{0,5} \cdot \mathrm{y}_{\mathrm{etanol}}^{0,5}+\mathrm{a}_{1,5} \cdot \mathrm{y}_{\mathrm{etanol}}^{1,5}+\mathrm{a}_{2,5} \cdot \mathrm{y}_{\mathrm{etanol}}^{2,5}+\mathrm{a}_{4,5} \cdot \mathrm{y}_{\mathrm{etanol}}^{4,5}\right)(41)
$$

\footnotetext{
${ }^{16}$ Inclui: vinho antes da destilação, álcool hidratado obtido na destilação e vinhaça (com teor alcoólico de $\left.0,03^{\circ} \mathrm{GL}\right)$.
} 
onde: $\mathrm{a}_{0}=-3,63868 \times 10^{5}+1,83829 \times 10^{3} \cdot \mathrm{T}-2,32763 \cdot \mathrm{T}^{2}$

$$
\begin{aligned}
& \mathrm{a}_{0,5}=9,25982 \times 10^{5}-4,83586 \times 10^{3} \cdot \mathrm{T}+6,37228 \cdot \mathrm{T}^{2} \\
& \mathrm{a}_{1,5}=-14,04894 \times 10^{5}+7,51661 \times 10^{3} \cdot \mathrm{T}-10,1128 \cdot \mathrm{T}^{2} \\
& \mathrm{a}_{2,5}=10,91318 \times 10^{5}-5,89498 \times 10^{3} \cdot \mathrm{T}+7,98868 \cdot \mathrm{T}^{2} \\
& \mathrm{a}_{4,5}=-2,79986 \times 10^{5}+1,50557 \times 10^{3} \cdot \mathrm{T}-2,03127 \cdot \mathrm{T}^{2}
\end{aligned}
$$

\subsubsection{Coeficientes de Atividade}

Gmehling, Onken, e Arlt (1981) propõem as seguintes correlações para a determinação dos coeficientes de atividade de soluções água-etanol:

$$
\begin{aligned}
& \gamma_{\text {água }}=\exp \left[a_{21} \cdot\left(\frac{a_{12} \cdot y_{\text {etan ol }}}{a_{12} \cdot y_{\text {etan ol }}+a_{21} \cdot y_{\text {água }}}\right)^{2}\right] \\
& \gamma_{\text {etan ol }}=\exp \left[a_{12} \cdot\left(\frac{a_{21} \cdot y_{\text {água }}}{a_{12} \cdot y_{\text {etan ol }}+a_{21} \cdot y_{\text {água }}}\right)^{2}\right]
\end{aligned}
$$

\subsubsection{Equilíbrio Líquido-Vapor}

Mais uma vez a Lei de Raoult Modificada pode ser utilizada para determinação do equilíbrio líquido-vapor, agora para soluções água-etanol.

$$
\begin{aligned}
& \underset{\text { vapor }}{\mathrm{y}_{\text {água }}} \cdot \mathrm{p}_{\text {vapor }}=\gamma_{\text {água }} \cdot \underset{\text { sol }}{\mathrm{y}_{\text {água }}} \cdot \underset{\text { água }}{\mathrm{p}_{\text {sat }}}\left(\mathrm{T}_{\text {sol }}\right) \\
& \underset{\text { vapor }}{\mathrm{y}_{\text {etan ol }}} \cdot \mathrm{p}_{\text {vapor }}=\gamma_{\text {etan ol }} \cdot \underset{\text { sol }}{\mathrm{y}_{\text {etan ol }}} \cdot \mathrm{p}_{\text {sat }}\left(\mathrm{T}_{\text {sol ol }}\right)
\end{aligned}
$$

Ainda, as seguintes restrições devem ser utilizadas para determinação das frações molares em cada uma das fases:

$$
\underset{\text { vapor }}{\mathrm{y}_{\text {vaua }}}+\underset{\substack{\text { vapor } \\ \text { vapol }}}{\mathrm{y}_{\text {apo }}}=1
$$




$$
\mathrm{y}_{\substack{\text { água } \\ \text { solução }}}+\underset{\substack{\text { etan ol } \\ \text { solução }}}{y^{\prime}}=1
$$

\subsubsection{Entropia Específica}

A entropia específica de uma solução $(\mathrm{kJ} / \mathrm{kmol} . \mathrm{K})$ pode ser calculada pela soma da entropia específica de uma solução ideal e um termo de mistura, chamado de entropia de excesso (ABBOT; SMITH; VAN NESS, 2001). Assim, para uma solução água-etanol:

$$
\mathrm{s}_{\mathrm{sol}}=\left[\mathrm{y}_{\text {água }} \cdot \mathrm{s}_{\text {água }}+\mathrm{y}_{\mathrm{etan} \mathrm{ol}} \cdot \mathrm{s}_{\mathrm{etan} \mathrm{ol}}+\mathrm{R} \cdot\left(\mathrm{y}_{\text {água }} \cdot \ln \mathrm{y}_{\text {água }}+\mathrm{y}_{\mathrm{etan} \mathrm{ol}} \cdot \ln \mathrm{y}_{\mathrm{etan} \mathrm{ol}}\right)\right]+\mathrm{s}^{\mathrm{E}}
$$

Da mesma forma que para a entalpia, os valores para a entropia podem ser obtidos de uma biblioteca de propriedades termodinâmicas. Para determinação da entropia de excesso, é possível utilizar a definição da Energia Livre de Gibbs de Excesso:

$$
g^{E}=h^{E}-T \cdot s^{E} \Rightarrow s^{E}=\frac{h^{E}-g^{E}}{T}
$$

Sendo a Energia Livre de Gibbs de Excesso calculada por (ABBOT; SMITH; VAN NESS, 2001):

$$
\frac{\mathrm{g}^{\mathrm{E}}}{\mathrm{R} \cdot \mathrm{T}}=\mathrm{y}_{\text {etan ol }} \cdot \ln \gamma_{\text {etan ol }}+\mathrm{y}_{\text {água }} \cdot \ln \gamma_{\text {água }}
$$

\subsubsection{Exergia Específica}

Dado o ambiente de referência, a exergia da solução água-etanol pode ser calculada de acordo com as seguintes equações (SZARGUT; MORRIS; STEWARD, 1988):

\section{Parcela Física $(\mathrm{kJ} / \mathrm{kg})$ :}

$$
\mathrm{b}_{\text {fis }}=\mathrm{h}_{\text {sol }}(\mathrm{T}, \mathrm{p})-\mathrm{h}_{\text {sol }}\left(\mathrm{T}_{0}, \mathrm{p}_{0}\right)-\mathrm{T}_{0} \cdot\left(\mathrm{s}_{\mathrm{sol}}(\mathrm{T}, \mathrm{p})-\mathrm{s}_{\mathrm{sol}}\left(\mathrm{T}_{0}, \mathrm{p}_{0}\right)\right)
$$




\section{Parcela Química (kJ/kg):}

$$
\begin{aligned}
\mathrm{b}_{\text {qui }}=\frac{1}{\mathrm{MM}_{\text {sol }}} \cdot\left[\left(\mathrm{y}_{\text {água }} \cdot \mathrm{b}_{\text {qui,água }}^{00}+\mathrm{y}_{\text {e tan ol }} \cdot \mathrm{b}_{\text {qui, e tan ol }}^{00}\right)+\right. \\
\left.\mathrm{R} \cdot \mathrm{T}_{0} \cdot\left(\mathrm{y}_{\text {água }} \cdot \ln \left(\mathrm{y}_{\text {água }} \cdot \gamma_{\text {água }}\right)+\mathrm{y}_{\text {e tan ol }} \cdot \ln \left(\mathrm{y}_{\text {etan ol }} \cdot \gamma_{\text {etan ol }}\right)\right)\right]
\end{aligned}
$$

\subsubsection{Bagaço de Cana}

\subsubsection{Exergia Específica}

Há duas metodologias para determinação da exergia específica do bagaço (WITTWER, 1993; SZARGUT; MORRIS; STEWARD, 1988). Segundo Sosa-Arnao e Nebra (2005), a metodologia proposta por Szargut, Morris e Steward (1988) é mais eficaz e foi a escolhida para determinação da exergia do bagaço. Desta maneira, a exergia específica do bagaço pode ser calculada, a partir do seu Poder Calorífico Inferior (PCI), por:

$$
\begin{aligned}
\mathrm{b}_{\text {qui }}=\beta \cdot\left(\mathrm{PCI}_{\text {bagaço }}+\right. & \left.\mathrm{x}_{\text {umidade }} \cdot \mathrm{h}_{\mathrm{lv}}\right)+\mathrm{x}_{\text {umidade }} \cdot \mathrm{b}_{\text {qui,água }}^{00}+ \\
& \mathrm{x}_{\text {enxofre }} \cdot\left(\mathrm{b}_{\text {qui,enxofre }}^{00}-\mathrm{PCI}_{\text {enxofre }}\right)+\mathrm{x}_{\text {cinzas }} \cdot \mathrm{b}_{\text {qui,cinzas }}^{00}
\end{aligned}
$$

Essa metodologia leva em consideração correlações obtidas de características de compostos orgânicos e estendidas para materiais mais complexos, como a madeira (SZARGUT, 2005):

$$
\beta=\frac{1,0412+0,2160 \cdot \frac{\mathrm{x}_{\mathrm{H}_{2}}}{\mathrm{x}_{\mathrm{C}}}+0,2499 \cdot \frac{\mathrm{x}_{\mathrm{O}_{2}}}{\mathrm{x}_{\mathrm{C}}} \cdot\left[1+0,7884 \cdot \frac{\mathrm{x}_{\mathrm{H}_{2}}}{\mathrm{x}_{\mathrm{C}}}\right]+0,0450 \cdot \frac{\mathrm{x}_{\mathrm{N}_{2}}}{\mathrm{x}_{\mathrm{C}}}}{1-0,3035 \cdot \frac{\mathrm{x}_{\mathrm{O}_{2}}}{\mathrm{x}_{\mathrm{C}}}}
$$

O PCI do bagaço pode ser calculado, através da sua composição elementar (CORTEZ; LORA, 1997), por:

$$
\mathrm{PCI}=\left[339 \cdot \mathrm{x}_{\mathrm{C}}+1030 \cdot \mathrm{x}_{\mathrm{H}}-109 \cdot\left(\mathrm{x}_{\mathrm{O}}-\mathrm{x}_{\mathrm{S}}\right)-24 \cdot \mathrm{x}_{\text {umidade }}\right] \cdot 100
$$


Ou a partir da quantidade de sacarose e água na sua composição (HUGOT, 1986):

$$
\mathrm{PCI}=17791-\left(42 \cdot \mathrm{x}_{\text {sacarose }}+200,8 \cdot \mathrm{x}_{\text {umidade }}\right) \cdot 100
$$

Nos modelos elaborados, optou-se pela segunda expressão.

\subsubsection{Entalpia de Formação}

Para o cálculo da reação de combustão nas caldeiras ou da gaseificação, é necessário conhecer a entalpia de formação do bagaço. Para tanto, utilizou-se a seguinte expressão (LI et al., 2004):

$$
\mathrm{h}_{\mathrm{f}, 298 \mathrm{~K}}=\mathrm{PCS}-\left(327,63 \cdot \mathrm{x}_{\mathrm{C}}+1417,94 \cdot \mathrm{x}_{\mathrm{H}}+92,57 \cdot \mathrm{x}_{\mathrm{S}}+158,67 \cdot \mathrm{x}_{\text {umidade }}\right) \cdot 100
$$

\subsubsection{Cana}

A exergia da cana pode ser calculada como a soma das exergias da fibra e do caldo presente na cana, considerando uma mistura ideal (MODESTO; ZEMP; NEBRA, 2006a):

$$
\mathrm{b}_{\text {cana }}=\mathrm{x}_{\text {fibra }} \cdot \mathrm{b}_{\text {fibra }}+\left(1-\mathrm{x}_{\text {fibra }}\right) \cdot \mathrm{b}_{\text {caldo }} \text { cana }
$$

A exergia da fibra pode ser calculada utilizando a mesma metodologia apresentada para o bagaço, porém sem a presença da umidade e da sacarose, ou seja, eqs.(55), (56) e (57). A exergia do caldo é calculada conforme demonstrado anteriormente, sendo o teor de sólidos desse caldo calculado por:

$$
\mathrm{X}_{\substack{\text { sólidos solúveis } \\
\text { caldo }}}=\frac{\mathrm{X}_{\text {sólidos solúveis }} \text { cana }}{\mathrm{X}_{\begin{array}{c}
\text { sólidos solúveis } \\
\text { cana }
\end{array}}+\mathrm{X}_{\text {água }}}
$$

\subsection{5. Água e Vapor}

A biblioteca de propriedades STEAM_IAPWS do software EES ${ }^{\circledR}$ foi utilizada para o cálculo das propriedades da água e vapor puros. 


\subsubsection{Ar, Gases de Combustão e Gás Proveniente da Gaseificação}

A exergia específica, associada ao ar, gases de combustão e gás produzido (considerados uma mistura ideal de gases ideais), foi determinada por:

\section{Química $(\mathrm{kJ} / \mathrm{kg})$ :}

$$
\mathrm{b}_{\text {qui }}=\frac{1}{\mathrm{MM}_{\text {mist }}} \cdot\left(\sum_{\mathrm{i}} \mathrm{y}_{\mathrm{i}} \cdot \mathrm{b}_{\text {qui,i }}^{00}+\mathrm{R} \cdot \mathrm{T}_{0} \cdot \sum_{\mathrm{i}} \mathrm{y}_{\mathrm{i}} \ln \mathrm{y}_{\mathrm{i}}\right)
$$

\section{Física $(\mathrm{kJ} / \mathrm{kg})$ :}

$$
\mathrm{b}_{\text {fis }}=\sum_{\mathrm{i}} \mathrm{x}_{\mathrm{i}}\left(\mathrm{h}_{\mathrm{i}}-\mathrm{T}_{0} \cdot \mathrm{s}_{\mathrm{i}}\right)-\left(\mathrm{h}_{0}-\mathrm{T}_{0} \cdot \mathrm{s}_{0}\right)
$$

Sendo as entalpias e entropias calculadas a partir do uso da biblioteca de propriedades termodinâmicas do $\mathrm{EES}^{\circledR}$.

As equações mostradas foram utilizadas para o desenvolvimento de modelos dos principais processos de conversão de energia de uma usina. 


\section{ANÁLISE EXERGÉTICA DE UMA USINA SUCROALCOOLEIRA TRADICIONAL}

\subsection{MODELAGEM DOS PROCESSOS DE CONVERSÃO DE ENERGIA EM USINAS SUCROALCOOLEIRAS}

Para a avaliação exergética dos processos de conversão de energia, modelos foram desenvolvidos para simular a produção simultânea de açúcar, álcool e eletricidade. Os modelos dos diferentes equipamentos/processos da usina são compostos por balanços de massa, energia, exergia e custos para, permitindo variar os principais parâmetros de operação de usinas reais:

\footnotetext{
$\checkmark$ Composição da cana moída;

$\checkmark$ Quantidade de água de embebição;

$\checkmark$ Quantidade de caldo para produção de açúcar e de álcool.
}

Além disso, é possível fazer alterações que modifiquem a estrutura física dos componentes da usina:

$\checkmark$ Pressão dos efeitos do evaporador;

$\checkmark$ Opção do efeito no evaporador para extração do vapor a ser utilizado nos diferentes processos de aquecimento;

$\checkmark$ Escolha da pressão e temperatura de geração do vapor nas caldeiras;

$\checkmark$ Escolha pela eletrificação ou não dos acionamentos mecânicos da moenda.

Alguns parâmetros necessários para o desenvolvimento dos modelos (concentração do xarope, das massas cozidas, dos méis, do caldo filtrado, quantidade de torta de filtro produzidado) foram retirados da operação da Usina Iracema, do Grupo São Martinho, durante os anos de 2004 e 2005, por meio de levantamentos de campo e discussões com engenheiros e técnicos responsáveis pelas áreas nas usinas, além de contatos com fabricantes de equipamentos para essa agroindústria (Dedini, TGM Turbinas, NG Metalúrgica, Equipalco e HPB). Contudo, o modelo final desenvolvido pode ser adpatado a qualquer usina a partir da alteração desses parâmetros para a usina a ser avaliada. 
A seguir, as principais características dos modelos desenvolvidos para cada operação unitária da usina serão descritas, o equacionamento utilizado é apresentado no Apêndice A.

\subsubsection{Sistema de Extração}

O modelo desenvolvido para a moenda consiste de balanços de massa total, para sólidos solúveis, para sacarose e para fibra, considerando uma vazão e composição de cana, uma dada razão entre a quantidade de água de embebição e a fibra da cana e uma eficiência de extração (razão entre a sacarose no caldo e a sacarose na cana). A potência consumida pela operação foi fixada em $15 \mathrm{kWh} / \mathrm{tc}$ e o consumo de vapor consumido pelos turboacionadores determinados por balanços de energia nesses equipamentos.

\subsubsection{Planta de Tratamento de Caldo}

Nessa etapa do processo, ocorre basicamente o aquecimento do caldo até a temperatura desejada na entrada dos evaporadores ou da fermentação. Assim, dadas as temperaturas de entrada e saída do caldo, o balanço de energia para o trocador de calor fornece como resultado a quantidade de vapor necessário para o aquecimento, considerando que na saída do trocador o condensado está saturado. Considera-se uma eficiência de $98 \%$ na troca térmica. Com relação ao tanque flash, a aplicação conjunta dos balanços de massa e energia permite determinar a quantidade de vapor evaporada, e o balanço de sólidos solúveis, a concentração de caldo na saída. Para o decantador, utilizaram-se dados levantados na literatura e na usina para a determinação do volume de lodo e de torta de filtro produzido.

\subsubsection{Sistema de Evaporação}

Os parâmetros de entrada do modelo são: vazão, temperatura e concentração do caldo na entrada, concentração requerida na saída, demandas de extrações de vapor em cada evaporador (definidas pelos consumos de vapor na planta de tratamento de caldo e cozimento), pressão de cada corpo (as pressões consideradas foram as praticadas na Usina Iracema). Os balanços de massa são responsáveis pela determinação da concentração do caldo na saída de cada efeito, além da vazão de vapor vegetal gerado. A temperatura do caldo na saída de cada efeito é determinada pelo equilíbrio líquido-vapor determinado pela Lei de 
Raoult Modificada (eq.(36)). O balanço de energia determina a vazão de vapor necessária em cada efeito.

\subsubsection{Cozimento e Centrifugação}

Como para os evaporadores, os tachos de cozimento foram modelados utilizando considerações do equilíbrio líquido-vapor. Porém, para esses cálculos é necessário o conhecimento da concentração da massa cozida, parâmetro retirado da operação da Usina Iracema. Com relação às centrífugas, foram elaborados balanços de massa total e para sólidos solúveis para a determinação da vazão de água de lavagem necessária.

\subsubsection{Produção de Álcool}

A produção de álcool foi modelada a partir de parâmetros operacionais como: rendimento fermentativo $^{17}$, rendimento de destilação, consumo de vapor por litro de álcool e fração de vinho para produção de anidro ${ }^{18}$. O modelo considera ainda a diluição do mosto com água para obter concentrações que não inibam o processo de fermentação - a concentração do mosto foi limitada a $16^{\circ}$ Brix. Desta maneira, a partir de uma dada quantidade de Açúcares Redutores Totais (ART), utilizando-se as relações estequiométricas 0,65030 L de álcool anidro/kg de ART e 0,67866 L de álcool hidratado/kg de ART (FERNANDES, 2003) e os rendimentos fermentativo e da destilação é possível determinar as vazões de álcool hidratado e álcool anidro produzidas (ver eq. A.77). A partir do consumo de vapor por litro de álcool, obtém-se o consumo de vapor na destilaria. Não foi levada em consideração a vazão de água de resfriamento das dornas de fermentação.

\subsubsection{Caldeiras}

Para a modelagem das caldeiras, foi desenvolvido o balanço de energia da reação de combustão, considerando uma composição para o bagaço e um dado excesso de ar. Esse balanço permite avaliar a temperatura de exaustão dos gases de combustão, partindo de uma

\footnotetext{
${ }^{17}$ Relação entre a conversão de ART em álcool e a relação estequiométrica teórica dessa conversão.

${ }^{18}$ Não foram desenvolvidos equacionamentos para: as reações de conversão de ART em álcool, recuperação da levedura e separação da solução etanol-água (destilação).
} 
eficiência com base no PCI. O balanço de energia na caldeira define a quantidade de bagaço necessária para atender aos processos da usina, no caso em que se deseja operar com paridade térmica com o processo. Quando se está simulando configurações que utilizem turbinas de condensação, a vazão de bagaço deve ser fixada e a vazão de vapor é definida pelo balanço de energia.

\subsubsection{Turbinas}

Os turboacionadores já foram discutidos anteriormente. As turbinas são modeladas considerando as eficiências isoentrópicas desses equipamentos ou consumos específicos de vapor ( $\mathrm{kg}$ de vapor $/ \mathrm{kWh}$ gerado). O consumo de eletricidade na usina foi fixado em 15 $\mathrm{kWh} / \mathrm{tc}$, podendo ser modificado em função da usina estudada. Para configurações onde não há geração excedente de eletricidade, o balanço de energia na turbina de contrapressão determina a vazão de vapor que passa pela mesma. A diferença entre o consumo de vapor de escape no processo (vapor para sistema de evaporação e para o último aquecimento do caldo clarificado) e o vapor proveniente das turbinas de potência elétrica e das moendas é igual ao vapor que é expandido na válvula. Para configurações com geração de eletricidade excedente, não há vapor expandido na válvula. Quando há utilização da condensação, a quantidade excedente de vapor (excesso em relação ao consumo pelo processo) é enviada para o condensador.

\subsection{SIMULAÇÃO DOS PROCESSOS DE CONVERSÃO DE ENERGIA EM USINAS SUCROALCOOLEIRAS}

Os modelos desenvolvidos para os diferentes processos de conversão de energia, cujos equacionamentos são apresentados nos Apêndices A e C, foram implementados no software $\operatorname{EES}^{\circledR}$ (KLEIN, 2008) para a simulação da operação em regime permanente da usina. Para o desenvolvimento, foram criadas rotinas de cálculo para as propriedades termodinâmicas das soluções água-sacarose e água-etanol, além de outras para os diferentes equipamentos presentes na usina.

Para as simulações é necessário especificar:

$\checkmark$ Composição da cana moída; 
$\checkmark$ Quantidade de água de embebição;

$\checkmark$ Quantidade de caldo misto e filtrado para produção de açúcar e de álcool;

$\checkmark$ Rendimento fermentativo e rendimento da destilação para a produção de álcool;

$\checkmark$ Consumo específico de vapor para produção de álcool $(\mathrm{kg} / \mathrm{L})$;

$\checkmark$ Consumo específico energia mecânica nas moendas ( $\mathrm{kWh} / \mathrm{tc})$;

$\checkmark$ Consumo de energia elétrica na usina (kWh/tc);

$\checkmark$ Concentração dos fluxos no processo de cozimento e centrifugação.

E os resultados das simulações apresentam:

$\checkmark$ Quantidades de açúcar, álcool e/ou eletricidade produzidos;

$\checkmark$ Consumo de vapor;

$\checkmark$ Excedentes de bagaço;

$\checkmark$ Quantificação dos subprodutos e emissões.

Alguns dos resultados dos modelos desenvolvidos foram publicados em diferentes congressos, destacando-se Pellegrini e Oliveira Jr. (2006a, 2006b e 2007b).

\subsection{ANÁliSE EXERGÉtICA DE UMA USINA SUCROALCOOLEIRA TRADICIONAL}

Para essa usina tradicional, foi considerada uma estratégia de operação 50/50, ou seja, metade dos açúcares redutores totais foi utilizada para produção de açúcar e metade para a produção de álcool hidratado. Além disso, não há geração de eletricidade excedente, sendo a energia elétrica gerada em turbinas de contrapressão (eficiência isoentrópica igual a 65\%) utilizando vapor de 21 bar e $300^{\circ} \mathrm{C}$. O consumo de energia elétrica considerado foi de $15 \mathrm{kWh} / \mathrm{tc}$. O sistema de preparo e os ternos da moenda também são acionados por turbinas de contrapressão (eficiência isoentrópica de 55\%), considerando uma energia mecânica de 15 $\mathrm{kWh} / \mathrm{tc}$. Ainda, considerou-se uma eficiência de extração (recuperação de ART no caldo) de $95,7 \%$, parâmetro usual em moendas. A eficiência energética da caldeira foi fixada em $82 \%$, sendo que a recuperação de condensado limpo do processo é igual a $95 \%{ }^{19}$

\footnotetext{
19 Valores baseados em levantamentos realizados entre 2003 e 2005 junto à Usina Iracema da Companhia Agroindustrial Ometto, localizada no município de Iracemápolis/SP.
} 
Com relação aos processos de fabricação de açúcar e álcool, foi utilizado um evaporador com 5 efeitos (concentração de $60 \%$ de sólidos na saída do último efeito) e um sistema de 2 massas para o cozimento. O consumo de vapor na destilaria foi avaliado a partir de parâmetros operacionais de usinas tradicionais e ineficientes, sendo igual a 3,5 $\mathrm{kg}$ (saturado a 2,5 bar)/L de álcool hidratado.

Para as simulações foi considerada a composição da cana e da fibra mostradas nas Tabs. 6.1 e 6.2 , respectivamente.

Tabela 6.1 - Composição da Cana.

\begin{tabular}{cc}
\hline Componente & Fração Mássica (\%) \\
\hline Fibra & 12,5 \\
Umidade & 71,5 \\
Sacarose & 13,7 \\
Glicose e Frutose & 0,5 \\
Não-açúcares & 1,8 \\
\hline
\end{tabular}

Tabela 6.2 - Composição da fibra.

\begin{tabular}{cc}
\hline Componente & Fração Mássica (\%) \\
\hline Carbono & 46,7 \\
Hidrogênio & 5,8 \\
Oxigênio & 46,5 \\
Cinzas & 1,0 \\
\hline
\end{tabular}

A Tab. 6.3 mostra os resultados obtidos na simulação.

Tabela 6.3 - Resultados da Simulação de uma Usina Sucroalcooleira Tradicional

\begin{tabular}{lc}
\hline Açúcar Produzido $(\mathrm{kg} / \mathrm{tc})$ & 62,4 \\
Álcool Produzido $(\mathrm{L} / \mathrm{tc})$ & 42,8 \\
Geração de Vapor $(\mathrm{kg} / \mathrm{tc})$ & 507 \\
Excesso de bagaço produzido $(\%)$ & 18 \\
Exergia Perdida com o bagaço excedente $(\mathrm{kWh} / \mathrm{tc})$ & 132 \\
Consumo específico de vapor no processo $(\mathrm{kg} / \mathrm{tc})$ & 490 \\
Exergia destruída específica total $(\mathrm{kWh} / \mathrm{tc})$ & 743 \\
\hline
\end{tabular}


A Tab. 6.4 mostra valores de referência para temperatura, pressão, concentração e exergia específica para alguns fluxos da usina.

Tabela 6.4 - Valores de referência para propriedades de alguns fluxos da usina.

\begin{tabular}{ccccc}
\hline Fluxo & $\begin{array}{c}\text { Temperatura } \\
(\mathbf{0 C})\end{array}$ & $\begin{array}{c}\text { Pressão } \\
\text { (bar) }\end{array}$ & $\begin{array}{c}\text { Fração } \\
\text { Mássica de } \\
\text { Sólidos }\end{array}$ & $\begin{array}{c}\text { Exergia } \\
\text { (kJ/kg) }\end{array}$ \\
\hline Cana-de-Açúcar & 25 & 1,01 & $16.00 \%$ & 5614 \\
Bagaço & 25 & 1,01 & $50.00 \% *$ & 9892 \\
Caldo Bruto & 35 & 1,01 & $15,45 \%$ & 3154 \\
Caldo Clarificado & 115 & 2 & $16,25 \%$ & 3330 \\
Xarope & 62,39 & 0,2 & $60.00 \%$ & 10736 \\
Açúcar & 60,06 & 0,2 & $99,96 \%$ & 17485 \\
Mel Final & 60,06 & 0,2 & $76,72 \%$ & 13585 \\
Mosto & 44,18 & 1,01 & $16.00 \%$ & 3247 \\
Álcool Hidratado & 25 & 1,01 & - & 27224 \\
Vapor para Processo & 140 & 2,5 & - & 1152 \\
\hline
\end{tabular}

*50\% de umidade.

A Fig. 6.1 a seguir mostra a distribuição de irreversibilidades na usina.

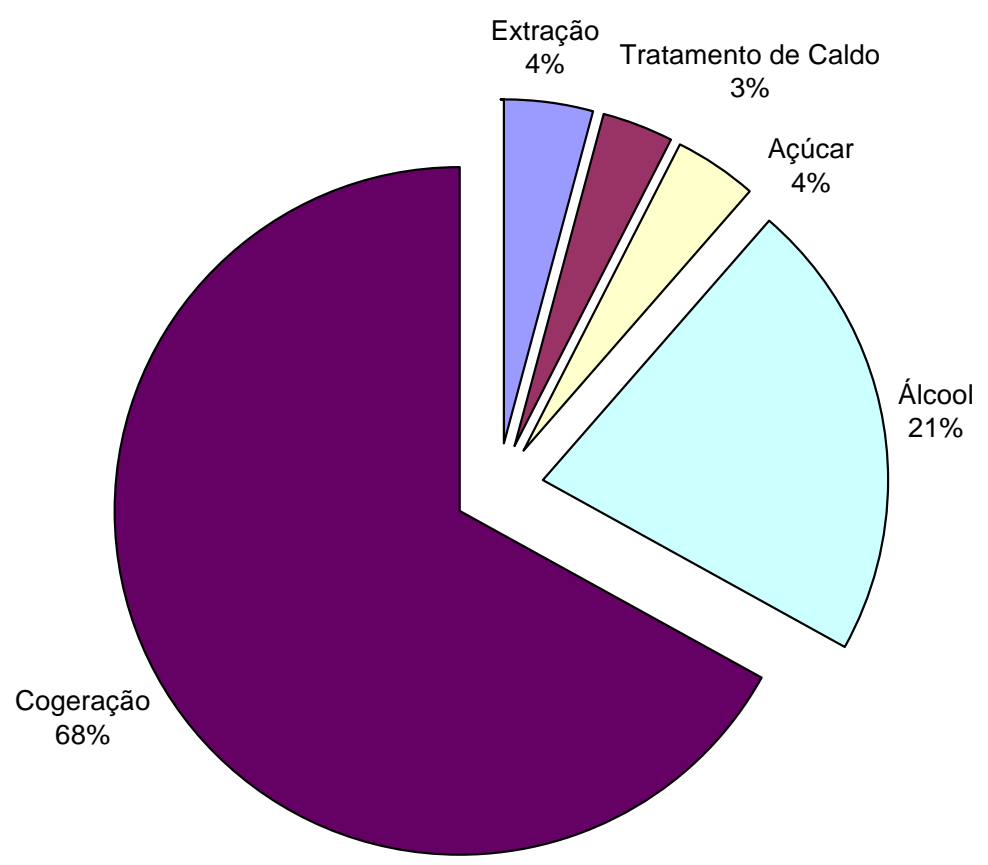

Figura 6.1 - Distribuição da Exergia Destruída na Usina. 
Vale ressaltar que esses valores estão em conformidade com trabalhos anteriores (GOUTTE, 1987, CASTIER; RAJAGOPAL, 1988; GUALLAR; VALERO, 1989).

A principal área responsável pela destruição de exergia é o sistema de cogeração, seguido da produção de álcool. Ou seja, modificações no sistema de cogeração deverão levar a ganhos com relação ao aumento da eficiência exergética nas usinas (BEYER, 1970; BRODYANSKY; SORIN; LE GOFF, 1994; KOTAS, 1995).

A proposta nos próximos parágrafos é discutir as fontes da destruição de exergia em cada um dos volumes de controle definidos e identificar potenciais formas de ganhos de eficiência.

\subsection{SISTEMA DE EXTRAÇÃO}

O objetivo deste sistema é separar a fibra (na forma de bagaço) do caldo presentes na cana, utilizando para isso energia mecânica proveniente das turbinas no caso de uma usina tradicional. Assim, pode-se definir o rendimento exergético da extração como a razão entre a diferença das exergias dos produtos separados (bagaço e caldo) e da cana e a variação da exergia do vapor que passa pelas turbinas somada à exergia da água de embebição (eq. (62)):

$$
\eta=\frac{\left(\dot{\mathrm{B}}_{\text {caldo }}+\dot{\mathrm{B}}_{\text {bagaço }}\right)-\dot{\mathrm{B}}_{\text {cana }}}{\dot{\mathrm{m}}_{\text {vapor }} \cdot\left(\mathrm{b}_{\text {entrada }}-\mathrm{b}_{\text {saída }}\right)+\dot{\mathrm{B}}_{\text {água }}}
$$

O valor da eficiência exergética do sistema de extração é igual a $52 \%$. O aumento da eficiência pode ser obtido ou pelo aumento da exergia dos produtos (bagaço e caldo) ou pela diminuição da exergia dos insumos (potência mecânica - variação da exergia do vapor - e água de embebição). No primeiro caso, a exergia dos produtos está diretamente relacionada à exergia da cana e à eficiência de recuperação da sacarose da mesma. A redução da exergia dos insumos é interessante apenas para a geração de potência mecânica, já que a redução do consumo da água de embebição reduz a eficiência de recuperação de sacarose o que não é conveniente para a fabricação de açúcar e álcool. Ainda, as irreversibilidades das turbinas do preparo e da moenda representam quase $40 \%$ do total do sistema de extração. Assim, a substituição dessas turbinas por motores elétricos é uma opção mais eficiente visto que a 
eletricidade utilizada nesses motores poderá ser gerada em turbinas mais eficientes que as utilizadas para o acionamento direto.

O uso do difusor não foi avaliado nesse trabalho. Porém, algumas considerações são feitas a seguir:

Difusores apresentam maiores eficiências de recuperação de sacarose, o que deve aumentar a exergia do caldo;

$>$ Utilizam uma maior quantidade de água de embebição

> Consomem exergia térmica e mecânica para a separação ao invés de apenas exergia mecânica como nas moendas;

Apresentam menos problemas relacionados à operação e manutenção.

Todavia, o uso de difusores no Brasil é pouco difundido e não há muitas informações disponíveis sobre seu desempenho em usinas. Do ponto de vista operacional, os operadores de usinas de açúcar e álcool preferem o uso da moenda, pois essa permite a extração de dois tipos de caldo: primário e secundário. $\mathrm{O}$ caldo primário apresenta uma pureza mais elevada, o que tem um impacto positivo na qualidade do açúcar produzido; o caldo secundário de pureza inferior é normalmente utilizado para a formação do mosto antes da fermentação.

Ensinas, Modesto e Nebra (2007) concluem que o uso de difusores é uma boa opção para maior geração de eletricidade excedente em comparação com moendas movidas com turbinas a vapor, porém o impacto nos custos exergéticos de produção de açúcar, álcool e eletricidade é muito pequeno; ainda, com a eletrificação dos acionamentos a quantidade de eletricidade excedente quase não varia com o sistema de extração escolhido. Conforme mostrado na Fig. 6.1, o sistema de extração é responsável por apenas $4 \%$ das irreversibilidades da usina e, portanto, o impacto de modificações nesse sistema nos custos de produção de açúcar, álcool e eletricidade deverá ser muito pequeno.

\subsection{TRATAMENTO DE CALDO}

A etapa de tratamento de caldo visa adequar o $\mathrm{pH}$ do caldo a um nível onde as perdas de sacarose por inversão sejam minimizadas. Além disso, durante o tratamento ocorre a remoção do material insolúvel e outras substâncias indesejáveis. Durante o tratamento, o caldo é 
aquecido de aproximadamente $40^{\circ} \mathrm{C}$ até $105^{\circ} \mathrm{C}$ com o objetivo de eliminar microorganismos pela esterilização, completar as reações químicas com agentes alcalinizantes, flocular impurezas e remover os gases dissolvidos (“flasheamento”).

Do ponto de vista da destruição de exergia, o aquecimento do caldo é responsável por aproximadamente $50 \%$, enquanto que as etapas de decantação e filtração do lodo por $40 \%$. No caso desses últimos, as irreversibilidades estão associadas principalmente à quantidade de torta de filtro produzida (resíduo gerado a partir da remoção do material insolúvel e outras substâncias indesejáveis), ou seja, pouco pode ser feito para sua redução. Para efeitos do modelo, a exergia da torta de filtro foi considerada com uma exergia destruída.

Todavia, as irreversibilidades associadas ao aquecimento do caldo têm sua origem na diferença de temperatura entre o agente de aquecimento (vapor) e o caldo a ser aquecido. No caso base em estudo, esse aquecimento é feito utilizando-se vapor do primeiro efeito do sistema de evaporação e vapor de escape das turbinas, conforme mostrado na Fig. 6.2.

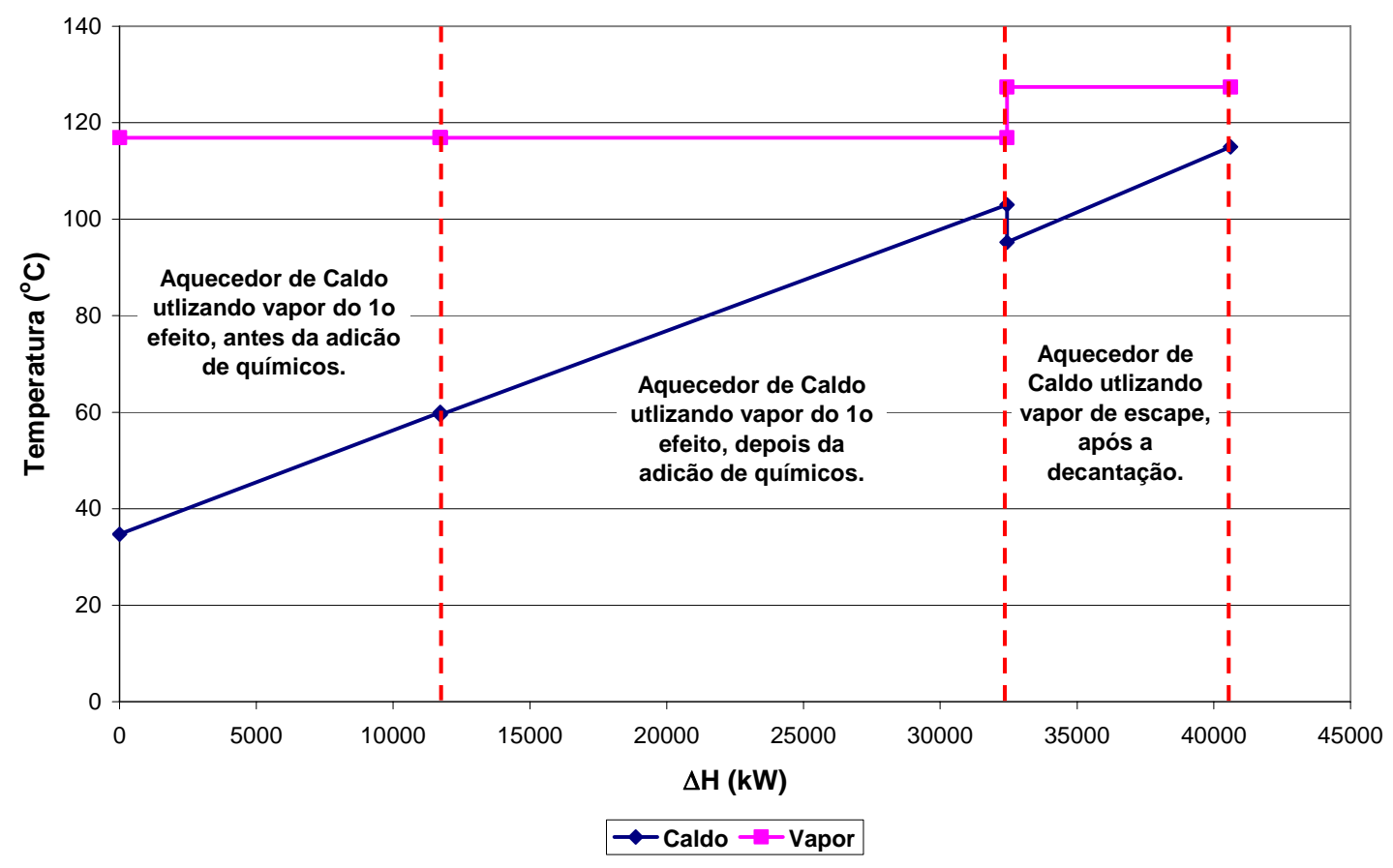

Figura 6.2 - Diagrama Temperatura vs. $\Delta \mathrm{H}$ para o sistema de aquecimento de caldo. 


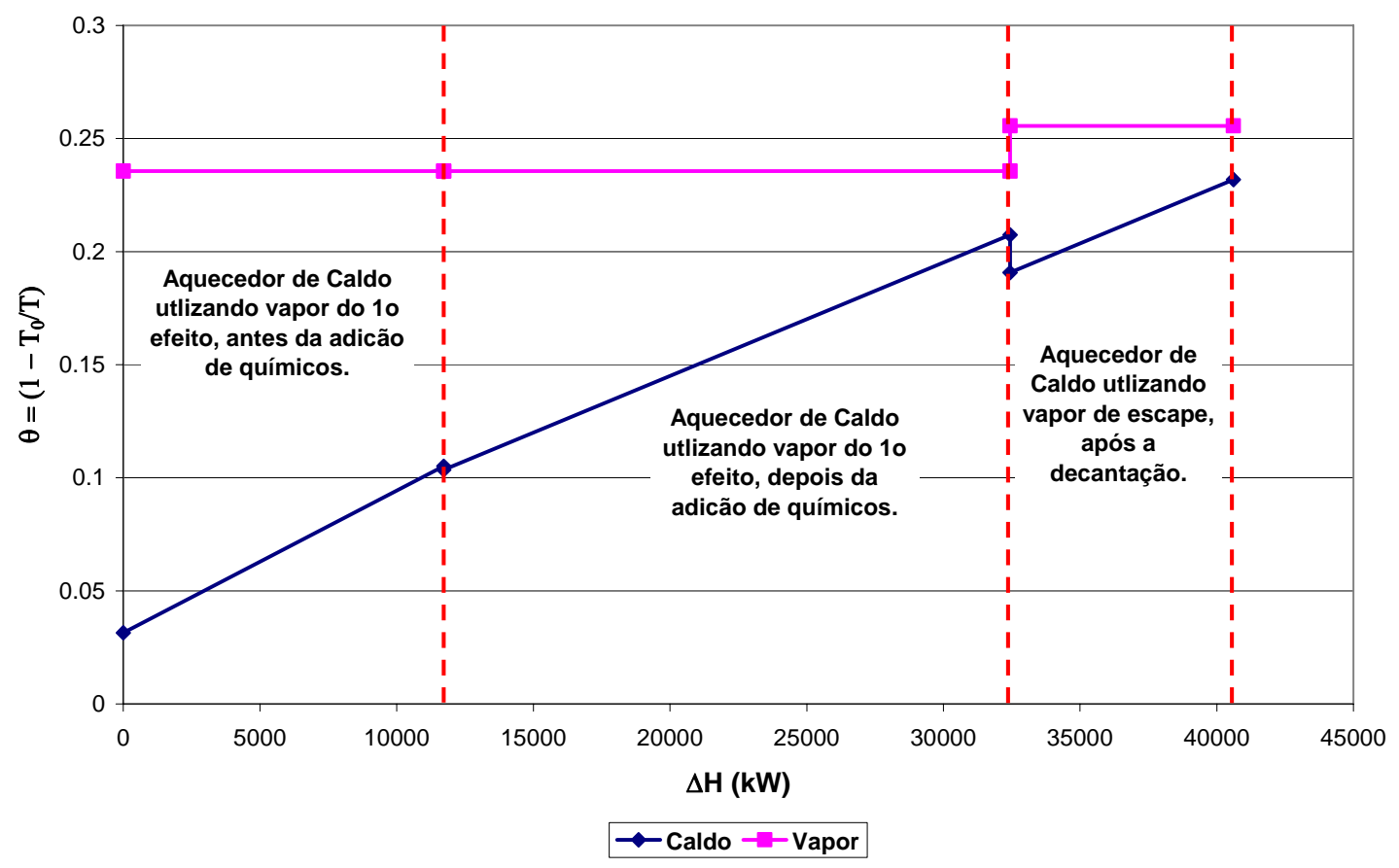

Figura 6.3- Diagrama Fator de Carnot $(\theta)$ vs. $\Delta \mathrm{H}$ para o sistema de aquecimento de caldo.

Como é possível observar na Fig. 6.2, a diferença de temperatura entre o agente de aquecimento (vapor) e o caldo é muito grande, resultando na destruição de exergia representada pela área entre as linhas para o caldo e o vapor na Fig. 6.3. Uma aproximação entre as curvas teria um grande impacto na destruição de exergia, devido à diminuição das diferenças de temperatura entre as correntes quentes e frias (redução da área entre as linhas na Fig. 6.3) (KOTAS, 1985; RIVERO; OLIVEIRA JR.; LE GOFF, 1990). Para tanto, algumas alternativas devem ser levadas em consideração:

i) Trocadores de calor regenerativos, aproveitando a exergia térmica do condensado dos evaporadores;

ii) Uso de vapor extraído de outros efeitos do sistema de evaporação (com temperaturas mais baixas em relação ao vapor do $1^{\circ}$ efeito).

Aliás, o uso de vapor dos diferentes efeitos do sistema de evaporação resulta na redução do consumo de vapor de escape e melhor desempenho exergético da evaporação.

Para a integração térmica do processo de aquecimento do caldo com as correntes quentes existentes na usina e com os diferentes vapores do sistema de evaporação, diversos autores utilizaram o método Pinch, sobretudo em fábricas de açúcar de beterraba (TWAITE; 
DAVENPORT; MACDONALD, 1986; CHRISTODOULO, 1996; HIGA, 1999, 2003; FRANCO, 2001; RAM; BANERJEE, 2003).

Ensinas (2008) desenvolveu uma estratégia de otimização termoeconômica associada ao método Pinch para a integração térmica de uma usina de produção de açúcar e álcool. A rede de trocadores de calor proposta utiliza praticamente todas as correntes quentes disponíveis (vapores vegetais, vinhaça, condensados diversos, mosto) para providenciar o aquecimento do caldo durante o tratamento, do caldo clarificado antes da evaporação, do cozimento do xarope e do vinho após a fermentação.

\subsection{PRODUÇÃO DE AÇÚCAR}

O processo de produção de açúcar consiste basicamente em separar a água da sacarose presentes no caldo. Para isso, faz-se uso de evaporadores de múltiplos-efeitos, tachos de cozimento (cozedores) e centrífugas. Nos evaporadores, o caldo é concentrado até $60-75 \%$ de sólidos utilizando vapor de escape no primeiro efeito. Em seguida, o xarope (caldo concentrado) é enviado para os cozedores, onde os cristais de açúcar são formados dentro de soluções supersaturadas, devido à evaporação da água. Os cristais são separados da solução através de centrífugas mecânicas.

As principais fontes de irreversibilidades da produção de açúcar são: tachos de cozimento (46\%), evaporadores (31\%) e condensador barométrico (17\%).

Nos evaporadores e tachos cozimentos, a diferença de temperatura entre as correntes quente e fria é o principal mecanismo de geração de entropia. Para esses sistemas a eficiência exergética é definida como a razão entre a diferença entre a exergia dos produtos (caldo concentrado e vapor gerado) e a exergia do caldo na entrada e a variação da exergia do vapor de aquecimento (eq.(63)):

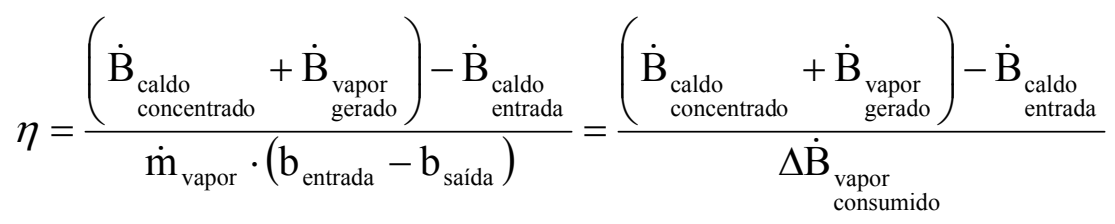


Analisando o caso dos evaporadores, a Tab. 6.5 a seguir mostra a pressão, a diferença de temperatura entre as correntes, a eficiência exergética, a participação de cada efeito na exergia destruída total e a exergia consumida em cada efeito em função da quantidade de água evaporada para os 5 efeitos.

Tabela 6.5 - Parâmetros de Desempenho do Sistema de Evaporação.

\begin{tabular}{cccccc}
\hline Efeito & Pressão & $\Delta \mathbf{T}\left({ }^{\circ} \mathbf{C}\right)$ & $\begin{array}{c}\text { Eficiência } \\
\text { Exergética (\%) }\end{array}$ & $\begin{array}{c}\text { Participação na } \\
\text { Exergia Destruída } \\
\text { Total (\%) }\end{array}$ & $\begin{array}{c}\text { Exergia } \\
\text { Consumida } \\
\text { (kJ/kg evap) }\end{array}$ \\
\hline $1^{\circ}$ & 1,80 & 9,8 & 90,6 & 50,6 & 583,4 \\
$2^{\circ}$ & 1,34 & 8,1 & 91,7 & 5,9 & 470,0 \\
$3^{\circ}$ & 0,94 & 9,1 & 89,7 & 7,5 & 446,8 \\
$4^{\circ}$ & 0,56 & 12,4 & 84,1 & 11,5 & 408,9 \\
$5^{\circ}$ & 0,20 & 21,8 & 63,9 & 24,4 & 345,7 \\
\hline
\end{tabular}

Nos evaporadores, dois mecanismos são os principais responsáveis pela geração de entropia: separação do fluxo em caldo concentrado e vapor, e a diferença de temperatura entre o vapor de aquecimento e o caldo em ebulição. O $1^{\circ}$ efeito é responsável por mais de $50,6 \%$ das irreversibilidades desse sistema, já que é responsável por $57 \%$ da água evaporada. Além disso, nesse efeito é necessário aquecer mais o caldo até a temperatura de evaporação, diferentemente dos outros corpos. $\mathrm{O} 1^{\circ}$ efeito é também o que mais consome exergia para evaporar $1 \mathrm{~kg}$ de água, porém faz isso de forma mais eficiente quando comparado com os últimos efeitos.

Partindo da equação anterior definida para eficiência exergética de um efeito, é possível escrever:

$$
\dot{\mathrm{I}}_{\text {Total }}=\sum_{\text {efeitos }} \Delta \dot{\mathrm{B}}_{\substack{\text { vapor } \\ \text { consumido }}} \cdot\left(1-\eta_{\mathrm{i}}\right)
$$

Ou seja, a irreversibilidade total do múltiplo-efeito é uma relação de troca entre o consumo de exergia e a eficiência exergética em cada um dos efeitos. Assim, o melhor desempenho desse equipamento deve buscar:

i) A distribuição das vazões de evaporação em cada efeito que minimizem a exergia consumida; 
ii) A distribuição de pressão nos efeitos que reduzam as diferenças de temperatura entre as correntes, elevando a eficiência exergética da troca térmica.

O primeiro item está relacionado diretamente à variação da concentração do caldo entre a entrada e a saída do efeito, ou seja, à diferença de potencial químico. O segundo item está relacionado à temperatura de operação do efeito (a qual também sofre influência da variação da concentração), ou seja, relaciona-se com a diferença de potencial térmico do processo.

Conforme discutido por Tondeur e Kvaalen $(1987)^{20}$, a configuração ótima termodinamicamente de um trocador de calor e/ou massa, cuja carga está definida, é aquela na qual a taxa de produção de entropia é distribuída mais uniformemente; ou seja, o quanto mais uniforme é a distribuição da geração de entropia entre as variáveis de tempo e espaço que caracterizam um trocador de calor e/ou massa, menor será a geração de entropia total. Desta maneira, a configuração ótima para o evaporador de múltiplos-efeitos é aquela na qual há uma distribuição mais uniforme da participação de cada efeito na Exergia Destruída Total, ou seja, uma solução de compromisso entre a variação da concentração em cada efeito e a pressão de operação do mesmo. A solução de compromisso implica um balanceamento entre a exergia destruída devido à troca de calor e à separação (troca de massa).

Oliveira Jr. (1991) e Rivero (1993) aplicaram a minimização da geração de entropia para trocadores de calor e colunas de destilação, chegando à conclusão que o ponto ótimo é aquele no qual a geração de entropia é uniformemente distribuída entre as variáveis características dos equipamentos.

A integração térmica do evaporador de múltiplos-efeitos com outros processos de transferência de calor presentes na usina permite a utilização dos diferentes vapores gerados no evaporador, melhorando a distribuição das vazões de evaporação em cada efeito. Ainda, tal integração permite reduzir a exergia destruída nos outros equipamentos pela diminuição da diferença de temperatura entre as correntes quentes e frias, conforme discutido anteriormente. O resultado final dessa integração é a redução do consumo de vapor no processo, o qual pode viabilizar uma maior produção de vapor para geração de eletricidade ou um aumento no excedente de bagaço que pode ser destinado para a fabricação de etanol.

\footnotetext{
${ }^{20}$ Teorema da Eqüipartição da Produção de Entropia.
} 
O uso de evaporadores com maiores coeficientes de transferência de calor (p.ex., evaporadores a placas de filme descendente) permite o uso de pressões mais elevadas nos últimos efeitos, reduzindo a diferença de temperatura nos efeitos, melhorando a eficiência exergética desses e do sistema como um todo.

Os tachos de cozimento operam de maneira similar aos evaporadores ${ }^{21}$, assim pode-se definir a eficiência desses equipamentos como a razão entre a diferença da exergia dos produtos (massa cozida e vapor gerado) e a exergia dos insumos (xarope e mel) e a variação da exergia do vapor (eq. (65)):

$$
\eta=\frac{\left(\begin{array}{c}
\dot{\mathrm{B}}_{\text {massa }}+\dot{\mathrm{B}}_{\text {vazida }} \\
\text { gerado }
\end{array}\right)-\left(\dot{\mathrm{B}}_{\text {xarope }}+\dot{\mathrm{B}}_{\text {mel }}\right)}{\dot{\mathrm{m}}_{\text {vapor }} \cdot\left(\mathrm{b}_{\text {entrada }}-\mathrm{b}_{\text {saida }}\right)}=\frac{\left(\begin{array}{c}
\dot{\mathrm{B}}_{\text {massa }}+\dot{\mathrm{B}}_{\text {cozida }} \\
\text { gerado }
\end{array}\right)-\left(\dot{\mathrm{B}}_{\text {xarope }}+\dot{\mathrm{B}}_{\text {mel }}\right)}{\Delta \dot{\mathrm{B}}_{\substack{\text { vapor } \\
\text { consumido }}}}
$$

A Tab. 6.6 mostra a pressão, a diferença de temperatura entre as correntes, a eficiência exergética e a exergia consumida em cada efeito em função da quantidade de água evaporada para esses equipamentos.

Tabela 6.6 - Parâmetros de Desempenho do Sistema de Cozimento.

\begin{tabular}{ccccc}
\hline Tacho & Pressão & $\Delta \mathbf{T}\left({ }^{\circ} \mathbf{C}\right)$ & $\begin{array}{c}\text { Eficiência } \\
\text { Exergética (\%) }\end{array}$ & $\begin{array}{c}\text { Exergia } \\
\text { Consumida } \\
(\mathbf{k J} / \mathbf{k g} \text { evap) }\end{array}$ \\
\hline $\mathrm{A}$ & 0,20 & 56,9 & 32,9 & 568,4 \\
$\mathrm{~B}$ & 0,20 & 56,9 & 27,6 & 569,0 \\
\hline
\end{tabular}

Comparando esses valores com os do sistema de evaporação, observa-se que os tachos são muito ineficientes, consumindo uma grande quantidade de exergia para evaporar $1 \mathrm{~kg}$ de água e com grandes diferenças de temperatura. Diante deste cenário, duas medidas devem ser avaliadas para diminuir as irreversibilidades do cozimento:

i) Aumentar a concentração do xarope nos evaporadores, antes do cozimento;

\footnotetext{
21 Devido à elevada viscosidade do xarope (caldo concentrado), não é mais possível concentrá-lo em evaporadores comuns. Os tachos de cozimento operam individualmente sob vácuo de maneira contínua ou descontínua.
} 
ii) Utilização de vapor de pressão mais baixa do evaporador de múltiplos-efeitos (p.ex. do $2^{\circ}$ ou $3^{\circ}$ efeito).

A primeira opção visa reduzir o consumo de exergia no sistema, enquanto a segunda objetiva reduzir a diferença de temperatura para a troca térmica, melhorando a eficiência exergética do sistema. Deve-se observar que o uso de vapor do $3^{\circ}$ efeito requer a utilização de agitadores no interior dos tachos para aumentar o coeficiente de troca, evitando tempos de operação muito elevados.

Os vapores gerados no último efeito do evaporador e aqueles provenientes dos tachos de cozimento são condensados utilizando água fria em equipamentos chamados de condensadores barométricos. Esses equipamentos são responsáveis por quase $20 \%$ das irreversibilidades dentro da fábrica de açúcar, além de serem um dos maiores consumidores de água da usina. A redução da exergia destruída nesses equipamentos é obtida pela redução da vazão de vapor a ser condensado. Assim, duas possibilidades podem ser identificadas:

i) Utilização de todo vapor gerado no sistema de evaporação como vetores térmicos para os processos da usina;

ii) Diminuição da quantidade de água evaporada no cozimento, ou seja, elevação da concentração do caldo na saída dos evaporadores.

A separação dos cristais de açúcar do mel é obtida através do uso de centrífugas acionadas por motores elétricos e que utilizam água quente para lavagem das partes internas, evitando a incrustação dos cristais. Por ser um sistema de separação, sua eficiência exergética pode ser definida por:

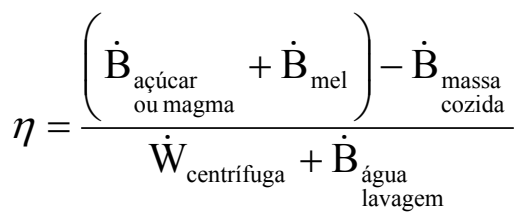

Para as centrífugas da usina analisada, os valores das eficiências são $92 \%$ e $94 \%$ para a Centrífuga A e Centrífuga $\mathrm{B}$, respectivamente. Ou seja, esses equipamentos são bastante eficientes para a separação dos componentes. 
Analisando agora a fábrica de açúcar como um todo, as seguintes alternativas devem ser estudadas para a redução da destruição de exergia:

a) Maior integração térmica entre o evaporador e os processos de aquecimento da usina, reduzindo o consumo de vapor de escape e aumentando a eficiência térmica do sistema;

b) Diminuição da diferença de temperatura entre as correntes quentes e frias do evaporador, utilizando pressões mais elevadas nos efeitos ou aumentando o número de efeitos de evaporação;

c) Elevação da concentração final do caldo antes do cozimento (sendo esta concentração limitada a $70-72^{\circ}$ Brix, dependendo da temperatura), diminuindo a quantidade de água evaporada nos tachos, o que resulta em um menor consumo de água no condensador barométrico (menos destruição de exergia).

\subsection{PRODUÇÃO DE ÁLCOOL}

A etapa de produção de álcool pode ser dividida em 2 operações: fermentação (conversão dos açúcares em álcool) e a destilação. No modelo desenvolvido, essas operações foram modeladas a partir de parâmetros operacionais típicos:

$>$ Eficiência de fermentação: $90 \%$

$>$ Eficiência de destilação: 99,5\%

Consumo específico de vapor: $3,5 \mathrm{~kg}$ de vapor/L de álcool hidratado

As irreversibilidades da produção de álcool representam $21 \%$ da exergia destruída na usina. Considerando os principais mecanismos de geração de entropia nesse volume de controle, pode-se destacar:

$\checkmark$ Reação química de conversão dos açúcares em álcool;

$\checkmark$ Dissipação de calor dada a natureza exotérmica das reações de fermentação;

$\checkmark$ Transferência de calor nas colunas da destilaria;

$\checkmark$ Produção de vinhaça, tratada nesse modelo como um resíduo. 
Com relação à conversão dos açúcares, pouco pode-se fazer para redução da geração de entropia, pois se trata de uma reação química inevitável para o processo. Porém, a busca de melhor eficiência do processo de fermentação pode reduzir a formação de sub-produtos indesejáveis, como aldeídos.

O aumento do teor alcoólico do vinho ao final da fermentação reduziria a carga térmica nas colunas de destilação. Tal aumento requer o desenvolvimento de leveduras capazes de sobreviver em condições de elevado teor alcoólico (MIT, 2007). Outra alternativa é o uso da fermentação extrativa. Segundo Luong (1985), o etanol que se acumula no meio fermentativo inibe a atividade metabólica do microrganismo. A utilização de técnicas de extração do etanol do meio fermentativo assim que ele é produzido, melhora o desempenho do processo. Dentre as configurações possíveis para esse processo destacam-se:

Fermentação associada a um sistema de flash (ATALA, 2004)

$>$ Fermentação associada a um processo de pervaporação (membrana semipermeável) (HOFFMANN; SCHEPER; SCHÜRGEL, 1987; KARGUPTA; DATTA; SANYAL, 1998);

Fermentação associada a um extrator líquido-líquido (BOLUDA et al., 2005)

Contudo, nenhum desses sistemas é atualmente utilizado em usinas sucroalcooleiras.

O processo de destilação é basicamente um processo de separação do álcool misturado com a água. No Brasil, são comumente utilizadas duas colunas:

$\checkmark$ Coluna A, cujo produto principal é o flegma (vapor em equilíbrio termodinâmico com o vinho) com aproximadamente $50 \%$ Vol. de etanol. O produto de topo dessa coluna é o álcool de segunda e o produto de fundo é chamado de vinhaça;

$\checkmark$ Coluna B, cujo produto final é o álcool hidratado. O produto de fundo dessa coluna é a flegmaça. Há também a extração de óleo fúsel, composto por produtos secundários da fermentação.

A obtenção do álcool anidro é feita utilizando sistemas de desidratação regenerativos (p.ex., peneiras moleculares). 
A principal fonte de geração de entropia em colunas de destilação é a diferença de temperatura entre o agente térmico utilizado para fornecimento de calor e a corrente da mistura a ser separada. Considerando cada estágio de maneira isolada, as irreversibilidades são fruto da troca térmica entre as correntes de líquido e vapor e da transferência de massa no estágio. Rivero (1993) e Faria (2003) mostram que o melhor desempenho termodinâmico de uma coluna está relacionado a uma distribuição uniforme da geração de entropia em seu interior $^{22}$.

$\mathrm{Na}$ análise aqui proposta as colunas de destilação foram tratadas como simples consumidores de vapor. Assim, a redução da exergia destruída nesses sistemas é função da redução do consumo de vapor para a produção de álcool. O consumo de vapor na destilaria sofreu uma considerável redução desde o lançamento do Proálcool no final dos anos 70, conforme avalia Olivério (2007). O consumo para a produção de álcool hidratado baixou pela metade, passando a 1,6 kg/L de álcool. Já o consumo para o anidro diminuiu para 2,8 kg/L de álcool (40\% menor). Seemann (2003) apresenta configurações para a destilaria que permitem reduções do consumo de vapor até valores de $1,4 \mathrm{~kg} / \mathrm{L}$ de álcool, utilizando destilação multipressão. Uma alternativa interessante para redução do consumo de vapor na destilação é o uso de sistemas de pervaporação após a coluna A. Assim, o flegma passaria por membranas que promoveriam a separação da mistura água-etanol sem o consumo de vapor (WHITEFOX, 2008; VAPERMA, 2008).

De uma maneira geral, a redução da destruição de exergia na produção de álcool pode ser obtida através das seguintes medidas:

a) Elevação do teor alcoólico do vinho enviado para a destilação;

b) Redução do consumo de vapor na destilação.

Cardona e Sánchez (2007) e Haelssig, Tremblay e Thilbault (2008) apresentam uma revisão das alternativas de integração entre as diferentes tecnologias de fermentação e destilação para o melhor desempenho técnico e econômico da produção de álcool.

\footnotetext{
${ }^{22}$ Teorema da Eqüipartição da Produção de Entropia.
} 


\subsection{SISTEMA DE COGERAÇÃO}

As caldeiras são os principais equipamentos responsáveis pela destruição de exergia no sistema de cogeração (95\%). A eficiência exergética da caldeira é definida como a razão entre a variação da exergia do vapor e a exergia do bagaço.

$$
\eta=\frac{\dot{m}_{\text {vapor }} \cdot\left(b_{\text {vapor }}-b_{\text {aggua }} \text { alimentação }\right)}{\dot{B}_{\text {bagaço }}}
$$

Para a caldeira analisada, a eficiência exergética é igual a 23\%. As fontes de irreversibilidades nesse equipamento incluem:

i. Reação de combustão (inclui perdas nas cinzas e combustível não convertido) (63\%);

ii. Transferência de calor $(24 \%)$;

iii. Exergia perdida nos gases de exaustão (13\%).

Conforme indicado, a reação de combustão é a principal responsável pela destruição de exergia na caldeira. Como o bagaço é queimado com 50\% de umidade, uma alternativa para redução da exergia destruída pela reação de combustão é secar essa biomassa. Todavia, o sistema de secagem deve utilizar a exergia contida nos gases de exaustão (SOSA-ARNAO; NEBRA, 2006 e 2007) ou ser mais eficiente que a secagem durante a reação de combustão. Ou seja, não é vantagem utilizar bagaço seco na caldeira, se para secá-lo a exergia destruída é maior que a redução obtida na caldeira. O uso do bagaço seco reduz a exergia destruída na combustão e também a exergia perdida com os gases de exaustão, já que a quantidade desses gases diminui com a menor quantidade de umidade e a necessidade de menos excesso de ar, porém há um aumento na exergia destruída devido à transferência de calor, resultante de uma temperatura de chama adiabática mais elevada com o combustível seco. De qualquer maneira, o efeito líquido é uma redução da exergia destruída na caldeira. Portanto, a secagem do bagaço é vantajosa quando a exergia destruída para secagem é inferior à diminuição da exergia destruída na caldeira. Morgenroth e Batstone (2005) avaliaram dois sistemas de secagem para bagaço: uso de gases de exaustão da caldeira e secagem com vapor superaquecido. Os resultados indicam que ambos os sistemas permitem ganhos na geração de eletricidade excedente, sendo os ganhos maiores para a secagem com vapor superaquecido. 
A redução da exergia destruída devido à diferença de temperatura no interior da caldeira é possível considerando o aumento da temperatura e da pressão de geração do vapor.

Outro fator relacionado a um melhor desempenho das caldeiras refere-se ao sistema de queima. Sistemas de queima ineficientes resultam em taxas de conversão do combustível baixas, com aumento da exergia perdida no cinzeiro. Sistemas atuais permitem até $98 \%$ de eficiência de conversão, sendo que a utilização de leitos fluidizados permitiria $99 \%$ de conversão (PERUCCHI, 2007).

Resumindo, o aumento da eficiência da caldeira pode ser conseguido através de:

$\checkmark$ Aumento dos parâmetros de geração de vapor;

$\checkmark$ Diminuição do excesso de ar utilizado e/ou redução da umidade do bagaço;

$\checkmark$ Alteração do sistema de queima;

$\checkmark$ Melhor aproveitamento da energia contida nos gases de combustão.

Outra fonte de irreversibilidade é a válvula de expansão, onde $43 \mathrm{~kg} / \mathrm{tc}$ de vapor provenientes das caldeiras (quase $10 \%$ do vapor gerado) é expandido sem realizar um efeito útil (p.ex. trabalho de eixo). Essa quantidade de vapor pela válvula é equivalente a 3,5 kWh/tc de exergia destruída. A simples eliminação da válvula e aquisição de uma nova turbina já permitiria um aumento na potência gerada de aproximadamente $2,5 \mathrm{kWh} / \mathrm{tc}$, considerando os mesmos níveis de eficiência atuais.

As irreversibilidades relacionadas à turbina de potência são resultado da baixa eficiência isoentrópica do equipamento e das condições de entrada do vapor. A relação entre a exergia destruída e a baixa eficiência isoentrópica é direta, ou seja, uma eficiência isoentrópica maior implica uma menor variação da entropia entre os estados de saída e entrada, portanto uma redução da geração de entropia (dado que as condições de entrada e a pressão de saída do vapor se mantenham constantes para diferentes valores da eficiência isoentrópica).

As condições de entrada do vapor, fixadas a eficiência isoentrópica e pressão de saída, apresentam valores ótimos (mínima geração de entropia ou máxima geração de potência) em função das razões entre as temperaturas de entrada e saída e entre as pressões de entrada e 
saída (SZARGUT; MORRIS; STEWARD, 1988; BEJAN, 1996). Todavia, as condições de entrada do vapor estão relacionadas diretamente com a geração de vapor na caldeira, desta maneira essa otimização deve levar em consideração também o consumo de combustível para uma mesma quantidade de potência gerada nas diversas condições.

As turbinas atualmente em operação na maioria das usinas utilizam vapor a 21 bar e $300^{\circ} \mathrm{C}$ com eficiências isoentrópicas variando entre 55\% (simples estágio) e 65\% (múltiplosestágios). Nessa avaliação, foi considerada uma turbina com eficiência isoentrópica de $65 \%$. Essa turbina gera $16,2 \mathrm{kWh} / \mathrm{tc}$ de eletricidade, sendo a exergia destruída igual a $6,5 \mathrm{kWh} / \mathrm{tc}$, ou seja, uma eficiência exergética de 71,4\%. Considerando uma eficiência isoentrópica de $70 \%$ para essa mesma turbina, a eficiência exergética passaria para 75,8\%, com uma redução de $15 \%$ na exergia destruída. Hoje, as turbinas disponíveis no mercado são capazes de operar com até 120 bar e $520^{\circ} \mathrm{C}$ e eficiências isoentrópicas próximas a $85 \%$ no setor sucroalcooleiro.

Outra fonte de irreversibilidades é o sistema de retorno de condensado, sendo essas relacionadas com a perda de calor e de carga na tubulação e o uso de tanques de flash (onde parte do condensado é re-evaporado e rejeitado para o ambiente), já que o retorno do condensado não é pressurizado. O uso de um sistema de retorno pressurizado, além de reduzir a destruição de exergia e a exergia perdida, reduz o consumo de água de reposição e de vapor no desaerador. Aliás, o aumento da temperatura da água na saída do desaerador traz benefícios para a redução da destruição de exergia na caldeira, pois diminui a diferença média de temperatura na transferência de calor entre a água e os gases de combustão.

Finalmente, o bagaço excedente representa uma exergia perdida equivalente a 125,8 kWh/tc (aproximadamente, $8,1 \%$ da exergia da cana). Caso essa exergia fosse convertida em eletricidade, considerando os níveis de eficiência descritos anteriormente, seria possível obter $20,7 \mathrm{kWh} / \mathrm{tc}$.

\subsection{COMENTÁRIOS GERAIS}

Uma usina sucroalcooleira pode ser tratada como um grande conjunto de sistemas de separação mecânica, térmica e química, ou seja, é possível considerá-la como um sistema de separação/reação química multi-componentes: 
i) Separação Mecânica: moenda (extração do caldo e do bagaço presentes na cana);

ii) Separação Térmica: fábrica de açúcar (evaporação da água do caldo para obtenção dos cristais de sacarose - açúcar) e a destilaria (separação do álcool da solução etanol-água proveniente da fermentação);

iii) Reação química: fermentação (obtenção de uma solução etanol-água a partir de uma solução água-sacarose) e a planta de cogeração (conversão da exergia química do bagaço em exergia térmica e mecânica e eletricidade).

Portanto, é possível definir a eficiência global de uma usina sucroalcooleira da seguinte maneira: a razão entre a exergia dos produtos (açúcar, álcool e, eventualmente, eletricidade excedente) e a diferença da exergia da cana (insumo do processo) e a exergia do bagaço excedente (parte da exergia da cana que não é utilizada no processo):

$$
\eta=\frac{\dot{\mathrm{B}}_{\text {açúcar }}+\dot{\mathrm{B}}_{\text {álcool }}+\dot{\mathrm{W}}_{\text {excedente }}}{\dot{\mathrm{B}}_{\text {cana }}-\dot{\mathrm{B}}_{\begin{array}{c}
\text { bagacoo } \\
\text { excedente }
\end{array}}-\dot{\mathrm{B}}_{\text {vinhaça }}}
$$

Para a usina analisada nesse capítulo, na qual não há geração de eletricidade excedente, essa eficiência é igual a 43,5\%.

A soma das irreversibilidades dos processos da usina e a exergia perdida com o bagaço excedente e a vinhaça é de $974 \mathrm{kWh} / \mathrm{tc}$, ou seja, 60,9\% da exergia da cana. Esse valor permite outra definição da eficiência da usina, como:

$$
\eta=1-\frac{\dot{\mathrm{I}}_{\text {processos }}+\dot{\mathrm{B}}_{\text {bagaco }}+\dot{\mathrm{B}}_{\text {excedente }}}{\dot{\mathrm{B}}_{\text {cana }}}
$$

O valor dessa nova formulação de eficiência é igual a 37,5\%. 
A parametrização desses índices em função da variação das quantidades de açúcar e álcool ${ }^{23}$ produzidas mostra pequena variação dos valores (inferior a 3\%), porém apresenta comportamentos opostos:

Segunda a eq. (68), a maior produção de álcool na usina melhora a eficiência da usina, devido à redução do consumo de vapor nos processos. A redução do consumo de vapor nos processos implica maior excedente de bagaço (pois não é considerada a geração de eletricidade para venda, nem a produção de álcool via hidrólise), portanto há uma diminuição do denominador da equação para um valor praticamente inalterado do numerador.

$>$ De acordo com a eq.(69), a melhor opção é a maior produção de açúcar, com conseqüente aumento do consumo de vapor nos processos. Assim, há uma redução do bagaço excedente e, portanto, uma diminuição do segundo termo do lado direito da equação e, desta forma, aumento do valor do rendimento.

A questão levantada na definição de uma eficiência exergética para a usina é como considerar o bagaço excedente, cuja exergia específica é maior que a da cana. A primeira opção (eq.(68)) trata-o como um subproduto do processo; a segunda (eq.(69)) como uma "irreversibilidade" externa (resíduo).

Ao tratar o bagaço como um subproduto, segue que esse tem um valor associado ao seu conteúdo exergético e esse poderia ser comercializado, caso houvesse um mercado para esse. Como resíduo, considera-se que não há outro destino para o bagaço naquela planta, além do seu descarte.

Nas usinas atualmente, as duas condições acima acontecem. Em algumas regiões, há um mercado para venda de bagaço excedente, enquanto em outras os usineiros doam o mesmo para quem se dispuser a retirá-lo da usina; sendo a segunda opção a mais corriqueira atualmente. Todavia, a tendência para as próximas safras é um aumento do valor atribuído ao bagaço, devido à possibilidade de usá-lo como insumo na geração de eletricidade, produção de álcool e produção de pellets para uso como combustível industrial.

\footnotetext{
${ }^{23}$ Os modelos desenvolvidos permitem variar a quantidade ART enviada para a produção de açúcar entre $35 \%$ e $55 \%$.
} 
Diante da racionalidade de considerar o bagaço como um sub-produto, os resultados para as eficiências apresentadas nessa tese são calculadas a partir da eq.(68). Porém, na determinação dos custos de produção, optou-se pela atribuição de valor nulo a este bagaço excedente, penalizando os produtos da usina pelo uso não-racional deste insumo.

O Potencial de Melhoria (PM) ${ }^{24}$ proposto por Rivero (1993) o qual considera tanto aspectos qualitativos (eficiências) como quantitativos (irreversibilidades). Para a usina é possível definir:

$$
\mathrm{PM}=\left(1-\frac{\dot{\mathrm{B}}_{\text {açúcar }}+\dot{\mathrm{B}}_{\text {álcool }}+\dot{\mathrm{W}}_{\text {excedente }}}{\dot{\mathrm{B}}_{\text {cana }}-\dot{\mathrm{B}}_{\begin{array}{c}
\text { bagaco } \\
\text { excedente }
\end{array}}-\dot{\mathrm{B}}_{\text {vinhaça }}}\right) \cdot \dot{\mathrm{I}}_{\text {processos }}+\dot{\mathrm{B}}_{\begin{array}{c}
\text { bagaco } \\
\text { excedente }
\end{array}}+\dot{\mathrm{B}}_{\text {vinhaça }}
$$

Para a usina estudada o valor do Potencial de Melhoria é igual a $652 \mathrm{kWh} / \mathrm{tc}$. Esse valor é maior que a exergia dos produtos da usina avaliada, ou seja, o sistema é bastante ineficiente com um grande potencial para melhor utilizar a exergia da cana.

Outra maneira de avaliar os processos de conversão de energia na usina á fazendo uso do custeio em base exergética. Considerando o custo em base exergética para a cana igual a 1 $\mathrm{kJ} / \mathrm{kJ}$, é possível calcular o custo dos diferentes fluxos de exergia na usina (Tab. 6.7). Para a distribuição dos custos em volumes de controle com mais de um produto adotou-se o critério da igualdade entre os custos em base exergética desses produtos. Os balanços utilizados são mostrados no Apêndice A.

Tabela 6.7 - Custo em base exergética de diferentes fluxos de exergia na usina.

\begin{tabular}{cc}
\hline Fluxo de Exergia & Custo em base Exergética (kJ/kJ) \\
\hline Eletricidade & 7,11 \\
Energia Mecânica & 7,32 \\
Vapor & 7,25 \\
Açúcar & 1,92 \\
Álcool & 3,65 \\
\hline
\end{tabular}

\footnotetext{
${ }^{24}$ Ver Cap. 5.
} 
Esses custos podem ser utilizados para a comparação de modificações feitas em diferentes processos da usina, identificando os impactos positivos e/ou negativos na formação dos custos de conversão de energia para os diferentes produtos da usina.

Dentre as alternativas propostas neste capítulo para a redução das irreversibilidades, as modificações abaixo serão analisadas nos próximos capítulos a partir dos custos em base exergética:

$\checkmark$ Eletrificação dos acionamentos do sistema de extração;

$\checkmark$ Melhor integração térmica dos processos de aquecimento de caldo com as diferentes extrações de vapor do evaporador de múltiplos-efeitos;

$\checkmark$ Variação das pressões em cada efeito do evaporador;

$\checkmark$ Diminuição dos parâmetros de consumo de vapor na destilaria;

$\checkmark$ Pressões e temperaturas mais elevadas para geração de vapor nas caldeiras;

$\checkmark$ Utilização de turbinas com eficiências isoentrópicas mais elevadas.

O principal objetivo das análises subseqüentes é avaliar o impacto de alterações nos processos de conversão de energia, sobretudo na planta de cogeração, nos custos em base exergética do açúcar, álcool e eletricidade. 


\section{TECNOLOGIAS DE COGERAÇÃO APLICÁVEIS A PLANTAS DE UTILIDADES}

Este capítulo apresenta as tecnologias de cogeração estudadas na tese, mostrando aspectos tecnológicos dessas e sua integração em usinas sucroalcooleiras. Inicialmente, são discutidas as tecnologias disponíveis atualmente, baseadas em sistemas a vapor. Em seguida, são apresentadas as tecnologias mais avançadas de cogeração, baseadas em sistemas a vapor supercrítico e sistemas com gaseificação de biomassa e turbinas a gás. Apresenta também que a utilização de tecnologias mais avançadas está relacionada a uma redução do consumo de vapor pelo processo, bem como pela adoção de um combustível adicional. Finalmente, as configurações analisadas na tese são mostradas e seus parâmetros de projeto discutidos.

\subsection{TECNOLOGIAS ATUAIS}

Conforme mostram Payne (1989) e Walter (1994), a maior parte das usinas de cana-de-açúcar no mundo utiliza um dos seguintes arranjos para geração de eletricidade e calor, todos operando com sistemas a vapor:

Sistemas baseados exclusivamente em turbinas de contrapressão (BPST "Backpressure Steam-Turbine") (Fig. 7.1);

$\checkmark$ Sistemas combinados com turbinas de contrapressão alimentando o processo, e turbinas de condensação utilizando o vapor excedente (Fig. 7.2);

$\checkmark$ Sistemas baseados em turbinas de extração e condensação, com controle automático (CEST - “Condensing-Extraction Steam Turbine”) (Fig. 7.3).

A maioria das usinas brasileiras usa os sistemas com turbinas de contrapressão. Esses sistemas foram projetados para atender às demandas térmicas do processo, gerando quasetoda ou toda a eletricidade necessária na usina. Nesses casos, a geração de eletricidade segue as variações da demanda de vapor no processo, sendo a comercialização de excedentes encarada como energia interruptível. O uso de turbinas de condensação possibilita uma estabilização da geração de eletricidade excedente, porém a adequação da planta para 
comercialização de eletricidade excedente normalmente implica o uso de sistemas de extração-condensação (WALTER, 1994).

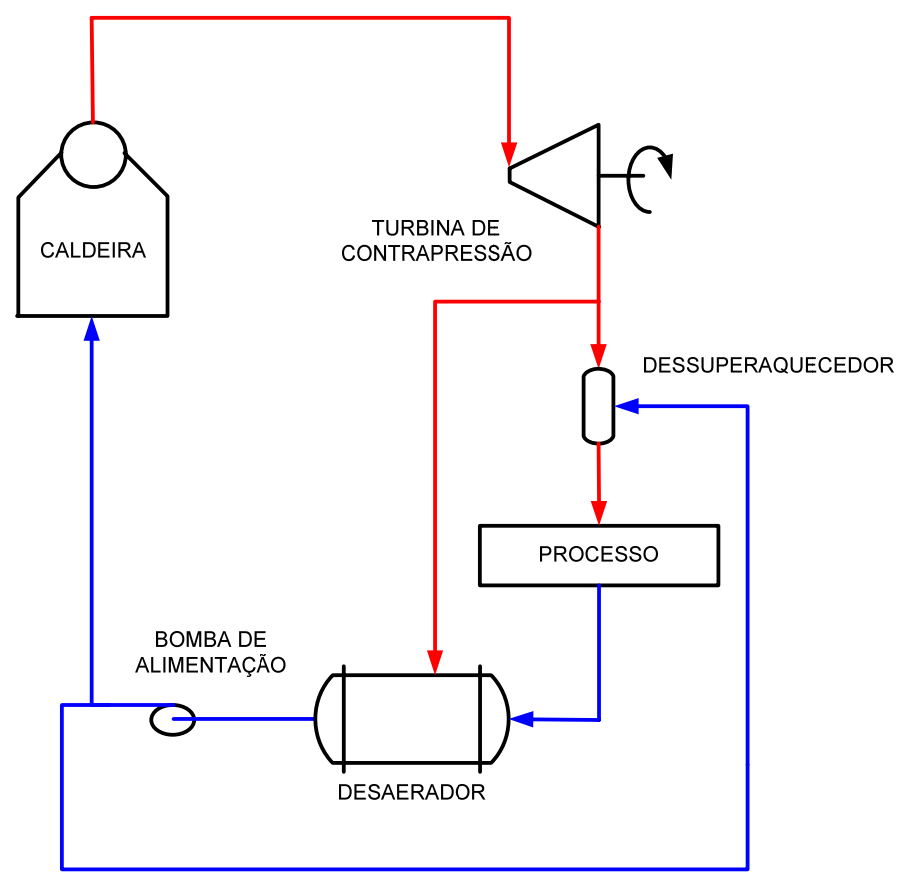

Figura 7.1 - Sistema de Cogeração com Turbina de Contrapressão.

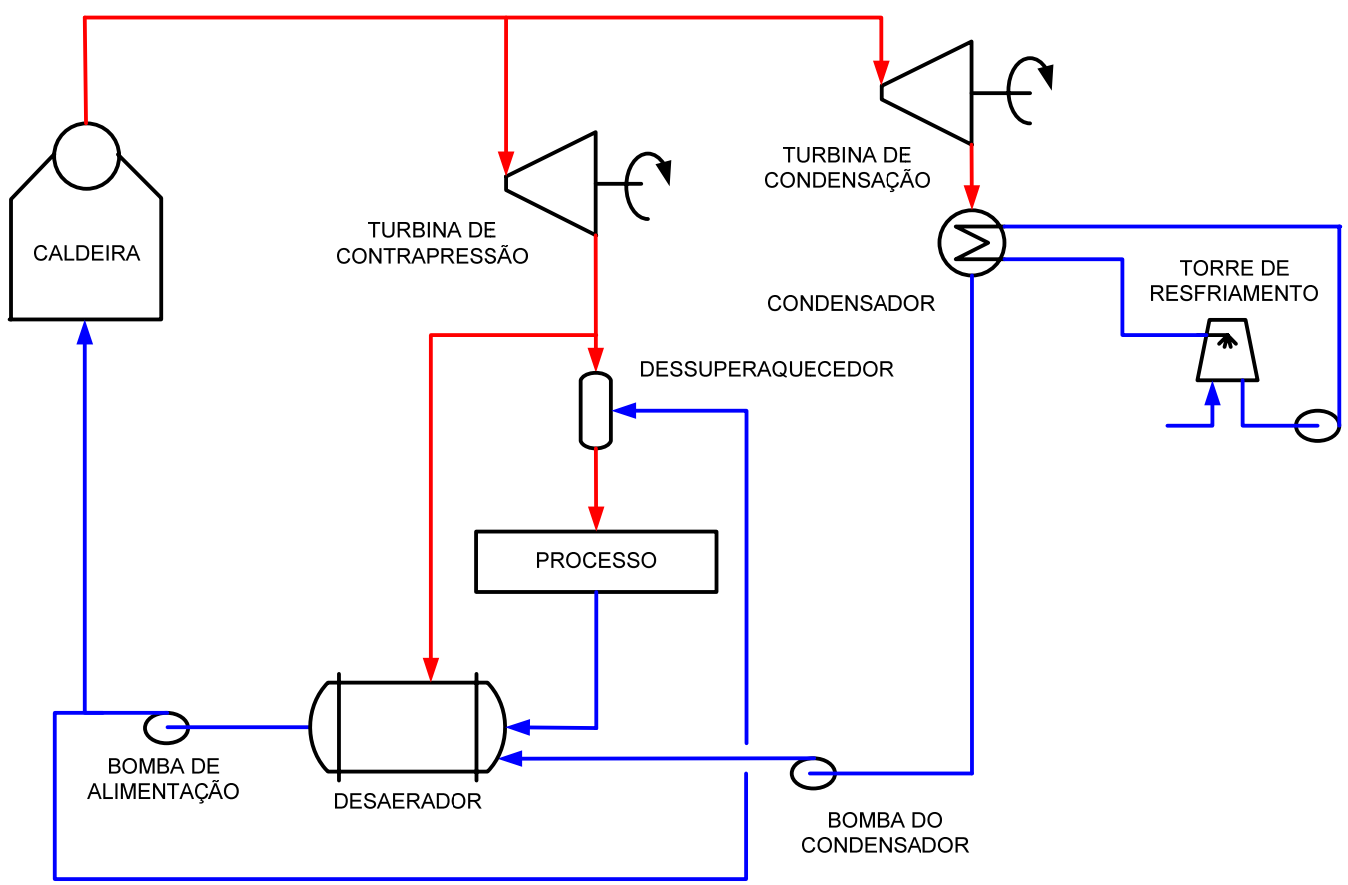

Figura 7.2 - Sistema de Cogeração com Turbinas de Contrapressão e de Condensação.

No Brasil, o sistema de contrapressão normalmente opera com pressão de 21 bar e temperatura de $300^{\circ} \mathrm{C}$, o vapor é expandido em turbinas de simples estágio (moendas e 
turbobombas) e/ou de múltiplos estágios (turbogeradores) até a pressão de processo (2,5 bar). Em alguns casos, parte do vapor alimentado ao processo é expandido em válvulas de expansão. Em todas as usinas, o condensado do vapor de escape do processo é retornado à caldeira, porém algumas unidades ainda utilizam o retorno de condensado não pressurizado, fazendo uso de tanques de flash.

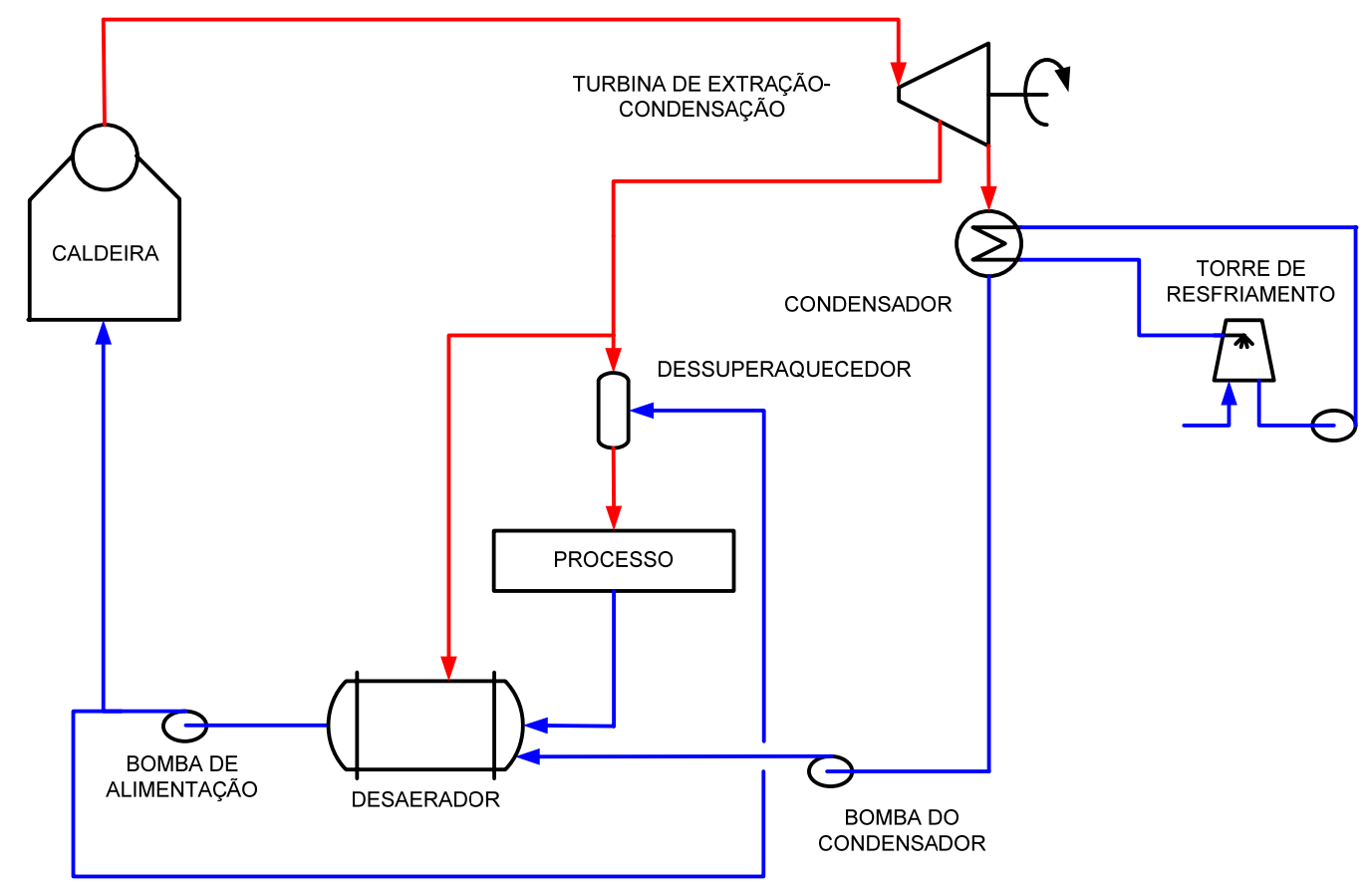

Figura 7.3 - Sistema de Cogeração com Turbina de Extração-Condensação.

Conforme destaca Walter (1994), grande parte das unidades industriais do setor foi construída ou ampliada, principalmente durante o Proálcool, sem grandes preocupações referentes à homogeneização dos equipamentos. Assim, arranjos onde o vapor é gerado e consumido em diversos níveis de pressão são típicos. Associado a isso, é comum também haver uma grande diversidade de equipamentos, principalmente geradores de vapor, com diferentes capacidades numa mesma planta (LEAL; MACEDO, 2004; PRIETO; BARATA, 2006).

As estações de geração de vapor mais antigas eram projetadas para atender às variações de carga das moendas (principais consumidores de vapor direto), assim o uso de várias caldeiras de pequena capacidade operando em paralelo garantia a estabilidade, mesmo que de forma pouco controlada, da geração do vapor. 
A Tab. 7.1 mostra a evolução da tecnologia das caldeiras utilizadas no setor sucroalcooleiro.

Tabela 7.1 - Evolução da tecnologia das caldeiras no setor sucroalcooleiro.

\begin{tabular}{|c|c|}
\hline Situação das caldeiras em 1981 & Situação das caldeiras em 1996 \\
\hline $\begin{array}{l}\checkmark 48 \% \text { delas com capacidades inferiores a } 30 \\
t / h\end{array}$ & $\checkmark 66 \%$ com capacidades superiores a $40 \mathrm{t} / \mathrm{h}$ \\
\hline$\checkmark 56 \%$ com fornalhas do tipo ferradura & $\checkmark 11 \%$ com capacidades superiores a $100 \mathrm{t} / \mathrm{h}$ \\
\hline$\checkmark$ Tiragem natural & $\begin{array}{l}\checkmark 75 \% \text { gerando vapor a pressões iguais ou } \\
\text { superiores a } 20 \text { bar }\end{array}$ \\
\hline$\checkmark$ Sem pré-aquecedor & $\checkmark 5 \%$ gerando a pressões superiores a 30 bar \\
\hline$\checkmark$ Vapor: saturado@19 ou 22 bar & $\checkmark 35 \%$ com economizadores \\
\hline$\checkmark 30 \%$ com pré-aquecedores & $\begin{array}{l}\checkmark \text { Predominam sistemas com grelha } \\
\text { basculante, ar secundário e melhor } \\
\text { automação }\end{array}$ \\
\hline $\begin{array}{l}\checkmark \text { Automação rudimentar (nível do tubulão } \\
\text { superior) }\end{array}$ & $\begin{array}{l}\checkmark \text { Alguns sistemas operam com queima em } \\
\text { suspensão (maior capacidade) }\end{array}$ \\
\hline $\begin{array}{l}\checkmark \text { Poucas com superaquecedor (temperatura de } \\
\text { superaquecimento }-280^{\circ} \mathrm{C} \text { ) e grelhas } \\
\text { basculantes }\end{array}$ & $\begin{array}{l}\checkmark \text { Melhor tratamento de água (desaeradores, } \\
\text { desmineralizadores) }\end{array}$ \\
\hline$\checkmark$ Eficiência média (base PCI): $71,6 \%$ & $\checkmark$ Eficiência média (base PCI): $82,0 \%$ \\
\hline
\end{tabular}

Fonte: Leal e Macedo, 2004

A questão principal, ainda hoje, referente ao uso da energia em usinas é a busca do equilíbrio entre a oferta de energia primária (bagaço) e a demanda de energia secundária nos processos (potência e calor). Conforme destacam Leal e Macedo (2004), este equilíbrio é função das condições de operação específicas de cada usina, como: quantidade de fibra na cana, aproveitamento do tempo de moagem, relação entre a cana moída para produção de açúcar e a moída para álcool, tipos de açúcar e álcool produzidos. Desta maneira, poucas usinas geram excedentes de eletricidade para comercialização na rede.

As novas usinas e unidades, buscando melhorar seus balanços energéticos, estão optando por utilizar caldeiras com pressões de até 100 bar, a fim de viabilizar a venda do excedente de eletricidade (PRIETO; BARATA, 2006). O uso de pressões mais elevadas está limitado a 180 bar e a questões econômico-financeiras relacionadas à venda da eletricidade excedente. A eficiência dessas novas caldeiras é de $85-87 \%$ (base PCI), sendo possível elevar esses valores para $89-90 \%$ com a queima de bagaço seco (PERUCHI, 2007). 
Considerando o sistema de queima, as caldeiras modernas utilizam grelhas rotativas, "pinhole" ou basculantes, oferecendo eficiências de conversão da biomassa de até 97\%. Caldeiras com leito fluidizado borbulhante ou circulante permitem eficiências de conversão de $99 \%$, porém seus custos ainda não justificam a sua implantação em usinas sucroalcooleiras. Embora, alguns fabricantes de caldeiras estão começando a pesquisar esses sistemas de queima (SOSA-ARNAO, 2008)

Outro aspecto relevante às caldeiras de biomassa está relacionado ao número de tambores ("drums"). As caldeiras mais antigas eram constituídas por três tambores de separação com múltiplos passes no lado dos gases, trazendo problemas com relação à manutenção e ao tamanho desses equipamentos. As vazões dessas caldeiras não passavam de $60 \mathrm{t} / \mathrm{h}$, com pressão de vapor de até 30 bar. As caldeiras com dois tambores ("bi-drums") de múltiplos passes significaram um grande avanço para geração de vapor, possibilitando o aumento da vazão de vapor até 100 t/h e pressões de 43 bar. Durante a década de 90, caldeiras bi-drums com passe único tornaram-se a referência para o setor, minimizando os problemas relacionados às caldeiras de múltiplos passes, como erosão e o uso de material refratário estrutural, reduzindo os custos de manutenção, além de possibilitarem vazões acima de 100 t/h e pressões de até 120 bar. Atualmente, as caldeiras com um tambor ("single drum") representam o estado-da-arte da indústria nacional, e as únicas capazes de operar com vazões maiores que 200 t/h e pressões de até 180 bar (CORTEZ; LORA, 1997; PRIETO; BARATA, 2006). A Tab. 7.2 mostra os parâmetros mais importantes dos diferentes tipos de caldeiras utilizados na indústria sucroalcooleira.

A evolução das turbinas a vapor passou pela utilização de turbinas de simples estágio de ação direta, com eficiências isoentrópicas baixas $(\sim 55 \%)$ e potências inferiores a $2 \mathrm{MW}$, até turbinas de múltiplos estágios de ação/reação, com eficiências de até $85 \%$ e potências até 150 MW. 
Tabela 7.2 - Parâmetros de Diferentes Tipos de Caldeira.

\begin{tabular}{|c|c|c|c|c|}
\hline \multirow[b]{2}{*}{$\begin{array}{c}\text { Dados e } \\
\text { Parâmetros }\end{array}$} & \multicolumn{4}{|c|}{ Tipos de Caldeiras } \\
\hline & de Tubos Retos & $\begin{array}{c}\text { de Tubos } \\
\text { Curvos e } \\
\text { Vários Balões }\end{array}$ & $\begin{array}{l}\text { Convectivas } \\
\text { (Bi-drum) }\end{array}$ & $\begin{array}{c}\text { Radiantes } \\
\text { (Single Drum) }\end{array}$ \\
\hline Tipo de fornalha & $\begin{array}{c}\text { Ferradura e } \\
\text { Grelha Inclinada }\end{array}$ & $\begin{array}{l}\text { Ferradura e } \\
\text { Grelha } \\
\text { Basculante }\end{array}$ & $\begin{array}{c}\text { Grelha } \\
\text { Basculante e } \\
\text { Queima em } \\
\text { Suspensão }\end{array}$ & $\begin{array}{c}\text { Grelha } \\
\text { Basculante, } \\
\text { Queima em } \\
\text { Suspensão e } \\
\text { Leito Fluidizado }\end{array}$ \\
\hline Eficiência & $50-60 \%$ & $50-70 \%$ & $70-80 \%$ & $80-89 \%$ \\
\hline $\begin{array}{l}\text { Pressão de vapor } \\
\text { (bar) }\end{array}$ & 18 & $18-30$ & $18-120$ & $70-180^{25}$ \\
\hline $\begin{array}{l}\text { Temperatura do } \\
\text { Vapor }\left({ }^{\circ} \mathrm{C}\right)\end{array}$ & 300 & 320 & 510 & $400-549$ \\
\hline $\begin{array}{c}\text { Geração de } \\
\text { vapor máx. }(\mathrm{t} / \mathrm{h})\end{array}$ & 35 & 60 & 200 & 500 \\
\hline
\end{tabular}

Antes da década de 80, turbinas de simples estágios de ação direta eram utilizadas principalmente para a movimentação das moendas, sem maiores preocupações com relação ao uso eficiente do vapor e da energia elétrica, comprada diretamente da rede devido aos baixos preços praticados. É importante ressaltar que muitas dessas turbinas são utilizadas até hoje. Objetivando um melhor desempenho da planta de utilidades a partir da década de 80, as turbinas dos geradores foram substituídas por turbinas multiestágios de ação direta (eficiências isoentrópicas de 60-65\%), bem como as turbinas dos acionamentos de maiores potências, devido aos menores investimentos nesses equipamentos quando comparados aos de aquisição de uma nova caldeira. Porém, as potências dificilmente passavam de $8 \mathrm{MW}$. Conforme destaca Walter (1994), até meados da década de 90 nenhuma usina brasileira possuía sistemas com turbinas de extração-condensação. Recentemente, turbinas de açãoreação com potências maiores e eficiências mais elevadas (até 85\%) vêm substituindo os turbogeradores para possibilitar a geração excedente de eletricidade. Essas máquinas podem ter até duas extrações, possibilitando atender à demanda de vapor de 21 bar nos acionamentos das moendas e de vapor de 2,5 bar no processo, além da condensação que viabiliza um maior potencial de geração (LORA; NASCIMENTO, 2004; LEAL; MACEDO, 2004). Atualmente, os equipamentos nacionais são capazes de trabalhar com pressões de entrada de até 120 bar.

\footnotetext{
${ }^{25}$ Segundo informações levantadas junto a fabricantes, as maiores caldeiras sendo construídas no Brasil para usinas sucroalcooleiras tem capacidade para $400 \mathrm{t} / \mathrm{h}$ de vapor a 100 bar (PERUCHI, 2007).
} 
A utilização dessas tecnologias em usinas de açúcar e álcool foi estudada por diferentes autores, destacando-se os trabalhos de Walter (1994), Coelho, Zylbersztjan e Oliveira Jr. (1997) e Prieto (2003).

\subsection{TECNOLOGIAS MAIS AVANÇADAS}

É conhecido que a elevação dos parâmetros de geração do vapor em ciclos Rankine eleva a eficiência deste, assim como o uso de regeneradores de vapor. Dessa forma, a integração de sistemas supercríticos de vapor poderia elevar o potencial de geração de eletricidade excedente em usinas sucroalcooleiras.

Ciclos combinados são capazes de oferecer eficiências superiores a sistemas a vapor convencionais, dadas as maiores temperaturas de operação obtidas nas turbinas a gás (1200$1400^{\circ} \mathrm{C}$ nos gases de combustão na entrada do expansor da turbina a gás), em relação às temperaturas de geração do vapor em sistemas a vapor convencionais $\left(\sim 500^{\circ} \mathrm{C}\right)$, sendo as temperaturas de rejeição de calor iguais no condensador (KEHLHOFER, 1991; KOROBITSYN, 1998). A Tab. 7.3 mostra um comparativo de três sistemas simples e um combinado, considerando as temperaturas médias de fornecimento e rejeição de calor e a eficiência de Carnot.

Assim, torna-se interessante avaliar a aplicação de ciclos combinados para cogeração em usinas, utilizando a gaseificação do bagaço, pontas e folhas para produzir o gás a ser queimado na turbina a gás.

Tabela 7.3 - Comparativo entre sistemas simples e combinados.

\begin{tabular}{ccccc}
\cline { 2 - 5 } & $\begin{array}{c}\text { Turbina a } \\
\text { Gás }\end{array}$ & $\begin{array}{c}\text { Sistema a } \\
\text { Vapor, sem re- } \\
\text { aquecimento }\end{array}$ & $\begin{array}{c}\text { Sistema a } \\
\text { Vapor, com re- } \\
\text { aquecimento }\end{array}$ & $\begin{array}{c}\text { Ciclo } \\
\text { Combinado }\end{array}$ \\
\hline $\begin{array}{c}\text { Temperatura média de } \\
\text { fornecimento de calor }\left({ }^{\circ} \mathrm{C}\right) \\
\text { Temperatura média de } \\
\text { rejeição de calor }\left({ }^{\circ} \mathrm{C}\right)\end{array}$ & 730 & 360 & 430 & 730 \\
Eficiência de Carnot $(\%)$ & 51 & 50 & 50 & 50 \\
\hline
\end{tabular}

Fonte: Kehlhofer, 1991 
Ogden, Hochgreb e Hylton (1990) analisaram a economia de vapor em usinas e a aplicação de diferentes opções de ciclos de cogeração. Neste trabalho foram consideradas as três opções de cogeração mais comuns na literatura:

Ciclos baseados em turbinas de contrapressão (como os utilizados numa Usina Típica);

$\checkmark$ Ciclos baseados em turbinas de extração e condensação (CEST);

$\checkmark$ Ciclos com gaseificação de bagaço e turbinas a gás (BIG-STIG - "Biomass Integrated Gasification Steam Injection Gas Turbine”).

A Figura 7.4 indica o potencial de geração de eletricidade e vapor dos ciclos analisados. Conforme pode ser observado, a utilização de sistemas com gaseificação de biomassa podem gerar mais de $220 \mathrm{kWh} / \mathrm{tc}$ de energia eletromecânica, ou seja, pelo menos 7 vezes mais que a capacidade instalada em usinas convencionais, enquanto sistemas a vapor com extraçãocondensação podem gerar entre 70 e $150 \mathrm{kWh} / \mathrm{tc}$, dependendo do consumo de vapor e das condições de geração do vapor. Walter (1994) apresenta valores parecidos para os mesmos sistemas.

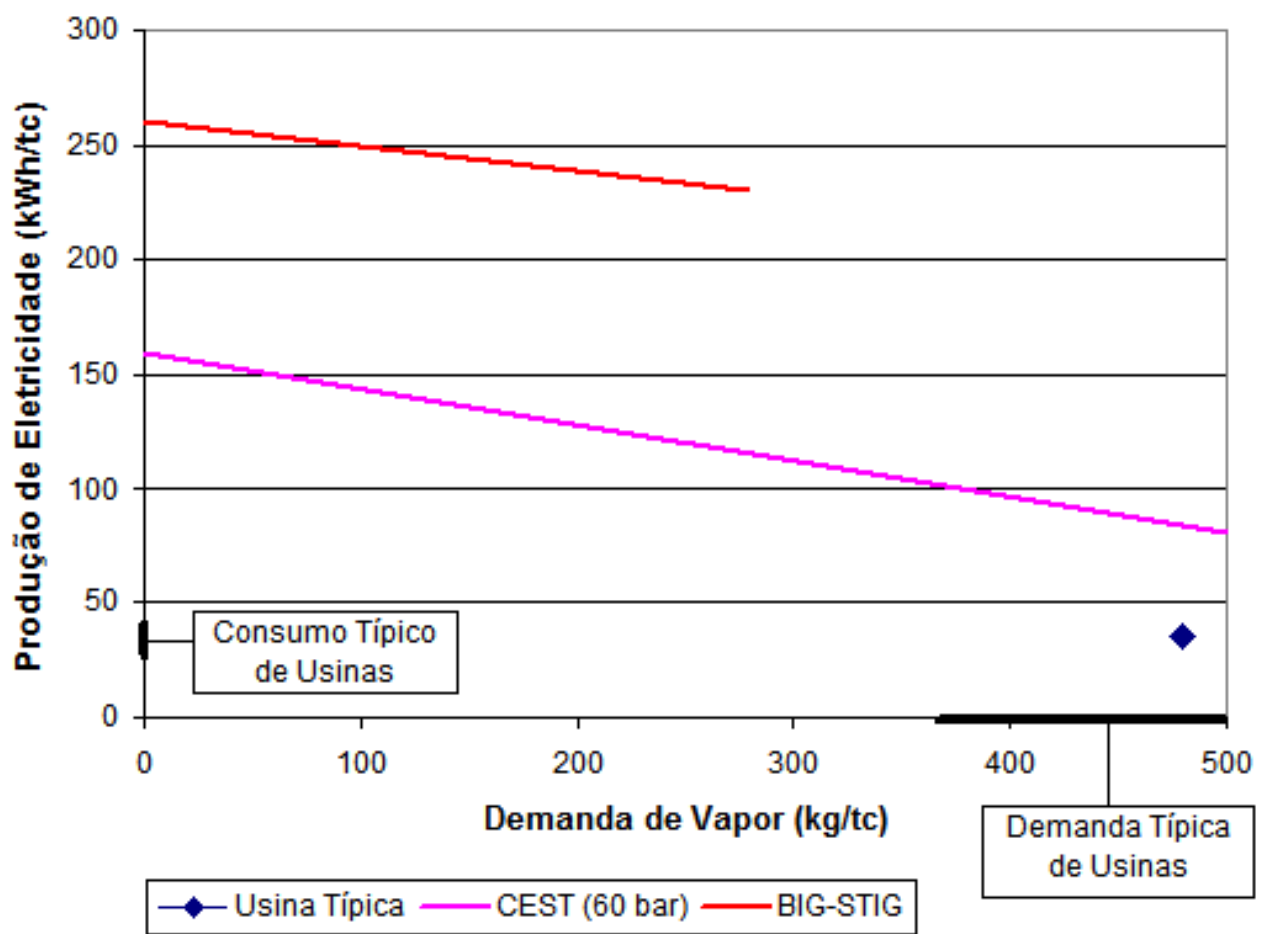

Figura 7.4 - Produção de eletricidade e vapor de sistemas de cogeração com queima de bagaço (OGDEN; HOCHGREB; HYLTON, 1990). 
Larson, Williams e Leal (2001) analisaram a integração de um sistema CEST e um sistema BIGCC a uma usina cubana ${ }^{26}$. Os resultados mostraram que o sistema CEST tem uma capacidade de geração da ordem de $120 \mathrm{kWh} / \mathrm{tc}$ na safra e $175 \mathrm{kWh} / \mathrm{tc}$ na entressafra, enquanto o sistema BIGCC pode gerar $150 \mathrm{kWh} / \mathrm{tc}$ na safra e $200 \mathrm{kWh} / \mathrm{tc}$ na entressafra.

Pellegrini, Burbano e Oliveira Jr. (2007 e 2008) avaliaram o desempenho de sistemas supercríticos e BIGCC em usinas sucroalcooleiras. Os resultados indicaram que durante a safra, esses sistemas são capazes de gerar aproximadamente $150 \mathrm{kWh} / \mathrm{tc}$ e, durante a entressafra, quase $200 \mathrm{kWh} / \mathrm{tc}$, neste caso considerando o recolhimento da palha.

A seguir uma revisão das principais características de sistemas supercríticos a vapor e BIGCC será apresentada a fim de contextualizar essas tecnologias para aplicação em usinas sucroalcooleiras.

\subsubsection{Plantas Supercríticas de Potência}

A expressão "supercrítico" refere-se ao estado termodinâmico a pressões e temperaturas acima do ponto crítico $\left(\mathrm{T}_{\mathrm{c}}=647 \mathrm{~K}=374^{\circ} \mathrm{C}\right.$ e $\mathrm{p}_{\mathrm{c}}=22,1 \mathrm{MPa}=221$ bar $)$, onde não é possível fazer uma distinção entre as fases líquida e vapor.

De acordo com Beér (2007), as plantas supercríticas (Fig. 7.5) para geração de potência vêm sendo utilizadas desde os anos 30 do século passado, principalmente na Europa. Nos Estados Unidos, as primeiras plantas supercríticas foram desenvolvidas nas décadas de 50 e 60 . Contudo, as primeiras unidades não foram muito bem sucedidas devido à falta de confiabilidade e flexibilidade operacional, de maneira que plantas subcríticas se tornaram um padrão naquele país. Apesar disso, o desenvolvimento continuou na Europa e, atualmente, a diferença de confiabilidade entre plantas subcríticas e supercríticas é praticamente inexistente (RICHARDSON; SHIMOGORI; KIDERA, 2004).

\footnotetext{
${ }^{26}$ A safra para uma usina cubana dura 150 dias e o fator de capacidade é de $87 \%$.
} 


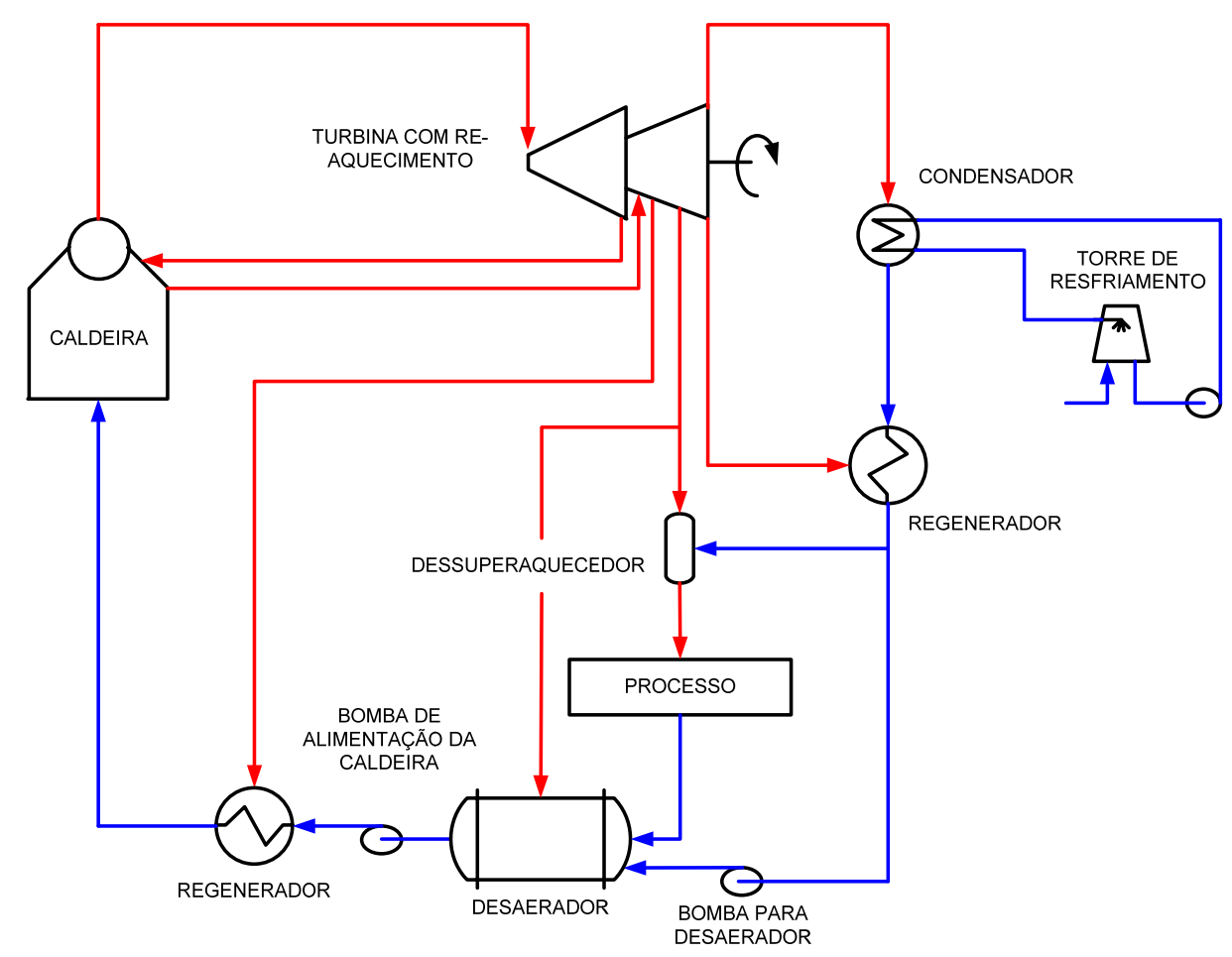

Figura 7.5 - Sistema de Cogeração com Vapor Supercrítico.

O progresso no desenvolvimento de novos materiais e o aumento da demanda por unidades de geração de potência mais eficientes vêm tornando as plantas supercríticas a melhor opção para plantas de potência a carvão ao redor do mundo (BEÉR, 2007). O Departamento de Energia dos Estados Unidos (DOE - "Department of Energy") desenvolveu um documento sobre sistemas avançados de geração de potência (plantas supercríticas e gaseificação integrada emciclos combinados) utilizando carvão, de maneira a fornecer dados econômicos e análises para determinação de custos dessas tecnologias (DOE, 1999). O Departamento de Comércio e Indústria da Inglaterra (DTI - "Department of Trade and Industry") também promoveu um documento sobre sistemas avançados de geração de potência que utilizam caldeiras e turbinas de alta eficiência, mostrando os recentes avanços das pesquisas relacionadas a sistemas supercríticos (DTI, 2006).

A maior parte das plantas que entrou em operação nas décadas de 60 e 70 utilizava vapor a 250 bar e temperaturas de $540^{\circ} \mathrm{C}$ a $560^{\circ} \mathrm{C}$, com re-aquecimento simples ou duplo. Em 1957 , uma planta, que operava a 310 bar e $621^{\circ} \mathrm{C}$ com re-aquecimento duplo $\left(565^{\circ} \mathrm{C} / 538^{\circ} \mathrm{C}\right)$, foi projetada e posta em operação para demonstrar a viabilidade de sistemas supercríticos. Esta planta operou até 1979 (SMITH, 1998). 
No início da década passada, os japoneses foram os primeiros a operar uma planta com temperaturas próximas a $600^{\circ} \mathrm{C}$ (JIN et al., 1997; BUGGE; KJÆR; BLUM, 2006). No final da década de 90, o conceito de Plantas Ultra-Supercríticas (USC - "Ultra-Supercritical Plants") foi introduzido para denominar plantas que utilizavam vapor a 290 bar e temperaturas em torno de $600^{\circ} \mathrm{C}$. Bugge, Kjær e Blum (2006) apresentam dados de diferentes plantas ultrasupercríticas em operação ou em construção (Tab. 7.4). As eficiências mostradas variam de $40 \%$ até $50 \%$ (base PCI) para plantas a 300 bar com re-aquecimento simples $\left(580^{\circ} \mathrm{C} / 600^{\circ} \mathrm{C}\right)$, localizadas na Dinamarca.

Tabela 7.4 - Plantas Supercríticas " $600^{\circ} \mathrm{C} "$

\begin{tabular}{|c|c|c|c|c|c|}
\hline Planta & $\begin{array}{c}\text { Capacidade } \\
\text { (MW) }\end{array}$ & $\begin{array}{c}\text { Parâmetros do } \\
\text { Vapor }\end{array}$ & Combustível & Ano & $\begin{array}{c}\eta \\
(\mathbf{P C I})\end{array}$ \\
\hline Matsuura 2 & 1000 & $255 \mathrm{bar} / 598^{\circ} \mathrm{C} / 596^{\circ} \mathrm{C}$ & $\begin{array}{c}\text { Carvão } \\
\text { Pulverizado }\end{array}$ & 1997 & \\
\hline Skaerbaek 3 & 400 & $290 \mathrm{bar} / 580^{\circ} \mathrm{C} / 580^{\circ} \mathrm{C}$ & Gás Natural & 1997 & $49 \%$ \\
\hline Haramachi & 1000 & $259 \mathrm{bar} / 604^{\circ} \mathrm{C} / 602^{\circ} \mathrm{C}$ & $\begin{array}{c}\text { Carvão } \\
\text { Pulverizado }\end{array}$ & 1998 & \\
\hline Nordjylland & 400 & $290 \mathrm{bar} / 580^{\circ} \mathrm{C} / 580^{\circ} \mathrm{C}$ & $\begin{array}{c}\text { Carvão } \\
\text { Pulverizado }\end{array}$ & 1998 & $47 \%$ \\
\hline Nanaoota & 700 & $255 \mathrm{bar} / 597^{\circ} \mathrm{C} / 595^{\circ} \mathrm{C}$ & $\begin{array}{c}\text { Carvão } \\
\text { Pulverizado }\end{array}$ & 1998 & \\
\hline Misumi 1 & 1000 & $259 \mathrm{bar} / 604^{\circ} \mathrm{C} / 602^{\circ} \mathrm{C}$ & $\begin{array}{c}\text { Carvão } \\
\text { Pulverizado }\end{array}$ & 1998 & \\
\hline Lippendorff & 934 & $267 \mathrm{bar} / 554^{\circ} \mathrm{C} / 583^{\circ} \mathrm{C}$ & Lignito & 1999 & $42.3 \%$ \\
\hline Boxberg & 915 & $267 \mathrm{bar} / 555^{\circ} \mathrm{C} / 578^{\circ} \mathrm{C}$ & Lignito & 2000 & $41.7 \%$ \\
\hline Tsuruga 2 & 700 & $255 \mathrm{bar} / 597^{\circ} \mathrm{C} / 595^{\circ} \mathrm{C}$ & $\begin{array}{c}\text { Carvão } \\
\text { Pulverizado }\end{array}$ & 2000 & \\
\hline Tachibanawan 2 & 1050 & $264 \mathrm{bar} / 605^{\circ} \mathrm{C} / 613^{\circ} \mathrm{C}$ & $\begin{array}{c}\text { Carvão } \\
\text { Pulverizado }\end{array}$ & 2001 & \\
\hline Avedore 2 & 400 & $300 \mathrm{bar} / 580^{\circ} \mathrm{C} / 600^{\circ} \mathrm{C}$ & $\begin{array}{c}\text { Gás Natural / } \\
\text { Carvão / } \\
\text { Biomassa }\end{array}$ & 2001 & $49.7 \%$ \\
\hline Niederaussen & 975 & $265 \mathrm{bar} / 565^{\circ} \mathrm{C} / 600^{\circ} \mathrm{C}$ & Lignito & 2002 & $>43 \%$ \\
\hline Isogo 1 & 600 & $280 \mathrm{bar} / 605^{\circ} \mathrm{C} / 613^{\circ} \mathrm{C}$ & $\begin{array}{c}\text { Carvão } \\
\text { Pulverizado }\end{array}$ & 2002 & \\
\hline
\end{tabular}

Fonte: Bugge, Kjær e Blum (2006)

De acordo com Beér (2007), entre 7 e 10 anos uma planta de potência a carvão utilizando vapor a $700^{\circ} \mathrm{C}$ deverá ser construída, sendo estabelecido um novo padrão para plantas com $50 \%$ de eficiência. A concretização técnica das plantas a $700^{\circ} \mathrm{C}$ depende do sucesso de desenvolvimento e certificação de ligas especiais ferríticas, austeníticas e a base de níquel. 
Com relação às ligas austeníticas e a base de níquel resultados promissores já foram obtidos (BUGGE; KJÆR; BLUM, 2006).

\subsubsection{Tecnologia de Geração de Vapor}

Mark Benson foi o primeiro a aplicar comercialmente as caldeiras de passe único ("Oncethrough Boilers") nas décadas de 20 e 30, fornecendo duas unidades que operavam na pressão crítica. Os direitos referentes ao conceito da Caldeira Benson foram adquiridos pela Siemens, que desenvolveu ainda mais a tecnologia e hoje licencia esta ao redor do mundo (SMITH, 1998).

As caldeiras de passe único são as únicas capazes de operar com condições supercríticas, como não há distinção entre as fases vapor e líquida, não é possível fazer, nem é necessária, uma separação no tambor. Em contraste às caldeiras com tambor de separação, a água de alimentação passa pelo economizador, pelas paredes da fornalha (paredes d'água) e superaquecedor, mudando de fase de água saturada, para vapor saturado, para vapor superaquecido em um único passe (Fig. 7.6). As principais características dessa tecnologia são: o fim da evaporação muda automaticamente dentro de uma ou mais superfícies de aquecimento dependendo da condição de operação, e é possível operar com pressões subcríticas ou supercríticas (EL-WAKIL, 1984).

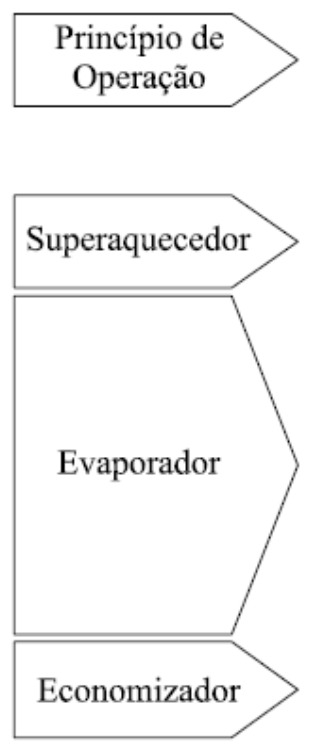

\section{Circulação Natural \\ (Tambor)}

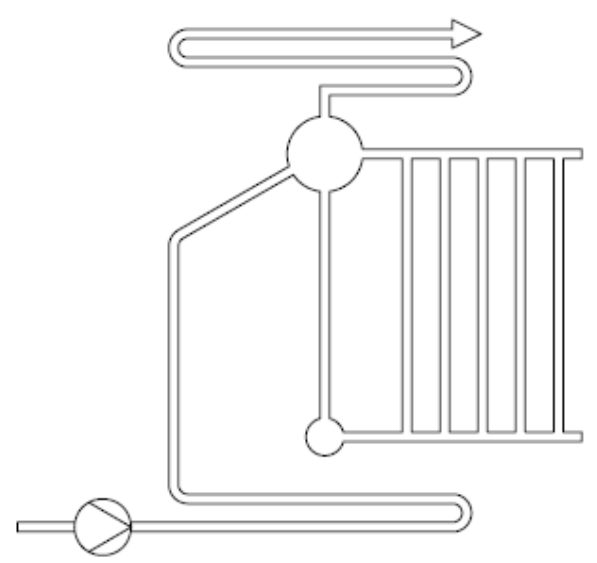

Passe Único

(Benson)

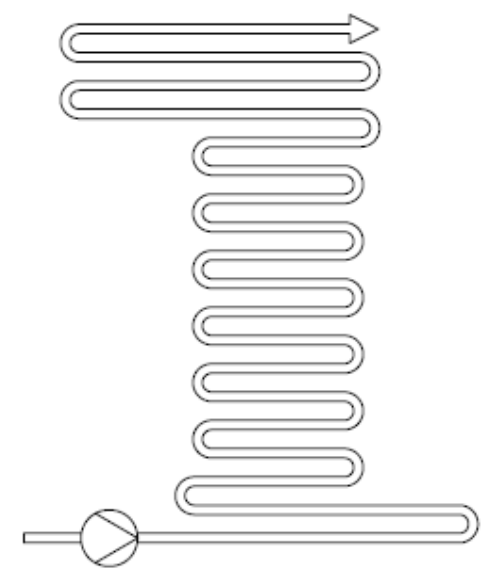

Figura 7.6 - Passagem da Água/Vapor em Caldeiras de Tambor e de Passe Único. 


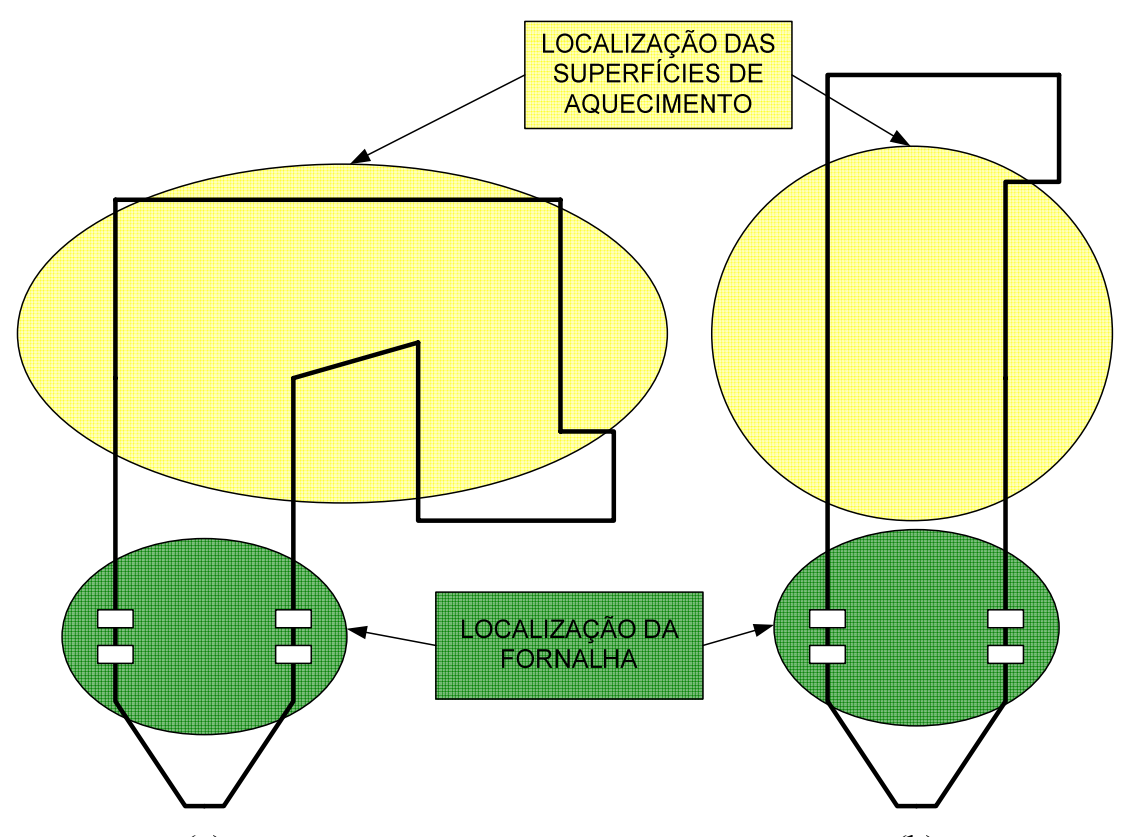

(a)

(b)

Figura 7.7 - Configurações Existentes para Caldeiras Supercríticas: a) em forma de U e b) torre.

A Fig. 7.7 mostra as duas principais configurações disponíveis atualmente para caldeiras supercríticas: em forma de $U$ e torre. As duas configurações são amplamente difundidas, porém a em forma de U é a líder de mercado. Todas as plantas que queimam linhito utilizam a configuração de torre. Ambas as configurações existem na Europa para queima de carvão betuminoso, porém no Japão e nos Estados Unidos a configuração de dupla passagem é a mais comum.

Um outro aspecto interessante relativo ao projeto da caldeira é o arranjo dos tubos na zona de combustão. O arranjo mais popular é o de paredes de água em espiral ("spiral wound furnace"), o qual usa altas taxas de fluxo mássico para promover o resfriamento adequado das paredes da fornalha. Novos conceitos estão utilizando tubos verticais aletados internamente para aumentar a troca térmica. A principal vantagem desse arranjo é a redução da perda de carga na caldeira, melhorando a eficiência global (DTI, 1999 e 2006; LUNDQVIST et al., 2003). Segundo Lora e Nascimento (2004), a Siemens já construiu quase 1000 caldeiras Benson, sendo aproximadamente 300 com paredes de água em espiral e $600 \mathrm{com}$ paredes de água vertical.

Os materiais são ainda a questão mais importante a ser discutida com relação à tecnologia de caldeiras supercríticas. Os diferentes componentes da caldeira são expostos a diferentes 
condições de pressões, temperaturas, ambientes corrosivos e condições de oxidação. Portanto, o desenvolvimento de melhores materiais para condições de vapor supercrítico é uma tarefa muito importante, na qual muitos pesquisadores estão envolvidos. A série de ligas necessárias para melhor atender às demandas de projeto varia desde aços carbono-manganês (CMn) e aços de baixa liga (quantidades de outros elementos químicos inferiores a 5\% em massa) até as famílias de ligas martensíticas com quantidades de cromo entre 9 e $12 \%$ em massa e as austeníticas com a quantidade de cromo variando de 18 até 25\% em massa (DTI, 2006). Uma listagem desses materiais utilizados para a construção de caldeiras pode ser encontrada em Lora e Nascimento (2004).

Paul (1999) afirma que para condições de vapor até $300 \mathrm{bar} / 600^{\circ} \mathrm{C} / 620^{\circ} \mathrm{C}$, é possível utilizar aços com $12 \%$ de cromo. Para condições até 315 bar $/ 620^{\circ} \mathrm{C} / 620^{\circ} \mathrm{C}$, as ligas austeníticas devem ser usadas, os quais são materiais já testados e certificados, porém mais caros. Já para condições mais severas, ligas a base de níquel permitiriam condições de 350 bar $/ 700^{\circ} \mathrm{C} / 720^{\circ} \mathrm{C}$, levando a eficiências do sistema de cerca de $48 \%$. Bugge, Kjær e Blum (2006) discutem os novos desenvolvimentos que vêm ocorrendo para a obtenção de materiais que atendam condição de uso em temperaturas entre $700^{\circ} \mathrm{C}$ e $720^{\circ} \mathrm{C}$.

A tecnologia de leito fluidizado circulante para caldeiras (CFB - "Circulating Fluidized Bed") com circulação natural atingiu escala comercial na última década. Plantas com até $300 \mathrm{MWe}$ de capacidade estão em operação. Um desenvolvimento natural é trazer essa tecnologia para aplicação em plantas de maior capacidade e/ou utilizando parâmetros supercríticos para geração de vapor. Essas caldeiras têm algumas características que as tornam muito vantajosas para a aplicação em sistemas de passe único. Uma vantagem das caldeiras CFB é a sua grande flexibilidade com relação à variação da composição/tipo do combustível e menores níveis de emissão de poluentes. Ainda, dada a natureza da combustão em leitos fluidizados, esta resulta em um baixo e uniforme fluxo de calor devido à baixa temperatura de chama e a uniformidade da mesma na fornalha resultante da circulação de sólidos no seu interior. Embora pareça evidente que a circulação de sólidos promova uma uniformização da temperatura, diminuindo picos de temperatura no interior da fornalha, essa característica ainda deve ser comprovada sob diferentes condições de operação para garantir que não ocorra o superaquecimento dos tubos na fornalha (LUNDQVIST ET Al., 2003). 
Em suma, a tecnologia de caldeiras para sistemas supercríticos pode ser considerada madura, após o grande desenvolvimento ocorrido nos últimos 30-40 anos tanto com relação ao seu projeto quanto ao uso de melhores materiais. Contudo, o estado-da-arte dessa tecnologia ainda pode ser mais desenvolvido para atingir pressões da ordem de 350 bar e temperaturas de $700^{\circ} \mathrm{C}$.

\subsubsection{Tecnologia das Turbinas}

Muito embora o princípio de funcionamento das turbinas a vapor pouco mudou nos 150 anos de uso industrial, estes equipamentos passaram por um contínuo processo de desenvolvimento ao longo dos anos. As turbinas produzidas no início do século XX eram projetadas para pressões e temperaturas de admissão de aproximadamente 13,7 bar e $260^{\circ} \mathrm{C}$. Atualmente, esses equipamentos são projetados para condições de entrada de 300 bar e $620^{\circ} \mathrm{C}$, com reaquecimento simples ou duplo em plantas supercríticas queimando carvão mineral (RETZLAFF; RUEGGER, 1996; BUGGE; KJÆR; BLUM, 2006).

O projeto de uma turbina a vapor para aplicações supercríticas depende do número de reaquecimentos escolhidos, capacidade de geração e características de contrapressão da instalação (temperatura de condensação). Para re-aquecimento simples e capacidade de geração entre $600 \mathrm{MW}$ e $1000 \mathrm{MW}$, o típico arranjo do conjunto da turbina é constituído de três carcaças (módulos) separadas operando a diferentes pressões e temperaturas. Esses módulos são: turbina de alta pressão (HP - "High Pressure Turbine"), turbina de média pressão ou pressão intermediária (IP - "Intermediate Pressure Turbine") e até três turbinas de baixa pressão (LP - "Low Pressure Turbine"). A Fig. 7.7 a seguir mostra um conjunto de uma turbina da classe 600-1000 MW da Siemens (ROSENKRANZ; WICHTMANN, 2005). 


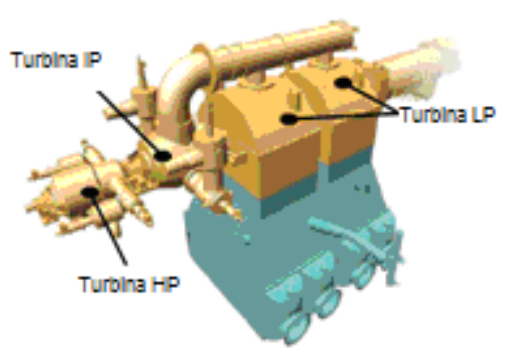

(a)

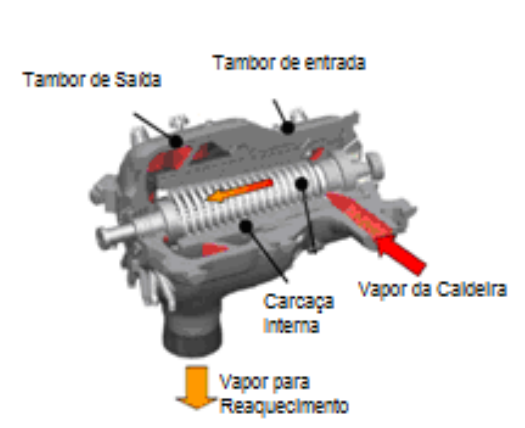

(b)

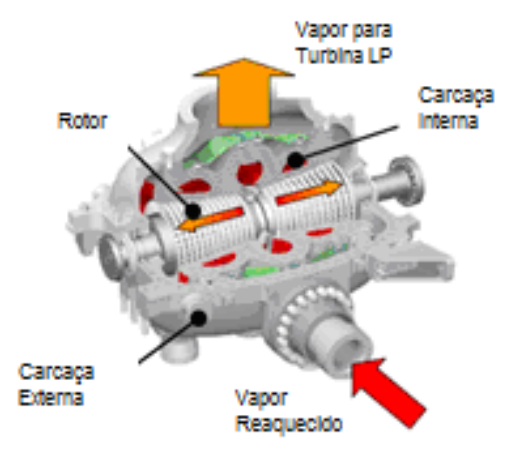

(c)

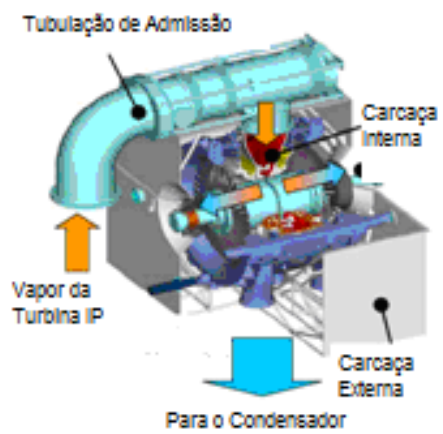

(d)

Figura 7.8 - (a) Conjunto de uma turbina da classe 600-1000 MW. (b) Turbina de alta pressão do tipo barril (HP). (c) Turbina de media pressão (IP). (d) Turbina de baixa pressão (LP) (ROSENKRANZ; WICHTMANN, 2005).

O projeto básico da turbina de alta pressão capaz de lidar com as condições do vapor supercrítico é o projeto da carcaça tipo cilindro ("barrel type outer casing"). Atualmente, esse projeto permite pressões da ordem de 300 bar e temperaturas em torno de $620^{\circ} \mathrm{C}$. Os componentes submetidos a altas temperaturas, tais como cilindro de admissão ("inlet barrel"), rotor e invólucro interno ("inner casing"), são fabricados utilizando aços $12 \%$ Cr com adições de $\mathrm{Mo}, \mathrm{V}$ e $\mathrm{Nb}$. A carcaça externa bipartida verticalmente permite lidar com altas cargas devido a altas pressões, adotando menores espessuras de parede. A turbina de média pressão é projetada para operar com vapor reaquecido de até $620^{\circ} \mathrm{C}$. O rotor e o invólucro interno dessa turbina também são fabricados com ligas de aços com cromo, molibidênio e vanádio, com a quantidade de cromo variando de 9 até 12\% em massa. Altas temperaturas são possíveis, devido à redução da temperatura superficial do rotor pelo princípio de resfriamento por vórtices. Esse princípio de resfriamento permite uma redução da temperatura de até $20^{\circ} \mathrm{C}$ na superfície do rotor, devido à menor velocidade relativa do vapor. Além disso, as palhetas dos primeiros estágios dessa turbina são fabricadas com ligas de aço contendo níquel de maneira a suportar os carregamentos devido às forças centrífugas e às altas temperaturas. Por outro lado, 
a turbina de baixa pressão consiste de uma carcaça de duplo fluxo bipartida horizontalmente. As condições típicas do vapor na entrada dessas turbinas são 7 bar e $350^{\circ} \mathrm{C}$. O vapor expande no seu interior até atingir a pressão do condensador, que varia entre 30 e 100 mbar (3 a 10 $\mathrm{kPa}$ ). Além disso, um cuidado especial deve ser tomado para a escolha apropriada da área e projeto da seção de exaustão da turbina, dadas as elevadas vazões volumétricas nesta. $\mathrm{O}$ desenvolvimento de famílias de palhetas ótimas e duráveis para os últimos estágios é muito importante para evitar perdas na seção de exaustão (ROSENKRANZ; WICHTMANN, 2005).

De acordo com o documento produzido pelo DTI (2006), o estado-da-arte das turbinas a vapor são baseados no uso de 9-12 Cr aços ferríticos/martensíticos para a fabricação dos rotores e das carcaças, sendo ligas a base de níquel ou aços austeníticos de alta dureza necessários apenas nas palhetas dos primeiros estágios.

Korobitsyn (1998) discute que as plantas supercríticas modernas, com re-aquecimento e regeneração, operando com temperaturas de $600^{\circ} \mathrm{C}$ e pressões de 300 bar têm eficiências não maiores que 48-49\%, conforme mostrado na Tab. 7.3. Rosenkranz e Wichtmann (2005) e Bugge, Kjær e Blum (2006) afirmam que os novos desenvolvimentos irão permitir a operação de turbinas a vapor com temperaturas de $700^{\circ} \mathrm{C}$, dando uma eficiência térmica de $56 \%$ e uma eficiência líquida de 51\%. Contudo, o ganho termodinâmico relativo a esse aumento está sujeito a retornos decrescentes na eficiência, já que a redução da vazão volumétrica nessas condições leva à construção de palhetas mais curtas e largas sujeitas a maiores perdas durante a passagem do vapor e ao aumento das perdas devido ao vazamento entre os primeiros estágios (AVRUTSKII et al., 2005; DTI, 2006).

Rosenkranz e Wichtmann (2005) afirmam que o principal objetivo das plantas de potência, dadas as condições de contorno do mercado, é mais que nunca garantir elevados níveis de eficiência (para obter a máxima redução dos impactos ambientais, principalmente relativos a emissões atmosféricas), ao mesmo tempo em que aumentam sua competitividade econômicofinanceira em relação a outras alternativas existentes. $\mathrm{O}$ desenvolvimento de conceitos tanto economicamente quanto ambientalmente eficientes precisa avaliar todos os componentes da planta (caldeiras, sistema de limpeza de gases, turbinas, bombas, trocadores de calor) e promover a otimização do sistema de alimentação de água para caldeira. 
Considerando trocas de calor reversíveis e um número infinito de regeneradores de calor resultaria em uma eficiência do ciclo igual à de Carnot, assim conclui-se que quanto mais regeneradores forem utilizados, maior será a eficiência. Contudo, o ganho marginal relativo à introdução de um novo trocador é decrescente, dado os benefícios decrescentes ao se aproximar do sistema regenerativo ideal. Devido ao ganho marginal decrescente, ao aumento nos custos de capital e limitações físicas do arranjo das turbinas, os benefícios econômicos da introdução de regeneradores adicionais é limitada. A Tab. 7.4 a seguir mostra os números típicos de regeneradores para plantas de diversas capacidades.

Tabela 7.5 - Número típico de regeneradores em função da capacidade de geração.

\begin{tabular}{cc}
\hline Capacidade (MW) & Número de Regeneradores \\
\hline $0-50$ & $3-5$ \\
$50-100$ & 5 ou 6 \\
$100-200$ & $5-7$ \\
Acima de 200 & $6-8$ \\
\hline
\end{tabular}

Fonte: Drbal, 1996

Retzlaff e Ruegger (1996) avaliaram a temperatura final da água de alimentação e a seleção de trocadores de calor para o sistema de alimentação, objetivando a maximização da eficiência para sistemas supercríticos, com conseqüente otimização do arranjo dos regeneradores de calor. Assim, a seleção de condições de geração de vapor mais elevadas resulta na instalação de mais regeneradores e uma maior temperatura final ótima da água de alimentação da caldeira. Características de projetos para regeneradores para plantas supercríticas podem ser encontradas em El-Wakil (1984) e Drbal (1996). Considerando um projeto eficiente com relação ao ganho termodinâmico e ao custo dos trocadores, a temperatura final da água de alimentação não deve ultrapassar os $300^{\circ} \mathrm{C}$ (FRANKE; KRAL, 2003).

Avrustkii et al. (2005) analizaram o uso de re-aquecimentos em plantas de potência a vapor. Os autores indicaram que, para uma estimativa preliminar, a pressão de re-aquecimento deve ser de 40 bar, a fim de se obter a máxima eficiência para o sistema. Considerando o número de re-aquecimentos, é bastante conhecido que melhores desempenhos (maiores eficiências) são obtidos com duplo re-aquecimento. Contudo, o uso do duplo re-aquecimento pode trazer problemas relacionados ao aumento de custo devido à maior complexidade do arranjo da caldeira, às tubulações e à turbina (RETZLAFF; RUEGGER, 1996). De acordo com Avrustkii et al. (2005), pode se estabelecer como regra que o uso do duplo re-aquecimento é mais 
interessante para unidades onde a temperatura da água de resfriamento é muito baixa, ou seja, onde a pressão do condensador é muito baixa; deste modo, o segundo re-aquecimento se faz necessário a fim de evitar um título muito baixo na saída da turbina.

As potenciais melhorias na eficiência dos sistemas a vapor devido às modificações nos parâmetros termodinâmicos do sistema são mostradas na Tab. 7.6.

Tabela 7.6 - Ganhos relativos na eficiência do sistema (os parâmetros são apenas indicativos).

Aumento da Temperatura de Geração do Vapor

Aumento da Pressão de Geração do Vapor

Aumento da Temperatura de Reaquecimento

Uso de um Segundo Reaquecimento

Diminuição da Pressão do Condensador

Aumento da Temperatura Final da Água de Alimentação

Fonte: Avrustkii et al., 2005
$0.02 \% /{ }^{\circ} \mathrm{C}$

$0.01 \% / \mathrm{MPa}$

$0.015 \% /{ }^{\circ} \mathrm{C}$

$1.2 \%$

$1 \% / \mathrm{MPa}$

$0.02 \% /{ }^{\circ} \mathrm{C}$

Comparados aos custos de desenvolvimento da tecnologia de turbinas a gás, os investimentos em pesquisa e desenvolvimento relativos às turbinas supercríticas são considerados modestos, mas resultam em ganhos significativos no consumo de combustível e nos níveis de emissão (ASHMORE, 2006).

Paul (1999) mostra como há um desentendimento com relação ao projeto e à fabricação de componentes de plantas supercríticas, os quais só poderiam ser feitos em países desenvolvidos. $\mathrm{O}$ autor ressalta que as diferenças tecnológicas entre as plantas subcríticas e supercríticas estão limitadas a um pequeno número de componentes. Ele menciona a China e a Índia como exemplos, onde já existe uma grande capacidade instalada para a fabricação de componentes específicos para plantas supercríticas.

\subsubsection{Aplicabilidade a Plantas Utilizando biomassa}

A queima combinada ("co-firing") de carvão e biomassa ajuda a reduzir as emissões totais por energia gerada, quando comparada com a queima do carvão sozinho. As composições desses dois combustíveis são bastante diferentes, sendo a queima combinada uma opção para diminuição dos níveis de emissão de $\mathrm{NO}_{\mathrm{x}}$ e $\mathrm{SO}_{\mathrm{x}}$ em plantas de potência que utilizam carvão pulverizado. Ainda, esse sistema de co-firing permite uma redução dos custos dos 
combustíveis, uma minimização dos resíduos e da poluição terrestre e aquática, dependendo da composição da biomassa utilizada (DEMIRBAS, 2004).

Por outro lado, a composição da biomassa pode variar consideravelmente, especialmente com relação aos constituintes inorgânicos (cinzas), sendo suas concentrações de grande importância para a avaliação de problemas críticos como corrosão e incrustações. Álcalis e metais alcalinos, combinados com outros componentes do combustível como sílica e enxofre, na presença de cloro, são responsáveis por uma série de reações indesejáveis nas fornalhas das caldeiras. A redução do teor de metais alcalinos e cloro, através da lixiviação com água desses componentes, leva a melhoras muito significativas com relação à temperatura de fusão das cinzas (JENKINS et al., 1998). Durante a combustão, o material mineral se volatiliza, podendo ser depositado nas superfícies de aquecimento ou em outras. O fenômeno é conhecido por "slagging" (se a deposição ocorre num estado fundido ou muito viscoso) ou "fouling" (se a deposição é formada por espécies que vaporizaram e em seguida condensaram) (WALTER et al., 2007).

Além disso, a biomassa apresenta grandes quantidades de umidade e baixa densidade, levando a um grande consumo dessa para prover todo o calor requerido nas plantas supercríticas. Desta maneira, é muito importante buscar alternativas para redução da umidade da biomassa, utilizando os gases de exaustão da caldeira, por exemplo.

Assim, a aplicabilidade de plantas supercríticas utilizando biomassa como combustível principal deve ser avaliada considerando a disponibilidade do combustível, a sua composição e características de combustão. Com respeito a este último aspecto, o uso de caldeiras CFB parece ser a melhor alternativa dada a sua flexibilidade para operar com combustíveis de baixa qualidade.

\subsubsection{Ciclos Combinados com Gaseificação de Biomassa}

A tecnologia de ciclos combinados com gaseificação de biomassa (BIGCC - "Biomass Integrated-Gasifier/Gas Turbine Combined Cycle") foi proposta pela primeira vez há mais de uma década como sendo uma tecnologia avançada com potencial para ser competitiva economicamente com a tecnologia convencional de turbinas de extração-condensação utilizando subprodutos do processamento da cana-de-açúcar como combustíveis, ao mesmo 
tempo que aumentaria a quantidade de eletricidade gerada por unidade de cana processada (LARSON; WILLIAMS; LEAL, 2001).

Nos últimos 15 anos, diferentes trabalhos foram desenvolvidos para avaliar diferentes aspectos relativos à aplicação de sistemas BIGCC em usinas sucroalcooleiras (OGDEN; HOCHGREB; HYLTON, 1990; LARSON et al., 1991; WALTER, 1994; SOUZA-SANTOS, 1997; WALTER; OVEREND, 1998a 1998b, ARRIETA; LORA; NEBRA, 2001; LARSON; WILLIAMS; LEAL, 2001; TURN; BAIN; KINOSHITA, 2002; PELLEGRINI, 2003; HASSUANI; LEAL; MACEDO, 2005; PELLEGRINI; OLIVEIRA Jr, 2007a). Outros trabalhos discutem o uso combinado do gás derivado da biomassa com gás natural em plantas de cogeração, de maneira a superar alguns problemas relativos ao sistema BIGCC (RODRIGUES; FAAIJ; WALTER, 2003a, 2003b e 2007; ZAMBONI et al., 2005; ZANETTI; PELLEGRINI; OLIVEIRA Jr., 2007; WALTER et al., 2007).

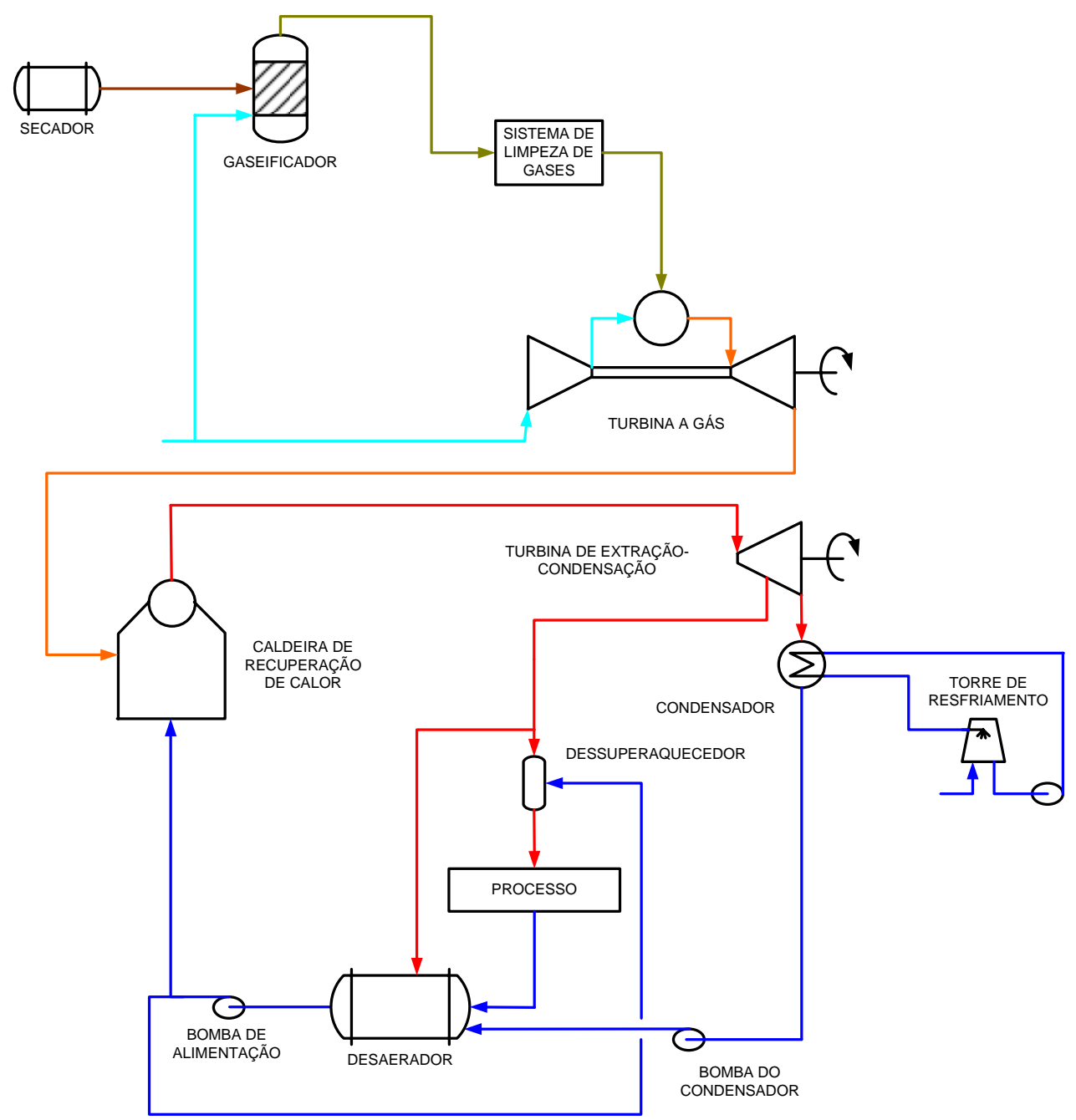

Figura 7.9 - Sistema de Cogeração BIGCC. 
Os principais componentes de um sistema BIGCC (Fig. 7.9) incluem (LARSON; WILLIAMS; LEAL; 2001):

Secador de biomassa (utilizando gases quentes da caldeira de recuperação, p.ex.);

Gaseificador para conversão da biomassa em uma gás combustível, sistema de limpeza para o gás produzido ("produced gas");

> Turbina a gás alimentada com o gás produzido;

Caldeira de recuperação (HRSG - "Heat Recovery Steam Generator") para geração de vapor com os gases de escape da turbina;

$>$ Turbina a vapor para geração adicional de eletricidade.

A seguir uma breve discussão sobre os principais aspectos relativos a essa tecnologia será apresentada.

\subsubsection{Gaseificação}

A gaseificação pode ser definida como um processo termo-químico, no qual um combustível, sólido ou líquido, é convertido com o uso de calor, numa atmosfera sub-oxidante, em um gás (mistura de gases) com baixo/médio poder calorífico, composto basicamente de $\mathrm{H}_{2}$ e $\mathrm{CO}$ (PELLEGRINI; OLIVEIRA, 2007a). Este gás é normalmente chamado de gás produzido ("produced gas”). O processo de gaseificação de biomassa ocorre em quatro etapas (REED; GAUR, 2001):

i. Secagem - evaporação da umidade presente no combustível;

ii. Pirólise - decomposição dos materiais ligno-celulósicos por ação térmica. Os produtos dessa reação de pirólise são:

$\checkmark$ "Gases de pirólise": representa entre 75 e 90\% da massa total da biomassa original e é composto por: gases combustíveis (metano, monóxido de carbono e hidrogênio), alcatrões, dióxido de carbono e vapor d'água;

$\checkmark$ Coque (Carbono Livre): representa entre 10 e $25 \%$ da massa total de biomassa. Este produto pode ser convertido para gás ao reagir com dióxido de carbono e/ou vapor d'água. 
iii. Combustão Parcial - parte dos produtos da pirólise são oxidados pela injeção de ar (ou oxigênio puro), formando dióxido de carbono e vapor. Esta etapa é responsável pelo fornecimento de calor necessário para as demais;

iv. Redução (Gaseificação) - o coque e alcatrões não oxidados na combustão reagem com o dióxido de carbono e o vapor, para a formação de monóxido de carbono e hidrogênio. Essas reações são fortemente endotérmicas. Ainda, o hidrogênio pode reagir com o dióxido de carbono, formando vapor d'água e monóxido de carbono, ou o inverso.

A Fig. 7.10 ilustra os principais processos envolvidos na gaseificação.
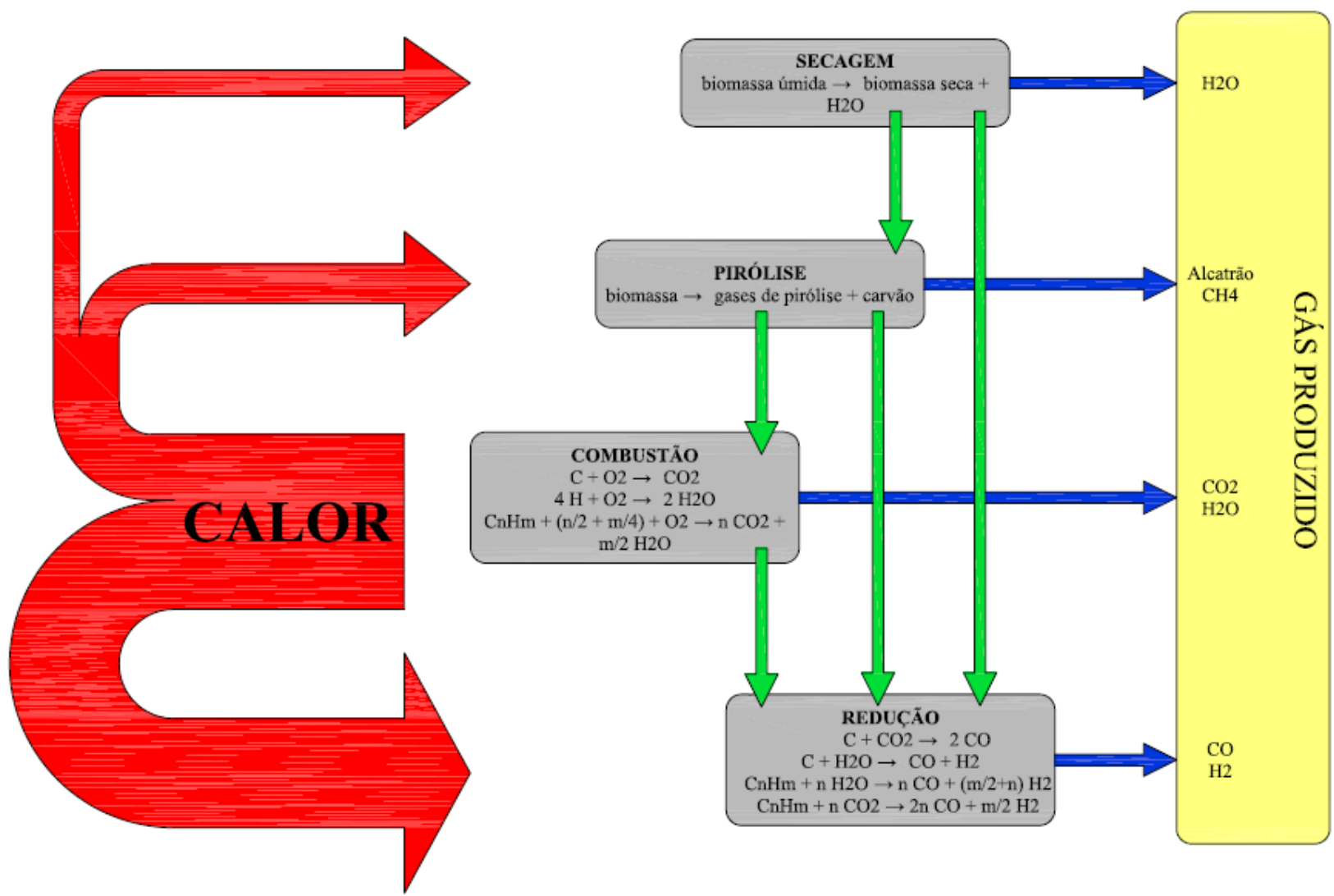

Figura 7.10 - Esquema das etapas do processo de gaseificação (Fonte: www.btgworld.com).

As reações listadas acontecem no interior de um equipamento chamado de gaseificador, o qual pode ser classificado de diferentes maneiras:

Pressão de operação: atmosférico ou pressurizado;

> Tipo de leito: fixo ou fluidizado (borbulhante ou circulante);

Método de aquecimento: direto (utilizando ar ou oxigênio) ou indireto. 
As etapas listadas anteriormente ocorrem de maneira distinta em gaseificadores de leito fixo. Já em leitos fluidizados é impossível distinguir as diferentes etapas. Para uma análise mais rigorosa dos tipos de gaseificadores existentes faz-se referência aos trabalhos de Consonni e Larson (1996), Reed e Gaur (2001) e Coelho, Martins e Santos (2002).

Sistemas de pequena escala utilizam normalmente gaseificadores de leito fixo com aquecimento direto, associados a motores de combustão interna para geração de potência. Para sistemas de grande escala associados a turbinas a gás, o leito fluidizado é preferível e diferentes configurações podem ser utilizadas. Os gaseificadores de leito fluidizado têm maior capacidade de produção se comparados aos de leito fixo, incluindo a possibilidade de lidar com matérias-primas de baixa densidade, como resíduos agrícolas não-compactados. A sua habilidade de lidar como uma grande variedade de biomassas com o mínimo de préprocessamento do gás produzido torna os gaseificadores de leito fluidizado a tecnologia a ser escolhida para muitas biomassas (WILLIAMS; LARSON, 1996).

Craig e Mann (1996) e Consonni e Larson (1996) descrevem as principais configurações disponíveis para gaseificadores aplicados a sistemas BIGCC. A Tab.7.7 mostra um comparativo entre essas configurações. Desde meados da década de 90 do século passado, muitas plantas-piloto foram comissionadas e postas em marcha a fim de mostrar a viabilidade técnica de sistemas BIGCC. Dentre elas, a planta de Värnamo (Suécia) pode ser considerada o caso mais importante, tendo operado por milhares de horas entre 1995 e 2000. Outras plantas são citadas por Consonni e Larson (1996).

Hussuani, Leal e Macedo (2005) apresentam uma análise completa de uma planta de cogeração baseada em um gaseificador atmosférico, com aquecimento direto, aplicada a uma usina sucroalcooleira. Este trabalho apresenta resultados de testes de gaseificação de bagaço, pontas e folhas para diferentes condições dessas biomassas, bem como resultados referentes ao sistema de limpeza do gás produzido. 
Tabela 7.7 - Comparativo entre as diferentes configurações do sistema BIGCC.

\begin{tabular}{|c|c|c|}
\hline $\begin{array}{c}\text { Tipo do } \\
\text { Gaseificador }\end{array}$ & Vantagens & Desvantagens \\
\hline $\begin{array}{l}\text { Atmosférico, } \\
\qquad \text { com } \\
\text { aquecimento } \\
\text { direto (ar) }\end{array}$ & $\begin{array}{l}>\text { Fácil alimentação do combustível } \\
\text { Sistema Convencional de Limpeza } \\
\text { do Gás } \\
\text { D Apropriado economicamente para } \\
\text { plantas de modestas capacidades }\end{array}$ & $\begin{array}{l}>\text { Água residual gerada durante a } \\
\text { limpeza do gás } \\
>\text { Necessidade de um compressor } \\
\text { para o gás produzido, aumentando o } \\
\text { custo e diminuindo a eficiência } \\
>\text { Limitado economicamente a } \\
\text { plantas de modestas capacidades }\end{array}$ \\
\hline $\begin{array}{l}\text { Atmosférico, } \\
\qquad \text { com } \\
\text { aquecimento } \\
\text { indireto }\end{array}$ & $\begin{array}{l}>\text { Fácil alimentação do combustível } \\
\text { Sistema Convencional de Limpeza } \\
\text { do Gás } \\
>\text { Apropriado economicamente para } \\
\text { plantas de modestas capacidades } \\
>\text { Gás com maior poder calorífico }\end{array}$ & $\begin{array}{l}\text { Água residual gerada durante a } \\
\text { limpeza do gás } \\
>\text { Necessidade de um compressor } \\
\text { para o gás produzido, porém menor } \\
\text { que o da primeira configuração } \\
>\text { Limitado economicamente a } \\
\text { plantas de modestas capacidades } \\
>\text { Operação mais complexa }\end{array}$ \\
\hline $\begin{array}{l}\text { Pressurizado, } \\
\qquad \text { com } \\
\text { aquecimento } \\
\text { direto (ar) }\end{array}$ & $\begin{array}{l}>\text { Mais eficiente, não necessita de } \\
\text { um compressor do gás produzido } \\
>\text { Sistema de limpeza a quente, sem } \\
\text { uso de água } \\
>\text { Apropriado economicamente para } \\
\text { plantas de grandes capacidades }\end{array}$ & $\begin{array}{l}>\text { Dificuldades relacionadas à } \\
\text { alimentação do combustível } \\
>\text { Maiores desafios tecnológicos para } \\
\text { limpeza dos gás } \\
>\text { Maior emissão de } \mathrm{NO}_{\mathrm{x}} \\
>\text { Limitado economicamente a } \\
\text { plantas de grandes capacidades }\end{array}$ \\
\hline
\end{tabular}

Fonte: Larson, Williams e Leal (2001)

$\mathrm{Na}$ literatura, diferentes abordagens para modelagem da gaseificação estão disponíveis baseadas tanto em considerações relacionadas a equilíbrio químico quanto em aspectos cinéticos. Esses modelos pretendem prever a composição do gás produzido, sua temperatura, dentre outras características (PELLEGRINI; OLIVEIRA JR, 2007a). No apêndice B é mostrada a modelagem do processo de gaseificação baseado em um modelo de equilíbrio químico.

A parte a escolha pela tecnologia de gaseificação, as principais relações de "trade-off" envolvidas no projeto e comercialização dos sistemas BIGCC referem-se a: gaseificação atmosférica ou pressurizada, sistema de limpeza quente ou frio, adaptabilidade a turbinas a gás existentes no mercado e integração entre o secador, os equipamentos de processamento do gás e às turbomáquinas (CONSONNI; LARSON, 1996). 
A gaseificação pressurizada irá produzir um gás adequado para ser aplicado diretamente em uma turbina a gás, aumentando a eficiência global do sistema (TURN; BAIN; KINOSHITA, 2002). Contudo, a fim de tirar proveito dessa pressurização, diversos equipamentos auxiliares devem ser desenvolvidos. Sistemas de alimentação de biomassa para sistemas de alta pressão ainda não provaram a sua confiabilidade comercialmente (BAIN; OVEREND; CRAIG, 1998).

\subsubsection{Sistema de Limpeza}

O gás que sai do gaseificador contém material particulado, alcatrão e outras impurezas que podem interferir/danificar a operação dos equipamentos a jusante. $\mathrm{O}$ teor de cada uma dessas impurezas depende do sistema de gaseificação utilizado, conforme mostrado na Tab. 7.8.

Tabela 7.8 - Comparação entre os diferentes teores de material particulado e alcatrão para diferentes tipos de gaseificador.

\begin{tabular}{ccc}
\hline Tipo do Gaseificador & $\begin{array}{c}\text { Material Particulado } \\
\left(\mathbf{g} / \mathbf{N m}^{3}\right)\end{array}$ & Alcatrão $\left(\mathbf{g} / \mathbf{N m}^{3}\right)$ \\
\hline Leito Fixo Contracorrente & $0,1-0,2$ & $20-100$ \\
Leito Fixo Concorrente & $0,1-0,2$ & $0,1-1,2$ \\
Leito Fluidizado Borbulhante & $2,0-20$ & $1-15$ \\
Leito Fluidizado Circulante & $8,0-35$ & $1-15$ \\
\hline Fonte: Stevens (2001) &
\end{tabular}

Fonte: Stevens (2001)

Turbinas a gás impõem restrições no conteúdo de material particulado, metais alcalinos e alcatrão no gás produzido alimentado na câmara de combustão. O material particulado pode causar erosão nas palhetas, assim como os metais alcalinos. Se o alcatrão condensar nas superfícies frias das turbinas, problemas críticos poderão ocorrer, incluindo redução do diâmetro das tubulações, entupimento de válvulas e filtros. Além disso, o alcatrão tem um poder calorífico relativamente alto e poderia ser queimado na câmara de combustão; assim, a sua remoção do gás produzido resultaria numa perda de eficiência. Duas abordagens vêm sendo estudadas para o sistema de limpeza: rota quente e rota fria.

$\mathrm{Na}$ rota quente, considerada para gaseificação pressurizada, o sistema deve remover as impurezas do gás produzido sem diminuir sua temperatura abaixo da temperatura de orvalho do alcatrão, tipicamente em torno de $538^{\circ} \mathrm{C}$. Desta maneira, antes da remoção dos metais alcalinos e do material particulado, o gás deve passar por um craqueador de alcatrão, a fim de 
diminuir a temperatura de orvalho. Após o craqueador, o gás é resfriado até $538^{\circ} \mathrm{C}-649^{\circ} \mathrm{C}$, a fim de minimizar o teor de metais alcalinos volatilizados. Em seguida, passa por um filtro cerâmico para remoção dos sólidos. Esses processos evitam perdas termodinâmicas relacionadas à diminuição da temperatura do gás e o consumo adicional de energia para compressão do mesmo antes de entrar na câmara de combustão (CONSONNI; LARSON, 1996; BAIN; OVEREND; CRAIG, 1998).

Na rota fria, um craqueador de alcatrão também será utilizado para diminuir o teor de alcatrão e evitar a condensação deste durante o resfriamento do gás. Como estes sistemas são utilizados principalmente para gaseificadores atmosféricos, os conteúdos de alcatrão e água devem ser os menores possíveis a fim de evitar condensação durante a compressão. Normalmente, a temperatura deve ser mantida a aproximadamente $93^{\circ} \mathrm{C}$. Trocadores de calor são utilizados para diminuir a temperatura do gás desde a saída do craqueador até a menor temperatura de orvalho do alcatrão residual, além de lavadores de gases. Uma integração térmica entre os requisitos de resfriamento do gás e as demandas de aquecimento do sistema BIGCC deve ser avaliada para aumentar a eficiência do sistema como um todo. O gás na saída do lavador de gases está saturado com água (CONSONNI; LARSON, 1996; BAIN; OVEREND; CRAIG, 1998).

\subsubsection{Turbina a Gás}

Três assuntos devem ser considerados ao avaliar a compatibilidade entre o gás produzido e a turbina a gás: estabilidade da combustão, perda de carga no sistema de injeção do combustível e limites de vazão mássica pela turbina. Devido ao menor poder calorífico do gás, a câmara de combustão da turbina a gás deve acomodar uma maior vazão volumétrica de gás para atingir uma quantidade equivalente de energia liberada (CONSONNI; LARSON, 1996).

De acordo com esses autores, combustores do tipo caneca ("can-type combustors"), utilizados em diversas turbinas industriais, fornecem seções transversais e volumes adequados para a combustão completa e estável, com perdas de carga aceitáveis. Mais além, aplicações comerciais com gases de alto-forno estão disponíveis nas últimas três décadas. Todavia, ainda não há nenhuma experiência de aplicação comercial utilizando turbinas a gás aeroderivativas. Com relação à perda de carga associada à injeção de grandes volumes de combustível, algumas turbinas talvez necessitem um re-projeto dos bocais. Neilson (1998) discute as 
modificações necessárias numa turbina a gás aeroderivativa (GE LM 2500) para operação com gases de baixo poder calorífico.

Turbinas a gás operam em condições de escoamento blocado na entrada do expansor, assim uma maior vazão mássica só pode ser acomodada aumentando-se a razão de pressão no compressor ou diminuindo a temperatura de entrada na turbina (já que isso diminui a quantidade de combustível necessária). A primeira opção pode trazer o compressor a operar em uma condição limite ("stall limit"). Por outro lado, a diminuição da temperatura de entrada na turbina ("de-rating") implica uma redução da eficiência termodinâmica da mesma.

Walter et al. (1998a) e Rodrigues, Faaij e Walter (2003a e 2007) avaliaram a performance de turbinas a gás operando com gás de baixo poder calorífico, considerando diversas estratégias de controle ("de-rating", fechamento das palhetas de admissão do compressor e "blast-off"). Para gaseificação pressurizada, a operação com "blast-off" é uma boa opção, já que a vazão mássica necessária para gaseificação é aproximadamente igual à vazão mássica do gás produzido no gaseificador, assim a vazão que passa pela turbina é praticamente igual à vazão que passa pelo compressor (CONSONNI; LARSON, 1996).

\subsubsection{Equipamentos Auxiliares}

Diversas oportunidades existem para a integração térmica do sistema de gaseificação com a planta de potência em sistemas BIGCC. Consonni e Larson (1996) mostram diferentes configurações, baseadas em diferentes projetos de gaseificador com integração térmica dos equipamentos para recuperação de calor.

\subsection{INTEGRAÇÃO TÉRMICA ENTRE AS TECNOLOGIAS E AS DEMANDAS TERMO-MECÂNICAS DE UMA USINA SUCROALCOOLEIRA}

Conforme comentado anteriormente, a demanda eletromecânica em usinas sucroalcooleiras tradicionais é aproximadamente $30 \mathrm{kWh} / \mathrm{tc}$, enquanto a demanda térmica é de $500 \mathrm{~kg} / \mathrm{tc}^{27}$ $(303 \mathrm{kWh} / \mathrm{tc})$. Esses valores resultam em uma relação potência/calor igual a 0,099. Para esse valor, os sistemas utilizando turbinas de contrapressão podem ser considerados as melhores

\footnotetext{
${ }^{27}$ Vapor saturado a 2,5 bar.
} 
opções (BALESTIERI, 2002), tendo sido escolhidos pela totalidade das usinas sucroalcooleiras brasileiras a partir da década de 80 (WALTER, 1994).

Normalmente, os sistemas de cogeração empregados nas usinas utilizam vapor a 21 bar e $300^{\circ} \mathrm{C}$ para o acionamento de turbinas de acionamento mecânico e de geração de eletricidade, cujo vapor de escape a 2,5 bar é enviado para o processo. Considerando que o consumo específico de vapor nessas turbinas é aproximadamente 12-16 kg/kWh (KOBLITZ, 1996) e a demanda de vapor no processo é igual a $500 \mathrm{~kg} / \mathrm{tc}$, essas turbinas são capazes de gerar entre 31 e $42 \mathrm{kWh} / \mathrm{tc}$, ou seja, há um excedente de energia eletromecânica de até $12 \mathrm{kWh} / \mathrm{tc}$. A comercialização desse excedente não é comum, assim parte do vapor necessário ao processo é obtida pela expansão do vapor de alta em válvulas, chegando a representar até $20 \%$ do total gerado. Ainda, considerando o consumo específico de bagaço nas caldeiras entre 2,15 e 2,30 $\mathrm{kg}$ de vapor/kg de bagaço (KOBLITZ, 1996; PERUCHI, 2007), é possível obter um excesso de bagaço $^{28}$ entre 7 e $13 \%$ (esses valores variam em função do teor de fibra da cana).

Os valores mostrados no parágrafo anterior indicam que já é possível obter um excedente de eletricidade em usinas tradicionais. A potencialização desse excedente é viável através do aumento dos parâmetros de geração de vapor e substituição das turbinas de geração de eletricidade por outras mais eficientes. Ainda, a eletrificação dos acionamentos mecânicos permitiria um ganho adicional. É importante ressaltar que a geração desse excedente em sistemas de contrapressão está diretamente relacionada à demanda de vapor pelo processo. A Fig. 7.11 mostra a variação da eletricidade excedente em função da demanda de vapor no processo e os parâmetros de geração de vapor, considerando modificações apenas na geração de eletricidade ${ }^{29}$. É interessante notar que para consumos de vapor inferiores a $410 \mathrm{~kg} / \mathrm{tc}$, a geração a 21 bar e $300^{\circ} \mathrm{C}$ não é capaz de atender à demanda por eletricidade do processo, representado pelos valores negativos do excedente gerado (excedente = eletricidade gerada eletricidade consumida).

Conforme destaca Walter (1994) a elevação do consumo de vapor no processo para aumentar a geração de eletricidade excedente não é justificável, face principalmente aos desequilíbrios que poderiam existir entre a disponibilidade e a demanda de bagaço, causando déficit de

\footnotetext{
${ }^{28}$ Quantidade de bagaço disponível igual a $250 \mathrm{~kg} / \mathrm{tc}$ (ou seja, 12\% de fibra na cana).

${ }^{29}$ Foram considerados os ganhos de eficiência da substituição das caldeiras e das turbinas.
} 
bagaço durante a safra. A Fig. 7.12 mostra a variação do excedente de bagaço em função da demanda de vapor no processo e os parâmetros de geração de vapor, considerando modificações apenas na geração de eletricidade. Para consumos de vapor no processo acima de $560 \mathrm{~kg} / \mathrm{tc}$, começa a haver um déficit de bagaço para atender às demandas da usina.

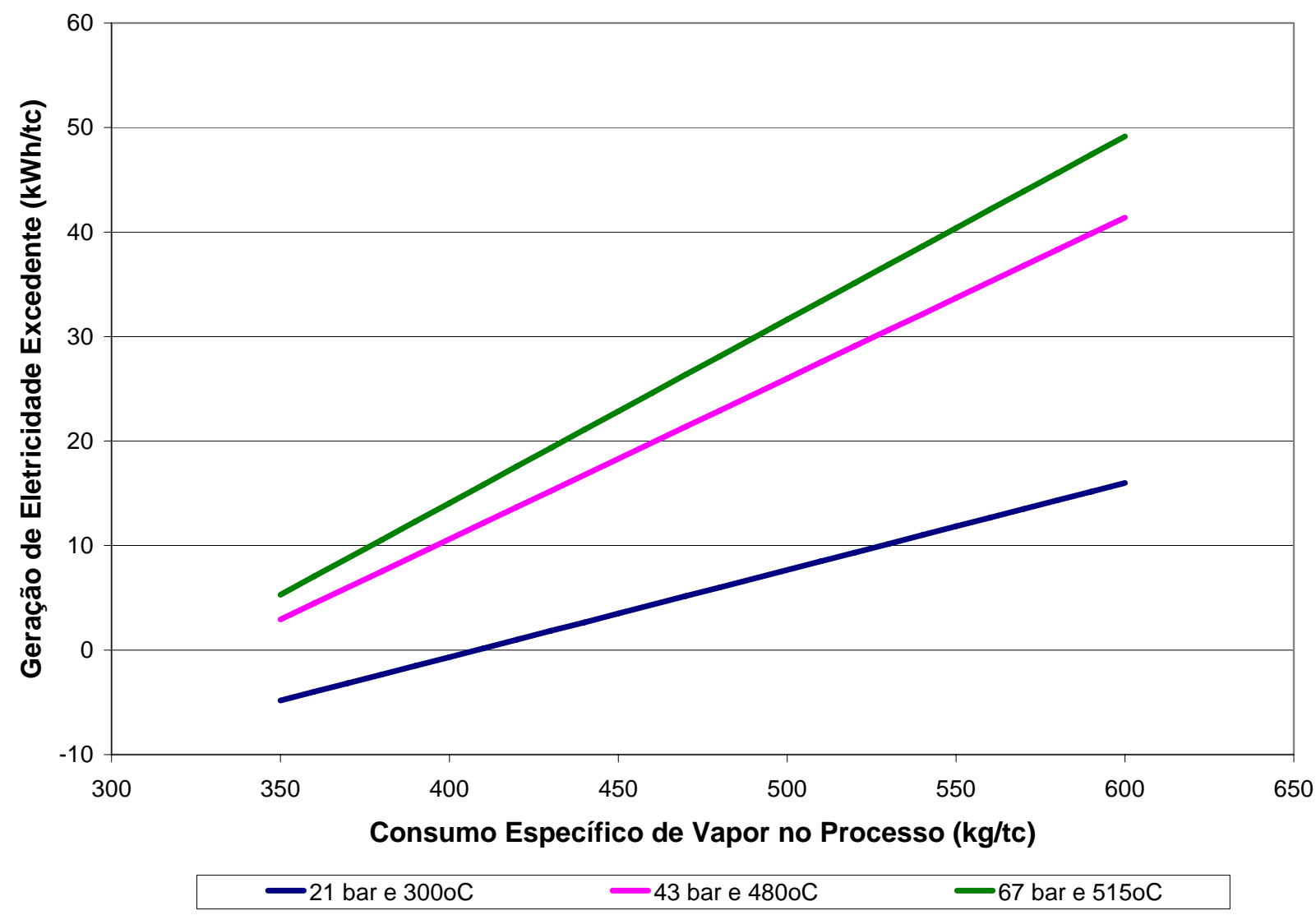

Figura 7.11 - Influência do consumo de vapor e dos parâmetros de geração de vapor na geração de eletricidade excedente em sistemas de contrapressão. 


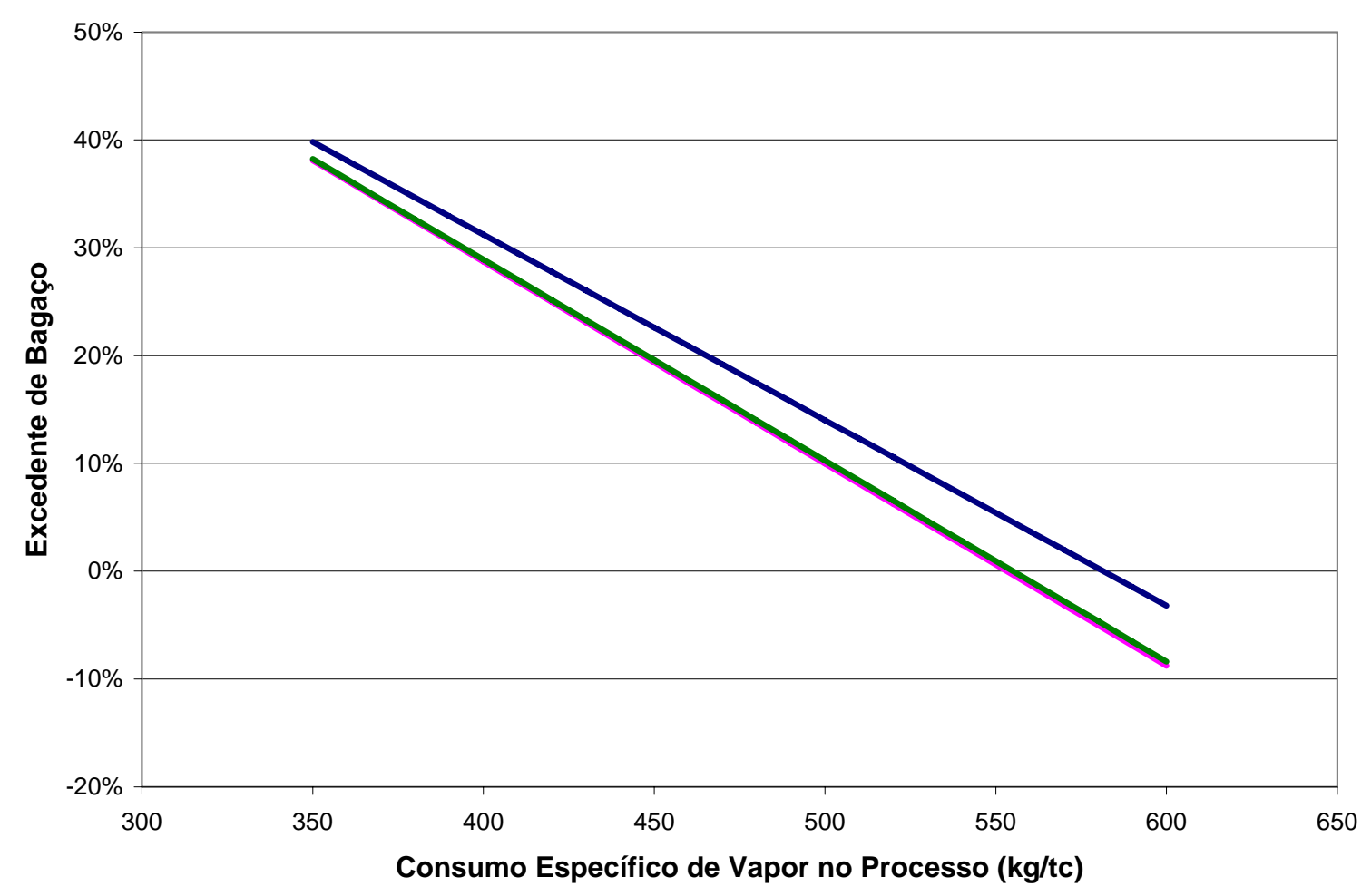

-21 bar e 300oC $\quad-43$ bar e 480oC $\quad-67$ bar e 5150C

Figura 7.12 - Influência do consumo de vapor e dos parâmetros de geração de vapor no excedente de bagaço.

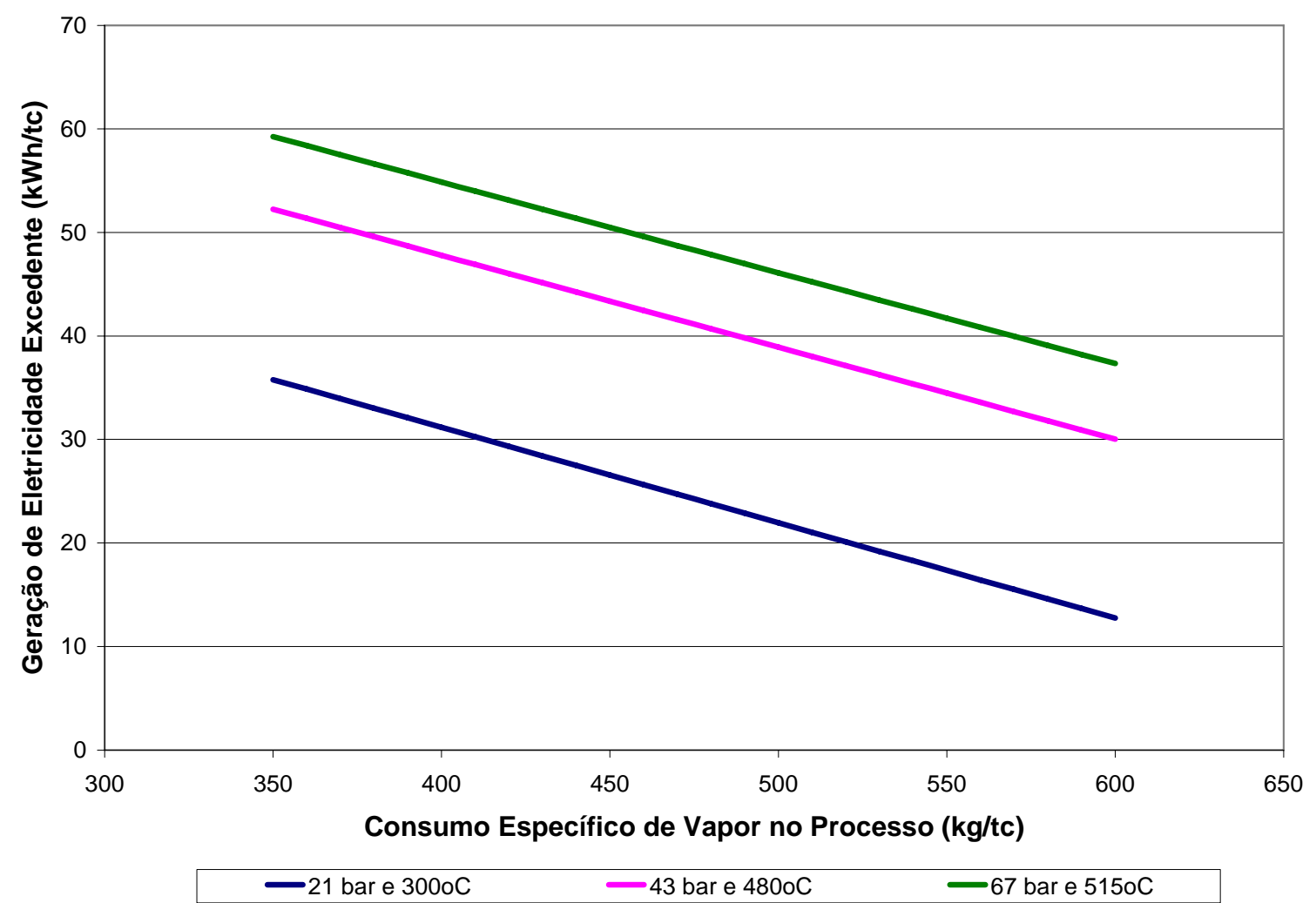

Figura 7.13- Influência do consumo de vapor e dos parâmetros de geração de vapor na geração de eletricidade excedente em sistemas de contrapressão com condensação do vapor excedente. 
Todavia, para consumos de vapor abaixo de $500 \mathrm{~kg} / \mathrm{tc}$, os excedentes de bagaço são maiores que $10 \%$ do total gerado. Assim, pode-se aumentar a geração de eletricidade excedente fazendo-se uso de turbinas de condensação (ver Fig. 7.13).

Comparando-se as Figs. 7.11 e 7.13, é possível ver os aumentos da geração de eletricidade excedente em função do uso das turbinas de condensação utilizando vapor gerado a partir do bagaço excedente.

O uso de sistemas com turbinas de extração-condensação permite um aumento ainda maior na geração de eletricidade excedente, já que todo o vapor pode ser gerado a pressões e temperaturas mais elevadas e ser parcialmente expandido nas turbinas até a pressão de admissão nos acionamentos, gerando um adicional de eletricidade. Ainda, a condensação permite a possibilidade de geração durante o ano todo e não apenas durante a safra, como nos sistemas de contrapressão pura. Porém para geração ao longo do ano todo, é necessário verificar se o excedente de bagaço gerado durante a safra é suficiente para manter os mesmos padrões de geração durante a entressafra. Caso contrário, é necessário o uso de um combustível complementar, como por exemplo, a palha da cana (pontas e folhas). Além disso, o uso de sistemas mais avançados de cogeração requer uma redução do consumo de vapor no processo para possibilitar a integração dessas tecnologias.

No caso de sistemas supercríticos de vapor, é necessário fazer diversas extrações na turbina para alimentar os regeneradores de vapor, além de fazer uso de um re-aquecimento para evitar valores muito baixos do título na saída do último estágio da turbina. Assim, é importante avaliar cuidadosamente o impacto do número de regeneradores sobre a quantidade de vapor disponibilizada para o processo.

Conforme já mostrado por diversos autores, os sistemas BIGCC não são capazes de atender a demandas de vapor superiores a $350 \mathrm{~kg} / \mathrm{tc}$. Pellegrini et al. (2005) analisaram a integração térmica de sistemas BIGCC, considerando que parte do bagaço é enviado para o gaseificador e parte é queimado na caldeira com os gases quentes da turbina. Partindo desta idéia, e baseando-se nos modelos desenvolvidos por Zanetti, Pellegrini e Oliveira Jr. (2007) e possível construir o gráfico mostrado na Fig. 7.14. As hipóteses para a construção do gráfico são apresentadas na Tab. 7.9. 
Tabela 7.9 - Considerações para avaliação da integração térmica de sistemas BIGCC.

Quantidade de bagaço disponível, com 50\% de umidade (kg/tc) 250

Razão Gás Produzido/Bagaço a 20\% (kg/kg) 2,23

$\mathrm{PCI}$ gás produzido $(\mathrm{kJ} / \mathrm{kg})$

Eficiência térmica da TG, considerando o compressor de gás (\%) 30

Razão Gás Produzido/Gases de Exaustão da TG $(\mathrm{kg} / \mathrm{kg})$

Temperatura dos Gases de Exaustão da TG $\left({ }^{\circ} \mathrm{C}\right) \quad 450$

Temperatura dos Gases de Chaminé da HRSG $\left({ }^{\circ} \mathrm{C}\right) \quad 180$

Consumo específico de vapor nas turbinas de geração de eletricidade $(\mathrm{kg} / \mathrm{kWh}) \quad$ 6,8

Consumo de energia eletro-mecânica no processo $(\mathrm{kWh} / \mathrm{tc})$

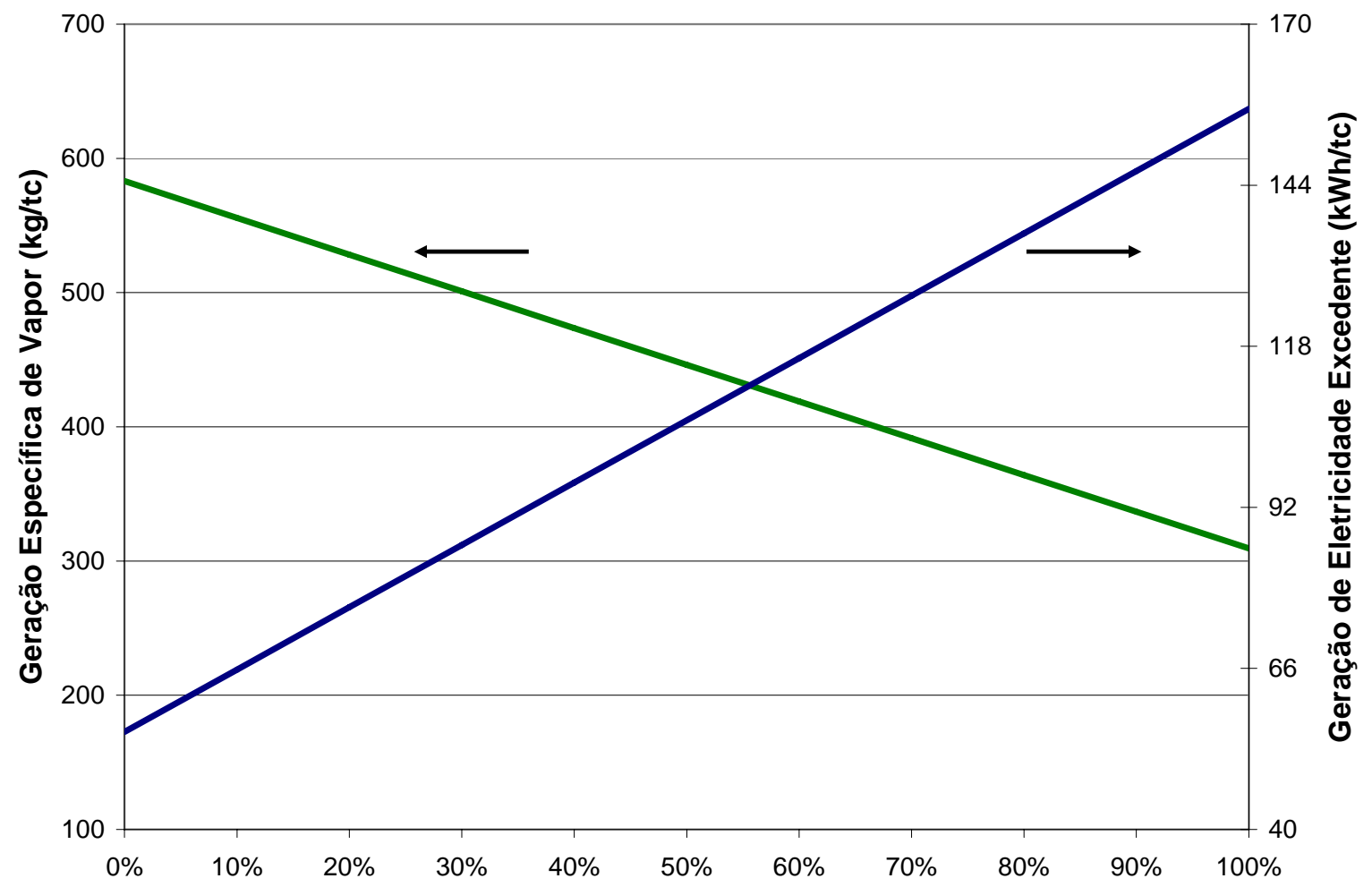

Quantidade de Bagaço Enviada para o Gaseificador

Figura 7.14 - Variações da Geração de Vapor e Eletricidade Excedente em função da quantidade de bagaço enviada para o gaseificador.

Conforme pode ser visto na Fig. 7.14, o sistema BIGCC "puro" gera apenas $310 \mathrm{~kg} / \mathrm{tc}$ de vapor, sendo necessário queimar quase que $70 \%$ do bagaço para possibilitar a geração de 500 $\mathrm{kg} / \mathrm{tc}$ de vapor para o processo. Com relação ao excedente de eletricidade gerado, o sistema BIGCC "puro" é capaz de gerar quase $160 \mathrm{kWh} / \mathrm{tc}$. É importante salientar que os resultados 
ora apresentados são meramente ilustrativos, sendo a análise feita muito mais qualitativa que quantitativa. Valores mais rigorosos serão apresentados no Cap. 8.

Vale ressaltar que a análise contempla exclusivamente a geração somente durante a safra, para geração durante o ano todo é necessário o uso de um combustível complementar.

De uma maneira geral, a geração de energia elétrica excedente em usinas sucroalcooleiras está intimamente ligada ao consumo de vapor pelo processo, já que esse é responsável pelo gasto de combustível nas caldeiras. Portanto, a geração de excedente de bagaço e a redução do consumo de vapor nos processos são questões que podem ser tratadas como uma só sob o ponto de vista de uma melhor integração térmica dos processos de troca de calor nas usinas. Além disso, a geração de eletricidade ao longo do ano todo requer o uso de um combustível complementar, caso o excedente de bagaço durante a safra não seja suficiente. Este é o caso, sobretudo, dos sistemas mais avançados de cogeração.

O processo de concentração do caldo de cana (evaporação) é o principal consumidor de vapor de escape das turbinas de uma usina sucroalcooleira. Ainda, este processo é responsável pela "produção" do vapor vegetal utilizado nos mais diversos processos de aquecimento do processo produtivo (tratamento de caldo, cozimento, destilação, dentre outros). Assim, podese dizer que este processo é o responsável pela integração entre a planta de utilidades e o processo numa usina. Pellegrini e Oliveira Jr. (2006b) mostram a relação existente entre o consumo de vapor de escape nesses equipamentos e a geração de entropia em função das extrações feitas nos diferentes efeitos da evaporação. Uma integração térmica entre as extrações de cada efeito e os diferentes consumidores de vapor configura a melhor opção sob uma perspectiva termodinâmica. Ou seja, as extrações devem ser feitas de maneira a se evitar que haja grandes quantidades de vapor vegetal do último efeito sendo enviadas ao condensador barométrico. Pellegrini e Oliveira Jr. (2007b) propõem uma integração térmica entre o evaporador e os consumidores de vapor vegetal, onde o consumo final de vapor de escape é igual a $390 \mathrm{~kg} / \mathrm{tc}$.

Ensinas et al. (2006 e 2007) e Ensinas (2008) desenvolveram uma estratégia de otimização termoeconômica para a integração térmica de uma usina de produção de açúcar e álcool. A rede de trocadores de calor proposta utiliza praticamente todas as correntes quentes disponíveis (vapores vegetais, vinhaça, condensados diversos, mosto) para providenciar o 
aquecimento do caldo durante o tratamento, do caldo clarificado antes da evaporação, do cozimento do xarope e do vinho após a fermentação. Para destilação, as colunas convencionais atmosféricas, foram substituídas por um sistema de dupla-pressão, com o refervedor da coluna de esgotamento (operando sob vácuo) servindo de condensador da coluna de retificação (SEEMANN, 2003). A configuração final apresenta um consumo de vapor de $278 \mathrm{~kg} / \mathrm{tc}$. A configuração obtida por Ensina et al. (2007) é bastante semelhante à proposta por Avram, Morgenroth e Seemann (2004) que otimizaram a produção de açúcar, álcool e eletricidade, reduzindo o consumo de vapor para $305 \mathrm{~kg} / \mathrm{tc}$. Essas configurações permitem a utilização de sistemas BIGCC.

Finalmente, o uso da palha da cana para promover a geração de eletricidade durante o ano todo deve ser considerado, principalmente para os sistemas supercríticos e BIGCC. Conforme mostram Hassuani, Leal e Macedo (2005), a quantidade de pontas e folhas disponível no campo equivale a $140 \mathrm{~kg}$ de matéria seca/tc, ou seja, praticamente a mesma quantidade de bagaço disponível na usina. A Tab. 7.10 mostra a caracterização desse material.

Tabela 7.10 - Composição das pontas e folhas em comparação com o bagaço.

\begin{tabular}{ccccc}
\hline $\begin{array}{c}\text { Componente } \\
\text { (\% massa, base seca) }\end{array}$ & Folhas Secas & Folhas Verdes & Pontas & Bagaço \\
\hline Carbono & 46,2 & 45,7 & 43,9 & 44,6 \\
Hidrogênio & 6,2 & 6,2 & 6,1 & 5,8 \\
Nitrogênio & 0,5 & 1,0 & 0,8 & 0,6 \\
Oxigênio & 43,0 & 42,8 & 44,0 & 44,5 \\
Enxofre & 0,1 & 0,1 & 0,1 & 0,1 \\
Cloro & 0,1 & 0,4 & 0,7 & 0,02 \\
Cinzas & 3,9 & 3,7 & 4,3 & 2,2 \\
Umidade & 13,5 & 67,7 & 82,3 & 50,2 \\
\hline
\end{tabular}

Fonte: Hassuani, Leal e Macedo (2005).

Uma questão muito importante relativa ao uso das pontas e folhas está relacionada ao transporte desse material até a usina. O Centro de Tecnologia Canavieira (CTC) estudou 5 possíveis rotas para o transporte das pontas e folhas até a usina (HASSUANI; LEAL; MACEDO, 2005).

Rota A - colheita da cana inteira, transporte conjunto da cana e das pontas e folhas, separação na usina; 
$\checkmark$ Rota B - colheita da cana inteira, transporte da cana limpa e picada, enfardamento das pontas e folhas no campo;

$\checkmark$ Rota C - colheita da cana picada, separação das pontas e folhas na colheitadeira, enfardamento das pontas e folhas no campo;

$\checkmark$ Rota D - colheita da cana picada, transporte conjunto com as pontas e folhas, separação na usina.

$\checkmark$ Rota E - colheita da cana picada, com limpeza parcial da cana, deixando parte das pontas e folhas para serem transportadas em separado.

As rotas A e B não se mostraram adequadas para lidar com produtividades acima de 70 tc/ha, sendo descartadas. A Tab. 7.10 mostra os resultados para as demais rotas.

Tabela 7.11 - Avaliação da recuperação das pontas e folhas com a colheita mecanizada.

\begin{tabular}{cccc}
\cline { 2 - 4 } & Rota C & Rota D & Rota E \\
\hline Quantidade de matéria seca disponível $(\mathrm{kg} / \mathrm{tc})$ & 140 & 140 & 140 \\
Quantidade de matéria seca recuperada $(\mathrm{kg} / \mathrm{tc})$ & 90 & 92 & 70 \\
Eficiência de recuperação & 64 & 66 & 50 \\
Custo (US\$/t de matéria seca) & 18,49 & 31,12 & 13,70 \\
\hline
\end{tabular}

Fonte: Hassuani, Leal e Macedo (2005).

Considera-se que a umidade das pontas e folhas na usina é de aproximadamente $12-15 \%$ para as Rotas $\mathrm{C}$ e $\mathrm{E}$, e $50 \%$ para a rota $\mathrm{D}$. Ainda essa última requer maiores cuidados na usina para promover a separação da cana, pontas e folhas.

Com relação ao uso da palha como combustível nas caldeiras existentes, é importante avaliar o desempenho desses equipamentos para operação com um combustível com teor de cinzas mais elevado e umidade mais baixa. Para novos projetos, não há impedimentos tecnológicos para queima desse combustível (PERUCHI, 2007).

Apresentadas as opções tecnológicas disponíveis para aplicação em usinas sucroalcooleiras, no próximo capítulo os impactos dessas tecnologias no desempenho dos processos de produção combinada de açúcar, álcool e eletricidade serão avaliados sob a perspectiva dos custos de produção desses produtos em base exergética. 


\section{AVALIAÇÃO DO CUSTO EM BASE EXERGÉTICA DAS OPÇÕES DE CONFIGURAÇÕES PARA A PRODUÇÃO COMBINADA DE AÇÚCAR, ÁLCOOL E ELETRICIDADE}

Dentro do contexto do uso racional da energia em usinas sucroalcooleiras, diversas configurações para a produção de açúcar, álcool e eletricidade foram discutidas. Tais configurações visam trabalhar os mecanismos de geração de entropia discutidos anteriormente, a fim de minimizar as irreversibilidades nos processos, melhorando o desempenho termodinâmico dos mesmos.

Assim, este capítulo objetiva quantificar o impacto das modificações propostas, utilizando como referência o custeio em base exergética para avaliar os custos do açúcar, álcool e eletricidade. Essa abordagem permite avaliar como as modificações nos processos de conversão de energia alteram o processo de formação de custo dos produtos, identificando e quantificando as vantagens e/ou desvantagens dessas alterações.

Para determinação dos custos, optou-se pela utilização do método da igualdade para fazer a alocação dos custos em volumes de controle com mais de um produto, além da atribuição de custo nulo para os fluxos de exergia perdida (p.ex., gases de combustão, bagaço excedente, vinhaça) que saem do sistema e custo unitário para fluxos de exergia de entrada. O Apêndice A apresenta as equações adicionais necessárias para a determinação dos custos em base exergética, considerando o critério da igualdade.

Considerou-se na análise quatro opções tecnológicas para o sistema de cogeração da usina, além de diferentes níveis de integração térmica dos processos (redução do consumo de vapor):

i. Sistemas a vapor com turbinas de contrapressão;

ii. Sistemas a vapor com turbinas de contrapressão e condensação;

iii. Sistemas supercríticos;

iv. Sistemas com gaseificação de biomassa e ciclos combinados (BIGCC). 
Para as opções i) e ii), analisou-se ainda a manutenção das turbinas de acionamento mecânico das moendas e a eletrificação desses acionamentos. Para as outras opções, considerou-se apenas a eletrificação desses equipamentos.

As configurações analisadas foram integradas ao modelo computacional da usina, descrito no Cap. 6. A fim de estabelecer uma comparação entre cada configuração, os seguintes índices foram determinados:

$\checkmark$ Custo em base exergética do açúcar;

$\checkmark$ Custo em base exergética do álcool;

$\checkmark$ Excesso de bagaço produzido;

$\checkmark$ Exergia perdida específica devido a não utilização do bagaço excedente;

$\checkmark$ Quantidade específica de eletricidade excedente;

$\checkmark$ Custo em base exergética da eletricidade produzida;

$\checkmark$ Consumo específico de vapor;

$\checkmark$ Custo em base exergética do vapor de processo;

$\checkmark$ Exergia destruída específica total;

$\checkmark$ Eficiência exergética da usina.

A proposta para a eficiência exergética da usina proposta na eq. (68) busca avaliar quanto da exergia efetivamente disponibilizada pela cana para a produção de açúcar, álcool e eletricidade foi realmente utilizada. Assim, subtraem-se do denominador as exergias do bagaço excedente e da vinhaça, as quais são originárias da exergia da cana.

\subsection{SISTEMAS A VAPOR COM TURBINAS DE CONTRAPRESSÃO, SEM MODIFICAÇÕES NOS PROCESSOS}

Como mostrado na Fig. 6.1, o sistema de cogeração é responsável por $68 \%$ das irreversibilidades presentes na usina. Assim, modificações que visem melhorar o desempenho desse sistema têm um impacto direto na redução dos custos de produção de açúcar, álcool e eletricidade.

Conforme discutido anteriormente, a redução das irreversibilidades no sistema de cogeração está relacionada ao aumento da eficiência das caldeiras e dos turbogeradores. 
As modificações propostas nesse item envolvem apenas a substituição das caldeiras e dos turbogeradores de uma usina tradicional, por equipamentos mais eficientes e capazes de operar com vapor de pressões e temperaturas mais elevadas. A Fig. 8.1 mostra um diagrama esquemático para o sistema proposto.

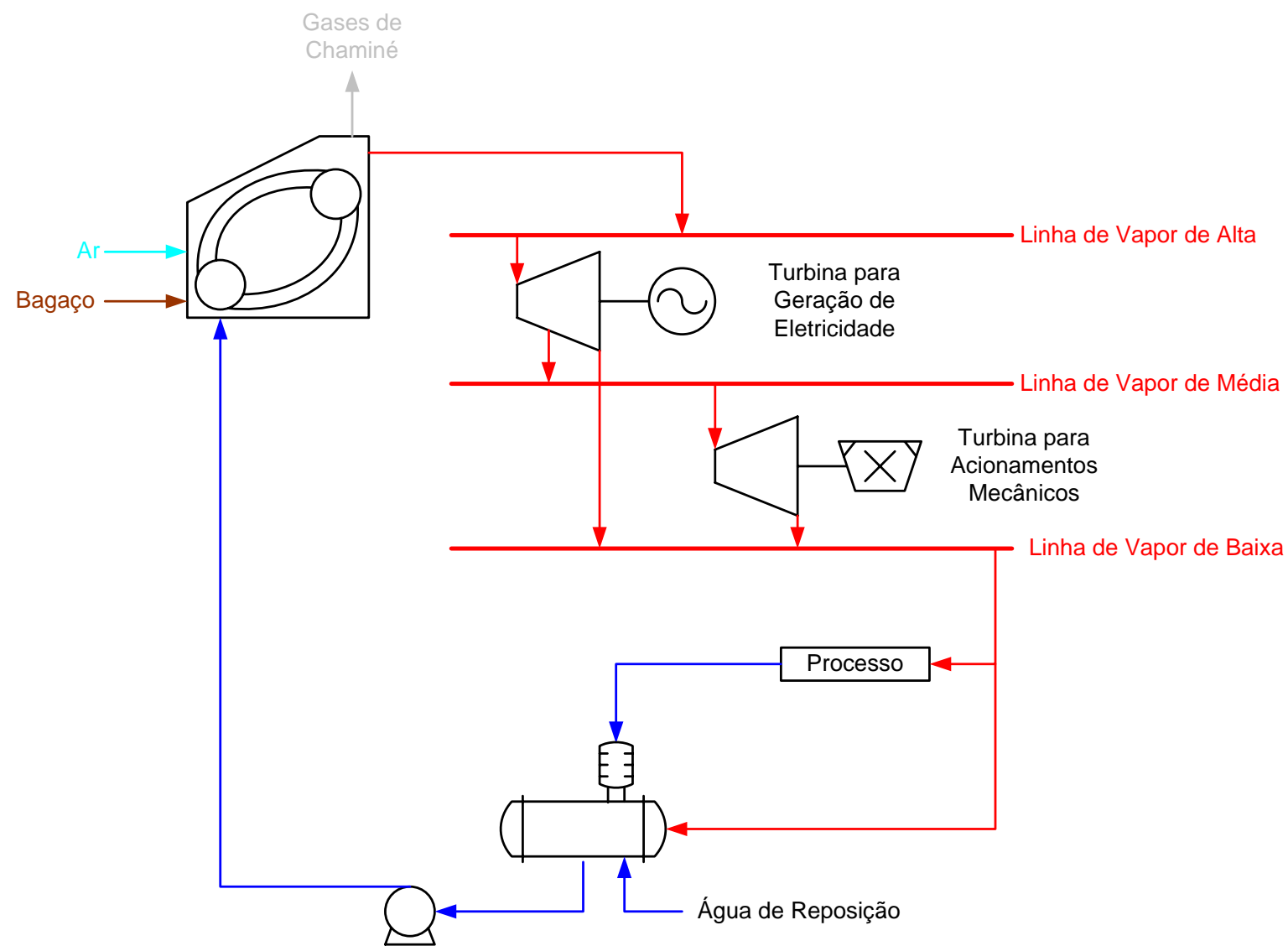

Figura 8.1 - Sistema a vapor com turbinas de contrapressão.

A Tab. 8.1 mostra os parâmetros técnicos utilizados na simulação para esse sistema.

Tabela 8.1 - Parâmetros Técnicos Utilizados na Simulação.

Eficiência da Caldeira $(\% \text {, base PCI })^{\mathrm{a}}$

Eficiência Isoentrópica da Extração dos Turbogeradores (\%) 82

Eficiência Isoentrópica da Contrapressão dos Turbogeradores (\%) 80

Eficiência do Conjunto Redutor-Gerador (\%) 95

Eficiência Isoentrópica das Turbinas dos Acionamentos Mecânicos (\%) 55 Eficiência Isoentrópica das Bombas (\%) 70

${ }^{\mathrm{a}}$ Excesso de ar $-35 \%$, Temperatura dos gases de exaustão $-167^{\circ} \mathrm{C}$, Temperatura da água de alimentação $-115^{\circ} \mathrm{C}$. 
Os parâmetros estabelecidos representam o estado-da-arte dos equipamentos fabricados na indústria nacional, conforme consulta feita junto aos fornecedores desses equipamentos.

A Fig. 8.2 apresenta a variação da eficiência exergética da caldeira em função da pressão e temperatura de geração do vapor, considerando as mesmas condições de operação para cada par pressão-temperatura.

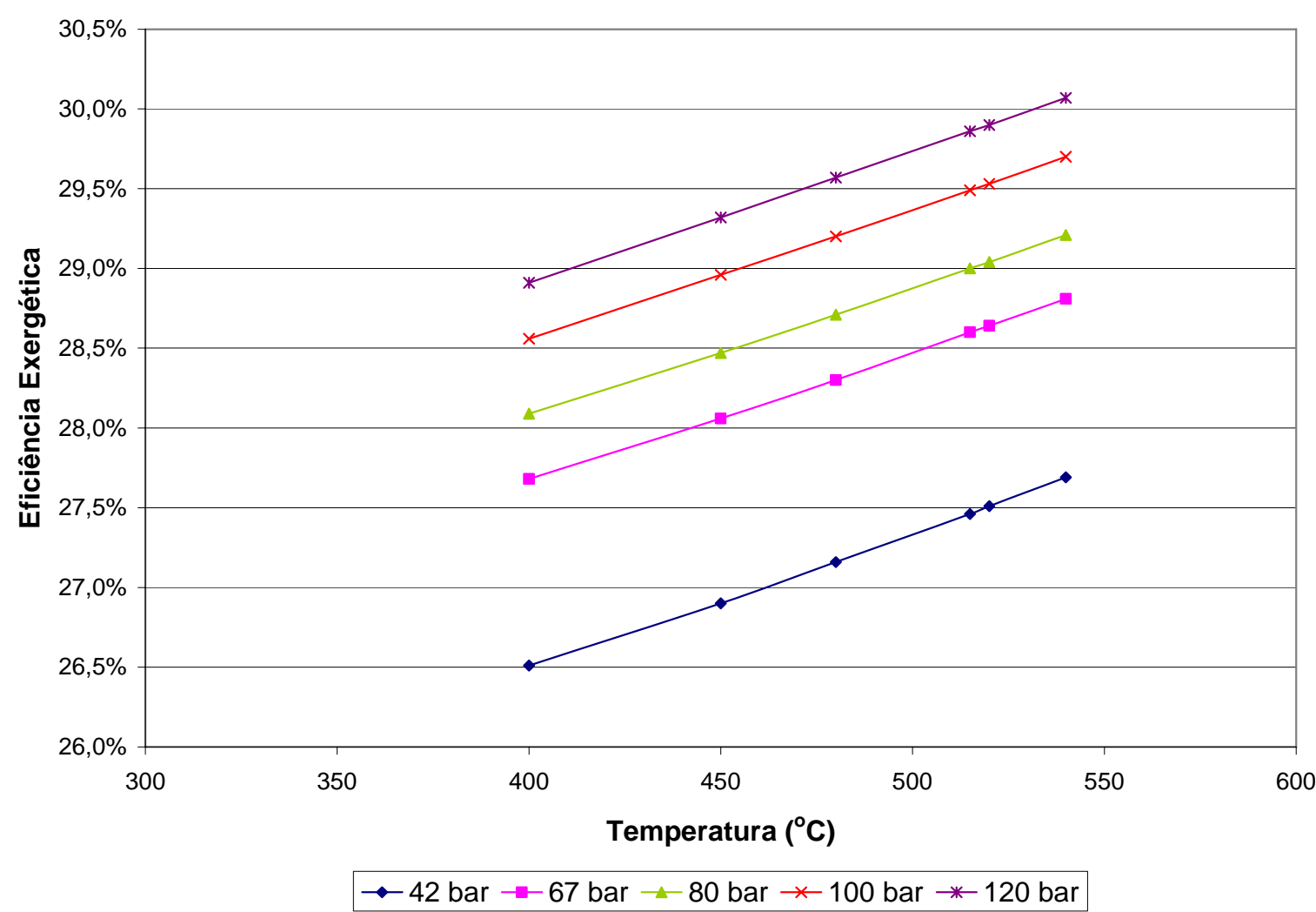

Figura 8.2- Variação da eficiência exergética da caldeira em função da pressão e temperatura de geração do vapor.

Como pode ser visto na Fig. 8.2, o aumento da pressão de geração de 42 bar para 67 bar representa um ganho de quase 5\%, enquanto que os aumentos adicionais representam um ganho de pouco mais que $1 \%$. Com relação ao aumento da temperatura, os ganhos são de aproximadamente $1,5 \%$ para cada $50^{\circ} \mathrm{C}$ de aumento da temperatura do vapor superaquecido. Dado que as características da combustão para todos os casos é a mesma, o aumento da eficiência da caldeira está relacionado à elevação da temperatura média da água no interior da mesma, diminuindo a diferença média de temperatura entre os gases de combustão e a água.

Para as avaliações subseqüentes, os seguintes pares pressão-temperatura serão avaliados: 

a) 42 bar e $400^{\circ} \mathrm{C}$;
b) 42 bar e $450^{\circ} \mathrm{C}$;
c) 67 bar e $480^{\circ} \mathrm{C}$;
d) 67 bar e $515^{\circ} \mathrm{C}$;
e) 100 bar e $520^{\circ} \mathrm{C}$;
f) 120 bar e $540^{\circ} \mathrm{C}$.

Esses valores representam a faixa das caldeiras mais eficientes em operação e/ou em construção no setor sucroalcooleiro atualmente (PERUCHI, 2007).

A Fig. 8.3 mostra a variação da eletricidade excedente gerada, as irreversibilidades e a exergia perdida devido à não utilização do bagaço excedente em função da pressão e da temperatura de geração do vapor.

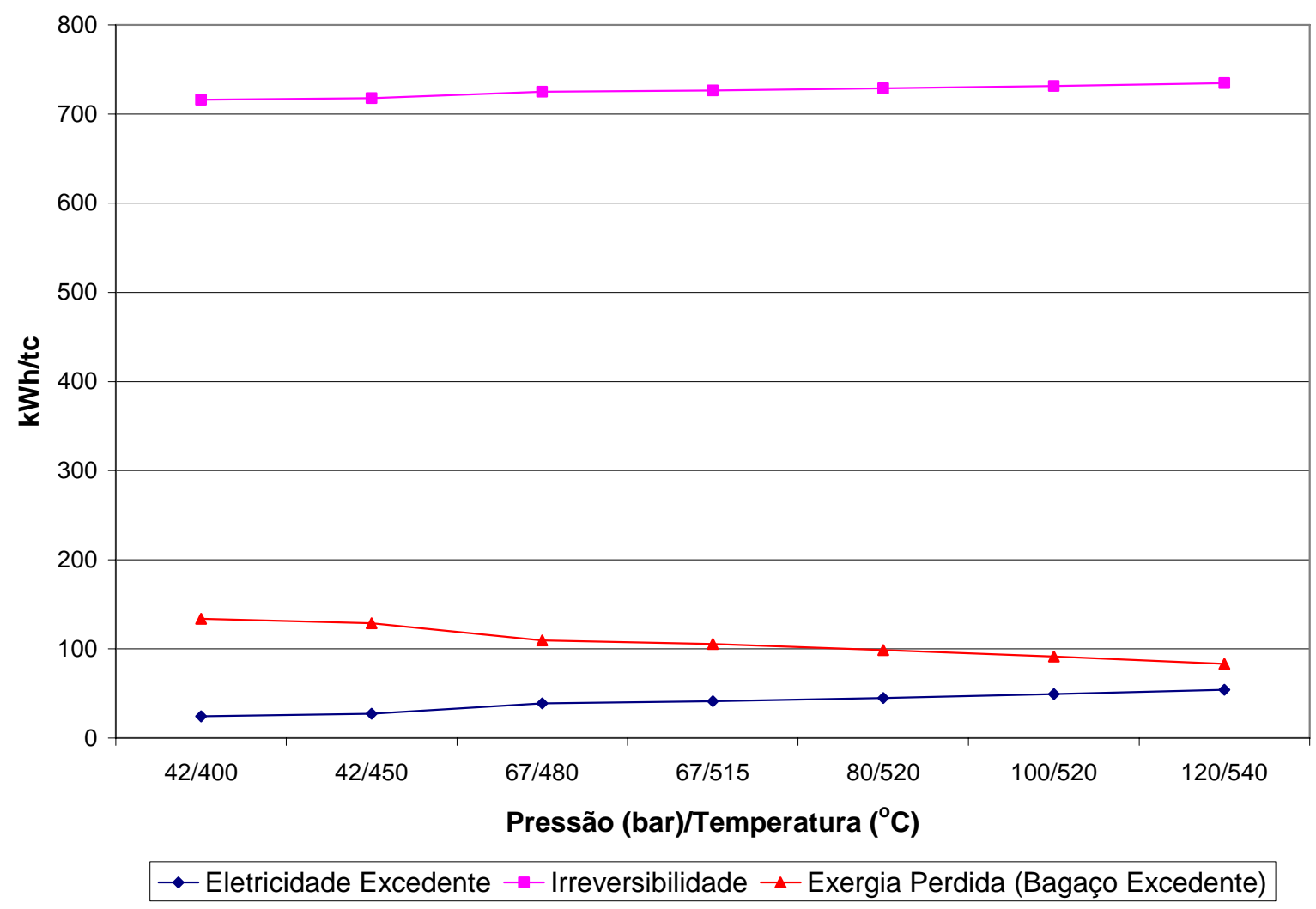

Figura 8.3 - Variação da eletricidade excedente gerada, as irreversibilidades e a exergia perdida devido à não utilização do bagaço excedente. 
É interessante notar que o aumento dos parâmetros de geração do vapor leva a uma transferência de uma parte das exergias destruída e perdida na planta para a geração de eletricidade, evidenciando o aumento da eficiência do sistema de cogeração. Tal ganho de eficiência tem um impacto positivo nos custos em base exergética do açúcar, álcool e eletricidade, como pode ser visto na Fig. 8.4.

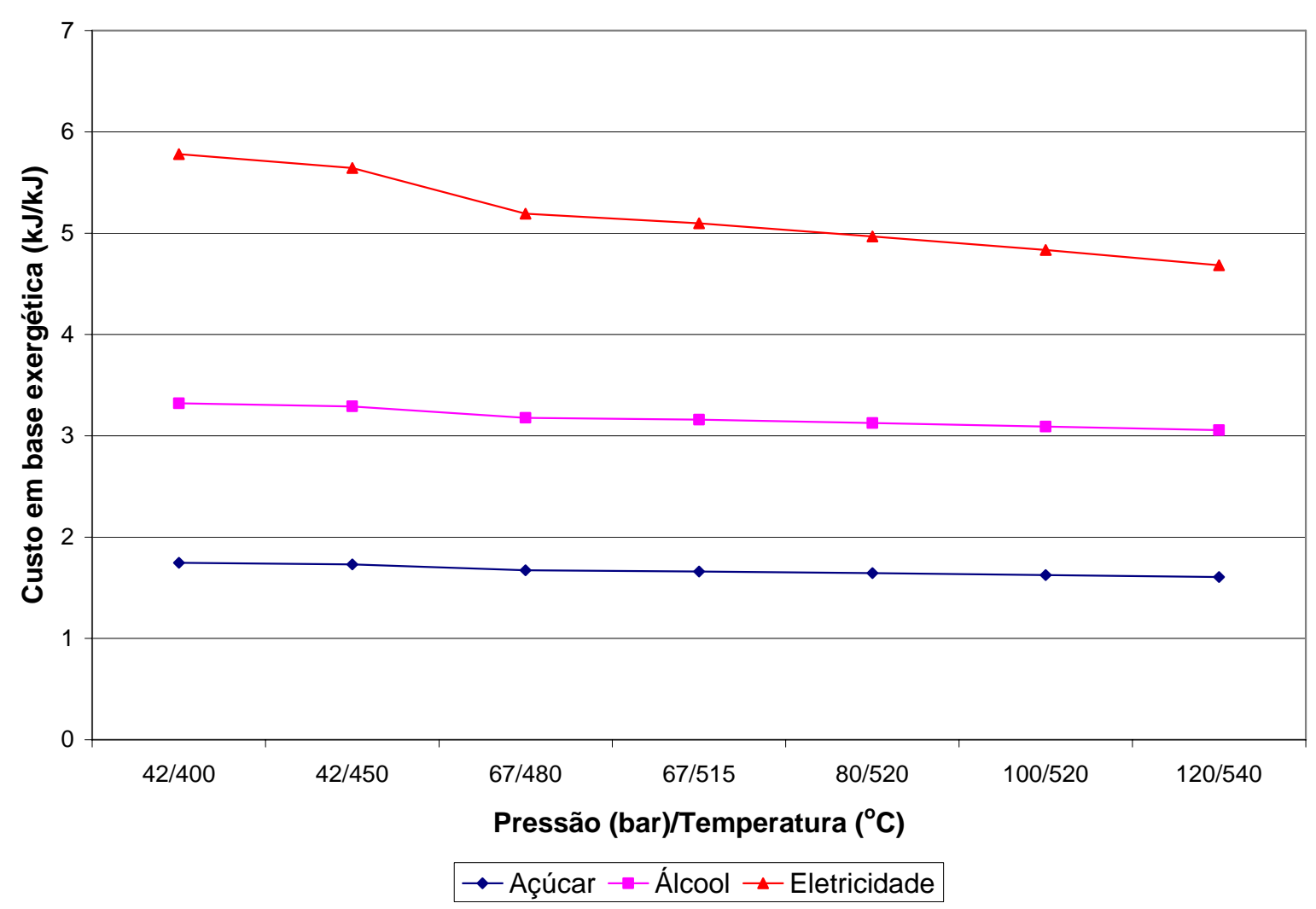

Figura 8.4 - Variação dos Custos em Base Exergética do Açúcar, Álcool e Eletricidade.

É interessante notar que os custos em base exergética do açúcar e do álcool apresentam uma variação (entre os pares $42 \mathrm{bar} / 400^{\circ} \mathrm{C}$ e $120 \mathrm{bar} / 540^{\circ} \mathrm{C}$ ) muito inferior $(8 \%)$ àquela dos custos em base exergética da eletricidade (23\%). Isso é conseqüência do processo de formação de custo dos produtos. Enquanto o custo da eletricidade é função do custo do bagaço utilizado nas caldeiras e da eficiência do sistema de cogeração, os custos do açúcar e do álcool dependem também das irreversibilidades nos demais processos da usina, os quais são os mesmos para todas as condições de geração de vapor. Assim, os ganhos no sistema de cogeração são atenuados pela manutenção das demais irreversibilidades dos processos. Ainda, é importante observar que o maior ganho acontece na passagem da geração de $42 \mathrm{bar} / 450^{\circ} \mathrm{C}$ para a de $67 \mathrm{bar} / 480^{\circ} \mathrm{C}$, onde há a maior redução das irreversibilidades. 
A Tab. 8.2 mostra os valores para os diferentes índices exergéticos para o par $67 \mathrm{bar} / 515^{\circ} \mathrm{C}$, sem e com a eletrificação das moendas, para comparação com os resultados apresentados na Tab. 6.6.

Tabela 8.2 - Índices Exergéticos para o par 67 bar $/ 515^{\circ} \mathrm{C}$, sem e com eletrificação das moendas

\begin{tabular}{lcc}
\hline & $\begin{array}{c}\text { Sem } \\
\text { Eletrificação }\end{array}$ & $\begin{array}{c}\text { Com } \\
\text { Eletrificação }\end{array}$ \\
\hline Custo em base exergética do açúcar $(\mathrm{kJ} / \mathrm{kJ})$ & 1,66 & 1,62 \\
Custo em base exergética do álcool $(\mathrm{kJ} / \mathrm{kJ})$ & 3,16 & 3,08 \\
Excesso de bagaço produzido $(\%)$ & 14,4 & 12,8 \\
Exergia perdida específica - bagaço excedente $(\mathrm{kWh} / \mathrm{tc})$ & 105 & 93 \\
Quantidade específica de eletricidade excedente $(\mathrm{kWh} / \mathrm{tc})$ & 41,1 & 48,5 \\
Custo em base exergética da eletricidade produzida $(\mathrm{kJ} / \mathrm{kJ})$ & 5,10 & 5,01 \\
Custo em base exergética da energia mecânica $(\mathrm{kJ} / \mathrm{kJ})$ & 5,43 & 5,01 \\
Consumo específico de vapor $(\mathrm{kg} / \mathrm{tc})$ & 490 & 490 \\
Custo em base exergética do vapor de processo $(\mathrm{kJ} / \mathrm{kJ})$ & 5,16 & 4,77 \\
Exergia destruída específica total $(\mathrm{kWh} / \mathrm{tc})$ & 726 & 730 \\
Eficiência exergética da usina $(\%)$ & 45,6 & 45,8 \\
\hline
\end{tabular}

Há uma redução de quase 14\% nos custos em base exergética do açúcar e do álcool para a situação sem eletrificação das moendas. O custo da eletricidade é $28 \%$ inferior ao da usina tradicional, o mesmo valendo para o vapor de processo. Essa redução é a principal responsável pela redução dos custos do açúcar e do álcool, já que os processos não sofreram nenhum tipo de alteração. A diminuição dos custos em base exergética está diretamente relacionada à redução da exergia destruída (2\%) e ao menor excedente de bagaço, representando uma menor exergia perdida devido ao excedente ( $20 \%$ menor). Por conseqüência, o rendimento exergético da usina também aumenta, de 43,5\% para 45,6\%.

A eletrificação das moendas melhora ainda mais o desempenho da configuração, dado que o custo em base exergética da energia mecânica é menor, reduzindo o custo do bagaço e do caldo, que por conseqüência diminuem os custos do açúcar, do álcool e da eletricidade (em média $2 \%$ ). Por outro lado, há um aumento da exergia destruída devido ao maior consumo de bagaço nas caldeiras (diminuição do excesso de bagaço). A maior quantidade de vapor gerado na caldeira resulta da diminuição do uso de água no dessuperaquecedor de vapor de escape, devido à redução da temperatura desse vapor na saída da turbina de alta pressão em função da 
maior eficiência isoentrópica desse equipamento em comparação às turbinas de acionamento das moendas. Com relação ao aumento da geração de eletricidade excedente, esta passa de $41,1 \mathrm{kWh} / \mathrm{tc}$ para $48,5 \mathrm{kWh} / \mathrm{tc}$ (18\% maior).

\subsection{SISTEMAS A VAPOR COM TURBINAS DE CONTRAPRESSÃO, COM MODIFICAÇÕES NOS PROCESSOS}

O consumo de vapor no processo é uma restrição a ser atendida pela planta de utilidades, impedindo-a de expandir o vapor até pressões mais baixas, o que maximizaria a geração de eletricidade a partir dessa corrente. Desta maneira, a redução do consumo de vapor no processo está diretamente relacionada com o aumento da geração de eletricidade excedente, maximizando a geração em sistemas de condensação. Neste item, propõe-se a avaliação da redução do consumo de vapor, sem levar em consideração o uso de turbinas de condensação, com o objetivo de avaliar o impacto dessas reduções nos custos de produção de açúcar, álcool e eletricidade. A comparação será feita com os resultados apresentados no item 8.1 deste capítulo.

Como discutido anteriormente, a redução do consumo de vapor nos processos está relacionada a:

i) Melhor integração térmica entre as extrações de vapor dos efeitos do evaporador e as demandas de aquecimento durante o tratamento do caldo;

ii) Aumento da concentração de sólidos do xarope enviado para o cozimento;

iii) Diminuição do consumo de vapor na destilaria, a partir de colunas mais eficientes. 


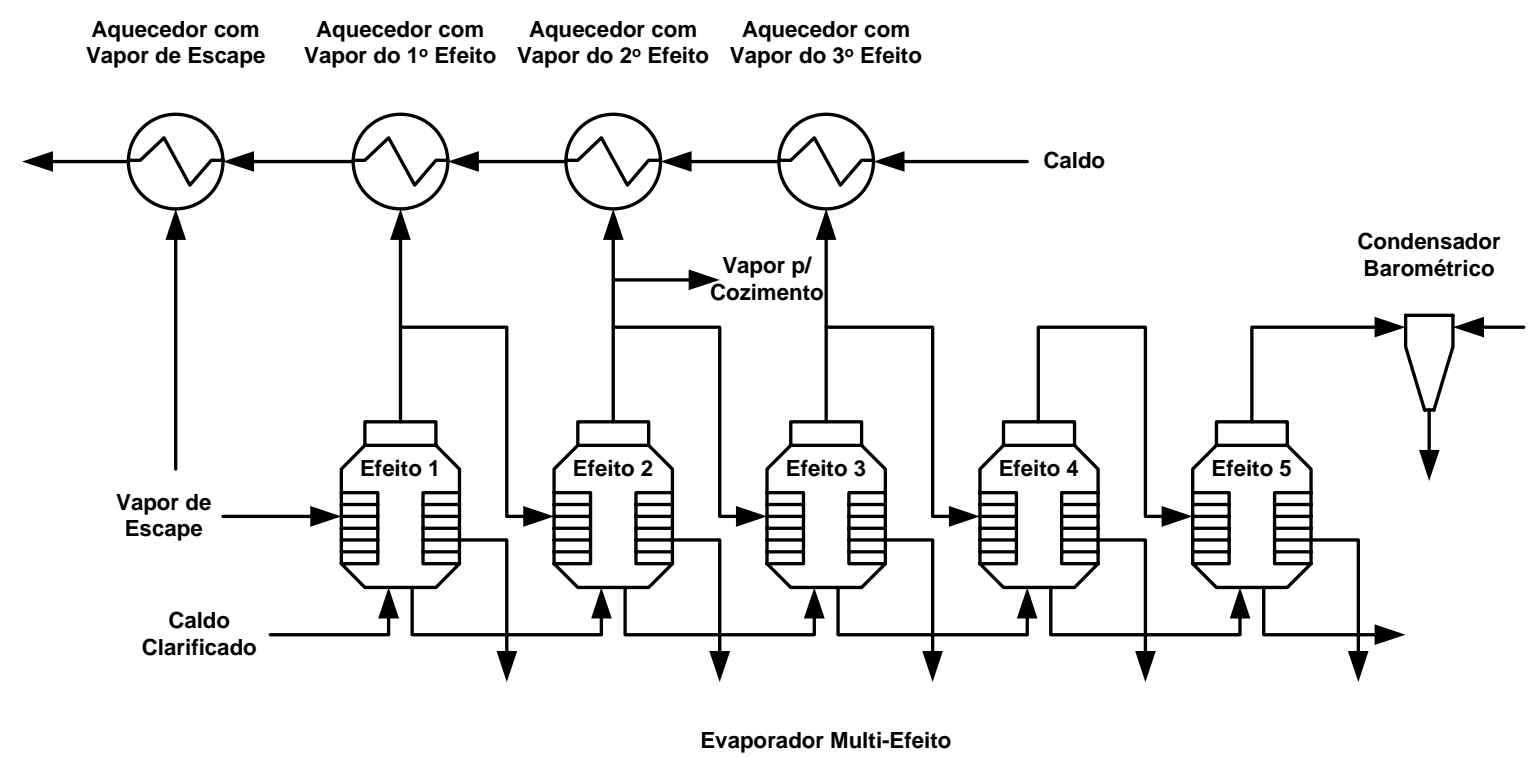

Figura 8.5 - Diagrama esquemático da rede trocadores de calor do tratamento de caldo.

A Tab. 8.3 mostra os parâmetros utilizados para a nova configuração da rede de trocadores de calor para a etapa de tratamento do caldo (Fig. 8.5), considerando uma melhor integração térmica entre as extrações do evaporador de múltiplos-efeitos e as demandas de aquecimento $(\Delta \mathrm{H})$, conforme pode ser visto na Fig $8.6^{30}$.

Tabela 8.3 - Parâmetros utilizados para a nova rede de trocadores de calor.

\begin{tabular}{ccc}
\hline Origem do Vapor & $\begin{array}{c}\text { Temperatura de } \\
\text { Saturação }\left({ }^{\circ} \mathbf{C}\right)\end{array}$ & $\begin{array}{c}\text { Faixa de Operação - } \\
\Delta \mathbf{T}\left({ }^{\circ} \mathbf{C}\right)\end{array}$ \\
\hline Escape & 127 & $95-115$ \\
$1^{\circ}$ Efeito & 117 & $85-103$ \\
$2^{\text {o }}$ Efeito & 107 & $60-85$ \\
$3^{\circ}$ Efeito & 98 & $35-60$ \\
$4^{\text {o }}$ efeito & 84 & - \\
$5^{\circ}$ Efeito & 60 & - \\
\hline
\end{tabular}

${ }^{30} \mathrm{O}$ tratamento do caldo para a produção de álcool requer as mesmas demandas de aquecimento. A única diferença entre as redes, no entanto, é a existência de um trocador de calor líquido-líquido (caldo das moendas/caldo clarificado) no lugar do trocador de calor com vapor do $3^{\circ}$ efeito. 


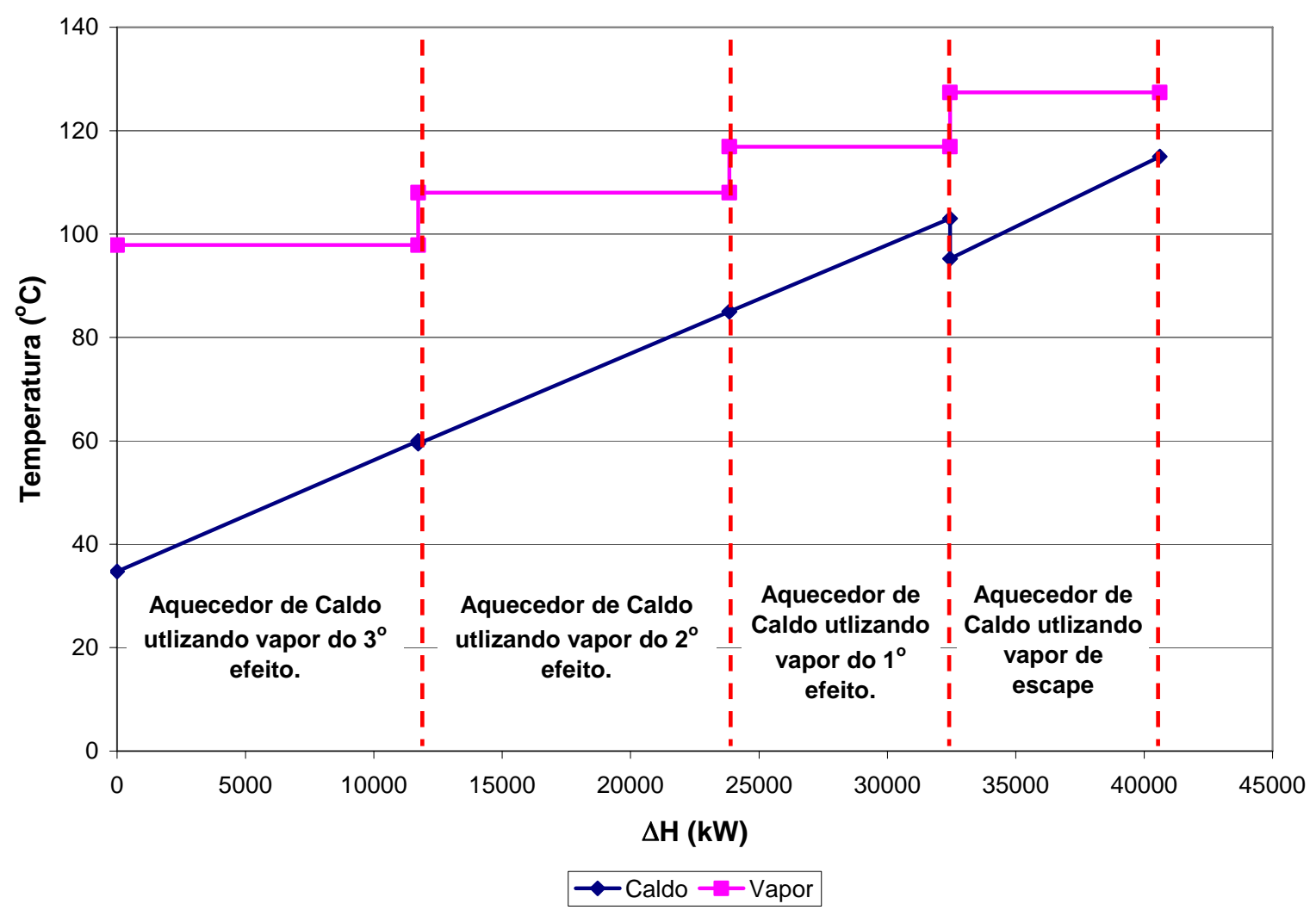

Figura 8.6 - Diagrama Temperatura vs. $\Delta \mathrm{H}$ para o sistema de aquecimento de caldo utilizando vapores extraídos do evaporador de múltiplos-efeitos.

A redução das irreversibilidades (aproximadamente 7\%) devido a essa integração pode ser vista pela diminuição da área entre as curvas na Fig. 8.7 em comparação às da Fig. 6.3. 


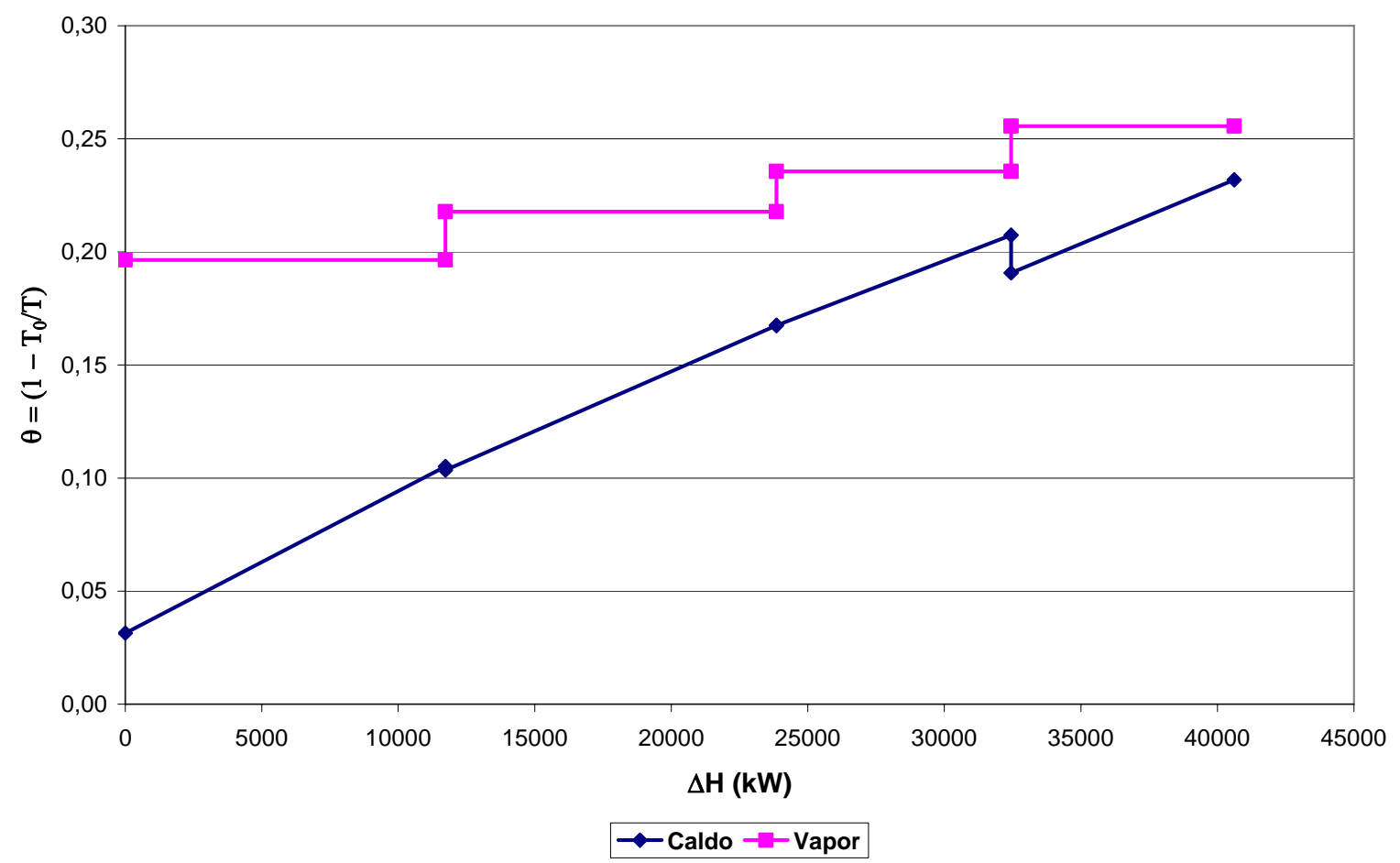

Figura 8.7 - Diagrama Fator de $\operatorname{Carnot}(\theta)$ vs. $\Delta \mathrm{H}$ para o sistema de aquecimento de caldo.

É interessante destacar também a menor geração de entropia no processo de evaporação ( $8 \%$ menos), em função da melhor distribuição das irreversibilidades em cada efeito, como pode ser observado na Tab. 8.4.

Tabela 8.4 - Parâmetros de desempenho da nova configuração do sistema de evaporação.

\begin{tabular}{cccccc}
\hline Efeito & Pressão & $\Delta \mathbf{T}\left({ }^{\circ} \mathbf{C}\right)$ & $\begin{array}{c}\text { Eficiência } \\
\text { Exergética (\%) }\end{array}$ & $\begin{array}{c}\text { Participação na } \\
\text { Exergia Destruída } \\
\text { Total (\%) }\end{array}$ & $\begin{array}{c}\text { Exergia } \\
\text { Consumida } \\
\text { (kJ/kg evap) }\end{array}$ \\
\hline $1^{\mathrm{o}}$ & 1,80 & 9,9 & 90,5 & 43,1 & 584,8 \\
$2^{\mathrm{o}}$ & 1,34 & 7,7 & 91,3 & 29,7 & 518,7 \\
$3^{\mathrm{o}}$ & 0,94 & 8,3 & 90,4 & 8,1 & 463,3 \\
$4^{\mathrm{o}}$ & 0,56 & 11,4 & 86,2 & 4,8 & 385,5 \\
$5^{\mathrm{o}}$ & 0,20 & 20,1 & 66,5 & 14,3 & 335,0 \\
\hline
\end{tabular}

Comparando os valores da Tab. 8.4 com os da Tab. 6.4, verifica-se uma diminuição das diferenças de temperatura nos efeitos, com conseqüente aumento da eficiência dos mesmos. Além disso, foi considerado o uso de tanques de flash entre os efeitos, a fim de recuperar parte da exergia do condensado de cada um dos efeitos, excluindo o do $1^{\mathrm{o}}$ efeito que retorna para a caldeira. 
Optou-se também pelo aumento da concentração do xarope enviado ao cozimento de $60 \%$ para $70 \%$, reduzindo as irreversibilidades nesse processo em $25 \%$, ou seja, menos vapor é consumido nesses equipamentos.

Outro benefício da melhor integração térmica entre o evaporador de múltiplos-efeitos e as demandas de aquecimento é a redução do consumo de água no condensador barométrico, em virtude da menor quantidade de vapor enviada para esse equipamento tanto pelo evaporador como pelos tachos de cozimento. Assim, as irreversibilidades nesse sistema são 29\% menores em relação à situação anterior.

Com relação à destilaria, utilizou-se um consumo de $2,8 \mathrm{~kg}$ de vapor/L de álcool hidratado, parâmetro que representa o valor utilizado em novos equipamentos sendo fabricados atualmente.

Todas essas modificações permitem uma redução de 20\% no consumo de vapor no processo, passando de $490 \mathrm{~kg} / \mathrm{tc}$ para $392 \mathrm{~kg} / \mathrm{tc}$. A seguir, é proposta a avaliação do impacto dessas modificações no desempenho termodinâmico da usina, utilizando a mesma configuração da planta de utilidades apresentada na Fig. 8.1, sem considerar a eletrificação das moendas.

A Fig. 8.8 mostra a variação da exergia destruída, da exergia perdida devido ao excedente de bagaço e da eletricidade excedente gerada em função de diversas pressões e temperaturas de vapor na caldeira. 


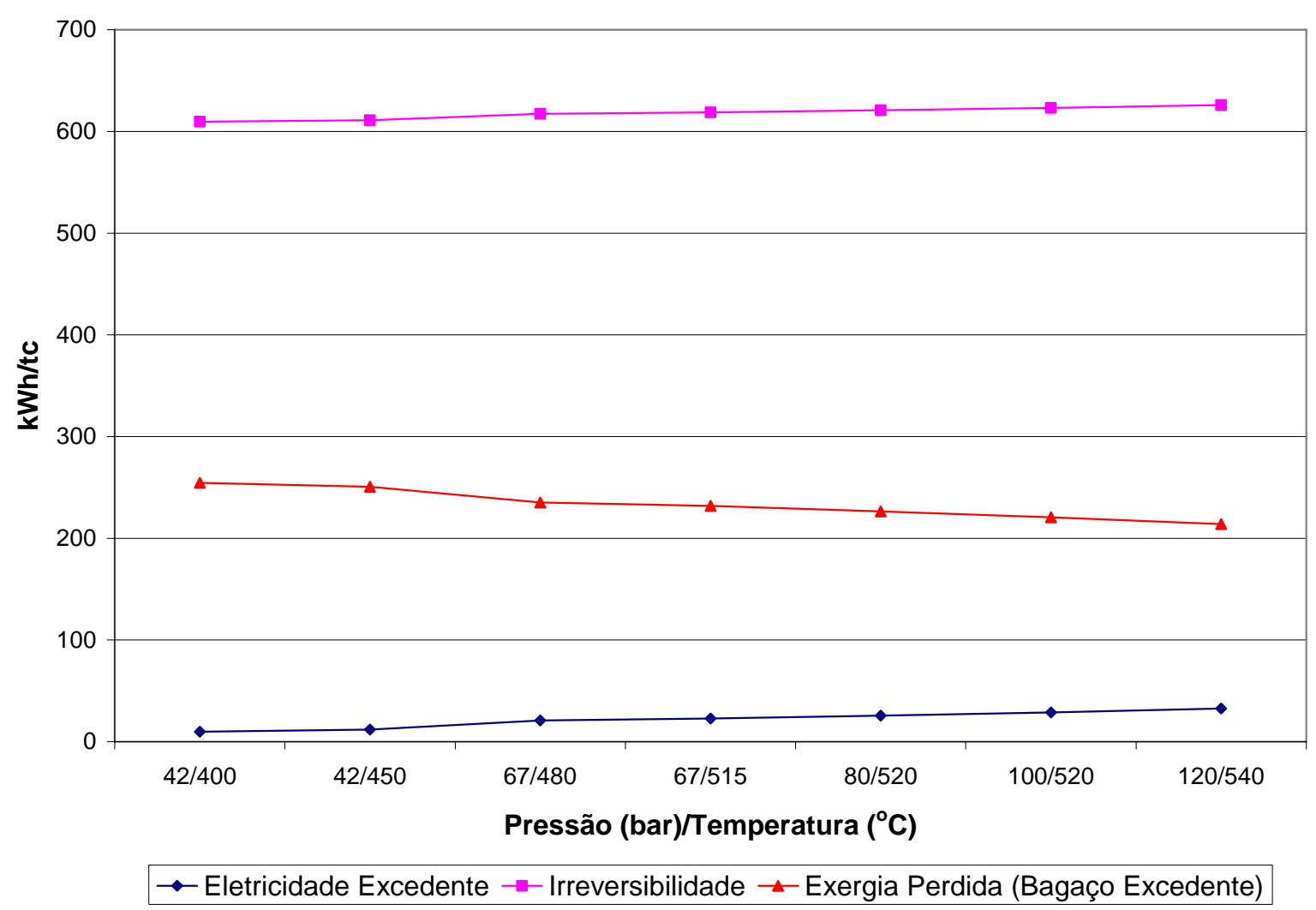

Figura 8.8 - Variação da eletricidade excedente gerada, as irreversibilidades e a exergia perdida devido à não utilização do bagaço excedente.

Comparando as Figs. 8.3 e 8.7, é possível observar uma redução média de $108 \mathrm{kWh} / \mathrm{tc}$ na exergia destruída na usina e um aumento em torno de $126 \mathrm{kWh} / \mathrm{tc}$ na exergia perdida com o excedente de bagaço. Assim, o efeito líquido da redução do consumo de vapor é um aumento de aproximadamente $18 \mathrm{kWh} / \mathrm{tc}$ das irreversibilidades totais da usina. Esse aumento é refletido nos custos mais elevados de produção de açúcar, álcool e eletricidade, como mostra a Fig. 8.9, já é atribuído custo zero ao bagaço excedente, penalizando os custos dos produtos. Ainda, a geração de eletricidade excedente é inferior, já que essa está relacionada diretamente com o consumo de vapor no processo para sistemas de contrapressão, como visto no capítulo anterior.

O aumento de custo é mais acentuado para a eletricidade, dado o grande volume de bagaço excedente em função da redução do consumo de vapor no processo. Assim, o custo do bagaço queimado na caldeira aumentou aproximadamente $27 \%$, por conseqüência o custo da eletricidade excedente e do vapor de escape aumentaram na mesma proporção. Por outro lado, a redução da exergia destruída nos processos de produção de açúcar e álcool (aproximadamente 15\%) atenuou o impacto desse aumento no custo do vapor. Portanto, o 
acréscimo no custo destes produtos foi de 4\% para o açúcar e 6\% para o álcool. Caso, não fosse atribuído custo zero ao bagaço excedente, os custos de produção de açúcar e álcool seriam em média $10 \%$ menores que os calculados anteriormente.

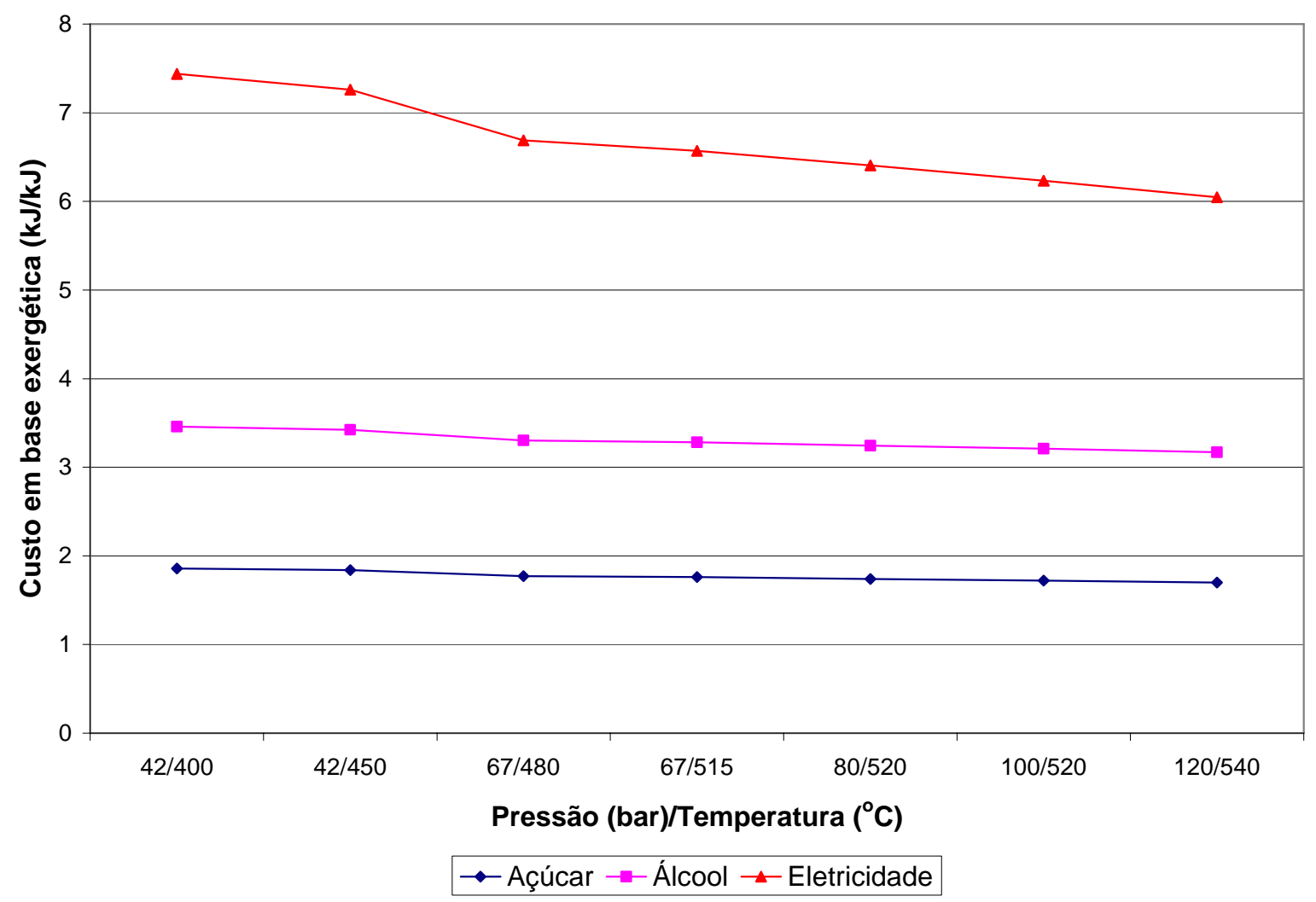

Figura 8.9 - Variação dos Custos em Base Exergética do Açúcar, Álcool e Eletricidade.

Diante desses resultados, é possível afirmar que a redução do consumo de vapor no processo apresenta ganhos sob o ponto de vista da redução da exergia destruída no processo, porém essa redução eleva o excedente de bagaço, aumentando os custos de produção de açúcar, álcool e eletricidade. Desta maneira, é imperativo que haja uma utilização para esse bagaço excedente para evitar esses aumentos. Uma alternativa para esse uso é a geração de eletricidade utilizando turbinas de condensação, discutida no próximo item. Outra possibilidade, não contemplada nessa tese, é fabricação de álcool a partir do bagaço.

\subsection{SISTEMAS A VAPOR COM TURBINAS DE CONDENSAÇÃO}

$\mathrm{O}$ uso de turbinas de condensação é uma alternativa para dar um uso final ao bagaço excedente em usinas, conforme discutido anteriormente. Esse item apresenta os resultados da introdução de turbinas de condensação associado ao menor consumo de vapor no processo. $\mathrm{O}$ 
uso de turbinas de condensação maximiza a geração de eletricidade, pois permite a expansão do vapor até pressões mais baixas (com temperaturas de saturação próximas à ambiente), diminuindo a exergia do vapor que sai da turbina e, portanto, maximiza a geração de eletricidade.

A Fig. 8.10 mostra um diagrama esquemático para o sistema com turbinas de condensação.

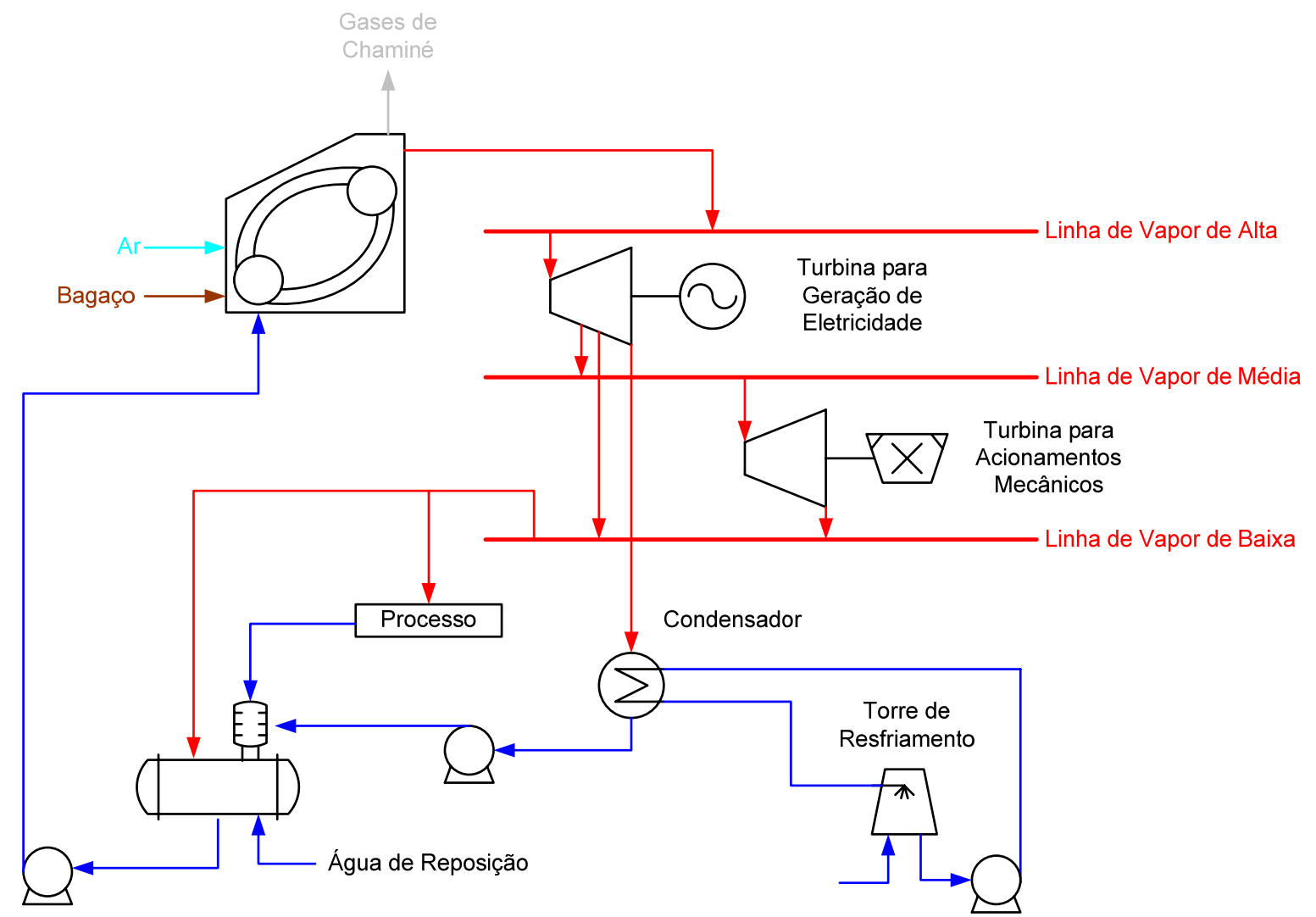

Figura 8.10 - Sistema a vapor com turbinas de condensação.

Os parâmetros técnicos utilizados nas simulações são os mesmos da Tab. 8.1, incluindo uma eficiência isoentrópica de $79 \%$ para a turbina de condensação.

A Fig. 8.11 mostra a variação da eletricidade excedente gerada, as irreversibilidades e a exergia perdida devido à não utilização do bagaço excedente em função da pressão e da temperatura de geração do vapor. Não foi avaliada a eletrificação da moenda nesse caso. 


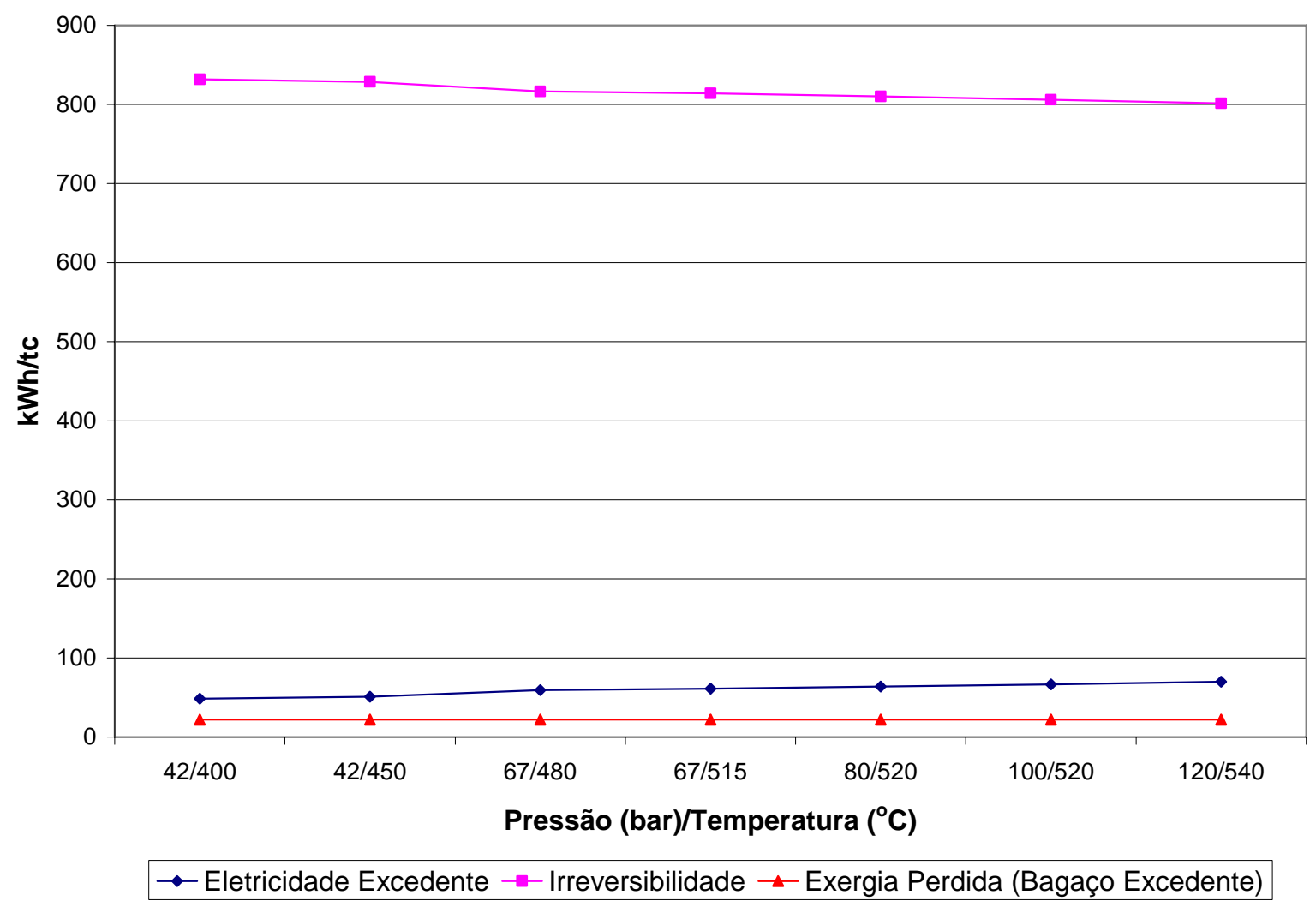

Figura 8.11 - Variação da eletricidade excedente gerada, as irreversibilidades e a exergia perdida devido a não utilização do bagaço excedente.

Comparando a Fig. 8.11 com a Fig. 8.3, nota-se que parte da exergia perdida com o bagaço excedente da Fig 8.3 é convertida em eletricidade excedente e em exergia destruída na Fig. 8.11. A redução média de $80 \%$ no bagaço excedente é compensada por um aumento médio de $12 \%$ nas irreversibilidades e $56 \%$ na eletricidade excedente (sendo $100 \%$ para o par 42 bar $/ 400^{\circ} \mathrm{C}$ e $29 \%$ para o par $\left.120 \mathrm{bar} / 540^{\circ} \mathrm{C}\right)$.

O impacto dessas variações nos custos em base exergética de açúcar, álcool e eletricidade é apresentado na Fig. 8.12. 


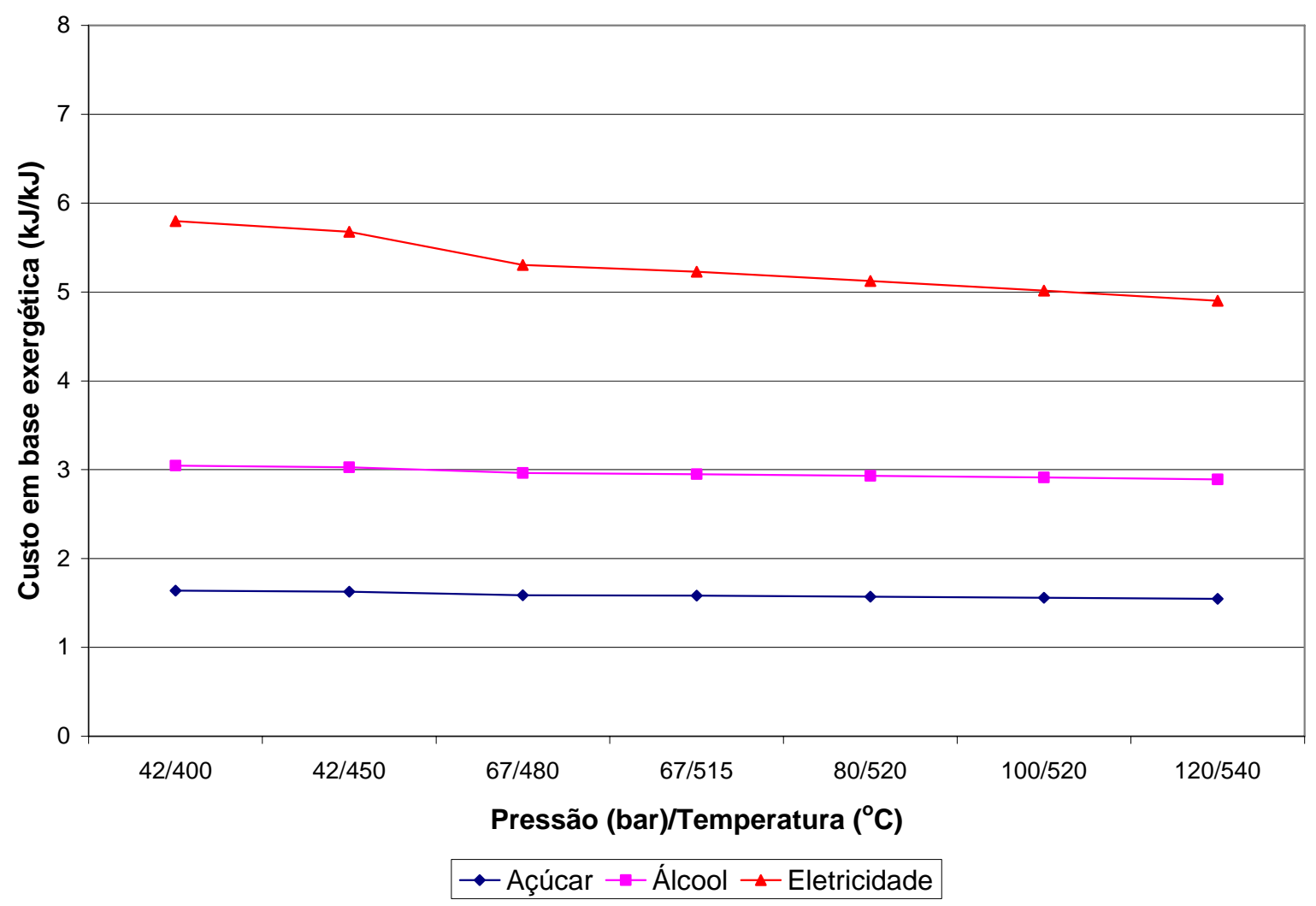

Figura 8.12 - Variação dos Custos em Base Exergética do Açúcar, Álcool e Eletricidade.

Comparando com os valores da Fig. 8.4, observa-se uma redução de 6\% em média nos custos do açúcar e do álcool, sendo a redução menor para pressões e temperaturas mais elevadas. O custo da eletricidade, por outro lado, aumentou em relação aos sistemas de contrapressão.

Para melhor avaliar esses efeitos, a Tab. 8.5 mostra os índices exergéticos de desempenho para o par 67 bar $/ 515^{\circ} \mathrm{C}$, sem e com a eletrificação das moendas.

Tabela 8.5 - Índices exergéticos para o par 67 bar $/ 515^{\circ} \mathrm{C}$, sem e com eletrificação das moendas

\begin{tabular}{lcc}
\hline & $\begin{array}{c}\text { Sem } \\
\text { Eletrificação }\end{array}$ & $\begin{array}{c}\text { Com } \\
\text { Eletrificação }\end{array}$ \\
\hline Custo em base exergética do açúcar $(\mathrm{kJ} / \mathrm{kJ})$ & 1,58 & 1,56 \\
Custo em base exergética do álcool $(\mathrm{kJ} / \mathrm{kJ})$ & 2,95 & 2,91 \\
Excesso de bagaço produzido $(\%)$ & 3,0 & 3,0 \\
Exergia perdida específica - bagaço excedente $(\mathrm{kWh} / \mathrm{tc})$ & 22 & 22 \\
Quantidade específica de eletricidade excedente $(\mathrm{kWh} / \mathrm{tc})$ & 61,0 & 64,9 \\
Custo em base exergética da eletricidade produzida $(\mathrm{kJ} / \mathrm{kJ})$ & 5,23 & 5,16 \\
Custo em base exergética da energia mecânica $(\mathrm{kJ} / \mathrm{kJ})$ & 5,26 & 5,16 \\
Consumo específico de vapor $(\mathrm{kg} / \mathrm{tc})$ & 392 & 392 \\
\hline
\end{tabular}


Custo em base exergética do vapor de processo $(\mathrm{kJ} / \mathrm{kJ})$

5,08

4,78

Exergia destruída específica total $(\mathrm{kWh} / \mathrm{tc})$

A partir dos valores mostrados na Tab. 8.5, nota-se uma redução de 5\% e de 7\% nos custos do açúcar e do álcool, respectivamente, quando comparados as da Tab. 8.2 $2^{31}$ - sem considerar a eletrificação das moendas. A geração de eletricidade excedente é quase o dobro, porém o custo dessa é 2,5\% maior. Esse aumento resulta do maior custo de geração de eletricidade nas turbinas de condensação. Ainda, o aumento do custo mostra a ineficiência desse sistema como um sistema de geração de potência (eficiência próxima a 20\%). Uma alternativa para melhorar essa eficiência é o uso de torcadores de calor regenerativos no retorno de condensado da caldeira, porém isso requer estudar a viabilidade frente ao consumo de vapor no processo.

É interessante assinalar que, mesmo com o aumento da eletricidade gerada e as mesmas das quantidades de açúcar e álcool produzidas, a eficiência exergética da usina com turbinas de condensação é inferior ao da com turbinas de contrapressão exclusivamente. Isso ocorre devido à maneira como o índice foi proposto, subtraindo a exergia do bagaço excedente do denominador. Portanto, o denominador é menor quanto maior é o excedente de bagaço, elevando o valor da eficiência, mesmo com um numerador menor. Avaliando a efíciência pelo lado das irreversibilidades e da exergia perdida, a diferença entre os sistemas com turbinas de contrapressão e os com turbinas de contrapressão e condensação é mínima.

Todavia, a vantagem do uso de turbinas de condensação é a possibilidade de geração de energia elétrica ao longo do ano todo. A Tab. 8.6 mostra os resultados da simulação para geração de eletricidade ao longo do ano todo (considerou-se a eletrificação das moendas).

\footnotetext{
${ }^{31}$ Comparando esses valores aos de uma Usina Tradicional, os custos são quase $20 \%$ menores.
} 
Tabela 8.6 - Índices exergéticos para o par 67 bar $/ 515^{\circ} \mathrm{C}$, com geração de eletricidade ao longo do ano todo

\begin{tabular}{lcc}
\hline & Safra & Entressafra \\
\hline Horas de operação & 4488 & 3078 \\
Custo em base exergética do açúcar $(\mathrm{kJ} / \mathrm{kJ})$ & 1,54 & - \\
Custo em base exergética do álcool $(\mathrm{kJ} / \mathrm{kJ})$ & 2,88 & - \\
Excesso de bagaço produzido $(\%)$ & 3,0 & - \\
Exergia perdida específica - bagaço excedente $(\mathrm{kWh} / \mathrm{tc})$ & 22 & - \\
Quantidade específica de eletricidade excedente $(\mathrm{kWh} / \mathrm{tc})^{*}$ & 51,0 & 20,3 \\
Custo em base exergética da eletricidade produzida $(\mathrm{kJ} / \mathrm{kJ})^{*}$ & 4,98 & 6,39 \\
Custo em base exergética da energia mecânica $(\mathrm{kJ} / \mathrm{kJ})$ & 4,98 & - \\
Consumo específico de vapor $(\mathrm{kg} / \mathrm{tc})$ & 392 & - \\
Custo em base exergética do vapor de processo $(\mathrm{kJ} / \mathrm{kJ})$ & 4,65 & - \\
Exergia destruída específica total $(\mathrm{kWh} / \mathrm{tc})^{*}$ & 737 & 106 \\
Eficiência exergética da usina $(\%)$ & 46,1 & - \\
\hline
\end{tabular}

*Valores para o ano todo: eletricidade excedente $-64,9 \mathrm{kWh} / \mathrm{tc}$, custo em base exergética da eletricidade $-5,18$ $\mathrm{kJ} / \mathrm{kJ}$, exergia destruída específica $-809 \mathrm{kWh} / \mathrm{tc}$.

A geração de eletricidade ao longo do ano todo não tem um impacto muito grande nos custos de produção de açúcar e álcool (1\%), pois não há variação das irreversibilidades dos processos de fabricação desses produtos. A redução de $1 \%$ no custo é função dos menores custos da eletricidade gerada e do vapor de processo, esses sim mais influenciados pela geração ao longo do ano todo. Isso porque a redução das irreversibilidades na planta de cogeração é de quase $13 \%$, em virtude do menor consumo de bagaço na caldeira durante a safra.

O bagaço excedente da safra é utilizado na entressafra para geração exclusiva de eletricidade utilizando as turbinas de condensação. Desta maneira, a geração de eletricidade total $(64,9$ $\mathrm{kWh} / \mathrm{tc}$ ) é igual à geração exclusiva na safra (Tab. 8.5), porém a capacidade instalada para gerar essa quantidade é menor, pois opera mais horas no ano. Portanto, do ponto de vista econômico é vantajoso a operação ao longo do ano todo, já que isso reduz o investimento necessário, mantendo a mesma receita anual. Essa questão será melhor discutida no Cap. 10.

A partir do custo em base exergética da eletricidade gerada na entressafra é possível determinar a eficiência exergética de geração de eletricidade nesse período, a qual é próxima a $17 \%$. Ou seja, esse sistema de geração de eletricidade é muito ineficiente se comparado a plantas termelétricas a carvão ou gás natural. 


\subsection{REDUÇÃO DO CONSUMO DE VAPOR DE PROCESSO PARA INTEGRAÇÃO DOS SISTEMAS AVANÇADOS DE COGERAÇÃO.}

Conforme discutido anteriormente (Cap. 7), para integração térmica dos sistemas avançados de cogeração, Sistemas Supercríticos e Sistemas com gaseificação de biomassa e ciclos combinados, é necessário a redução do consumo de vapor no processo para valores abaixo de $320 \mathrm{~kg} / \mathrm{tc}$.

Para os Sistemas supercríticos, esta restrição está relacionada à necessidade da utilização de trocadores de calor regenerativo para o retorno do condensado para a caldeira, a fim de evitar consumos excessivos de combustível para produção de vapor em condições supercríticas e ainda suprir energia para o re-aquecimento, além de melhorar a eficiência do sistema como um todo como discutido no capítulo anterior.

Com relação aos Sistemas com gaseificação de biomassa, a restrição é conseqüência da capacidade limitada desses sistemas para a geração de vapor como mostrado na Fig. 7.14.

Para diminuir o consumo de vapor no processo ainda mais, optou-se por alterar a configuração da rede de trocadores de calor e do evaporador de múltiplos-efeitos como proposto por Avram e Stark (2004) e o uso de sistema destilação de duplo-efeito como proposto por Seemann (2003).

A melhor integração térmica entre o evaporador de múltiplos-efeitos e as demandas de aquecimento do caldo é obtida a partir das seguintes alterações nos processos:

$\checkmark$ Diminuição da diferença de temperatura entre o vapor de aquecimento e o caldo evaporando nos efeitos do evaporador (conseqüente modificação da pressão de operação em cada efeito, aumentando a temperatura dos vapores extraídos desse sistema);

$\checkmark$ Utilização de vapores extraídos de todos os efeitos de evaporação para aquecimento do caldo;

$\checkmark$ Separação do $3^{\circ}$ efeito em dois corpos (Efeito 3 e Efeito 3a), permitindo a entrada do caldo clarificado diretamente no primeiro corpo (Efeito 3a), sendo todo vapor desse 
utilizado no cozimento. Isso evita o aquecimento do caldo utilizando vapor de escape das turbinas;

$\checkmark$ Não há envio de vapor do sistema de evaporação para o condensador barométrico.

Além disso, adotou-se o uso de um trocador de calor líquido-líquido para aquecimento do caldo proveniente das moendas utilizando os diversos condensados do sistema de evaporação e da rede de trocadores de calor. A Fig. 8.13 mostra de maneira esquemática a nova proposta da rede de trocadores de calor.

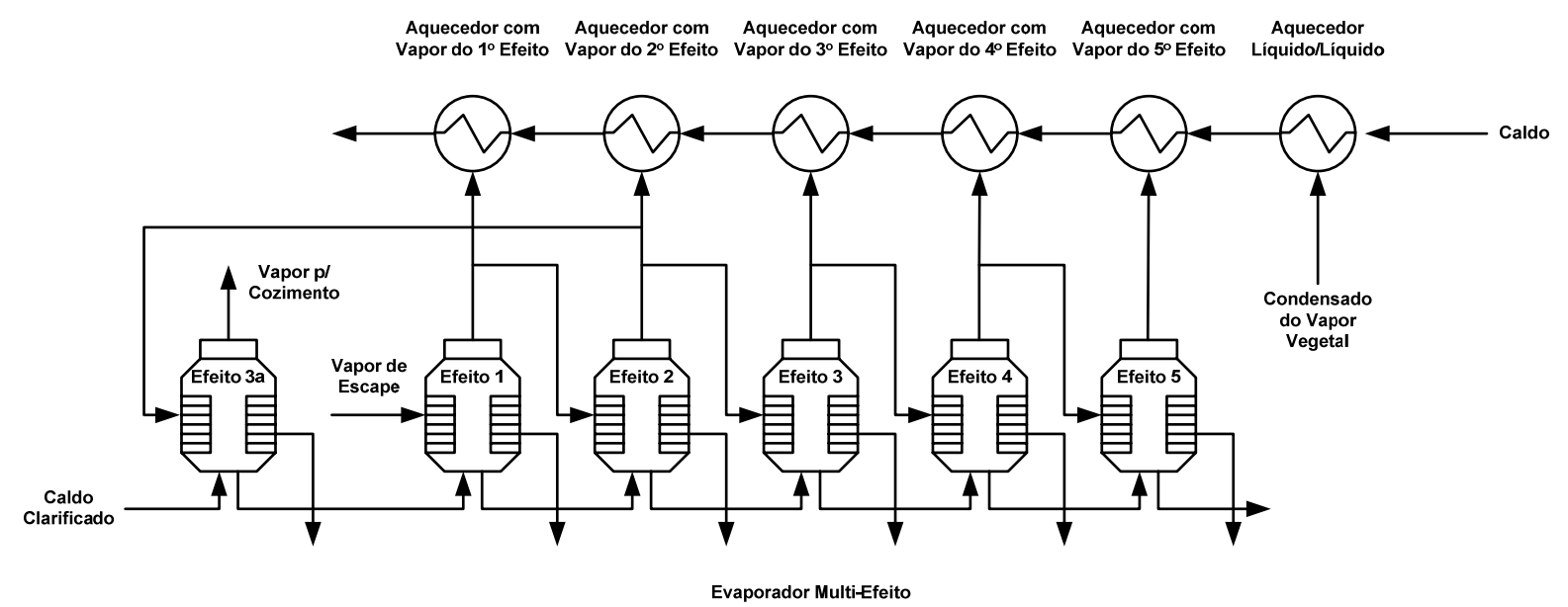

Figura 8.13 - Diagrama esquemático da rede trocadores de calor do tratamento de caldo.

As Figs. 8.14 e 8.15 mostram os diagramas Temperatura- $\Delta \mathrm{H}$ e Fator de Carnot- $\Delta \mathrm{H}$ para a nova rede de trocadores de calor. 


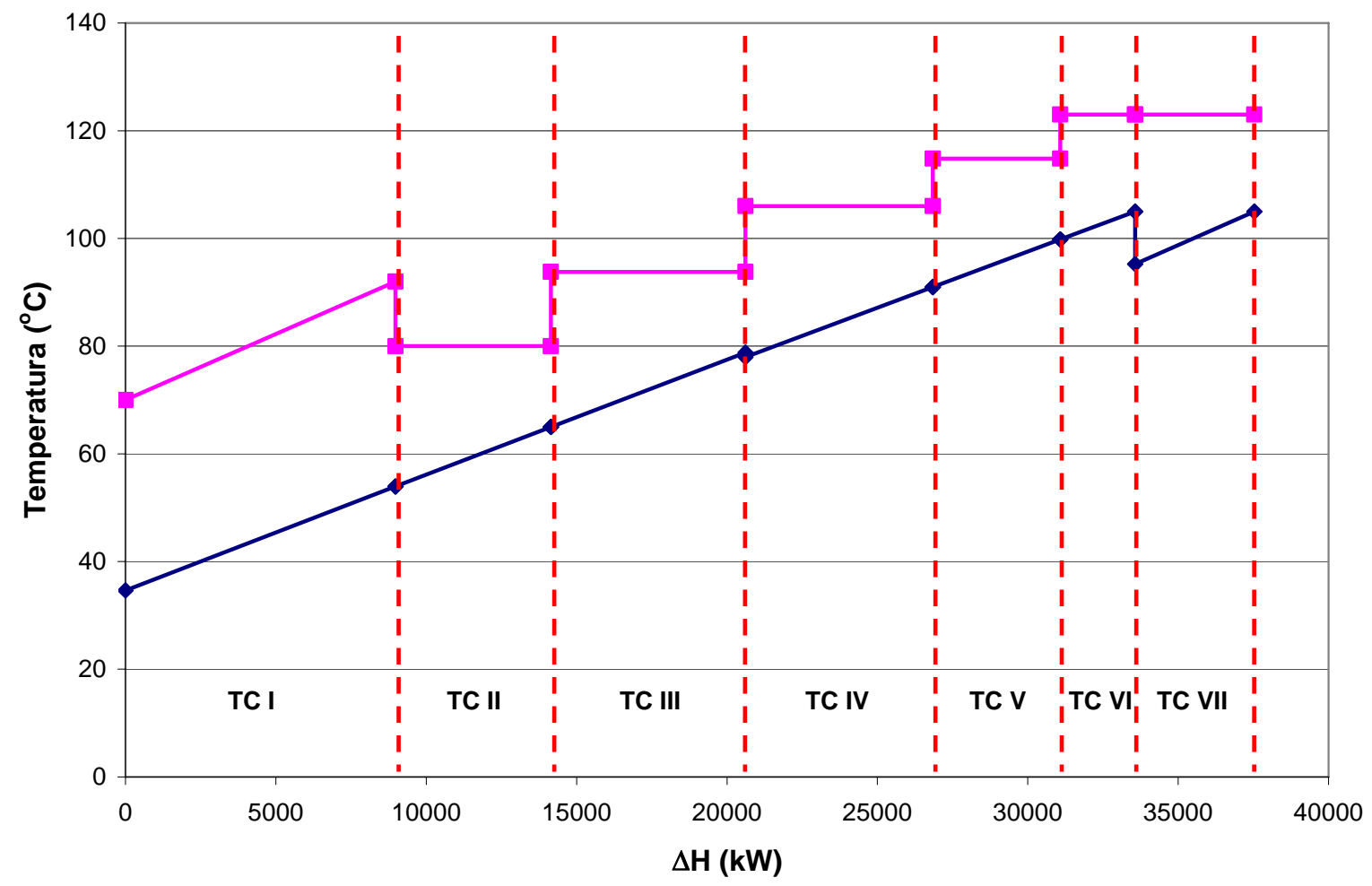

Caldo $\rightarrow-$ Corrente Quente

TC I - trocador de calor líquido-líquido.

TC II - trocador de calor utilizando vapor do $5^{\circ}$ efeito.

TC III - trocador de calor utilizando vapor do $4^{\circ}$ efeito.

TC IV - trocador de calor utilizando vapor do $3^{\circ}$ efeito.

TC V - trocador de calor utilizando vapor do $2^{\circ}$ efeito.

TC VI - trocador de calor utilizando vapor do $1^{\circ}$ efeito, antes do decantador.

TC VII - trocador de calor utilizando vapor do $1^{\circ}$ efeito, depois do decantador.

Figura 8.14 - Diagrama Temperatura vs. $\Delta \mathrm{H}$ para o sistema de aquecimento de caldo. 


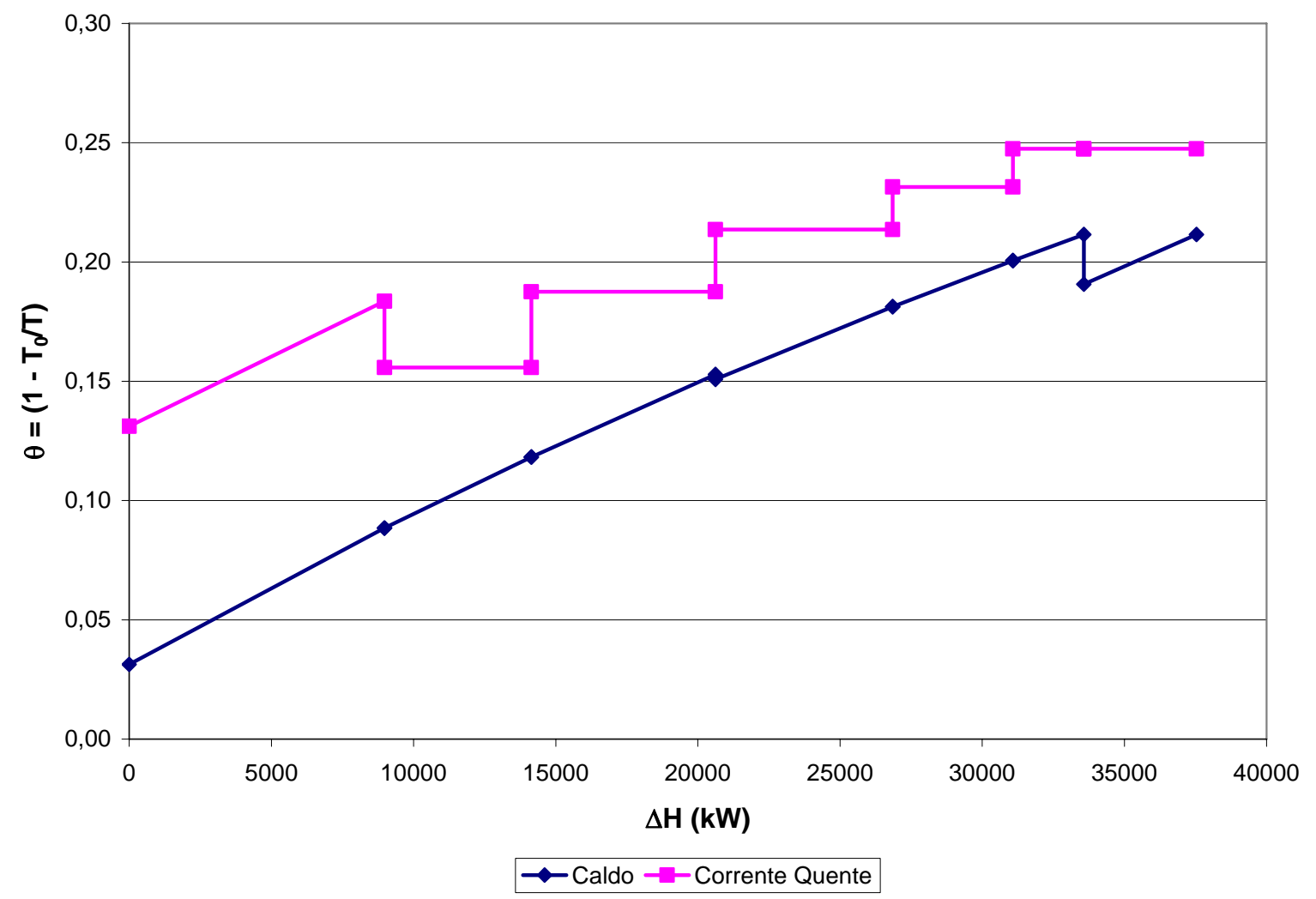

Figura 8.15 - Diagrama Fator de $\operatorname{Carnot}(\theta)$ vs. $\Delta \mathrm{H}$ para o sistema de aquecimento de caldo.

Tabela 8.7 - Parâmetros de desempenho da nova configuração do sistema de evaporação.

\begin{tabular}{cccccc}
\hline Efeito & Pressão & $\boldsymbol{\Delta} \mathbf{T}\left({ }^{\circ} \mathbf{C}\right)$ & $\begin{array}{c}\text { Eficiência } \\
\text { Exergética (\%) }\end{array}$ & $\begin{array}{c}\text { Participação na } \\
\text { Exergia Destruída } \\
\text { Total (\%) }\end{array}$ & $\begin{array}{c}\text { Exergia } \\
\text { Consumida } \\
\text { (kJ/kg evap) }\end{array}$ \\
\hline $1^{\circ}$ & 2,18 & 3,8 & 94,2 & 30,9 & 631,9 \\
$2^{\circ}$ & 1,68 & 6,8 & 92,6 & 29,6 & 539,8 \\
$3^{\circ}$ & 1,25 & 6,6 & 92,4 & 8,9 & 498,0 \\
$3^{\circ} \mathrm{a}$ & 1,25 & 8,4 & 90,7 & 20,9 & 539,7 \\
$4^{\circ}$ & 0,81 & 8,4 & 89,7 & 7,1 & 453,9 \\
$5^{\circ}$ & 0,47 & 7,9 & 88,9 & 2,6 & 383,6 \\
\hline
\end{tabular}

Comparando os valores da Tab. 8.7 com os da Tab. 8.4 é possível ver um aumento na eficiência exergética de todos os efeitos, em razão da menor diferença de temperatura. Assim, mesmo com um aumento do consumo de exergia para evaporação em cada efeito, esse consumo é feito de maneira mais eficiente, ou seja, há menos destruição de exergia. Além disso, a distribuição da exergia destruída entre os efeitos é mais uniforme. Esse resultado está de acordo com a proposta que a uniformização da geração de entropia entre as variáveis características de um trocador de calor e/ou massa leva à menor geração de entropia no sistema como um todo (TONDEUR; KVAALEN, 1987). 
Com relação à destilação duplo-efeito ou de múltiplos-efeitos, as colunas de epuração e de retificação operam em pressões diferentes, sendo que o condensador da segunda serve de refervedor para a primeira, propiciando uma redução de consumo de vapor nesse processo. Foi considerado o valor de 1,6 kg/L de álcool, quase $43 \%$ inferior ao valor avaliado no item 8.2 (PELLEGRINI; et al., 2008). Esse parâmetro está em consonância com os valores apresentados para a tecnologia Split-Feed ${ }^{\circledR}$, desenvolvida pela empresa Dedini, tradicional fornecedor do setor sucroalcooleiro, em conjunto com as empresas Chemtech e Siemens (NOLASCO, 2006). Esse consumo de vapor também é possível de se obter utilizando sistemas de pervaporação (FRANÇA, 2008).

As alterações propostas reduzem o consumo de vapor para $278 \mathrm{~kg} / \mathrm{tc}$, aproximadamente $43 \%$ e $29 \%$ inferior aos consumos para a usina tradicional e à configuração proposta no item 8.2 , respectivamente.

\subsection{SISTEMAS SUPERCRÍTICOS}

Conforme mostrado, a elevação da pressão e temperatura de geração do vapor aumenta a geração de eletricidade excedente em sistemas de cogeração tradicionais. Propõe-se agora estudar o que ocorreria caso fosse desenvolvido um sistema de cogeração utilizando condições supercríticas de geração de vapor, com uso de re-aquecimento do vapor e trocadores de calor regenerativos para aquecimento do condensado de retorno. Esse tipo de configuração representa os sistemas mais eficientes para geração de eletricidade baseados no Ciclo Rankine (BUGGE; KJÆR; BLUM, 2006; BEÉR, 2007).

O sistema proposto neste trabalho (Fig. 8.16) é baseado em Jin et al. (1997) e Drbal (1996), com 6 regeneradores e re-aquecimento simples. A eficiência da caldeira foi fixada em $88 \%$ (base PCI), e os gases de exaustão são utilizados para secagem do bagaço (até $40 \%$ de umidade). $\mathrm{O}$ vapor é gerado a 300 bar e $600^{\circ} \mathrm{C}$, sendo reaquecido até $600^{\circ} \mathrm{C}$ após a expansão na turbina até 62 bar, considerando os valores mais altos praticados atualmente (BUGGE; KJÆR; BLUM, 2006; BEÉR, 2007). Os valores para as eficiências isoentrópicas dos diferentes estágios das turbinas foram baseados em Jin et al. (1997), variando entre 85\% e 65\% entre cada estágio. Para a determinação das pressões de operação dos regeneradores, utilizou-se uma metodologia de otimização, cuja função-objetivo era a maximização da 
geração de eletricidade excedente (STRAMBI, 2007). A otimização foi desenvolvida utilizando o algoritmo genético do software EES ${ }^{\circledR}$ (KLEIN, 2008). A Fig. 8.17 mostra do diagrama Temperatura-Entropia da configuração proposta.

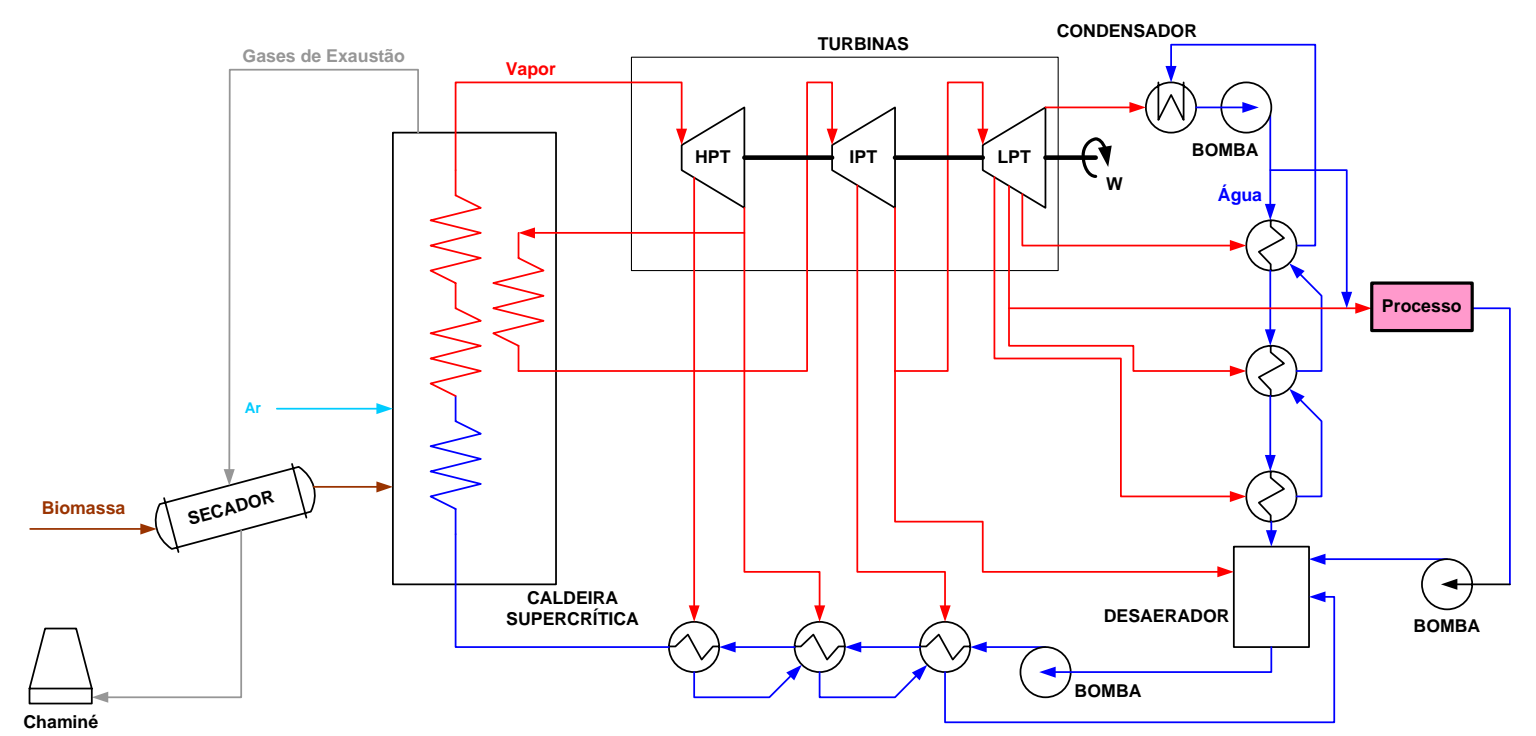

Figura 8.16 - Sistema Supercrítico.

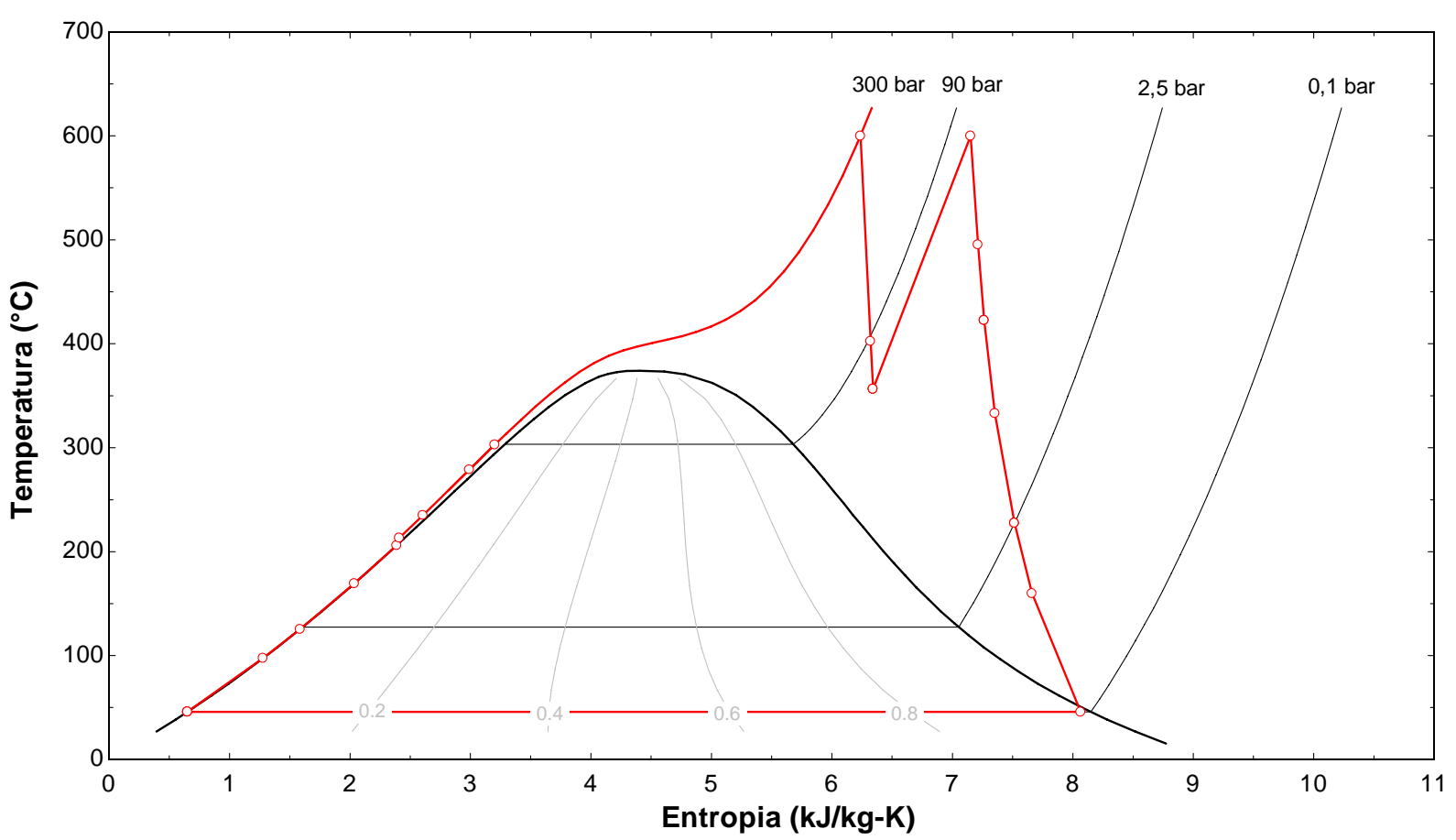

Figura 8.17 - Diagrama Temperatura-Entropia do Sistema Supercrítico proposto.

A Tab. 8.8 mostra os parâmetros de desempenho do sistema supercrítico. As equações utilizadas para a modelagem dessa configuração são apresentadas no Apêndice $\mathrm{C}$. 
Tabela 8.8 - Índices exergéticos para o Sistema Supercrítico.

\begin{tabular}{lc} 
Custo em base exergética do açúcar $(\mathrm{kJ} / \mathrm{kJ})$ & 1,39 \\
Custo em base exergética do álcool $(\mathrm{kJ} / \mathrm{kJ})$ & 2,54 \\
Excesso de bagaço produzido $(\%)$ & 3,0 \\
Exergia perdida específica - bagaço excedente $(\mathrm{kWh} / \mathrm{tc})$ & 22 \\
Quantidade específica de eletricidade excedente $(\mathrm{kWh} / \mathrm{tc})$ & 142,3 \\
Custo em base exergética da eletricidade produzida $(\mathrm{kJ} / \mathrm{kJ})$ & 3,66 \\
Custo em base exergética da energia mecânica $(\mathrm{kJ} / \mathrm{kJ})$ & 3,66 \\
Consumo específico de vapor $(\mathrm{kg} / \mathrm{tc})$ & 278 \\
Custo em base exergética do vapor de processo $(\mathrm{kJ} / \mathrm{kJ})$ & 3,78 \\
Exergia destruída específica total $(\mathrm{kWh} / \mathrm{tc})$ & 740 \\
Eficiência exergética da usina $(\%)$ & 50,0 \\
\hline
\end{tabular}

Os custos de produção de açúcar e álcool são quase 30\% menores que os da usina tradicional. Ainda, comparando com os sistemas de contrapressão e com os de condensação, o sistema supercrítico apresenta uma redução média nos custos de açúcar e álcool de 18\% e 13\%, respectivamente. Essa diminuição de custos é resultado da menor destruição de exergia nos processos (aproximadamente, 10\% em relação aos sistemas anteriores) e da redução do custo de produção de eletricidade e vapor utilizados nos processos.

A redução do custo de produção da eletricidade e do vapor de processo está relacionada à maior eficiência do sistema de cogeração. Essa maior eficiência significa menor destruição de exergia em relação aos sistemas anteriores, com conseqüente aumento da geração de eletricidade excedente (mais que o dobro que a geração excedente do sistema com turbinas de condensação e eletrificação as moendas). Com essa maior geração de eletricidade excedente, a eficiência da usina chega a 50\%. Com relação à eficiência de conversão da exergia da cana em eletricidade, essa fica próxima a $27 \%^{32}$, valor muito superior às eficiências dos sistemas atuais, porém abaixo dos obtidos em sistemas como ciclo combinado com turbinas a gás ou mesmo sistemas supercríticos movidos a carvão mineral (EL-WAKIL, 1984; DRBAL, 1996; LORA; NASCIMENTO, 2004).

\footnotetext{
${ }^{32}$ A eficiência é calculada como o inverso do custo em base exergética.
} 


\subsection{SISTEMAS COM GASEIFICAÇÃO DE BIOMASSA E CICLOS COMBINADOS}

Ciclos combinados apresentam as mais altas eficiências de conversão para geração de eletricidade. O uso de um gaseificador permite converter o bagaço proveniente da moenda em um gás com baixo poder calorífico, o qual pode servir de insumo energético para um ciclo combinado em um sistema de cogeração em usinas.

Neste trabalho serão avaliadas três configurações para esse sistema, todas baseadas no trabalho de Zanetti, Pellegrini e Oliveira Jr. (2007):

a) Atmosférico I: Sistema com gaseificação atmosférica e geração de vapor em 42 bar e $400^{\circ} \mathrm{C}$, com recuperação do calor rejeitado no sistema de limpeza dos gases para geração de vapor e pré-aquecimento do ar fornecido ao gaseificador (Fig. 8.18) ;

b) Atmosférico II: Sistema com gaseificação atmosférica e geração de vapor em 80 bar e $510^{\circ} \mathrm{C}$, com recuperação do calor rejeitado no sistema de limpeza dos gases para superaquecimento do vapor e pré-aquecimento do ar fornecido ao gaseificador (Fig. 8.19);

c) Pressurizado: Sistema com gaseificação pressurizada, com recuperação do calor rejeitado no sistema de limpeza dos gases para geração de vapor em 80 bar e $510^{\circ} \mathrm{C}$ (Fig. 8.20). 


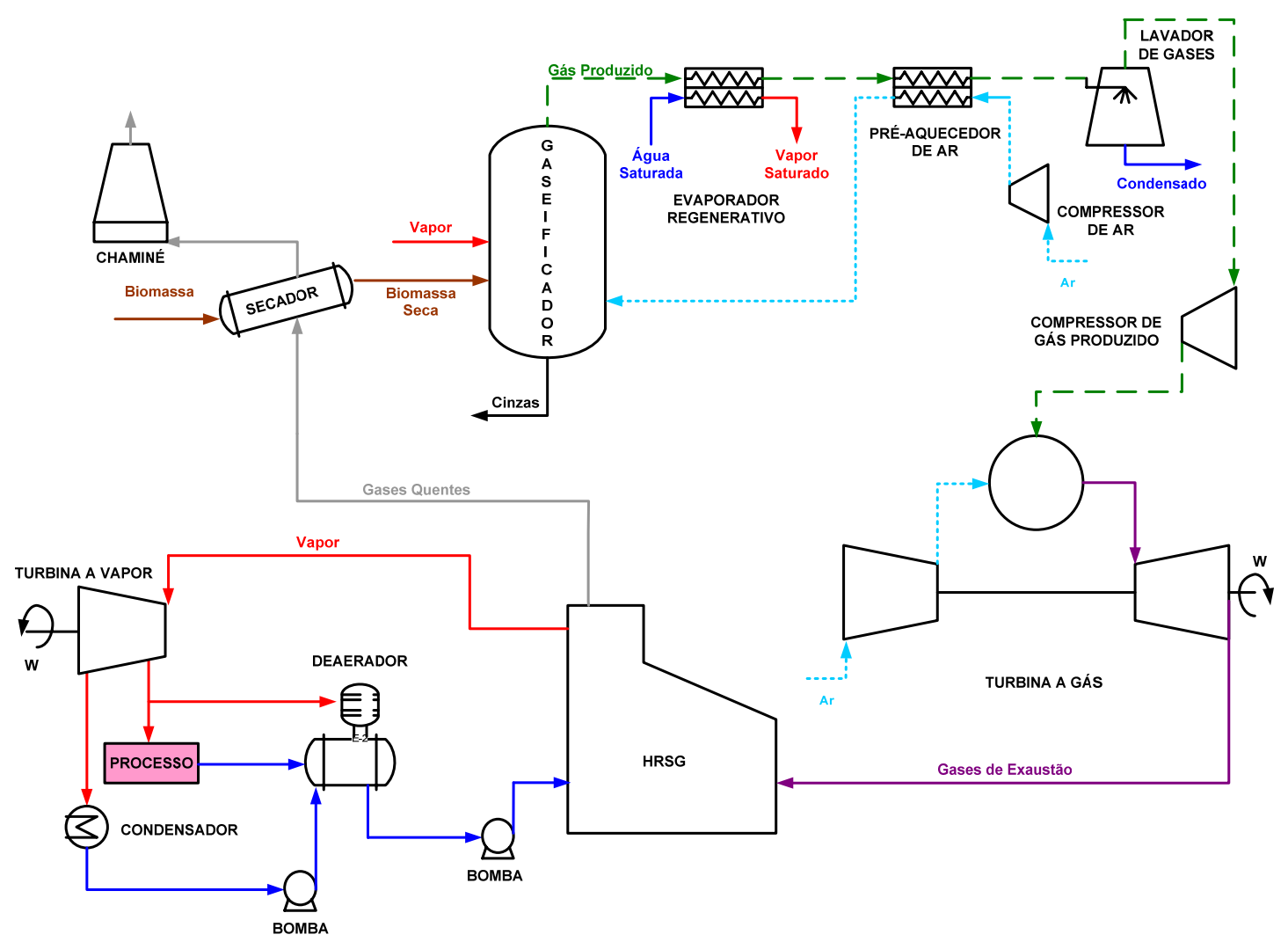

Figura 8.18 - Sistema com gaseificação atmosférica e geração de vapor em 42 bar e $400^{\circ} \mathrm{C}$.

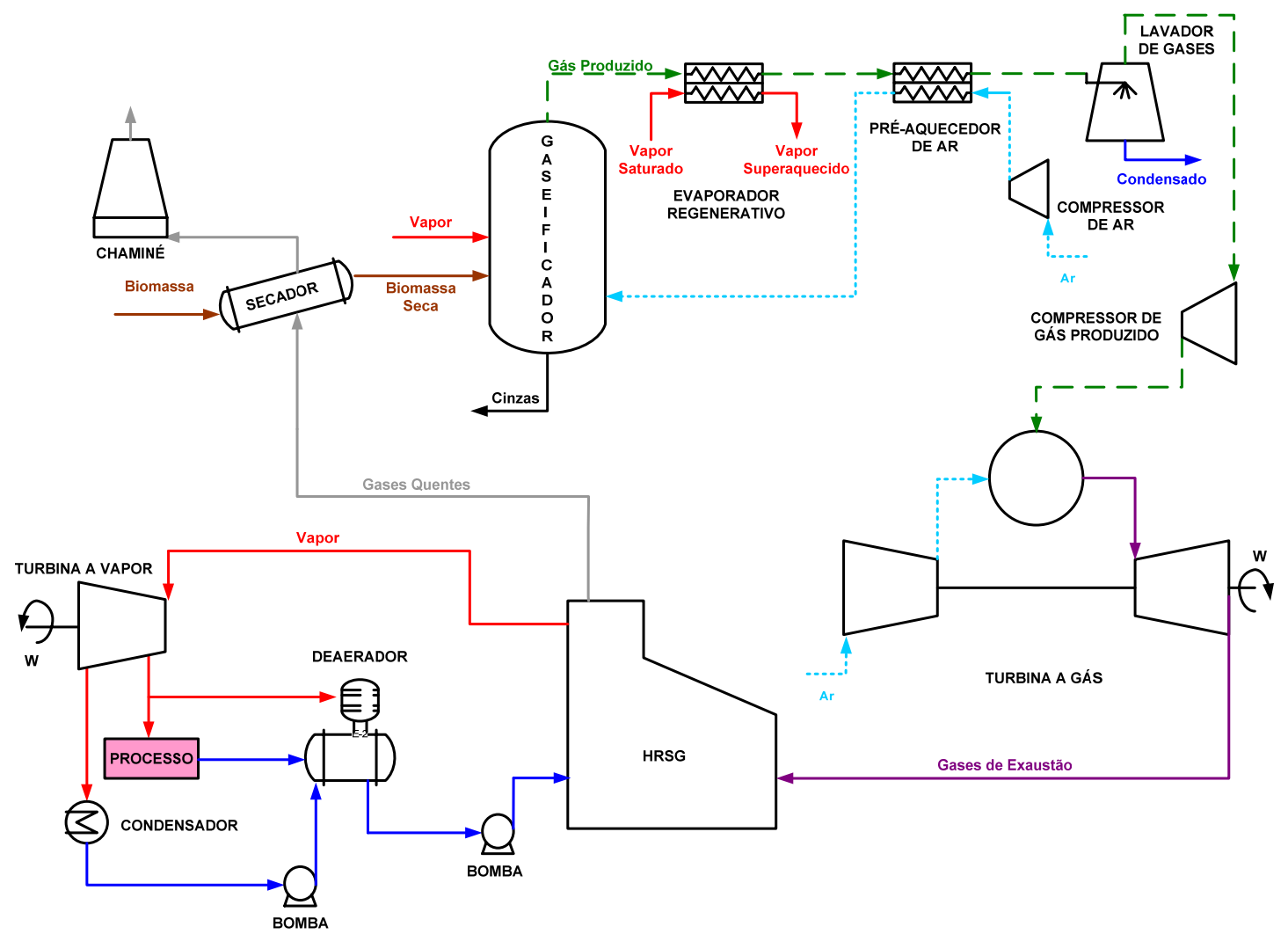

Figura 8.19 - Sistema com gaseificação atmosférica e geração de vapor em 80 bar e $510^{\circ} \mathrm{C}$.. 


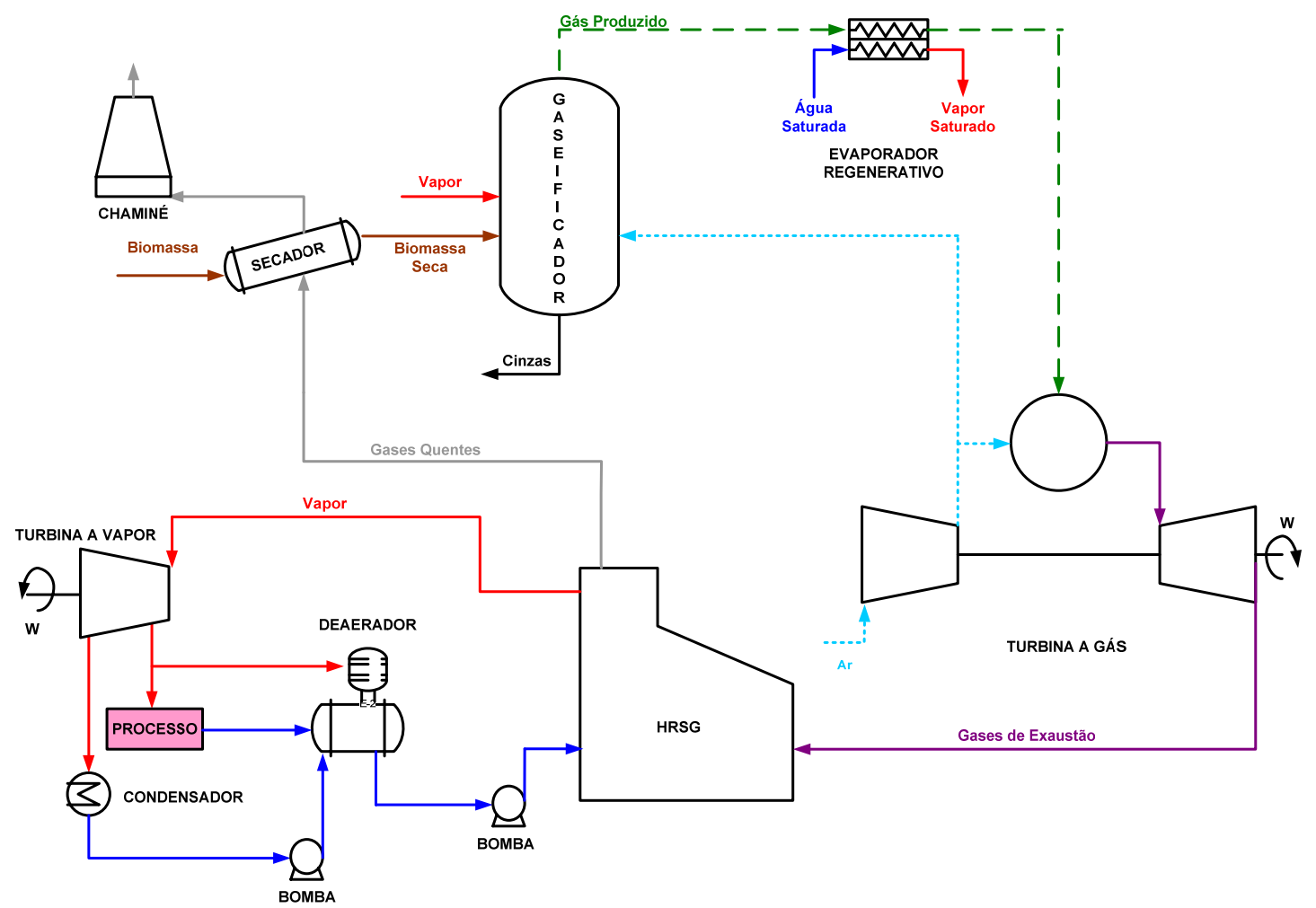

Figura 8.20 - Sistema com gaseificação pressurizada e geração de vapor em 80 bar e $510^{\circ} \mathrm{C}$.

A Tab. 8.9 mostra as principais características técnicas dos sistemas de gaseificação avaliados, enquanto as equações utilizadas para modelagem são descritas no Apêndice C.

Tabela 8.9 - Características técnicas dos sistemas de gaseificação.

\begin{tabular}{|c|c|c|c|}
\hline Parâmetro & Atmosférico I & Atmosférico II & Pressurizado \\
\hline Razão de equivalência & 0,3 & 0,3 & 0,3 \\
\hline $\begin{array}{l}\text { Pressão de operação do gaseificador } \\
\text { (bar) }\end{array}$ & 2 & 2 & 16 \\
\hline $\begin{array}{l}\text { Temperatura do ar na entrada do } \\
\text { gaseificador }\left({ }^{\circ} \mathrm{C}\right)\end{array}$ & 300 & 261 & 452 \\
\hline $\begin{array}{l}\text { Temperatura dos gases na saída do } \\
\text { gaseificador }\left({ }^{\circ} \mathrm{C}\right)\end{array}$ & 761 & 751 & 858 \\
\hline $\begin{array}{l}\text { Temperatura dos gases após o sistema } \\
\text { de limpeza }\left({ }^{\circ} \mathrm{C}\right)\end{array}$ & 35 & 35 & 550 \\
\hline $\begin{array}{l}\text { Temperatura dos gases de combustão } \\
\text { na entrada da turbina }\left({ }^{\circ} \mathrm{C}\right)\end{array}$ & 995 & 995 & 1119 \\
\hline $\begin{array}{l}\text { Temperatura dos gases de exaustão da } \\
\text { turbina a gás }\left({ }^{\circ} \mathrm{C}\right)\end{array}$ & 458 & 458 & 542 \\
\hline $\begin{array}{l}\text { Temperatura dos gases de exaustão } \\
\text { após a caldeira }\left({ }^{\circ} \mathrm{C}\right)\end{array}$ & 189 & 218 & 186 \\
\hline Pressão de geração do vapor (bar) & 40 & 80 & 80 \\
\hline Temperatura de geração do vapor $\left({ }^{\circ} \mathrm{C}\right)$ & 400 & 510 & 510 \\
\hline
\end{tabular}


A opção pela geração de vapor em 40 bar e $400^{\circ} \mathrm{C}$ na configuração Atmosférico I é devido a limitações do superaquecimento do vapor na caldeira de recuperação em função da baixa temperatura dos gases de exaustão da turbina a gás. Assim, a configuração Atmosférico II, apenas vapor saturado é produzido na caldeira de recuperação e o superaquecimento acontece no trocador de calor regenerativo do sistema de limpeza dos gases. A baixa temperatura dos gases de exaustão da turbina é resultado da estratégia de operação adotada para simular esse equipamento - “de-rating”. Essa condição de simulação envolve a redução da temperatura de entrada da turbina ("de-rating"), seguindo a metodologia proposta por Walter (2000), e, portanto, diminui a temperatura dos gases de exaustão. Para as simulações foram utilizadas como base os dados operacionais da Turbina ALSTOM GT11 (GTW, 2003).

No caso da configuração Pressurizado, parte do ar comprimido no compressor é extraído antes da câmara de combustão e enviado para o gaseificador como agente oxidante. Desta maneira, praticamente não há variação da quantidade de massa (volume) que irá passar pela turbina após a câmara de combustão, não havendo a necessidade do “de-rating”.

Outros parâmetros utilizados nas simulações são mostrados na Tab. 8.10.

Tabela 8.10 - Parâmetros utilizados para as simulações dos Sistemas com Gaseificação e Ciclos Combinados.

\begin{tabular}{lc}
\hline "Pinch Point” da Caldeira de Recuperação $\left({ }^{\circ} \mathrm{C}\right)$ & 10 \\
“Approach Point” da Caldeira de Recuperação $\left({ }^{\circ} \mathrm{C}\right)$ & 5 \\
Eficiência Isoentrópica dos Compressores $(\%)$ & 80 \\
Eficiência Isoentrópica da Extração dos Turbogerador $(\%)$ & 80 \\
Eficiência Isoentrópica da Condensação do Turbogerador $(\%)$ & 79 \\
Eficiência do Conjunto Redutor-Gerador $(\%)$ & 95 \\
Rendimento Isoentrópico das Bombas $(\%)$ & 70 \\
\hline
\end{tabular}

Para todas as configurações foi considerada a utilização de um secador o qual utiliza os gases provenientes da caldeira para secar o bagaço até $20 \%$ de umidade.

A Tab. 8.11 mostra os resultados das simulações. 
Tabela 8.11 - Índices exergéticos para os Sistemas com Gaseificação e Ciclos Combinados

\begin{tabular}{|c|c|c|c|}
\hline & Atmosférico I & Atmosférico II & Pressurizado \\
\hline $\begin{array}{l}\text { Custo em base exergética do açúcar } \\
(\mathrm{kJ} / \mathrm{kJ})\end{array}$ & 1,38 & 1,35 & 1,31 \\
\hline $\begin{array}{l}\text { Custo em base exergética do álcool } \\
(\mathrm{kJ} / \mathrm{kJ})\end{array}$ & 2,53 & 2,48 & 2,42 \\
\hline Excesso de bagaço produzido (\%) & 3,0 & 3,0 & 3,0 \\
\hline $\begin{array}{l}\text { Exergia perdida específica - bagaço } \\
\text { excedente }(\mathrm{kWh} / \mathrm{tc})\end{array}$ & 22 & 22 & 22 \\
\hline $\begin{array}{l}\text { Quantidade específica de eletricidade } \\
\text { excedente }(\mathrm{kWh} / \mathrm{tc})\end{array}$ & 151,9 & 154,6 & 205,5 \\
\hline $\begin{array}{l}\text { Custo em base exergética da } \\
\text { eletricidade produzida }(\mathrm{kJ} / \mathrm{kJ})\end{array}$ & 3,28 & 3,18 & 2,67 \\
\hline $\begin{array}{l}\text { Custo em base exergética da energia } \\
\text { mecânica }(\mathrm{kJ} / \mathrm{kJ})\end{array}$ & 3,28 & 3,18 & 2,67 \\
\hline Consumo específico de vapor $(\mathrm{kg} / \mathrm{tc})$ & 278 & 278 & 278 \\
\hline $\begin{array}{l}\text { Custo em base exergética do vapor de } \\
\text { processo }(\mathrm{kJ} / \mathrm{kJ})\end{array}$ & 3,95 & 3,53 & 3,18 \\
\hline $\begin{array}{l}\text { Exergia destruída específica total } \\
(\mathrm{kWh} / \mathrm{tc})\end{array}$ & 704 & 693 & 662 \\
\hline Eficiência exergética da usina (\%) & 50,7 & 50,9 & 54,4 \\
\hline
\end{tabular}

Os comentários feitos para o sistema supercrítico em relação aos sistemas de contrapressão e condensação seguem para os casos dos sistemas com gaseificação de bagaço. Assim, a discussão a seguir será focada na comparação dos sistemas com gaseificação em relação ao sistema supercrítico.

Comparando os valores para as configurações Atmosférico I e Atmosférico II com o Sistema Supercrítico, observa-se uma pequena variação dos custos de produção do açúcar e do álcool, sendo estes maiores para a primeira configuração e menor para a segunda. Para o Atmosférico I, apesar da redução da exergia destruída total, o sistema de geração de vapor é bastante ineficiente se comparado ao sistema supercrítico, elevando o custo do vapor de escape utilizado no processo, responsável pelos maiores custos do açúcar e do álcool. Na configuração Atmosférico II, a geração de vapor é mais eficiente que a anterior e mesmo sendo mais ineficiente que um sistema supercrítico, o custo do vapor de escape é menor, reduzindo os custos de produção de açúcar e álcool. Todavia, a variação dos custos do açúcar e do álcool desses sistemas em comparação aos do Sistema Supercrítico não variam mais que $2 \%$. 
Com relação à geração de eletricidade excedente, há um aumento de $7 \%$ e 9\%, para as configurações Atmosférico I e Atmosférico II respectivamente, em comparação ao Sistema Supercrítico. Ainda, a redução do custo de geração é ainda mais acentuada dada a maior eficiência de conversão bagaço-eletricidade de um ciclo combinado, mesmo impondo uma redução da temperatura de entrada da turbina a gás.

É interessante notar que a utilização do calor rejeitado pelo sistema de limpeza dos gases é melhor aproveitado quando é utilizado para superaquecer o vapor da caldeira. O resultado líquido é uma geração adicional de quase $3 \mathrm{kWh} / \mathrm{tc}$ e uma redução de $11 \mathrm{kWh} / \mathrm{tc}$ na exergia destruída.

Já os ganhos da configuração Pressurizado com relação à geração de eletricidade são ainda mais expressivos, quase $45 \%$ mais geração que o Sistema Supercrítico. A razão para essa maior quantidade de eletricidade excedente é a ausência de um compressor de gás produzido antes da injeção deste na câmara de combustão da turbina a gás, o qual consome aproximadamente $54 \mathrm{kWh} / \mathrm{tc}$. Além disso, a eliminação do sistema de limpeza a frio dos gases reduz a destruição de exergia no sistema de cogeração. Desta maneira, há uma redução nos custos de produção de açúcar, álcool e eletricidade.

A eficiência de conversão cana-eletricidade nos sistemas com gaseificação de bagaço chega a $37 \%$ para a configuração Pressurizado, aproximadamente $26 \%$ inferior ao rendimento de uma unidade termelétrica com ciclo combinado.

\subsection{COMENTÁRIOS GERAIS}

As Figs. 8.21 e 8.22 mostram um resumo dos principais resultados apresentados neste capítulo. 


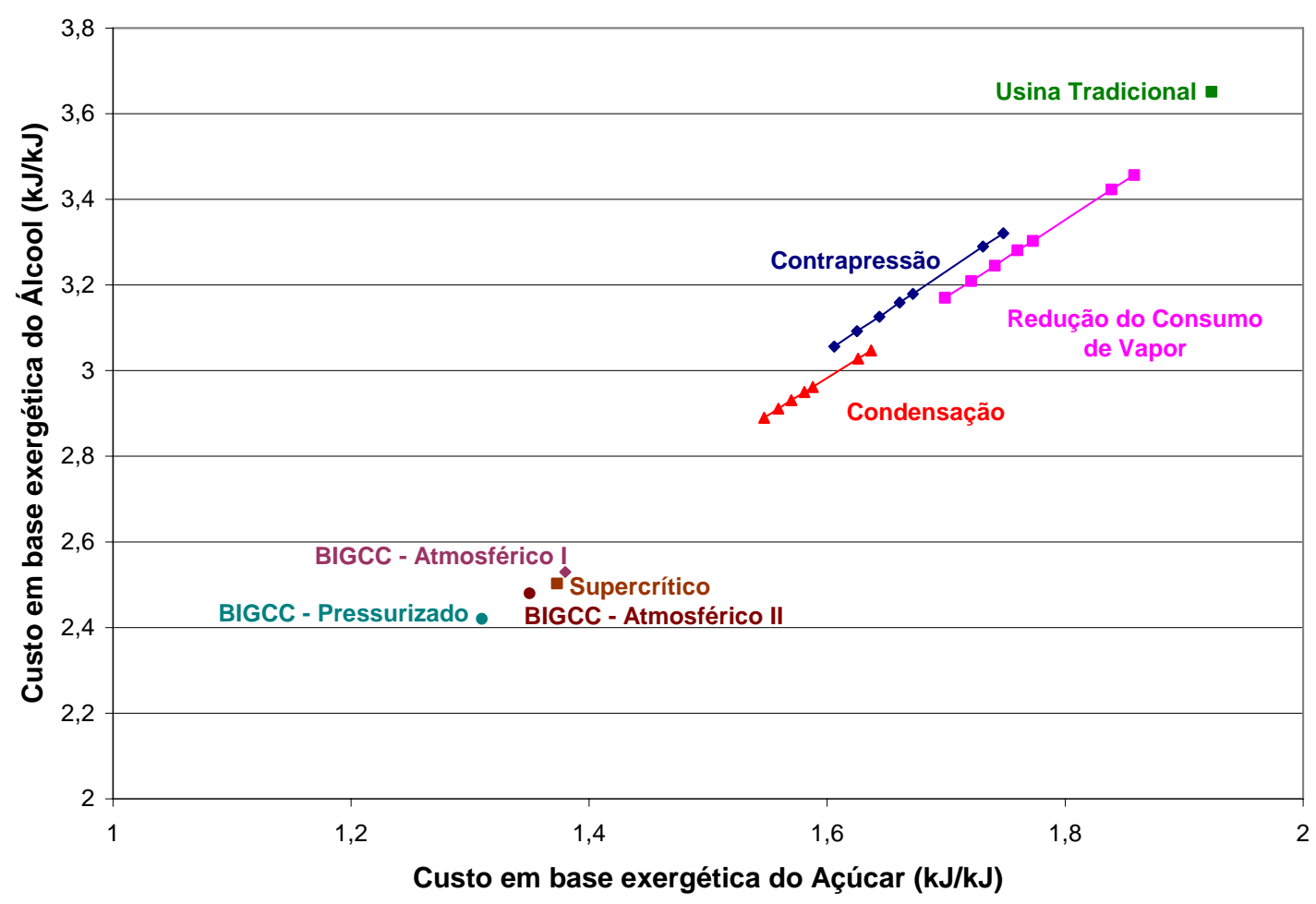

Figura 8.21 - Custo em base exergética do açucar e do álcool, para as configurações avaliadas.

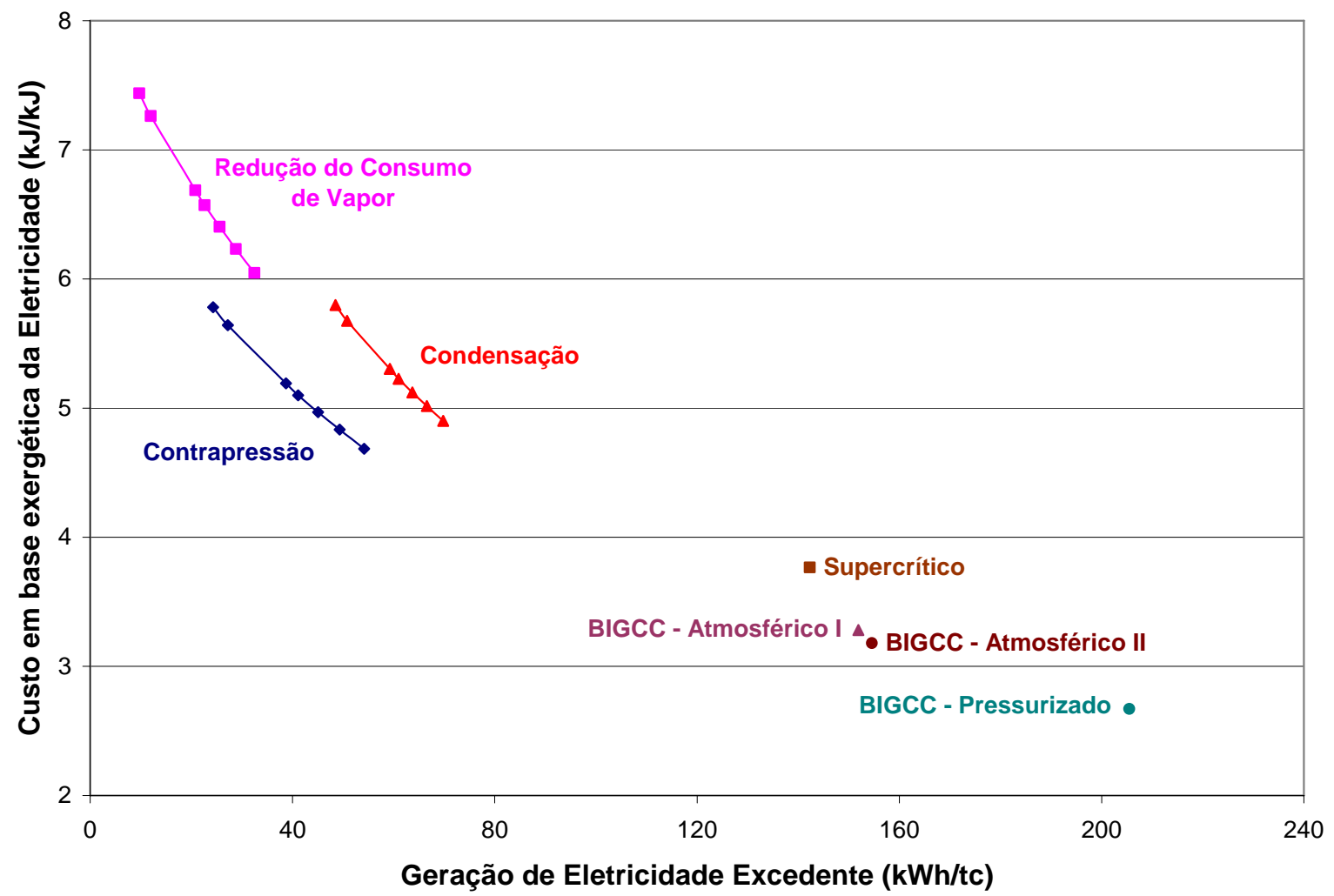

Figura 8.22 - Custo em base exergética da eletricidade em função da geração de eletricidade excedente, para as diferentes configurações analisadas. 
Os resultados apresentados e sumarizados nas Figs. 8.21 e 8.22 indicam que a maximização da eficiência do sistema de cogeração leva à minimização dos custos em base exergética de produção de açúcar, álcool e eletricidade. É claro que a otimização do sistema de cogeração requer uma melhoria na eficiência dos processos de conversão de energia nos processos produtivos. Para tanto, os mecanismos de geração de entropia nesses processos, avaliados no Cap. 6, foram explorados para o desenvolvimento de algumas alternativas para sua minimização.

Avaliando a Fig. 8.21 é evidente o impacto positivo nos custos do açúcar e do álcool em função do aumento da pressão e temperatura de geração do vapor. Ainda, a redução do consumo de vapor no processo com o uso de turbinas de condensação melhora o desempenho da usina como um todo. A utilização de sistemas avançados de cogeração reduz significativamente os custos, sendo a variação máxima dos custos do açúcar e do álcool entre esses sistemas - sistema supercrítico e o sistema com gaseificação pressurizada - igual a 5\%.

Os sistemas com turbinas de condensação apresentam custos em base exergética de produção de eletricidade muito próximos aos sistemas de contrapressão, porém o seu excedente de geração é muito superior (Fig. 8.22). Os sistemas de contrapressão são penalizados pela não utilização do bagaço excedente, enquanto os sistemas de condensação são penalizados pela baixa eficiência desses como sistemas de geração de potência.

As configurações mais avançadas de cogeração permitem a elevação da eficiência de conversão cana-eletricidade em até $36 \%$, produzindo quase três vezes mais eletricidade excedente que os sistemas com turbinas de condensação.

Para a usina tradicional avaliada no Cap. 6 (pg. 100), o Potencial de Melhoria era igual a 652 kWh/tc. A Fig. 8.23 mostra a variação desse índice em função da eletricidade excedente. 


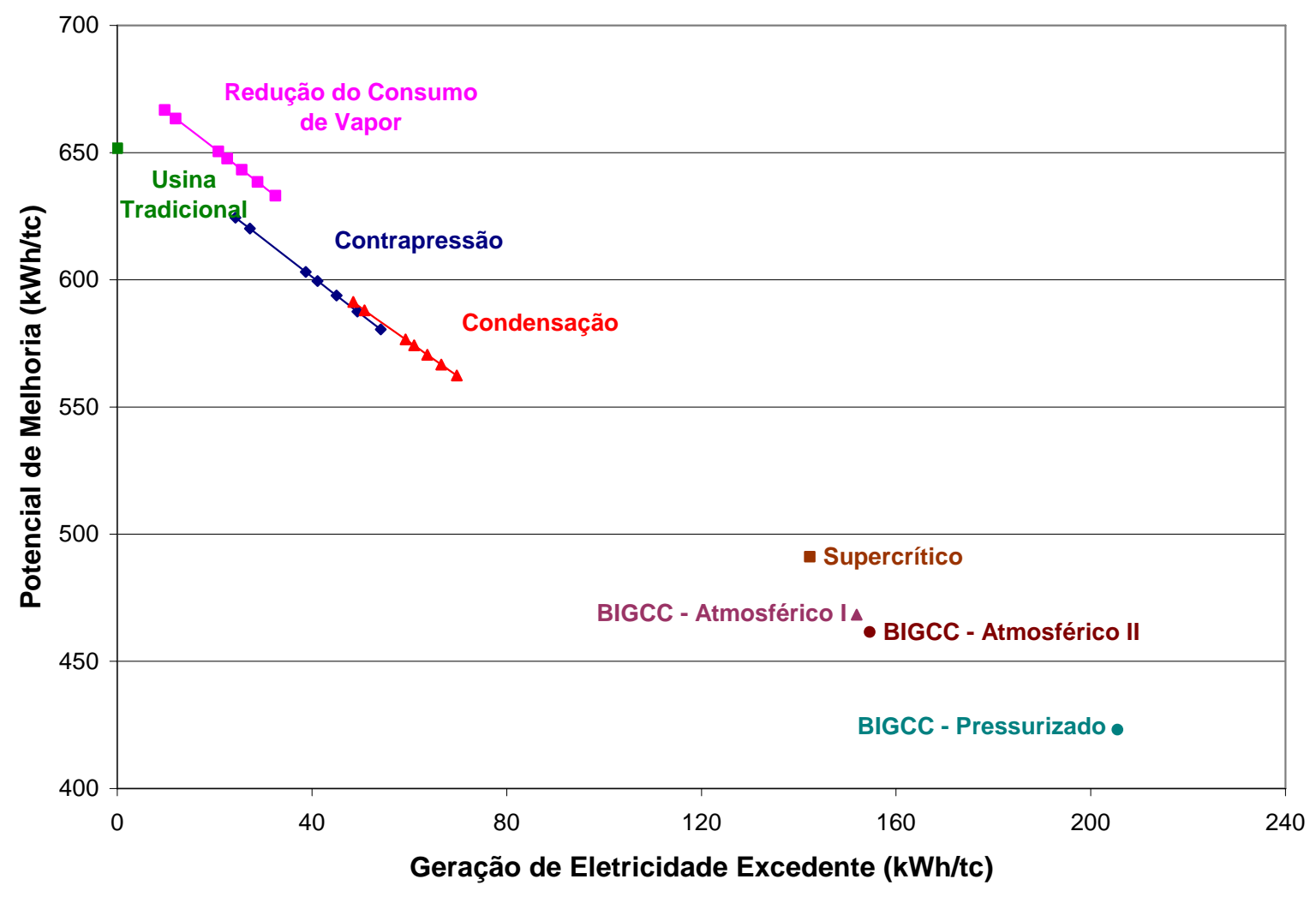

Figura 8.23 - Variação do Potencial de Melhoria em função da tecnolgia de cogeração.

Os resultados indicam que as configurações analisadas vão diminuindo o valor do Potencial de Melhoria para maiores quantidades de eletricidade excedente, indicando que esse potencial é convertido em um produto útil melhorando o desempenho termodinâmico da usina. A simples redução do consumo de vapor não apresenta grandes vantagens, pois eleva muito a produção de bagaço excedente, o que significa uma exergia perdida e que poderia ser aproveitada para a geração de eletricidade, por exemplo.

No próximo capítulo, os ganhos termodinâmicos identificados nesse capítulo serão utilizados para avaliar a rentabilidade dos produtos e sua participação na composição da receita da usina. 


\section{AVALIAÇÃO DA MARGEM DE CONTRIBUIÇÃO DOS PRODUTOS POR MEIO DA ANÁLISE TERMOECONÔMICA}

A análise da margem de contribuição dos produtos permite ao gestor da produção tomar decisões acerca do mix de produtos que maximizem o lucro operacional da empresa. A grande vantagem desta análise é que não se prende a dúvidas quanto aos custos fixos que cabe para cada produto, pois são tratados como custos de estrutura que devem ser pagos pela somatória das margens de contribuição. Assim, a questão de rateio dos custos fixos, que normalmente acarretam em distorções, é considerada apenas no final, isto é, comum a todos os produtos.

Rosa (2004) utilizou o custeio direto (custeio variável) como ferramenta de controle do processo de produção combinado de destilado e álcool em uma destilaria autônoma de médio porte. A idéia do trabalho é propor uma ferramenta de tomada de decisão sobre o mix de produção da planta baseado em parâmetros operacionais - volumes de produção, produtividade, entre outros - e condições econômicas existentes - preço dos produtos. A determinação do mix de produção é uma função da margem de contribuição de cada produto para o lucro da empresa, o qual varia de acordo com os custos diretos do processo produtivo e os preços de mercado dos produtos. Todavia, para a atribuição dos custos variáveis aos produtos é feita com base em parâmetros de conversão equivalente de um produto em outro. Esse critério mascara a partição do custo das ineficiências dos processos, já que os critérios de transformação são baseados em relações derivadas de balanços de massa e energia.

Outra abordagem para o rateio de custos comuns entre os produtos da usina é a distribuição baseada na quantidade ART destinada a cada produto (CHAVES, 2005). Segundo esse trabalho, o custo da matéria-prima (cana) representa aproximadamente $70 \%$ do custo total de produção de açúcar e álcool. Porém, essa metodologia falha na atribuição de custos em uma usina com geração excedente de eletricidade, pois não prevê uma maneira de atribuir custo ao bagaço utilizado no sistema de cogeração.

A proposta deste capítulo é apresentar uma avaliação da margem de contribuição dos produtos da usina, porém tomando a Termoeconomia como metodologia de atribuição de custos, utilizando os mesmos critérios de partição do Cap. 8. Considera-se que o único custo exógeno 
é o de aquisição da cana, sendo atribuído valor zero aos custos dos demais insumos. Assim, o rateio do custo da cana entre o açúcar e o álcool é feito com base na exergia desses produtos, além de ser possível atribuir um custo ao bagaço e, portanto, definir um custo para a eletricidade excedente eventualmente gerada. Não são consierados custos relativos à amortização dos equipamentos nem relacionados a outros insumos do processo.

Porém, antes é importante a definição de alguns conceitos:

Receita Bruta (RB): valor monetário recebido pela venda do produto, ou seja, o preço do produto multiplicado pela quantidade vendida;

> Receita Líquida (RL): receita bruta com os descontos das despesas de venda (DV) (impostos, fretes, seguros, etc.);

$>$ Custo (C): gastos incorridos para a produção de um determinado produto. Pode ser dividido em custo fixo (CF), quando os valores não se alteram com o volume produzido, e em custo variável $(\mathrm{CV})$, quando seus valores variam com o volume produzido.

> Margem de contribuição (MC): diferença entre a receita líquida e o custo variável de um produto. É possível estabelecer a margem de contribuição unitária (MCU), ou seja, a margem de contribuição por unidade de produto $(\mathrm{Q})$.

Matematicamente, esses conceitos podem ser resumidos por:

$$
\begin{aligned}
& R L=R B-D V \\
& M C=R L-C V \\
& M C U=\frac{M C}{Q}
\end{aligned}
$$

A somatória das margens de contribuição dos produtos, chamada margem de contribuição total, é responsável pela amortização dos custos fixos e pela formação do lucro da empresa. Assim, é possível avaliar qual produto tem maior rentabilidade e qual produto que mais contribui para a formação do lucro. 
A Fig. 9.1 mostra o esquema do volume de controle considerado para a determinação das margens de contribuição.

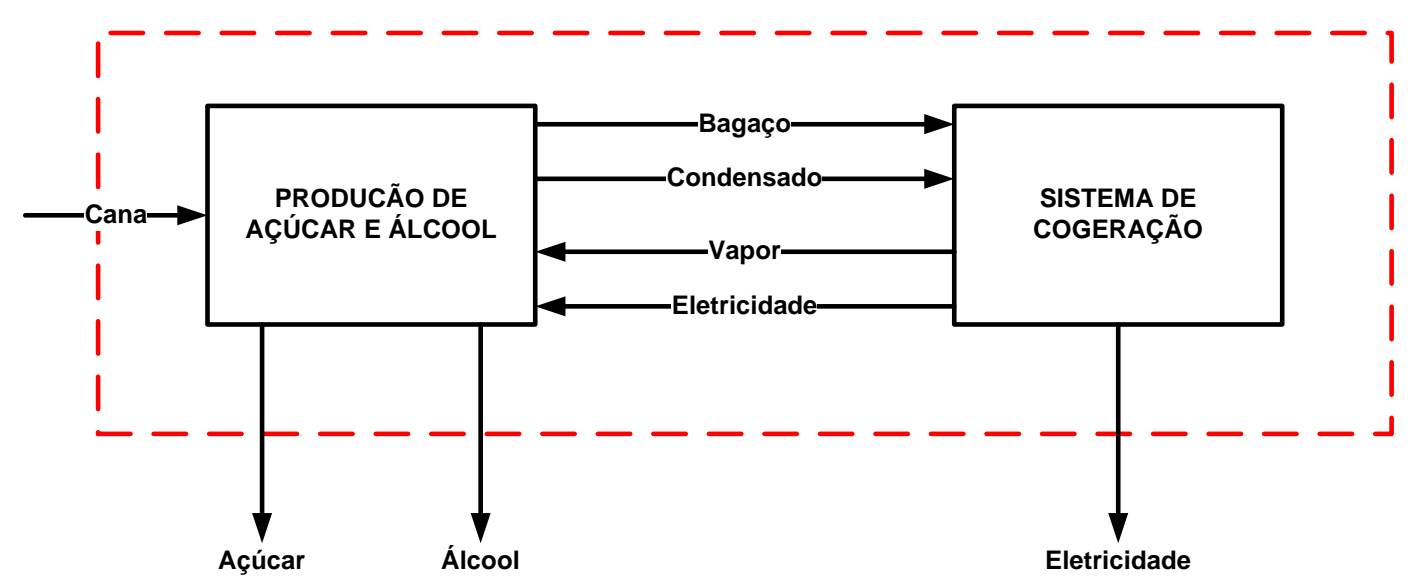

Figura 9.1- Volumes de Controle para Avaliação da Margem de Contribuição dos Produtos.

O volume de controle considera a usina como um todo, sendo a margem de contribuição total a diferença entre a receita pela venda de açúcar, álcool e eletricidade excedente e o custo de aquisição da cana. A margem de contribuição dos produtos é calculada a partir da diferença entre o preço unitário de venda e o custo unitário determinado pela Análise Termoeconômica, considerando os diversos sistemas de conversão de energia no interior da usina.

Vale ressaltar que na análise ora proposta o bagaço é "vendido" ao sistema de cogeração com um preço igual ao seu custo de produção calculado pela Análise Termoeconômica, diferentemente de outros trabalhos que atribuíram um valor a esse insumo baseado em outros critérios (WALTER, 1994; COELHO, 1999; BARREDA DEL CAMPO, 1999), ou mesmo, impuseram custo zero por tratar o bagaço como um resíduo do processo de extração. Da mesma maneira, o sistema de cogeração vende o vapor e a eletricidade que os processos necessitam a um preço igual ao custo de produção desses produtos.

A margem de contribuição unitária será calculada em base exergética a fim de permitir uma avaliação comparativa mais racional, por se tratar da mesma base de comparação para todos os produtos.

Para as avaliações, serão utilizados os preços, sem impostos, para cana, açúcar, álcool e eletricidade mostrados na Tab. 9.1. 
Tabela 9.1 - Preços, sem impostos, utilizados nas análises das margens de contribuição dos produtos.

\begin{tabular}{|c|c|}
\hline Cana $(\mathrm{R} \$ / \mathrm{t})^{(1)}$ & 30,19 \\
\hline Açúcar $(\mathrm{R} \$ / \mathrm{t})^{(2)}$ & 514,73 \\
\hline Álcool $(\mathrm{R} \$ / \mathrm{L})^{(3)}$ & 0,75 \\
\hline Eletricidade $(\mathrm{R} \$ / \mathrm{MWh})^{(4)}$ & 130,00 \\
\hline
\end{tabular}

É interessante também assinalar o preço de cada produto em função da sua exergia, de maneira que seja possível comparar a rentabilidade de cada um dos produtos na mesma base. Assim, os preços em base exergética são: R\$ 19,36/MWhex, R\$ 105,98 $\mathrm{MWh}_{\mathrm{ex}}$, R\$ 123,97/MWh $\mathrm{Mx}_{\mathrm{ex}}$ e R $\$ 130,00 / \mathrm{MWh}$, para cana, açúcar, álcool e eletricidade, respectivamente. É interessante notar a proximidade dos valores em base exergética de cada um desses produtos.

\subsection{USINA TRADICIONAL}

Para a usina tradicional, a margem de contribuição total é obtida simplesmente pela diferença entre a receita da venda de açúcar e álcool e o custo da cana, já que não há venda de eletricidade excedente, sendo igual a $\mathrm{R} \$ 35,51 / \mathrm{t}$. As margens de contribuição de açúcar e álcool representam 59\% e 41\% da margem total, respectivamente. Ou seja, o açúcar contribui mais para a formação do lucro que o álcool.

A Tab. 9.2 mostra o custo de produção e a margem de contribuição de açúcar, álcool e eletricidade.

Tabela 9.2 - Custo de produção e margens de contribuição dos produtos.

\begin{tabular}{cccc}
\hline Produto & $\begin{array}{c}\text { Custo de } \\
\text { Produção }\end{array}$ & $\begin{array}{c}\text { Margem de } \\
\text { Contribuição }\end{array}$ & $\begin{array}{c}\text { Margem de } \\
\text { Contribuição } \\
\text { Exergética } \\
\text { (R\$/MWh }\end{array}$ \\
\hline Açúcar $(\mathrm{R} \$ / \mathrm{t})$ & 179,76 & 334,71 & 68,96 \\
Álcool $(\mathrm{R} \$ / \mathrm{L})$ & 0,43 & 0,32 & 52,27 \\
Eletricidade $(\mathrm{R} \$ \mathrm{MWh})$ & 136,78 & - & - \\
\hline
\end{tabular}

\footnotetext{
${ }^{33}$ Disponível em: http://www.udop.com.br.

${ }^{34}$ Disponível em: http://www.cepea.esalq.usp.br.
} 
Observa-se que a margem de contribuição unitária em base exergética do açúcar é 31\% maior que a do álcool. Ou seja, para uma usina tradicional, o açúcar é um produto mais lucrativo que o álcool, segundo os preços correntes do mercado e os critérios de atribuição de custos adotados.

Diante desses resultados, a otimização da mix de produção, ou seja, a escolha da quantidade a ser produzida de açúcar e álcool que maximiza o lucro, leva a uma predileção para a produção do açúcar. Nesse caso todo o caldo obtido nas moendas seria enviado para a produção de açúcar, enquanto o álcool seria produzido apenas a partir do mel B, sub-produto da produção de açúcar. O novo valor da nova margem total é R\$ 35,94/t.

Outro dado interessante a ser observado é o custo de produção da eletricidade, esse é maior que o preço da mesma caso fosse ser vendida ao mercado. Isso mostra a ineficiência com que a eletricidade é gerada na usina e como essa ineficiência onera os processos produtivos.

A Tab. 9.3 mostra os valores calculados quando a atribuição de custos é feita pela quantidade de ART destinada para cada produto. Nessa condição, as margens de contribuição do açúcar e do álcool representam $49 \%$ e $51 \%$ da margem total, respectivamente.

Tabela 9.3 - Custo de Produção e Margens de Contribuição dos Produtos.

\begin{tabular}{cccc}
\hline Produto & $\begin{array}{c}\text { Custo de } \\
\text { Produção }\end{array}$ & $\begin{array}{c}\text { Margem de } \\
\text { Contribuição }\end{array}$ & $\begin{array}{c}\text { Margem de } \\
\text { Contribuição } \\
\text { Exergética } \\
\text { (R\$/MWh }\end{array}$ \\
\hline Açúcar $(\mathrm{R} \$ / \mathrm{t})$ & 246,50 & 273,93 & 56,40 \\
Álcool $(\mathrm{R} \$ / \mathrm{L})$ & 0,35 & 0,40 & 64,64 \\
Eletricidade $(\mathrm{R} \$ \mathrm{MWh})$ & - & - & - \\
\hline
\end{tabular}

É interessante notar que a hierarquização de rentabilidade é invertida com a atribuição de custos com base na ART dos produtos. Isso ocorre, pois como a estratégia de operação é 50/50 (metade dos ART's para açúcar e metade para álcool) ${ }^{35}$, ambos apresentam o mesmo custo de produção em base ART, aproximadamente R\$234,90/t de ART. Assim, devido ao

\footnotetext{
${ }^{35} 1 \mathrm{~kg}$ de açúcar com pol de 99,6\% equivale a 1,0492 kg de ART. $1 \mathrm{~L}$ de álcool hidratado equivale a 1,4735 $\mathrm{kg}$ de ART (FERNANDES, 2003).
} 
maior preço do álcool em relação ao açúcar, em base ART, o primeiro apresenta uma rentabilidade maior.

A otimização do mix de produção nesse caso também prioriza a fabricação de açúcar para a maximização do lucro, isso porque durante a produção do álcool ocorre a maior perda de ART. Assim, mesmo sendo o álcool mais rentável que o açúcar, sua produção não é priorizada.

Essa metodologia penaliza de forma igual a perda de ART nos processos de produção, porém não leva em consideração as perdas termodinâmicas, além de não atribuir custo à eletricidade e ao vapor utilizados nos processos, haja visto que é considerado custo zero para o bagaço. Assim, essa abordagem não contempla potenciais reduções de custos no açúcar e no álcool em função do melhor desempenho dos processos de conversão de energia na usina, sobretudo na planta de cogeração.

Pode-se concluir, portanto, que uso da Termoeconomia na avaliação da rentabilidade de cada produto é um método mais direto para a avaliação do melhor mix de produção na usina.

Nos próximos itens, serão apresentados os efeitos da melhoria do desempenho dos processos de conversão de energia na rentabilidade dos produtos da usina.

\subsection{SISTEMAS A VAPOR COM TURBINAS DE CONTRAPRESSÃO, SEM MODIFICAÇÕES NOS PROCESSOS}

No Cap. 8, diferentes níveis de pressão e temperatura foram avaliados para o sistema com turbinas de contrapressão. A fim de evitar repetições desnecessárias, serão apresentados os resultados apenas para o caso de geração de vapor a 67 bar e $515^{\circ} \mathrm{C}$, sem eletrificação das moendas (Tab. 9.4). 
Tabela 9.4 - Custo de Produção e Margens de Contribuição dos Produtos.

\begin{tabular}{cccc}
\hline Produto & $\begin{array}{c}\text { Custo de } \\
\text { Produção }\end{array}$ & $\begin{array}{c}\text { Margem de } \\
\text { Contribuição }\end{array}$ & $\begin{array}{c}\text { Margem de } \\
\text { Contribuição } \\
\text { Exergética } \\
\text { (R\$/MWh }\end{array}$ \\
\hline Açúcar $(\mathrm{R} \$ / \mathrm{t})$ & 155,31 & 359,39 & 74,00 \\
Álcool $(\mathrm{R} \$ / \mathrm{L})$ & 0,37 & 0,38 & 61,73 \\
Eletricidade $(\mathrm{R} \$ \mathrm{MWh})$ & 98,11 & 31,89 & 31,89 \\
\hline
\end{tabular}

Como mostrado no Cap. 8, o aumento da eficiência do sistema de cogeração reduz os custos de produção de açúcar (13\%), álcool (13\%) e eletricidade (28\%). Assim, a margem de contribuição unitária desses produtos aumentou, bem como a margem de contribuição total, passando de $\mathrm{R} \$ 35,51 / \mathrm{t}$ para $\mathrm{R} \$ 40,86 / \mathrm{t}$ (ganho de 15\%). O açúcar é o produto que mais contribui para a margem total (55\%), seguido pelo álcool (42\%) e pela eletricidade (3\%). É possível observar uma redução da participação do açúcar pela introdução da eletricidade, isso porque a margem de contribuição do álcool sofreu um aumento muito maior que a do açúcar.

Finalmente, comparando a rentabilidade dos produtos com base na margem de contribuição exergética, observa-se que o açúcar apresenta maior rentabilidade por unidade de exergia. Todavia, sua diferença para a rentabilidade do álcool diminuiu para $20 \%$.

A eletrificação das moendas implica um aumento das margens de contribuição unitárias, sem grandes alterações nas participações dos produtos na margem total. O mesmo segue para elevação dos parâmetros de geração do vapor.

\subsection{SISTEMAS A VAPOR COM TURBINAS DE CONTRAPRESSÃO, COM MODIFICAÇÕES NOS PROCESSOS}

Como discutido no Cap. 8, a redução do consumo de vapor leva a uma menor destruição de exergia no processo e a um aumento do excedente de bagaço. Assim, o resultado líquido dessa redução é um aumento dos custos em base exergética do açúcar, álcool e eletricidade. Ainda, a redução do consumo de vapor, significa uma menor geração de eletricidade, já que a geração é feita em turbinas de contrapressão que acompanham o consumo de vapor no processo (operação em paridade térmica). A Tab. 9.5 mostra o impacto do menor consumo de vapor nas margens de contribuição dos produtos, para a geração de vapor a 67 bar e $515^{\circ} \mathrm{C}$, sem a eletrificação das moendas. 
Tabela 9.5 - Custo de Produção e Margens de Contribuição dos Produtos.

\begin{tabular}{cccc}
\hline Produto & $\begin{array}{c}\text { Custo de } \\
\text { Produção }\end{array}$ & $\begin{array}{c}\text { Margem de } \\
\text { Contribuição }\end{array}$ & $\begin{array}{c}\text { Margem de } \\
\text { Contribuição } \\
\text { Exergética } \\
\text { (R\$/MWh }\end{array}$ \\
\hline Açúcar $(\mathrm{R} \$ / \mathrm{t})$ & 164,66 & 350,04 & 72,07 \\
Álcool $(\mathrm{R} \$ / \mathrm{L})$ & 0,39 & 0,36 & 59,36 \\
Eletricidade $(\mathrm{R} \$ \mathrm{MWh})$ & 126,56 & 3,44 & 3,44 \\
\hline
\end{tabular}

A margem de contribuição total dessa opção é igual a $\mathrm{R} \$ 38,45 / \mathrm{t}$, ou seja, $8 \%$ superior à da usina tradicional, porém 6\% inferior à do item anterior. Há uma perda de 3\% e 4\% nas rentabilidades do açúcar e do álcool, enquanto a da eletricidade é muito inferior ao caso anterior.

Esses resultados permitem concluir que a redução do consumo de vapor no processo deve ser feita em função de se utilizar o bagaço excedente de maneira a produzir valor (geração de eletricidade ou venda para terceiros, p.ex.), caso contrário é preferível apenas aumentar os parâmetros de geração de vapor na caldeira.

\subsection{SISTEMAS A VAPOR COM TURBINAS DE CONDENSAÇÃO}

Conforme já discutido, a redução do consumo de vapor leva a um aumento do excedente de bagaço, o qual permite uma maior geração de eletricidade a partir do uso de turbinas de condensação. Além disso, o uso de turbinas de condensação permite a geração de eletricidade ao longo do ano todo, diminuindo a capacidade instalada para a mesma geração.

Considerando a geração de vapor a 67 bar e $515^{\circ} \mathrm{C}$, com eletrificação das moendas e geração apenas durante a safra, a margem de contribuição total é igual a R \$43,95/t, um ganho de 8\% sobre os sistemas com turbinas de contrapressão e altos consumos de vapor no processo. É importante lembrar que a diferença de geração excedente entre essas duas configurações é de $58 \%$, maior para os sistemas de condensação. Ou seja, apesar do aumento do volume da eletricidade excedente, a sua participação na margem total ainda é pequena $(5 \%)$ frente às contribuições do açúcar (53\%) e do álcool (42\%). 
A Tab. 9.6 mostra os valores dos custos de produção e margens de contribuição para essa configuração.

Tabela 9.6 - Custo de Produção e Margens de Contribuição dos Produtos.

\begin{tabular}{cccc}
\hline Produto & $\begin{array}{c}\text { Custo de } \\
\text { Produção }\end{array}$ & $\begin{array}{c}\text { Margem de } \\
\text { Contribuição }\end{array}$ & $\begin{array}{c}\text { Margem de } \\
\text { Contribuição } \\
\text { Exergética } \\
\text { (R\$/MWh }\end{array}$ \\
\hline Açúcar $(\mathrm{R} \$ / \mathrm{t})$ & 144,17 & 370,53 & 76,29 \\
Álcool $(\mathrm{R} \$ / \mathrm{L})$ & 0,34 & 0,41 & 67,23 \\
Eletricidade $(\mathrm{R} \$ \mathrm{MWh})$ & 96,03 & 33,97 & 33,97 \\
\hline
\end{tabular}

Comparando com os valores da Tab. 9.4, observa-se uma redução dos custos de produção com conseqüente aumento da margem de contribuição unitária dos produtos, principalmente para o açúcar e o álcool. Assim, os principais responsáveis pelo aumento da margem total são a redução do custo de produção de açúcar e álcool e a maior quantidade de geração de eletricidade com o uso de turbinas de condensação.

A geração de eletricidade ao longo do ano todo não eleva a margem de contribuição total, já que as quantidades de produzidas de cada produto não se alteram, nem a quantidade de insumo (cana). Assim, tanto o custo total quanto a receita total são iguais à geração apenas durante a safra. Todavia, é possível separar a margem de contribuição total em duas parcelas: safra e entressafra. A margem da safra é igual a $\mathrm{R} \$ 43,66 / t$ - há uma redução do custo de produção de açúcar, álcool e eletricidade, devido à distribuição de parte das irreversibilidades ao longo do ano todo - e a da entressafra, R\$ 0,39/t. A baixa margem da entressafra é conseqüência do alto custo da eletricidade gerada na entressafra ( $\$$ \$ 113,70/MWh). O custo médio de geração de eletricidade é de $\mathrm{R} \$$ 96,44/MWh, mais elevada que o de geração somente na safra.

Por outro lado, a geração ao longo do ano todo permite uma redução da capacidade instalada na usina em aproximadamente $15 \%$, o que significa investimentos menores para a obtenção da mesma margem de contribuição total. Essa questão será aprofundada no próximo capítulo. 


\subsection{SISTEMAS SUPERCRÍTICOS}

Conforme já discutido anteriormente, os sistemas supercríticos podem ser considerados uma alternativa aos sistemas baseados na gaseificação de biomassa, para a cogeração em usinas sucroalcooleiras. Esses sistemas são capazes de gerar mais que o dobro da eletricidade excedente dos sistemas com turbinas de condensação. Além disso, dada alta eficiência dessa configuração, os custos em base exergética do açúcar, álcool e eletricidade (Tab. 9.7) são menores que os custos dos sistemas com turbinas de condensação. A conseqüência direta desses aspectos é uma margem total de contribuição igual a $\mathrm{R} \$ 53,99 / \mathrm{t}, 23 \%$ superior à dos sistemas com turbinas de condensação, ou ainda, $52 \%$ maior que a de uma usina tradicional. Ainda, a margem de contribuição unitária de cada produto também é mais alta que as margens para os sistemas anteriores (Tab. 9.7).

Tabela 9.7 - Custo de Produção e Margens de Contribuição dos Produtos.

\begin{tabular}{cccc}
\hline Produto & $\begin{array}{c}\text { Custo de } \\
\text { Produção }\end{array}$ & $\begin{array}{c}\text { Margem de } \\
\text { Contribuição }\end{array}$ & $\begin{array}{c}\text { Margem de } \\
\text { Contribuição } \\
\text { Exergética } \\
\text { (R\$/MWh }\end{array}$ \\
\hline Açúcar $(\mathrm{R} \$ / \mathrm{t})$ & 128,20 & 386,50 & 79,57 \\
Álcool $(\mathrm{R} \$ / \mathrm{L})$ & 0,30 & 0,45 & 74,20 \\
Eletricidade $(\mathrm{R} \$ \mathrm{MWh})$ & 67,31 & 62,69 & 62,69 \\
\hline
\end{tabular}

A margem de contribuição unitária da eletricidade é quase o dobro da margem para a configuração com turbinas de condensação - a geração de eletricidade excedente é quase duas vezes maior que a geração dos sistemas de condensação. Portanto, sua participação na margem de contribuição é maior, passando para $17 \%$.

Observa-se também que a rentabilidade do álcool fica mais próxima à do açúcar. Na usina tradicional, a diferença entre as rentabilidades era de $32 \%$, enquanto que para essa configuração é de $7 \%$.

\subsection{SISTEMAS COM GASEIFICAÇÃO DE BIOMASSA E CICLOS COMBINADOS}

As configurações que utilizam sistemas com gaseificação de biomassa e ciclos combinados apresentam as maiores gerações de eletricidade excedente entre as configurações estudadas. No Cap. 8, três opções para esses sistemas foram avaliadas, porém nesse capítulo ir-se-á 
avaliar apenas a configuração com gaseificação pressurizada, a fim de evitar repetições nas análises.

Para o sistema com gaseificação pressurizada, a margem de contribuição total é de $\mathrm{R} \$ 62,20 / \mathrm{t}$, 15\% maior que a margem do sistema supercrítico, conseqüência da maior geração de eletricidade excedente, $44 \%$ superior. Os custos de produção e as margens de contribuição unitária também são melhores para esse sistema (Tab. 9.8). A participação da eletricidade na margem de contribuição total passa de $17 \%$ (sistema supercrítico) para $26 \%$, enquanto que a do açúcar é de $40 \%$ e a do álcool de $34 \%$.

Tabela 9.8 - Custo de Produção e Margens de Contribuição dos Produtos.

\begin{tabular}{cccc}
\hline Produto & $\begin{array}{c}\text { Custo de } \\
\text { Produção }\end{array}$ & $\begin{array}{c}\text { Margem de } \\
\text { Contribuição }\end{array}$ & $\begin{array}{c}\text { Margem de } \\
\text { Contribuição } \\
\text { Exergética } \\
\text { (R\$/MWh }\end{array}$ \\
\hline Açúcar $(\mathrm{R} \$ / \mathrm{t})$ & 121,69 & 393,01 & 80,92 \\
Álcool $(\mathrm{R} \$ / \mathrm{L})$ & 0,28 & 0,47 & 76,34 \\
Eletricidade $(\mathrm{R} \$ \mathrm{MWh})$ & 50,70 & 79,30 & 79,30 \\
\hline
\end{tabular}

A diferença entre as margens unitárias do açúcar e do álcool diminui para $6 \%$. Todavia, é interessante notar que a rentabilidade da eletricidade nessa configuração é maior que a rentabilidade do álcool e apenas $2 \%$ inferior à do açúcar.

Qualquer ganho adicional na geração de eletricidade ou uma elevação do preço de venda pode levar esse produto a ser o com a maior rentabilidade na usina.

\subsection{COMENTÁRIOS GERAIS}

A metodologia proposta neste capítulo visa a avaliação da rentabilidade dos produtos de uma usina sucroalcooleira, baseado no conceito de margem de contribuição tendo a Termoeconomia como base para a determinação do custo dos produtos. A utilização da Termoeconomia elimina a questão usualmente levantada sobre o "valor" econômico do bagaço, além de permitir uma comparação direta entre as margens de contribuição unitária de cada produto. 
A fim de evitar repetições nas análises, optou-se por apresentar os resultados para algumas opções discutidas no Cap. 8. Na Fig. 9.2, são apresentados os resultados da margem de contribuição total para as seguintes configurações:

Sistemas com Turbinas de Contrapressão, sem alterações nos processos e eletrificação da moenda (CP);

$>$ Sistemas com Turbinas de Condensação, com alterações nos processos e eletrificação da moenda (CD);

$>$ Sistema Supercrítico $(\mathrm{SuST})$;

Sistema com Gaseificação de Biomassa e Ciclos Combinados (BIGCC).

Para as configurações $\mathrm{CP}$ e $\mathrm{CD}$, os números de 1 a 7 representam os seguintes pares de Pressão (bar)/Temperatura $\left({ }^{\circ} \mathrm{C}\right)$ para a geração do vapor: 42/400, 42/450, 67/480, 67/515, 80/520, 100/520, 120/540.

Para a configuração BIGCC, os números I, II e III, representam, respectivamente: gaseificação atmosférica com geração de vapor a 42 bar e $400^{\circ} \mathrm{C}$, gaseificação atmosférica com geração de vapor a 80 bar e $510^{\circ} \mathrm{C}$ e gaseificação pressurizada com geração de vapor a 80 bar e $510^{\circ} \mathrm{C}$. 


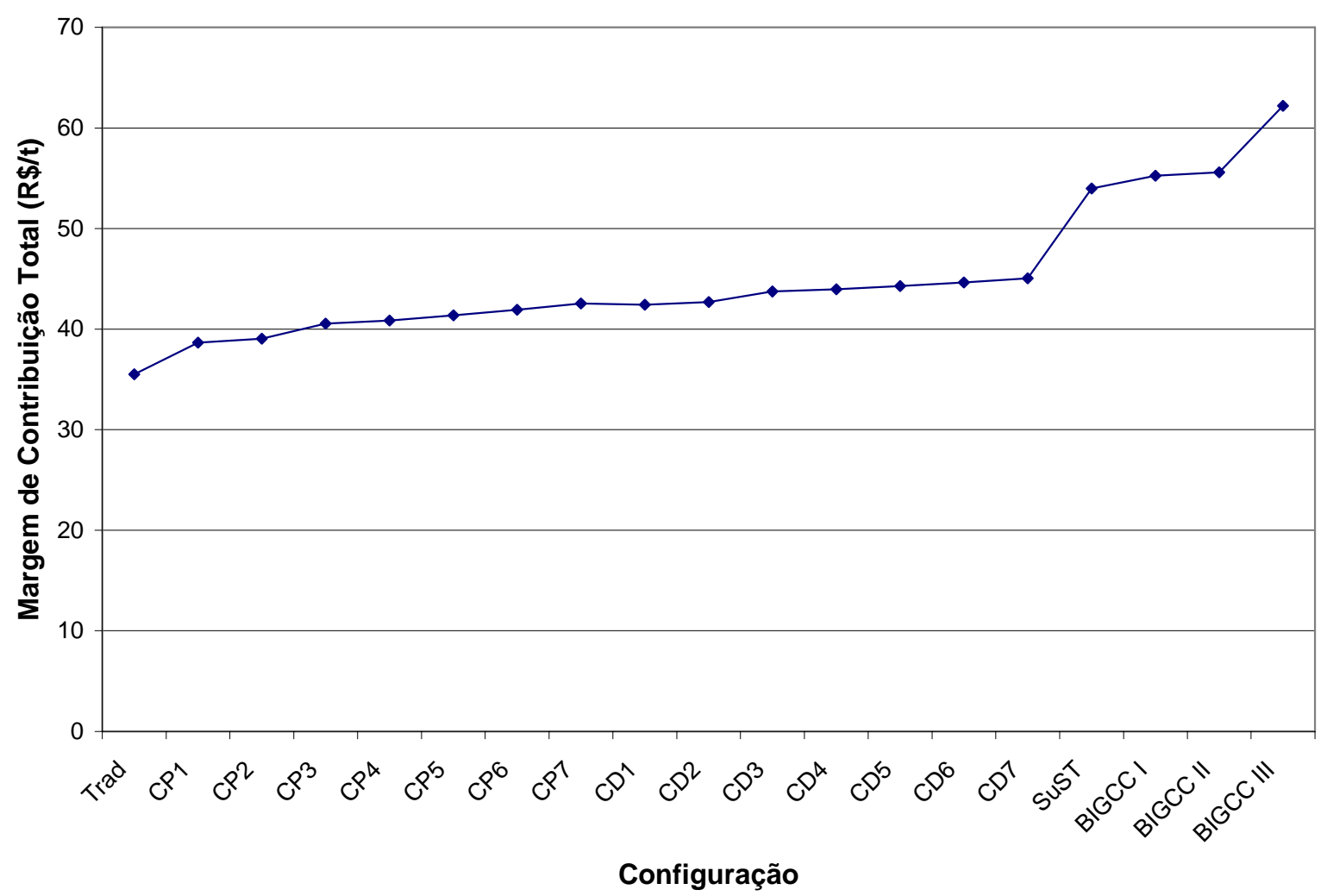

Figura 9.2 - Margem de Contribuição Total.

Como mostrado na Fig. 9.2, o aumento da eficiência dos processos de conversão de energia na usina levam a ganhos na margem de contribuição total. Assim, a maximização do lucro da usina está diretamente relacionada ao melhor uso da exergia disponível na cana, sobretudo com a otimização da planta de utilidades, a qual reduz os custos de produção da eletricidade e do vapor utilizados nos processos de produção de açúcar e álcool, além de acrescentar uma receita adicional com a venda do excedente de eletricidade. Para as configurações mais avançadas, essa contribuição chega a representar $26 \%$ da margem de contribuição total.

Além da receita adicional com a venda de eletricidade, o aumento da margem de contribuição total resulta da elevação das margens de contribuição unitária do açúcar e do álcool (Fig. 9.3), em função da redução de custos obtida a partir da otimização dos processos de conversão de energia. 


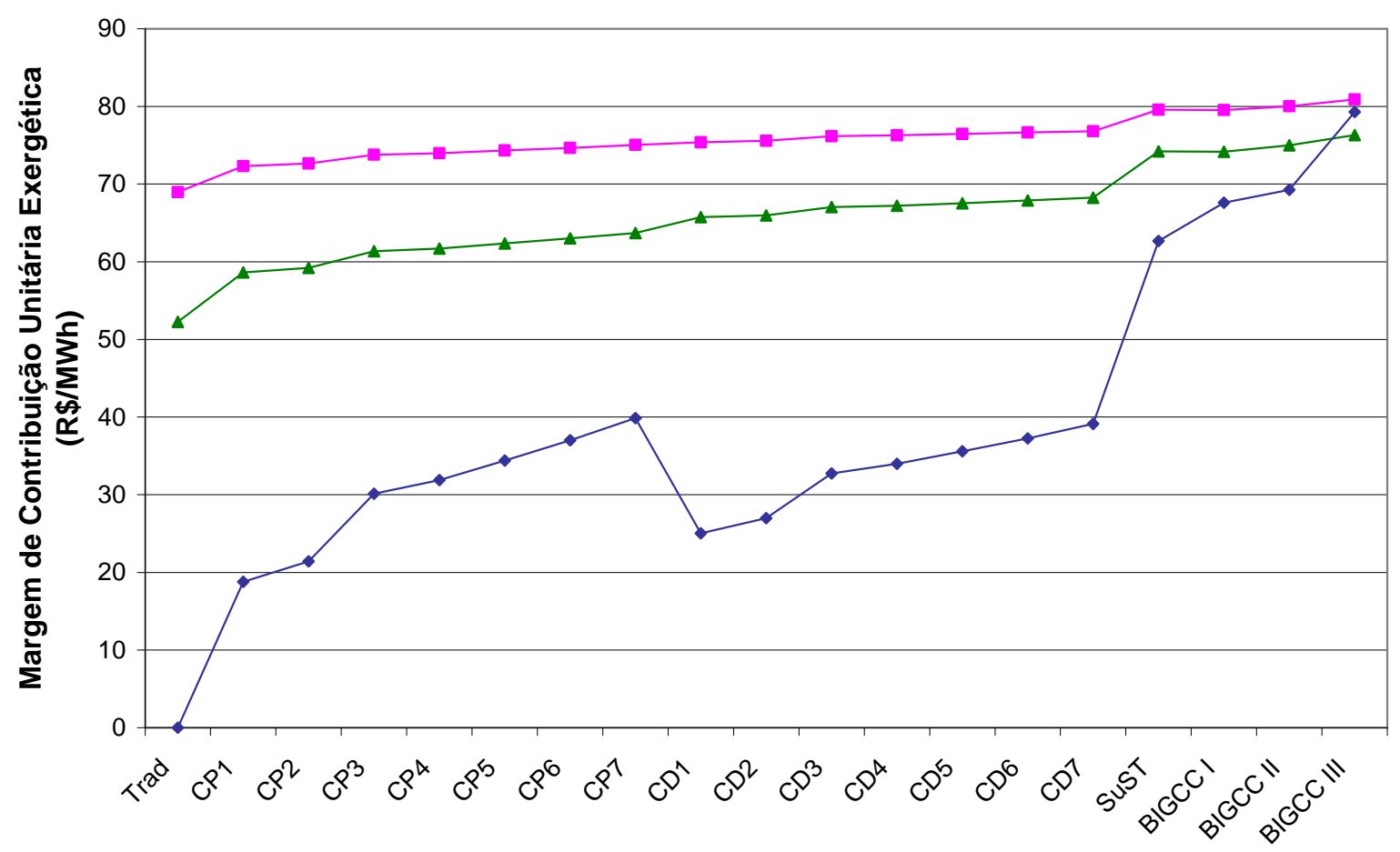

Configuração

Açúcar $\rightarrow$ Álcool $\rightarrow-$ Eletricidade

Figura 9.3 - Margem de Contribuição Unitária dos Produtos para as diversas Configurações.

É interessante notar que a margem de contribuição unitária da eletricidade para as configurações $\mathrm{CD}$ são praticamente as mesmas que as das configurações $\mathrm{CP}$. O mesmo não acontece para as margens do açúcar e do álcool devido à diminuição do consumo de vapor nos processos de fabricação. Dessa maneira, o ganho da margem total das configurações CD sobre as CP está relacionado aos menores custos de produção de açúcar e álcool e, principalmente, ao aumento da geração eletricidade.

A margem de contribuição da eletricidade para os sistemas avançados de cogeração é muito superior aos demais, havendo ganhos também nas margens dos demais produtos. Nota-se que para o sistema de cogeração mais eficiente, inclusive, a margem de contribuição da eletricidade é maior que do álcool e muito próxima à do açúcar.

Portanto, o uso final do bagaço que maximiza o lucro da usina pode ser avaliado a partir da metodologia proposta, a qual utiliza um critério mais racional para a atribuição de custos a esse insumo e utiliza dados de mercado para analisar a rentabilidade dos produtos. Desta maneira, a decisão entre a geração de eletricidade e a produção de álcool a partir do bagaço é feita visando a maximização do lucro da usina. 


\section{AVALIAÇÃO ECONÔMICA DAS OPÇÕES DE CONFIGURAÇÕES PARA A PRODUÇÃO COMBINADA DE AÇÚCAR, ÁLCOOL E ELETRICIDADE}

Nos capítulos anteriores, mostrou-se os benefícios que a otimização dos processos de conversão de energia na usina traz para a redução das irreversibilidades e o aumento da margem de contribuição total e unitária dos produtos. Todavia, a tomada de decisão com relação a se fazer ou não alterações nos processos de usina passa, necessariamente, por uma análise econômico-financeira a fim de verificar a viabilidade do investimento necessário.

A metodologia de avaliação econômico-financeira varia de acordo com o perfil do investidor e seus objetivos, mas, para todos, ela constitui um conjunto de indicadores que permitem a comparação das alternativas por diferentes critérios (HESS et al., 1984; NETO, 2001). Nesse trabalho, opta-se pela utilização de dois critérios:

> Valor Presente Líquido (VPL): igual à equivalência monetária atual da soma dos fluxos de caixa descontados futuros, dada uma taxa de desconto ${ }^{36}$. Projetos que apresentam VPL positivo são considerados atraentes e quanto maior o VPL, melhor.

$>$ Taxa Interna de Retorno (TIR): definida como a taxa de desconto que iguala a zero o VPL. Um investimento é atraente caso a TIR seja maior que uma determinada taxa de atratividade. A vantagem da TIR é que permite comparar projetos de tamanhos diferentes com facilidade.

Atualmente, $75 \%$ das empresas quase sempre calculam o VPL para tomada de decisão acerca de um investimento. Com relação à TIR, 76\% das empresas a utilizam para o processo decisório (GRAHAM; HARVEY, 2001). Brealey, Myers e Allen (2006) apresentam quatro situações onde o uso independente da TIR como critério de tomada de decisão leva a resultados piores que o uso do VPL como critério. Entre eles, a análise de investimentos mutuamente excludentes pode levar a uma hierarquização diferente e menos rentável que a

\footnotetext{
${ }^{36}$ Ao se considerar uma nova oportunidade de investimento, deve-se levar em conta que esta irá deslocar recursos disponíveis e, portanto, deixar-se-á de auferir retorno de outras possíveis fontes. Assim, a nova oportunidade deve render no mínimo, a taxa de juros equivalente à rentabilidade de uma aplicação de baixo risco (HESS et al., 1984).
} 
utilizando o VPL como critério, dependendo do fluxo de caixa descontado do projeto. Por isso, no presente trabalho, opta-se pela utilização dos dois critérios.

As análises a seguir avaliam a viabilidade econômica dos investimentos necessários para a implantação das modificações propostas no Cap. 8, tendo como receita para a remuneração do investimento a diferença entre a margem de contribuição total da configuração proposta e aquela da usina tradicional, ou seja, a receita adicional com a venda da eletricidade excedente. Portanto, trata-se de uma avaliação da economicidade de se fazer um retrofit nos processos da usina, principalmente na planta de utilidades, sem alterar as quantidades de açúcar e álcool produzidas.

A metodologia proposta difere de outros trabalhos (WALTER, 1994; PISTORE, 2004, p.ex.) dado que o custo do bagaço utilizado na planta de cogeração é dado pela Termoeconomia, assim como os custos da energia-eletromecânica e do vapor utilizados nos processos de fabricação de açúcar e álcool. Como o investimento deve ser remunerado pelo ganho de receita adicional (ou aumento da margem de contribuição total), a redução de custos de produção de açúcar e álcool deve contribuir para essa remuneração, de maneira a garantir para a usina a margem de contribuição igual à da configuração tradicional.

Os parâmetros econômicos utilizados são apresentadas na Tab. 10.1.

Tabela 10.1 - Parâmetros Econômicos.

\begin{tabular}{lc}
\hline Parâmetros & \\
\hline Vida útil (anos) & 20 \\
Depreciação (anos) & 20 \\
Taxa de Desconto & $10,00 \%$ a.a. \\
Custo de O\&M (R $\$$ MWh) & 12,00 \\
Imposto sobre receita & $4,08 \%$ \\
\hline
\end{tabular}

O valor de R\$ 130,00/MWh utilizado no Cap. 9 já considera o desconto das taxas do setor elétrico e os impostos sobre a venda de eletricidade (PIS e COFINS). Optou-se por uma 
estrutura de lucro presumido para o cálculo do Imposto de Renda (IR) e a Contribuição Social sobre o Lucro Líquido (CSLL) ${ }^{37}$.

A metodologia de cálculo é baseada na realização de uma Demonstração de Resultados do Exercício (DRE), a qual é considerada idêntica para cada ano de vida útil do projeto (Tab. 10.2) (LORA; NASCIMENTO, 2004). Na metodologia proposta, os impostos referentes à venda da eletricidade excedente e os encargos do setor elétrico não foram avaliados, dado que o preço da eletricidade utilizado já apresenta esses descontos.

Tabela 10.2 - Demonstração de Resultados do Exercício

\begin{tabular}{|cc|}
\hline \multicolumn{3}{|c|}{ Receita ou Venda Bruta } \\
$(-)$ & Impostos sobre a venda e encargos setoriais \\
$(=)$ & Receita Líquida (variação da margem de contribuição total) \\
$(-)$ & Custo Operacional (p.ex.,O\&M) \\
$(=)$ & Lucro Operacional \\
$(-)$ & Depreciação \\
$(-)$ & Despesas não-operacionais (p.ex., juros) \\
$(=)$ & Lucro antes da tributação \\
$(-)$ & Impostos sobre a receita (IR e CSLL) \\
$(=)$ & Lucro Líquido \\
$(+)$ & Depreciação \\
$(=)$ & Geração de Caixa do Projeto \\
\hline
\end{tabular}

O fluxo de caixa construído nessa metodologia contempla o investimento inicial e a geração de caixa do projeto durante a vida útil do mesmo (Fig. 10.1). Com base neste fluxo, são calculados o VPL e a TIR para a avaliação.

\footnotetext{
${ }^{37}$ Podem optar pelo lucro presumido, as pessoas jurídicas, cuja receita bruta total tenha sido igual ou inferior a $\mathrm{R} \$ 48.000 .000,00$.
} 


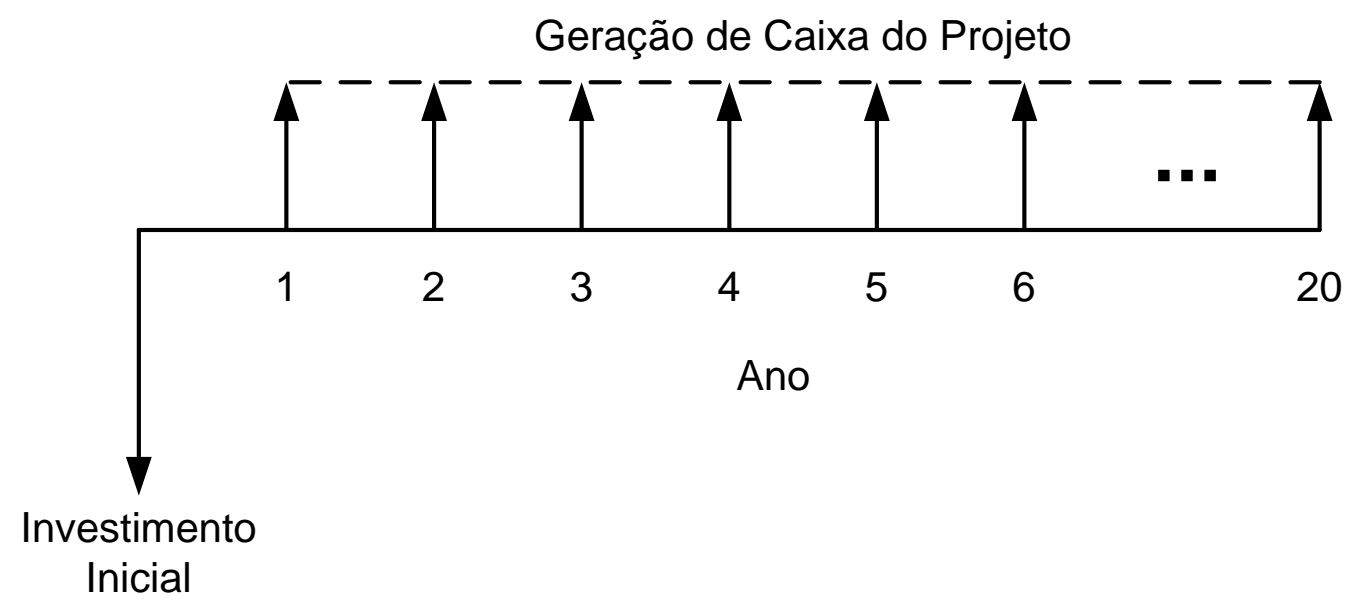

Figura 10.1 - Fluxo de Caixa considerado.

A determinação do custo do investimento inicial foi baseada nos dados levantados pela EPE junto às empresas que participaram do $1^{\circ}$ Leilão de Energia de Reserva, ocorrido em 14 de agosto de 2008 (Tab. 10.3).

Tabela 10.3 - Investimento necessário para Geração de Eletricidade por Termelétricas a Biomassa (adaptado de: EPE, 2008)

\begin{tabular}{lccccc}
\hline \multirow{2}{*}{ Dados } & \multicolumn{4}{c}{ Custo do Investimento (R\$/kW instalado) } \\
\cline { 2 - 6 } & Geral & \multicolumn{2}{c}{ São Paulo } & \multicolumn{2}{c}{ Outros Estados } \\
\cline { 2 - 6 } & & Novo & Ampliação & Novo & Ampliação \\
\hline Média & 2272,91 & 2519,16 & 2141,37 & 2175,56 & 1759,60 \\
Máximo & 4000,00 & 3865,3 & 3801,69 & 4000,00 & 2243,03 \\
Mínimo & 1060,36 & 1234,38 & 1060,36 & 1325,45 & 1325,45 \\
Desvio Padrão & 753,96 & 831,12 & 597,53 & 701,25 & 291,49 \\
Mediana & 2057,00 & 2437,94 & 2059,25 & 1930,59 & 1790,16 \\
\hline
\end{tabular}

Como adotado pela EPE, considera-se nesse trabalho um custo de $\mathrm{R} \$ 2.437,94 / \mathrm{kW}$ instalado $\left(\mathrm{kW}_{\text {inst }}\right.$ ), para as tecnologias convencionais (turbinas de contrapressão e de condensação). Para as tecnologias avançadas, uma discussão mais detalhada será feita adiante.

O custo do investimento para redução do consumo de vapor nos processos foi avaliado segundo dados da Tab. 10.4. É importante mencionar que as alterações propostas no Cap. 8 para a redução do consumo de vapor nos processos são similares às contempladas na Tab. 10.4 . 
Tabela 10.4 - Custos envolvidos na redução do consumo de vapor.

\begin{tabular}{lccc}
\hline & $\begin{array}{c}\text { Usina } \\
\text { Típica }\end{array}$ & $\begin{array}{c}\text { Economia } \\
\text { de Vapor } \\
\text { Fase I }\end{array}$ & $\begin{array}{c}\text { Economia } \\
\text { de Vapor } \\
\text { Fase II }\end{array}$ \\
\hline Consumo de Vapor no Processo $(\mathrm{kg} / \mathrm{tc})$ & $500^{\mathrm{a}}$ & $340^{\mathrm{b}}$ & $280^{\mathrm{c}}$ \\
Consumo de eletricidade no processo $(\mathrm{kWh} / \mathrm{tc})$ & $15-20$ & 28 & 29 \\
Custo do investimento (milhões de US\$) & - & 3,33 & 4,86 \\
\hline
\end{tabular}

Fonte: LARSON; WILLIAMS; LEAL, 2001 e HASSUANI; LEAL; MACEDO, 2005.

a) Usina com evaporador de 5 efeitos, vapor de 6 bar para centrífugas, perdas iguais a $10 \mathrm{~kg} / \mathrm{tc}$.

b) Extração de vapor do $1^{\circ}, 2^{\circ}$ e $3^{\circ}$ estágios para aquecimento do caldo, trocadores regenerativos para caldo/vinhaça e caldo/caldo, agitação mecânica no vácuo, sangria de vapor do $2^{\circ}$ estágio para vácuos, uso de tecnologia Flegstil e peneiras moleculares na destilaria.

c) Em adição àquelas já apresentadas, sangria do vapor do $4^{\circ}$ efeito para aquecimento do caldo, adição de mais um conjunto de aquecedor de caldo, sangria de vapor do $5^{\circ}$ efeito para os vácuos.

d) Valores em US\$ de 1998.

Os investimentos mostrados são para uma usina com moagem de 1,3 milhões de toneladas de cana (HASSUANI; LEAL; MACEDO, 2005). Para a atualização desses valores utilizou-se o índice Marshall \& Swift (M\&S) publicado pelo periódico Chemical Engineering Magazine (setembro de 2008):

$$
\text { Custo }_{2}=\text { Custo }_{1} \cdot \frac{M \& S_{2}}{M \& S_{1}}
$$

Em 1998, o índice era igual a 1061,9, e hoje vale 1431,7, o que representa um aumento de 35\%. Assim, utilizando a taxa de câmbio igual a R\$1,90/US\$, os investimentos necessários são, sem considerar ganhos de escala:

\footnotetext{
$\checkmark$ Para $340 \mathrm{~kg} / \mathrm{tc}, \mathrm{R} \$ 6,57 / \mathrm{tc}$;

$\checkmark$ Para $280 \mathrm{~kg} / \mathrm{tc}, \mathrm{R} \$ 9,59 / \mathrm{tc}$.
}

A estimativa de custo da eletrificação do preparo e da moenda foi baseada em uma configuração com preparo composto por um desfibrador, um picador e seis ternos de moenda, com capacidade para 350 tc/h. O custo estimado dessa eletrificação é de R 10 milhões, ou seja, aproximadamente, R \$6,08/tc (considerou-se uma safra de 4700 horas efetivas). 
É interessante notar que em uma notícia da agência Reuters ${ }^{38}$, a COSAN anunciou o investimento de R\$ 450 milhões em uma nova usina em Jataí, no Estado de Goiás, com capacidade para 4 milhões de toneladas de cana e geração de até $105 \mathrm{MW}$. A partir desses dados, é possível fazer a seguinte distinção: investimento para geração, R \$ 64,00/tc e para o processo R\$ 48,50/tc. Ou seja, os investimentos para redução do consumo de vapor e eletrificação das moendas descritos acima representam aproximadamente entre 13 e $32 \%$ do investimento necessário para um processo totalmente novo. Levando-se em consideração que o investimento em uma planta totalmente nova deverá prever ainda a compra da moenda e toda a parte de infra-estrutura, é possível dizer que os valores apresentados para as avaliações nesse trabalho são coerentes com os valores praticados no mercado.

Finalmente, foi considerada uma safra com 230 dias e $85 \%$ de horas úteis, totalizando 4692 horas efetivas de safra, ou 196 dias.

\subsection{SISTEMAS A VAPOR COM TURBINAS DE CONTRAPRESSÃO, SEM MODIFICAÇÕES NOS PROCESSOS}

\subsubsection{Aumento da Pressão e Temperatura de Geração do Vapor}

A primeira alternativa avaliada para aumentar a eficiência dos processos de conversão de energia em usinas sucroalcooleiras foi a substituição do sistema atual de cogeração, voltado exclusivamente para atender às demandas térmicas e eletromecânicas dos processos, por sistemas de cogeração mais eficientes, com geração de vapor a pressões e temperaturas mais elevadas. Os benefícios técnicos trazidos por tal substituição ficaram evidentes no Cap. 8 e o impacto positivo no aumento da margem total de contribuição foi mostrado no Cap. 9. Agora, é necessário avaliar se essa substituição é viável economicamente.

A Fig. 10.2 mostra a variação do VPL e da TIR em função de diferentes pares Pressão/Temperatura de geração do vapor.

\footnotetext{
${ }^{38}$ Agência Reuters, 08/08/2008, Cosan inicia construção de unidade de R\$ 450 mi em Goiás.
} 


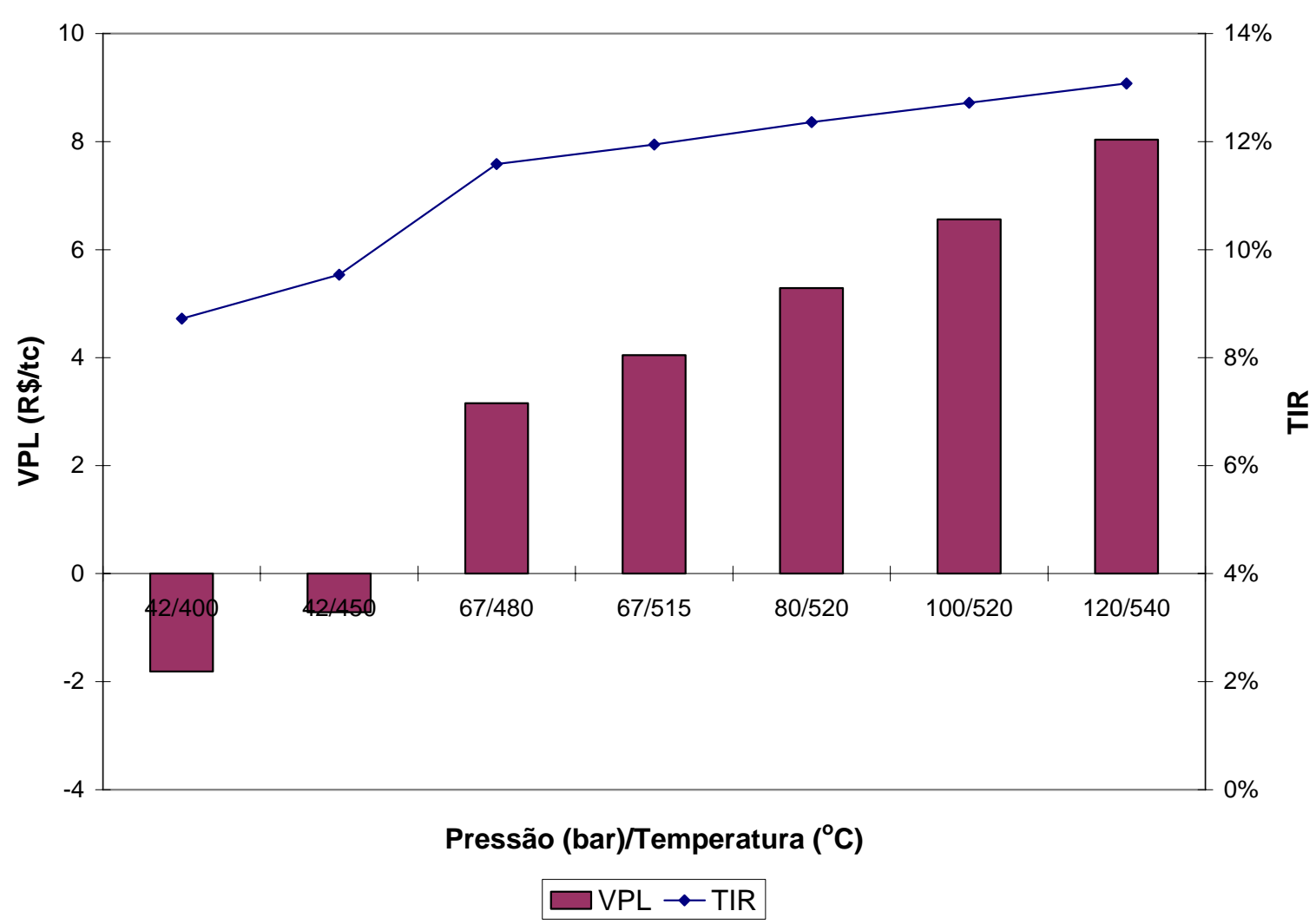

Figura 10.2 - Variação do VPL e da TIR para diferentes pressões e temperaturas de geração de vapor.

É interessante observar que a geração de vapor a 42 bar não apresenta viabilidade econômica, com TIR's inferiores a 10\% e VPL's negativos. Essas configurações apresentam 30\% menos capacidade de geração de eletricidade excedente que os sistemas a 67 bar, porém a capacidade instalada é apenas $22 \%$ inferior, assim não apresenta um desempenho econômico viável.

Para as demais opções, nota-se que a geração em pressões e temperaturas mais elevadas é mais interessante economicamente, o mesmo valendo para o desempenho termodinâmico (Cap. 8). Todavia, a elevação da temperatura acima de $510^{\circ} \mathrm{C}$ implica uma mudança do material da tubulação do vapor de alta pressão. Assim, para os parâmetros de geração inferiores a $67 \mathrm{bar} / 480^{\circ} \mathrm{C}$, o aço-liga ASTM-335 grau P11 é utilizado, enquanto para os demais o aço passa a ser o ASTM-335 grau P22 ou ainda ASTM-335 grau P91 (TELLES, 1994; PROCKNOR, 2008). Tal mudança de material resulta em um aumento do custo da tubulação de vapor de alta, porém o impacto no custo total da planta é mais difícil de avaliar. Deve-se levar em conta também, que pressões mais elevadas (80, 100 e 120 bar) requerem espessuras de parede maiores, aumentando o peso da tubulação e, por conseqüência, seu custo. Ainda, há algumas variações no nível de exigência da qualidade da água enviada para 
as caldeiras e alguns equipamentos na linha de vapor (válvulas, conexões, p.ex.) (TELLES, 1994; LORA; NASCIMENTO, 2004; PROCKNOR, 2008). Para avaliar essas questões, propõe-se uma análise paramétrica do VPL das alternativas 67/515, 80/520, 100/520 e 120/540, em função de aumentos no investimento entre 5 a 25\%. A Fig. 10.3 mostra a influência do aumento do investimento (em $\mathrm{R} \$ / \mathrm{kW}_{\text {inst }}$ ) necessário no VPL dessas alternativas.

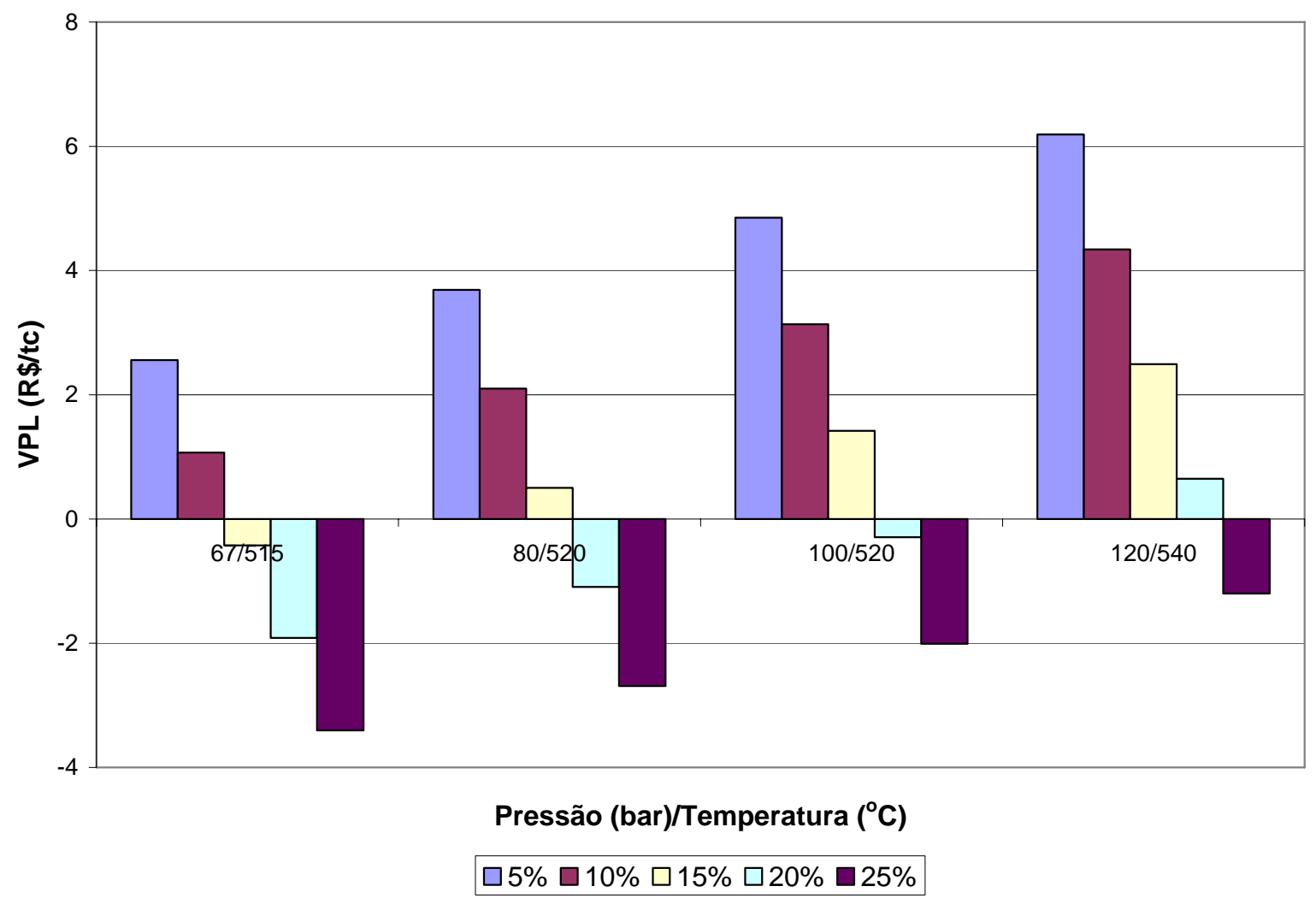

Figura 10.3 - Variação do VPL em função do aumento do investimento no $\mathrm{kW}_{\text {inst }}$ devido à mudança de material da tubulação e da espessura dos tubos.

Avaliando os resultados da Fig. 10.3, nota-se que para um aumento de 5\% no valor do investimento a alternativa de gerar vapor em 67 bar e $515^{\circ} \mathrm{C}$ é menos atrativa que a geração em $480^{\circ} \mathrm{C}$, dado que o VPL da primeira é $19 \%$ menor. Para um aumento acima de $10 \%$, nenhuma opção mostrou-se mais atrativa que a geração de vapor em 67 bar e $480^{\circ} \mathrm{C}$. Ainda, para aumentos superiores a 15\%, nenhuma alternativa é viável economicamente - os VPL's são negativos.

Atualmente, há uma grande discussão no setor sucroalcooleiro sobre a temperatura e a pressão de geração do vapor que levam aos melhores resultados (PROCKNOR, 2008). A Tab. 10.5 
mostra o aumento máximo do investimento, em $\mathrm{R} \$ / \mathrm{kW}$ inst, que tornam as opções acima de 67 bar $/ 480^{\circ} \mathrm{C}$ indiferentes, ou seja, trariam a mesma rentabilidade (TIR) para o projeto.

Tabela 10.5 - Aumento máximo do valor do $\mathrm{kW}_{\text {inst }}$ para manter a rentabilidade obtida com a geração em 67 bar e $480^{\circ} \mathrm{C}$.

\begin{tabular}{ccccc}
\hline $\begin{array}{c}\text { Temperatura } \\
\left({ }^{\circ} \mathbf{C}\right)\end{array}$ & $\begin{array}{c}\text { Pressão } \\
\text { (bar) }\end{array}$ & $\begin{array}{c}\text { Geração } \\
\text { Excedente } \\
\text { Adicional }\end{array}$ & $\begin{array}{c}\text { Capacidade } \\
\text { Instalada } \\
\text { Adicional }\end{array}$ & $\begin{array}{c}\text { Aumento } \\
\text { Máximo do } \\
\text { Investimento }\end{array}$ \\
\hline 67 & 515 & $6,2 \%$ & $4,2 \%$ & $2,3 \%$ \\
80 & 520 & $16,3 \%$ & $11,5 \%$ & $5,0 \%$ \\
100 & 520 & $27,3 \%$ & $19,9 \%$ & $7,3 \%$ \\
120 & 540 & $39,8 \%$ & $29,2 \%$ & $9,7 \%$ \\
\hline
\end{tabular}

a) Aumento percentual sobre o valor $\mathrm{R} \$ / \mathrm{kW}_{\text {inst }}$.

$\mathrm{O}$ aumento sobre o valor do investimento total $(\mathrm{R} \$ / \mathrm{tc})$ pode ser obtido multiplicando-se o ganho em capacidade instalada pelo aumento do investimento em $\mathrm{R} \$ / \mathrm{kW}$ inst. Ou seja, para o par 67 bar e $515^{\circ} \mathrm{C}$, a planta pode custar até $6,6 \%{ }^{39}$ a mais que a planta de 67 bar e $480^{\circ} \mathrm{C}$, valor igual ao ganho em geração excedente. Portanto, o aumento no investimento total não deve ultrapassar o benefício trazido, medido pela elevação da geração de eletricidade excedente.

\subsubsection{Eletrificação das Moendas}

A eletrificação das moendas permite um aumento na geração de eletricidade excedente, o qual varia entre $12 \%$ para o par $120 \mathrm{bar} / 540^{\circ} \mathrm{C}$ até $32 \%$ para $42 \mathrm{bar} / 400^{\circ} \mathrm{C}$. Porém, o ganho em geração também eleva a capacidade instalada do sistema de cogeração, além de requerer um investimento adicional para aquisição de motores elétricos, inversores de freqüência e redutores $-\mathrm{R} \$ 6,08 / \mathrm{tc}$. Contudo, não há a necessidade de aumento da capacidade da caldeira $\mathrm{e}$ a maioria dos periféricos se mantém, ou seja, o aumento de custo na planta de cogeração é devido à maior capacidade de geração da turbina com a eliminação da extração que alimentava os acionamentos da moenda. $\mathrm{O}$ valor da turbina representa entre $15 \%$ e $30 \%$ do investimento em uma central de cogeração (BALESTIERI, 2002). A Fig. 10.4 mostra a variação do VPL e da TIR para o pior cenário, onde a turbina representa $30 \%$ do valor do investimento na cogeração.

\footnotetext{
${ }^{39}(1+0,042) *(1+0,023)=1,066 \rightarrow \mathrm{O}$ primeiro termo se refere ao aumento da capacidade instalada e o segundo a elevação do investimento por $\mathrm{kW}_{\text {inst }}$.
} 


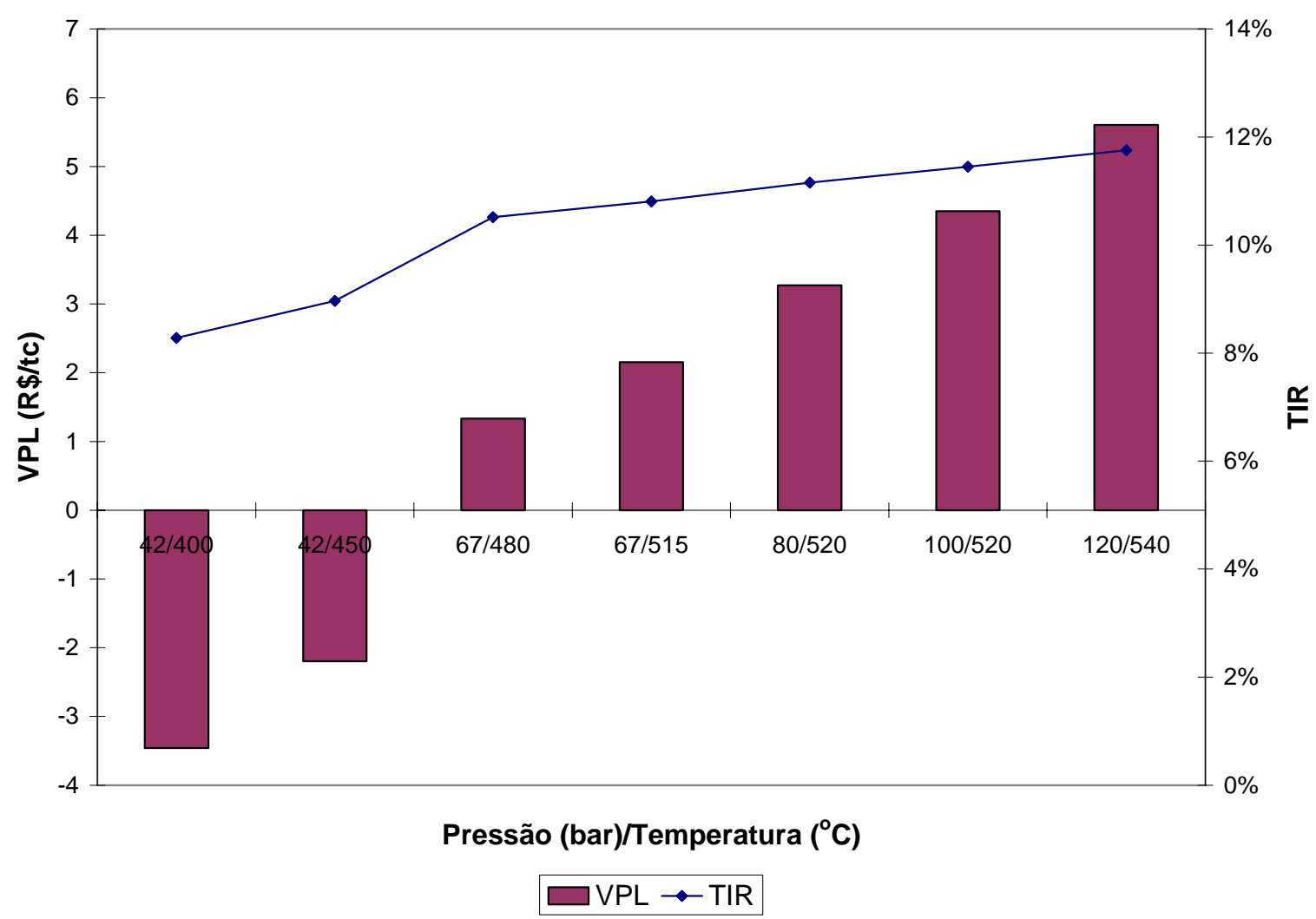

Figura 10.4 - Variação do VPL e da TIR para diferentes pressões e temperaturas de geração de vapor, considerando a aletrificação das moendas.

Comparando os resultados das Figs. 10.2 e 10.4, nota-se que a eletrificação das moendas não é viável economicamente para nenhuma das opções de geração de vapor, caso o investimento adicional da turbina equivalha um aumento de $30 \%$ do valor do $\mathrm{kW}_{\text {inst }}$ da planta de cogeração. Caso os 30\% passem para 15\%, apenas os sistemas com geração em 42 bar apresentam um resultado econômico melhor que a alternativa sem eletrificação das moendas.

Novamente, a questão da viabilidade está diretamente relacionada ao ganho em geração excedente frente ao aumento do valor do investimento. Por exemplo, considerando a equivalência de $15 \%$ para a turbina, para o par 42 bar $/ 400^{\circ} \mathrm{C}$, a eletrificação representa um investimento adicional de 35\% para um ganho em geração de $32 \%$ - ou seja, uma diferença de $10 \%$-, sendo o resultado líquido um ganho de $4 \%$ na TIR. Para o par $120 \mathrm{bar} / 540^{\circ} \mathrm{C}$, o aumento de investimento é igual a $20 \%$ para um ganho de $12 \%$, uma diferença relativa de $67 \%$, superior ao par $42 \mathrm{bar} / 400^{\circ} \mathrm{C}$. 
Apenas a eletrificação da moenda representa um aumento de $15 \%$ no investimento necessário para o par $120 \mathrm{bar} / 540^{\circ} \mathrm{C}$, maior que o ganho obtido com a geração excedente de eletricidade. Aliás, a vantagem da eletrificação é a geração de eletricidade adicional pelo vapor que é extraído a 21 bar para acionar as turbinas da moenda. Assim, com a eletrificação, esse vapor é expandido até 2,5 bar (pressão do processo), gerando eletricidade. Ou seja, o ganho, aproximadamente $7,3 \mathrm{kWh} / \mathrm{tc}$, é praticamente o mesmo para todas as pressões e temperaturas de geração na caldeira, por isso o impacto mais positivo para os sistemas com menos geração excedente.

Retomando os resultados dos Caps. 8 e 9, é possível prever que a eletrificação das moendas só seria viável para baixos valores de investimentos. Isso porque ocorre uma redução média de apenas $2 \%$ nos custos de produção de açúcar, álcool e eletricidade, o que leva a uma elevação de $2 \%$ margem de contribuição total, mesmo com o aumento médio de $20 \%$ no excedente de eletricidade, devido à pequena contribuição da eletricidade na margem total.

É importante ressaltar que na análise econômica para a eletrificação da moenda, foi considerado um projeto de substituição dos acionamentos usuais existentes (turbinas a vapor) por motores elétricos. Para uma usina nova, "greenfield”, ou quando a substituição é necessária devido ao fim da vida útil dos equipamentos, a análise deve considerar o custo das turbinas frente aos motores e os ganhos de geração devido ao uso desses últimos para a tomada de decisão.

No caso de uma substituição, o investimento necessário para aquisição das novas turbinas de acionamento mecânico é próximo a $\mathrm{R} \$ 600,00 / \mathrm{kW}_{\text {inst }}$, considerando que o consumo de energia mecânica na moenda é igual a $15 \mathrm{kWh} / \mathrm{tc}$, o investimento nas turbinas é de R\$1,92/tc. Ou seja, é um investimento necessário e sem retorno na forma de uma nova receita. Assim, este deve ser abatido do investimento necessário para a eletrificação, sendo a TIR e o VPL calculados com o fluxo de caixa contemplando os ganhos de geração e o investimento da eletrificação, descontado o investimento das turbinas de acionamento. Nesse novo cenário, a eletrificação é uma alternativa melhor economicamente para todas as pressões e temperaturas, considerando que a turbina representa $15 \%$ do investimento de uma planta de cogeração. 
De qualquer maneira, a eletrificação da moenda traz benefícios econômicos indiretos que deverão ser levados em consideração na hora da tomada de decisão (CAMARGO, 1990; PISTORE, 2004):

Controle mais completo da velocidade e do consumo de energia em cada moenda menos paradas;

$>$ Maior automação do processo - menores perdas;

$>$ Menor custo de manutenção;

> Eliminação dos problemas relativos à variação de carga nas turbinas, com conseqüente piora da sua eficiência e aumento da temperatura do vapor de escape.

De uma maneira geral, o ganho com a geração excedente de eletricidade deve ser capaz de remunerar o investimento adicional necessário com os devidos descontos relativos a outros benefícios econômicos diretos (necessidade da reforma ou substituição dos equipamentos existentes) e indiretos (redução dos custos de operação e manutenção). Os resultados aqui apresentados indicam que a simples inserção da eletrificação da moenda não se mostra viável economicamente para geração de vapor acima de 42 bar, pois os aumentos no investimentos são superiores aos ganhos em geração excedente. Todavia, o resultado de se optar pela eletrificação vis-à-vis a aquisição de novas turbinas para o acionamento se mostra mais interessante economicamente. A viabilidade econômica para a eletrificação ocorre tanto para usinas em expansão que devem modificar suas moendas e estão considerando a geração de eletricidade para exportação como para novas unidades.

\subsubsection{Análise de Sensibilidade}

Finalmente, é interessante fazer uma análise de sensibilidade para determinação do nível de dependência dos índices calculados com relação às variáveis utilizadas na sua determinação investimento, preço da eletricidade e tempo de safra. Para a análise, toma-se como base o par $67 \mathrm{bar} / 515^{\circ} \mathrm{C}$, cujo VPL é igual a R $\$ 4,05 /$ tc e a TIR, 12\%. As Figs. 10.5 e 10.6 mostram os resultados da análise de sensibilidade para esses índices. 


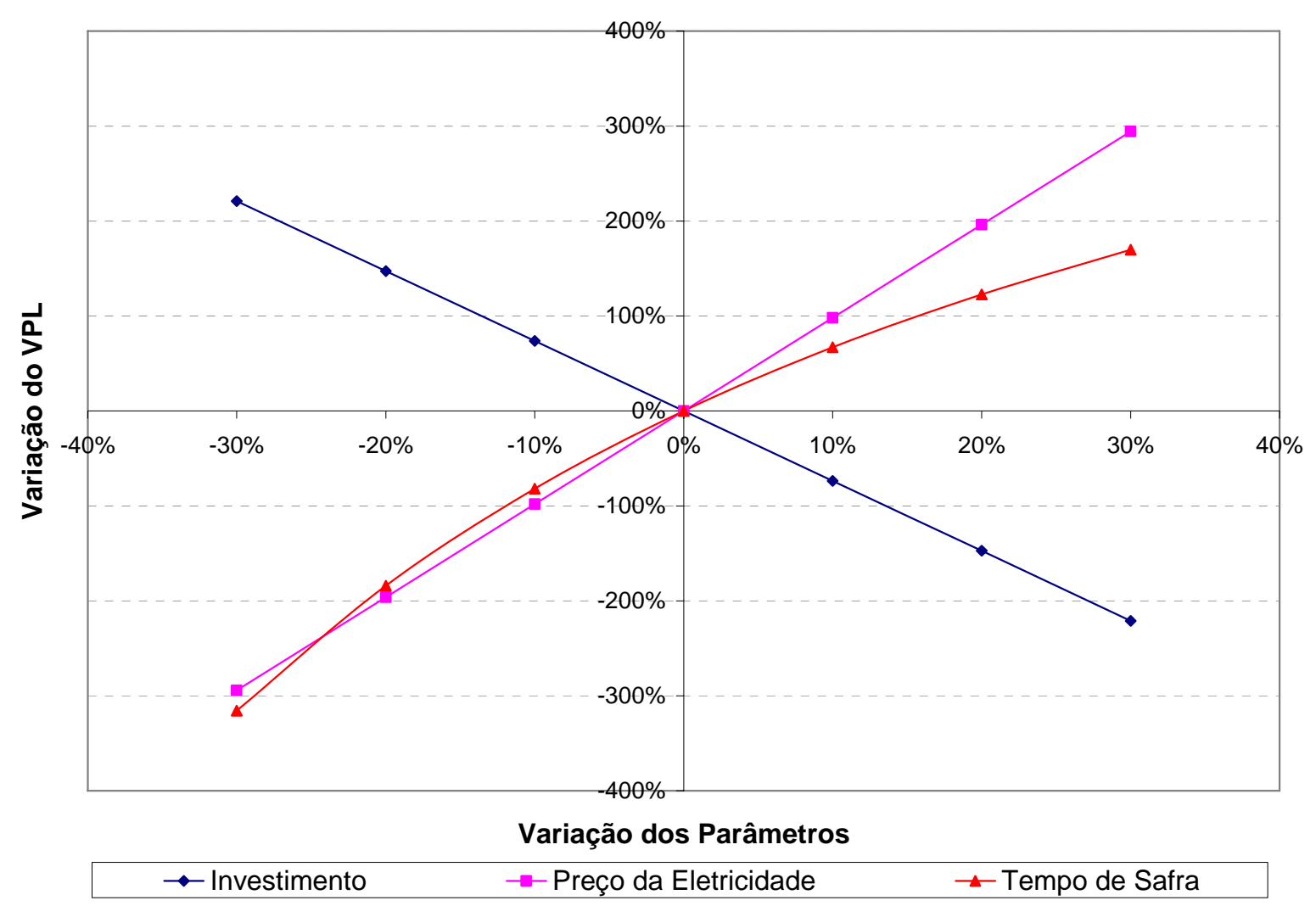

Figura 10.5 - Análise de Sensibilidade do VPL.

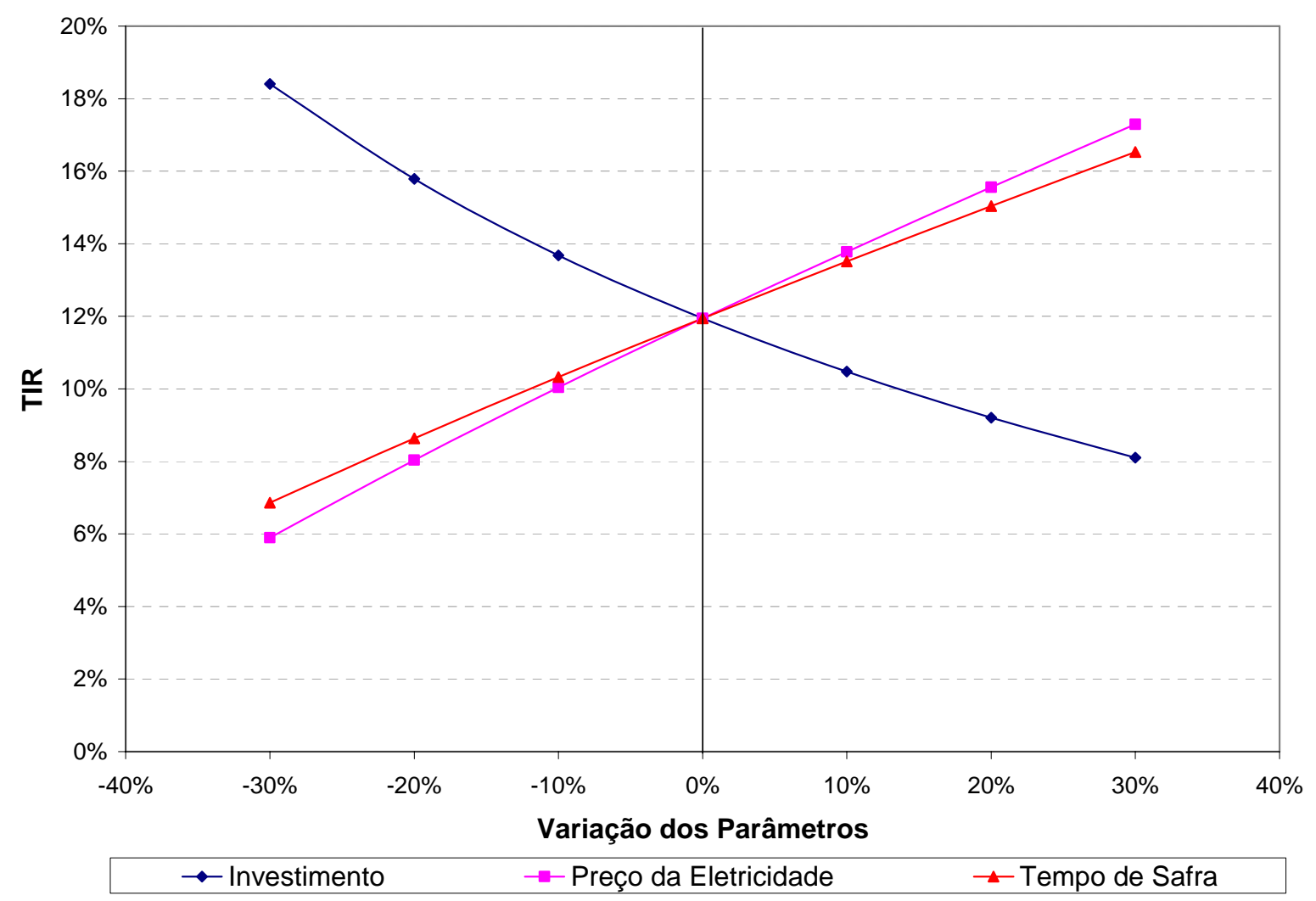

Figura 10.6 - Análise de Sensibilidade da TIR. 
Analisando os resultados das Figs. 10.5 e 10.6, pode-se ver que a viabilidade econômica do sistema é mantida para um aumento de até $12 \%$ do investimento total ou uma redução de $10 \%$ no preço da eletricidade.

O tempo de safra é uma variável tão impactante quanto as demais. Quanto maior é o tempo de operação da planta, maior é o volume de eletricidade exportada e, portanto, maior é a receita adicional obtida para o mesmo valor de investimento, contribuindo para a elevação do VPL e da TIR. O efeito contrário é evidente. Todavia, o tempo de safra é uma variável dependente do ciclo produtivo da cana e de condições climáticas, pois não é possível colher cana durante os meses de chuva. A extensão da safra pode acarretar em perda de ART, prejudicando a produção de açúcar e álcool. Porém, novas variedades de cana (HORII, 2004) e um manejo agrícola mais otimizado (FLORENTINO; MORENO; SARTORI, 2008) podem viabilizar safras mais longas.

Os resultados apresentados foram avaliados sem levar em consideração ganhos de escala para plantas maiores, já que o modelo econômico foi desenvolvido para obter valores específicos (por tonelada de cana moída na safra). Ou seja, para usinas com pequenas capacidades de moagem é esperado valores de investimento por $\mathrm{kW}_{\text {inst }}$ menores que para plantas de grandes moagens. Portanto, o aumento da eficiência do sistema de cogeração em usinas pequenas pode não apresentar viabilidade econômica, devido aos maiores custos de investimento por $\mathrm{kW}_{\text {inst }}$ (ver Tab. 10.3).

Considerando o custo da eletrificação da moenda, $\mathrm{R} \$ 6,08 / \mathrm{tc}$, é possível definir o preço do $\mathrm{kW}$ inst devido à eletrificação para o par 67 bar $/ 515^{\circ} \mathrm{C}$ (geração excedente igual a 7,3 kWh/tc): $\mathrm{R} \$ 3907,86 / \mathrm{kW}_{\text {inst }}$. Esse valor é $60 \%$ superior ao valor utilizado, sendo que o aumento máximo no valor do investimento para manter a viabilidade é de 12\% (Fig. 10.5 e 10.6). Ou seja, a eletrificação das moendas diminui o VPL do projeto de aumento de eficiência da cogeração, mesmo que o investimento total seja viável economicamente. 


\subsection{SISTEMAS A VAPOR COM TURBINAS DE CONDENSAÇÃO, COM MODIFICAÇÕES NOS PROCESSOS}

\subsubsection{Geração de Vapor apenas na Safra}

Não há sentido econômico nem técnico em se reduzir o consumo de vapor no processo e aumentar o excedente de bagaço, se este não for utilizado de maneira a gerar algum benefício para o processo/usina, como já mostrado nos Caps. 8 e 9. Desta maneira, propõe-se a redução do consumo de vapor no processo associado ao uso de turbinas de condensação para aumentar a geração de eletricidade excedente. Nesse contexto, a receita adicional devido à elevação da geração de eletricidade excedente deve ser capaz de remunerar o investimento adicional necessário para a nova planta de cogeração e as modificações no processo.

A Fig. 10.7 mostra a variação do VPL e da TIR em função de diferentes pares Pressão/Temperatura de geração do vapor.

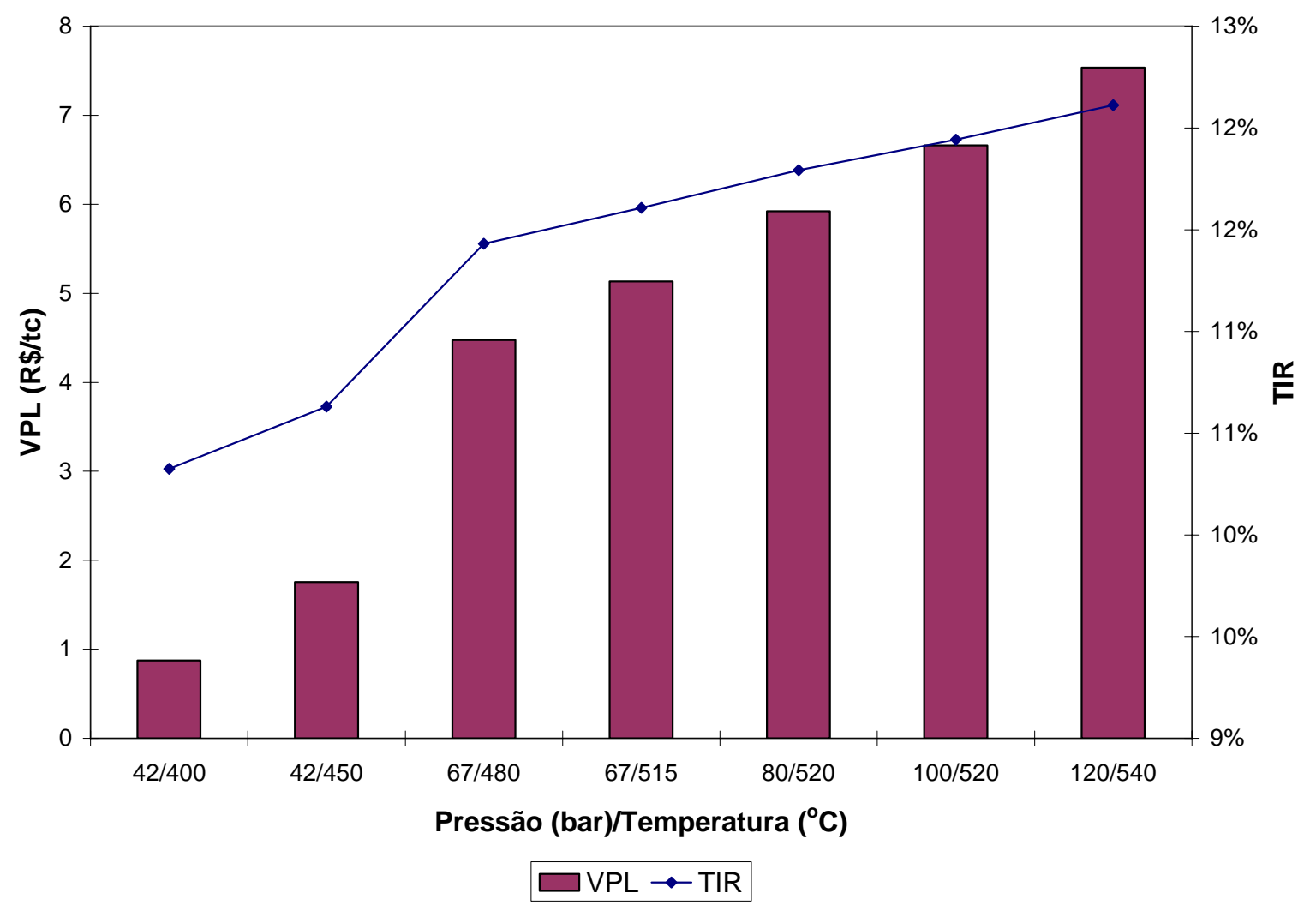

Figura 10.7 - Variação do VPL e da TIR para diferentes pressões e temperaturas de geração de vapor. 
A redução do consumo de vapor e o uso de turbinas de condensação aumentam a capacidade instalada da usina. Isso significa um maior investimento necessário na planta de cogeração em relação aos sistemas com turbinas de contrapressão. Esse maior investimento é justificável economicamente caso seja na mesma proporção que o ganho em geração excedente, como mostrado anteriormente para a eletrificação das moendas. Nas configurações avaliadas, apenas a geração de vapor em 42 bar, tanto a $400^{\circ} \mathrm{C}$ como a $450^{\circ} \mathrm{C}$, mostrou-se mais interessante em relação aos sistemas com turbinas de contrapressão, já que o aumento no investimento é de $87 \%$ e $79 \%$, respectivamente, enquanto que a geração adicional é $100 \%$ e $87 \%$ superior. Para o par $67 / 480^{\circ} \mathrm{C}$, a TIR é praticamente a mesma para o sistema com turbinas de contrapressão e sistemas com turbinas de contrapressão e condensação, porém dado o maior VPL da segunda opção, essa deve ser a escolha, caso não haja restrição de orçamento. Para os demais casos, a TIR dos sistemas com turbinas de condensação é inferior à dos com turbinas de contrapressão, o que indica uma rentabilidade inferior do investimento no primeiro sistema.

É importante assinalar que a análise comparativa feita com os sistemas de contrapressão leva em consideração o investimento adicional para a redução do consumo de vapor no processo. Caso esse custo não fosse levado em consideração ou se ele fosse inferior ao utilizado, a opção pelas turbinas de condensação seria mais interessante economicamente que a por turbinas de contrapressão. Ainda, para usinas existentes com baixos consumos de vapor, a opção por turbinas de condensação com a elevação da pressão e temperatura de geração do vapor é mais interessante que o uso apenas de turbinas de contrapressão, dada a limitação dessa configuração com relação à geração de eletricidade (operação em paridade térmica).

Novas usinas ou as que estudam a ampliação da sua moagem já estão sendo projetadas considerando sistemas mais eficientes com relação ao consumo de vapor, viabilizando economicamente o uso de turbinas de condensação.

\subsubsection{Geração ao Longo do Ano Todo}

Como mostrado na Figs. 10.5 e 10.6, o tempo de operação do sistema tem um grande impacto na economicidade do sistema de cogeração. O uso de turbinas de condensação possibilita a geração de eletricidade ao longo do ano todo, permitindo a redução da capacidade instalada na usina para a geração da mesma quantidade de eletricidade excedente. A conseqüência direta 
da redução da capacidade instalada é o menor investimento requerido e a melhora dos índices de desempenho econômico das alternativas (Fig. 10.8).

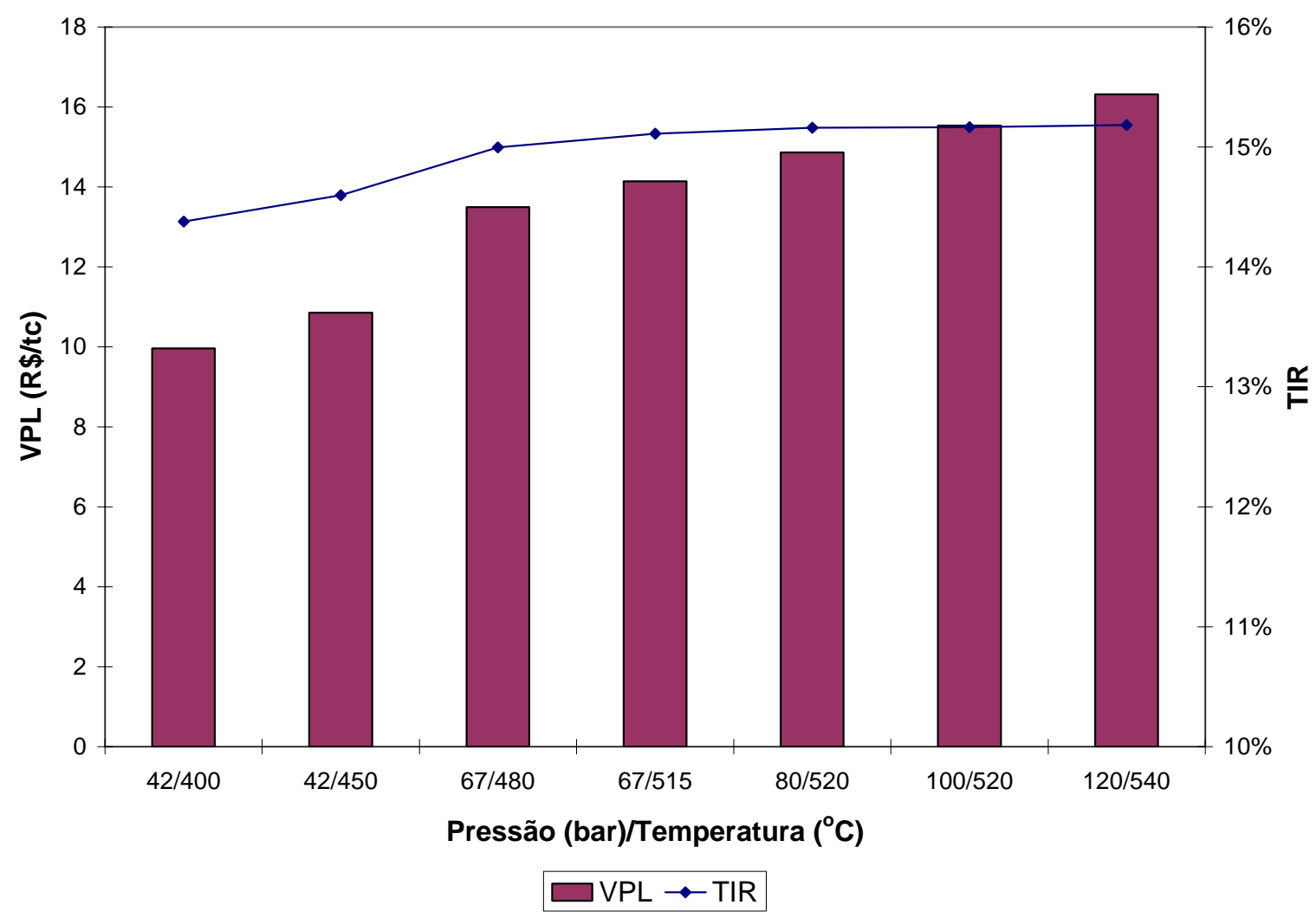

Figura 10.8 - Variação do VPL e da TIR para diferentes pressões e temperaturas de geração de vapor.

Todas as opções de pressão e temperatura apresentaram resultados superiores ao de sistemas com turbinas de contrapressão, pois há um aumento do investimento necessário bastante inferior à elevação da geração excedente. Ou seja, a geração de eletricidade durante o ano todo é a melhor alternativa para o sistema de cogeração sob o ponto de vista econômico dentre as alternativas baseadas em tecnologias convencionais.

Todavia, a geração ao longo do ano todo requer o armazenamento de grandes quantidades de bagaço, o que pode ser bastante complexo, dado que esse material pode entrar em fermentação anaeróbica e, conseqüentemente, se auto-incinerar. Ainda, a baixa densidade do bagaço $\left(180 \mathrm{~kg} / \mathrm{m}^{3}\right)$ requer grandes áreas de estoque para a biomassa a ser queimada na entressafra. Uma alternativa para o armazenamento do bagaço é sua secagem e compactação na forma de briquetes ou pellets, evitando os problemas relacionados à fermentação e à área de armazenagem. Além disso, como durante a entressafra apenas a turbina de condensação irá operar, a quantidade de vapor necessário é muito inferior à da safra, ou seja, o projeto do 
sistema de geração do vapor deverá levar em consideração a modularização das caldeiras. Esse fato pode inviabilizar a geração durante o ano todo para usinas com pequenas capacidades de moagem (caldeiras aquatubulares têm um limite inferior para sua construção de 30-40 t/h e uma limitação de operação em carga parcial até 75\% sem perdas significativas de eficiência).

\subsubsection{Mudança de Materiais e Eletrificação das Moendas}

Da mesma maneira que para os sistemas com turbinas de contrapressão, a opção de temperaturas acima de $510^{\circ} \mathrm{C}$ e pressões mais elevadas requer a mudança de materiais e aumento da espessura das tubulações. Nessas condições, o par 67 bar $/ 480^{\circ} \mathrm{C}$ é a melhor alternativa caso o aumento do investimento no $\mathrm{kW}_{\text {inst }}$ seja superior a $10 \%$, mesmo para a geração ao longo do ano todo.

Com relação à eletrificação das moendas, essa não se justifica economicamente também para os sistemas com turbinas de condensação.

\subsection{SISTEMAS SUPERCRÍTICOS}

Os sistemas supercríticos são capazes de gerar quase três vezes mais eletricidade excedente que os sistemas com turbinas de contrapressão e mais que o dobro dos com turbinas de condensação em usinas sucroalcooleiras, evidenciando o melhor desempenho termodinâmico dos sistemas supercríticos frente aos sistemas convencionais.

No entanto, é importante lembrar que os sistemas supercríticos requerem o uso de ligasmetálicas especiais capazes de operar com pressões acima de 250 bar e temperaturas de até $600^{\circ} \mathrm{C}$, além de uma rede de trocadores de calor regenerativos para evitar o consumo excessivo de combustível na caldeira. Esses materiais não são fabricados no Brasil nem as caldeiras de passe único e as turbinas para operação com vapor supercrítico, o que eleva o investimento necessário. Por outro lado, dado que a capacidade instalada desses sistemas é muito maior que a de sistemas convencionais, ganhos de escala deverão ser obtidos. Deste modo é difícil avaliar o custo do $\mathrm{kW}_{\text {inst }}$ destes sistemas. 
Portanto, propõe-se uma avaliação paramétrica do custo do investimento do $\mathrm{kW}_{\text {inst }}$ desses sistemas para analisar a sua economicidade frente às demais alternativas, considerando ainda os custos para a eletrificação das moendas e da redução do consumo de vapor no processo (Fig. 10.9).

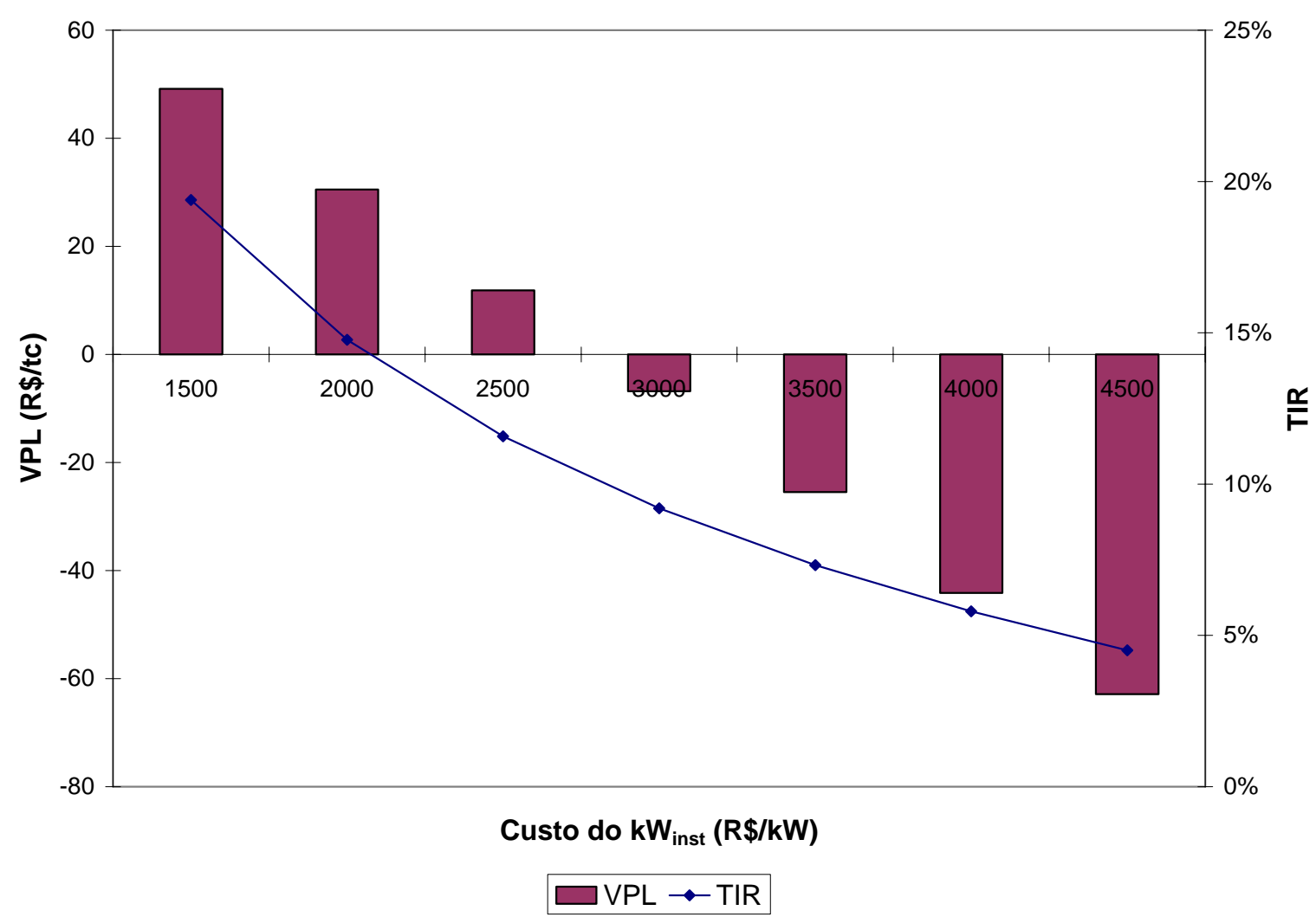

Figura 10.9 - Variação do VPL e da TIR para diferentes Custos de $\mathrm{kW}_{\text {inst. }}$

Os valores apresentados na Fig. 10.9 indicam que os sistemas supercríticos não são viáveis economicamente para valores de $\mathrm{kW}_{\text {inst }}$ acima de $\mathrm{R} \$ 3000,00$, aproximadamente. Não obstante, caso o custo do $\mathrm{kW}_{\text {inst }}$ seja o mesmo dos sistemas analisados anteriormente, os sistemas supercríticos são mais interessantes economicamente que a opção com turbinas de contrapressão e a com turbinas de condensação operando durante a safra exclusivamente.

O investimento estimado para a planta termelétrica ${ }^{40}$ de Avedøre localizada na Dinamarca foi de US\$ 500 milhões para uma capacidade instalada de 570 MW, ou seja, US\$ 877,19/kW inst. $_{\text {. }}$

\footnotetext{
${ }^{40}$ Essa planta opera com vapor a 300 bar e $580^{\circ} \mathrm{C}$, com re-aquecimento até $600^{\circ} \mathrm{C}$, atingindo uma eficiência térmica igual a $48 \%$. A planta conta com duas caldeiras supercríticas, sendo uma operando exclusivamente com biomassa.
} 
Essa planta opera com duas caldeiras supercríticas queimando gás natural, biomassa e/ou óleo combustível, além de contar com duas turbinas a gás (ZIĘBIK ET AL, 2006; POWERTECHNOLOGY, 2008). Apesar de contar com duas turbinas a gás, a maior capacidade instalada provém do sistema supercrítico $(80 \%)$, assim o investimento indicado é uma referência para sistemas supercríticos. Considerando uma taxa de câmbio de R \$1,90 para US\$ 1,00, o investimento por $\mathrm{kW}_{\text {inst }}$ na planta de Avedøre é igual a R\$1666,66. Beér (2007) cita investimentos próximos a US\$1290,00/ $\mathrm{kW}_{\text {inst }}\left(\mathrm{R} \$ 2451,00 / \mathrm{kW}_{\text {inst }}\right)$. Como a maior parte dos equipamentos deverá ser importada para uma instalação no Brasil, os valores encontrados são um limite inferior para esses sistemas. Assim, a viabilidade econômica dos sistemas supercríticos fica comprometida. Uma alternativa para viabilizar esses sistemas é a geração ao longo do ano todo.

A geração de eletricidade ao longo do ano utilizando os sistemas supercríticos requer a utilização de um combustível adicional, sendo uma opção as pontas e folhas que poderiam ser recuperadas no campo. Os benefícios da operação da planta de cogeração durante um período de tempo maior traz benefícios econômicos para o desempenho econômico da mesma, como mostrado nas Figs. 10.5, 10.6 e 10.8. Todavia, o recolhimento de pontas e folhas implica um aumento do custo de corte, carregamento e transporte (CCT) da cana, o qual impacta diretamente na margem de contribuição total da usina. Sendo assim a análise deve contrapor redução da margem de contribuição da usina, frente aos benefícios da operação dos sistemas supercríticos durante um período maior que a safra. Esse estudo é deixado para trabalhos futuros, dado a incertezas relativas aos impactos dos custos CCT com a recuperação de pontas e folhas.

\subsection{SISTEMAS COM GASEIFICAÇÃO DE BIOMASSA E CICLOS COMBINADOS}

Os sistemas com gaseificação de biomassa e ciclos combinados foram os que apresentaram o melhor desempenho termodinâmico entre todas as opções avaliadas. Todavia, não há nenhuma planta em operação comercial no mundo atualmente. O primeiro sistema BIGCC a entrar em operação foi a planta de Värnamo na Suécia (STÅHL; NEERGAARD, 1998) , a qual operou por quase 4000 horas como um BIGCC puro (STÅHL et al., 2004), porém sua operação foi interrompida em 1999. Esta planta pode ser considerada a experiência mais bem sucedida para a demonstração da tecnologia BIGCC. 
No Brasil, o Centro de Tecnologia Canavieira iniciou, em 1998, o desenvolvimento de um projeto para mostrar a viabilidade de um sistema BIGCC a partir de bagaço, pontas e folhas. Testes para a gaseificação desses materiais foram feitos, porém a operação da planta BIGCC não foi realizada (HASSUANI; LEAL; MACEDO, 2005).

Diferentes trabalhos buscaram avaliar a viabilidade econômica do uso de sistemas BIGCC em usinas sucroalcooleiras (LARSON et al., 1990; WALTER, 1994; WALTER; OVEREND, 1998; NETO, 2001; LARSON; WILLIAMS; LEAL, 2001; RODRIGUES; FAAIJ; WALTER, 2003b; HASSUANI; LEAL; MACEDO, 2005). Nesses trabalhos diferentes valores de investimento para a instalação foram calculados, variando entre US\$1300,00 (R\$2470,00) a US\$ $2450,00(\mathrm{R} \$ 4655,00) / \mathrm{kW}_{\text {inst }^{4}}^{41}$.

Neste trabalho, são avaliadas três configurações para o sistema BIGCC:

d) Sistema com gaseificação atmosférica e geração de vapor em 42 bar e $400^{\circ} \mathrm{C}$, com recuperação do calor rejeitado no sistema de limpeza dos gases para geração de vapor e pré-aquecimento do ar fornecido ao gaseificador;

e) Sistema com gaseificação atmosférica e geração de vapor em 80 bar e $510^{\circ} \mathrm{C}$, com recuperação do calor rejeitado no sistema de limpeza dos gases para superaquecimento do vapor e pré-aquecimento do ar fornecido ao gaseificador;

f) Sistema com gaseificação pressurizada, com recuperação do calor rejeitado no sistema de limpeza dos gases para geração de vapor em 80 bar e $510^{\circ} \mathrm{C}$.

As Figs. 10.10 e 10.11 mostram a variação do VPL e da TIR em função do investimento por $\mathrm{kW}_{\text {inst }}$ para os sistemas com gaseificação atmosférica.

\footnotetext{
${ }^{41}$ US\$ 2450,00/ $\mathrm{kW}_{\text {inst }}$ representa o investimento necessário para a primeira planta a ser construída no Brasil (LARSON; WILLIAMS; LEAL, 2001).
} 


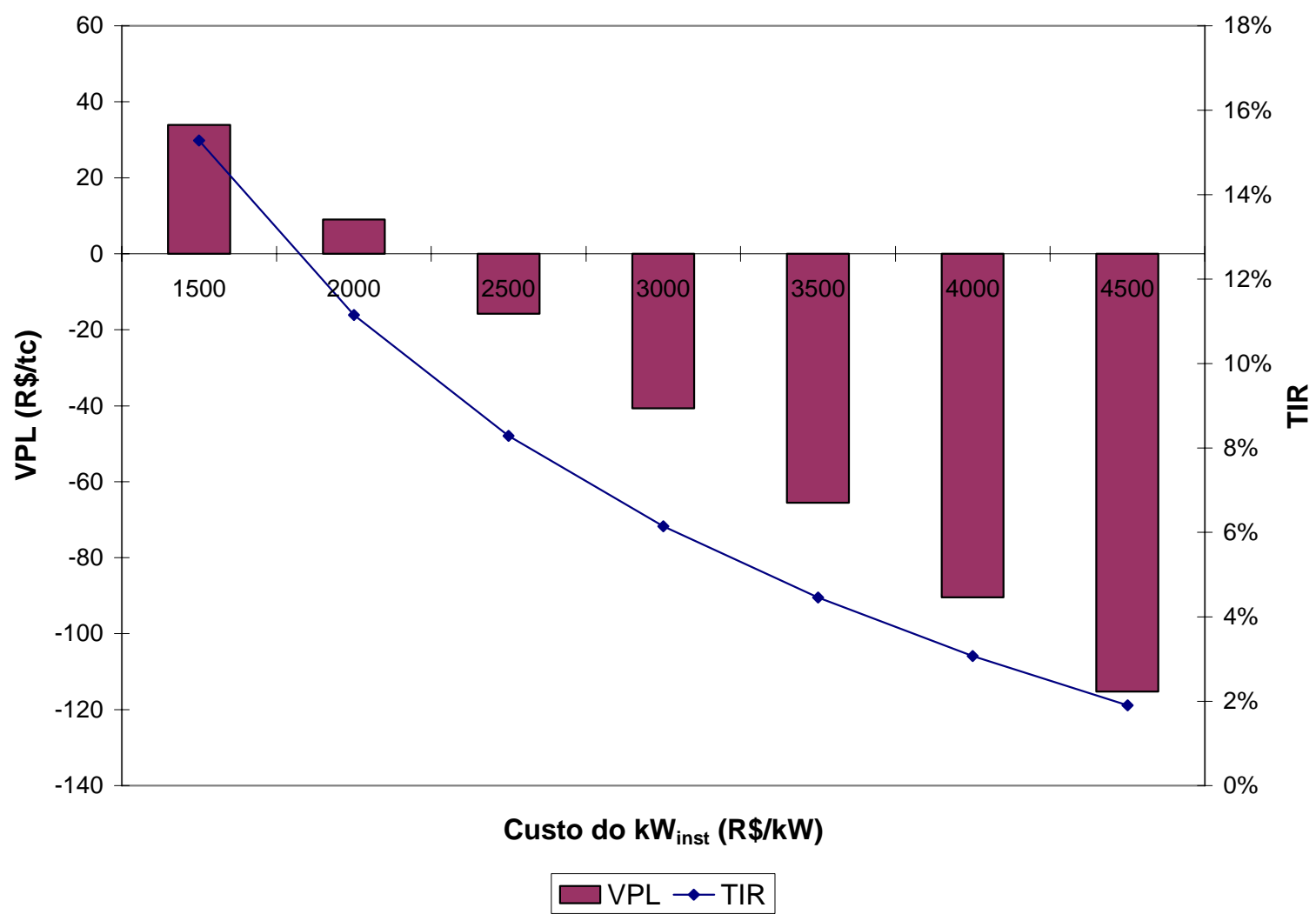

Figura 10.10 - Variação do VPL e da TIR para diferentes Custos de $\mathrm{kW}_{\text {ins }} \mathrm{t}$ - Sistema com gaseificação atmosférica e geração de vapor em 42 bar e $400^{\circ} \mathrm{C}$.

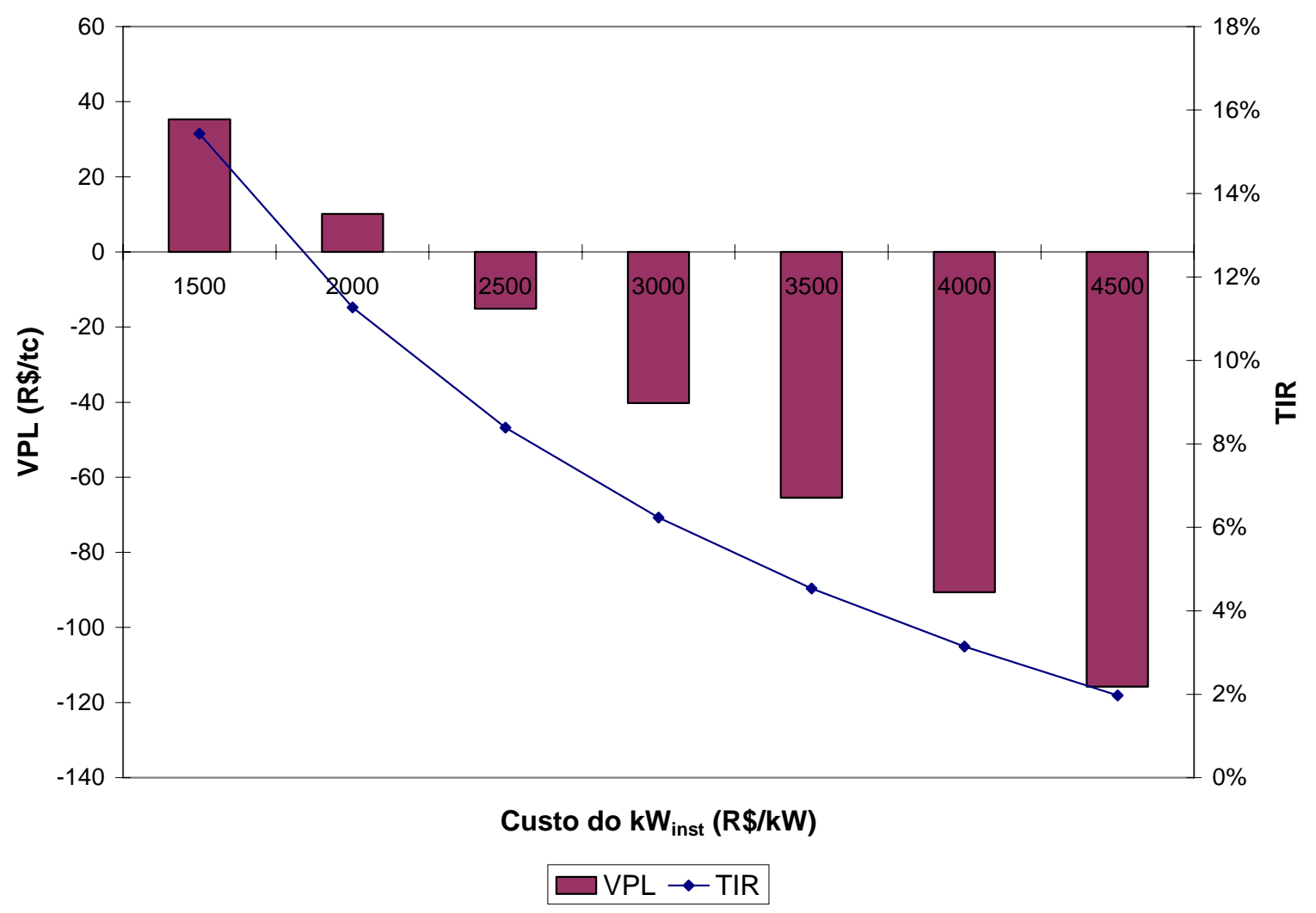

Figura 10.11 - Variação do VPL e da TIR para diferentes Custos de $\mathrm{kW}_{\text {inst }}$ - Sistema com gaseificação atmosférica e geração de vapor em 80 bar e $510^{\circ} \mathrm{C}$. 
Os resultados das Figs. 10.10 e 10.11 indicam que os sistemas BIGCC com gaseificação atmosférica não apresentam viabilidade econômica para os valores de investimentos levantados na literatura, considerando o custo da eletricidade de R\$ 130,00/MWh. Esses sistemas têm viabilidade para investimentos abaixo de $\mathrm{R} \$ 2200,00 / \mathrm{kW}_{\text {inst }}$, sendo competitivo com os demais para valores inferiores a $\mathrm{R} \$ 2000,00 / \mathrm{kW}_{\text {inst. }}$ Tanto a geração a 42 bar e $400^{\circ} \mathrm{C}$ quanto à 80 bar e $510^{\circ} \mathrm{C}$ apresentaram praticamente os mesmos valores de VPL e TIR.

Mesmo com gerações de eletricidade excedente superiores a de sistemas supercríticos, a capacidade instalada para os sistemas BIGCC atmosféricos é muito mais elevada, pois o consumo interno dos mesmos é muito maior que os sistemas supercríticos, devido ao compressor de gás produzido. Ou seja, o compressor de gás produzido prejudica o desempenho termodinâmico - consome mais de $20 \%$ de toda energia elétrica gerada (Cap. 8) - e econômico dos sistemas BIGCC atmosféricos. A geração excedente de eletricidade representa 59\% total gerado nos sistemas BIGCC atmosférico, enquanto que nos sistemas supercríticos, representa 74\%. Sendo assim, para um mesmo valor de $\mathrm{kW}_{\text {inst, }}$ sistemas supercríticos são mais atrativos que sistemas BIGCC atmosféricos, mesmo os últimos sendo um pouco mais eficientes.

A opção BIGCC pressurizada também foi avaliada e os resultados apresentados na Fig. 10.12. 


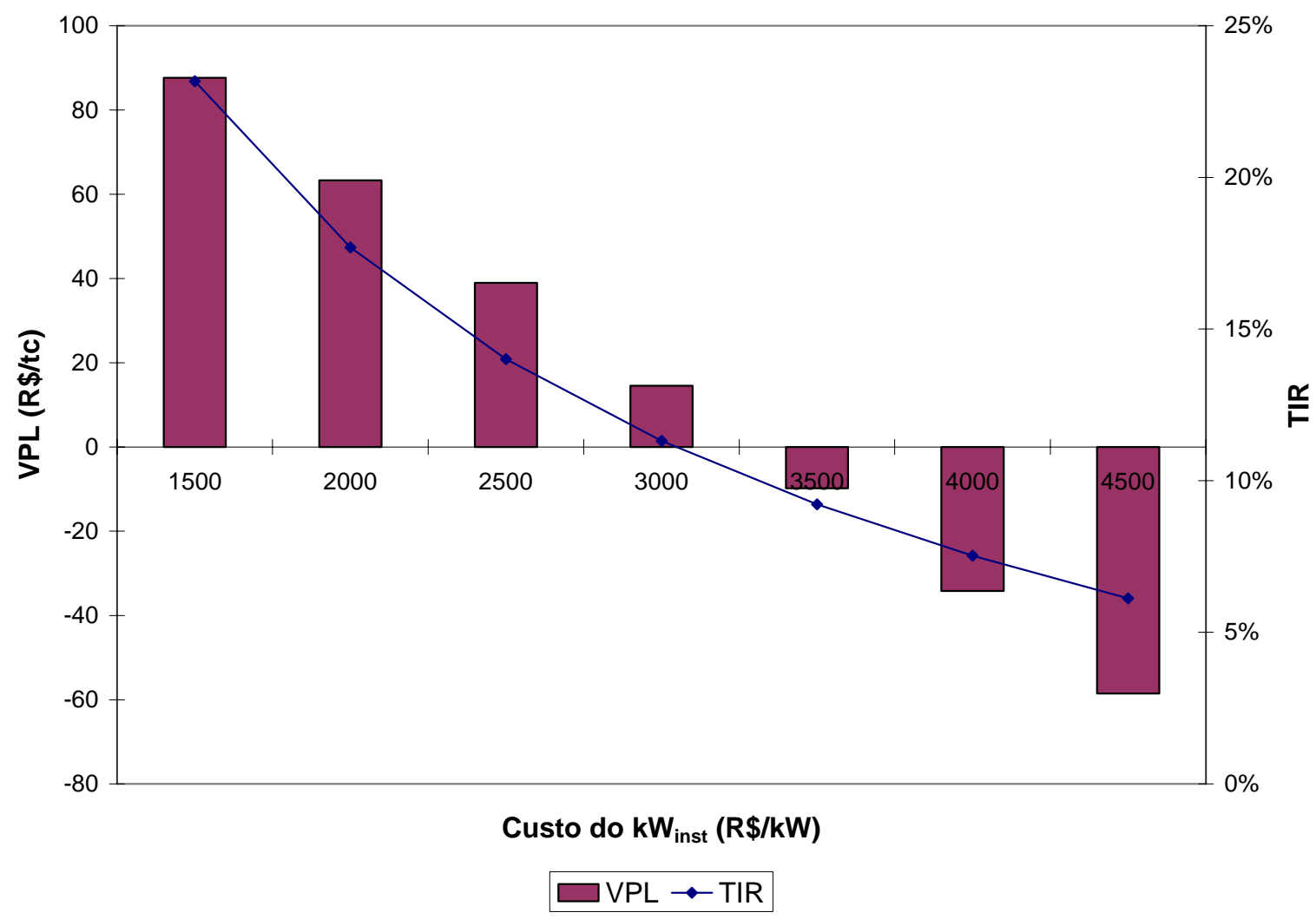

Figura 10.12 - Variação do VPL e da TIR para diferentes Custos de $\mathrm{kW}_{\text {inst }}$ - Sistema com gaseificação pressurizada e geração de vapor em 80 bar e $510^{\circ} \mathrm{C}$.

O sistema BIGCC pressurizado é viável economicamente para investimentos inferiores a R\$ $3300,00 / \mathrm{kW}_{\text {inst }}$, sendo competitivo com os sistemas convencionais para valores abaixo de $\mathrm{R} \$$ $3000,00 / \mathrm{kW}_{\text {inst. }}$ A geração de eletricidade excedente representa $81 \%$ da eletricidade total gerada pelo sistema, pois não apresenta o mesmo consumo interno dos sistemas atmosféricos. Desta maneira, esses sistemas são mais atrativos economicamente que o sistema supercrítico para o mesmo valor de investimento por $\mathrm{kW}_{\text {inst. }}$ Todavia, a utilização de gaseificação pressurizada para bagaço apresenta entraves técnicos como o manuseio do combustível e sua alimentação no sistema pressurizado.

Assim como para o sistema supercrítico, a geração ao longo do ano todo requer a utilização de um combustível adicional, por exemplo, as pontas e folhas da cana. Outra opção é o uso de gás natural, o que traria benefícios para a operação da turbina a gás, sobretudo para os sistemas com gaseificação atmosférica (RODRIGUES; FAAIJ; WALTER, 2003a). Essas opções foram avaliadas em diferentes estudos (LARSON; WILLIAMS; LEAL, 2001; RODRIGUES; FAAIJ; WALTER, 2003b; HASSUANI; LEAL; MACEDO, 2005; 
ZAMBONI; PELLEGRINI; TRIBESS; OLIVEIRA JR, 2005; ZANETTI; PELLEGRINI; OLIVEIRA JR., 2007).

\subsection{COMENTÁRIOS GERAIS}

A avaliação econômica das diferentes alternativas para a otimização do uso da energia em usinas sucroalcooleiras é importante para indicar se os benefícios termodinâmicos indicados no Cap. 8 apresentam benefícios econômicos também.

A metodologia adotada considera o aumento da margem de contribuição total da usina (Cap. 9) como a receita para a remuneração do investimento necessário. Isso significa que a receita é exatamente igual à receita obtida pela venda de eletricidade excedente. Desta maneira, o aumento percentual do investimento necessário deve ser compensado por um aumento igual ou superior na geração excedente. As Figs. 10.13 e 10.14 apresentam os principais resultados obtidos pela análise economica das alternativas analisadas.

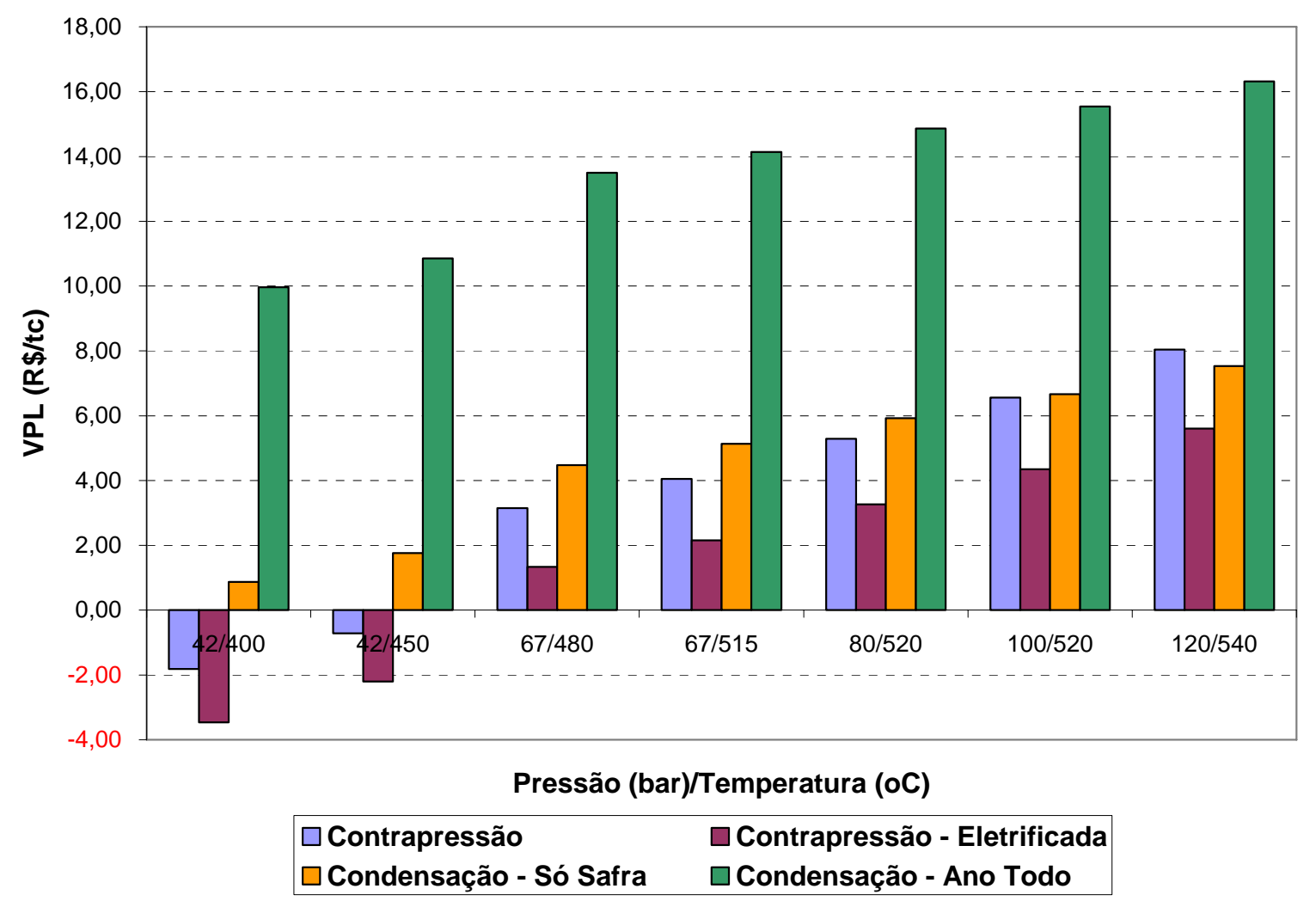

Figura 10.13 - Variação do VPL para as diversas alternativas avaliadas. 


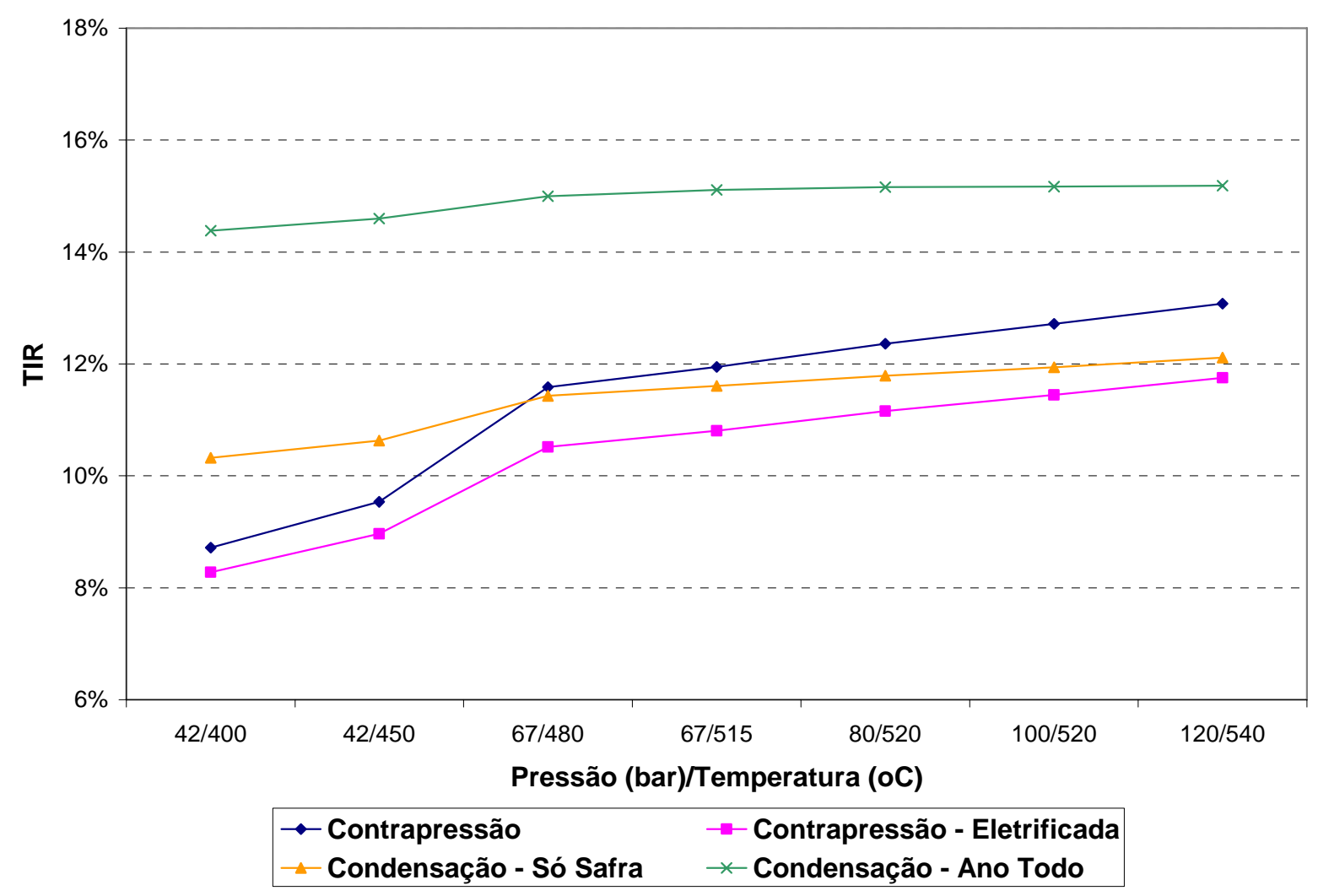

Figura 10.14 - Variação do VPL para as diversas alternativas avaliadas.

A eletrificação das moendas não se mostrou viável economicamente para sistemas com geração de vapor acima de 67 bar, pois o ganho de geração excedente não é capaz de remunerar o investimento necessário. Todavia, caso a substituição das turbinas de acionamento da moenda seja necessária devido ao esgotamento da sua vida útil ou para aumento da capacidade de moagem, então a eletrificação é uma alternativa mais atrativa.

Comparando os sistemas com turbina de contrapressão com os sistemas com turbinas de condensação, os primeiros apresentam uma atratividade maior, pois não requerem investimentos adicionais no processo para redução do consumo de vapor. Todavia, em usinas com baixos consumos de vapor ou em novas unidades projetadas com processos mais eficientes de transferência de calor, os sistemas com turbinas de condensação são a melhor opção. As análises desenvolvidas não consideram nenhuma receita relacionada à comercialização de créditos de carbono, o que eventualmente, poderiam melhorar o desempenho econômico da opção por turbinas de condensação frente às turbinas de contrapressão. 
A análise de sensibilidade desenvolvida para os sistemas de contrapressão indicou que o aumento do tempo de safra tem um impacto muito positivo na economicidade desses sistemas. Isto foi confirmado na análise dos sistemas de condensação operando durante o ano todo, que apresentam TIR's e VPL's mais elevados para todas as configurações convencionais avaliadas.

A opção por pressões e temperaturas mais elevadas requer a utilização de materiais mais avançados, com maior custo. Portanto, o ganho termodinâmico deve compensar a elevação do investimento. As Tabs. 10.6 e 10.7 mostram os aumentos máximos no investimento para pressões e temperaturas acima de 67 bar e $480^{\circ} \mathrm{C}$, tanto para sistemas de contrapressão quanto de condensação.

Tabela 10.6 - Aumentos máximos no investimento para sistemas de contrapressão.

\begin{tabular}{cccc}
\hline Pressão (bar) & $\begin{array}{c}\text { Temperatura } \\
\left({ }^{\circ} \mathbf{C}\right)\end{array}$ & $\begin{array}{c}\text { Geração } \\
\text { Excedente } \\
\text { Adicional }\end{array}$ & $\begin{array}{c}\text { Aumento } \\
\text { Máximo no } \\
\text { Investimento }\end{array}$ \\
\hline 67 & 515 & $6,2 \%$ & $6,6 \%$ \\
80 & 520 & $16,3 \%$ & $17,1 \%$ \\
100 & 520 & $27,3 \%$ & $28,7 \%$ \\
120 & 540 & $39,8 \%$ & $41,7 \%$ \\
\hline
\end{tabular}

Tabela 10.7 - Aumentos máximos no investimento para sistemas de condensação.

\begin{tabular}{cccc}
\hline Pressão (bar) & $\begin{array}{c}\text { Temperatura } \\
\left({ }^{\circ} \mathbf{C}\right)\end{array}$ & $\begin{array}{c}\text { Geração } \\
\text { Excedente } \\
\text { Adicional }\end{array}$ & $\begin{array}{c}\text { Aumento } \\
\text { Máximo no } \\
\text { Investimento }\end{array}$ \\
\hline 67 & 515 & $2,9 \%$ & $3,5 \%$ \\
80 & 520 & $7,5 \%$ & $8,9 \%$ \\
100 & 520 & $12,4 \%$ & $14,6 \%$ \\
120 & 540 & $17,8 \%$ & $21,0 \%$ \\
\hline
\end{tabular}

Tomando por base os aumentos de investimentos mostrados em Procknor (2008), os resultados indicam que a geração de vapor a 67 bar e $480^{\circ} \mathrm{C}$ é a alternativa mais atrativa economicamente, sobretudo em sistemas de condensação, já que os aumentos de investimento para geração de vapor em pressões e temperaturas mais elevadas são superiores aos valores mostrados nas Tabs. 10.6 e 10.7 . 
Para as tecnologias mais avançadas de cogeração, é interessante notar que os sistemas supercríticos são mais atrativos economicamente que os sistemas BIGCC atmosféricos, mesmo sendo menos eficientes. Isto é resultado dos elevados consumos internos dos sistemas BIGCC atmosféricos (compressor de gás produzido), requerendo maiores capacidades instaladas para a geração de eletricidade excedente similar ao do sistema supercrítico.

Por outro lado, o sistema BIGCC pressurizado não requer o compressor de gás produzido, elevando a quantidade de eletricidade excedente em relação ao total gerado, tornando-o mais atrativo economicamente que o sistema supercrítico.

Os valores de investimento levantados para os sistemas supercríticos indicam que esses podem ser uma alternativa interessante para usinas sucroalcooleiras, além de estarem disponíveis comercialmente. Porém, sua aplicação é restrita a usinas com grandes capacidades de moagem (acima de 6 milhões de toneladas de cana), devido ao tamanho das turbinas, não inferior a $250 \mathrm{MW}$. No Brasil apenas três usinas são capazes de moer essa quantidade de cana.

Para os valores de investimento levantados, apenas o sistema BIGCC pressurizado apresenta viabilidade econômica dentre as opções com gaseificação de biomassa, considerando o preço de R\$130,00/MWh.

A aplicação das tecnologias avançadas para a geração de eletricidade durante o ano todo requer a utilização de um combustível adicional. As pontas e folhas, atualmente ou são deixadas no campo quando da colheita mecanizada ou são eliminadas pela queima antes da colheita manual, são uma opção. Porém, o recolhimento de pontas e folhas implica um aumento do custo de corte, carregamento e transporte (CCT) da cana, o qual impacta diretamente na margem de contribuição total da usina, devendo ser melhor analisadas frente aos benefícios da geração ao longo do ano todo. Outra opção é o uso de gás natural, a qual traz vantagens para a operação da turbina a gás, mas prejudica a condição de geração de energia elétrica com emissão zero de gases de efeito estufa. A avaliação da utilização combinada de bagaço e gás natural em usinas sucroalcooleiras foi estudada por (ZAMBONI ET AL; 2005; ZANETTI; PELLEGRINI; OLIVEIRA JR, 2007). 


\section{DISCUSSÃO EXERGO-AMBIENTAL A RESPEITO DA RENOVABILIDADE DAS CONFIGURAÇÕES PARA A PRODUÇÃO COMBINADA DE AÇÚCAR, ÁLCOOL E ELETRICIDADE}

Até o momento, discutiu-se como a elevação dos padrões de eficiência exergética do uso racional de energia em usinas sucroalcooleiras impacta no desempenho termodinâmico e econômico-financeiro da usina. Agora, propõe-se uma discussão acerca do desempenho ambiental, principalmente a questão da renovabilidade dos produtos/processos, das modificações propostas com base no uso da exergia como parâmetro de avaliação de desempenho ambiental.

Muitos trabalhos (PIMENTEL, 2008; MACEDO; SEABRA; SILVA, 2008) mostram a questão da renovabilidade em função apenas de balanços de massa e energia, sem levar em consideração a redução da disponibilidade da energia consumida nos processos (destruição de exergia). Ou seja, essas abordagens não levam em consideração a eficiência do uso da energia (exergia) dos insumos para a produção dos produtos. Portanto, este capítulo visar dar uma nova visão a respeito da renovabilidade dos produtos/processos de conversão de energia com base em um índice exergético de renovabilidade.

\subsection{INTRODUÇÃO}

Segundo Berthiaume, Bouchard e Rosen (2001), a renovabilidade total de um recurso significa a existência de um mecanismo de regeneração, o qual mantém a disponibilidade do recurso intacta sem causar danos/distúrbios ao meio-ambiente dentro de um determinado horizonte de tempo. Os recursos renováveis são aqueles que retornam periodicamente para o meio-ambiente por meio de transformações cíclicas. Essa definição guarda uma grande relação com a operação de máquinas térmicas em ciclos termodinâmicos, onde o estado inicial é sempre restaurado após interações (calor e trabalho) do sistema com o meio.

O planeta Terra pode ser visto como um sistema operando em um ciclo termoquímico entre dois reservatórios: o Sol e o Espaço (Fig. 11.1). Desta maneira, a Terra aproveita a exergia do 
Sol para manter os ciclos naturais, a vida no planeta, o desequilíbrio químico entre os sistemas e, inclusive, pode armazená-la (combustíveis fósseis) (WALL, 1977).

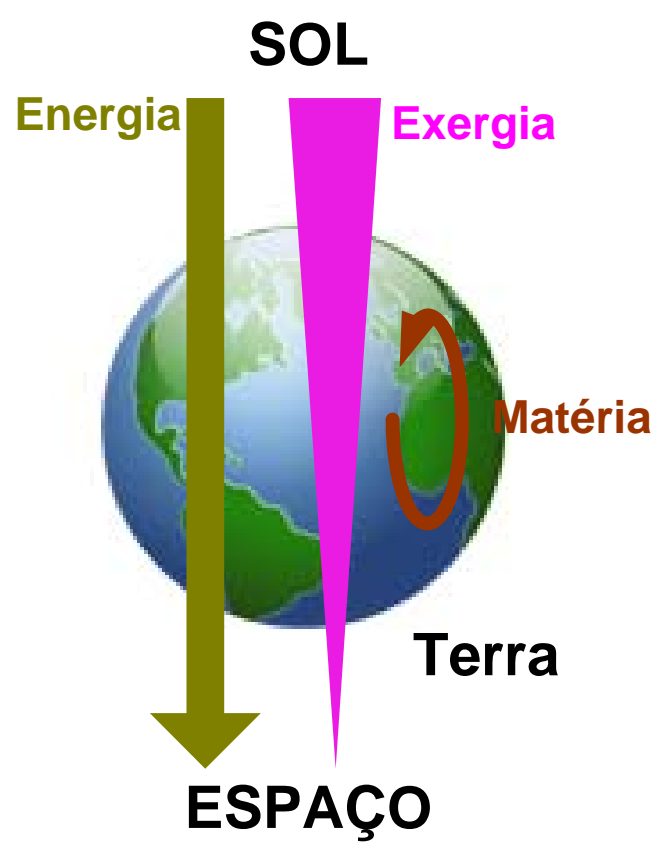

Figura 11.1 - Os fluxos de matéria e energia na Terra são dirigidos pelo contraste enre o Sol e o Espaço (WALL, 1977).

A variação da exergia originada do contraste entre o Sol e o Espaço é o principal motor que impulsiona os fluxos de massa e energia na superfície terrestre. Como em um ciclo termodinâmico, a Terra recebe uma quantidade de energia com alta exergia, a qual é utilizada para movimentar os diferentes sistemas do planeta (biosfera, litosfera, atmosfera, hidrosfera e sociosfera - sociedade humana), rejeitando uma quantidade de energia com baixa exergia (WALL; GONG, 2001).

Enquanto há um balanço entre a energia que chega e a que é dissipada, a menos de uma parte desprezível que é armazenada como combustível fóssil, e calor proveniente de fontes geotérmicas; outra relação pode ser estabelecida entre o aporte de exergia da radiação solar e seu consumo pelos processos naturais na Terra. Aproximadamente um quarto da exergia da radiação solar é refletido, sendo o restante absorvido pela Terra e a maior parte é destruída para permitir o funcionamento dos sistemas de regulação terrestre que viabilizam a vida. A parcela da exergia que não é utilizada por esses sistemas é armazenada na forma de combustíveis fósseis, depósitos minerais, etc (WALL; GONG, 2001). 
Durante milhões de anos, esse aporte de exergia criou condições ambientais que permitiram o desenvolvimento e evolução da vida na Terra, originando uma diversidade de espécies com diferentes níveis de complexidade, além da formação de estoques de exergia na forma de matéria orgânica viva (florestas) e morta (combustíveis fósseis). Assim, uma sociedade, cujo consumo dos estoques de exergia ocorre a uma taxa muito superior a que esses são renovados, é considerada não sustentável (WALL; GONG, 2001). Ou seja, uma relação de estabilidade entre a "oferta" de exergia (exergia da radiação solar) para a regeneração dos recursos e a "demanda" por esses, dado pelo consumo dos mesmos pelos seres-vivos (BERTHIAUME; BOUCHARD; ROSEN, 2001).

Uma questão deve ser, portanto, levantada:

A exergia proveniente da radiação solar é suficiente para garantir a regeneração/reciclagem dos recursos naturais?

Essa questão envolve discussões relacionadas com a Termodinâmica do Não-equilíbrio e ultrapassa o escopo da tese ora apresentada. Porém, uma breve discussão é realizada.

O meio-ambiente é um sistema que funciona longe do estado de equilíbrio termodinâmico, sendo a geração de entropia devida ao consumo da exergia da radiação solar acompanhada de processos que originam estruturas dissipativas responsáveis pelas condições ambientais atuais (SZARGUT, 2002).

Segundo discutido por Jørgensen, Patten e Straškraba (2000), um sistema que recebe um influxo de exergia irá utilizá-la primeiramente para mantê-lo em um estado distante do equilíbrio termodinâmico, através da destruição dessa exergia. Caso mais exergia seja disponibilizada, essa será utilizada para afastar ainda mais o sistema do estado de equilíbrio, segundo o caminho que maximize o estoque de exergia do sistema. A hipótese formulada por esses autores é que o desenvolvimento de um ecossistema em todos os seus estágios irá distanciá-lo do estado de equilíbrio termodinâmico e escolherá níveis de organização que maximizem o fluxo de energia através do sistema e o estoque de exergia. É importante ressaltar a questão da etapa final desse desenvolvimento, quando quase a totalidade dos recursos (nutrientes) está contida nos organismos, ou seja, não há recursos para o desenvolvimento de novas estruturas (talvez, melhores) para manter a distância do sistema do 
estado de equilíbrio. Nessa situação, a Seleção Natural, proposta por Darwin, atua sobre o ecossistema criando uma competição entre os organismos com a sobrevivência apenas dos mais aptos (mais complexos e que contêm mais informação), aqueles que dada a condição do meio-ambiente são capazes de manter o ecossistema em um estado distante do equilíbrio termodinâmico a partir da destruição da exergia da radiação solar. Os demais organismos morrem e seus constituintes retornam à natureza para iniciar o novo ciclo de desenvolvimento. Deve-se levar em conta que o tempo tem um importante papel para essas transformações, bem como a incapacidade de reciclagem total dos recursos, imposta pela $2^{\mathrm{a}}$ Lei da Termodinâmica. Como destacam Wall e Gong (2001), a Natureza passou por enormes mudanças durante bilhões de anos que alteraram completamente as condições de vida no planeta.

Portanto, voltando à questão posta, a resposta é: não. O Sol, ou melhor, a exergia proveniente da radiação solar é um vetor para a evolução de organismos mais adaptados aos ecossistemas, dadas mudanças ocorridas no meio-ambiente devido ao desenvolvimento de sistemas anteriores. No muito longo prazo, a homogeneização das concentrações dos componentes (minimização dos gradientes) e a redução do aporte de exergia proveniente do Sol deverão inviabilizar as condições necessárias para a manutenção da distância do meio-ambiente com relação ao estado de equilíbrio termodinâmico e, conseqüentemente, eliminarão a vida no planeta. Provavelmente, a humanidade não sobreviverá para ver esse final trágico.

Como destacam Wall e Gong (2001), a Natureza tem um mecanismo de criação de estruturas cada vez mais sofisticadas e ordenadas (alta exergia) ${ }^{42}$, com uma estratégia atuando por trás desse desenvolvimento (essa estratégia é o que Jørgensen e colaboradores (JØRGENSEN; SVIREZHEV, 2004; JØRGENSEN; NIELSEN, 2007) vêm buscando entender utilizando o conceito da exergia). Até o momento, essa evolução levou a habilidade de pensar, ou seja, a criação de consciência e uma mente - ser humano ${ }^{43}$.

\footnotetext{
${ }^{42}$ Essas estruturas são capazes de manter os estados longe do equilíbrio termodinâmico, maximizando a extração das energias livres (exergia).

43 Outras discussões relacionadas à Termodinâmica do Não-Equilíbrio aplicada aos processos que ocorrem no planeta e à evolução da vida na Terra podem ser encontradas em Kleidon e Lorenz (2005).
} 
A habilidade de pensar e ser consciente são o que diferencia o ser humano dos demais seres vivos no planeta. Tal condição permite à humanidade atuar sobre o meio-ambiente alterandoo para suprir as suas necessidades.

Desde a Revolução Industrial iniciada no final do século XVIII, o homem mudou de maneira drástica a maneira com que se relaciona com o meio-ambiente, alterando, portanto, a relação de estabilidade anteriormente discutida. Houve um aumento do padrão de vida e, com isso, uma conseqüente elevação da demanda por recursos com elevada exergia química (baixa entropia), principalmente combustíveis fósseis e minerais ${ }^{44}$. Tal elevação veio com uma velocidade superior à capacidade do meio-ambiente de repor os recursos, causando um desequilíbrio no sistema. A esse desequilíbrio devido à atividade humana pode-se chamar impacto ambiental antropogênico. Como discutido por Wall (2002), a atuação do homem sobre a Natureza modifica o meio-ambiente e, por conseqüência, as condições de vida. Como discutido nos parágrafos anteriores, essas novas condições podem ser danosas a organismos existentes, porém possibilitam a criação de novos organismos mais adaptados. Assim, é possível dizer que a atuação do homem sobre a natureza causa uma aceleração dos mecanismos de evolução, de uma maneira que pode ser prejudicial para a sobrevivência da espécie humana.

Szargut (2002) apresenta uma análise do balanço de exergia para a superfície terrestre e a atmosfera, baseando-se no aporte de exergia da radiação solar e a diferenciação entre a as perdas de exergia naturais e antropogênicas. Os resultados mostram que as perdas de exergia naturais (responsáveis pela manutenção das condições ambientais) são quase 6000 vezes superiores às exergias perdidas antropogênicas ${ }^{45}$. Ou seja, a atividade humana tem um impacto pequeno no balanço de energia do planeta. Porém, como a origem da exergia utilizada pelos seres-humanos é, sobretudo, os combustíveis fósseis - não renováveis no horizonte de tempo da vida humana -, a emissão de poluentes pode ter uma influência muito negativa para a estabilidade do meio-ambiente, alterando, assim, as condições de

\footnotetext{
${ }^{44}$ Voltando ao que foi discutido no Cap. 1, Sachs (2007) destaca que a história da humanidade pode ser resumida como a história da produção e alocação do excedente econômico, ritmada por revoluções energéticas.

${ }^{45}$ Chen (2005) apresenta um balanço de exergia para a Terra, porém considera a temperatura de referência como a temperatura devido à radiação de fundo do universo. Os resultados desse autor indicam que a perda antropogênica de exergia é próxima a $0,3 \%$ da exergia utilizada para manter os sistemas de regulação da Terra.
} 
sobrevivência das espécies. Szargut conclui que a enorme desproporção entre as perdas naturais e antropogênicas de exergia indicam uma grande reserva de recursos renováveis e, portanto, o desenvolvimento econômico deveria ser avaliado a partir do melhor aproveitamento desses recursos renováveis (SZARGUT, 2002).

Georgescu-Roegen (1971) foi o primeiro economista a incorporar a entropia na avaliação do processo econômico, identificando que o processo econômico não deve ser tratado como um sistema mecanicista circular, similar a um moto-perpétuo consumindo, substituindo e reciclando recursos indefinadamente, pois interage com o meio-ambiente consumindo recursos de baixa entropia e rejeitando resíduos de alta entropia (Fig. 11.2).

Segundo Cechin e Magalhães (2007), a conclusão central do trabalho de Georgescu-Roegen (1971) é que o processo econômico é unidirecional, seguindo o princípio da $2^{\mathrm{a}}$ Lei, e não circular como mostram os manuais de Economia. Cechin (2008) destaca ainda que esse autor atentou para o fato que a reciclagem total dos materiais dissipados pelos processos industriais exigiria quantidades crescentes de aporte de energia (exergia) solar no sistema econômico. Seria necessário supor que a eficiência deveria aumentar continuamente para capturar quantidades cada vez maiores da energia que chega à Terra, a qual é tida como constante. Dado que a eficiência também é limitada pela $1^{\text {a }}$ Lei (sempre menor ou igual a $100 \%$ ), pois não é possível criar energia e pela $2^{\mathrm{a}}$ Lei, a qual indica a degradação da energia capturada, a reciclagem total é impossível, exatamente devido às irreversibilidades e a inexistência de crescentes aportes de energia solar. 


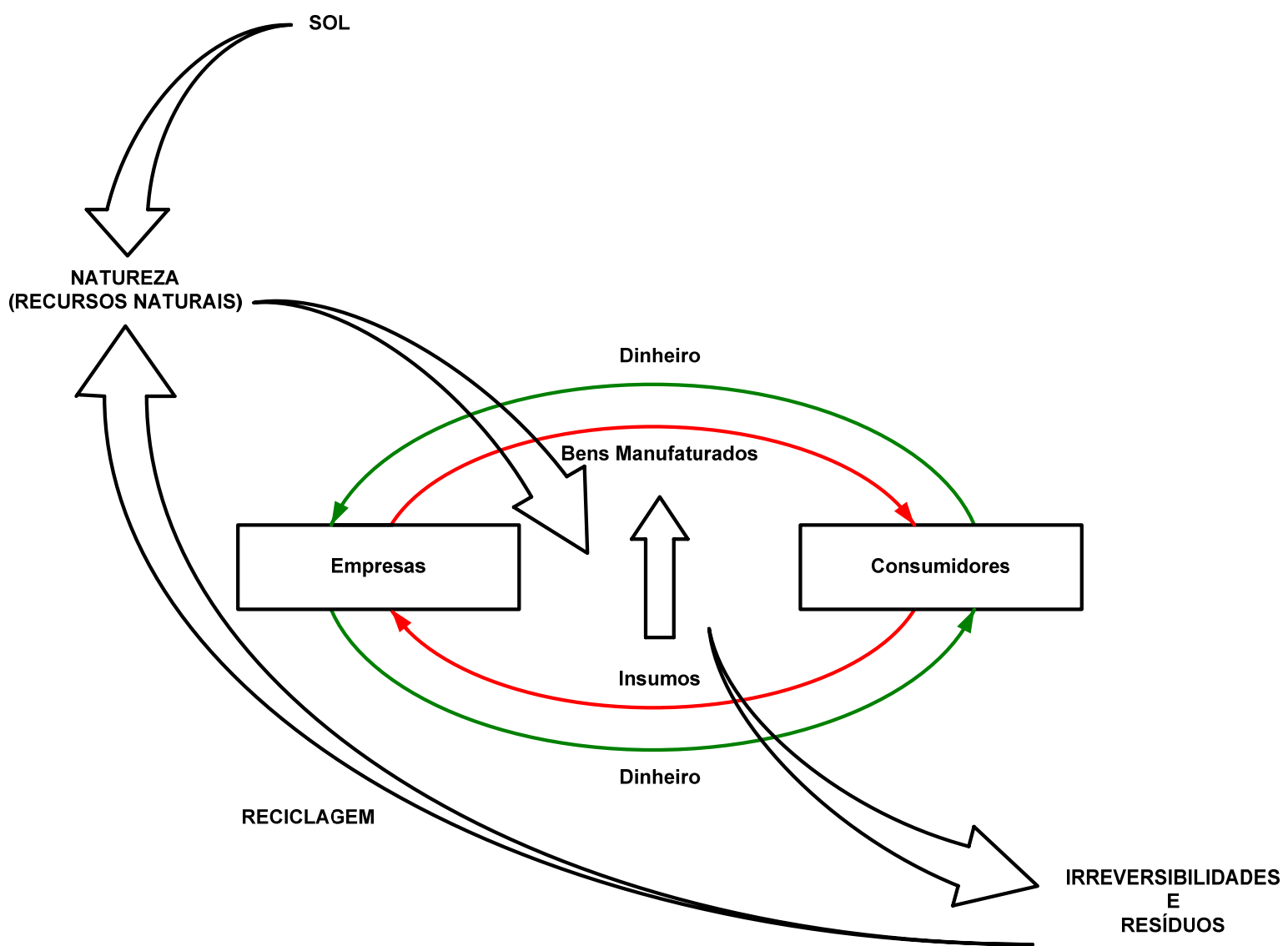

Figura 11.2 - Processo Econômico considerando as idéias de Georgescu-Roegen (elaboração do autor $)^{46}$.

O principal aporte de recursos naturais no ciclo econômico provém de combustíveis fósseis, sendo claramente não sustentável dentro da escala de tempo da vida humana. Como destacam Wall e Gong (2001), a exaustão dos recursos e a destruição ambiental são duas partes do mesmo problema, o uso dos depósitos de exergia que levaram milhões de anos para serem formados. Assim, a velocidade com que a sociedade (o ciclo econômico) utiliza esses depósitos é muito maior que o tempo que a natureza levará para regenerá-los, o que no curto prazo pode ter impactos sérios nas condições de sobrevivência da humanidade.

Uma questão que pode ser levantada após a exposição feita é: existe algum padrão de consumo ou desenvolvimento que seja sustentável? O conceito de sustentabilidade envolve obrigatoriamente a questão da escala de tempo. Caso a pergunta seja feita para o muito longo

\footnotetext{
${ }^{46}$ A parte mais interna da figura é a representação clássica do processo econômico, encontrada em livros-texto de economia (SAMUELSON; NORDHAUS, 2004).
} 
prazo, a resposta à questão é negativa, dadas as limitações impostas pela $2^{\mathrm{a}}$ Lei da Termodinâmica.

Todavia, dentro do contexto colocado pela Comissão Mundial sobre Meio Ambiente e Desenvolvimento da Organização das Nações Unidas (ONU) em 1987, Desenvolvimento Sustentável é uma forma de desenvolvimento ou progresso que satisfaça as necessidades do presente sem comprometer a capacidade de as futuras gerações satisfazerem as suas próprias necessidades (SCMIDHEINY, 1992). A escala de tempo, neste caso, é a duração da vida de um ser humano. Nessa condição os ciclos naturais de regeneração dos recursos terrestres podem ser vistos como imutáveis devido às suas gerações internas de entropia.

Diante dessa premissa, é possível estabelecer a idéia de recurso renovável como aquele possível de ser regenerado sem causar danos imediatos ao meio-ambiente dentro da escala de tempo da vida humana.

\subsection{INDICADOR EXERGÉTICO DE RENOVABILIDADE}

A atual preocupação mundial com relação ao aquecimento global, devido ao aumento das emissões de gases de efeito estufa, vem levantando a questão sobre a renovabilidade das matrizes energéticas dos países e das possíveis alternativas ao uso dos combustíveis fósseis.

Para avaliar essa renovabilidade, uma diversidade de índices em base exergética vem sendo proposta na literatura (SEWALT; TOXOPEUS; HIRS, 2001; BERTHIAUME; BOUCHARD; ROSEN, 2001; GONG; WALL, 2001; DEWULF; VAN LANGENHOVE, 2005 e 2006; SZARGUT, 2005; TOXOPEUS; LUTTERS; HOUTEN, 2006).

O índice apresentado nesta tese é um desenvolvimento iniciado em Velásquez, Benjumea e Oliveira Jr. (2007) e Velásquez, Ruiz e Oliveira Jr. (2008), culminando na proposta apresentada por Velásquez, Pellegrini e Oliveira Jr. (2008).

O índice leva em consideração a relação entre a exergia dos produtos e as exergias nãorenováveis utilizadas, a exergia destruída, a exergia de desativação e a exergia das emissões (eq. (75)). 


$$
\lambda=\frac{\sum \mathrm{B}_{\mathrm{p}}}{\mathrm{B}_{\text {não-renovável }}+\mathrm{B}_{\text {destruida }}+\mathrm{B}_{\text {desativąão }}+\sum \mathrm{B}_{\text {emissões /residuos }}}
$$

A exergia de desativação é a exergia necessária para tratar os resíduos do processo até as condições de equilíbrio com o meio-ambiente (ROSEN, 2002). Essa exergia aparece no índice caso o sistema de tratamento de efluentes esteja incluído no volume de controle analisado, como por exemplo, na análise de uma planta de produção de celulose incluindo a etapa de tratamento do lodo residual proveniente dos processos. Caso a planta de tratamento dos efluentes não esteja contida no volume de controle em estudo, devem ser utilizadas as exergias das emissões/resíduos, já que estas são uma medida de desequilíbrio entre esses fluxos e o meio-ambiente (ROSEN; DINCER, 1999).

A análise dos processos a partir desse índice implica processos:

- Ambientalmente desfavoráveis: $0<\lambda<1$;

- Interna e externamente reversíveis, com uso apenas de insumos não-renováveis: $\lambda=1$;

- Ambientalmente favoráveis: $\lambda>1$;

- Interna e externamente reversíveis, com uso apenas de insumos renováveis: $\lambda \rightarrow \infty$.

É interessante observar que esse índice leva em consideração a exergia destruída pelo processo, de maneira que mesmo com o aporte de insumos renováveis, uma operação muito ineficiente prejudica o desempenho ambiental do processo. Ao mesmo tempo que processos que fazem uso apenas de insumos não-renováveis, caso sejam muito eficientes, podem vir a ter desempenhos superiores àqueles com insumos renováveis.

Outro detalhe refere-se ao significado de o índice de renovabilidade ser maior que 1. Isso quer dizer que a exergia dos produtos poderia ser usada para restaurar o meio-ambiente às condições de antes do processo e ainda obter um fluxo positivo de exergia para outro uso. Essa condição está diretamente relacionada à definição feita anteriormente de recurso renovável $^{47}$. Nesse caso, o efeito líquido seria que os ciclos naturais de regulação terrestre seriam responsáveis apenas pela regeneração da exergia renovável utilizada.

\footnotetext{
${ }^{47}$ Recurso renovável é aquele possível de ser regenerado sem causar danos imediatos ao meio-ambiente dentro da escala de tempo da vida humana.
} 
O índice guarda forte relação com o tamanho do volume de controle considerado, devido ao número de processos de conversão de energia que pode abranger. Quanto maior for o volume de controle considerado na análise, menor será o valor do índice em função do aumento das irreversibilidades e da possibilidade do aporte de insumos não-renováveis ao processo. Por isso, ao comparar processos diferentes é importante atentar para os tamanhos e a compatibilidade dos volumes de controle a fim de evitar distorções nas análises.

\subsection{APLICAÇÃO DO ÍNDICE EXERGÉTICO DE RENOVABILIDADE ÀS CONFIGURAÇÕES PARA A PRODUÇÃO COMBINADA DE AÇÚCAR, ÁLCOOL E ELETRICIDADE}

A Fig. 11.3 mostra os volumes de controle considerados para a determinação do índice exergético de renovabilidade $(\lambda)$ para a usina como um todo (eq. (76)) e para o sistema de cogeração apenas (eq. (77)).

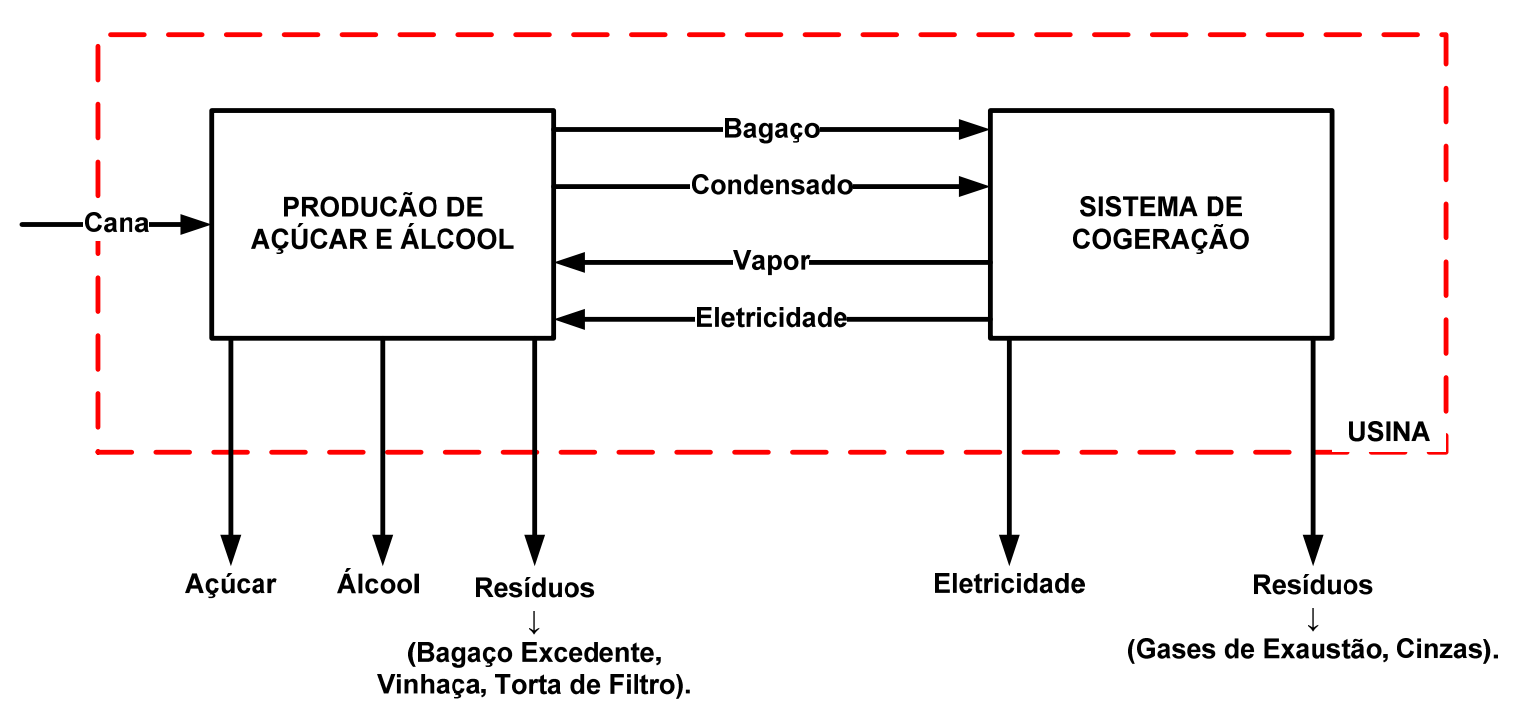

Figura 11.3 - Volumes de controle considerados para a determinação do índice exergético de renovabilidade

$$
\begin{gathered}
\lambda_{\text {u sin a }}=\frac{\mathrm{B}_{\text {açúcar }}+\mathrm{B}_{\text {álcool }}+\mathrm{W}_{\text {excedente }}}{\mathrm{B}_{\text {destruída }}+\mathrm{B}_{\text {vinhaça }}+\mathrm{B}_{\substack{\text { bagaco } \\
\text { excedente }}}+\mathrm{B}_{\substack{\text { gases de } \\
\text { exaustão }}}+\mathrm{B}_{\text {torta de }}+\mathrm{B}_{\text {cinzas }}} \\
\lambda_{\text {cogeração }}=\frac{\mathrm{W}_{\text {gerado }}+\mathrm{B}_{\text {processo }}^{\mathrm{Q}}}{\mathrm{B}_{\text {destruída }}+\mathrm{B}_{\substack{\text { gases de } \\
\text { exaustão }}}+\mathrm{B}_{\text {cinzas }}}
\end{gathered}
$$


Os resultados para as diferentes configurações estudadas para a produção combinada de açúcar, álcool e eletricidade são mostrados na Fig. 11.4.

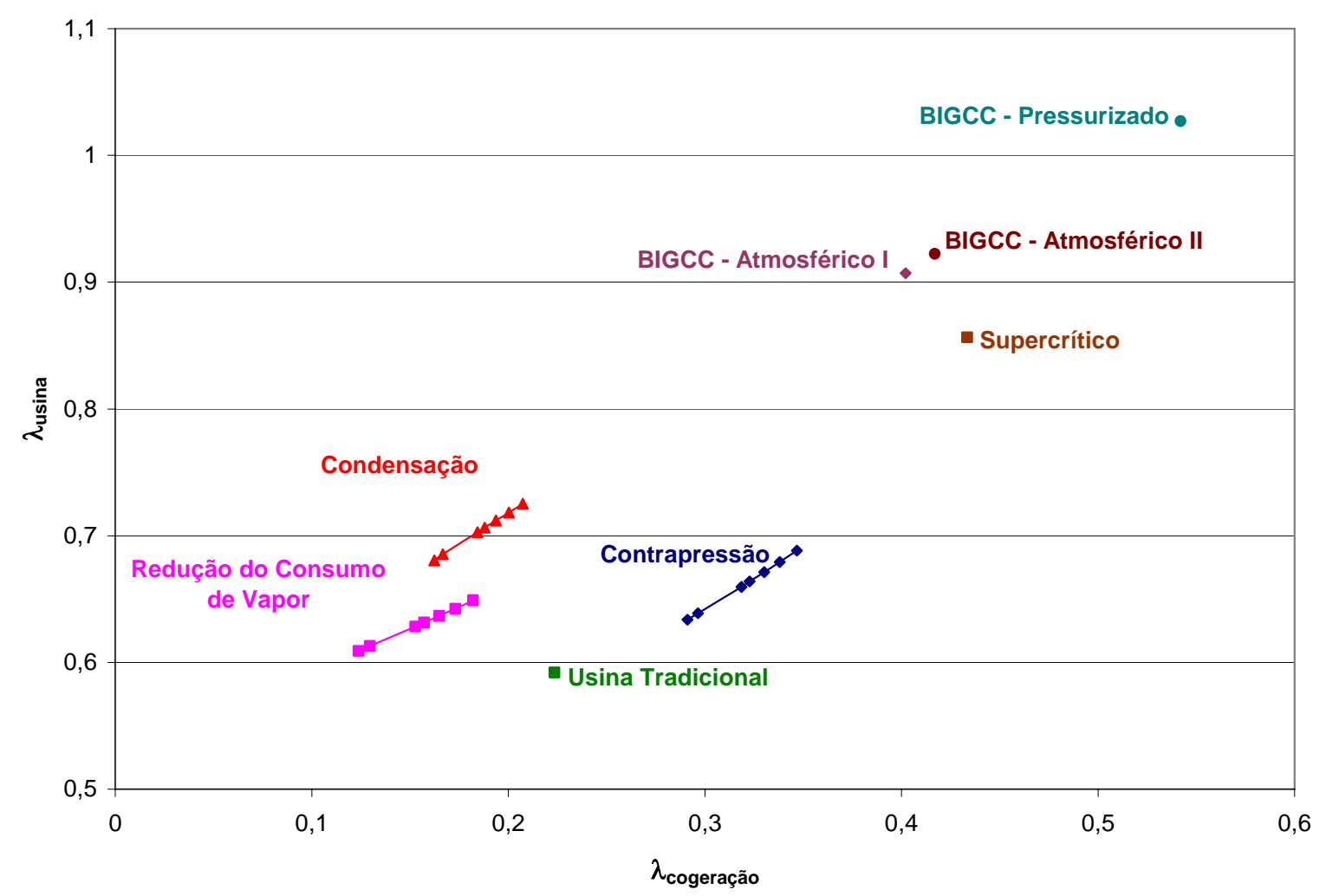

Figura 11.4 - Índice exergético de renovabilidade para a usina em função do índice do sistema de cogeração.

Observa-se que o índice para a usina como um todo é superior ao índice do sistema de cogeração. Isto ocorre devido às irreversibilidades do sistema de cogeração representarem em média $67 \%$ das irreversibilidades totais de uma usina, sendo seus produtos a energiaeletromecânica e o calor utilizado nos processos de produção de açúcar e álcool, além da eletricidade excedente vendida para a rede. Porém, esses produtos equivalem a apenas $18 \%$ da exergia do açúcar e do álcool para uma usina tradicional e $42 \%$ para o sistema BIGCC pressurizado. Ou seja, o sistema de cogeração é responsável por $67 \%$ das irreversibilidades da usina para produzir uma exergia equivalente muito inferior à exergia dos produtos da usina, portanto o $\lambda$ do sistema de cogeração é menor que o da usina.

Fazendo uma avaliação comparativa das configurações apresentadas, nota-se que o aumento da eficiência do sistema de cogeração (maior geração de eletricidade excedente) e a melhor integração térmica dos processos da usina (redução do consumo de vapor) melhoram o 
desempenho ambiental da usina como um todo. Essas duas medidas têm como objetivo: a) otimizar o uso do bagaço como combustível para o sistema de cogeração, maximizando a geração de eletricidade excedente; b) diminuir a geração de entropia dos processos de transferência de calor e massa nos processos. Desta maneira, aumentam a exergia dos produtos (numerador do $\lambda$ ) enquanto diminuem as exergias destruídas e perdidas (denominador do $\lambda$ ).

Todavia, para o sistema de cogeração, o uso de turbinas de contrapressão mostra um desempenho ambiental superior ao uso de turbinas de condensação. Isso evidencia a baixa eficiência exergética dos sistemas de cogeração como unidades de geração de eletricidade, utilizados atualmente nas usinas com geração excedente.

É interessante notar o melhor desempenho na cogeração do sistema supercrítico frente aos sistemas BIGCC atmosféricos. Isso é um resultado direto do grande consumo interno de eletricidade desses últimos, devido ao compressor de gás produzido para injeção na turbina a gás. Por outro lado, os sistemas BIGCC apresentam os melhores valores de $\lambda$ devido à maior geração de eletricidade excedente desses sistemas. Outra informação interessante é que o valor de $\lambda$ só é maior que 1 para o sistema BIGCC pressurizado, o sistema mais eficiente de cogeração com o menor consumo de vapor no processo. Ou seja, nenhuma das demais configurações pode ser considerada como sendo um processo renovável mesmo só com insumos renováveis, pois a geração de entropia por esses sistemas é maior que a exergia produzida.

De uma maneira geral, o desempenho ambiental da usina é melhor quanto maior for a geração de eletricidade excedente.

As configurações para a produção combinada de açúcar, álcool e eletricidade que foram desenvolvidas neste trabalho visam a maximização da geração de eletricidade excedente em usinas sucroalcooleiras. Portanto, é interessante comparar os valores dos índices exergéticos de renovabilidade dessas configurações com os valores de $\lambda$ para plantas termelétricas que utilizam combustíveis fósseis. Para esses sistemas, $\lambda$ pode ser calculado a partir da eficiência exergética dessas plantas (eqs. (78) e (79)): 


$$
\begin{aligned}
& \eta_{\text {exergético }}=\frac{\mathrm{W}_{\text {liquido }}}{\mathrm{B}_{\text {combustivel }}} \\
& \lambda_{\substack{\text { plantas } \\
\text { termelétricas }}}=\frac{\mathrm{W}_{\text {liquido }}}{\mathrm{B}_{\text {combustivel }}+\mathrm{B}_{\text {destruída }}+\mathrm{B}_{\substack{\text { gases de } \\
\text { exaustão }}}}= \\
& \frac{\eta_{\text {exergético }} \cdot \mathrm{B}_{\text {combustivel }}}{\mathrm{B}_{\text {combustivel }}+\left(1-\eta_{\text {exergético }}\right) \cdot \mathrm{B}_{\text {combustivel }}}=\frac{\eta_{\text {exergético }}}{\left(2-\eta_{\text {exergético }}\right)}
\end{aligned}
$$

A Fig. 11.3 mostra a variação de $\lambda$ em função da eficiência exergética.

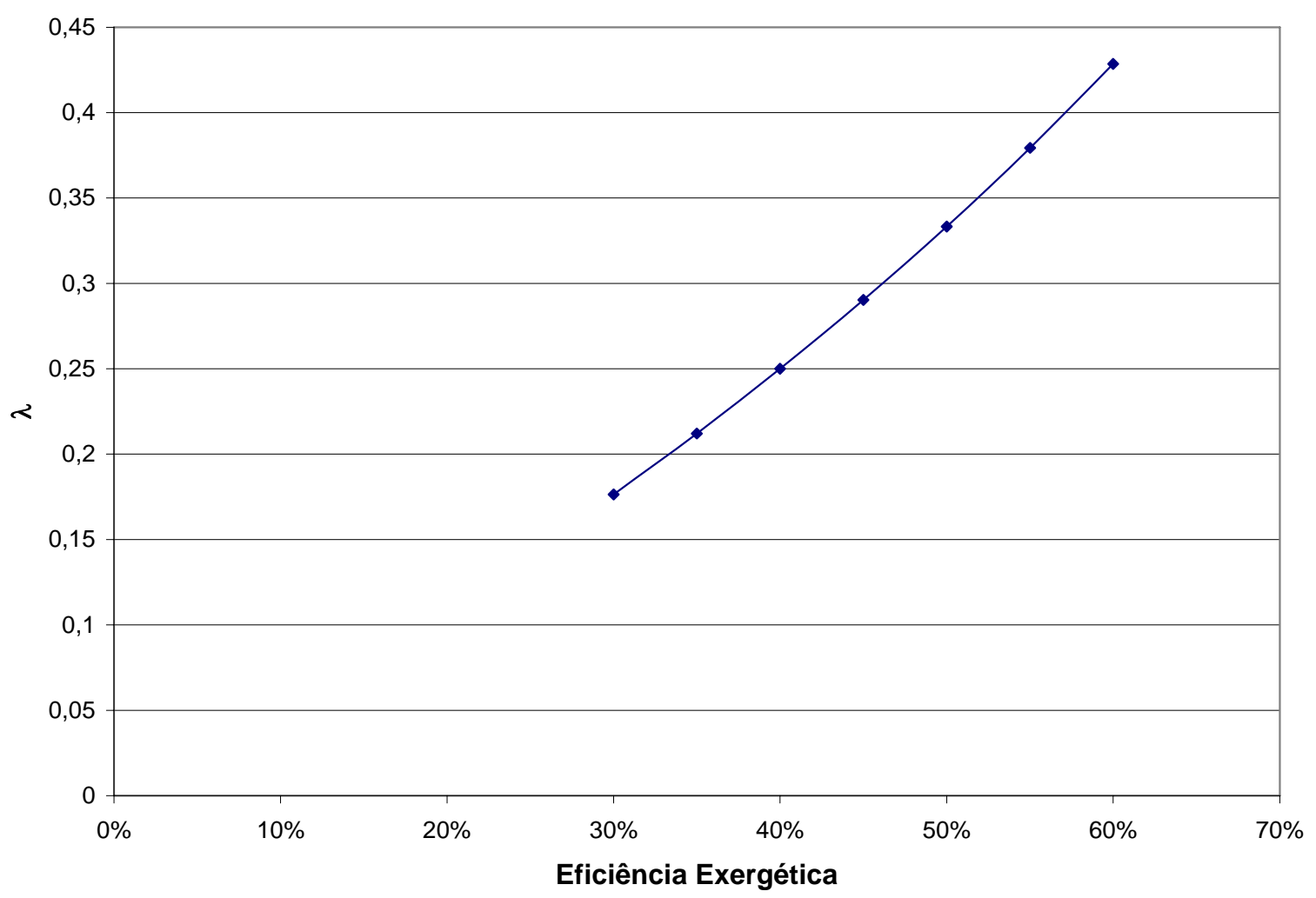

Figura 11.5 - Variação de $\lambda$ em função da eficiência exergética.

As unidades termelétricas a vapor movidas a carvão mineral apresentam eficiências entre $35 \%$ para plantas subcríticas e 50\% para modernas plantas supercríticas. As plantas baseadas em ciclos combinados apresentam eficiências de até $60 \%$. Esse valores representam $\lambda$ 's entre 0,18 e 0,43 . 
Os sistemas com turbinas de condensação apresentam um desempenho ambiental similar às plantas termelétricas com eficiências abaixo de 30\%. As plantas com turbinas de contrapressão e altos consumos de vapor no processo tem desempenho superior a plantas termelétricas de eficiências até $50 \%$. Neste caso, o calor consumido no processo produzido em conjunto com a energia eletro-mecânica evidencia os benefícios ambientais dos sistemas de cogeração com relação à plantas de geração exclusiva de eletricidade a partir de combustíveis fósseis. Entretanto, não deve ser esquecido o fato de que olhando a usina como um todo, altos consumos de vapor no processo representam menores valores de $\lambda$.

Os sistemas avancados de cogeração mostraram desempenhos ambientais superiores a plantas termelétricas com $60 \%$ de eficiência, as mais avançadas atualmente.

\subsection{COMENTÁRIOS GERAIS}

A discussão inicial deste capítulo permitiu a seguinte definição para um insumo renovável: aquele possível de ser regenerado sem causar danos imediatos ao meio-ambiente dentro da escala de tempo da vida humana.

Diante dessa definição, um índice exergético de renovabilidade é proposto. Esse indicador leva em consideração a exergia destruída pelo processo, de maneira que mesmo com o aporte de insumos renováveis, uma operação muito ineficiente prejudica o desempenho ambiental da planta. Ao mesmo tempo em que processos que fazem uso apenas de insumos não-renováveis, caso sejam muito eficientes, podem vir a ter desempenhos superiores àqueles com insumos renováveis.

A aplicação de $\lambda$ às configurações propostas para a produção combinada de açúcar, álcool e eletricidade indicou que o desempenho ambiental é melhor quanto maior for a geração de eletricidade excedente.

Os resultados mostraram também que os sistemas de cogeração com turbinas de condensação são uma alternativa pouco atrativa ambientalmente quando comparada com plantas termelétricas movidas a combustíveis fósseis. Os sistemas com turbinas de contrapressão com altos consumos de vapor são ambientalmente melhores, caso apenas o sistema de cogeração 
seja levado em consideração, porém diminuem o desempenho ambiental da usina como um todo devido à maior geração de entropia dos processos de produção de açúcar e álcool.

O sistema supercrítico tem um desempenho ambiental superior aos sistemas BIGCC atmosféricos. Isso é um resultado direto do grande consumo interno de eletricidade desses últimos, devido ao compressor de gás produzido para injeção na turbina a gás. Todavia, os últimos são melhores considerando a usina como um todo devido à maior geração de eletricidade excedente. O sistema BIGCC pressurizado foi o que apresentou o maior valor para $\lambda$, dentre todas as opções analisadas.

Esses resultados indicam que a conversão bagaço-eletricidade nos sistemas de cogeração em usinas deve ser otimizada buscando o melhor desempenho ambiental da usina como um todo e também da cogeração.

É importante observar que a ampliação do volume de controle da análise para levar em consideração o combustível utilizado nos caminhões de transporte da cana tem um impacto negativo nos valores de $\lambda$ para a usina, sendo importante uma maior discussão sobre a questão da renovabilidade do álcool, atualmente feita considerando apenas balanços de massa e energia. 


\section{CONCLUSÕES}

A questão levantada nessa tese foi a maximização da geração do excedente de eletricidade em usinas sucroalcooleiras e seu impacto nas produções de açúcar, álcool e eletricidade, considerando uma abordagem termo-econômica-ambiental. Desta maneira, uma proposta para a avaliação do uso racional da energia em usinas foi desenvolvida, utilizando as análises exergética e termoeconômica como ferramentas de avaliação das alternativas propostas sob o ponto de vista da Termodinâmica, da análise econômico-financeira e da perspectiva ambiental.

O levantamento bibliográfico indicou que Agroindústria Canavieira Brasileira evoluiu desde o seu início no séc. XVI de uma cultura baseada exclusivamente na produção de açúcar para exportação para uma atividade agroindustrial complexa com a produção simultânea de diversos produtos (podendo ser chamada de uma planta de poligeração), ou como muitos preferem, uma empresa de energia no séc. XXI. Recentemente, a UNICA lançou o termo setor sucroenergético.

Foram mostrados os diferentes processos de conversão de energia pertinentes a essa agroindústria, desde a absorção da exergia da radiação solar pela planta até a conversão de cana em açúcar, álcool e eletricidade. Priorizando a parte industrial da cadeia (da usina para dentro), uma análise exergética rigorosa foi desenvolvida para uma usina, cujos parâmetros de operação podem ser considerados médios para o setor. Para tanto, um modelo computacional foi elaborado, o qual permite simular os diferentes equipamentos que compõem a usina.

Os resultados da análise indicaram que a planta de utilidades (sistema de cogeração) é o responsável por mais da metade das irreversibilidades geradas na usina. Assim, foi proposta a avaliação de diferentes tecnologias de cogeração aplicáveis a usinas sucroalcooleiras. A idéia por trás dessa avaliação é que nenhuma otimização isolada em outra parte do processo seria capaz de gerar ganhos superiores a modificações que visassem melhorar o desempenho do sistema de cogeração. Todavia, mesmo o aumento da eficiência do sistema de cogeração requer modificações nos demais processos de conversão de energia, dada a grande interrelação entre os diversos processos da usina. A análise exergética revelou ainda o impacto 
negativo da baixa integração térmica dos processos de transferência de calor na geração de entropia, sobretudo no evaporador de múltiplos-efeitos.

A caldeira é o equipamento responsável pela maior destruição de exergia na usina, seguido pelo sistema de fermentação. Nas moendas, as turbinas dos acionamentos mecânicos são responsáveis por $40 \%$ das irreversibilidades. O uso de válvulas de expansão representa uma perda de potencial de realização de trabalho próximo a $10 \%$ da geração de energia eletromecânica total da usina. Os fluxos de condensados quentes são resfriados em sistemas abertos, rejeitando calor para o meio-ambiente. As grandes diferenças de temperatura entre o agente de aquecimento e o fluxo a ser aquecido evidencia as altas irreversibilidades dos processos de transferência de calor. A baixa integração térmica entre o evaporador de múltiplos-efeitos e os processos de aquecimento resulta em uma grande quantidade de vapor de baixa qualidade que deve ser condensado sem realizar nenhum efeito útil. Diante desse cenário, as modificações propostas foram:

$\checkmark$ Eletrificação dos acionamentos do sistema de extração;

$\checkmark$ Melhor integração térmica dos processos de aquecimento de caldo com as diferentes extrações de vapor do evaporador de múltiplos-efeitos;

$\checkmark$ Variação das pressões em cada efeito do evaporador;

$\checkmark$ Diminuição dos parâmetros de consumo de vapor na destilaria;

$\checkmark$ Pressões e temperaturas mais elevadas para geração de vapor nas caldeiras;

$\checkmark$ Utilização de turbinas com eficiências isoentrópicas mais elevadas;

$\checkmark$ Integrar tecnologias mais avançadas de cogeração, considerando o uso de vapor supercrítico e ciclos combinados com gaseificação de biomassa.

Para todas as modificações propostas foi avaliado o desempenho termodinâmico, econômico e ambiental da usina, a fim de estabelecer as melhores opções.

Sob a ótica da Termodinâmica, utilizou-se a Termoeconomia como a ferramenta-base para identificar como as propostas de configurações impactam no desempenho termodinâmico da usina, por meio do cálculo dos custos em base exergética do açúcar, álcool e eletricidade. Os resultados indicaram que a maximização da eficiência do sistema de cogeração leva à minimização dos custos em base exergética de produção de açúcar, álcool e eletricidade. Sendo tal maximização função da maior geração excedente de eletricidade. 
O impacto positivo nos custos do açúcar e do álcool em função do aumento da pressão e temperatura de geração do vapor é evidente, pois essa modificação altera diretamente a geração de entropia no principal equipamento de destruição de exergia (caldeira). Ainda, a redução do consumo de vapor no processo com o uso de turbinas de condensação melhora o desempenho da usina como um todo. A utilização de sistemas avançados de cogeração reduz significativamente os custos, sendo a variação máxima dos custos do açúcar e do álcool entre esses sistemas - sistema supercrítico e o sistema com gaseificação pressurizada - igual a 5\%.

É importante mencionar que a modificação da metodologia de atribuição de custos não altera a hierarquização das alternativas propostas, ou seja, os resultados qualitativos são independentes do critério de atribuição de custos.

Por outro lado, a atribuição de custo zero ao bagaço excedente para os sistemas de contrapressão implica uma forte penalização aos custos de produção de açúcar, álcool e eletricidade. Aliás, a questão de como avaliar o bagaço excedente influencia a maneira como a eficiência exergética da usina deve ser calculada. As duas propostas mostradas na tese não apresentaram resultados convergentes com a variação das produções de açúcar e álcool para uma determinada configuração do sistema de cogeração.

Desta maneira, a melhor alternativa como medida de desempenho na usina é o Potencial de Melhoria, pois trata o bagaço como um sub-produto que poderia ser utilizado para produção de um novo produto. Para essa tese, o foco foi a geração de eletricidade a partir deste excedente.

Os sistemas convencionais de cogeração permitem uma geração de até 80-100 kWh/tc dependendo do consumo de vapor no processo. O sistema supercrítico é capaz de gerar 142 $\mathrm{kWh} / \mathrm{tc}$, um aumento de mais de $40 \%$. Todavia, sua utilização é restrita a usinas com grandes capacidades de moagem, dadas as restrições técnicas impostas pelas turbinas supercríticas (não menores que $280 \mathrm{MW}$ ). Entretanto, uma característica do sistema supercrítico pode e deve ser utilizada pelas usinas para melhorar a eficiência dos sistemas de cogeração, o uso de trocadores de calor regenerativos, elevando a temperatura da água de alimentação da caldeira. Com os atuais níveis de consumo de vapor no processo é possível avaliar o impacto da instalação desses trocadores. 
Os sistemas com ciclos combinados e gaseificação de biomassa apresentam as maiores gerações de eletricidade excedente, chegando a $200 \mathrm{kWh} / \mathrm{tc}$ para os sistemas pressurizados. Tomando a safra 2008/09 como base, esses sistemas representam um potencial de 111 TWh/ano, ou seja, 25\% da geração brasileira. Os sistemas com gaseificação atmosférica apresentam uma desvantagem que é a necessidade do uso de um compressor para o gás produzido antes desse ser injetado na turbina a gás, o que eleva muito o consumo interno de potência do sistema de cogeração.

Comparativamente, os sistemas com ciclos combinados são mais eficientes que o sistema supercrítico, porém esse último é uma tecnologia madura, com plantas em operação comercial queimando biomassa, enquanto os primeiros ainda estão em fase de desenvolvimento para geração comercial.

Outro aspecto relevante avaliado foi como a melhor eficiência dos processos de conversão de energia altera a rentabilidade dos produtos da usina. Para tanto, foi proposta uma análise da margem de contribuição para esses produtos, tendo como base os custos calculados, porém em base monetária, e sem levar em consideração os custos fixos. Conclui-se que a maximização do lucro da usina está diretamente relacionada ao melhor uso da exergia disponível na cana, sobretudo com a otimização da planta de utilidades, a qual reduz os custos de produção da eletricidade e do vapor utilizados nos processos de produção de açúcar e álcool, além de acrescentar uma receita com a venda do excedente de eletricidade. Ainda, a margem de contribuição da eletricidade para os sistemas avançados de cogeração é muito superior aos demais, havendo ganhos também nas margens dos demais produtos. Nota-se que para o sistema de cogeração mais eficiente (ciclo combinado com gaseificação pressurizada), inclusive, a margem de contribuição da eletricidade é maior que do álcool e muito próxima à do açúcar.

Apesar dos evidentes benefícios obtidos pela otimização dos processos de conversão de energia, a tomada de decisão com relação a se fazer ou não alterações nos processos da usina passa, necessariamente, por uma análise econômico-financeira a fimm de verificar a viabilidade do investimento necessário. Optou-se, portanto, por verificar se o ganho econômico obtido com o aumento da margem de contribuição total da usina seria suficiente para remunerar o investimento necessário. Verificou-se que as modificações mais atrativas financeiramente são 
aquelas cujos aumentos de investimento ocorrem na mesma proporção que os ganhos termodinâmicos.

Assim, para os sistemas convencionais, a geração de vapor a 67 bar e $480^{\circ} \mathrm{C}$ é a alternativa mais atrativa economicamente, já que os aumentos de investimento para geração de vapor em pressões e temperaturas mais elevadas não é compensado pelos ganhos termodinâmicos, tanto para os sistemas de contrapressão quanto para os de condensação. A eletrificação das moendas não se mostrou viável economicamente para sistemas com geração de vapor acima de 67 bar, pois o ganho de geração excedente não é capaz de remunerar o investimento necessário. Todavia, caso a substituição das turbinas de acionamento da moenda seja necessária devido ao esgotamento da sua vida útil ou para aumento da capacidade de moagem, então a eletrificação é uma alternativa mais atrativa. Comparando os sistemas com turbina de contrapressão com os sistemas com turbinas de condensação, os primeiros apresentam uma atratividade maior, pois não requerem investimentos adicionais no processo para redução do consumo de vapor. Muito embora, em usinas com baixos consumos de vapor ou em novas unidades projetadas com processos mais eficientes de transferência de calor, os sistemas com turbinas de condensação são a melhor opção. A análise de sensibilidade desenvolvida para os sistemas de contrapressão indicou que o aumento do tempo de safra tem um impacto muito positivo na economicidade desses sistemas. Isto foi confirmado na análise dos sistemas de condensação operando durante o ano todo, que apresentam TIR's e VPL's mais elevados para todas as configurações convencionais avaliadas. Para as tecnologias mais avançadas de cogeração, é interessante notar que os sistemas supercríticos são mais atrativos economicamente que os sistemas BIGCC atmosféricos, mesmo sendo menos eficientes. Isto é resultado dos elevados consumos internos dos sistemas BIGCC atmosféricos (compressor de gás produzido), requerendo maiores capacidades instaladas para a geração de eletricidade excedente similar ao do sistema supercrítico.

Finalmente, uma discussão sobre a renovabilidade dos processos foi desenvolvida a partir da proposta de um índice exergético de renovabilidade $(\lambda)$. Esse índice leva em consideração a eficiência do processo de conversão de energia e não apenas o balanço de massa entre as entradas e saída. Dessa maneira, mesmo com o aporte de insumos renováveis, uma operação muito ineficiente prejudica o desempenho ambiental do processo. Ao mesmo tempo que processos que fazem uso apenas de insumos não-renováveis, caso sejam muito eficientes, podem vir a ter desempenhos superiores àqueles com insumos renováveis. 
Utilizando o índice para comparar o desempenho das alternativas propostas, observou-se que que o aumento da eficiência do sistema de cogeração (maior geração de eletricidade excedente) e a melhor integração térmica dos processos da usina (redução do consumo de vapor) melhoram o desempenho ambiental da usina como um todo. Essas duas medidas têm como objetivo: a) otimizar o uso do bagaço como combustível para o sistema de cogeração, maximizando a geração de eletricidade excedente; b) diminuir a geração de entropia dos processos de transferência de calor e massa nos processos. Desta maneira, aumentam a exergia dos produtos (numerador do $\lambda$ ) enquanto diminuem as exergias destruídas e perdidas (denominador do $\lambda$ ).

Os resultados mostraram também que os sistemas de cogeração com turbinas de condensação são uma alternativa pouco atrativa ambientalmente quando comparada com plantas termelétricas movidas a combustíveis fósseis. Os sistemas com turbinas de contrapressão com altos consumos de vapor são ambientalmente melhores, caso apenas o sistema de cogeração seja levado em consideração, porém diminuem o desempenho ambiental da usina como um todo devido à maior geração de entropia dos processos de produção de açúcar e álcool.

O sistema supercrítico tem um desempenho ambiental superior aos sistemas BIGCC atmosféricos. Isso é um resultado direto do grande consumo interno de eletricidade desses últimos, devido ao compressor de gás produzido para injeção na turbina a gás. Todavia, os últimos são melhores considerando a usina como um todo devido à maior geração de eletricidade excedente. O sistema BIGCC pressurizado foi o que apresentou o maior valor para $\lambda$, dentre todas as opções analisadas.

De uma maneira geral, mostrou-se que a redução da geração de entropia nos processos de conversão de energia trazem benefícios técnicos, econômicos e ambientais, sobretudo quando o desempenho do sistema de cogeração é melhor. Dentre as alternativas avaliadas, o sistema com gaseificação pressurizada integrado a um ciclo combinado mostrou-se como a melhor opção, tomando-se como "função-objetivo" tanto a redução dos custos em base exergética como o índice exergético de renovabilidade. Porém, sob o ponto de vista da análise econômica, a geração de eletricidade ao longo do ano todo com turbinas de condensação e vapor a 67 bar e $480^{\circ} \mathrm{C}$ apresentou os melhores indicadores econômicos, muito parecidos com 
os valores encontrados para o sistema com gaseificação pressurizada integrado a um ciclo combinado, caso seu custo por $\mathrm{kW}_{\text {inst }}$ seja $\mathrm{R} \$ 2.500$, mesmo valor dos sistemas com turbinas de condensação.

Para as usinas existentes, é necessário estudar qual a configuração melhor se adéqua a sua condição de consumo de vapor, baseando esse estudo nos ganhos termodinâmicos possíveis de serem obtidos frente aos investimentos necessários. Essa relação deve ainda abordar a questão dos benefícios ambientais de se optar por plantas mais eficientes.

Com relação a novos projetos, é importante manter o foco na busca por sistemas que maximizem a eficiência exergética da usina, pois isso claramente irá melhorar o desempenho econômico e ambiental da mesma.

O índice exergético de renovabilidade abre um novo campo de discussão sobre o quão renovável é o álcool produzido a partir da cana, pois para apenas uma configuração seu valor foi maior que 1 .

Como já discutido, o foco dessa tese é a geração de eletricidade excedente para comercialização. Todavia, essa não é a única alternativa para o uso do bagaço. Assim, os critérios apresentados para estudar comparativamente as diversas alternativas de geração, poderão ser usados para comparar qualitativa e quantitavimente a melhor rota de conversão do bagaço.

\subsection{SUGESTÃO PARA TRABALHOS FUTUROS}

a) Desenvolver uma análise dedicada ao sistema com gaseificação pressurizada integrado a um ciclo combinada, utilizando informações mais detalhadas sobre os equipamentos que compõem esse sistema, a fim de maximizar a sua geração de eletricidade;

b) Ampliar o modelo computacional desenvolvido, incluindo procedimentos para simular a fermentação e a destilação. Incluir também um módulo que permita avaliar o uso do bagaço para a produção de álcool;

c) Estudar os benefícios ou malefícios do uso do difusor, considerando o impacto nos custos em base exergética dos produtos;

d) Estudar o uso de diferentes tipos de secagem de bagaço; 
e) Fazer o estudo integrado de uma usina associado a uma planta para a produção de biodiesel;

f) Avaliar o recolhimento da palha para viabilização da geração ao longo do ano todo para os sistemas mais avançados de cogeração;

g) Explorar a questão da uniformização da geração de entropia nos efeitos do evaporador de múltiplos-efeitos para maximização do desempenho desse equipamento;

h) Estudar diferentes arranjos para a produção de álcool, utilizando novas tecnologias de separação;

i) Avaliar os possíveis benefícios do uso de trocadores regenerativos para aquecimento da água de alimentação das caldeiras;

j) Utilizar a proposta de avaliação da margem de contribuição para comparar a rentabilidade do uso do bagaço (eletricidade vs. álcool);

k) Utilizar o $\lambda$ para avaliar outros processos de produção de combustíveis tidos como renováveis e compará-los com o álcool da cana;

1) Ampliação da metodologia descrita nessa tese para avaliar outros setores com sistemas de cogeração (p.ex., papel e celulose). 


\section{REFERÊNCIAS BIBLIOGRÁFICAS}

ABBOT, M. M.; SMITH, J. M.; VAN NESS, H. C. Introduction to Chemical Engineering Thermodynamics. $6^{\text {th }}$ edition. Boston: McGraw-Hill, 2001. $789 \mathrm{p}$.

AGAZZANI, A.; MASSARDO, A. F.; FRANGOPOULOS, C. A. Environmental Influence on the Thermoeconomic Optimization of a Combined Plant with $\mathrm{NO}_{\mathrm{x}}$ Abatement. Journal of Engineering Gas Turbines and Power, v. 120, p. 557-565, jul. 1998.

AGROBYTE, Cana-de-Açúcar. Disponível em: http://www.agrobyte.com.br/cana n.htm, Acessado em: 01 out. 2007.

ALTAFINI, C. R.; WANDER, P. R.; BARRETO, R. M. Prediction of the Working Parameters of a Wood Waste Gasifier Through an Equilibrium Model. Energy Conversion and Management, v. 44, p. 2763-2777, 2003.

ARRIETA, F. R., LORA, E. S.; NEBRA, S. A. Thermoeconomic Analysis of BIG GT Cogeneration Plant". In: 8th Brazilian Congress of Thermal Engineering Sciences, 2000, Porto Alegre. Proceedings of the 8th Brazilian Congress of Thermal Engineering Sciences, 2000 (em CD-ROM).

ASHMORE, C. Steam Turbines. Energy Focus, n. 6, pp. 128-130, 2006.

ATALA, D. I. P. Montagem, instrumentação, controle e desenvolvimento experimental de um processo fermentativo extrativo de produção de etanol. $152 \mathrm{p}$. Tese (Doutorado) - Faculdade de Engenharia de Alimentos, Universidade Estadual de Campinas, Campinas, 2004.

AVRAM, P.; MORGENROTH, B.; SEEMANN, F. Benchmarking Concept for an Integrated Sugar, Ethanol and Cogeneration Plant. Zuckerindustrie, v. 129, n. 12, p. 875-879, 2004.

AVRAM, P.; STARK, T. Integration of Ethanol Production with a Sugar Factory Producing Maximum Cogeneration. International Sugar Journal, v. 106, n. 1263, p. 126-137, 2004

AVRUTSKII, G.D.; SAVENKOVA, I.A.; LAZAREV, M.V.; AKULENKO, V.V.; SHVARTS, A. L.; IVANOV, S. A. Development of Engineering Solutions for Creation of Turbine Plant for Power Unit with Supercritical Steam Parameters. Power Technology and Engineering, v. 39, n. 6, p. 342-346, 2005.

AYRES, R. U.; AYRES, L. W.; MARTINÁS, K. Exergy, Waste Accounting, and Life-cycle Analysis. Energy, v. 23, n. 5, p. 355-363, mai. 1998.

AZAPAGIC, A.; PERDAN, S.; CLIFT, R. (Ed.) Sustainable Development in Practice: Case Studies for Engineers and Scientists. West Sussex: Wiley, 2004. 446 p.

BAER, W. A Economia Brasileira. São Paulo: Nobel, 2a Ed., 2003. 509 p. 
BAIN, R. L.; OVEREND, R. P.; CRAIG, K. R. "Biomass-fired Power Generation. Fuel Processing Technology, v. 54, n. 1-3, p. 1-16, 1998.

BALESTIERI, L. A. P. Cogeração - Geração Combinada de Eletricidade e de Calor. Florianópolis: Editora UFSC, 2001. 279 p.

BALOH, T. Methods for Energy Investigations in Sugar Factories. Zuckerindustrie, v. 106, n. 1, p. 29-40, 1981.

BALOH, T.; Wärmewirtschaft. In: SCHNEIDER, F. (Org.) Technologie des Zuckers. $2^{\text {nd }}$ Edition. Hannover : M \& H Schaper, 1968.

BALOH, T.; WITTWER, E. Energy Manual for Sugar Factories. $2^{\text {nd }}$ Edition. Berlin: Bartens, 1995. $198 \mathrm{p}$.

BAPTISTA, M. A. C. Desenvolvimento de Tecnologia da Gaseificação de Bagaço de Cana em Leito Fluidizado. São Paulo: Instuto de Pesquisas Tecnológicas (IPT), 1986. (Rel. No 24574).

BARREDA DEL CAMPO, E. R. Avaliação Termoeconômica do Sistema de Cogeração da Usina Vale do Rosário. 283 p. Tese (Doutorado) - Faculdade de Engenharia Mecânica, Universidade Estadual de Campinas, Campinas, 1999.

BARREDA DEL CAMPO, E. R.; CERQUEIRA, S. A. A. G.; NEBRA, S. A. Thermoeconomic Analysis of a Cuban Sugar Cane Mill. Energy Conversion and Management, v. 39, p. 1773-1780, 1998.

BARROS, G. S. C.; MORAES, M. A. F. D. A Desregulamentação do Setor Sucroalcooleiro. Revista de Economia Política, vol. 22, p. 156-173, 2002.

BAYARAK, M.; MIDILLI, A.; NURVEREN, K. Energy and Exergy Analysis of Sugar Production Stages. International Journal of Energy Research, v. 27, p. 989-1001, 2003.

BEÉR J. M. High Efficiency Electric Power Generation: The Environmental Role. Energy, v. 33, p. 107-134, 2007.

BEJAN, A. Entropy Generation Minimization : The Method of Thermodynamic Optimization of Finite-Size Systems and Finite-Time Processes. Boca Raton : CRC Press, 1996. 362 p.

BEJAN, A.; MORAN, M.; TSATSARONIS, G. Thermal Design and Optimization. New York: John Wiley \& Sons, 1996. 542 p.

BEJARANO, C. H. M. Indicadores Exergéticos para Avaliação do Impacto Ambiental de Processos de Conversão de Energia. 134 p. Dissertação (Mestrado) - Escola Politécnica, Universidade de São Paulo, São Paulo, 2004.

BEJARANO, C. H. M.; OLIVEIRA JR., S. Environmental Exergy Analysis of Wastewater Treatment Plants. In: The $18^{\text {th }}$ International Conference on Efficiency, Costs, Optimization, Simulation and Environmental Impact of Energy Systems, Trondheim, 2005. Proceedings of The $\mathbf{1 8}^{\text {th }}$ International Conference on Efficiency, Costs, 
Optimization, Simulation and Environmental Impact of Energy Systems, v. 1, Trondheim: Tapi Academic Press. P. 85-93.

BENÍTEZ, A. J. Thermoeconomic Method Applied to New Energetic Proposals for Sugarcane Industry. In: In: $15^{\text {th }}$. International Conference on Efficiency, Costs, Optimisation, Simulation and Environmental Impacts of Energy Systems, 2002, Berlim. Proceedings of the $15^{\text {th }}$. International Conference on Efficiency, Costs, Optimization, Simulation and Environmental Impact of Energy Systems. Berlim: Technische Universität Berlin, Institute for Energy Engineering, 2002. v. II. p. 777-784.

BERTHIAUME, R.; BOUCHARD, C.; ROSEN, M. A. Exergetic Evaluation of the Renewability of a Biofuel. Exergy, An International Journal, v. 1,n. 4, p. 256-268, 2001

BEYER, J. Strukturuntersuchungen-notwendinger Bestandteil der Effektivitätsanalyse von Wärmeverbrauchersystemen (Structural Investigations - An Essential Part of the Analysis of the Efficiency of Thermal Systems). Energieanwendung, v. 19, n. 12, p. 358-361, dez. 1970.

BICKEL, P.; FRIEDRICH, R. ExternE - Externalities of Energy: Methodology 2005 Update. Luxemburgo: Office for Official Publications of the European Communities, 2004. $270 \mathrm{p}$.

BISIO, G.; BISIO, G. Some Thermodynamic Remarks on Photosynthetic Energy Conversion. Energy Conversion and Management, v. 39, n. 8, p. 741-748, 1998.

BOLUDA, N.; GOMIS, V.; RUIZ, F.; BAILADOR, H. The Influence of Temperature on the Liquid-Liquid-Solid Equilibria of the Ternary System Water + Ethanol + 1-Dodecanol. Fluid Phase Equilibra, v. 235, p. 99-103, 2005.

BORCHIELINI, R.; MASSARDO, A. F.; SANTARELLI, M. Analytical Procedure for Carbon Tax Evaluation. Energy Conversion and Management, v. 41, p. 1509-1531, 2000 .

BORCHIELINI, R.; MASSARDO, A. F.; SANTARELLI, M. Carbon Tax vs $\mathrm{CO}_{2}$ Sequestration Effects on Environomic Analysis of Existing Power Plants. Energy Conversion and Management, v. 43, p. 1425-1443, 2002.

BRASIL. Agência Nacional de Energia Elétrica (ANEEL). BIG - Banco de Informações de Geração. 2008. Disponível em: http://www.aneel.gov.br/aplicacoes/capacidadebrasil/CombustivelPorClasse.asp?Classe= Biomassa. Acessado em: 13 nov. 2008.

BRASIL. Associação Nacional dos Fabricantes de Veículos Automotores (ANFAVEA). Anuário da Indústria Automobilística Brasileira. 2007. Disponível em: http://www.anfavea.com.br/anuario.html. Acesso em: 01 out. 2007.

BRASIL. Companhia de Tecnologia de Saneamento Ambiental (CETESB). A Produção Mais Limpa no Setor Sucroalcooleiro, 2002. Disponível em: http://www.cetesb.sp.gov.br/Tecnologia/camaras/texto_ca/documentos/procao_mais_limp a sucroalcooleiro.pdf. Acessado em: 01 out. 2007. 
BRASIL. Companhia Nacional de Abastecimento (CONAB). Acompanhamento da Safra Brasileira Cana-de-Açúcar. Safra 2008/2009, Segundo Levantamento, agosto/2008. Brasília: Conab, 2008. Disponível em: http://www.conab.gov.br/conabweb/download/safra/cana.pdf. Acessado em: 13 nov. 2008.

BRASIL. Companhia Nacional de Abastecimento (CONAB). Acompanhamento da Safra Brasileira de Grãos. Safra 2008/09, Segundo Levantamento, novembro/2008. Brasília: Conab, 2008. Disponível em: http://www.conab.gov.br/conabweb/download/safra/2graos_08.09.pdf. Acessado em: 13 nov. 2008.

BRASIL. Empresa de Planejamento Energético (EPE). Leilão de Energia de Reserva negocia 2.379 MW de térmicas à biomassa. Rio de Janeiro: EPE, 2008. Disponível em: http://www.epe.gov.br/Lists/LeilaoFA2008/Leilao.aspx. Acessado em: 13 nov. 2008.

BRASIL. Empresa de Planejamento Energético (EPE). Plano Decenal de Energia 20072016. Rio de Janeiro: EPE, 2007. Disponível em: http://www.epe.gov.br/PDEE/Forms/EPEEstudo.aspx. Acessado em: 01 out. 2007.

BRASIL. Ministério das Minas e Energia (MME). Empresa de Planejamento Energético (EPE). Balanço Energético Nacional 2007: Ano Base 2006. Rio de Janeiro: EPE, 2007. Disponível em: http://www.mme.gov.br/site/menu/select_main_menu_item.do?channelId=1432\&pageId= 14493. Acessado em: 01 out. 2007.

BRASIL. Ministério das Minas e Energia (MME). Empresa de Planejamento Energético (EPE). Balanço Energético Nacional 2008: Ano Base 2007. Rio de Janeiro: EPE, 2008. Disponível em: http://www.mme.gov.br/site/menu/select main menu item.do?channelId=1432\&pageId= 17036. Acessado em: 13 nov. 2008.

BRASIL. União da Agroindústria Canavieira (ÚNICA). Avaliação Final da Safra 06/07 Região Centro-Sul, 2006 Disponível em: http://www.portalunica.com.br/portalunica/files/referencia_palestraseapresentacoes_coleti vas-10-Arquivo.pdf. Acessodo em: 01 out. 2007.

BRAUNBECK, O.; BAUEN, A.; ROSILlO-CALLE, F.; CORTEZ, L. Prospects for green cane harvesting and cane residue use in Brazil. Biomass and Bioenergy, v. 17, pp. 495$506,1999$.

BREALEY, R. A.; MYERS, S. C.; ALLEN, F. Principles of Corporate Finance. New York: McGraw-Hill/Irwin, $8^{\text {th }}$ Ed., 2006. 1028 p.

BRITISH PETROLEUM (BP). BP Statistical Review of World Energy June 2007. Londres: British Petroleum, 2007. 45 p. Disponível em: http://www.bp.com/statisticalreview. Acesso em: 01 out. 2007.

BRODYANSKY, V. M.; SORIN, M. V.; LE GOFF, P. The Efficiency of Industrial Processes: Exergy Analysis and Optimization. Amsterdã: Elsevier, 1994. 487 p. 
BUGGE, J.; KJÆR, S.; BLUM, R. High-efficiency Coal-fired Power Plants Development and Perspectives. Energy, v. 31, p. 1437-1445, 2006.

BURER, M.; TANAKA, K.; FAVRAT, D.; YAMADA, K. Multi-criteria Optimization of a District Cogeneration Plant Integrating a Solid Oxide Fuel Cell-Gas Turbine Combined Cycle, Heat Pumps and Chillers. Energy, v. 24, p. 497-518, 2003.

CAMARGO, A. C. (Coord.) Conservação de Energia na Indústria do Açúcar e do Álcool. São Paulo: Instituto de Pesquisas Tecnológicas (IPT), 1990. 796 p.

CÁRDENAS, G. J.; PAZ, D.; WITTWER, E. Análisis Energético y Exergético de um Sistema Caldera-Secadero de Bagazo. International Sugar Journal, v. 96, p. 213-219, 1994.

CARVALHO, C. P. Novas Estratégias Competitivas para o Setor Sucro-alcooleiro: o Caso de Alagoas. Revista Política Agrícola, Ano IX, n. 01, pp. 14-26, jan.-mar. 2000.

CASTIER, M.; RAJAGOPAL, K. Thermodynamic Analysis of an Alcohol Distillery, Energy, v. 13, p. 455-459, 1988.

CECHIN, A. D. Georgescu-Roegen e o Desenvolvimento Sustentável: Diálogo ou Anátema?. 208 p. Dissertação (Mestrado) - Programa de Pós-Gradução em Ciência Ambiental, Universidade de São Paulo, 2008.

CECHIN, A. D.; MAGALHÃES, R. S. A Economia da Sobrevivência e seus Fundamentos Sociais. In: VII Encontro da Sociedade Brasileira de Economia Ecológica, Foratleza, 2830 nov. 2007.

CERQUEIRA, S. A. A. G. Metodologias de Análise Termoeconômica de Sistemas. 137 p. Tese (Doutorado) - Faculdade de Engenharia Mecânica, Universidade Estadual de Campinas, Campinas, 1999.

CHAVES, I. Custo de Produção de Cana, Açúcar e Álcool. Ribeirão Preto: Chaves Planejamento e Consultoria Ltda, 2005.

CHEN, G. Q. Exergy Consumption of the Earth. Ecological Modelling, v. 184, n. 2-4, p. 363-380, 2005.

CHRISTODOULO, P. Energy Economy Otimization in the Separation Processes: Optimizing the Separation of Sucrose/Water and Non-Sugars. International Sugar Journal, v. 98, p. 419-430, 1996.

COELHO, S. T. Avaliação da Cogeração de Eletricidade a Partir de Cana de Açúcar em Sistemas de Gaseificação e Turbina a Gás. 148 p. + anexos. Dissertação (Mestrado) Instituto de Eletrotécnica e Energia, Universidade de São Paulo, São Paulo, 1992.

COELHO, S. T. Mecanismos para Implementação da Cogeração de Eletricidade a partir da Biomassa: um Modelo para o Estado de São Paulo. 200 p. + anexos. Tese (Doutorado) - Instituto de Eletrotécnica e Energia, Universidade de São Paulo, São Paulo, 1999. 
COELHO, S. T.; MARTINS, S.; SANTOS, S. M. A. O Estado da Arte da Gaseificação. Comparação entre Tecnologias de Gaseificação de Biomassa existentes no Brasil e no Exterior e Formação de Recursos Humanos na Região Norte, CENBIO, 2002.

COELHO, S. T.; OLIVEIRA JR., S.; ZYLBERSTJAN, D. Thermoeconomic Analysis of Electricity Cogeneration from Sugarcane Origin. In: Third Biomass Conference of the Americas, 1997, Montreal. Proceedings of the Third Biomass Conference of the Americas, 1997, Montreal: Elsevier, p. 1631-1640.

CONSONNI, S.; LARSON, E. D. Biomass-Gasifier/Aeroderivative Gas Turbine Combined Cycles: Part A - Technologies and Performance Modeling and Part B - Performance Calculations and Economic Assessment. Journal of Engineering for Gas Turbine and Power, v. 118, p. 507-525, 1996.

COPERSUCAR, Piracicaba. Disponível em: http://www.copersucar.com.br. Acessado em: 01 out. 2007.

CORDONA, C. A.; SANCHEZ, O. J. Fuel Ethanol Production - Process Design Trends and Integration Opportunities. Bioresource Technology, v. 98, p. 2415-2457, 2007.

CORELLA, J.; SANZ, A. Modeling Circulating Fluidized Bed Biomass Gasifiers: A PseudoRigorous Model for Stationary State. Fuel Processing Technology, v. 86, n. 9, p. 10211053, mai. 2005.

CORNELISSEN, R. A. Thermodynamics and Sustainable Development: The Use of Exergy Analysis and the Reduction of Irreversibility. 170 p. Tese (Doutorado) University of Twente, Enschede, 1997.

CORNELISSEN, R. A.; HIRS, G. G. The Value of the Exergetic Life Cycle Assessment Besides the LCA. Energy Conversion and Management, v. 43, n. 9-12, p. 1417-1424, jun.-ago. 2002.

CORTEZ, L. A. B.; LORA, E. S. (Coord.) Tecnologias de Conversão Energética da Biomassa. Manaus: EDUA/EFEI, 1997. 540 p.

CRAIG, K. R.; MANN, M. K. Cost and Performance Analysis of Three Integrated Biomass Gasification Combined Cycle Power Systems. NREL, 1997

CURTI, V.; VON SPAKOVSKY, M. R.; FAVRAT, D. An Environomic Approach for the Modeling and Optimization of a District Network based on Centralized and Decentralized Heat Pumps, Cogeneration and/or Gas Furnace. Part I: methodology. Part II: application. International Journal of Thermal Sciences, v. 39, p. 721-741, 2000.

DERMIBAS, A. Combustion Characteristics of Different Biomass Fuels. Progress in Energy and Combustion Science, v. 30, n. 2, p. 219-230, 2004.

DEWUlF, J.; VAN LANGENHOVE, H. (eds). Renewables-Based Technology. West Sussex: John Wiley \& Sons, 2006. 368 p.

DEWULF, J.; VAN LANGENHOVE, H. Integrating industrial ecology principles into a set of environmental sustainability indicators for technology assessment. Resources, Conservation and Recycling, v. 43, n. 4, p. 419-432, 2005. 
DRBAL, L. F. (Ed.) Power Plant Engineering. New York: Chapman \& Hall, 1996. 858 p.

EL-SAYED, Y. M. The Thermoeconomics of Energy Conversion. Oxford: Elsevier, 2003. $264 \mathrm{p}$.

EL-SAYED, Y. M.; EVANS, M. Thermoeconomics and Design of Heat Systems, Journal of Engineering for Power, v. 92, n. 1, p. 27-35, jan. 1970.

EL-WAKIL, M. M. Powerplant Technology. New York: Mc-Graw-Hill International Editions, 1984. $861 \mathrm{p}$.

ENSINAS, A. V. Integração Térmica e Otimização Termoeconômica aplicada ao Processo Industrial de Produção de Açúcar e Etanol a partir da Cana-de-Açúcar. 2008. 216 p. Tese (Doutorado) - Faculdade de Engenharia Mecânica, Universidade Estadual de Campinas, Campinas, 2008.

ENSINAS, A. V.; MODESTO, M., NEBRA, S. A. Analysis of Different Cane Juice Extraction Systems for Sugar and Ethanol Production: Influences on Electricity Generation and Final Products Exergetic Costs. In: The 20th International Conference on Efficiency, Costs, Optimization, Simulation and Environmental Impact of Energy Systems, Padova, 2007. Proceedings of the $\mathbf{2 0}^{\text {th }}$ International Conference on Efficiency, Costs, Optimization, Simulation and Environmental Impact of Energy Systems, Padova: Sevizi Grafici Editoriali, 2007. v. 1. p. 727-734.

ENSINAS, A. V.; MODESTO, M., NEBRA, S. A., SERRA, L. Exergy loss minimization in A sugarcane industry with integrated sugar, ethanol and electricity production. In: 4th Dubrovnik Conference on Sustainable Development of Energy, Water and Environment System, 2007, Dubrovnik. Proceedings of the Conference on Sustainable Development of Energy, Water and Environment Systems. Dubrovnik, 2007a.

ENSINAS, A. V.; MODESTO, M., NEBRA, S. A., SERRA, L. Reduction of irreversibility generation in sugar and ethanol production from sugarcane. Energy, 2008. (no prelo)

ENSINAS, A. V.; NEBRA, S. A.; LOZANO, M. A.; SERRA, L. Analysis of process steam demand reduction and electricity generation in sugar and ethanol production from sugarcane. Energy Conversion and Management, v. 48, n. 11, p. 2978-2987, 2007 b.

ENSINAS, A. V.; NEBRA, S. A.; LOZANO, M. A.; SERRA, L. Optimization of Thermal Energy Consumption in Sugar Cane Factories. In: The $19^{\text {th }}$ International Conference on Efficiency, Costs, Optimization, Simulation and Environmental Impact of Energy Systems, Aghia Pelagia, 2006. Proceedings of The $19^{\text {th }}$ International Conference on Efficiency, Costs, Optimization, Simulation and Environmental Impact of Energy Systems, Aghia Pelagia: Spyros Zervos, 2006. v. 1. p. 207-214.

ERLACH, B.; SERRA, L.; VALERO, A. Structural Theory as Standard for Thermoeconomics. Energy Conversion and Management, v. 40, p. 1627-1649, 1999.

ERLACH, B.; TSATSARONIS, G.; CZIESLA, F. A New Approach for Assigning Costs and Fuels to Cogeneration Products. International Journal of Applied Thermodynamics, $v$ 4, n 3, p. 145-156, set. 2001. 
FAO. Oportunidades e Riscos do Uso da Bioenergia para a Segurança Alimentar para a América Latina e Caribe. Food and Agriculture Organization of the United Nations, 2007. Disponível em: http://www.rlc.fao.org/prior/segalim/pdf/bioenergiapor.pdf. Acessado em: 01 out. 2007.

FARIA, S. H. B. Estudo Energético de Colunas de destilação através de Analise Exergética - sistemas não ideais. 199 p. Tese (Doutorado) - Faculdade de Engenharia Química, Universidade Estadual de Campinas, Campinas, 2001.

FERnANDES, A. C. Cálculos na Agroindústria da Cana de Açúcar. Piracicaba: Stab e Editora EME, 2a Ed., 2003. 240 p.

FERNÁNDEZ PARRA, M. I.; NEBRA, S. A. Comparação do Desempenho do Processo de Evaporação através de uma Análise de Custo Exergético. In: XVI Congresso Brasileiro de Engenharia Mecânica, 2001, Uberlândia. Anais do XVI Congresso Brasileiro de Engenharia Mecânica. Uberlândia: Universidade Federal de Uberlândia, 2001. p. 386395.

FINGUERUT, J. Produção de Álcool: Pesquisa e Desenvolvimento. In: Curso Internacional "Energia na Indústria de Açúcar e Álcool", Núcleo de Estudos em Sistemas Térmicos, Universidade Federal de Itajubá, jul. 2004. Disponível em: http://www.nest.unifei.edu.br/portugues/Novidades/curso $\% 20 \mathrm{CYTED} / \mathrm{PDF} / \mathrm{Tema} \% 205 \%$ $\underline{20-}$ \%20Producao $\% 20 \mathrm{e} \% 20$ Uso $\% 20 \mathrm{do} \% 20$ Etanol $\% 20$ como $\% 20$ Combustivel/ProducaoAlcoo 1.PDF. Acessado em: 01 out. 2007.

FLORENTINO, H. O.; MORENO, E. V.; SARTORI, M. M. P. Multiobjective Optimization on Economic Balance from Harvesting Sugarcane Biomass. Scientia Agricola, v. 65, p. 561-564, 2008

FOCK, F.; THOMSEN, K. P. B. Modeling a Biomass Gasification System by Means of EES. In: The Scandinavian Simulation Society, Kgs. Lyngby : Technical University of Denmark, 2000.

FRANÇA, J. L.. Comunicação Pessoal. Proeng, 2008.

FRANCO, M. Integração Energética de Sistemas de Evaporação Localizados Abaixo do Ponto Pinch. 150 p. Dissertação (Mestrado) - Faculdade de Engenharia Química, Universidade Estadual de Campinas, Campinas, 2001

FRANGOPOULOS, C. A. An Introduction to Environomic Analysis and Optimization of Energy-Intensive Systems. In: International Symposium on Efficiency, Costs, Optimization and Simulation of Energy Systems, 1992, Zaragosa. Proceedings of the International Symposium on Efficiency, Costs, Optimization and Simulation of Energy Systems, Zaragosa, 1992. p. 231-239.

FRANGOPOULOS, C. A. Thermo-economic Functional Analysis and Optimization. Energy, v. 12, n. 7, p. 563-571, jul. 1987.

FRANGOPOULOS, C. A.; CARALIS, Y. C. A Method for Taking into Account Environmental Impacts in the Economic Evaluation of Energy Systems. Energy Conversion and Management, v. 38, n. 15-17, p. 1751-1763, 1997. 
FRANKE, J.; KRAL, R. Supercritical Boiler Technology for Future Market Conditions. In: Parsons Conference 2003, Dublin, 2003.

FRATZSCHER, W. Exergy and Possible Applications. Revue Générale de Thermique, v. 36, n. 9, p. 690-696, out. 1997.

GAGGIOLI, R. A.; EL-SAYED, Y. M. Critical review of second law costing methods. In: IV International Syposium on Second Law Analysis of Thermal Systems, New York, 1987. Proceedings of the IV International Syposium on Second Law Analysis of Thermal Systems. New York: ASME, 1987. p. 59-73. (ASME Book I00236).

GAGGIOLI, R. A.; WEPFER, W. J. Exergy Economics: I. Cost Accounting Applications, II. Benefit-Cost Conservation. Energy, v. 5, n. 8-9, p. 823-837, ago.-set. 1980.

GAGGIOLI, R. Efficiency and Costing. ACS Symposium Series, v. 235, n. 3, 1983.

GANDOLFI, R.; PELlEGRINI, L. F.; SILVA, G. A. L.; OlIVEIRA JR., S. Aircraft Air Management Systems Trade-off Study using Exergy Analysis as a Design Comparison Tool. In: 19th International Congress of Mechanical Engineering, 2007, Brasília. Proceedings of 19th International Congress of Mechanical Engineering, 2007. (em CD-ROM).

GAVIAO, A.; JAMOUTTE, A. L. Evaluation Économique de la Pollution de L'Environment par une Activité Industrielle: Application aux Centrales Électriques. Entropie, n. 121, p. $5-11,1985$.

GEORGESCU-ROEGEN, N. The Entropy Law and the Economic Process. Cambridge: Harvard University Press, 1971. 457 p.

GMEHLING, J.; ONKEN, U.; ARLT, W. Vapor-Liquid Equilibrium Data Collection Aqueous-Organic Systems. (Supplement I). DECHEMA Chemistry Data Series, vol. I, Part 1a, 1981.

GOLDEMBERG, J. Ethanol for Sustainable Energy Future. Science, v. 315, n. 5813, p. 808810, fev. 2007.

GOLDEMBERG, L.; LUCON, O. Energia e Meio ambiente no Brasil. Estudos Avançados, v. 21, n. 59, p. 21-38, jan.-abr. 2007.

GONG, M.; WALL, G. On Exergy and Sustainable Development - Part 2: Indicators and Methods. Exergy, v.1, p. 217-233, 2001.

GONZÁleZ, A. E. C. Aplicación del Método Exergético de Análisis a la Industria Azucarera. Resumo da Tese (Doutorado) - Instituto Superior Politécnico José Antonio Echeverría, Havana, 1990.

GOUTTE, D. Analyse Exergétique, Gestion et Économie d'Energie en Sucrerie et Sucrerie-Distillerie. 400 p. Tese (Doutorado) - L'Institut National Poltytechnique de Lorraine, Nancy, 1987.

GRAHAM, J .R.; HARVEY, C. R. The theory and practice of corporate finance: evidence from the field. Journal of Financial Economics, v. 60, n. 2-3, p. 187-243, 2001. 
GUALLAR, J.; VALERO, A. Termodinámica y Costes en la Industria Azucarera - I: Actividades en Disoluciones Técnicas de Sacarosa. Alimentción: Equipos y Tecnologia, p. 213-220, mar.-abr. 1989a.

GUALLAR, J.; VALERO, A. Termodinámica y Costes en la Industria Azucarera -II: Exergía de sus Flujos. Alimentción: Equipos y Tecnologia, p. 155-159, mai.-jun. 1989b.

GUALlAR, J.; VALERO, A. Termodinámica y Costes en la Industria Azucarera -III: Análisis Termodinámico. Alimentción: Equipos y Tecnologia, p. 199-210, set.-out. 1989c.

HAELSSIG, J. B.; TREMBLAY, A. Y.; THIBAULT, J. Technical and Economic Considerations for Various Recovery Schemes in Ethanol Production by Fermentation. Industrial \& Engineering Chemistry Research, v. 47, n. 16, p. 6185-6191, 2008.

HASSUANI, S. J., LEAL, M. R. L. V.; MACEDO, I. C. (Ed.) Biomass Power Generation: Sugarcane Bagasse and Trash. Piracicaba: United Nations Development Programme (UNDP), Centro de Tecnologia Canavieira (CTC), 2005. 217 p.

HESS, G.; MARQUES, J. L. M.; PAES, L. C. M. R.; PUCCINI, A. L. Engenharia Econômica. Rio de Janeiro: Editora Bertrand Brasil, 17ª ed., 1984. 80 p.

HIGA, M. Cogeração e Integração Térmica em Usinas de Açúcar e Álcool. 137 p. Tese (Doutorado) - Faculdade de Engenharia Mecânica, Universidade Estadual de Campinas, Campinas, 2003.

HIGA, M. Otimização do Consumo de Energia em Usinas de Açúcar e do Álcool através dos Métodos do “Pinch-Point” e Programação Linear. 157 p. Dissertação (Mestrado) - Faculdade de Engenharia Mecânica, Universidade Estadual de Campinas, Campinas, 1999.

HIGA, M.; BANNWART, A. C. Integração Térmica e Redução do Consumo de Vapor em Usinas de Açúcar e Álcool. In: XVI Congresso Brasileiro de Engenharia Mecânica, 2001, Uberlânida. Anais do XVI Congresso Brasileiro de Engenharia Mecânica, 2001 (em CD-ROM).

HOFFMANN, H.; SCHEPER, T.; SCHÜRGEL, K. Use of Membranes to Improve Bioreactor Performance. The Chemical Engineering Journal, v. 34, p. B13-B19, 1987.

HORII, J. A Qualidade da Matéria-Prima, na Visão Industrial. Visão Agrícola, v. 1, jan/jun, p. 91-93, 2004.

HUGOT, E. Handbook of Cane Sugar Engineering. Amsterdã: Elsevier, 1986. 1184 p.

JAMBEIRO, M. B. Engenhos de Rapadura: Racionalidade do Tradicional numa Sociedade em Desenvolvimento, São Paulo: Inst. Estudos Brasileiros, 1973. 193 p.

JENKINS, B.M.; BAXTER, L.L.; MILES JR., T. R.; MILES, T. R. Combustion Properties of Biomass. Fuel Processing Technology, v. 54, p. 17-46, 1998. 
JIN, H.; ISHIDA, M.; KOBAYASHI, M.; NUNOKAWA, M. Exergy Evaluation of Two Current Advanced Power Plants: Supercritical Steam Turbine and Combined Cycle. Journal of energy resources technology, v. 119, No. 4, p. 250-256, 1997.

JOHANSSON, T. B.; GOLDEMBERG, J. (Ed.) World Energy Assessment Overview: 2004 Update. New York:UNDP, UN-DESA and the World Energy Council, 2004. 85 p. Disponível em: http://www.energyandenvironment.undp.org/undp/index.cfm?module=Library\&page=Do cument\&DocumentID=5027. Acesso em: 01 out. 2007.

JØRGENSEN, S. E.; NIELSEN, S. N. Application of exergy as thermodynamic indicator in ecology. Energy, v. 32, n. 5, p. 673-685, 2007

JØRGENSEN, S. E.; PATTEN, B. C.; STRAŠKRABA, M. Ecosystems emerging: 4. growth. Ecological Modelling, v. 126, n. 2-3, 28 p. 249-284, 2000.

JØRGEnSEN, S. E.; SVIREZHEV, Y. M. Towards a Thermodynamic Theory for Ecological Systems. Amsterdam: Elsevier, 2004. 366 p.

KARGUPTA, K.; DATTA, S.; SANYAL, S. K. Analysis of the Performance of a Continuous Membrane Bioreactor with Cell Recycling during Ethanol Fermentation. Biochemical Engineering Journal, v. 1, p. 31-37, 1998.

KEHLHOFER, R. Combined-Cycle Gas \& Steam Turbine Power Plants. Lilburn: The Fairmont Press, 1991. 388 p.

KLEIDON, A.; LORENZ, R. D. (eds). Non-equilibrium Thermodyamics and the Production of Entropy. Berlin: Springer, 2005.

KLEIN, S. A. Engineering Equation Solver (EES). F-Chart Software, 2008.

KOBLITZ, L. O. Turbinas a Vapor. Koblitz Ltda, 1996.

KOROBTSYN, M. A. New and Advanced Energy Conversion Technologies. Tese (Doutorado) - Twente University, Enschede, 1998.

KOTAS, T. J. The Exergy Method of Thermal Plants Analysis. Londres: Butterworths, 1985. $296 \mathrm{p}$.

LARKIN, J. A. Thermodynamic Properties of Aqueous Non-electrolyte Mixtures I. Excess Enthalpy for Water + Ethanol at 298,15 to $383,15 \mathrm{~K}$. Journal Chemical Thermodynamics, v. 7, p. 137-148, 1975.

LARSON, E. D.; WILLIAMS, R. H., OGDEN, J. M.; HYLTON, M. G. Biomass-Gasifier Steam-Injected Gas Turbine Cogeneration for the Cane Sugar Industry. Energy from Biomass and Wastes XIV, Chicago: Institute of Gas Technology, p. 781-795, 1991.

LARSON, E. D.; WILLIAMS, R. H.; LEAL, M. R. L. V. A Review of Biomass IntegratedGasifier/Gas Turbine Combined Cycle Technology and its Application in Sugarcane Industries, with an Analysis for Cuba. Energy for sustainable Development, v. 5, n. 1, p. 54-75, 2001. 
LATTOUF, R. Avaliação Exergética de Processos Mitigadores de Impacto Ambiental. 147 p. Dissertação (Mestrado) - Escola Politécnica, Universidade de São Paulo, São Paulo, 2003.

LAZZARETTO, A.; TSATSARONIS, G. SPECO: A Systematic and General Methodology for Calculating Efficiencies and Costs in Thermal Systems. Energy, v. 31, n. 8-9, p. 1257-1289, jul. 2006.

LEAL, M. R. L. V.; MACEDO, I. C. Evolução Tecnológica dos Sistemas de Geração de energia nas Usinas de Açúcar e Álcool. Biomassa \& Energia, v. 1, n. 3, p. 245-253, 2004.

LEITE, A. D. A Energia do Brasil. Rio de Janeiro: Nova Fronteira, 1997. 528 p.

LEME, R. M. Estimativa das emissões atmosféricas e consume de água na produção de eletricidade a partir de resíduos de cana-de-açúcar. 160 p. Dissertação (Mestrado) Faculdade de Engenharia Mecânica, Universidade Estadual de Campinas, Campinas, 2005 .

LI, H.; MARÉCHAL, F.; BURER, M.; FAVRAT, D. Multi-objective Optimization of an Advanced Combined Cycle Power Plant including $\mathrm{CO}_{2}$ Separation Options. Energy, v. 31, n. 15, p. 3117-3134, dez. 2006.

LI, X. T.; GRACE, J. R.; LIM., C. J.; WATKINSON, J. R.; CHEN, H. P.; KIM, J. R. Biomass Gasification in a Circulating Fluidized Bed. Biomass and Bioenergy, v. 26, p. 171-193, 2004.

LORA, E. S.; NASCIMENTO, M. A. R. (Coord.) Geração Termelétrica. Rio de Janeiro: Editora Interciência Ltda., 2004. 1296 p.

LOZANO, M. A.; VALERO, A. Theory of the Exergetic Cost. Energy, v. 18, n. 9, p. 939960, set. 1993.

LUCAS, J. P.; LIM, C. J.; WATKINSON, A. P. A Nonisothermal Model of a Spouted Bed Gasifier. Fuel, v. 77, n. 7, p. 683-694, mai. 1998.

LUNDQVIST, R.; SCRIEF, A.; KINNUNEN, P.; MYÖHÄNEN, K.; SESHAMANI, M. A Major Step Forward - The Supercritical CFB Boiler. in: PowerGen International 2003, Las Vegas, 2003.

LUONG, J. H. T. Kinetics of Ethanol Inhibition in Alcohol Fermentation. Biotechnology and Bioengineering, v. 27, n. 3, p. 280-285, 1985.

MACEDO, I. C. (Org.) A Energia da Cana-de-Açúcar. São Paulo: Berlendis \& Vertecchia: União da Agroindústria Canavieira (UNICA), 2005. 235 p.

MACEDO, I. C., LEAL, M. R. L. V.; HASSUANI, S. J. Sugar Cane Residues for Power Generation in the Sugar/Ethanol Mills in Brazil. Energy for Sustainable Development, v. 5, n. 1, p. 77-82, mar. 2001. 
MACEDO, I. C.; SEABRA, J. E. A.; SILVA, J. E. A. R. Green house gases emissions in the production and use of ethanol from sugarcane in Brazil: The 2005/2006 averages and a prediction for 2020. Biomass and Bioenergy, v. 32, n. 7, p. 582-595, 2008.

MAKARYTCHEV, S. V. Environmental Impact Analysis of ACFB-based Gas and Power Cogeneration, Energy, Vol. 23, n. 9 p. 711-717, 1997.

MAS-COLlel, A.; Whinston, M. D.; GREEN, J. R. Microeconomic Theory. New York: Oxford University Press, 1995. 981 p.

MASSARDO, A. F.; SANTARELLI, M.; BORCHIELLINI, R. Carbon exergy tax (CET): its impact on conventional energy system design and its contribution to advanced systems utilization. Energy, v. 28, n. 7, p. 607-625, 2003.

MATHIEU, P.; DUBUISSON, R. Performance Analysis of a Biomass Gasifier. Energy Conversion and Management, v. 43, p. 1291-1299, 2002.

MODESTO, M.; NEBRA, S. A.; ZEMP, R. J. A Proposal to Calculate the Exergy of Nonideal Mixtures Ethanol-Water using Properties of Excess. In: 14th European Biomass Conference \& Exhibition: Biomass for Energy, Industry and Climate Protection, 2005, Paris. Proceedings of the 14th European Biomass Conference \& Exhibition: Biomass for Energy Industry and Climate Protection. Paris, 2006. p. 1924-1927.

MODESTO, M.; ZEMP, R. J.; NEBRA, S. A. Ethanol Production from Sugar Cane: Comparison of Juice Cane Extractions Systems Mill and Diffuser through Exergetic Cost Analysis. In: 19th International Conference on Efficiency, Cost, Optimization, Simulation and Environmental Impact of Energy Systems, 2006a, Aghia Pelagia. Proceedings of 19th International Conference on Efficiency, Cost, Optimization, Simulation and Environmental Impact of Energy Systems. Aghia Pelagia: Spyros Zervos, 2006a. v. 2. p. 739-747.

MODESTO, M.; ZEMP, R.; NEBRA, S. A. Ethanol Production from Sugar Cane: Assess of Possibilities of Decrease of Thermal Energy Consumption through Exergetic Cost Analysis. In: $11^{\text {th }}$ Brazilian Congress of Thermal Sciences and Engineering, 2006b, Curitiba. Proceedings of ENCIT 2006, 2006b (em CD-ROM).

MORAES, M. A. D; SHIKIDA, P. F. A. (Org.) Agroindústria Canavieira no Brasil: Evolução, Desenvolvimento e Desafios. São Paulo: Editora Atlas, 2002. 367 p.

MORAES, M. A. F. D. A Desregulamentação do Setor Sucroalcooleiro do Brasil. Piracicaba: Caminho Editorial (Coleção CEPEA), 2000.

MORGENROTH, B.; BATSTONE, D. Development and Prospects for Drying Bagasse by Steam. International Sugar Journal, v. 107, n. 1279, p. 410-415, 2005.

MUÑOZ, J. D. Optimization Strategies for the Synthesis/Design of Highly Coupled, Highly Dynamic Energy Systems. 219 p. Tese (Doutorado) - Faculty of Virginia Polytechnic Institute and State University, Blacksburg, 2000.

NEBRA, S. A. Projeto Bioetanol - Segundo Relatório. Financiadora de Estudos e Projetos FINEP, Campinas, jul. 2007. 
NEBRA, S. A.; PARRA, M. I. F. The exergy of Sucrose - Water Solutions: Proposal of a Calculation Method. In: ECOS 2005 - 18th International Conference on Efficiency, Cost, Optimization, Simulation and Environmental Impact of Energy Systems, 2005, Trondheim. Proceedings of the 18th International Conference on Efficiency, Cost, Optimization, Simulation and Environmental Impact of Energy Systems. Trondheim: Tapir Academic Press, 2005. v. I. p. 385-392.

NEILSON, C. E. LM2500 Gas Turbine Modifications for Biomass Fuel Operation. Biomass and Bioenergy, v. 15, n. 3, p. 269-273, 1998.

NETO, A. O. B. Aspectos da Extração de Sacarose da Cana-de-Açúcar por Difusão. Sertãozinho: Boletim Uni-systems, 2008.

NETO, V. C. Análise de Viabilidade da Cogeração de Enrgia Elétrica em Ciclo Combinado com Gaseificação de Biomassa. 194 p. Dissertação (Mestrado) - COPPE, Universidade Federal do Rio de Janeiro, Rio de Janeiro, 2001.

NOLASCO, J. Destilação de Álcool com Split-Feed. Ribeirão Preto, 16 ago. 2006. Palestra sobre a Otimização Energética da Destilação de Álcool, Ribeirão Preto, 2006.

ODUM, E. P. Fundamentals of Ecology. $3^{\text {rd }}$ edition, Philadelphia: W. B. Saunders Company, $1971.574 \mathrm{p}$.

OGDEN, J. M.; HOCHGREB, S.; HYLTON, M. Steam Economy and Cogeneration in Cane Sugar Factories. International Sugar Journal, v. 92, p. 131-140, 1990.

OLIVEIRA Jr. S. Revalorisation des Effluents Thermiques Industriels - Analyse Exergétique, Entropique et Economique, 400 p. Tese (Doutorado) - Institut National Polytechnique de Lorraine, Nancy, 1991.

OLIVEIRA JR., S. Fundamentos da Análise Exergética e Termoeconômica de Processos de Conversão de Energia. São Paulo: EPUSP, 2006. 47 p. Apostila para a disciplina de Pós-Graduação de Engenharia Mecânica, PME-5202 Análise Exergética e Termoeconômica de Sistemas Térmicos.

OLIVÉRIO, J. L. Usinas de Açúcar, Álcool, Eletricidade e Biodiesel. In: VII Encontro Nacional dos Produtores de Cana, Araçatuba, mar. 2007.

PAUL, I. Supercritical Coal Fired Power Plants. Energy Issues, Vol. 19, 1999.

PAYNE, J. H. Operações Unitárias na Produção de Açúcar de Cana. São Paulo: Nobel / STAB, 1989.

PAZ, D.; CÁRDENAS, G. J. Análisis Exergético de um Sistema de CalentamientoEvaporación-Cocimiento. International Sugar Journal, v. 98, p. 263-267 e 317-320, 1997.

PEACOCK, S. Predicting Physical Properties of Factory Juices and Syrups. International Sugar Journal, v. 97, n. 1162, p. 571-577, 1995. 
PELlEGRINI, L. F. Estudo da Cogeração em Ciclos Combinados com Gaseificação de Bagaço de Cana de Açúcar. Trabalho de Formatura - Escola Politécnica, Universidade de São Paulo, São Paulo, 2003.

PELLEGRINI, L. F.; BURBANO, J. C.; OLIVEIRA JR., S. Exergy Analysis of Advanced Cogeneration Plants for Sugarcane Mills: Supercritical Steam Cycles and Biomass Integrated Gasification Combined Cycles. In: 19th International Congress of Mechanical Engineering, 2007, Brasília. Proceedings of 19th International Congress of Mechanical Engineering, 2007. (em CD-ROM).

PELlEGRINI, L. F.; BURBANO, J. C.; OLIVEIRA JR., S. Supercritical Steam Cycles and Biomass Integrated Gasification Combined Cycles for Sugarcane Mills. In: The $21^{\text {st }}$ International Conference on Efficiency, Costs, Optimization, Simulation and Environmental Impact of Energy Systems, Krakow, 2008. Proceedings of the $21^{\text {st }}$ International Conference on Efficiency, Costs, Optimization, Simulation and Environmental Impact of Energy Systems, Gliwice: Zakład Graficzny Politechniki Śląskiej, 2008. v. 2. p. 649-658.

PELlEGRINI, L. F.; COSTA, R. P.; OLIVEIRA JUNIOR, S. Atribuição de Custos em Sistemas Energéticos: A Termoeconomia como Base de Cálculo. In: XXV Encontro Nacional de Engenharia de Produção, Porto Alegre, 2005. Anais do XXV Encontro Nacional de Engenharia de Produção, 2005. (em CD-ROM).

PELLEGRINI, L. F.; GANDOLFI, R.; SILVA, G. A. L.; OLIVEIRA JR., S. Exergy Analysis as a Tool for Decision Making in Aircraft Systems Design. In: 45th AIAA Aerospace Sciences Meeting and Exhibition, Reno, 2007. Proceedings of 45th AIAA Aerospace Sciences Meeting and Exhibition, 2007. (em CD-ROM).

PELLEGRINI, L. F.; MODESTO, M.; NEBRA, S. A.; OlIVEIRA JR., S. A. Modern Concept for Ethanol Distilleries: Maximization of the Electricity Surplus. In: $12^{\text {th }}$ Brazilian Congress of Thermal Sciences and Engineering, Belo Horizonte, 2008. Proceedings of ENCIT 2008, 2008 (em CD-ROM).

PELLEGRINI, L. F.; OLIVEIRA JR., S. Exergetic Evaluation of Multiple-effect Evaporators in Sugarcane Mills. In: $19^{\text {th }}$ International Conference on Efficiency, Cost, Optimization, Simulation and Environmental Impact of Energy Systems, Aghia Pelagia, 2006. Proceedings of the $19^{\text {th }}$ nternational Conference on Efficiency, Cost, Optimization, Simulation and Environmental Impact of Energy Systems, Athens: National Technical University of Athens, 2006a, v. 1, p. 207-214.

PELLEGRINI, L. F.; OLIVEIRA JR., S. Exergy Analysis of Different Configurations of Multiple-effect Evaporators in Sugarcane Mills. In: $11^{\text {th }}$ Brazilian Congress of Thermal Sciences and Engineering, 2006, Curitiba. Proceedings of ENCIT 2006, 2006b (em CD$\mathrm{ROM})$.

PELLEGRINI, L. F.; OLIVEIRA JR., S. Exergy Analysis of Sugarcane Bagasse Gasification. Energy, v. 32, p. 314, 2007a.

PELLEGRINI, L. F.; OLIVEIRA JR., S. Exergy Efficiency of the Combined Sugar, Ethanol and Electricity Production and its Dependence of the Exergy Optimization of the Utilities Plants. In: The $20^{\text {th }}$ International Conference on Efficiency, Costs, Optimization, 
Simulation and Environmental Impact of Energy Systems, Padova, 2007. Proceedings of the ${ }^{2}{ }^{\text {th }}$ International Conference on Efficiency, Costs, Optimization, Simulation and Environmental Impact of Energy Systems, Padova: Sevizi Grafici Editoriali, 2007b. v. 1. p. 819-828.

PELLEGRINI, L. F.; ZANETTI, A. A.; ZAMBONI, L. M.; OLIVEIRA JR., S.; TRIBESS, A. Integration of BIGCC Based Systems to Sugarcane Mills. In: $18^{\text {th }}$ International Congress of Mechanical Engineering, 2005, Ouro Preto. Proceedings of the $\mathbf{1 8}^{\text {th }}$ International Congress of Mechanical Engineering, 2005 (em CD-ROM).

PELSTER, S., FAVRAT, D.; VON SPAKOVSKY, M. R. The Thermoeconomic and Environomic Modeling and Optimization of the Synthesis, Design, and Operation of Combined Cycles with Advanced Options. Journal of Engineering Gas Turbine and Power, v. 123, p. 717-726, 2001.

PERUCHI, W. Comunicação Pessoal. HPB Caldeiras, 2007.

PETELA, R. An Approach to the Exergy Analysis of Photosynthesis. Solar Energy, v. 82, n. 4, p. 311-328, 2008.

PIMENTEL, D. (org.). Biofuels, Solar and Wind as Renewable Energy Systems. New York: Springer, 2008. $513 \mathrm{p}$.

PISTORE, T. T. Avaliação Técnico-econômica e Ambiental da Eletrificação das Moendas durante a Cogeração na indústria Sucroalcooleira. 200 p. Dissertação (Mestrado) Faculdade de Engenharia Mecânica, Universidade Federal de Itajubá, Itajubá, 2004.

POWER TECHNOLOGY. Apresenta informações sobre sistemas de geração de potência. < http://www.power-technology.com/projects/avedore/>. Acesso em: 12 set. 2008.

PRADO, T. G. F. Externalidades do Ciclo Produtivo da Cana de Açúcar com Ênfase na Produção de Energia Elétrica. 254 p. Dissertação (Mestrado). Instituto de Eletrotécnica e Energia, Universidade de São Paulo, São Paulo, 2007.

PRIETO, M. G. S. Alternativas de Cogeração na Indústria Sucro-alcooleira: Estudo de Caso. 253 p. Tese (Doutorado) - Faculdade de Engenharia Mecânica, Universidade Estadual de Campinas, Campinas, 2003.

PRIETO, M. G. S.; BARATA, J. C. F. The Evolution Through the Single-Drum Steam Boiler inside the Expansion of Cogeneration in the Brazilian Sugar Mill Context. In: $11^{\text {th }}$ Brazilian Congress of Thermal Sciences and Engineering, 2006, Curitiba. Proceedings of ENCIT 2006, 2006 (em CD-ROM).

PRIETO, M. G. S.; NEBRA, S. A. Thermodynamic and Exergetic Cost Analysis of Two Steam Based Cogeneration Schemes proposed for a Brazilian Sugar Mill. In: $17^{\text {th }}$ International Conference on Efficiency, Cost, Optimization, Simulation and Environmental Impact of Energy Systems, 2004, Guanajuato. Proceedings of the $\mathbf{1 7}^{\text {th }}$ International Conference on Efficiency, Cost, Optimization, Simulation and Environmental Impact of Energy Systems. Cidade do México: Instituto Mexicano del Petróleo, 2004. v. 3. p. 1023-1030. 
PRIETO, M. G. S.; NEBRA, S. A. Thermoeconomic Analysis of a Cogeneration System of a Sugar Mill Plant. In: $15^{\text {th }}$. International Conference on Efficiency, Costs, Optimisation, Simulation and Environmental Impacts of Energy Systems, 2002, Berlim. Proceedings of the $15^{\text {th }}$. International Conference on Efficiency, Costs, Optimization, Simulation and Environmental Impact of Energy Systems. Berlim: Technische Universität Berlin, Institute for Energy Engineering, 2002. v. I. p. 258-265.

PRINS, M. J.; PTASINSKI, K. J. Energy and Exergy Analysis of Oxidation and Gasification of Carbon. Energy, v. 30 p. 982-1002, 2005.

PRINS, M. J.; PTASINSKI, K. J.; JANSSEN, F. J. J. G. Thermodynamics of Gas-char Reactions: First and Second Law Analysis. Chemical Engineering Science, v. 58 p. 1003-1011, 2003.

PROCKNOR, C. Cogeração de Energia Elétrica com Difusor. Revista Stab, Julho, 2001.

PROCKNOR, C. Potencial de Energia da Indústria depende do Bagaço de Cana Disponível. Visão Agrícola, v. 8, jan/jun, p. 59-62, 2008

RAM, J. R.; BANERJEE, R. Energy and Cogeneration Targeting for a Sugar Factory. Applied Thermal Engineering, v. 23, p. 1567-1575, 2003.

RANCRUEL, D. F. A Decomposition Strategy Based on Thermoeconomic Isolation Applied to the Optimal Synthesis/Design and Operation of an Advanced Fighter Aircraft System. 225 p. Dissertação (Mestrado) - Faculty of Virginia Polytechnic Institute and State University, Blacksburg, 2002.

REED, T. B.; GAUR, S. A Survey of Biomass Gasification 2000. The National Renewable Laboratory and The Biomass Energy Foundation, 2001.

REIN, P. Cane Sugar Engineering. Berlin: Bartens, 2007. 768 p.

REISTAD, G. M. Availability: Concepts and Applications. Tese (Doutorado) - The University of Winsconsin, Ann Arbor, 1970.

RETZLAFF, K.M.; RUEGGER, W. A. Steam Turbines for Ultrasupercritical Power Plants. GE Reference Document GER-3945A, General Electrics, 1996.

RICHARDSON, M.; SHIMOGORI, Y.; KIDERA, Y. Supercritical Boiler Technology Matures. In: Coal Gen 2004; July 28-30, 2004; Available at: http://www.hitachi.us/Apps/hitachicom/content.jsp?page=TechnicalPublications/index.ht ml\&level=1\&section=TechnicalPublications\&parent=TechnicalPublications\&nav=left\&p

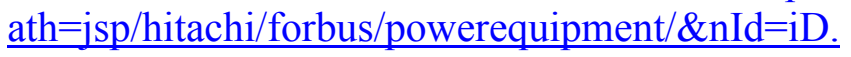

RIVERO, R. L'Analyse d'Exergie: Application à la Distillation Diabatique et aux Pompes à Chaleur à Absorption. 680 p. Tese (Doutorado) - Institut National Polytechnique de Lorraine, Nancy, 1993.

RIVERO, R. The Exergoecologic Improvement Potential of Industrial Processes. In: Thermodynamic Analysis and Improvement of Energy Systems, 1997, Beijing. Proceedings of Thermodynamic Analysis and Improvement of Energy Systems. Beijing: World Publishing Corporation, 1997. p. 299-304. 
RIVERO, R.; OLIVEIRA JR., S.; LE GOFF, P. Température de Carnot $\Theta$, Diagramme $\Theta / Q$, Méthode du Pincement. Application à l'analyse analyse exergétiques des procédés industriels. Entropie, v. 157/158, p. 13-20, 1990.

RODRIGUES, J. D. Fisiologia da Cana-de-Açúcar. Instituto de Biociências, Campus de Botucatu, Universidade Estadual Paulista, 2005. 99 p.

RODRIGUES, M.; WALTER, A.; FAAIJ, A. Co-firing of Natural Gas and Biomass Gas in Biomass Integrated Gasification/Combined Cycle Systems. Energy, v. 28, p. 1115-1131, 2003a.

RODRIGUES, M.; WALTER, A.; FAAIJ, A. Performance Evaluation of Atmospheric Biomass Integrated Gasifier Combined Cycle Systems under Different Strategies for the Use of Low Calorific Gases. Energy Conversion and Management, v. 48, n. 4, p. 12891301, abr. 2007.

RODRIGUES, M.; WALTER, A.; FAAIJ, A. Techno-economic Analysis of Co-fired Biomass Integrated Gasification/Combined Cycle Systems with Inclusion of Economies of Scale. Energy, v. 28, p. 1129-1258, 2003 b.

ROSA, L. C. Interface Física e Econômica em Gestão de Processo de Produção de Produtos Conjuntos. 119 p. Tese (Doutorado) - Escola Politécnica, Universidade de São Paulo, São Paulo, 2004.

ROSEN, M .A. Assessing Energy Technologies and Environmental Impacts with the Principles of Thermodynamics. Applied Energy, v. 72, p. 427-441, 2002.

ROSEN, M. A.; DINCER, I. Exergy Analysis of Waste Emissions. International Journal of Energy Research, v. 23, n. 3, p. 1153-1163, out. 1999.

ROSEN, M. A.; DINCER, I. On Exergy and Environmental Impact. International Journal of Energy Research, v. 21, n. 7, p. 643-654, jun. 1997.

ROSENKRANZ, J.; WICHTMANN, A., Balancing Economics and Environmental Friendliness - The Challenge for Supercritical Coal-fired Power Plants with Highest Steam Parameters in the Future. Siemens Power Generation (PG), 2006.

ROSSETO, R. A Cultura da Cana, da Degradação à Conservação. Visão Agrícola, v. 1, p.8085 , jan-jun 2004.

RUGGIERO, M.; MANFRIDA, G. An Equilibrium Model for Biomass Gasification Processes. Renewable Energy, v. 16, p. 1106-1009, 1999.

SACHS, I. A Revolução Energética do Século XXI. Estudos Avançados, v. 21, n. 59, p. 21 38, jan.-abr. 2007.

SANT'ANA, M. M. Contribuição à História do Açúcar em Alagoas. Recife: Instituto do Açúcar e do Álcool, 1970. 514 p.

SANTARELLI, M. Carbon exergy tax: a thermo-economic method to increase the efficient use of exergy resources. Energy Policy, v. 32, 413-427, 2004. 
SANTARELLI, M. Considerazzioni Termodinamiche, Economiche ed Ambientali de nella Analisi ed Optimizzazione di Sistemi Energetici. 299 p. Tese (Doutorado) Dipartimento di Energetica, Politecnico di Torino, Turim, 1998.

SCHLEISNER, L. Comparison of Methodologies for Externality Assessment. Energy Policy, v. 28, p. 1127-1136, 2000.

SCHMIDHEINY, S. Mudando o Rumo: Uma Perspectiva Empresarial Global sobre Desenvolvimento e Meio ambiente. Rio de Janeiro: Editora da Fundação Getúlio Vargas, 1992. $372 \mathrm{p}$.

SCHNEIDER, F. (Org.) Technologie des Zuckers. $2^{\text {nd }}$ Edition. Hannover : M \& H Schaper, 1968.

SCIUBBA, E. Beyond Thermoeconomics? The Concept of Extended Exergy Accounting and its Application to the Analysis and Design of Thermal Systems. Exergy, An International Journal, v. 1, n. 2, p. 64-84, 2001.

SCIUBBA, E. Exergo-economics - thermodynamic foundation for a more rational resource use. International Journal of Energy Research, v. 29, p. 613-636, 2005.

SEEMANN, F. Energy Reduction in Distillation for Bioethanol Plants. International Sugar Journal, v. 105, n. 1257, p. 420-423, 2003.

SERRA, L. M. Optimización Exergoenómica de Sistemas Térmicos. 214 p. Tese (Doutorado) - Departamiento de Ingeniería Mecânica, Universidad de Zaragoza, Zaragoza, 1994.

SEWALT, M. P. G.; TOXOPEUS, M. E.; HIRS, G. G. Thermodynamics Based Sustainability Concept. International Journal of Thermodynamics, v. 4, n. 1, p. 35-41, 2001.

SHAPOURI, H.; DUFFIELD, J. A.; WANG, M. The Energy Balance of Corn Ethanol: An Update. Agricultural Economic Report No. 813, U.S. Department of Agriculture, Office of the Chief Economist, Office of Energy Policy and New Uses, 2006.

SHIKIDA, P. F. A. A Evolução Diferenciada da Agroindústria Canavieira no Brasil de 1975 a 1995, Cascavel: Edunioeste, 1998. 191 p.

SHIKIDA, P. F. A.; BACHA, C. J. C. A Evolução da Agroindústria Canavieira Brasileira Desde A Sua Origem Até 1995: A Institucionalização do Paradigma Subvencionista. Nova Economia, vol. 8, p. 85-108, 1998.

SINÍCIO, M. F.; BAJAY, S. V. Otimização do Uso Energético nas Usinas Sucroalcooleiras, Revista Brasileira de Energia, v. 2, 1992.

SMEETS, E.; JUNGINGER, M.; FAAIJ, A.; WALTER, A.; DOLZAN, P. Sustainability of Brazilian Bio-ethanol. Amsterdã: The Netherlands Agency for Sustainable Development and Innovation, 2006. 136 p. (Report NWS-E-2006-110).

SMITH, J.W. Babcock \& Wilcox Company Supercritical (Once Through) Boiler Technology. Ohio: Babcock \& Wilcox Co., 1998 (BR-1658). 
SORIN, M. V.; BRODYANSKY, V. M. A Method for Thermodynamic Optimization Theory and Application to an Ammonia-Synthesis Plant. Energy, v. 17, n. 11, p. 10191031, 1992.

SORIN, M. V.; BRODYANSKY, V. M.; VALERO, A. Transit Exergy in the Costing Definition. In: Energy Systems and Ecology (ENSEC '93), 1993, Cracóvia. Proceedings of the International Conference, v. 1, Cracóvia, 1993. p. 367-378.

SOSA-ARnAO, J. H., Comunicação Pessoal. Equipalco, 2008.

SOSA-ARNAO, J. H.; NEBRA, S. A. First and second law analysis applied on boilers fuelled by sugar cane bagasse. In: 20th International Conference on Efficiency, Cost, Optimization, Simulation and Environmental Impact of Energy Systems, 2007, Padova. Proceedings of The 20th International Conference on Efficiency, Cost, Optimization, Simulation and Environmental Impact of Energy Systems. Padova : Servizi Grafici Editoriali, 2007. v. 1. p. 847-854.

SOSA-ARNAO, J. H.; NEBRA, S. A. Second Law Analysis Applied on Booilers Fueled by Sugar Cane Bagasse. In: 11th Brazilian Congress of Thermal Sciences and Engineering, 2006, Curitiba. Proceedings of ENCIT 2006, 2006 (em CD-ROM).

SOSA-ARNAO, J. H.; NEBRA, S. A. The Exergy of Sugar Cane Bagasse. In: 14th European Biomass Conference \& Exhibition: Biomass for Energy, Industry and Climate Protection, 2005, Paris. Proceedings of the 14th European Biomass Conference \& Exhibition: Biomass for Energy Industry and Climate Protection. Paris, 2005. p. 1843-1846.

SOUZA-SANTOS, M. L. A Feasibility Study of an Alternative Power Generation System Based on Biomass Gasification/Gas Turbine Concept. Fuel, v. 78, p. 529-538, 1999.

STÅHL, K.; WALDHEIM, L.; MORRIS, M.; JOHNSSON, U.; GARDMARK, L. Biomass IGCC at Värnamo, Sweden - Past and Future. In: GCEP Energy Workshop, Stanford University, CA, USA, 2004.

STÅHL, K; NEERGAARD, M. IGCC Power Plant for Biomass Utilisation, Värnamo, Sweden. Biomass and Bioenergy, v. 15, n. 3, p. 205-211, 1998.

STARZAK, M.; PEACOCK, S. D. Water Activity Coefficient in Aqueous Solutions of Sucrose - A Comprehensive data Analysis. Zuckerindustrie, v. 122, p. 380-387, 1997.

STEVENS, D. J. Hot Gas Conditioning: Recent Progress with Larger-Scale Biomass Gasification Systems. Pacific Northwest National Laboratory, Richland, Washington, NREL, 2001.

STRAMBI, R. P. Otimização de planta supercrítica em usinas de açúcar e álcool. 2007. 150 p. Trabalho de Formatura, Escola Politécnica, Universidade de São Paulo, São Paulo, 2007.

SUNDQVIST, T. What Causes the Disparity of Electricity Externality Estimates? Energy Policy, v. 32, n. 15, p. 1753-1766, out. 2004.

SZARGUT, J. Anthropogenic and natural exergy losses (exergy balance of the Earth's surface and atmosphere). Energy, v. 28, n. 11, p. 1047-1054, 2002. 
SZARGUT, J. Exergy Method: Technical and Ecological Applications. Boston: WIT Press, 2005. $164 \mathrm{p}$.

SZARGUT, J.; MORRIS, D. R.; STEWARD, F. R. Exergy Analysis of Thermal, Chemical and Metallurgical Processes. New York: Hemisphere Publishing Corporation, 1988. 332 p.

SZARGUT, J.; Ziębik, A.; Stanek, W. Depletion of the Non-renewable Natural Exergy Resources as a Measure of the Ecological Cost. Energy Conversion and Management, v. 43, n. 9-12, p. 1149-1163, jun.-ago. 2002.

SZMRECSÁNYI, T. O Planejamento da Agroindústria Canavieira do Brasil (1930-1975). São Paulo: Hucitec/Unicamp, 1979. 540 p.

TAIZ, L.; ZEIGER, E. Plant Physiology. $3^{\text {rd }}$ Edition, Porto Alegre : Artmed, 2004. 764 p.

TEKIN, T.; BAYARAMOĞLU, M. Exergy Analysis of the Sugar Production Process from Sugar Beets. International Journal of Energy Research, v. 22, p. 591-601, 1998.

TEKIN, T.; BAYARAMOĞLU, M. Exergy and Structural Analysis of Raw Juice Production and Steam-Power Units of a Sugar Production Plant, Energy, v. 26, p. 287-297, 2001.

TELLES, P. C. S. Tubulações Industriais. Rio de Janeiro: Livros Tecnicos Cientificos, $8^{\text {a }}$ Ed., 1994. 252 p.

TOFFOLO, A.; LAZZARETTO, A. Energy, Economy and Environment as Objectives in Multi-criterion Optimization of Thermal Systems Design. Energy, v. 29, p. 1139-1157, 2004.

TOFFOLO, A.; LAZZARETTO, A. Evolutionary Algorithms for Multi-objective Energetic and Economic Optimization in Thermal System Design. Energy, v. 27, p. 549-567, 2002.

TONDEUR, D.; KVAALEN, E. Equipartition of Entropy Production. An Optimally Criterion for Transfer and Separation Processes. Industrial \& Engineering Chemistry Research, v. 26, n. 1, p. 50-56, 1987.

TOXOPEUS, M. E; LUTTER, E.; VAN HOUTEN, F. J. A. M. Environmental Indicators \& Engineering: An Alternative for Weighting Factors. In: $13^{\text {th }}$ CIRP International Conference on Life Cycle Engineering, Leuven, 31 mai-2 jun. 2006. Disponível em: http://www.mech.kuleuven.be/lce2006/Registration_papers.htm.

TRAVERSO, A.; MASSARDO, A.; SANTARELLI, M.; CALI, M. A New Generalized Carbon Exergy Tax: na Effective Rule to Control Global Warming. Journal of Engineering Gas Turbine and Power, v. 125, p. 972-978, 2003.

TSATSARONIS, G. Invited Papers of Exergoeconomics. Energy, v. 9, 1994.

TSATSARONIS, G. Thermoeconomic Analysis and Optimization of Energy Systems. Progress in Energy and Combustion Science, v. 19, n. 3, p. 227-257, 1993. 
TSATSARONIS, G.; WINHOLD, M. Exergoeconomic Analysis and Evaluation of EnergyConversion Plants - I. A New General Methodology, II. Analysis of a Coal-fired Steam Power Plant. Energy, v. 10, n. 1, p. 69-94, jan. 1985.

TURN, S. Q.; BAIN, R. L.; KINOSHITA, C. M. Biomass Gasification for Combined Heat and Power in the Cane Sugar Industry. International Sugar Journal, v. 104, p. 268-273, 2002.

TWAITE, N. R.; DAVENPORT, H. J.; MACDONALD, E. K. Energy Reduction and Processo Integration. International Sugar Journal, v. 88, n. 1055, p. 217-236, 1986.

UNITED KINGDOM. Department of Trade and Industry (DTI). Advanced Power Plant Using High Efficiency Boiler/Turbine. DTI Best Practice Brochure No. BPB010, 2006 (DTI/Pub URN 06/655).

UNITED KINGDOM. Department of Trade and Industry (DTI). Supercritical Steam Cycles for Power Generation Applications, DTI Technology Status, 1999 (Report No. TSR009).

UNITED STATES. Department of Energy (DOE). Market-based Advanced Coal Power Systems: Final Report. Washington: Office of Fossil Fuel, 1999 (Report DOE/FE-0400).

UNITED STATES. Gas Turbina World (GTW). 2003 GTW Handbook. Vol. 23, Fairfield: Pequot Publishing Inc, 2003.

UNITED STATES. Massachusetts Institute of Technology (MIT). Engineered Microbes Boost Ethanol, Technology Review, 2007. Disponível em: http://www.technologyreview.com/Energy/17871/page1/. Acessado em: 25 fev. 2007.

URBANIEC, K.; ZALEWSKI, P.; ZHU, X. X. A Decomposition Approach for Retrofit Design of Energy Systems in the Sugar Industry. Applied Thermal Engineering, v. 20, p. 1431-1442, 2000.

USHIMA, A. H. Testes de Sistemas de Geração para Consumidores Remotos Baseados na Gaseificação de Biomassa. São Paulo: Instuto de Pesquisas Tecnológicas (IPT), 2004. (Rel. No 73/93-205).

VALERO, A.; SERRA, L.; LOZANO, M. A. Structural Theory of Thermoeconomics. In: Thermodynamics and the Design, Analysis, and Improvement of Energy Systems, 1993. Advanced Energy Systems Division (Publication) AES, 1993. v. 30, p 189-198.

VALERO, A.; SERRA, L.; UCHE, J. Fundamentals of Exergy Cost Accounting and Thermoeconomics: Part I - Theory, Part II - Applications. Journal of Energy Resources Technology, v. 128, p. 1-15, mar. 2006.

VAMVUKA, D.; WOODBURN, E. T.; SENIOR, P. R. Modelling of an Entrained Flow Coal Gasifier. 1. Development of the model and general predictions. Fuel, v. 74, n. 10, p. 1452-1460, out. 1995.

VAN WYlEN, R. E.; SONNTAG, R. E.; BORGNAKKE, C. Fundamentos da

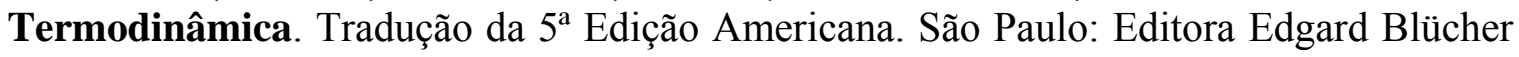
Ltda., 1998.537 p. 
VAPERMA. Québec. Apresenta informações sobre sistemas de pervaporação. < http://www.vaperma.com>. Acesso em: 12 set. 2008.

VELÁSQUEZ, H. I. Evaluación Energética de los Procesos Productivos de la Panela en Colombia. 130 p. Dissertação (Mestrado) - Universidad Pontificia Bolivariana, Medelim, 2002.

VELÁSQUEZ, H. I., CHEJNE, J. F.; AGUDELO, S. A. F. Diagnóstico Energético de los Procesos Productivos de la Panela en Colombia. Revista Facultad Nacional de Agronomía, v. 57, n. 2, 2004.

VELÁSQUEZ, H. I.; BENJUMEA, P.; OLIVEIRA JR., S. Exergy and Environmental Analysis of the Palm Oil Biodiesel Production Process. In: The $20^{\text {th }}$ International Conference on Efficiency, Costs, Optimization, Simulation and Environmental Impact of Energy Systems, Padova, 2007. Proceedings of The $\mathbf{2 0}^{\text {th }}$ International Conference on Efficiency, Costs, Optimization, Simulation and Environmental Impact of Energy Systems, Padova: Sevizi Grafici Editoriali, 2007. v. 1. p. 777-784.

VELÁSQUEZ, H. I.; GUTIÉRREZ, J. C.; OLIVEIRA JR., S. Análisis Termodinâmico y Termoeconómico para um Proceso de Producción de Panela em Colômbia. In: $11^{\text {th }}$ Brazilian Congress of Thermal Sciences and Engineering, 2006, Curitiba. Proceedings of ENCIT 2006, 2006 (em CD-ROM).

VELÁSQUEZ, H. I.; PELLEGRINI, L. F.; OLIVEIRA JR., S. Ethanol and Sugar Production Process from Sugarcane: Renewability Evaluation. In: $12^{\text {th }}$ Brazilian Congress of Thermal Sciences and Engineering, 2008, Belo Horizonte. Proceedings of ENCIT 2008, 2008 (em CD-ROM).

VELÁSQUEZ, H. I.; RUIZ, A. A.; OLIVEIRA JR., S. Ethanol Production Process from Banana Fruit and its Lignocellulosic Residues: Exergy and Environmental Analisys. In: The $21^{\text {st }}$ International Conference on Efficiency, Costs, Optimization, Simulation and Environmental Impact of Energy Systems, Krakow, 2008. Proceedings of the $\mathbf{2 1}^{\text {st }}$ International Conference on Efficiency, Costs, Optimization, Simulation and Environmental Impact of Energy Systems, Gliwice: Zakład Graficzny Politechniki Śląskiej, 2008. v. 1. p. 209-216.

VERTIOLA, S. R.; OLIVEIRA JR., S. Thermoeconomic Analysis of the Steam Cycle of a Brazilian Medium-Sized Sugar and Alcohol Mill. In: XI International Symposium on Alcohol Fuels, 1996, Sun City. Proceedings of XI International Symposium on Alcohol Fuels, Sun City. p. 14-17.

VIAN, C. E. F. Agroindústria Canavieira: Estratégias Competitivas e Modernização, Campinas: Ed. Átomo, 2003. 217 p.

VON SPAKOVSKY, M. R. Application of Engineering Functional Analysis to the Analysis and Optimization of the CGAM Problem. Energy, v. 19, n. 3, p. 343-364, mar. 1994.

VON SPAKOVSKY, M. R. The Thermodynamic, Thermoeconomic and Environomic Modeling and Optimization of Energy Systems - Discussion and Applications. Entropie, n. 205, p. 12-26, 1997. 
WALL, G. Conditions and tools in the design of energy conversion and management systems of a sustainable society. Energy Conversion and Management, v. 43, n. 9-12, p. 12351248, 2002.

WALL, G. Exergy - a Useful Concept within Resource Accounting. Report no. 77-42, Institute of Theoretical Physics, Götenborg, 1977. 58 p.

WALL, G.; GONG, M. On Exergy and Sustainable Development - Part 1: Conditions and Concepts. Exergy, v.1, p. 128-145, 2001.

WALTER, A. C. S. Viabilidade e Perspectivas da Co-geração e Geração Termelétrica no Setor Sucroalcooleiro. 1994. 263 p. Tese (Doutorado) - Faculdade de Engenharia Mecânica, Universidade Estadual de Campinas, Campinas, 1994.

WALTER, A. C. S.; OVEREND, R. P. Analysis of BIG-GT Cycles in the Sugarcane Industry. In: $10^{\text {th }}$ Biomass European Congress. 1998b. Wurzburg. Proceedings of the 10 $^{\text {th }}$ Biomass European Congress, 1998. v. 1, p. 1158-1161.

WALTER, A. C. S.; OVEREND, R. P. Financial and Environmental Incentives: Impact on the Potential of BIG-CC Technology at the Sugarcane Industry", In: World Renewable Energy Congress, 1998b, Florença. Proceedings of the World Renewable Energy Congress, 1998. v. 3, p. 1996-1999.

WALTER, A. Simulation of Gas Turbines Operating in Off-Design Condition. In: International Conference on Efficiency, Cost, Optimization, Simulation and Environmental Aspects of Energy and Process Systems, 2000, Enschede. Proceedings of International Conference on Efficiency, Cost, Optimization, Simulation and Environmental Aspects of Energy and Process Systems, 2000. v. 1. p. 457-467.

WALTER, A.; LlAGOSTERA, J., OLIVEIRA JR., S., PELLEGRINI, L. F. Gas Turbine Integration to Sugarcane Trash Boilers: Comparative Energy Analysis. In: The $20^{\text {th }}$ International Conference on Efficiency, Costs, Optimization, Simulation and Environmental Impact of Energy Systems, Padova, 2007. Proceedings of The $\mathbf{2 0}^{\text {th }}$ International Conference on Efficiency, Costs, Optimization, Simulation and Environmental Impact of Energy Systems, Padova: Sevizi Grafici Editoriali, 2007. v. 1.p. 801-808.

WHITEFOX. Londres. Apresenta informações sobre sistemas de pervaporação. < http://www.whitefox.com>. Acesso em: 12 set. 2008.

WILlIAMS, R. H.; LARSON, E. D. Biomass Gasifier Gas Turbine Power Generating Technology. Biomass and Bioenergy, v. 10, n. 2-3, p. 149-166, 1996.

WITTWER, E. Bagasse Exergy. Zuckerindustrie, v. 118, n. 11, p. 859-862, nov. 1993.

ZAINAL, Z. A.; ALI, R.; LEAN, C.H.; SEETHARAMU, K.N. Prediction of Performance of a Downdraft Gasifier Using Equilibrium Modeling for Different Biomass Materials. Energy Conversion and Management, v. 42, p. 1499-1515, 2001.

ZAMBONI, L. M.; PELlEGRINI, L. F.; TRIBESS, A.; OLIVEIRA JR., S. Comparative Evaluation of Natural Gas and Sugarcane Bagasse Based Cogeneration Systems. In: $18^{\text {th }}$ International Conference on Efficiency, Costs, Optimization, Simulation and 
Environmental Impacts of Energy Systems, 2005, Trondheim. Proceedings of the 18th International Conference on Efficiency, Cost, Optimization, Simulation and Environmental Impact of Energy Systems. Trondheim: Tapir Academic Press, 2005. v. 3, pp. 1105-1112.

ZANETTI, A. A.; PELLEGRINI, L. F.; OLIVEIRA JR., S. Thermoeconomic Analysis of a BIGCC Cogeneration System Using Natural Gas and Sugarcane Bagasse as Complementary Fuels. In: The $20^{\text {th }}$ International Conference on Efficiency, Costs, Optimization, Simulation and Environmental Impact of Energy Systems, Padova, 2007. Proceedings of The $20^{\text {th }}$ International Conference on Efficiency, Costs, Optimization, Simulation and Environmental Impact of Energy Systems, Padova: Sevizi Grafici Editoriali, 2007. v. 1. p. 829-838.

ZIĘBIK, A.; SZEGDA, D.; QVALE, B.; ELMEGAARD, B. Thermodynamic Simulation Analysis of a Multifuel CHP Plant basing on the Technological Diagram of Avedøre Unit 2. In: $19^{\text {th }}$ International Conference on Efficiency, Cost, Optimization, Simulation and Environmental Impact of Energy Systems, Aghia Pelagia, 2006. Proceedings of the $\mathbf{1 9}^{\text {th }}$ nternational Conference on Efficiency, Cost, Optimization, Simulation and Environmental Impact of Energy Systems, Athens: National Technical University of Athens, 2006a, v. 3, p. 1129-1136. 


\section{APÊNDICE A. MODELAGEM DOS PROCESSOS DE CONVERSÃO DE ENERGIA EM USINAS}

A seguir são apresentadas as equações utilizadas para a modelagem dos principais equipamentos de conversão de energia nas usinas. Também são mostradas as equações auxiliares para a determinação dos custos em base exergética dos fluxos.

As propriedades termodinâmicas e as exergias dos fluxos de massa foram calculadas a partir de funções implementadas no software EES ${ }^{\circledR}$ utilizando as equações mostradas no Cap. 5.

Para obtenção das equações auxiliares para determinação dos custos em base exergética, adotou-se o critério da igualdade dos custos em base exergética dos produtos do volume de controle determinado.

O equacionamento apresentado foi desenvolvido para a simulação de uma usina tradicional. Para as demais configurações, pequenas alterações foram realizadas para inclusão/exclusão de equipamentos, porém os balanços são iguais.

\section{A.1. SISTEMA DE EXTRAÇÃO}

A Fig. A.1 mostra o fluxograma simplificado do sistema de extração.

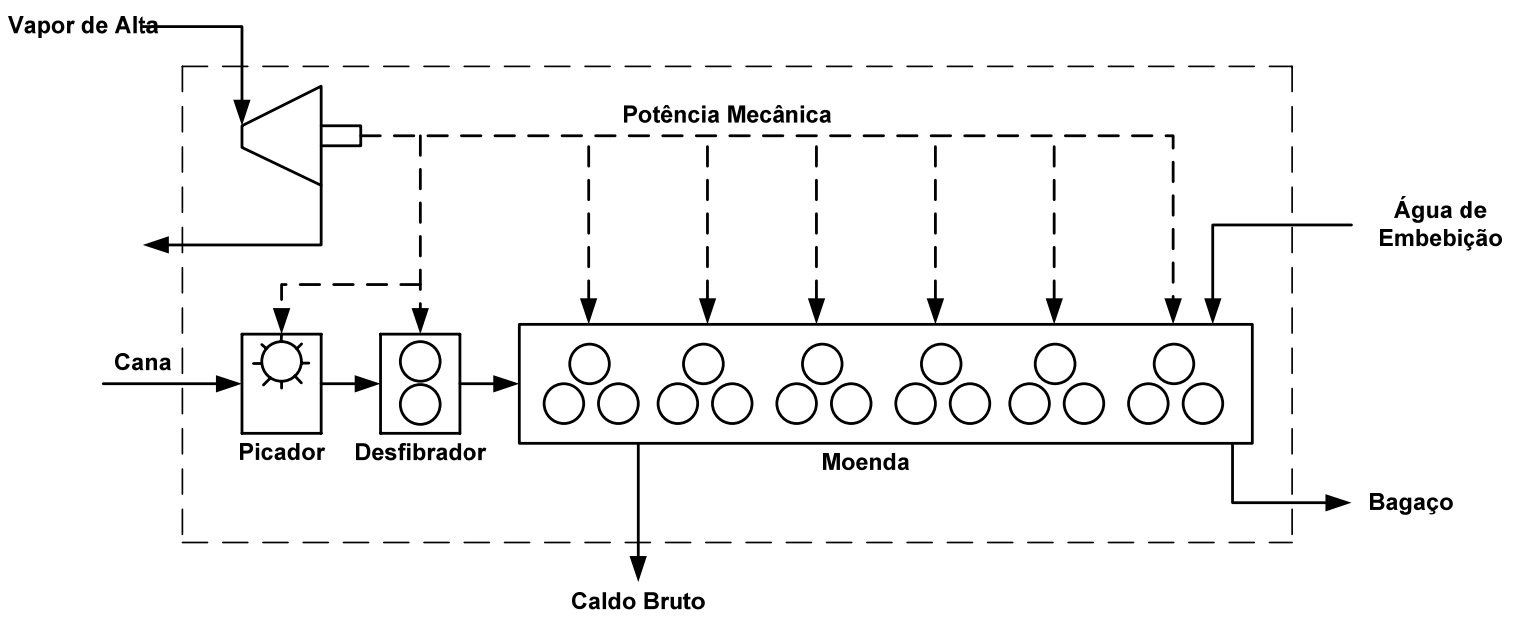

Figura A.1 - Fluxograma simplificado do sistema de extração. 
É possível identificar três fluxos de entrada (cana-de-açúcar, vapor de alta e água de embebição) e três fluxos de saída (caldo misto, bagaço e vapor de escape).

A vazão da água de embebição é função da quantidade de fibra e da eficiência de recuperação de sacarose. De forma geral, quanto maior o teor de fibra da cana, maior deve ser a adição da água de embebição durante a extração do caldo. A maior taxa de embebição permite uma melhor extração da sacarose. Com relação à capacidade dos equipamentos e o consumo energético, quanto maior a quantidade de água adicionada necessita-se de uma maior capacidade de tratamento e mais reagentes. $\mathrm{Na}$ evaporação e destilação, todo volume de água adicionado deverá ser removido posteriormente, e exigirá maior consumo de vapor de aquecimento (CAMARGO, 1990). Hugot (1986) indica um valor ótimo de embebição igual a $2 \mathrm{~kg}$ de água/kg de fibra na cana.

A eficiência de extração, dada pela razão entre a sacarose presente na cana e a sacarose presente no caldo misto, é igual a 95,7\%. Esse valor foi tirado de uma média entre a eficiência de extração das moendas no início do Proálcool e as atuais (OLIVÉRIO, 2007).

Já com relação ao consumo de energia eletromecânica, o valor de $15 \mathrm{kWh} / \mathrm{tc}$ foi adotado conforme discutido no Cap. 4. A eficiência isoentrópica da turbina foi fixada em $55 \%$ e a eficiência mecânica em 90\%.

Finalmente, a umidade do bagaço na saída foi fixada em 50\%, valor comumente encontrado em usinas brasileiras.

Além dessas considerações, a vazão e a variedade da cana (sua composição) deverão ser fornecidas pelo usuário.

Desta maneira, é possível estabelecer os seguintes balanços (Fig. A.1).

Balanços de Massa:

$$
\dot{\mathrm{m}}_{\text {cana }}+\dot{\mathrm{m}}_{\substack{\text { água } \\ \text { embebição }}}=\dot{\mathrm{m}}_{\substack{\text { caldo } \\ \text { bruto }}}+\dot{\mathrm{m}}_{\text {bagaço }}
$$




$$
\dot{\mathrm{m}}_{\text {cana }} \cdot \text { fibra }_{\text {cana }}=\dot{\mathrm{m}}_{\text {bagaço }} \cdot \text { fibra }_{\text {bagą̧o }}
$$

$$
\dot{\mathrm{m}}_{\text {vapor }}=\dot{\mathrm{m}}_{\text {vapor }}
$$

Balanço de Energia:

$$
\dot{\mathrm{m}}_{\text {vapor }} \cdot \mathrm{h}_{\text {vapor }}=\dot{\mathrm{m}}_{\text {vapor }} \cdot \mathrm{h}_{\text {vapape }}+\dot{\mathrm{W}}_{\text {escape }} \text { moenda }
$$

Balanço de Exergia:

$$
\begin{aligned}
& \dot{\mathrm{m}}_{\text {cana }} \cdot \mathrm{b}_{\text {cana }}+\dot{\mathrm{m}}_{\substack{\text { água } \\
\text { embebição }}} \cdot \mathrm{b}_{\substack{\text { água } \\
\text { embebição }}}+\dot{\mathrm{m}}_{\text {vapor }} \cdot \mathrm{b}_{\text {vapor }}= \\
& \dot{\mathrm{m}}_{\substack{\text { caldo } \\
\text { bruto }}} \cdot \mathrm{b}_{\substack{\text { caldo } \\
\text { bruto }}}+\dot{\mathrm{m}}_{\text {bagaço }} \cdot \mathrm{b}_{\text {bagaço }}+\dot{\mathrm{m}}_{\text {vapor }} \cdot \mathrm{b}_{\text {escape }} \text { vapor }_{\text {escape }}+\dot{\mathrm{B}}_{\substack{\text { destruído } \\
\text { extraçāo }}}
\end{aligned}
$$

Balanço de Custo:

$$
\begin{aligned}
& \dot{\mathrm{m}}_{\text {cana }} \cdot \mathrm{b}_{\text {cana }} \cdot \mathrm{c}_{\text {cana }}+\dot{\mathrm{m}}_{\substack{\text { água } \\
\text { embebição }}} \cdot \underset{\substack{\text { água } \\
\text { embebição }}}{\mathrm{c}_{\text {água }}}+\dot{\mathrm{m}}_{\text {embebição }} \dot{\text { vapor }}_{\text {alta }} \cdot \mathrm{b}_{\text {vapor }} \cdot \mathrm{c}_{\text {altapor }}= \\
& \dot{\mathrm{m}}_{\text {caldo }} \cdot \mathrm{b}_{\text {misto }}^{\text {misto }} \underset{\text { misto }}{\mathrm{c}_{\text {caldo }}}+\dot{\mathrm{m}}_{\text {bagaço }} \cdot \mathrm{b}_{\text {bagaço }} \cdot \mathrm{c}_{\text {bagaço }}+\dot{\mathrm{m}}_{\text {vapor }} \cdot \mathrm{b}_{\text {vapora }} \cdot \mathrm{c}_{\text {vapaper }} \\
& \dot{\mathrm{m}}_{\text {vapor }} \cdot \mathrm{b}_{\text {vapor }} \cdot \mathrm{c}_{\text {vapor }}=\underset{\text { alta }}{\mathrm{W}_{\text {mecânico }}} \cdot \underset{\text { moenda }}{\mathrm{c}_{\text {mecânico }}}+\dot{\mathrm{m}}_{\text {moenda }} \cdot \underset{\text { escape }}{\mathrm{b}_{\text {vapor }}} \cdot \underset{\text { escape }}{\mathrm{c}_{\text {vapor }}}
\end{aligned}
$$

Analisando a Fig. A.1, é possível observar que os produtos do sistema de extração são o bagaço e o caldo misto. O vapor de escape pode ser considerado um produto da turbina de acionamento da moenda e não do sistema de extração. Desta maneira, as seguintes equações auxiliares podem ser definidas:

$$
\underset{\text { misto }}{\mathrm{c}_{\text {caldo }}}=\mathrm{c}_{\text {bagaço }}
$$




$$
\underset{\text { moenda }}{\mathrm{c}_{\text {mecânico }}}=\mathrm{c}_{\text {vapor }}
$$

Para a cana-de-açúcar, insumo do processo, é atribuído custo em base exergética igual a 1 e o custo da água de embebição é igual ao do condensado do vapor vegetal.

$$
\begin{gathered}
\mathrm{c}_{\text {cana }}=1 \\
\mathrm{c}_{\text {água }}=\mathrm{c}_{\substack{\text { condensado } \\
\text { vapor vegetal }}}
\end{gathered}
$$

Quando a eletrificação das moendas é analisada, não há a necessidade do uso da turbina do acionamento. Portanto, as vazões de vapor de alta e escape são zero e os termos substituídos pela potência necessária para a movimentação da moenda.

Balanço de Exergia:

$$
\begin{aligned}
\dot{\mathrm{m}}_{\text {cana }} \cdot \mathrm{b}_{\text {cana }}+\dot{\mathrm{m}}_{\substack{\text { água } \\
\text { embebição }}} \cdot \mathrm{b}_{\substack{\text { água } \\
\text { embebição }}}+\dot{\mathrm{W}}_{\text {mecânico }}= \\
\\
\dot{\mathrm{m}}_{\substack{\text { caldo } \\
\text { bruto }}} \cdot \mathrm{b}_{\text {caldo }}+\dot{\mathrm{m}}_{\text {bruagaço }} \cdot \mathrm{b}_{\text {bagaço }}+\dot{\mathrm{B}}_{\begin{array}{c}
\text { destruído } \\
\text { extração }
\end{array}}
\end{aligned}
$$

Balanço de Custo:

$$
\begin{aligned}
& \dot{\mathrm{m}}_{\text {cana }} \cdot \mathrm{b}_{\text {cana }} \cdot \mathrm{c}_{\text {cana }}+\dot{\mathrm{m}}_{\text {água }}^{\text {embebição }} \underset{\substack{\text { água } \\
\text { embebição }}}{\mathrm{b}_{\text {água }}}+\dot{\mathrm{W}}_{\text {embebição }} \dot{\text { mecânico }}_{\text {moenda }} \cdot \mathrm{c}_{\text {eletricidade }}= \\
& \dot{\mathrm{m}}_{\substack{\text { caldo } \\
\text { misto }}} \cdot \underset{\text { misto }}{\mathrm{b}_{\text {caldo }}} \cdot \underset{\text { misto }}{\mathrm{c}_{\text {caldo }}}+\dot{\mathrm{m}}_{\text {bagaço }} \cdot \mathrm{b}_{\text {bagaço }} \cdot \mathrm{c}_{\text {bagaço }}
\end{aligned}
$$

As eqs. (A.8), (A.10) e (A.11) são novamente utilizadas para a eletrificação das moendas.

\section{A.2. TRATAMENTO DE CALDO}

A Fig. A.2 mostra um diagrama simplificado do processo de tratamento de caldo. 


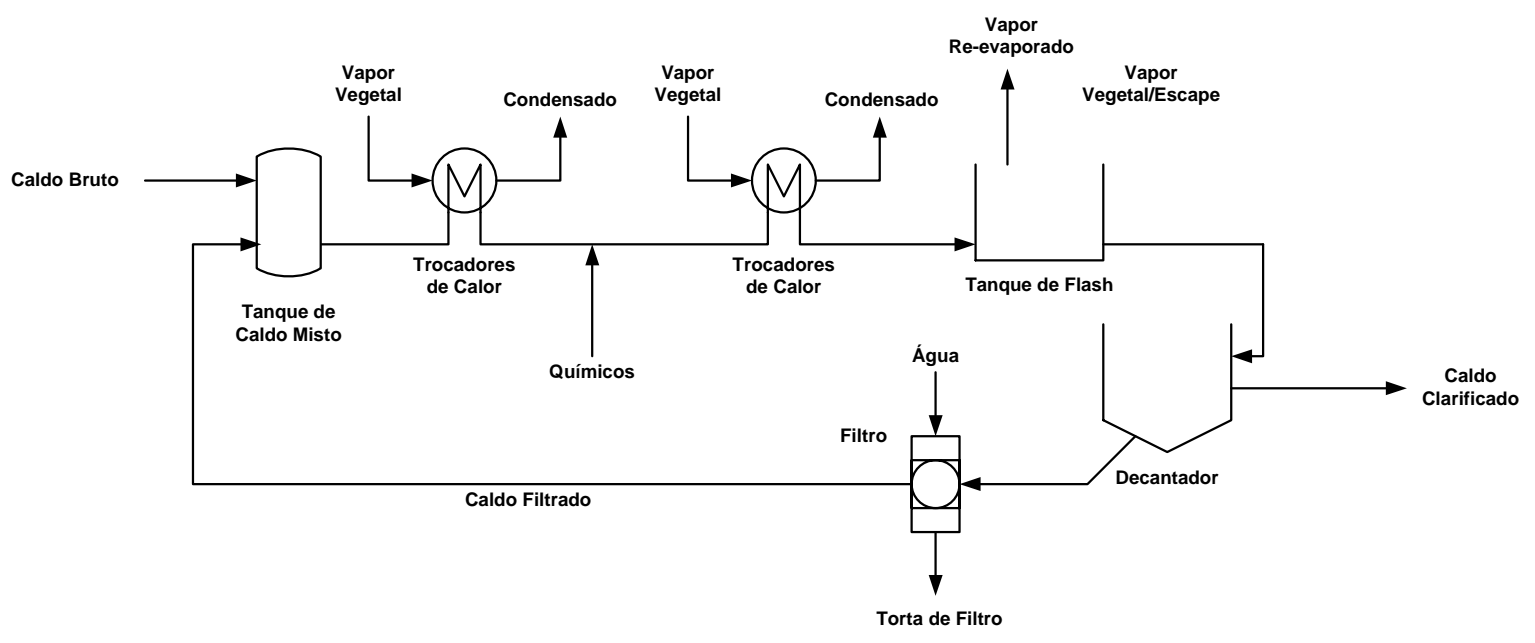

Figura A.2 - Esquema do Tratamento de Caldo.

Cada equipamento mostrado na Fig. A.2 foi modelado separadamente, com exceção do decantador e filtro. Para estes equipamentos, um volume de controle único foi considerado, devido à falta de informações disponíveis.

$\mathrm{O}$ retorno de caldo filtrado foi fixado em $0,2 \mathrm{~kg}$ de caldo filtrado $/ \mathrm{kg}$ de caldo misto, a temperatura do caldo filtrado foi fixada em $25^{\circ} \mathrm{C}$. A adição de químicos foi modelada com uma simples diluição com água a $25^{\circ} \mathrm{C}$, utilizando o valor de $15 \mathrm{~kg}$ de água/tc. A água adicionada no filtro foi fixada em $15 \mathrm{~kg}$ de água/tc. A torta de filtro foi fixada em $4 \mathrm{~kg}$ de torta/tc.

Uma eficiência energética de $98 \%$ foi adotada nos trocadores de calor, conforme Baloh e Wittwer (1995). O vapor vegetal deixa os trocadores como líquido saturado. Não há variação da quantidade de sacarose nos trocadores.

O vapor gerado no tanque de flash está em equilíbrio com a água contida caldo, sendo este equilíbrio calculado a partir da Lei de Raoult Modificado (NEBRA; FERNÁNDEZ-PARRA, 2005). A equação do equilíbrio é responsável pela determinação da temperatura do caldo na saída do tanque de flash. O caldo clarificado deixa o decantador com uma temperatura de $95^{\circ} \mathrm{C}$.

a) Tanque de Caldo Misto

Balanços de Massa: 


$$
\begin{aligned}
& \dot{\mathrm{m}}_{\text {caldo }}+\dot{\mathrm{m}}_{\substack{\text { caldo } \\
\text { frittrado }}}=\dot{\mathrm{m}}_{\substack{\text { caldo } \\
\text { misto }}} \\
& \dot{\mathrm{m}}_{\text {caldo }} \cdot \mathrm{X}_{\text {caldo }}+\dot{\mathrm{m}}_{\text {caldo }} \cdot \mathrm{X}_{\text {caldo }}=\dot{\mathrm{m}}_{\text {filtrado }} \dot{\text { caldo }}_{\text {misto }} \cdot \underbrace{\text { misto }}_{\text {caldo }}
\end{aligned}
$$

Balanço de Energia:

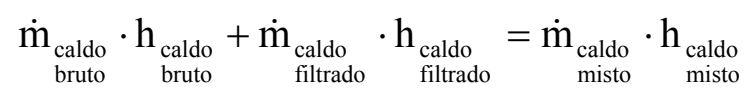

Balanço de Exergia:

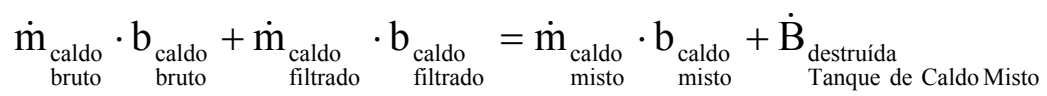

Balanço de Custo:

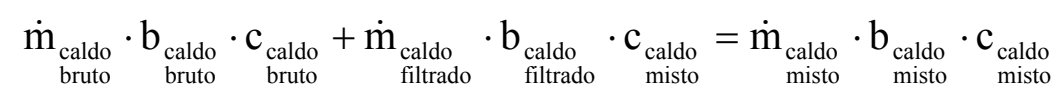

b) Trocadores de Calor:

Balanços de Massa:

$$
\begin{gathered}
\dot{\mathrm{m}}_{\substack{\text { caldo } \\
\text { entrada }}}=\dot{\mathrm{m}}_{\substack{\text { caldo } \\
\text { saída }}} \\
\dot{\mathrm{m}}_{\substack{\text { caldo } \\
\text { entrada }}} \cdot \mathrm{x}_{\text {caldo }}=\dot{\mathrm{m}}_{\substack{\text { caldo } \\
\text { saida }}} \cdot \mathrm{x}_{\substack{\text { caldo } \\
\text { saida }}} \\
\dot{\mathrm{m}}_{\text {vapor }}=\dot{\mathrm{m}}_{\text {condensado }}
\end{gathered}
$$




$$
\dot{\mathrm{m}}_{\substack{\text { caldo } \\ \text { saída }}} \cdot \mathrm{h}_{\substack{\text { caldo } \\ \text { saída }}}-\dot{\mathrm{m}}_{\substack{\text { caldo } \\ \text { entrada }}} \cdot \mathrm{h}_{\substack{\text { caldo } \\ \text { entrada }}}=\left(\dot{\mathrm{m}}_{\text {vapor }} \cdot \mathrm{h}_{\text {vapor }}-\dot{\mathrm{m}}_{\text {condensado }} \cdot \mathrm{h}_{\text {condensado }}\right) \cdot 0,98
$$

Balanço de Exergia:

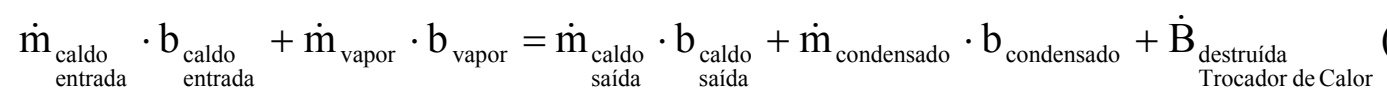

Balanço de Custo:

$$
\begin{aligned}
& \dot{\mathrm{m}}_{\text {caldo }}{ }_{\text {entrada }} \cdot \underset{\text { entrada }}{\mathrm{b}_{\text {caldo }}} \cdot \mathrm{c}_{\text {caldo }}^{\text {entrada }}\left(\dot{\mathrm{m}}_{\text {vapor }} \cdot \mathrm{b}_{\text {vapor }} \cdot \mathrm{c}_{\text {vapor }}=\right. \\
& \dot{\mathrm{m}}_{\substack{\text { caldo } \\
\text { saída }}} \cdot \underset{\substack{\text { caldo } \\
\text { saida }}}{\mathrm{b}_{\substack{\text { caldo } \\
\text { saida }}}}+\dot{\mathrm{m}}_{\text {condensado }} \cdot \mathrm{b}_{\text {condensado }} \cdot \mathrm{c}_{\text {condensado }}
\end{aligned}
$$

Para um trocador de calor, se reconhece apenas um produto, o fluxo sendo aquecido ou resfriado, dependendo do propósito do trocador. Isso implica atribuir todo o custo das irreversibilidades a esse fluxo, de maneira que o custo do fluxo do agente de aquecimento ou resfriamento, em base exergética, não se altera.

$$
\mathrm{c}_{\text {vapor }}=\mathrm{c}_{\text {condensado }}
$$

c) Tanque de Flash:

Balanços de Massa:

$$
\begin{gathered}
\dot{\mathrm{m}}_{\text {caldo }}^{\text {entrada }}=\dot{\mathrm{m}}_{\substack{\text { caldo } \\
\text { saída }}}+\dot{\mathrm{m}}_{\substack{\text { vapor } \\
\text { reevaporado }}} \\
\dot{\mathrm{m}}_{\substack{\text { caldo } \\
\text { entrada }}} \cdot \mathrm{x}_{\text {caldo }}=\dot{\mathrm{m}}_{\substack{\text { caldo } \\
\text { saía }}} \cdot \mathrm{X}_{\substack{\text { caldo } \\
\text { saida }}}
\end{gathered}
$$

Balanço de Energia: 


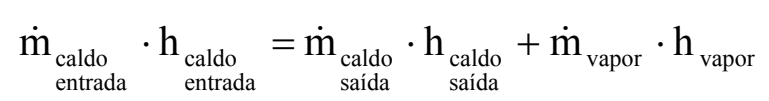

Equilíbrio líquido-vapor (Lei de Raoult Modificada), para determinação da temperatura do caldo na saída do tanque:

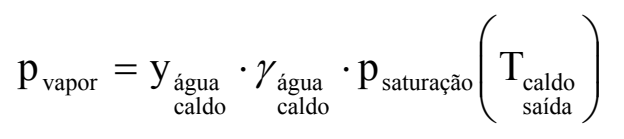

Balanço de Exergia:

$$
\underset{\substack{\text { caldo } \\ \text { entrada }}}{\dot{b_{\text {caldo }}}}=\dot{\mathrm{m}}_{\substack{\text { caldo } \\ \text { saida }}} \cdot b_{\text {caldo }} \mathrm{b}_{\text {saida }}+\dot{\mathrm{m}}_{\text {vapor }} \cdot \mathrm{b}_{\text {vapor }}+\dot{\mathrm{B}}_{\substack{\text { destruída } \\ \text { Tanque de Flash }}}
$$

Balanço de Custo:

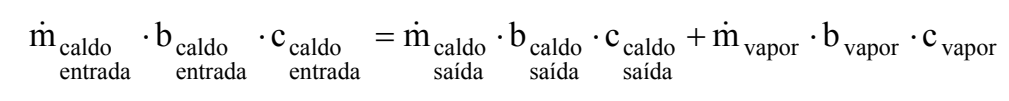

O vapor re-evaporado não é utilizado em nenhum outro processo, sendo perdido para o meio. Desta maneira, foi atribuído custo em base exergética nulo para esse fluxo.

$$
\mathrm{c}_{\text {vapor }}=0
$$

d) Decantador e Filtro:

Balanços de Massa:

$$
\begin{aligned}
& \dot{\mathrm{m}}_{\text {caldo }}^{\text {entrada }}+\mathrm{m}_{\text {água }}=\dot{\mathrm{m}}_{\text {caldo }}^{\text {calrificado }}+\dot{\mathrm{m}}_{\text {caldo }}+\dot{\mathrm{m}}_{\text {forttrado }}
\end{aligned}
$$

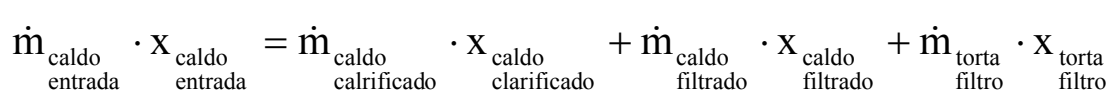


Balanço de Exergia:

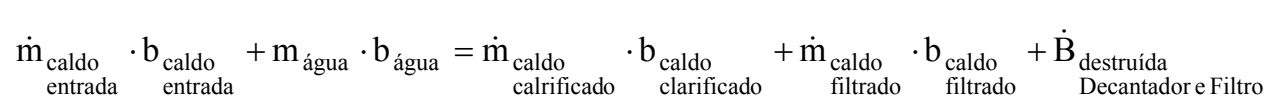

Balanço de Custo:

$$
\begin{aligned}
\dot{\mathrm{m}}_{\text {caldo }}^{\dot{\text { entrada }}_{\text {entrada }}} \cdot \mathrm{b}_{\text {caldo }} \cdot \mathrm{c}_{\text {caldo }}^{\text {entrada }} & +\mathrm{m}_{\text {água }} \cdot \mathrm{b}_{\text {água }} \cdot \mathrm{c}_{\text {água }}
\end{aligned}
$$

A exergia da torta de filtro não foi calculada, pois não há dados disponíveis sobre a sua composição. Assim, esse fluxo foi encarado com um fluxo de exergia que não produz nenhum efeito útil, sendo adicionada ao termo da exergia destruída e atribuído custo nulo.

Na saída do volume de controle, é possível identificar dois produtos (caldo clarificado e caldo filtrado). A torta de filtro é considerada um resíduo do processo sem valor para o processo. Desta maneira, a seguintes equação auxiliar foi definida:

$$
\underset{\text { clarificado }}{\mathrm{c}_{\text {caldo }}}=\underset{\text { filtrado }}{\mathrm{c}_{\text {caldo }}}
$$

Ainda, o custo em base exergética da água para o filtro foi igualado a um, já que esse fluxo é considerado um insumo do processo.

$$
\mathrm{c}_{\text {água }}=1
$$

\section{A.3. PRODUÇÃO DE AÇÚCAR}

A Figura A.3 mostra um diagrama simplificado do processo da produção de açúcar. 


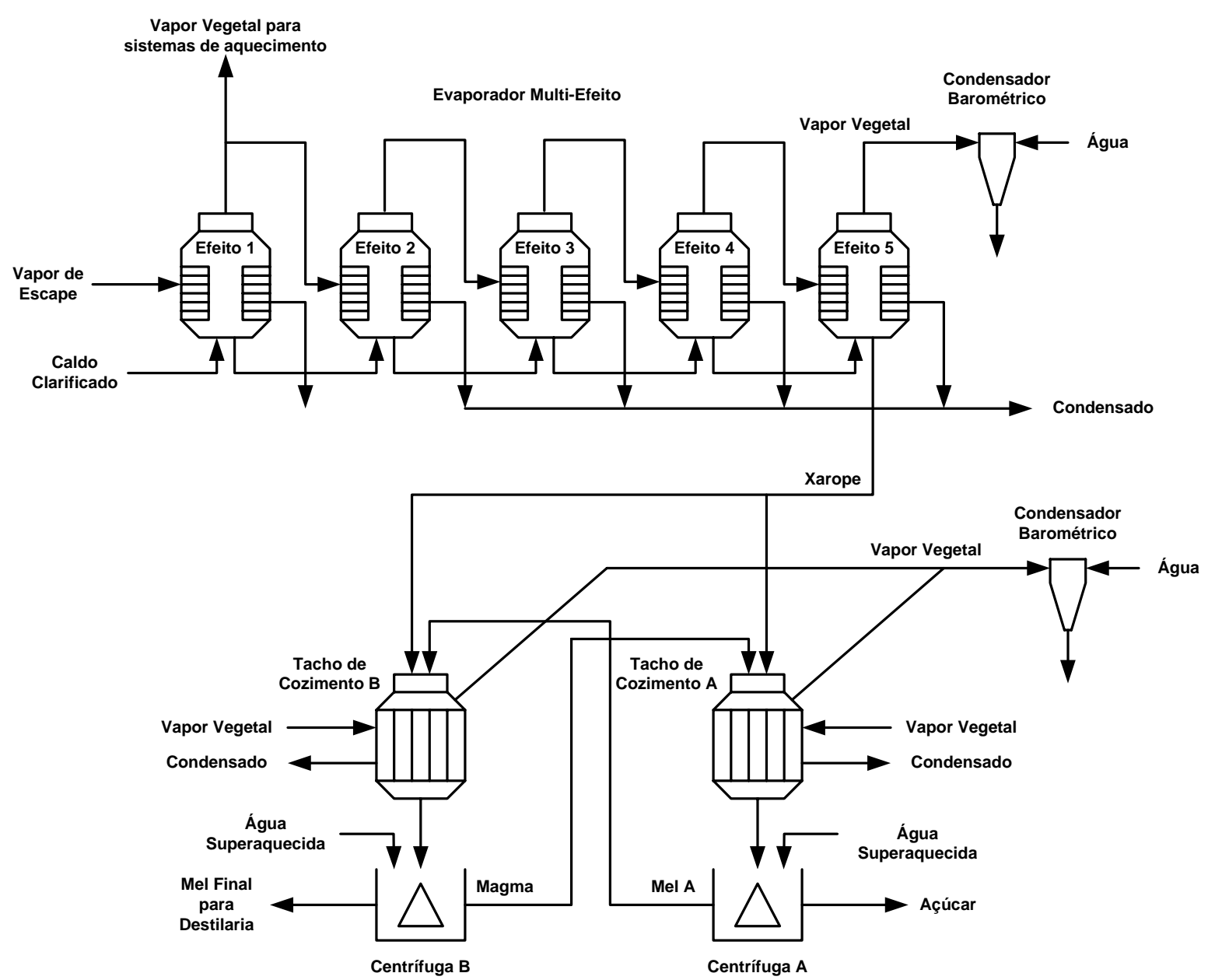

Figura A.3 - Esquema de Produção de Açúcar.

Cada equipamento mostrado na Fig. A.3 foi modelado a partir de balanços de massa e energia, utilizando as correlações mostradas em Nebra e Fernández-Parra (2005), para determinação das propriedades das soluções água-sacarose

A modelagem do sistema de evaporação seguiu a metodologia descrita em Pellegrini e Oliveira Jr (2006a). Já a modelagem dos sistemas cozimento e centrifugação baseou-se em valores de concentração de sólidos e sacarose (pol) de cada fluxo de massa de solução águasacarose (HUGOT, 1986).

Uma eficiência energética de $98 \%$ foi adotada nos corpos dos evaporadores e de $95 \%$ nos tachos de cozimento, conforme Baloh e Wittwer (1995). O vapor vegetal deixa os equipamentos como líquido saturado. Não há variação da quantidade de sacarose nos equipamentos. 
O vapor gerado nos corpos dos evaporadores e nos tachos de cozimento está em equilíbrio com a água contida caldo, sendo este equilíbrio calculado a partir da Lei de Raoult Modificado. A equação do equilíbrio é responsável pela determinação da temperatura do caldo na saída desses equipamentos.

As pressões de operação de cada corpo do múltiplo-efeito e dos tachos de cozimento são mostradas na Tab. A.1.

Tabela A.1 - Pressões de operação de cada corpo do múltiplo-efeito e dos tachos de cozimento.

\begin{tabular}{cc}
\hline $1^{\circ}$ efeito & $1,8 \mathrm{bar}$ \\
$2^{\circ}$ efeito & $1,34 \mathrm{bar}$ \\
$3^{\circ}$ efeito & $0,96 \mathrm{bar}$ \\
$4^{\circ}$ efeito & $0,54 \mathrm{bar}$ \\
$5^{\circ}$ efeito & $0,2 \mathrm{bar}$ \\
Tachos de cozimento & $0,2 \mathrm{bar}$ \\
\hline
\end{tabular}

A quantidade de água de lavagem adicionada nas centrífugas é determinada a partir dos balanços de massa nas mesmas. Essa água é chamada de superaquecida, pois se trata de um fluxo de água aquecido diretamente com vapor proveniente da caldeira. O balanço de massa e energia desse trocador determina as vazões de água fria e vapor utilizados.

A seguir os equacionamentos utilizados são apresentados.

\section{a) Efeito de Evaporação}

Balanços de Massa:

$$
\begin{gathered}
\dot{\mathrm{m}}_{\substack{\text { caldo } \\
\text { entrada }}}=\dot{\mathrm{m}}_{\substack{\text { caldo } \\
\text { saída }}}+\dot{\mathrm{m}}_{\substack{\text { vapor } \\
\text { vegetal }}} \\
\dot{\mathrm{m}}_{\substack{\text { caldo } \\
\text { entrada }}} \cdot \mathrm{x}_{\text {caldo }}=\dot{\mathrm{m}}_{\substack{\text { caldo } \\
\text { saida }}} \cdot \mathrm{x}_{\substack{\text { caldo } \\
\text { saida }}} \\
\dot{\mathrm{m}}_{\text {vapor }}=\dot{\mathrm{m}}_{\text {condensado }}
\end{gathered}
$$


Balanço de Energia:

$$
\begin{aligned}
& \left(\dot{\mathrm{m}}_{\substack{\text { caldo } \\
\text { saida }}} \cdot \mathrm{h}_{\substack{\text { caldo } \\
\text { saida }}}+\dot{\mathrm{m}}_{\substack{\text { vapor } \\
\text { vegetal }}} \cdot \mathrm{h}_{\text {vapor }}\right)-\dot{\mathrm{m}}_{\substack{\text { caldo } \\
\text { entrada }}} \cdot \mathrm{h}_{\substack{\text { caldo } \\
\text { entrada }}}= \\
& \left(\dot{\mathrm{m}}_{\text {vapor }} \cdot \mathrm{h}_{\text {vapor }}-\dot{\mathrm{m}}_{\text {condensado }} \cdot \mathrm{h}_{\text {condensado }}\right) \cdot 0,98
\end{aligned}
$$

Balanço de Exergia:

$$
\begin{aligned}
& \dot{\mathrm{m}}_{\substack{\text { caldo } \\
\text { entrada }}} \cdot \mathrm{b}_{\text {caldo }}+\dot{\mathrm{m}}_{\text {vapor }} \cdot \mathrm{b}_{\text {vapor }}= \\
& \dot{\mathrm{m}}_{\substack{\text { caldo } \\
\text { saida }}} \cdot \underset{\text { caldo }}{\mathrm{b}_{\text {saida }}}+\dot{\mathrm{m}}_{\substack{\text { vapor } \\
\text { vegetal }}} \cdot \underset{\substack{\text { vapor } \\
\text { vegetal }}}{\mathrm{b}_{\text {condensado }}} \cdot \dot{\mathrm{m}}_{\text {condensado }}+\dot{\mathrm{B}}_{\text {destruída }}
\end{aligned}
$$

Balanço de Custo:

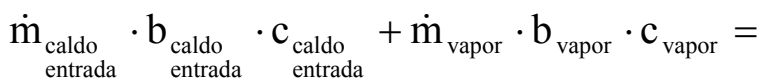

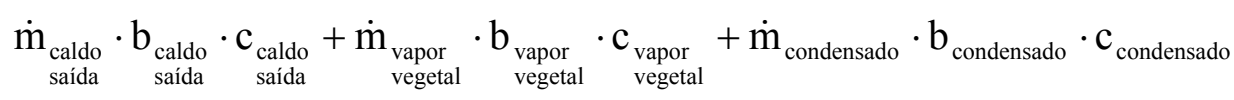

Da mesma forma que para um trocador de calor, o custo do fluxo do agente de aquecimento ou resfriamento, em base exergética, não se altera.

$$
\mathrm{c}_{\text {vapor }}=\mathrm{c}_{\text {condensado }}
$$

Todavia, ainda é possível identificar dois fluxos que saem desse equipamento (caldo concentrado e vapor vegetal). Dessa forma, utilizando o critério da igualdade, tem-se:

$$
\underset{\text { saída }}{\mathrm{c}_{\text {caldo }}}=\underset{\text { vegetal }}{\mathrm{c}_{\text {vapor }}}
$$

\section{b) Tachos de Cozimento}

Balanços de Massa: 


$$
\begin{aligned}
& \dot{\mathrm{m}}_{\text {xarope }}+\dot{\mathrm{m}}_{\text {magma } / \text { mel A }}=\dot{\mathrm{m}}_{\substack{\text { massa } \\
\text { cozida A } / \mathrm{B}}}+\dot{\mathrm{m}}_{\substack{\text { vapor } \\
\text { vegetal }}} \\
& \dot{\mathrm{m}}_{\text {xarope }} \cdot \mathrm{X}_{\text {xarope }}+\dot{\mathrm{m}}_{\text {magma } / \mathrm{melA}} \cdot \mathrm{X}_{\text {magma } / \text { mel A }}=\dot{\mathrm{m}}_{\substack{\text { massa } \\
\text { cozida A } / \mathrm{B}}} \cdot \mathrm{X}_{\text {massa }} \text { cozida A } / \mathrm{B} \\
& \dot{\mathrm{m}}_{\text {xarope }} \cdot \operatorname{pol}_{\text {xarope }}+\dot{\mathrm{m}}_{\text {magma/mel A }} \cdot \operatorname{pol}_{\text {magma/melA }}=\dot{\mathrm{m}}_{\substack{\text { massa } \\
\text { cozida A } / \mathrm{B}}} \cdot \operatorname{pol}_{\substack{\text { massa } \\
\text { cozida A } / \mathrm{B}}} \\
& \dot{\mathrm{m}}_{\mathrm{vapor}}=\dot{\mathrm{m}}_{\text {condensado }}
\end{aligned}
$$

Balanço de Energia:

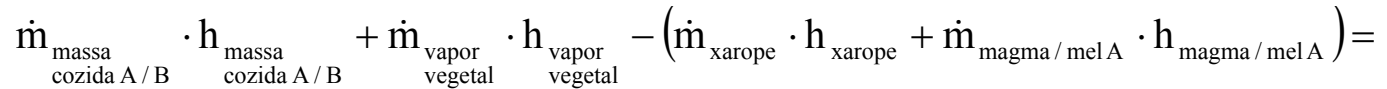

$$
\begin{aligned}
& \left(\dot{\mathrm{m}}_{\text {vapor }} \cdot \mathrm{h}_{\text {vapor }}-\dot{\mathrm{m}}_{\text {condensado }} \cdot \mathrm{h}_{\text {condensado }}\right) \cdot 0,95
\end{aligned}
$$

\section{Balanço de Exergia:}

$$
\begin{aligned}
& \dot{\mathrm{m}}_{\text {xarope }} \cdot \mathrm{b}_{\text {xarope }}+\dot{\mathrm{m}}_{\text {magma/mel A }} \cdot \mathrm{b}_{\text {magma/mel A }}+\dot{\mathrm{m}}_{\text {vapor }} \cdot \mathrm{b}_{\text {vapor }}= \\
& \quad \dot{\mathrm{m}}_{\substack{\text { massa } \\
\text { cozida A } / \mathrm{B}}} \cdot \mathrm{b}_{\text {massa }}+\dot{\mathrm{m}}_{\text {cozida A } / \mathrm{B}}+\dot{\mathrm{v}}_{\text {vegor }} \cdot \mathrm{b}_{\text {vapor }}+\dot{\mathrm{m}}_{\text {vendensado }} \cdot \mathrm{b}_{\text {condensado }}+\dot{\mathrm{B}}_{\text {destruída }}
\end{aligned}
$$

Balanço de Custo:

$$
\begin{aligned}
& \dot{\mathrm{m}}_{\text {xarope }} \cdot \mathrm{b}_{\text {xarope }} \cdot \mathrm{c}_{\text {xarope }}+\dot{\mathrm{m}}_{\text {magma } / \mathrm{mel} \mathrm{A}} \cdot \mathrm{c}_{\text {magma } / \mathrm{mel} \mathrm{A}} \cdot \mathrm{c}_{\text {magma } / \mathrm{mel} \mathrm{A}}+\dot{\mathrm{m}}_{\text {vapor }} \cdot \mathrm{b}_{\text {vapor }} \cdot \mathrm{c}_{\text {vapor }}=
\end{aligned}
$$

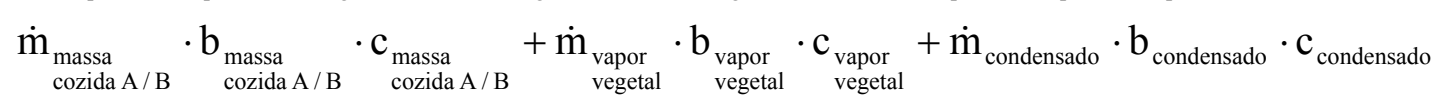

Os tachos têm a mesma função dos evaporadores. Assim, as equações auxiliares posem ser escritas como:

$$
\mathrm{c}_{\mathrm{vapor}}=\mathrm{c}_{\text {condensado }}
$$




\section{c) Centrífugas}

Balanços de Massa:

$$
\begin{aligned}
& \dot{\mathrm{m}}_{\text {massa }}^{\text {cozida A/B }}+\dot{\mathrm{m}}_{\text {água }}=\dot{\mathrm{m}}_{\text {açuçar } / \text { magma }}+\dot{\mathrm{m}}_{\text {mel A/mel final }} \\
& \dot{\mathrm{m}}_{\substack{\text { massa } \\
\text { cozida A / B }}} \cdot \mathrm{X}_{\text {cozida A /B }}=\dot{\mathrm{m}}_{\text {açuçar } / \text { magma }} \cdot \mathrm{X}_{\text {açúcar } / \text { magma }}+\dot{\mathrm{m}}_{\text {mel A } / \text { mel final }} \cdot \mathrm{X}_{\text {mel A /mel final }} \\
& \dot{\mathrm{m}}_{\text {massa }}{ }_{\text {cozida A / B }} \cdot \operatorname{pol}_{\substack{\text { massa } \\
\text { cozida A B B }}}=\dot{\mathrm{m}}_{\text {açuçar } / \text { magma }} \cdot \operatorname{pol}_{\text {açúcar } / \text { magma }}+\dot{\mathrm{m}}_{\text {mel A } / \text { mel final }} \cdot \operatorname{pol}_{\text {mel A } / \text { mel final }}
\end{aligned}
$$

Balanço de Exergia:

$$
\dot{\mathrm{m}}_{\substack{\text { massa } \\
\text { cozida A / B }}} \cdot \underset{\mathrm{b}_{\text {massa }}^{\text {cozida A } / \mathrm{B}}}{ }=\dot{\mathrm{m}}_{\text {açuçar } / \text { magma }} \cdot \mathrm{b}_{\text {açúcar/magma }}+\dot{\mathrm{m}}_{\text {mel A/mel final }} \cdot \mathrm{b}_{\text {mel A/mel final }}+\dot{\mathrm{B}}_{\begin{array}{c}
\text { destruída } \\
\text { centrifuga }
\end{array}}
$$

\section{Balanço de Custo:}

$$
\begin{aligned}
& \dot{\mathrm{m}}_{\text {massa }}{ }_{\text {cozida A } / \mathrm{B}} \cdot \underset{\text { cozida A } / \mathrm{B}}{\mathrm{b}_{\text {massa }}} \cdot \mathrm{c}_{\text {massa }}{ }_{\text {cozida } \mathrm{A} / \mathrm{B}}+\dot{\mathrm{m}}_{\text {água }} \cdot \mathrm{b}_{\text {água }} \cdot \mathrm{c}_{\text {água }}= \\
& \dot{\mathrm{m}}_{\text {açuụar } / \text { magma }} \cdot \mathrm{b}_{\text {açúcar } / \text { magma }} \cdot \mathrm{c}_{\text {açúcar } / \text { magma }}+\dot{\mathrm{m}}_{\text {mel A /mel final }} \cdot \mathrm{b}_{\text {mel A } / \text { mel final }} \cdot \mathrm{c}_{\text {mel A } / \text { mel final }}
\end{aligned}
$$

As centrífugas são responsáveis por separar os cristais de sacarose da solução sacarose-água. Desta maneira, é possível identificar dois fluxos que deixam esse equipamento (açúcar ou magma e méis). Assim, as seguintes equações auxiliares foram utilizadas:

$$
\mathrm{c}_{\text {mel A } / \text { mel final }}=\mathrm{c}_{\text {açúcar } / \text { magma }}
$$

\section{d) Condensador Barométrico}


A função do condensador barométrico é condensar o vapor vegetal proveniente do último efeito do evaporador e dos tachos de cozimento, mantendo o sistema de vácuo desses equipamentos. Para a condensação é utilizada água em contato direto com o vapor. A temperatura de saída do condensado foi fixada em $60^{\circ} \mathrm{C}$.

Balanços de Massa:

$$
\dot{\mathrm{m}}_{\substack{\text { vapor } \\ \text { vegetal }}}+\dot{\mathrm{m}}_{\text {água }}=\dot{\mathrm{m}}_{\text {condensado }}
$$

Balanço de Energia:

$$
\dot{\mathrm{m}}_{\text {vapor }} \cdot \mathrm{h}_{\text {vapor }}+\dot{\mathrm{m}}_{\text {aǵgua }} \cdot \mathrm{h}_{\text {água }}=\dot{\mathrm{m}}_{\text {condensado }} \cdot \mathrm{h}_{\text {condensado }}
$$

Balanço de Exergia:

$$
\dot{\mathrm{m}}_{\substack{\text { vapor } \\ \text { vegetal }}} \cdot \mathrm{b}_{\substack{\text { vapor } \\ \text { vegetal }}}+\dot{\mathrm{m}}_{\text {água }} \cdot \mathrm{b}_{\text {água }}=\dot{\mathrm{m}}_{\text {condensado }} \cdot \mathrm{b}_{\text {condensado }}+\underset{\substack{\text { cestruída } \\ \text { condensador } \\ \text { barométrico }}}{\dot{\mathrm{B}}_{\text {a }}}
$$

Balanço de Custo:

$$
\dot{\mathrm{m}}_{\substack{\text { vapor } \\ \text { vegetal }}} \cdot \underset{\text { vegetal }}{\mathrm{b}_{\text {vapor }}} \cdot \underset{\text { vapor }}{\mathrm{c}_{\text {vegetal }}}+\dot{\mathrm{m}}_{\text {água }} \cdot \mathrm{b}_{\text {água }} \cdot \mathrm{c}_{\text {água }}=\dot{\mathrm{m}}_{\text {condensado }} \cdot \mathrm{b}_{\text {condensado }} \cdot \mathrm{c}_{\text {condensado }}
$$

O custo em base exergética da água utilizada no condensador é igual ao custo do condensado do vapor vegetal da fábrica:

$$
\mathrm{c}_{\text {água }}=\mathrm{c}_{\substack{\text { condensado } \\ \text { vapor vegetal }}}
$$

d) Trocador de Calor para Produção da Água Superaquecida 
A. 16

Balanços de Massa:

$$
\dot{\mathrm{m}}_{\substack{\text { vapor } \\ \text { alta }}}+\dot{\mathrm{m}}_{\text {água }}=\dot{\mathrm{m}}_{\substack{\text { água } \\ \text { sup eraquecida }}}
$$

Balanço de Energia:

$$
\dot{\mathrm{m}}_{\text {vapor }} \cdot \mathrm{h}_{\text {vapor }}+\dot{\mathrm{m}}_{\text {água }} \cdot \mathrm{h}_{\text {água }}=\dot{\mathrm{m}}_{\substack{\text { água } \\ \text { sup eraquecida }}} \cdot \mathrm{h}_{\substack{\text { água } \\ \text { sup eraquecida }}}
$$

Balanço de Exergia:

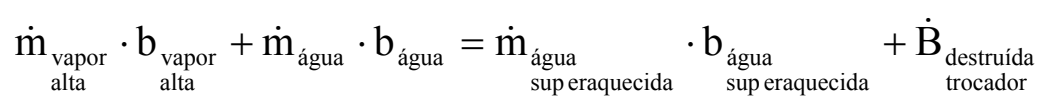

Balanço de Custo:

$$
\dot{\mathrm{m}}_{\text {vapor }} \cdot \mathrm{b}_{\text {vapor }} \cdot \mathrm{c}_{\text {vapor }}+\dot{\mathrm{m}}_{\text {água }} \cdot \mathrm{b}_{\text {água }} \cdot \mathrm{c}_{\text {água }}=\dot{\mathrm{m}}_{\substack{\text { água } \\ \text { sup eraquecida }}} \cdot \underset{\text { água }}{\text { sup eraquecida }} \cdot \underset{\substack{\text { água } \\ \text { sup eraquecida }}}{\mathrm{c}_{\text {alta }}}
$$

O vapor de alta é proveniente das caldeiras, enquanto a água é um insumo do processo e seu custo em base exergética é igual a 1 .

\section{A.4. PRODUÇÃO DE ÁLCOOL}

A Figura A.4 mostra um diagrama simplificado do processo de produção de álcool. 


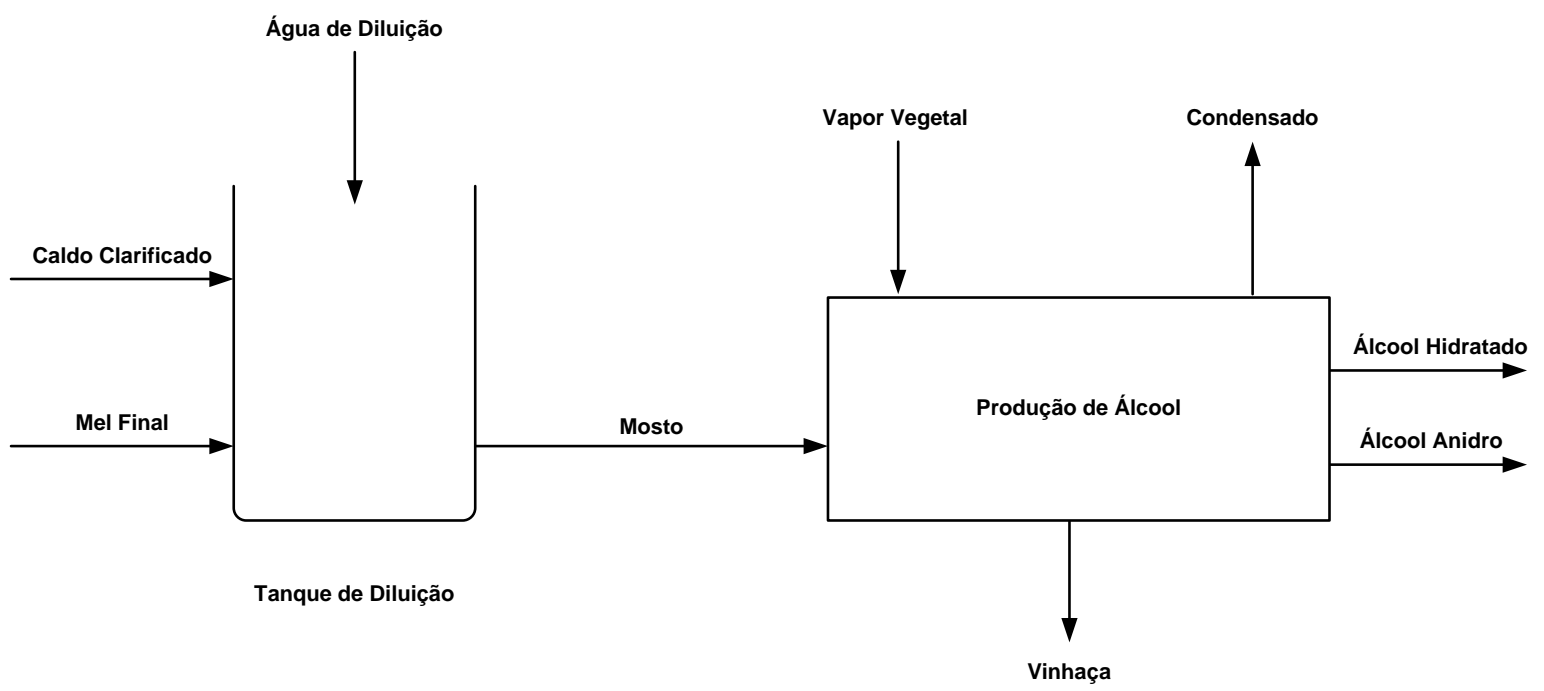

Figura A.4 - Esquema de Produção de Álcool.

A produção de álcool foi modelada a partir de parâmetros operacionais como: rendimento fermentativo, rendimento de destilação, consumo de vapor por litro de álcool e fração de vinho para produção de anidro. O modelo de baseou-se em índices e parâmetros de produção disponíveis na literatura (FERNANDES, 2003; MODESTO, ZEMP E NEBRA, 2006; OLIVÉRIO, 2007).

Para a etapa de fermentação, a relação estequiométrica de $0,64755 \mathrm{~L}$ de etanol $/ \mathrm{kg}$ de $\mathrm{ART}^{48}$ foi utilizada. Foi considerado um rendimento de fermentação de $90 \%$ e uma concentração de sólidos de 16\% para o mosto (ART de 13,25\%).

$\mathrm{Na}$ destilação, o consumo de vapor vegetal foi fixado em 4,5 kg/L de álcool anidro e 3,5 kg/L de álcool hidratado. Esses valores correspondem a situações de alto consumo, já que novas tecnologias já permitem consumos de $2,8 \mathrm{~kg} / \mathrm{L}$ de álcool anidro e $2 \mathrm{~kg} / \mathrm{L}$ de álcool hidratado (OLIVÉRIO, 2007). O rendimento da destilação foi definido igual a 99,5\%.

A transformação de etanol em álcoois anidro ou hidratado foi determinada pelos coeficientes estequiométricos 1,00425 L/L e 1,004645 L/L, respectivamente (FERNANDES, 2003).

\footnotetext{
${ }^{48}$ Açúcares Redutores Totais (ART) representam todos os açúcares da cana na forma de açúcares redutores ou invertidos $\left(\mathrm{ART}=\frac{\text { Pol }}{0,95}+\% \mathrm{gli}\right.$ cos e e frutose $)$.
} 
A quantidade de caldo clarificado e mel final enviada para a produção de álcool é determinada pelo usuário. A quantidade de álcool anidro e álcool hidratado fabricados também é fixada pelo usuário. Foi considerado ainda uma produção de vinhaça de $13 \mathrm{~L} / \mathrm{L}$ de etanol.

\section{a) Tanque de Diluição do Mosto}

Balanços de Massa:

$$
\begin{gathered}
\dot{\mathrm{m}}_{\substack{\text { caldo } \\
\text { misto }}}+\dot{\mathrm{m}}_{\text {melf final }}+\dot{\mathrm{m}}_{\substack{\text { água } \\
\text { diluição }}}=\dot{\mathrm{m}}_{\text {mosto }} \\
\dot{\mathrm{m}}_{\substack{\text { caldo } \\
\text { misto }}} \cdot \mathrm{x}_{\substack{\text { caldo } \\
\text { misto }}}+\dot{\mathrm{m}}_{\text {melf final }} \cdot \mathrm{x}_{\text {melf final }}=\dot{\mathrm{m}}_{\text {mosto }} \cdot \mathrm{x}_{\text {mosto }}
\end{gathered}
$$

Balanço de Energia:

$$
\dot{\mathrm{m}}_{\substack{\text { caldo } \\ \text { misto }}} \cdot \mathrm{h}_{\substack{\text { caldo } \\ \text { misto }}}+\dot{\mathrm{m}}_{\text {melf final }} \cdot \mathrm{h}_{\text {melf final }}+\dot{\mathrm{m}}_{\substack{\text { água } \\ \text { diluição }}} \cdot \mathrm{h}_{\substack{\text { água } \\ \text { diluição }}}=\dot{\mathrm{m}}_{\text {mosto }} \cdot \mathrm{h}_{\text {mosto }}
$$

Balanço de Exergia:

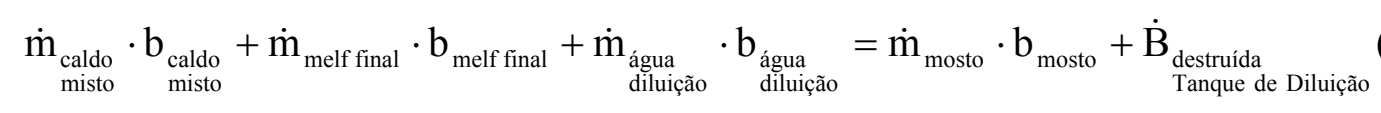

Balanço de Custo:

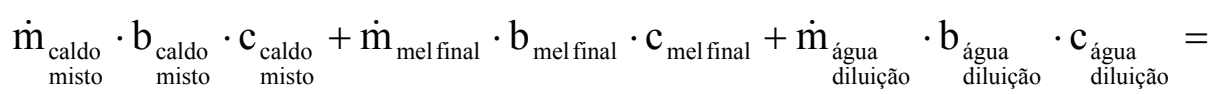

$$
\begin{aligned}
& \dot{\mathrm{m}}_{\text {mosto }} \cdot \mathrm{b}_{\text {mosto }} \cdot \mathrm{c}_{\text {mosto }}
\end{aligned}
$$

O custo em base exergética da água de diluição é igual ao custo do condensado do vapor vegetal da fábrica.

$$
\underset{\text { diluição }}{\mathrm{c}_{\text {áo }}}=\mathrm{c}_{\substack{\text { condensado } \\ \text { vapor vegetal }}}
$$


a) Produção de Álcool (Fermentação e Destilação)

Balanços de Massa:

$$
\begin{aligned}
& \dot{\mathrm{V}}_{\text {etan ol }}=0,64755 \cdot\left(\dot{\mathrm{m}}_{\substack{\text { caldo } \\
\text { clarificado }}} \cdot \mathrm{ART}_{\text {caldo }}^{\text {clarificado }}+\dot{\mathrm{m}}_{\text {mel final }} \cdot \mathrm{ART}_{\text {mel final }}\right) \cdot 0,90 \cdot 0,995
\end{aligned}
$$

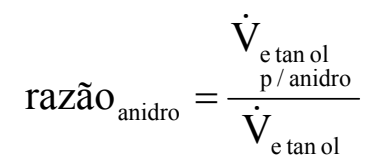

$$
\begin{aligned}
& \dot{\mathrm{V}}_{\substack{\text { ácool } \\
\text { anidro }}}=1,00425 \cdot \text { razão }{ }_{\text {anidro }} \cdot \dot{\mathrm{V}}_{\mathrm{etan} \mathrm{ol}} \\
& \dot{\mathrm{V}}_{\substack{\text { álcool } \\
\text { hidratado }}}=1,04645 \cdot\left(1-\text { razão }_{\text {anidro }}\right) \cdot \dot{\mathrm{V}}_{\mathrm{etan} \mathrm{ol}} \\
& \dot{\mathrm{m}}_{\substack{\text { vapor } \\
\text { escape }}}=4,5 \cdot \dot{\mathrm{V}}_{\substack{\text { álcool } \\
\text { anidro }}}+3,5 \cdot \dot{\mathrm{V}}_{\text {álcool }}^{\text {hidratado }} \\
& \dot{\mathrm{V}}_{\text {vinhaça }}=13 \cdot \dot{\mathrm{V}}_{\mathrm{etan} \mathrm{ol}}
\end{aligned}
$$

Balanços de Exergia:

$$
\begin{aligned}
& \dot{\mathrm{m}}_{\substack{\text { caldo } \\
\text { clarificado }}} \cdot \mathrm{b}_{\text {caldo }}^{\text {clarificado }}+\dot{\mathrm{m}}_{\text {mel final }} \cdot \mathrm{b}_{\text {mel final }}+\dot{\mathrm{m}}_{\substack{\text { vapor } \\
\text { escape }}} \cdot \mathrm{b}_{\text {vapor }}= \\
& \dot{\mathrm{m}}_{\text {e tan ol }} \cdot \mathrm{b}_{\text {etan ol }}+\dot{\mathrm{m}}_{\text {vinhaça }} \cdot \mathrm{b}_{\text {vinhaça }}+\dot{\mathrm{m}}_{\text {condensado }} \cdot \mathrm{b}_{\text {condensado }}+\dot{\mathrm{B}}_{\text {destruída }} \text { produçãodeálcool }
\end{aligned}
$$

Balanços de Custo:

$$
\begin{aligned}
& \dot{\mathrm{m}}_{\text {caldo }} \cdot \mathrm{b}_{\text {caldo }} \cdot \mathrm{c}_{\text {caldicado }}+\dot{\mathrm{m}}_{\text {melfinal }} \cdot \mathrm{b}_{\text {mel final }} \cdot \mathrm{c}_{\text {mel final }}+\dot{\mathrm{m}}_{\text {vapor }} \cdot \mathrm{b}_{\text {escape }} \mathrm{b}_{\text {vapor }} \cdot \mathrm{c}_{\text {vaporicado }}= \\
& \dot{\mathrm{m}}_{\mathrm{e} \text { tan ol }} \cdot \mathrm{b}_{\text {etan ol }} \cdot \mathrm{c}_{\text {etan ol }}+\dot{\mathrm{m}}_{\text {vinhaça }} \cdot \mathrm{b}_{\text {vinhaça }} \cdot \mathrm{c}_{\text {vinhaça }}+\dot{\mathrm{m}}_{\text {condensado }} \cdot \mathrm{b}_{\text {condensado }} \cdot \mathrm{c}_{\text {condensado }}
\end{aligned}
$$


O etanol foi considerado o único produto da produção de álcool, dessa forma o custo das irreversibilidades desse processo deve ser descarregado nele. A vinhaça não é utilizada mais no interior da usina, assim seu custo é nulo. Da mesma forma que para os trocadores de calor, o custo do fluxo do agente de aquecimento ou resfriamento, em base exergética, não se altera.

$$
\begin{gathered}
\mathrm{c}_{\text {vapor }}=\mathrm{c}_{\text {condensado }} \\
\mathrm{c}_{\text {vinhaça }}=0
\end{gathered}
$$

\section{A.5. SISTEMA DE COGERAÇÃO}

A Figura A.5 mostra um diagrama simplificado do sistema de cogeração.

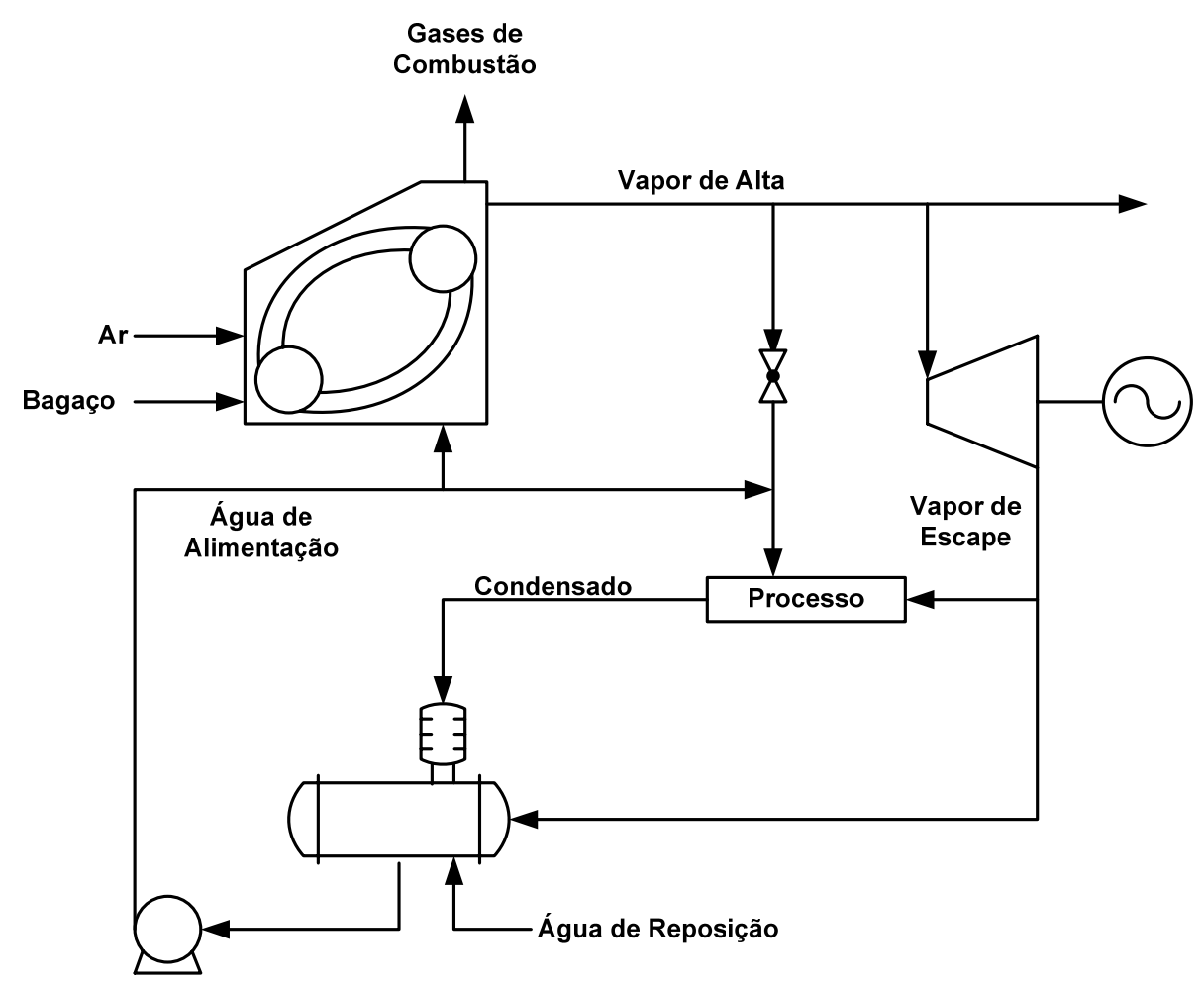

Figura A.5 - Diagrama simplificado do sistema de cogeração de uma usina tradicional.

O modelo da caldeira contemplou a reação de combustão completa do bagaço com $50 \%$ de excesso de ar, $2 \%$ de água perdida na purga e a temperatura dos gases de chaminé igual a 
$180^{\circ} \mathrm{C}$. Esses dados são equivalentes a um rendimento com base no PCI do bagaço igual a $82 \%{ }^{49}$. A composição do bagaço é mostrada na Tab. A.2.

Tabela A.2 - Considerações para a modelagem da extração

\begin{tabular}{cc}
\hline Elemento & Fração Mássica - base seca (\%) \\
\hline Carbono $(\mathrm{C})$ & 46,7 \\
Hidrogênio $(\mathrm{H})$ & 5,8 \\
Oxigênio $(\mathrm{O})$ & 46,5 \\
Cinzas & 1,0 \\
Umidade & 50,0 \\
\hline
\end{tabular}

Fonte: Cortez e Lora (2001).

Parte do vapor de alta é utilizada nas centrífugas conforme mostrado anteriormente.

A eficiência isoentrópica da turbina de potência foi fixada em $65 \%$ e o consumo de eletricidade igual a $15 \mathrm{kWh} / \mathrm{tc}$. O vapor que sai do dessuperaquecedor está a $140^{\circ} \mathrm{C}$ e 2,5 bar. Foi considerado que 5\% do vapor de escape fornecido ao processo é perdido nos purgadores, além disso, a temperatura do condensado que entra no desaerador é de $95^{\circ} \mathrm{C}$. A água deixa o desaerador a $120^{\circ} \mathrm{C}$ e a água de "make-up" está a $25^{\circ} \mathrm{C}$. Parte da água de alimentação da caldeira é utilizada no dessuperaquecedor após a válvula de redução de pressão.

\section{a) Caldeira}

Balanços de Massa:

$$
\dot{\mathrm{m}}_{\text {água }}=\dot{\mathrm{m}}_{\text {vapor }}
$$

\footnotetext{
${ }^{49} \mathrm{O}$ rendimento foi calculado com base em um modelo desenvolvido pelo autor para avaliação do desempenho termodinâmico de caldeira a biomassa.
} 
Balanço de Energia:

$$
\dot{\mathrm{m}}_{\text {bagaço }} \cdot \mathrm{PCI}_{\text {bagaço }} \cdot \eta_{\text {caldeira }}+\dot{\mathrm{m}}_{\text {água }} \cdot \mathrm{h}_{\text {água }}=\dot{\mathrm{m}}_{\text {vapor }} \cdot \mathrm{h}_{\text {vapor }}
$$

Balanço de Exergia:

$$
\dot{\mathrm{m}}_{\text {bagaço }} \cdot \mathrm{b}_{\text {bagaço }}+\dot{\mathrm{m}}_{\text {água }} \cdot \mathrm{b}_{\text {água }}=\dot{\mathrm{m}}_{\text {vapor }} \cdot \mathrm{b}_{\text {vapor }}+\dot{\mathrm{B}}_{\substack{\text { destruída } \\ \text { caldeira }}}
$$

Balanço de Custo:

$$
\dot{\mathrm{m}}_{\text {bagaço }} \cdot \mathrm{b}_{\text {bagaço }} \cdot \mathrm{c}_{\text {bagaço }}+\dot{\mathrm{m}}_{\text {água }} \cdot \mathrm{b}_{\text {água }} \cdot \mathrm{c}_{\text {água }}=\dot{\mathrm{m}}_{\text {vapor }} \cdot \mathrm{b}_{\text {vapor }} \cdot \mathrm{c}_{\text {vapor }}
$$

Esse equacionamento considera, portanto, custo zero para os gases de exaustão e as cinzas da caldeira.

b) Válvula e Dessuper

Balanço de Massa:

$$
\dot{\mathrm{m}}_{\text {vapor }}+\dot{\mathrm{m}}_{\substack{\text { água } \\ \text { des sup er }}}=\dot{\mathrm{m}}_{\text {vapor }}
$$

Balanço de Energia:

$$
\dot{\mathrm{m}}_{\text {vapor }} \cdot \mathrm{h}_{\substack{\text { vapor } \\ \text { alta }}}+\dot{\mathrm{m}}_{\substack{\text { água } \\ \text { dessup er }}} \cdot \underset{\substack{\text { água } \\ \text { des sup er }}}{\mathrm{h}_{\text {escape }}}=\dot{\mathrm{m}}_{\substack{\text { vapor } \\ \text { escape }}} \cdot \mathrm{h}_{\text {vapor }}
$$

Balanço de Exergia:

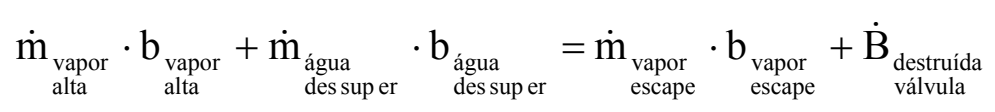


Balanço de Custo:

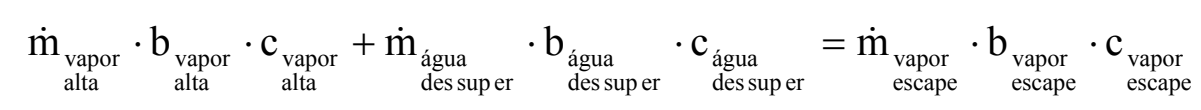

c) Turbina de Potência

Balanços de Massa:

$$
\dot{\mathrm{m}}_{\text {vapor }}=\dot{\mathrm{m}}_{\substack{\text { vapor } \\ \text { escape }}}
$$

Balanço de Energia:

$$
\dot{\mathrm{m}}_{\substack{\text { vapor } \\ \text { alta }}} \cdot \underset{\text { vapor }}{\mathrm{h}_{\text {alta }}}=\dot{\mathrm{m}}_{\substack{\text { vapor } \\ \text { escape }}} \cdot \mathrm{h}_{\text {vapor }}+\dot{\mathrm{W}}_{\text {elétrico }}
$$

Balanço de Exergia:

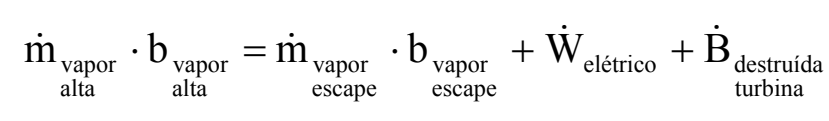

Balanço de Custo:

$$
\dot{\mathrm{m}}_{\text {vapor }} \cdot \mathrm{b}_{\text {vapor }} \cdot \mathrm{c}_{\text {vapor }}=\underset{\text { alta }}{\dot{\mathrm{m}}_{\text {vapor }}} \cdot \mathrm{b}_{\text {escape }} \text { eapor }_{\text {escape }} \cdot \underset{\text { escape }}{\mathrm{c}_{\text {vapor }}}+\dot{\mathrm{W}}_{\text {elétrico }} \cdot \mathrm{c}_{\text {elétrico }}
$$

Dois fluxos de exergia deixam o volume de controle da turbina (potência elétrica e vapor de escape). Assim, a seguintes equação auxiliar foi utilizada:

$$
\mathrm{c}_{\text {elétrico }}=\mathrm{c}_{\text {vapor }}
$$

d) Desaerador 
Balanço de Massa:

$$
\dot{\mathrm{m}}_{\text {vapor }}+\dot{\mathrm{m}}_{\text {condensado }}+\dot{\mathrm{m}}_{\substack{\text { água } \\ \text { reposição }}}=\dot{\mathrm{m}}_{\substack{\text { água } \\ \text { bombeamento }}}
$$

Balanço de Energia:

$$
\dot{\mathrm{m}}_{\substack{\text { vapor } \\ \text { escape }}} \cdot \mathrm{h}_{\text {vapor }}+\dot{\mathrm{m}}_{\text {condensado }} \cdot \mathrm{h}_{\text {condensado }}+\dot{\mathrm{m}}_{\substack{\text { água } \\ \text { reposição }}} \cdot \mathrm{h}_{\substack{\text { água } \\ \text { reposição }}}=\dot{\mathrm{m}}_{\substack{\text { água } \\ \text { bombeamento }}} \cdot \mathrm{h}_{\substack{\text { água } \\ \text { bombeamento }}}(
$$

Balanço de Exergia:

$$
\begin{aligned}
& \dot{\mathrm{m}}_{\substack{\text { vapor } \\
\text { escape }}} \cdot \mathrm{b}_{\text {vapor }}+\dot{\mathrm{m}}_{\text {condensado }} \cdot \mathrm{b}_{\text {condensado }}+\dot{\mathrm{m}}_{\substack{\text { água } \\
\text { reposição }}} \cdot \mathrm{b}_{\text {água }}^{\text {reposição }}= \\
& \dot{\mathrm{m}}_{\substack{\text { água } \\
\text { bombeamento }}} \cdot \mathfrak{b}_{\substack{\text { água } \\
\text { bombeamento }}}+\dot{\mathrm{B}}_{\substack{\text { destruída } \\
\text { desaerador }}}
\end{aligned}
$$

Balanço de Custo:

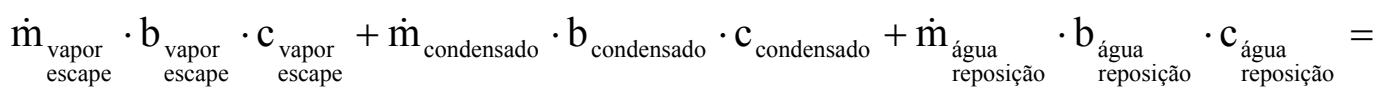

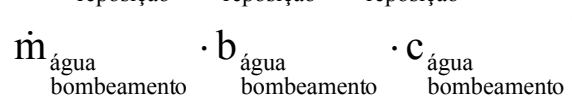

O custo da água de reposição é igual a 1, pois se trata de um insumo do sistema.

e) Bomba de Alimentação

Balanços de Massa:

$$
\dot{\mathrm{m}}_{\text {água }}^{\text {bombeamento }}=\dot{\mathrm{m}}_{\substack{\text { água } \\ \text { a lim entação }}}+\dot{\mathrm{m}}_{\substack{\text { água } \\ \text { des sup er }}}
$$

Balanço de Energia: 


$$
\begin{aligned}
& \dot{\mathrm{W}}_{\text {bombeamento }}=\dot{\mathrm{m}}_{\substack{\text { água } \\
\text { bombeamento }}} \cdot v_{\substack{\text { água } \\
\text { bombemamento }}} \cdot\left(\mathrm{p}_{\text {saída }}-\mathrm{p}_{\text {entrada }}\right) \\
& \dot{\mathrm{W}}_{\text {bomba }}=\frac{\dot{\mathrm{W}}_{\text {bombeamento }}}{0,7} \\
& \dot{\mathrm{m}}_{\text {água }}^{\text {bombeamento }} \cdot \mathrm{h}_{\substack{\text { água } \\
\text { bombeamento }}}+\dot{\mathrm{W}}_{\text {bomba }}=\dot{\mathrm{m}}_{\substack{\text { água } \\
\text { a limentação }}} \cdot \mathrm{h}_{\text {água }}^{\text {a limentação }}+\dot{\mathrm{m}}_{\substack{\text { água } \\
\text { des sup er }}} \cdot \mathrm{h}_{\text {água }}^{\text {des sup er }}
\end{aligned}
$$

Balanço de Exergia:

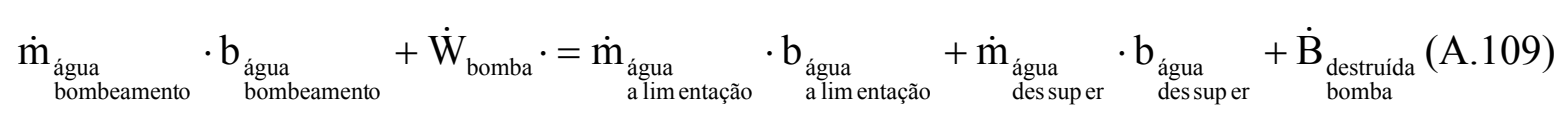

Balanço de Custo:

$$
\begin{aligned}
& \dot{\mathrm{m}}_{\substack{\text { água } \\
\text { bombeamento }}} \cdot \underset{\substack{\text { água } \\
\text { bombeamento }}}{\mathrm{c}_{\text {água }}}+\dot{\mathrm{W}}_{\text {bombeamento }} \cdot \mathrm{c}_{\text {elétrico }}=
\end{aligned}
$$

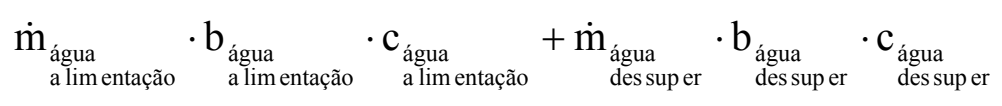

O custo em base exergética da água de alimentação é igual ao da água para o dessuperaquecedor (bifurcação).

$$
\begin{gathered}
\underset{\substack{\text { água } \\
\text { a limentação }}}{\mathrm{c}_{\text {des sup er }}}=\mathrm{c}_{\text {água }} \\
\mathrm{c}_{\substack{\text { vapor } \\
\text { alta }}}=\mathrm{c}_{\substack{\text { vapor } \\
\text { escape }}}
\end{gathered}
$$

\section{A.6. EQUAÇÕES ACOPLAMENTO}

Além dos balanços mostrados anteriormente, algumas equações adicionais são necessários para o acoplamento dos fluxos de massa entre os diferentes equipamentos. 
a) Retorno de condensado do vapor vegetal da fábrica

$$
\begin{aligned}
& \sum_{\text {trocadores }} \dot{\mathrm{m}}_{\text {condensado }}+\sum_{\text {evaporador }} \dot{\mathrm{m}}_{\text {condensado }}+\sum_{\text {tachos }} \dot{\mathrm{m}}_{\text {condensado }}=
\end{aligned}
$$

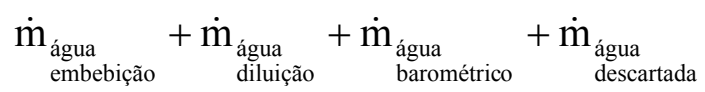

$$
\begin{aligned}
& \sum_{\text {trocadores }}(\dot{\mathrm{B}} \cdot \mathrm{c})_{\text {condensado }}+\sum_{\text {evaporador }}(\dot{\mathrm{B}} \cdot \mathrm{c})_{\text {condensado }}+\sum_{\text {tachos }}(\dot{\mathrm{B}} \cdot \mathrm{c})_{\text {condensado }}= \\
& \left(\dot{\mathrm{B}}_{\substack{\text { água } \\
\text { embebição }}}+\dot{\mathrm{B}}_{\substack{\text { água } \\
\text { diluiçãoo }}}+\dot{\mathrm{B}}_{\substack{\text { água } \\
\text { barométrico }}}\right) \mathrm{c}_{\begin{array}{c}
\text { condensado } \\
\text { vapor vegetal }
\end{array}}
\end{aligned}
$$

b) Extrações de vapor vegetal do evaporador de múltiplos-efeitos

$$
\begin{gathered}
\dot{\mathrm{m}}_{\substack{\text { vapor vegetal } \\
\text { efeito }}}=\dot{\mathrm{m}}_{\substack{\text { extracão } \\
\text { vapor vegetal }}} \dot{\mathrm{m}}_{\substack{\text { vapor vegetal } \\
\text { ponsumido } \\
\text { próximoefeito }}}=\sum_{\text {trocadores }} \dot{\mathrm{m}}_{\text {vapor vegetal }}+\sum_{\text {tachos }} \dot{\mathrm{m}}_{\text {vapor vegetal }} \\
\dot{\mathrm{m}}_{\substack{\text { extracão } \\
\text { vapor vegetal }}}=\sum_{\text {trocadores }} \dot{\mathrm{m}}_{\text {vapor vegetal }}+\sum_{\text {tachos }} \dot{\mathrm{m}}_{\text {vapor vegetal }}
\end{gathered}
$$

c) Produção e consumo de vapor de escape

$$
\sum_{\text {turbinas }} \dot{\mathrm{m}}_{\text {vapor }}+\sum_{\text {escape }} \dot{\mathrm{m}}_{\text {valuvulas }}=\dot{\mathrm{m}}_{\substack{\text { vapor escape } \\ \text { escape }}}+\dot{\mathrm{m}}_{\substack{\text { vapor escape } \\ \text { evaporador }}}+\dot{\mathrm{m}}_{\substack{\text { vapor escape } \\ \text { destilaria }}}
$$

$\mathrm{Na}$ implementação das equações mostradas no $\mathrm{EES}^{\circledR}$, desenvolveu-se uma série de funções específicas para cada um dos equipamentos. 


\section{APÊNDICE B. MODELO DE GASEIFICAÇÃO}

\section{B.1. INTRODUÇÃO}

A Gaseificação é um processo termo-químico, no qual um combustível, sólido ou líquido, é fragmentado com o uso de calor, numa atmosfera sub-oxidante, para a geração de um gás (mistura de gases) com baixo/médio poder calorífico. Reed e Gaur (2001) discutem a evolução da tecnologia desde a sua origem, para fins de aquecimento distrital, até os dias atuais, quando é utilizada para a produção de eletricidade e/ou calor em grandes centrais térmicas.

A gaseificação foi alvo de estudo de trabalhos visando mostrar tanto a potencialidade técnica quanto à viabilidade econômica da tecnologia dentro do setor sucroalcooleiro. Contudo, nenhum desses trabalhos se preocupa em analisar a performance ou identificar fontes de irreversibilidades e possíveis ganhos de eficiência na gaseificação. Para avaliação destes aspectos é necessário o desenvolvimento de um modelo, o qual represente o processo em questão e permita avaliar diferentes parâmetros de operação.

De acordo com Altafini, Wander e Barreto (2003) para processos ocorrendo a temperaturas até $800^{\circ} \mathrm{C}$ (gaseificação e pirólise), os modelos cinéticos são recomendados. Entretanto, dada a complexidade das reações envolvidas, o número de componentes e fases no interior do reator, estes modelos se tornam muito trabalhosos para uma análise dos principais parâmetros envolvidos. Modelos deste tipo podem ser encontrados nos trabalhos de Vamvuka, Woodburn e Senior (1995), Lucas, Lim e Watkinson (1998), Souza-Santos (2004) e Corella e Sanz (2005).

Assim, modelos de equilíbrio químico são uma alternativa menos custosa para essa avaliação. Estes modelos baseiam-se na minimização da energia livre de Gibbs do sistema, seja através de uma formulação estequiométrica - especificando-se as reações químicas principais -, ou pela formulação não-estequiométrica, na qual são especificados, apenas, os componentes finais da mistura; além dessas formulações balanços de massa e energia completam o modelo. É importante deixar claro que o equilíbrio não é atingido no interior do gaseificador, devido aos gradientes de temperatura, pressão e composição existente. 
Diversos autores já utilizaram essa abordagem para avaliar o processo de gaseificação (RUGGIERO; MANFRIDA, 1999; FOCK; THOMSEN, 2000; ZAINAL et al., 2001; MATHIEU; DUBUISSON, 2002; ALTAFINI; WANDER; BARRETO, 2003; PRINS; PTASINSKI; JANSSEN, 2003; LI et al., 2004; PRINS; PTASINSKI, 2005).

A seguir, uma breve fundamentação teórica sobre a definição do estado de equilíbrio será mostrada e em seguida o modelo de gaseificação desenvolvido será apresentado. Os resultados do modelo foram confrontados com resultados experimentais e duas abordagens para internalizar efeitos cinéticos no modelo de equilíbrio foram estudadas.

\section{B.2. DEFINIÇÃO DO ESTADO DE EQUILÍBRIO}

Dado um sistema heterogêneo fechado com as seguintes características (Fig. B.1):

O sistema não está em equilíbrio;

Temperatura e pressão uniformes;

$\mathrm{N}$ fases com composições uniformes;

$>\mathrm{O}$ sistema troca calor com o meio de forma reversível;

As alterações de volume do sistema ocorrem de maneira que o trabalho realizado/feito pelo/sobre o sistema é reversível.

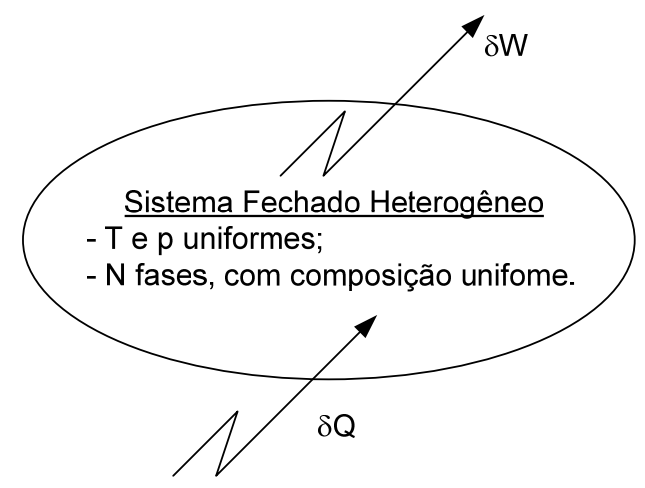

Figura B.1 - Sistema fechado heterogêneo. 
Assume-se que este sistema passa por um processo que o leva do estado atual (não-equilíbrio) para um estado de equilíbrio, com relação à distribuição dos componentes do sistema nas $\mathrm{N}$ fases. Para a troca de calor reversível, a variação da entropia do meio é dada por:

$$
\mathrm{dS}_{\text {meio }}=\frac{-\delta \mathrm{Q}}{\mathrm{T}}
$$

Pela Segunda Lei da Termodinâmica:

$$
\mathrm{dS}_{\text {meio }}+\mathrm{dS}_{\text {sistema }} \geq 0 \Rightarrow \mathrm{dS}_{\text {sistema }} \geq \frac{\delta \mathrm{Q}}{\mathrm{T}}
$$

A desigualdade representa um processo irreversível e a igualdade um processo reversível. A Primeira Lei da Termodinâmica, aplicada ao sistema, implica que:

$$
\mathrm{dU}_{\text {sistema }}=\delta \mathrm{Q}-\delta \mathrm{W}
$$

Como o trabalho da variação do volume do sistema é reversível:

$$
\delta \mathrm{W}=\mathrm{p} \cdot \mathrm{dV} \text { sistema }
$$

Assim, substituindo as eqs.(B.2) e (B.4) na eq.(B.3):

$$
\mathrm{dU}_{\text {sistema }}-\mathrm{T} \cdot \mathrm{dS}_{\text {sistema }}+\mathrm{p} \cdot \mathrm{dV}_{\text {sistema }} \leq 0
$$

Esta relação envolve apenas propriedades do sistema, ou seja, não depende do caminho adotado pelo processo. Assim, deve ser satisfeita para qualquer variação de estado de qualquer sistema fechado, sem restrições com relação às condições de reversibilidade assumidas na sua derivação.

A igualdade da eq.(B.5) é válida para qualquer sistema que sai de um estado de equilíbrio e evolui até outro estado de equilíbrio. Quando o sistema sai de um estado com temperatura e 
pressão uniformes, mas não de equilíbrio, e evolui até a um estado de equilíbrio, a desigualdade deverá ser satisfeita.

A eq.(B.5) indica que, dado um processo com entropia e volumes constantes, este só irá ocorrer de forma espontânea caso haja uma diminuição da energia interna, ou seja, o sistema atinge o equilíbrio no estado em a energia interna é minimizada. Relembrando os conceitos da Segunda Lei, pode-se dizer que um sistema isolado (com energia interna e volume constantes), um processo espontâneo só é possível caso cause um aumento da entropia do sistema (ver eq.(B.5)). Ou seja, no estado de equilíbrio a entropia do sistema está num ponto de máximo.

Os processos indicados acima requerem que ou a energia interna ou a entropia do sistema permaneça constante. Todavia, variáveis como pressão e temperatura são mais convenientemente tratadas como constantes que variáveis como energia interna ou entropia. Assim, da definição da Energia Livre de Gibbs:

$$
\begin{gathered}
\mathrm{G}=\mathrm{H}-\mathrm{TS}=\mathrm{U}-\mathrm{PV}-\mathrm{TS} \\
\mathrm{dG}=\mathrm{dU}-\mathrm{p} \cdot \mathrm{dV}-\mathrm{V} \cdot \mathrm{dp}-\mathrm{T} \cdot \mathrm{dS}-\mathrm{S} \cdot \mathrm{dT}
\end{gathered}
$$

Substituindo na eq.(B.5):

$$
\mathrm{dG}_{\text {sistema }}+\mathrm{S} \cdot \mathrm{dT}_{\text {sistema }}+\mathrm{V} \cdot \mathrm{dp}_{\text {sistema }} \leq 0
$$

A eq.(B.8) indica que qualquer processo irreversível acontece de maneira espontânea de tal forma que a Energia Livre de Gibbs do sistema diminua, mantidas pressão e temperatura constantes. Ainda, dada uma temperatura e uma pressão, o estado de equilíbrio é definido como o estado no qual a Energia Livre de Gibbs do sistema é mínima.

$$
\left(\mathrm{dG}_{\text {sistema }}\right)_{\mathrm{T}, \mathrm{p}}=0
$$




\section{B.3. DETERMINAÇÃO DO ESTADO DE EQUILÍBRIO}

Para um processo, a temperatura e pressão constantes, que envolve reações químicas, podemse definir duas abordagens para a determinação da condição imposta pela eq. (B.9):

$\checkmark$ Abordagem Estequiométrica: são especificadas as reações químicas que irão ocorrer no interior do reator. Esta abordagem é baseada no uso de equações derivada da estequiometria das reações de forma a produzir um problema de otimização sem restrições;

$\checkmark$ Abordagem não-Estequiométrica: nenhuma reação é especificada, somente são conhecidos os componentes existentes no final do processo. Assim, o problema de otimização é formulada com a adição de restrições com relação à conservação do número de átomos inicial existente no sistema.

\section{B.3.1. Abordagem Estequiométrica}

Como as reações químicas são dadas, é possível estabelecer a estequiometria de cada reação, baseada nos coeficientes estequiométricos $\left(v_{i, j}\right)^{50}$ dos reagentes e produtos. Estas relações podem ser escritas em função de uma variável chamada de extensão da reação $\left(\xi_{\mathrm{j}}\right)$, defina por:

$$
\mathrm{d} \xi_{\mathrm{j}}=\frac{\mathrm{dn} \mathrm{n}_{\mathrm{i}, \mathrm{j}}}{\mathrm{v}_{\mathrm{i}, \mathrm{j}}}
$$

Desta forma, a variação do número de mols do componente i pode ser dada por:

$$
\mathrm{dn}_{\mathrm{i}}=\sum_{\mathrm{j}=1}^{\mathrm{R}} \mathrm{v}_{\mathrm{i}, \mathrm{j}} \cdot \mathrm{d} \xi_{\mathrm{j}} \Rightarrow \mathrm{n}_{\mathrm{i}}=\mathrm{n}_{\mathrm{i}(\text { inicial })}+\sum_{\mathrm{j}=1}^{\mathrm{R}} \mathrm{v}_{\mathrm{i}, \mathrm{j}} \cdot \mathrm{d} \xi_{\mathrm{j}}
$$

Assim, o problema de minimização fica definido como:

\footnotetext{
${ }^{50} \mathrm{O}$ subscrito i refere-se ao componente, enquanto que o subscrito j refere-se à reação. Assim, o coeficiente $v_{\mathrm{i}, \mathrm{j}}$ é o coeficiente estequiométrico do componente i na reação j.
} 


$$
\min _{n_{\mathrm{i}}} \mathrm{G}_{\text {sistema }}\left(\mathrm{T}, \mathrm{p}, \mathrm{n}_{\mathrm{i}}\right)
$$

$$
\mathrm{n}_{\mathrm{i}}=\mathrm{n}_{\mathrm{i}(\text { inicial })}+\sum_{\mathrm{j}=1}^{\mathrm{R}} v_{\mathrm{i}, \mathrm{j}} \cdot \mathrm{d} \xi_{\mathrm{j}} \quad\left(\mathrm{i}=1, \ldots, \mathrm{N}^{\prime}\right)
$$

É possível substituir as restrições na função, de forma a obter um problema de otimização sem restrições:

$$
\min _{\xi_{\mathrm{j}}} \mathrm{G}_{\mathrm{sistema}}\left(\mathrm{T}, \mathrm{p}, \xi_{\mathrm{j}}\right)
$$

Ou seja, minimizar a energia livre de Gibbs, para um dado par de temperatura e pressão, em função das $\mathrm{R}$ variáveis $\left(\xi_{\mathrm{j}}\right)$. As condições de primeira ordem para a condição de mínimo são:

$$
\left(\frac{\partial \mathrm{G}}{\partial \xi_{j}}\right)_{T, p, \xi_{k \neq j}}=\sum_{i=1}^{N^{\prime}}\left(\frac{\partial G}{\partial n_{i}}\right)_{T, p, n_{k \neq i}} \cdot\left(\frac{\partial n_{i}}{\partial \xi_{j}}\right)_{T, p, \xi_{k \neq j}}=\sum_{i=1}^{N^{\prime}} \mu_{i} \cdot v_{i, j}=0 \quad(j=1, \ldots, R)
$$

Portanto, dada expressões apropriadas para a determinação do potencial químico dos componentes, em termos de dados de energia livre de Gibbs e número de mols, a solução das $\mathrm{R}$ equações representadas pela eq.(B.14) resulta na composição do sistema em equilíbrio.

\section{B.3.1. Abordagem não-Estequiométrica}

O problema de otimização por esta abordagem é o seguinte:

$$
\begin{aligned}
& \min _{\mathrm{n}_{\mathrm{i}}} \mathrm{G}_{\text {sistema }}\left(\mathrm{T}, \mathrm{p}, \mathrm{n}_{\mathrm{i}}\right) \\
& \text { sujeito a } \\
& \qquad \sum_{\mathrm{i}=1}^{\mathrm{n}^{\prime}} \mathrm{n}_{\mathrm{i}} \cdot \mathrm{a}_{\mathrm{i}, \mathrm{k}}=\mathrm{A}_{\mathrm{k}} \quad(\mathrm{k}=1, \ldots, \mathrm{w})
\end{aligned}
$$

Onde, $\mathrm{n}_{\mathrm{i}}$ - número de mols do componente i no equilíbrio;

$\mathrm{a}_{\mathrm{ik}}$ - número de átomos do elemento $\mathrm{k}$ na molécula do componente $\mathrm{i}$; 
$\mathrm{A}_{\mathrm{k}}$ - número total de átomos do elemento $\mathrm{k}$, definido a partir da composição inicial do sistema.

Qualquer método de otimização poderia ser utilizado a princípio para a solução deste problema. Todavia, o Método dos Multiplicadores de Langrange $(\lambda)$ é normalmente utilizado para a determinação de um sistema de equações não-lineares, a ser resolvido por algum algoritmo. Desta maneira, o problema passa a ter a seguinte forma:

$$
\begin{gathered}
\min \underset{\mathrm{n}, \lambda}{\mathrm{L}}=\mathrm{G}_{\text {sistema }}\left(\mathrm{T}, \mathrm{p}, \mathrm{n}_{\mathrm{i}}\right)+\sum_{\mathrm{k}=1}^{\mathrm{w}} \lambda_{\mathrm{k}} \cdot\left(\mathrm{A}_{\mathrm{k}}-\sum_{\mathrm{i}=1}^{\mathrm{n}^{\prime}} \mathrm{a}_{\mathrm{i}, \mathrm{k}} \cdot \mathrm{n}_{\mathrm{i}}\right) \\
\left(\frac{\partial \mathrm{L}}{\partial \mathrm{n}_{\mathrm{i}}}\right)_{\mathrm{n}_{\mathrm{j} \neq \mathrm{i}}, \lambda_{\mathrm{k}}}=\left(\frac{\partial \mathrm{G}}{\partial \mathrm{n}_{\mathrm{i}}}\right)_{\mathrm{n}_{\mathrm{j} \neq \mathrm{i}}, \lambda_{\mathrm{k}}}-\sum_{\mathrm{k}=1}^{\mathrm{w}} \mathrm{a}_{\mathrm{ik}} \cdot \lambda_{\mathrm{k}}=\mu_{\mathrm{i}}-\sum_{\mathrm{k}=1}^{\mathrm{w}} \mathrm{a}_{\mathrm{ik}} \cdot \lambda_{\mathrm{k}}=0 \quad \mathrm{i}=1, \ldots, \mathrm{n}^{\prime} \\
\left(\frac{\partial \mathrm{L}}{\partial \lambda_{\mathrm{k}}}\right)_{\mathrm{n}_{\mathrm{i}}, \lambda_{\mathrm{j} \neq \mathrm{k}}}=\mathrm{A}_{\mathrm{k}}-\sum_{\mathrm{k}=1}^{\mathrm{w}} \mathrm{a}_{\mathrm{ik}} \cdot \mathrm{n}_{\mathrm{i}}=0
\end{gathered}
$$

\section{B.4. CONSTRUÇÃO DO MODELO DE GASEIFICAÇÃO DE BIOMASSA}

\section{B.4.1. Modelo para Determinação das Propriedades Termodinâmicas}

Para as substâncias gasosas, correlações para o calor específico a pressão constante em função da temperatura foram tiradas da literatura (ABBOT; SMITH; VAN NESS, 2001).

$$
\frac{\mathrm{c}_{\mathrm{p}}^{\mathrm{gi}}(\mathrm{T})}{\mathrm{R}}=\mathrm{A}+\mathrm{B} \cdot \mathrm{T}+\mathrm{C} \cdot \mathrm{T}^{2}+\mathrm{D} \cdot \mathrm{T}^{-2}
$$

Além disso, a hipótese de gás ideal implica que:

$$
\mathrm{p} \cdot \mathrm{v}=\mathrm{R} \cdot \mathrm{T}
$$

A partir dessas relações, é possível determinar as entalpias e entropias das substâncias: 


$$
\begin{gathered}
\mathrm{dh}=\mathrm{c}_{\mathrm{p}} \cdot \mathrm{dT}+\left[\mathrm{v}-\mathrm{T} \cdot\left(\frac{\partial \mathrm{v}}{\partial \mathrm{T}}\right)_{\mathrm{p}}\right] \cdot \mathrm{dp} \Rightarrow \mathrm{h}=\mathrm{h}_{\mathrm{f}}+\int_{298,15}^{\mathrm{T}} \mathrm{c}_{\mathrm{p}}^{\mathrm{gi}}(\mathrm{T}) \cdot \mathrm{dT} \\
\mathrm{ds}=\mathrm{c}_{\mathrm{p}} \cdot \frac{\mathrm{dT}}{\mathrm{T}}-\left(\frac{\partial \mathrm{v}}{\partial \mathrm{T}}\right)_{\mathrm{p}} \cdot \mathrm{dp} \Rightarrow \mathrm{s}=\mathrm{s}_{\mathrm{f}}^{0}+\int_{298,15}^{\mathrm{T}} \frac{\mathrm{c}_{\mathrm{p}}^{\mathrm{gi}}(\mathrm{T})}{\mathrm{T}} \cdot \mathrm{dT}-\mathrm{R} \cdot \int_{\mathrm{p}_{0}}^{\mathrm{p}} \frac{\mathrm{dp}}{\mathrm{p}}
\end{gathered}
$$

A Tab. B.1 mostra os valores de A, B, C, D, entalpias de formação $\left(\mathrm{h}_{\mathrm{f}}\right)$ e entropia $\left(\mathrm{s}_{\mathrm{f}}{ }^{0}\right)$ no estado padrão, para os diferentes componentes gasosos considerados na modelagem (VAN WYLEN; SONNTAG; BORGNAKKE, 1998; ABBOT; SMITH; VAN NESS, 2001):

Tabela B.1 - Valores das constantes para a eq.(B.19), entalpias de formação e entropia no estado padrão para as substâncias modeladas como gases ideais.

\begin{tabular}{ccccccc}
\hline Substância & $\mathbf{A}$ & $\mathbf{1 0}^{\mathbf{3}} \mathbf{B}$ & $\mathbf{1 0}^{\mathbf{6}} \mathbf{C}$ & $\mathbf{1 0}^{-\mathbf{5}} \mathbf{D}$ & $\begin{array}{c}\mathbf{h}_{\mathbf{f}} \\
(\mathbf{k J} / \mathbf{k m o l})\end{array}$ & $\begin{array}{c}\mathbf{s}_{\mathbf{f}}^{\mathbf{0}} \\
(\mathbf{k J} / \mathbf{k m o l . K})\end{array}$ \\
\hline $\mathrm{CH}_{4}$ & 1,702 & 9,081 & $-2,164$ & - & -74873 & 186,251 \\
$\mathrm{CO}$ & 3,376 & 0,557 & - & $-0,031$ & -110527 & 197,653 \\
$\mathrm{CO}_{2}$ & 5,457 & 1,045 & - & $-1,157$ & -393522 & 213,795 \\
$\mathrm{H}_{2}$ & 3,249 & 0,422 & - & 0,083 & 0 & 130,678 \\
$\mathrm{H}_{2} \mathrm{O}$ & 3,470 & 1,450 & - & 0,121 & -241826 & 188,834 \\
$\mathrm{~N}_{2}$ & 3,280 & 0,593 & - & 0,040 & 0 & 130,678 \\
$\mathrm{O}_{2}$ & 3,639 & 0,506 & - & $-0,227$ & 0 & 205,148 \\
\hline
\end{tabular}

Dada a hipótese de mistura ideal, a entalpia e a entropia da mistura podem ser calculada a partir de:

$$
\begin{aligned}
& \mathrm{h}_{\text {mist }}=\sum_{\mathrm{i}=1}^{\mathrm{N}} \mathrm{y}_{\mathrm{i}} \cdot \mathrm{h}_{\mathrm{i}} \\
& \mathrm{s}_{\text {mist }}=\sum_{\mathrm{i}=1}^{\mathrm{N}} \mathrm{y}_{\mathrm{i}} \cdot \mathrm{s}_{\mathrm{i}}
\end{aligned}
$$

A entalpia da biomassa foi determinada por um procedimento similar ao das propriedades das substâncias gasosas. Assim, a seguinte correlação para o calor específico foi utilizada (FOCK; THOMSEN, 2000):

$$
\mathrm{c}(\mathrm{T})=0,003867 \cdot \mathrm{T}+0,1031
$$


A determinação do poder calorífico inferior da biomassa é resultado da aplicação da equação de Mendeliev (CORTEZ; LORA,1997):

$$
\begin{gathered}
\mathrm{PCI}_{\text {biomassa }}=339 \cdot \mathrm{C}^{\mathrm{t}}+1030 \cdot \mathrm{H}^{\mathrm{t}}-109 \cdot\left(\mathrm{O}^{\mathrm{t}}-\mathrm{S}^{\mathrm{t}}\right)-24 \cdot \mathrm{W}^{\mathrm{t}} \quad(\mathrm{kJ} / \mathrm{kg}) \\
\mathrm{PCS}_{\text {biomassa }}=\mathrm{PCI}_{\text {biomassa }}+2442 \cdot\left(8.936 \cdot \frac{\mathrm{H}^{\mathrm{t}}}{100}+\frac{\mathrm{W}^{\mathrm{t}}}{100}\right)(\mathrm{kJ} / \mathrm{kg})
\end{gathered}
$$

A entalpia de formação da biomassa foi determinada a partir do poder calorífico superior (PCS), conforme Li et al (2004):

$$
\mathrm{h}_{\mathrm{f}_{\text {biomassa }}}=\mathrm{PCS}_{\text {biomassa }}-\left(327,63 \cdot \mathrm{C}^{\mathrm{t}}+1417,94 \cdot \mathrm{H}^{\mathrm{t}}+92,57 \cdot \mathrm{S}^{\mathrm{t}}+158,67 \cdot \mathrm{W}^{\mathrm{t}}\right)
$$

Nas eqs. (26), (27) e (28) o sobrescrito t indica a quantidade mássica de cada elemento na biomassa.

\section{B.4.2. Modelo para a determinação do Potencial Químico $\left(\mu_{\mathrm{i}}\right)$}

O potencial químico de uma espécie em solução é dado a partir da definição de fugacidade de uma espécie em solução $\left(\hat{\mathrm{f}}_{\mathrm{i}}\right)$ :

$$
\mu_{i}=\Gamma_{i}(T)+R \cdot T \cdot \ln \hat{f}_{i}
$$

Ainda, para espécies puras no seu estado padrão, na mesma temperatura, é possível escrever:

$$
\mathrm{G}_{\mathrm{i}}^{0}=\Gamma_{\mathrm{i}}(\mathrm{T})+\mathrm{R} \cdot \mathrm{T} \cdot \ln \mathrm{f}_{\mathrm{i}}^{0}
$$

Assim, obtém-se a seguinte equação para o potencial químico:

$$
\mu_{i}=G_{i}^{0}+R \cdot T \cdot \ln \frac{\hat{f}_{i}}{f_{i}^{0}}
$$


B. 10

Dada a hipótese de mistura ideal de gases ideais, é possível simplificar a eq.(31) para (ABBOT; SMITH; VAN NESS, 2001):

$$
\mu_{\mathrm{i}}=\mathrm{G}_{\mathrm{i}}^{0}+\mathrm{R} \cdot \mathrm{T} \cdot \ln \frac{\mathrm{y}_{\mathrm{i}} \cdot \mathrm{p}}{\mathrm{p}^{0}}
$$

A Energia Livre de Gibbs de formação para elementos no estado padrão (p. ex., $\mathrm{O}_{2}, \mathrm{H}_{2}$ ) é nula. As demais foram calculadas a partir da regressão de valores encontrados em Turns (1996), a partir da seguinte relação:

$$
\mathrm{G}_{\mathrm{i}}^{0}=\mathrm{A}+\mathrm{B} \cdot \mathrm{T}+\mathrm{C} \cdot \mathrm{T}^{2}+\frac{\mathrm{D}}{\mathrm{T}^{2}}
$$

A regressão foi feita a partir do Método dos Mínimos Quadrados. A Tab. B.2 mostra o resultado das regressões.

Tabela B.2 - Constantes para a eq.(33).

\begin{tabular}{ccccc}
\hline Componente & $\mathbf{A}$ & $\mathbf{B}$ & $\mathbf{1 0}^{3} \mathbf{C}$ & $\mathbf{D}$ \\
\hline $\mathrm{CH}_{4}$ & -88635 & 108,41 & - & - \\
$\mathrm{CO}$ & -109370 & $-93,41$ & 2,57 & $-318,62$ \\
$\mathrm{CO}_{2}$ & -393673 & $-3,14$ & 0,89 & $-320,51$ \\
$\mathrm{H}_{2} \mathrm{O}$ & -244978 & 50,12 & 2,32 & $-319,49$ \\
\hline
\end{tabular}

\section{B.4.3. Balanço de energia}

Para a determinação da temperatura no interior do gaseificador, é possível considerar duas opções:

$\checkmark$ Fixar a temperatura a partir de um parâmetro exógeno;

$\checkmark$ Utilizar um balanço de energia para o sistema, considerando esse como sendo adiabático.

Com as propriedades determinadas, o balanço de energia para o processo pode ser escrita da seguinte maneira: 


$$
\dot{\mathrm{m}}_{\text {biomassa }} \cdot \mathrm{h}_{\text {biomassa }}+\dot{\mathrm{m}}_{\mathrm{ar}} \cdot \mathrm{h}_{\mathrm{ar}}=\dot{\mathrm{m}}_{\text {gás }} \cdot \mathrm{h}_{\text {gás }}
$$

\section{B.5. RESULTADOS}

A Fig. B.2 mostra os resultados do modelo para diferentes razões ar-combustível; são apresentados a composição do gás produzido e a temperatura de equilíbrio calculada pelo balanço de energia. Os seguintes componentes foram considerados: $\mathrm{CH}_{4}, \mathrm{CO}, \mathrm{H}_{2}, \mathrm{H}_{2} \mathrm{O}, \mathrm{CO}_{2} \mathrm{e}$ $\mathrm{N}_{2}$.

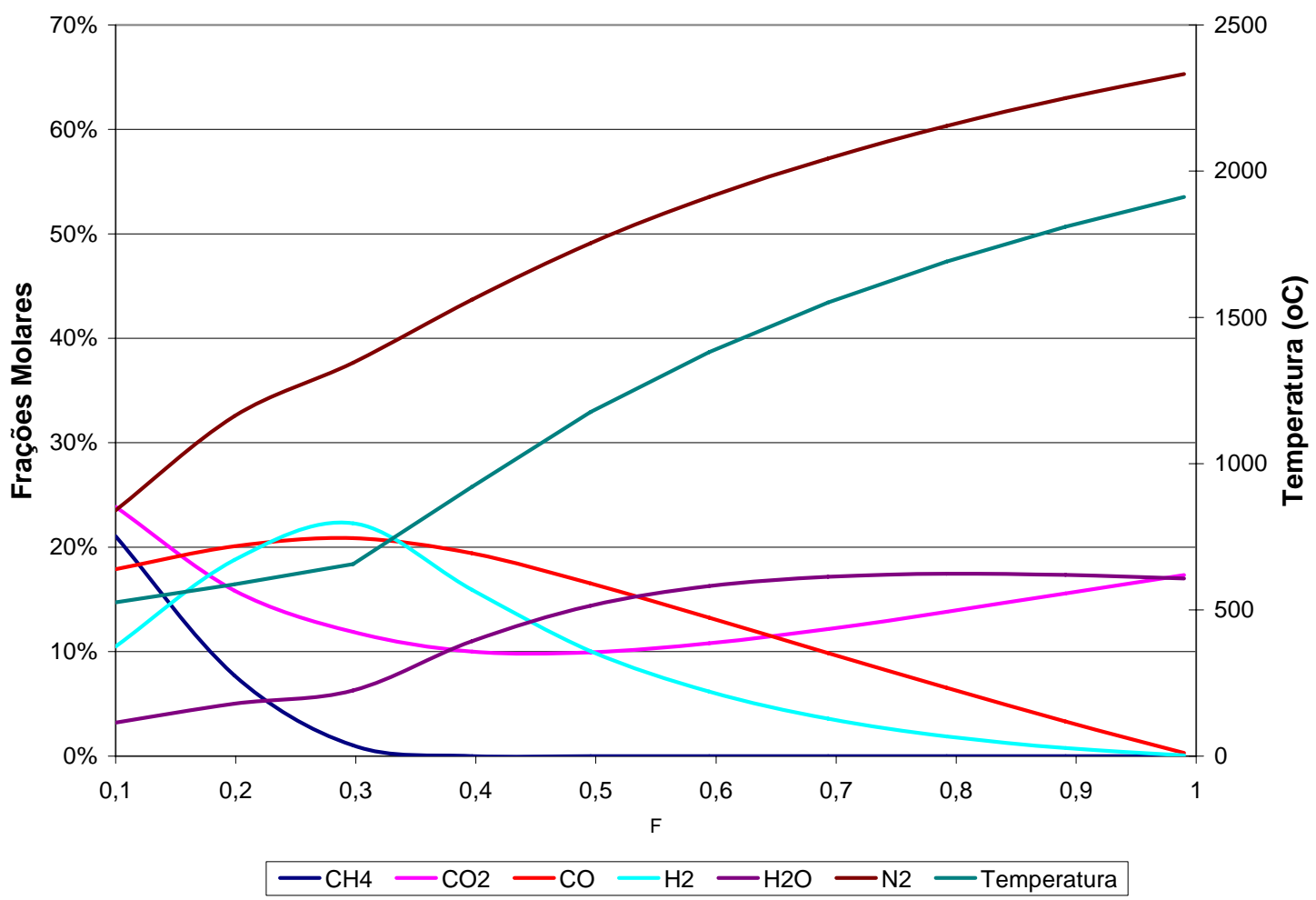

Figura B.2 - Resultados do Modelo de Equilíbrio Químico.

\section{B.6. ANÁLISE COMPARATIVA}

A fim de comparar o modelo com resultados experimentais, os resultados de três experimentos feitos no IPT (Instituto de Pesquisas Tecnológicas do Estado de São Paulo) com chips de eucalipto em um gaseificador downdraft foram utilizados (USHIMA, 2004). De acordo com Reed e Gaur (2001), os gaseificadores downdraft operam muito próximos às condições de equilíbrio, enquanto que gaseificadores de leito fluidizado operam longe dessas condições. 
A Tab. B.3 mostra as condições operacionais dos ensaios utilizados:

Tabela B.3 - Parâmetros operacionais dos testes com chips de eucalipto.

\begin{tabular}{lccc} 
& Teste 1 & Teste 2 & Teste 3 \\
\hline Vazão de Chips $(\mathrm{kg} / \mathrm{h})$ & 19,3 & 17,1 & 15,9 \\
Teor de Umidade $(\%)$ & 8,0 & 8,2 & 20,8 \\
Vazão de Ar $(\mathrm{kg} / \mathrm{h})$ & 33,1 & 31,8 & 28,7 \\
Temperatura do gás após o sistema de limpeza $\left({ }^{\circ} \mathrm{C}\right)$ & 14,6 & 11,0 & 10,3 \\
Vazão de Cinzas $(\mathrm{kg} / \mathrm{h})$ & 1,24 & 0,6 & 0,6 \\
Diferença entre as vazões de entrada e saída $(\mathrm{kg} / \mathrm{h})$ & 3,5 & 2,5 & 3,8 \\
\hline
\end{tabular}

Fonte: Ushima (2004)

Estas condições foram impostas ao modelo e os resultados são apresentados nas Tabs. B.4, B.5 e B.6.

Tabela B.4 - Resultados para o Teste 1 (Modelo de Puro Equilíbrio).

\begin{tabular}{cccc}
\hline $\begin{array}{c}\text { Frações Molares } \\
\text { (\% base úmida) }\end{array}$ & Teste 1 & Modelo & $\begin{array}{c}\text { Desvio } \\
\text { Relativo }\end{array}$ \\
\hline $\mathrm{CO}$ & 21,7 & 24,8 & $14,3 \%$ \\
$\mathrm{H}_{2}$ & 17,1 & 23,1 & $35,1 \%$ \\
$\mathrm{CH}_{4}$ & 2,0 & 0,1 & $-95,0 \%$ \\
$\mathrm{CO}_{2}$ & 11,0 & 8,7 & $-20,9 \%$ \\
$\mathrm{~N}_{2}$ & 47,0 & 41,6 & $-11,5 \%$ \\
$\mathrm{H}_{2} \mathrm{O}$ & 1,2 & 1,6 & $33,3 \%$ \\
$\mathrm{PCI}(\mathrm{MJ} / \mathrm{kg})$ & 5,1 & 5,5 & $7,8 \%$ \\
Vazão de gás produzido $(\mathrm{kg} / \mathrm{h})$ & 47,7 & 50,5 & $5,9 \%$ \\
\hline
\end{tabular}

Tabela B.5 - Resultados para o Teste 2 (Modelo de Puro Equilíbrio).

\begin{tabular}{cccc}
\hline $\begin{array}{c}\text { Frações Molares } \\
\text { (\% base úmida) }\end{array}$ & Teste 2 & Modelo & $\begin{array}{c}\text { Desvio } \\
\text { Relativo }\end{array}$ \\
\hline $\mathrm{CO}$ & 20,6 & 24,4 & $18,4 \%$ \\
$\mathrm{H}_{2}$ & 16,5 & 21,2 & $28,5 \%$ \\
$\mathrm{CH}_{4}$ & 2,0 & 0,0 & $-100,0 \%$ \\
$\mathrm{CO}_{2}$ & 11,2 & 8,6 & $-23,2 \%$ \\
$\mathrm{~N}_{2}$ & 47,8 & 44,5 & $-6,9 \%$ \\
$\mathrm{H}_{2} \mathrm{O}$ & 1,3 & 1,3 & $0,0 \%$ \\
$\mathrm{PCI}(\mathrm{MJ} / \mathrm{kg})$ & 4,9 & 5,1 & $4,1 \%$ \\
Vazão de gás produzido $(\mathrm{kg} / \mathrm{h})$ & 45,8 & 46,5 & $1,6 \%$ \\
\hline
\end{tabular}

Tabela B.6 - Resultados para o Teste 3 (Modelo de Puro Equilíbrio).

\begin{tabular}{cccc}
\hline $\begin{array}{c}\text { Frações Molares } \\
\text { (\% base úmida) }\end{array}$ & Teste 3 & Modelo & $\begin{array}{c}\text { Desvio } \\
\text { Relativo }\end{array}$ \\
\hline $\mathrm{CO}$ & 17,5 & 19,5 & $11,4 \%$ \\
$\mathrm{H}_{2}$ & 17,5 & 20,7 & $18,3 \%$ \\
$\mathrm{CH}_{4}$ & 2,0 & 0,0 & $-100,0 \%$
\end{tabular}




\begin{tabular}{cccc}
$\mathrm{CO}_{2}$ & 13,1 & 11,6 & $-11,5 \%$ \\
$\mathrm{~N}_{2}$ & 48,9 & 47,1 & $-3,7 \%$ \\
$\mathrm{H}_{2} \mathrm{O}$ & 1,0 & 1,2 & $20,0 \%$ \\
PCI (MJ/kg) & 4,7 & 4,3 & $-8,5 \%$ \\
Vazão de gás produzido $(\mathrm{kg} / \mathrm{h})$ & 40,2 & 40,7 & $1,2 \%$ \\
\hline
\end{tabular}

Os resultados indicam que, embora haja grandes diferenças entre as concentrações molares calculadas e as medida, os valores do PCI do gás produzido são bastante próximos. $\mathrm{O}$ modelo indica concentrações mais elevadas de $\mathrm{CO}, \mathrm{H} 2$ e $\mathrm{H}_{2} \mathrm{O}$, mas não indica a presença de $\mathrm{CH}_{4}$ no gás produzido.

Este modelo aponta vazões de gás produzido maiores que as observadas experimentalmente. Isto pode ser explicado devido a:

- Aspectos cinéticos das reações de gaseificação;

- Presença de nitrogênio, enxofre e cinzas na composição da biomassa (não considerado no modelo);

- Presença de carbono não-convertido (não considerado no modelo);

- Erros resultantes das medições durante os experimentos, já que a diferença entre as vazões de saída e as de entrada é da ordem de 15\% (Tab. B.1).

As grandes diferenças entre os valores calculados e os medidos para a fração de $\mathrm{CH}_{4}$ são resultado da repentina desaceleração das reações de gaseificação no fundo do reator, devido à diminuição da temperatura (USHIMA, 2004). Nos modelos de equilíbrio, é assumido que todas as reações atingem uma condição de equilíbrio permanente, sem fazer considerações com respeito a aspectos cinéticos.

A fim de diminuir a diferença entre os valores das frações molares e tentar trazer aspectos cinéticos ao modelo. Fock e Thomsen (2000) impuseram uma fração molar de $\mathrm{CH}_{4}$ ao sistema, assim como uma quantidade de carbono não convertido. Esta idéia foi implementada no modelo e os resultados aparecem nas Tabs. B.7 a B.9 (toda cinza foi considerada como carbono não-convertido, seguindo a proposta de Fock e Thomsen (2000)). 
B. 14

Tabela B.7 - Resultados para o Teste 1 (Modelo Modificado I).

\begin{tabular}{cccc}
\hline $\begin{array}{c}\text { Fração Molar } \\
\text { (\% base úmida) }\end{array}$ & Teste 1 & $\begin{array}{c}\text { Modelo } \\
\text { Modificado I }\end{array}$ & $\begin{array}{c}\text { Desvio } \\
\text { Relativo }\end{array}$ \\
\hline $\mathrm{CO}$ & 21,7 & 21,2 & $-2,3 \%$ \\
$\mathrm{H}_{2}$ & 17,1 & 16,0 & $-6,4 \%$ \\
$\mathrm{CH}_{4}$ & 2,0 & 2,0 & $0,0 \%$ \\
$\mathrm{CO}_{2}$ & 11,0 & 10,5 & $-4,5 \%$ \\
$\mathrm{~N}_{2}$ & 47,0 & 48,7 & $3,6 \%$ \\
$\mathrm{H}_{2} \mathrm{O}$ & 1,2 & 1,6 & $33,3 \%$ \\
$\mathrm{PCI}(\mathrm{MJ} / \mathrm{kg})$ & 5,1 & 4,6 & $-9,8 \%$ \\
Vazão de gás produzido $(\mathrm{kg} / \mathrm{h})$ & 47,7 & 46,8 & $-1,9 \%$ \\
\hline
\end{tabular}

Tabela B.8 - Resultados para o Teste 2 (Modelo Modificado I).

\begin{tabular}{cccc}
\hline $\begin{array}{c}\text { Fração Molar } \\
\text { (\% base úmida) }\end{array}$ & Teste 2 & $\begin{array}{c}\text { Modelo } \\
\text { Modificado I }\end{array}$ & $\begin{array}{c}\text { Desvio } \\
\text { Relativo }\end{array}$ \\
\hline $\mathrm{CO}$ & 20,6 & 21,9 & $6,3 \%$ \\
$\mathrm{H}_{2}$ & 16,5 & 15,2 & $-7,9 \%$ \\
$\mathrm{CH}_{4}$ & 2,0 & 2,0 & $0,0 \%$ \\
$\mathrm{CO}_{2}$ & 11,2 & 10,1 & $-9,8 \%$ \\
$\mathrm{~N}_{2}$ & 47,8 & 49,6 & $3,8 \%$ \\
$\mathrm{H}_{2} \mathrm{O}$ & 1,3 & 1,3 & $0,0 \%$ \\
$\mathrm{PCI}(\mathrm{MJ} / \mathrm{kg})$ & 4,9 & 4,5 & $-8,2 \%$ \\
Vazão de gás produzido $(\mathrm{kg} / \mathrm{h})$ & 45,8 & 44,5 & $-2,9 \%$ \\
\hline
\end{tabular}

Tabela B.9 - Resultados para o Teste 3 (Modelo Modificado I).

\begin{tabular}{cccc}
\hline $\begin{array}{c}\text { Fração Molar } \\
\text { (\% base úmida) }\end{array}$ & Teste 3 & $\begin{array}{c}\text { Modelo } \\
\text { Modificado I }\end{array}$ & $\begin{array}{c}\text { Desvio } \\
\text { Relativo }\end{array}$ \\
\hline $\mathrm{CO}$ & 17,5 & 16,7 & $-4,6 \%$ \\
$\mathrm{H}_{2}$ & 17,5 & 13,7 & $-21,7 \%$ \\
$\mathrm{CH}_{4}$ & 2,0 & 2,0 & $0,0 \%$ \\
$\mathrm{CO}_{2}$ & 13,1 & 13,1 & $0,0 \%$ \\
$\mathrm{~N}_{2}$ & 48,9 & 53,3 & $9,0 \%$ \\
$\mathrm{H}_{2} \mathrm{O}$ & 1,0 & 1,2 & $20,0 \%$ \\
$\mathrm{PCI}(\mathrm{MJ} / \mathrm{kg})$ & 4,7 & 3,4 & $-27,7 \%$ \\
Vazão de gás produzido $(\mathrm{kg} / \mathrm{h})$ & 40,2 & 38,6 & $-3,9 \%$ \\
\hline
\end{tabular}

Apesar de as diferenças entre os valores das frações molares diminuírem com a modificação feita, os valores do PCI pioram em relação ao modelo de puro equilíbrio. Este fato pode ser explicado pelas menores concentrações de $\mathrm{CO}$ e $\mathrm{H}_{2}$, diminuindo o teor de gases combustíveis no gás produzido (o aumento na concentração de $\mathrm{CH}_{4}$ não é suficiente para compensar esta perda). 
Li et al. (2004) propuseram o uso de correlações empíricas a fim de impor aspectos cinéticos ao modelo de equilíbrio. A Fig. B.3. mostra como o novo deverá ser implementado para definir as condições na saída.

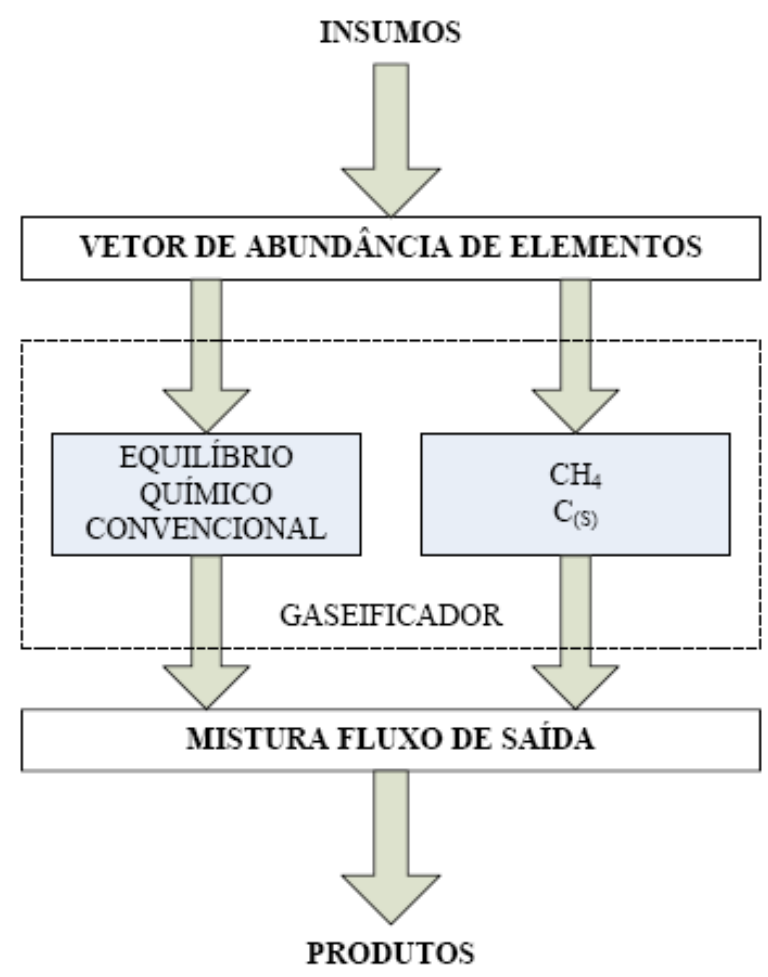

Figura B.3 - Representação esquemática do modelo modificado II (LI et al., 2004).

As quantidades de $\mathrm{CH}_{4}$ formado e de carbono não-convertido são definidas através de relações empíricas definidas a partir de dados experimentais, enquanto que as quantidades dos demais componentes são definidas pelo equilíbrio.

$$
\begin{gathered}
\beta_{\mathrm{CH}_{4}}=0,11 \cdot(1-\phi) \\
\mathrm{n}_{\mathrm{CH}_{4}}=\beta_{\mathrm{CH}_{4}} \cdot \mathrm{n}_{\mathrm{C}, \text { initial }} \\
\beta_{\mathrm{C}}=0,25+0,75 \cdot \exp (-\phi / 0,23) \\
\mathrm{n}_{\mathrm{C}}=\beta_{\mathrm{C}} \cdot \mathrm{n}_{\mathrm{C}, \text { initial }}
\end{gathered}
$$




$$
\begin{gathered}
\beta_{\mathrm{H}}=1-\frac{4 \cdot \beta_{\mathrm{CH}_{4}} \cdot \mathrm{n}_{\mathrm{C}, \text { initial }}}{\mathrm{n}_{\mathrm{H}, \text { initial }}} \\
\mathrm{n}_{\mathrm{H}}=\beta_{\mathrm{H}} \cdot \mathrm{n}_{\mathrm{H}, \text { initial }}
\end{gathered}
$$

Estes parâmetros alteram o número de átomos de carbono e hidrogênio enviados para o cálculo do equilíbrio. A Tab. B.10 a seguir mostra os resultados para o Teste 1 deste novo modelo.

Tabela B.10 - Resultados para o Teste 1 (Modelo Modificado II).

\begin{tabular}{cccc}
\hline $\begin{array}{c}\text { Fração Molar } \\
\text { (\% base úmida) }\end{array}$ & Teste 1 & $\begin{array}{c}\text { Modelo } \\
\text { Modificado II }\end{array}$ & $\begin{array}{c}\text { Desvio } \\
\text { Relativo }\end{array}$ \\
\hline $\mathrm{CO}$ & 21,7 & 8,7 & $-59,9 \%$ \\
$\mathrm{H}_{2}$ & 17,1 & 4,5 & $-73,7 \%$ \\
$\mathrm{CH}_{4}$ & 2,0 & 3,9 & $95,0 \%$ \\
$\mathrm{CO}_{2}$ & 11,0 & 16,6 & $50,9 \%$ \\
$\mathrm{~N}_{2}$ & 47,0 & 64,7 & $37,7 \%$ \\
$\mathrm{H}_{2} \mathrm{O}$ & 1,2 & 1,6 & $33,3 \%$ \\
PCI (MJ/kg) & 5,1 & 2,3 & $-54,9 \%$ \\
Vazão de gás produzido (kg/h) & 47,7 & 40,4 & $-15,3 \%$ \\
Vazão de carbono não-convertido & 1,2 & 3,9 & $225,0 \%$ \\
(kg/h) & & &
\end{tabular}

Todos os valores calculados são piores que aqueles encontrados pelo modelo baseado em Fock e Thomsen (2000). Estes resultados são bastante sensatos, já que as correlações foram derivadas da operação de um gaseificador de leito fluidizado, e não de um gaseificador downdraft.

De modo a testar a validade desta proposta, dados retirados de Li et al. (2004) foram utilizados para comparação com os resultados do modelo. As Tabs. B.11 mostram as condições e resultados dessas comparações.

Tabela B.11 - Parâmetros operacionais dos testes apresentados em Li et al. (2004).

Teste 14 Teste 15

\begin{tabular}{lcc}
\hline Vazão de Biomassa $(\mathrm{kg} / \mathrm{h})$ & 41,4 & 15,6 \\
Teor de Umidade $(\%)$ & 6,7 & 4,2 \\
Vazão de Ar $(\mathrm{kg} / \mathrm{h})$ & 63,1 & 38,0 \\
\hline
\end{tabular}


Tabela B.12 - Resultados para o Teste 14 (Modelo Modificado II).

\begin{tabular}{cccc}
\hline $\begin{array}{c}\text { Fração Molar } \\
\text { (\% base seca) }\end{array}$ & Teste 14 & $\begin{array}{c}\text { Modelo } \\
\text { Modificado II }\end{array}$ & $\begin{array}{c}\text { Desvio } \\
\text { Relativo }\end{array}$ \\
\hline $\mathrm{H}_{2}$ & 7,3 & 12,1 & $65,5 \%$ \\
$\mathrm{~N}_{2}$ & 55,4 & 60,0 & $8,4 \%$ \\
$\mathrm{CO}$ & 17,9 & 11,2 & $-37,5 \%$ \\
$\mathrm{CH}_{4}$ & 3,2 & 4,8 & $50,8 \%$ \\
$\mathrm{CO}_{2}$ & 16,3 & 11,9 & $-27,2 \%$ \\
$\mathrm{H}_{2}$ & 7,3 & 12,1 & $65,5 \%$ \\
PCI $(\mathrm{MJ} / \mathrm{kg})$ & 4,6 & 4,6 & $0,0 \%$ \\
\hline
\end{tabular}

Tabela B.13 - Resultados para o Teste 15 (Modelo Modificado II).

\begin{tabular}{cccc}
\hline $\begin{array}{c}\text { Fração Molar } \\
\text { (\% base seca) }\end{array}$ & Teste 15 & $\begin{array}{c}\text { Modelo } \\
\text { Modificado } \\
\text { II }\end{array}$ & $\begin{array}{c}\text { Desvio } \\
\text { Relativo }\end{array}$ \\
\hline $\mathrm{H}_{2}$ & 5,9 & 5,8 & $-1,4 \%$ \\
$\mathrm{~N}_{2}$ & 64,6 & 69,0 & $6,9 \%$ \\
$\mathrm{CO}$ & 10 & 10,0 & $-0,3 \%$ \\
$\mathrm{CH}_{4}$ & 1,2 & 2,8 & $135,2 \%$ \\
$\mathrm{CO}_{2}$ & 18,3 & 12,4 & $-32,5 \%$ \\
PCI $(\mathrm{MJ} / \mathrm{kg})$ & 2,54 & 2,9 & $18,1 \%$ \\
\hline
\end{tabular}

Apesar de existirem alguns desvios elevados, as correlações puderam ser validadas para avaliação do processo de gaseificação. A avaliação dessas correlações para outros tipos de biomassa (diferentes das apresentadas em Li et al., 2004), resultados experimentais da gaseificação de pellets de bagaço de cana-de-açúcar foram utilizados (BAPTISTA ET Al., 1986). O gaseificador utilizado neste experimento foi o de leito fluidizado atmosférico, similar ao descrito em Li et al., 2004. A Tabela B.14 mostra as condições operacionais de três testes apresentados em Baptista et al., 1986.

Tabela B.14 - Parâmetros operacionais dos testes apresentados em Baptista, 1986.

\begin{tabular}{lccc} 
& Teste $\mathbf{9}$ & Teste 15 & Teste 17 \\
\hline Vazão de pellets de bagaço $(\mathrm{kg} / \mathrm{h})$ & 182,2 & 246,1 & 226,7 \\
Teor de Umidade $(\%)$ & 9,2 & 9,2 & 9,2 \\
Vazão de Ar $(\mathrm{kg} / \mathrm{h})$ & 250,0 & 253,2 & 261,8 \\
Vazão de Vapor $(\mathrm{kg} / \mathrm{h})$ & 30,7 & 0,0 & 0,0 \\
\hline
\end{tabular}

As Tabelas B.15 a B.17 mostram os resultados das simulações. 
B. 18

Tabela B.15 - Resultados para o Teste 9 (Modelo Modificado II).

\begin{tabular}{cccc}
\hline $\begin{array}{c}\text { Fração Molar } \\
\text { (\% base seca) }\end{array}$ & Teste 9 & $\begin{array}{c}\text { Modelo } \\
\text { Modificado II }\end{array}$ & $\begin{array}{c}\text { Desvio } \\
\text { Relativo }\end{array}$ \\
\hline $\mathrm{CO}_{2}$ & 13,1 & 20,3 & $55,0 \%$ \\
$\mathrm{CO}$ & 15,6 & 6,3 & $-59,6 \%$ \\
$\mathrm{O}_{2}$ & 3,3 & 0 & $-100,0 \%$ \\
$\mathrm{CH}_{4}$ & 4,7 & 4,7 & $0,0 \%$ \\
$\mathrm{H}_{2}$ & 5,2 & 5,6 & $7,7 \%$ \\
$\mathrm{~N}_{2}$ & 58,1 & 63,1 & $8,6 \%$ \\
$\mathrm{PCS}(\mathrm{MJ} / \mathrm{kg})$ & 4,5 & 3,1 & $-31,2 \%$ \\
Vazão de Gás Produzido $(\mathrm{kg} / \mathrm{h})$ & 458,1 & 425,8 & $-7,0 \%$ \\
\hline
\end{tabular}

Tabela B.16 - Resultados para o Teste 15 (Modelo Modificado II).

\begin{tabular}{cccc}
\hline $\begin{array}{c}\text { Fração Molar } \\
\text { (\% base seca) }\end{array}$ & Teste 15 & $\begin{array}{c}\text { Modelo } \\
\text { Modificado II }\end{array}$ & $\begin{array}{c}\text { Desvio } \\
\text { Relativo }\end{array}$ \\
\hline $\mathrm{CO}_{2}$ & 15,2 & 21,0 & $38,4 \%$ \\
$\mathrm{CO}$ & 18,8 & 6,4 & $-66,0 \%$ \\
$\mathrm{O}_{2}$ & 1,2 & 0 & $-100,0 \%$ \\
$\mathrm{CH}_{4}$ & 5,6 & 6,7 & $19,6 \%$ \\
$\mathrm{H}_{2}$ & 7,4 & 5,2 & $-29,7 \%$ \\
$\mathrm{~N}_{2}$ & 51,8 & 60,7 & $17,2 \%$ \\
$\mathrm{PCS}(\mathrm{MJ} / \mathrm{kg})$ & 5,5 & 4,1 & $-25,6 \%$ \\
Vazão de Gás Produzido $(\mathrm{kg} / \mathrm{h})$ & 487,8 & 441,4 & $-9,5 \%$ \\
\hline
\end{tabular}

Tabela B.17 - Resultados para o Teste 17 (Modelo Modificado II).

\begin{tabular}{cccc}
\hline $\begin{array}{c}\text { Fração Molar } \\
\text { (\% base seca) }\end{array}$ & Teste 17 & $\begin{array}{c}\text { Modelo } \\
\text { Modificado II }\end{array}$ & $\begin{array}{c}\text { Desvio } \\
\text { Relativo }\end{array}$ \\
\hline $\mathrm{CO}_{2}$ & 15,3 & 20,2 & $32,0 \%$ \\
$\mathrm{CO}$ & 19,1 & 7,1 & $-62,8 \%$ \\
$\mathrm{O}_{2}$ & 1,1 & 0 & $-100,0 \%$ \\
$\mathrm{CH}_{4}$ & 5,1 & 5,8 & $13,7 \%$ \\
$\mathrm{H}_{2}$ & 5,9 & 5,1 & $-13,6 \%$ \\
$\mathrm{~N}_{2}$ & 53,5 & 61,8 & $15,5 \%$ \\
$\mathrm{PCS}(\mathrm{MJ} / \mathrm{kg})$ & 5,2 & 3,9 & $-25,6 \%$ \\
Vazão de Gás Produzido $(\mathrm{kg} / \mathrm{h})$ & 477,5 & 438,1 & $-8,2 \%$ \\
\hline
\end{tabular}

Como essas correlações não foram derivadas para gaseificação de bagaço, os resultados são piores que os encontrados nas Tabs. B.14 e B.15. Contudo, esses valores são melhores que os resultados para o modelo de puro equilíbrio. 


\section{B.7. COMENTÁRIOS GERAIS SOBRE AS COMPARAÇÕES}

O modelo de equilíbrio químico mostra boa adequação ao simular a operação de gaseificadores do tipo downdraft, principalmente com relação aos valores do PCI do gás produzido. Os resultados indicam que o modelo de equilíbrio pode ser útil na avaliação do comportamento termodinâmico de sistemas baseados na gaseificação de biomassa.

As modificações propostas por Fock e Thomsen (2000) fizeram com que a frações molares calculadas se aproximassem dos seus valores experimentais, sendo útil para a análise preditiva de gaseificadores do tipo downdraft.

O uso de relações empírico provou ser uma alternativa eficiente para trazer efeitos cinéticos dentro de modelos de equilíbrio. Todavia, sua aplicação é um pouco restrita a modelos baseados apenas na biomassa utilizada para a derivação das relações, bem como ao tipo do gaseificador.

De uma maneira geral, as modificações propostas por Fock e Thomsen (2000) provaram ser mais flexíveis, com uma boa adequação aos resultados experimentais. Portanto, essas deveriam ser integradas ao modelo de puro equilíbrio para a análise dos sistemas de gaseificação, a partir de dados operacionais conhecidos. Contudo, a avaliação de diferentes modos de operação e avaliações termodinâmicas paramétricas, o uso de correlações se torna mais interessante devido ao número de simulações necessárias. 


\section{APÊNDICE C. MODELAGEM DOS EQUIPAMENTOS DOS SISTEMAS AVANÇADOS DE COGERAÇÃO.}

A seguir são apresentadas as equações utilizadas para a modelagem dos principais equipamentos de conversão de energia dos sistemas avançados de cogeração utilizados na tese.

Para obtenção das equações auxiliares para determinação dos custos em base exergética, adotou-se o critério da igualdade dos produtos do volume de controle determinado.

\section{C.1. SISTEMA SUPERCRÍTICO}

\section{C.1.1. Caldeira Supercrítica}

A caldeira supercrítica foi modelada considerando a reação de combustão do bagaço com o ar, com excesso de ar de $30 \%$, os gases de exaustão saindo a $160^{\circ} \mathrm{C}$ e uso de bagaço com $40 \%$ de umidade. Essas condições equivalem a uma eficiência de $88 \%$ em base PCI. Ainda, o sistema supercrítico estudado na tese considera o re-aquecimento do vapor (ver Cap. 8, Fig. 8.16)).

Balanços de Massa:

$$
\begin{aligned}
& \dot{\mathrm{m}}_{\substack{\text { água } \\
\text { a limentação }}}=\dot{\mathrm{m}}_{\substack{\text { vapor } \\
\text { para turbina de alta }}} \\
& \dot{\mathrm{m}}_{\substack{\text { vapor para } \\
\text { re-aquecimento }}}=\dot{\mathrm{m}}_{\substack{\text { vapor } \\
\text { para turbina de média }}}
\end{aligned}
$$

Balanço de Energia:

$$
\begin{aligned}
& \dot{\mathrm{m}}_{\text {bagaço }} \cdot \mathrm{PCI}_{\text {bagą̧o }} \cdot \eta_{\text {caldeira }}+\dot{\mathrm{m}}_{\substack{\text { água } \\
\text { a limentação }}} \cdot \mathrm{h}_{\substack{\text { água } \\
\text { a lim entação }}}+\dot{\mathrm{m}}_{\substack{\text { vapor para } \\
\text { re-aquecimento }}} \cdot \mathrm{h}_{\substack{\text { vapor para } \\
\text { re-aquecimento }}}= \\
& \dot{\mathrm{m}}_{\text {vapor }} \cdot \mathrm{h}_{\text {papara turbina de alta }}+\dot{\mathrm{m}}_{\text {para turbina de alta }} \cdot \underset{\text { para turbina de média }}{ } \cdot \mathrm{h}_{\text {vapor }} \text { para turbina de média }
\end{aligned}
$$


Balanço de Exergia:

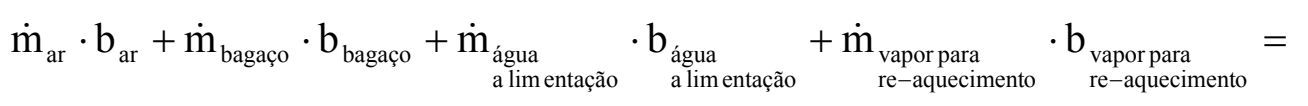

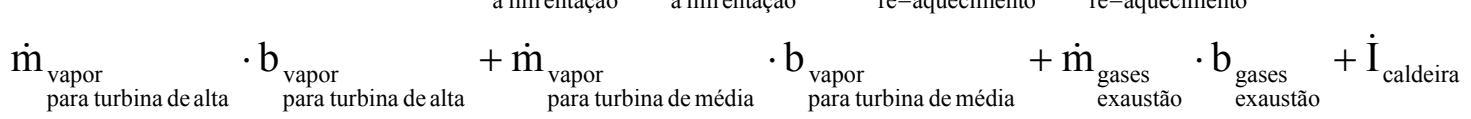

É importante assinalar que os gases de exaustão não são considerados como exergia perdida/destruída, pois são utilizados para secagem do bagaço antes deste ser enviado para a caldeira.

Para a atribuição de custos em base exergética aos fluxos de vapor, calculou-se o bagaço utilizado para produzir o vapor primário, utilizando uma equação similar à eq. (C.3), apenas considerando os fluxos de água de alimentação e vapor para turbina de alta. Da mesma maneira, foi determinado o consumo de bagaço para o re-aquecimento do vapor antes da turbina de média. Ainda, aos gases de exaustão não foi atribuído custo zero, pois esse fluxo é utilizado para secagem do bagaço; portanto o custo em base exergética dos gases de exaustão foi igualado ao custo do bagaço.

Balanço de Custo:

$$
\begin{aligned}
& \dot{\mathrm{m}}_{\mathrm{ar}} \cdot \mathrm{b}_{\mathrm{ar}} \cdot \mathrm{c}_{\mathrm{ar}}+\dot{\mathrm{m}}_{\text {bagaço,I }} \cdot \mathrm{b}_{\text {bagą̧o,I }} \cdot \mathrm{c}_{\text {bagaço,I }}+\dot{\mathrm{m}}_{\substack{\text { água } \\
\text { a limentação }}} \cdot \underset{\substack{\text { água } \\
\text { a limentação }}}{\mathrm{c}_{\text {água }}} \mathrm{c}_{\text {a lim entação }}=
\end{aligned}
$$

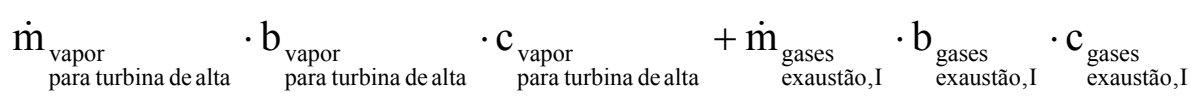

$$
\begin{aligned}
& \mathrm{c}_{\text {bagaço,I }}=\mathrm{c}_{\text {gases }}
\end{aligned}
$$

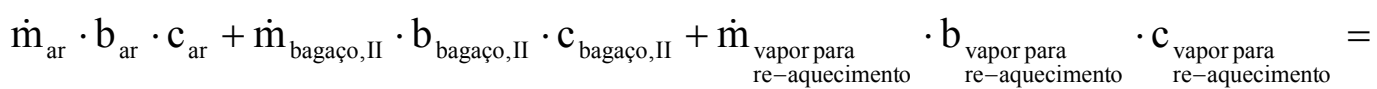

$$
\begin{aligned}
& \dot{\mathrm{m}}_{\text {vapor }} \cdot \mathrm{b}_{\text {para turbina de média }} \text { parar turbina de média }_{\text {para turbina de média }}+\dot{\mathrm{m}}_{\text {gases }} \cdot \mathrm{c}_{\text {exaustão,II }} \cdot \mathrm{b}_{\text {gases }}{ }_{\text {exaustão,II }} \cdot c_{\text {gases }} \mathrm{c}_{\text {exaustão,II }} \\
& \mathrm{c}_{\text {bagaço,II }}=\mathrm{c}_{\substack{\text { gases } \\
\text { exaustão,II }}}
\end{aligned}
$$


Essa abordagem implica que os custos do vapores para as turbinas de alta e média tenham valores diferentes, o que não é possível impondo-se apenas um balanço de custo. Outra abordagem possível é a metodologia proposta por Borelli e Oliveira Jr (2008) para atribuição de custos em caldeiras desde que conhecida a disposição e o perfil de temperatura nas diferentes partes da caldeira (superaquecedor, economizador, pré-aquecedor de ar etc).

\section{C.1.2. Secador}

Para o secador de bagaço, a composição dos gases de exaustão foi determinada baseada no balanço estequiométrico da combustão do bagaço, com a hipótese de que os gases deixam o secador saturados e há uma perda térmica de $1 \%$. O modelo desenvolvido é baseado no trabalho de Sosa-Arnao e Nebra (2007).

Balanços de Massa para Caldeira:

$$
\begin{aligned}
& \dot{\mathrm{m}}_{\text {bagaço }}+\dot{\mathrm{m}}_{\substack{\text { gases } \\
\text { exaustão }}}=\dot{\mathrm{m}}_{\substack{\text { bagaço } \\
\text { saida }}}+\dot{\mathrm{m}}_{\substack{\text { gases } \\
\text { exaustão } \\
\text { saturado }}} \\
& \dot{\mathrm{m}}_{\substack{\text { bagaço } \\
\text { entrada }}} \cdot \text { umidade }_{\text {entrada }}=\dot{\mathrm{m}}_{\substack{\text { bagaço } \\
\text { saida }}} \cdot \text { umidade }_{\text {saída }} \\
& \dot{\mathrm{m}}_{\substack{\text { gases } \\
\text { exaustão }}}+\dot{\mathrm{m}}_{\substack{\text { água } \\
\text { evaporada }}}=\dot{\mathrm{m}}_{\substack{\text { gases } \\
\text { exaustão } \\
\text { saturado }}}
\end{aligned}
$$

Balanço de Energia para Caldeira:

$$
\begin{aligned}
& \dot{\mathrm{m}}_{\substack{\text { gases } \\
\text { exaustão }}} \cdot\left(\mathrm{h}_{\substack{\text { gases } \\
\text { exaustão }}}-\mathrm{h}_{\substack{\text { gases } \\
\text { exaustão }}}\left(\mathrm{T}_{\substack{\text { gases } \\
\text { saída }}}\right)\right) \cdot 0,99= \\
& \underset{\substack{\text { bagaço } \\
\text { seco }}}{\mathrm{c}_{\text {bagaço }}} \cdot\left(\mathrm{T}_{\text {saída }}-\mathrm{T}_{\text {entrada }}\right)+\dot{\mathrm{m}}_{\substack{\text { água } \\
\text { evaporada }}} \cdot \Delta \mathrm{h}_{\text {vaporização, 1bar }}
\end{aligned}
$$

A temperatura de saída dos gases é dada pela temperatura de saturação dos gases à pressão atmosférica, sendo essa temperatura responsável pela determinação da temperatura do bagaço. A eq. (C.12) determina a quantidade de água que é possível evaporar, enquanto as equações 
do balanço de massa calculam a umidade final do bagaço. Lembrando que os gases deixam o secador saturados.

Balanço de Exergia:

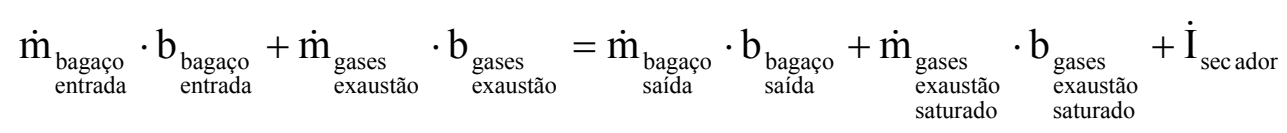

Balanço de Custo:

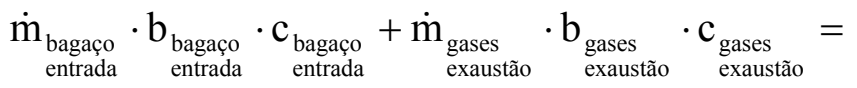

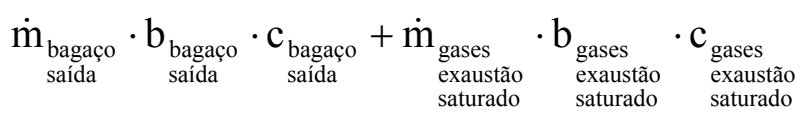

Dado que os gases após o secador são rejeitados para o meio-ambiente é atribuído custo zero para esse fluxo.

$$
\mathrm{c}_{\substack{\text { gases } \\ \text { exaustão } \\ \text { saturado }}}=0
$$

\section{C.1.3. Turbinas, Bombas e demais Equipamentos}

Esses equipamentos foram modelados de maneira similar à apresentada no Apêndice A. Os valores das eficiências isoentrópicas são apresentados no corpo da tese.

\section{C.1.4. Trocadores de Calor Regenerativos}

Os trocadores de calor regenerativos tem como objetivo pré-aquecer a água de alimentação da caldeira.

Balanços de Massa: 


$$
\begin{gathered}
\dot{\mathrm{m}}_{\substack{\text { água } \\
\text { entrada }}}=\dot{\mathrm{m}}_{\substack{\text { água } \\
\text { saida }}} \\
\dot{\mathrm{m}}_{\text {vapor extraído }}+\dot{\mathrm{m}}_{\substack{\text { condensado } \\
\text { trocador anterior }}}=\dot{\mathrm{m}}_{\text {condensado }}
\end{gathered}
$$

Balanço de Energia:

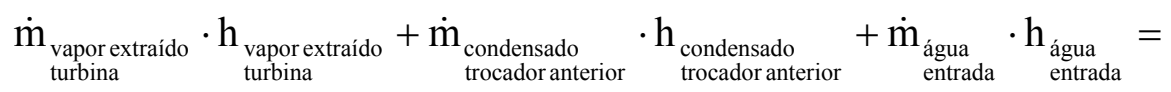

$$
\begin{aligned}
& \dot{\mathrm{m}}_{\text {condensado }} \cdot \mathrm{h}_{\text {condensado }}+\underset{\substack{\text { água } \\
\text { saída }}}{\dot{\mathrm{h}}_{\substack{\text { água } \\
\text { saida }}}}
\end{aligned}
$$

\section{Balanço de Exergia:}

$$
\begin{aligned}
& \dot{\mathrm{m}}_{\text {vapor extraído }} \cdot \underset{\text { turbina }}{\mathrm{b}_{\text {vapor extraído }}}+\underset{\text { turbina }}{\dot{\mathrm{m}}_{\text {condensado }}} \cdot \mathrm{b}_{\text {trocador anterior }} \mathrm{b}_{\text {trocador anterior }}+\underset{\substack{\text { água } \\
\text { entrada }}}{\dot{b}_{\text {água }}}= \\
& \dot{\mathrm{m}}_{\text {condensado }} \cdot \mathrm{b}_{\text {condensado }}+\dot{\mathrm{m}}_{\substack{\text { água } \\
\text { saida }}} \cdot \underset{\substack{\text { água } \\
\text { saida }}}{\dot{\mathrm{I}}_{\text {trocador }}} \text { regenerativo }
\end{aligned}
$$

Balanço de Custo:

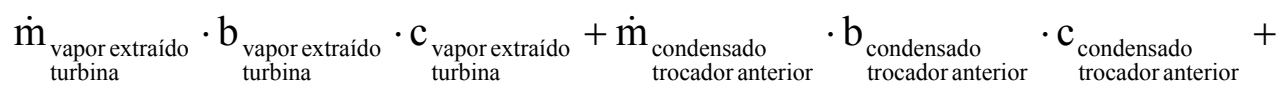

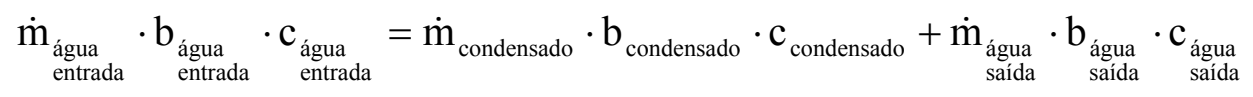

O único produto do trocador de calor é a água quente, assim o custo do condensado é uma composição dos custos do vapor e do condensado do trocador anterior.

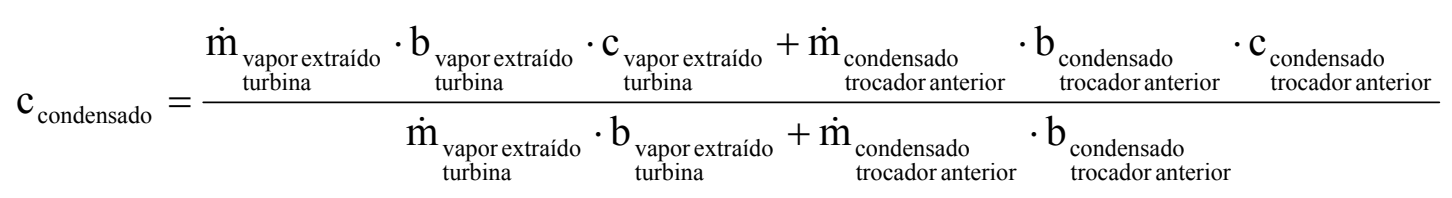

A temperatura da água na saída é determinada em função da pressão do vapor utilizado para o aquecimento (DRBAL, 1996). 


\section{C.2. CICLO COMBINADO COM GASEIFICAÇÃO DE BIOMASSA}

\section{C.2.1. Turbina a Gás}

A Fig. C.1 mostra o diagrama esquemático de uma turbina a gás.

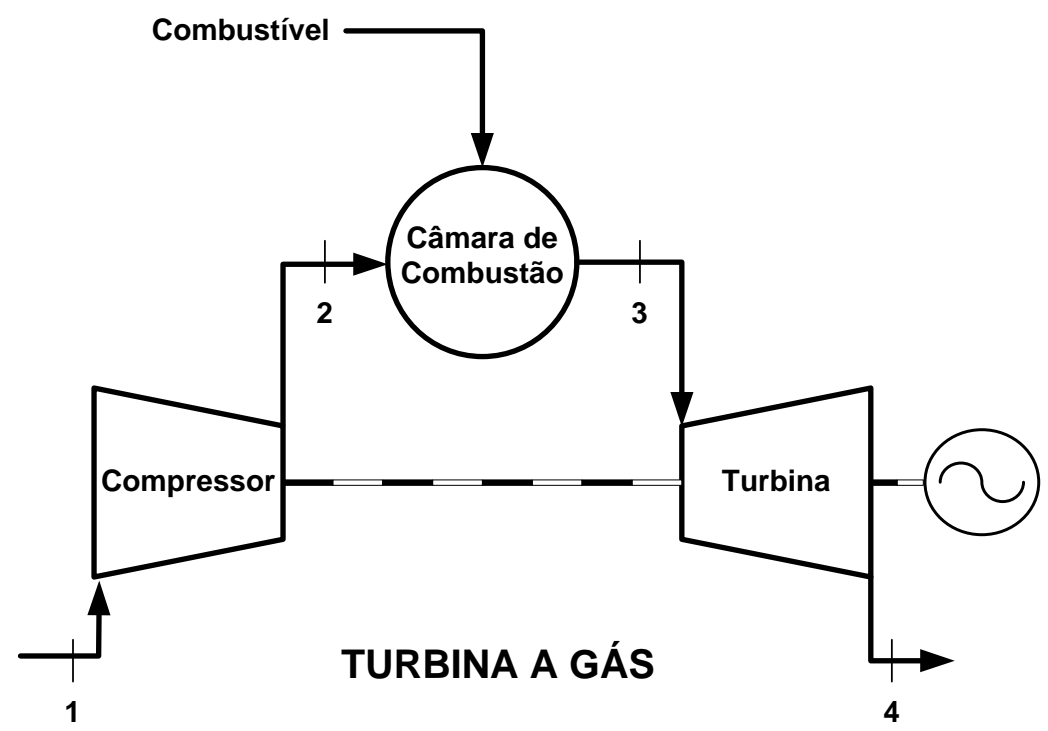

Figura C.1 - Diagrama Esquemático de uma Turbina a Gás.

O modelo da turbina a gás foi desenvolvido baseado em dados de operação de turbinas a gás reais (razão de pressão $-\mathrm{p}_{2} / \mathrm{p}_{1}$, fluxo de gases de exaustão $-\dot{\mathrm{m}}_{4}$, temperatura dos gases de exaustão $-\mathrm{T}_{4}$, heat rate - eficiência térmica, potência gerada). Dadas essas informações, balanços de massa e energia foram elaborados para determinação da:

$\checkmark$ Temperatura de entrada da turbina $-\mathrm{T}_{3}$ (ou seja, a temperatura dos gases após a câmara de combustão);

$\checkmark$ Eficiência politrópica do compressor;

$\checkmark$ Eficiência politrópica da turbina;

$\checkmark$ Vazão volumétrica dos gases na entrada da turbina $-\dot{\mathrm{V}}_{3}$.

Para a simulação da turbina a gás utilizando gás com baixo poder calorífico considerou-se que a vazão volumétrica dos gases na entrada da turbina é igual à calculada para os dados nominais. Isso é equivalente a impor uma restrição geométrica ao fluxo na entrada da turbina. 
Ainda, a razão de pressão no compressor é mantida constante a fim de evitar problemas operacionais desse equipamento. Diante dessas restrições, para a operação da turbina a gás considerou-se as seguintes estratégias:

$\checkmark$ De-rating: para atingir a temperatura nominal de entrada na turbina, é necessário aumentar a vazão de combustível com baixo poder calorífico, resultando em uma maior quantidade mássica na entrada da turbina. Todavia, como a vazão volumétrica está fixada, diminui-se a temperatura de entrada (de-rating) até a vazão volumétrica se igualar a vazão nominal.

$\checkmark$ Blast-off: outra maneira de garantir a vazão volumétrica de entrada da turbina e a temperatura de entrada da turbina, fazendo uma extração do ar após o compressor (Blast-off), diminuindo a vazão de ar para a câmara de combustão.

A primeira estratégia foi utilizada para a simulação dos sistemas com gaseificação atmosférica, enquanto a segunda foi aplicada para a gaseificação pressurizada, aproveitando o fluxo de ar extraído para o gaseificador. Essa metodologia foi desenvolvida baseada em Walter (2000) e Rodrigues, Walter e Faaij (2003).

Para a câmara de combustão foi desenvolvido um balanço de massa considerando a reação de combustão do ar com o gás produzido proveniente do gaseificador. As eficiências politrópicas calculadas foram utilizadas para determinação dos estados do ar e dos gases após o compressor e a turbina, respectivamente. Essas eficiências são as mesmas que para a condição nominal da turbina a gás operando com gás natural, sendo parâmetros de ajuste entre o modelo desenvolvido e os dados disponíveis em catálogos.

Balanços de Massa:

$$
\begin{gathered}
\dot{\mathrm{m}}_{1}=\dot{\mathrm{m}}_{2}+\dot{\mathrm{m}}_{\text {extraído }} \\
\dot{\mathrm{m}}_{2}+\dot{\mathrm{m}}_{\text {combustivel }}=\dot{\mathrm{m}}_{3} \\
\dot{\mathrm{m}}_{3}=\dot{\mathrm{m}}_{4}
\end{gathered}
$$


Balanços de Energia:

$$
\begin{gathered}
\dot{\mathrm{m}}_{1} \cdot \mathrm{h}_{1}+\dot{\mathrm{W}}_{\text {compressor }}=\left(\dot{\mathrm{m}}_{2}+\dot{\mathrm{m}}_{\text {extraído }}\right) \cdot \mathrm{h}_{2} \\
\dot{\mathrm{m}}_{2} \cdot \mathrm{h}_{2}+\dot{\mathrm{m}}_{\text {combustivel }} \cdot \mathrm{h}_{\text {combustivel }}=\dot{\mathrm{m}}_{3} \cdot \mathrm{h}_{3} \\
\dot{\mathrm{m}}_{3} \cdot \mathrm{h}_{3}=\dot{\mathrm{m}}_{4} \cdot \mathrm{h}_{4}+\dot{\mathrm{W}}_{\text {turbina }}
\end{gathered}
$$

Balanços de Exergia:

$$
\begin{gathered}
\dot{\mathrm{m}}_{1} \cdot \mathrm{b}_{1}+\dot{\mathrm{W}}_{\text {compressor }}=\left(\dot{\mathrm{m}}_{2}+\dot{\mathrm{m}}_{\text {extraído }}\right) \cdot \mathrm{b}_{2}+\dot{\mathrm{I}}_{\text {compressor }} \\
\dot{\mathrm{m}}_{2} \cdot \mathrm{b}_{2}+\dot{\mathrm{m}}_{\text {combustivel }} \cdot \mathrm{b}_{\text {combustivel }}=\dot{\mathrm{m}}_{3} \cdot \mathrm{b}_{3}+\dot{\mathrm{I}}_{\text {câmara }}^{\text {combustão }} \\
\dot{\mathrm{m}}_{3} \cdot \mathrm{b}_{3}=\dot{\mathrm{m}}_{4} \cdot \mathrm{b}_{4}+\dot{\mathrm{W}}_{\text {turbina }}+\dot{\mathrm{I}}_{\text {turbina }}
\end{gathered}
$$

Balanços de Custo:

$$
\begin{gathered}
\dot{\mathrm{m}}_{1} \cdot \mathrm{b}_{1} \cdot \mathrm{c}_{1}+\dot{\mathrm{W}}_{\text {compressor }} \cdot \mathrm{c}_{\text {turbina }}=\left(\dot{\mathrm{m}}_{2}+\dot{\mathrm{m}}_{\text {extraido }}\right) \cdot \mathrm{b}_{2} \cdot \mathrm{c}_{2} \\
\dot{\mathrm{m}}_{2} \cdot \mathrm{b}_{2} \cdot \mathrm{c}_{2}+\dot{\mathrm{m}}_{\text {combustivel }} \cdot \mathrm{b}_{\text {combustivel }} \cdot \mathrm{c}_{\text {combustivel }}=\dot{\mathrm{m}}_{3} \cdot \mathrm{b}_{3} \cdot \mathrm{c}_{3} \\
\dot{\mathrm{m}}_{3} \cdot \mathrm{b}_{3} \cdot \mathrm{c}_{3}=\dot{\mathrm{m}}_{4} \cdot \mathrm{b}_{4} \cdot \mathrm{c}_{4}+\dot{\mathrm{W}}_{\text {turbina }} \cdot \mathrm{c}_{\text {turbina }}
\end{gathered}
$$

A turbina apresenta dois produtos, assim adotando o critério da igualdade, o custo em base exergética da potência gerada é igual ao do fluxo dos gases de exaustão.

$$
\mathrm{c}_{4}=\mathrm{c}_{\text {turbina }}
$$




\section{C.2.2. Gaseificador}

O modelo desenvolvido para o sistema de gaseificação é apresentado no Apêndice B. Todavia, os balanços de exergia e custos são mostrados a seguir:

Balanços de Exergia:

$$
\dot{\mathrm{m}}_{\mathrm{ar}} \cdot \mathrm{b}_{\text {ar }}+\dot{\mathrm{m}}_{\substack{\text { bagaco } \\ \text { após sec ador }}} \cdot \mathrm{b}_{\text {bagaco }}=\dot{\mathrm{m}}_{\text {após sec ador }} \cdot \mathrm{b}_{\text {produzido }} \cdot \underset{\text { pás }}{\text { produzido }}+\dot{\mathrm{I}}_{\text {gaseificador }}
$$

Balanços de Custo:

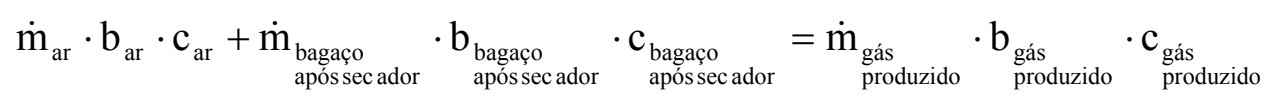

\section{C.2.3. Trocador de Calor}

Os sistemas BIGCC analisadas utilizam trocadores de calor tanto para produzir ou superaquecer vapor ou aquecer o ar antes do gaseificador. O objetivo desses trocadores é recuperar parte da exergia térmica dos gases.

Balanços de Massa:

$$
\begin{gathered}
\dot{\mathrm{m}}_{\substack{\text { gás produzido } \\
\text { entrada }}}=\dot{\mathrm{m}}_{\substack{\text { gás produzido } \\
\text { saida }}} \\
\dot{\mathrm{m}}_{\substack{\text { fluido } \\
\text { a ser aquecido } \\
\text { entrada }}}=\dot{\mathrm{m}}_{\substack{\text { fluido } \\
\text { a ser aquecido } \\
\text { saida }}}
\end{gathered}
$$

Balanço de Energia:

$$
\begin{aligned}
& \dot{\mathrm{m}}_{\substack{\text { gás produzido } \\
\text { entrada }}} \cdot \mathrm{h}_{\substack{\text { gás produzido } \\
\text { entrada }}}+\dot{\mathrm{m}}_{\begin{array}{c}
\text { fluido } \\
\text { a ser aquecido } \\
\text { entrada }
\end{array}} \cdot \mathrm{h}_{\substack{\text { fluido } \\
\text { a ser aquecido } \\
\text { entrada }}}= \\
& \dot{\mathrm{m}}_{\substack{\text { gás produzido } \\
\text { saída }}} \cdot \mathrm{h}_{\substack{\text { gás produzido } \\
\text { saída }}}+\dot{\mathrm{m}}_{\substack{\text { fluido } \\
\text { a ser aquecido } \\
\text { saída }}} \cdot \mathrm{h}_{\substack{\text { fluido } \\
\text { a ser aquecido } \\
\text { saída }}}
\end{aligned}
$$


Balanço de Exergia:

$$
\begin{aligned}
& \dot{\mathrm{m}}_{\substack{\text { gás produzido } \\
\text { entrada }}} \cdot \mathrm{b}_{\substack{\text { gás produzido } \\
\text { entrada }}}+\dot{\mathrm{m}}_{\substack{\text { fluido } \\
\text { a ser aquecido } \\
\text { entrada }}} \cdot \mathrm{b}_{\substack{\text { fluido } \\
\text { a ser aquecido } \\
\text { entrada }}}= \\
& \dot{\mathrm{m}}_{\substack{\text { gás produzido } \\
\text { saída }}} \cdot \mathrm{b}_{\substack{\text { gás produzido } \\
\text { saída }}}+\dot{\mathrm{m}}_{\substack{\text { fluido } \\
\text { a ser aquecido } \\
\text { saída }}} \cdot \mathrm{b}_{\substack{\text { fluido } \\
\text { a ser aquecido } \\
\text { saída }}}+\dot{\mathrm{I}}_{\text {trocador }}
\end{aligned}
$$

Balanço de Custo:

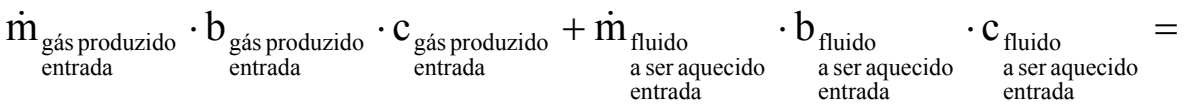

$$
\begin{aligned}
& \dot{\mathrm{m}}_{\substack{\text { gás produzido } \\
\text { saida }}} \cdot \underset{\text { gáda produzido }}{\mathrm{b}_{\text {gáda }}} \cdot \mathrm{c}_{\substack{\text { gás produzido } \\
\text { saída }}}+\dot{\mathrm{m}}_{\substack{\text { fluido } \\
\text { a ser aquecido } \\
\text { saída }}} \cdot \underset{\substack{\text { fluido } \\
\text { saída aquecido } \\
\text { saida }}}{\mathrm{b}_{\text {fla }}} \cdot \mathrm{c}_{\substack{\text { fluido a ser aquecido } \\
\text { saída }}}
\end{aligned}
$$

O objetivo desses trocadores de calor é recuperara exergia térmica do gás produzido, portanto o custo em base exergética deste fluxo não se altera.

$$
\underset{\text { gés produzido }}{\mathrm{c}_{\text {gida }}}=\mathrm{c}_{\substack{\text { gás produzido } \\ \text { saída }}}
$$

\section{C.2.4. Sistema de Limpeza de Gases}

O sistema de limpeza a frio utilizado para o gaseificador atmosférico resulta na condensação de parte do vapor presente no gás produzido devido à redução da temperatura até as condições ambientes, dessa maneira há uma alteração das concentrações dos componentes do gás produzido. Balanços de massa e energia são utilizados para a determinação da quantidade de água condensada, considerando que a concentração de vapor de água no gás produzido após o resfriamento é igual à fração molar de saturação.

Balanços de Massa:

$$
\dot{\mathrm{m}}_{\text {gás produzido }}=\dot{\mathrm{m}}_{\text {gás produzido }}+\dot{\mathrm{m}}_{\substack{\text { água } \\ \text { condensada }}}
$$


Balanço de Exergia:

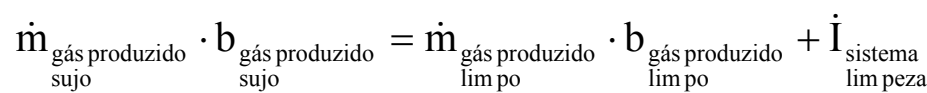

Balanço de Custo:

$$
\dot{\mathrm{m}}_{\substack{\text { gás produzido } \\ \text { sujo }}} \cdot \mathrm{b}_{\text {gás produzido }} \cdot \underset{\text { sujo }}{\mathrm{c}_{\text {gás produzido }}}=\underset{\substack{\text { gás produzido } \\ \text { lim po }}}{\mathrm{b}_{\text {gás produzido }}} \cdot \underset{\text { lim po }}{\mathrm{c}_{\text {gás produzido }}}
$$

Considera-se que o fluxo de água condensada não é mais utilizado no sistema, portanto sua exergia é perdida.

\section{C.2.5. Caldeira de Recuperação}

A Fig. C.2 mostra o diagrama esquemático de uma caldeira de recuperação, enquanto a Fig. C.3 apresenta o diagrama Temperatura vs. $\Delta \mathrm{H}$, para facilitar a apresentação das equações de balanço.

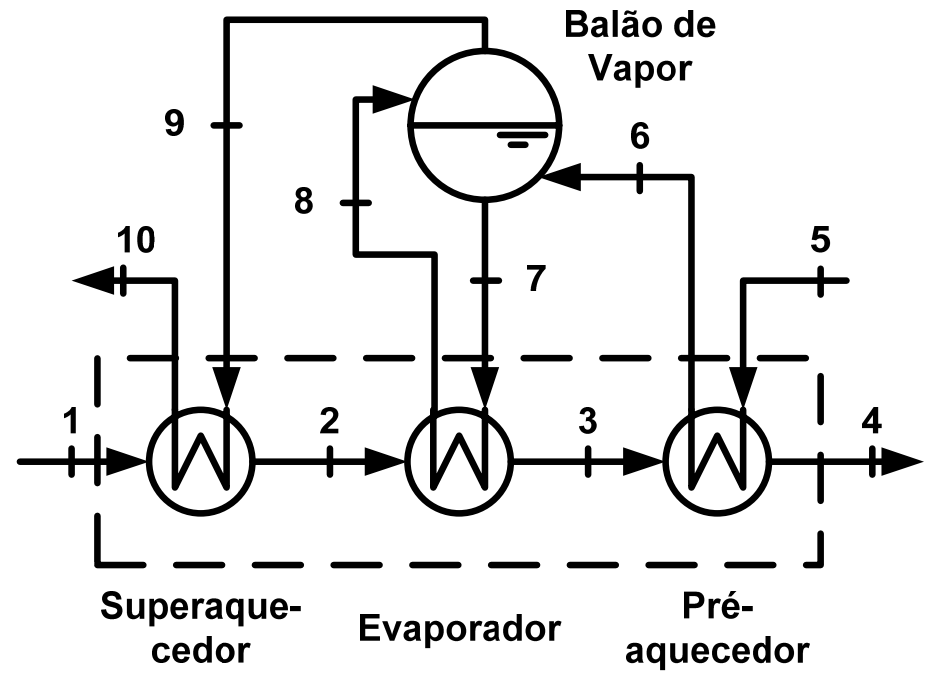

Figura C.2 - Diagrama Esquemático de uma Caldeira de Recuperação. 


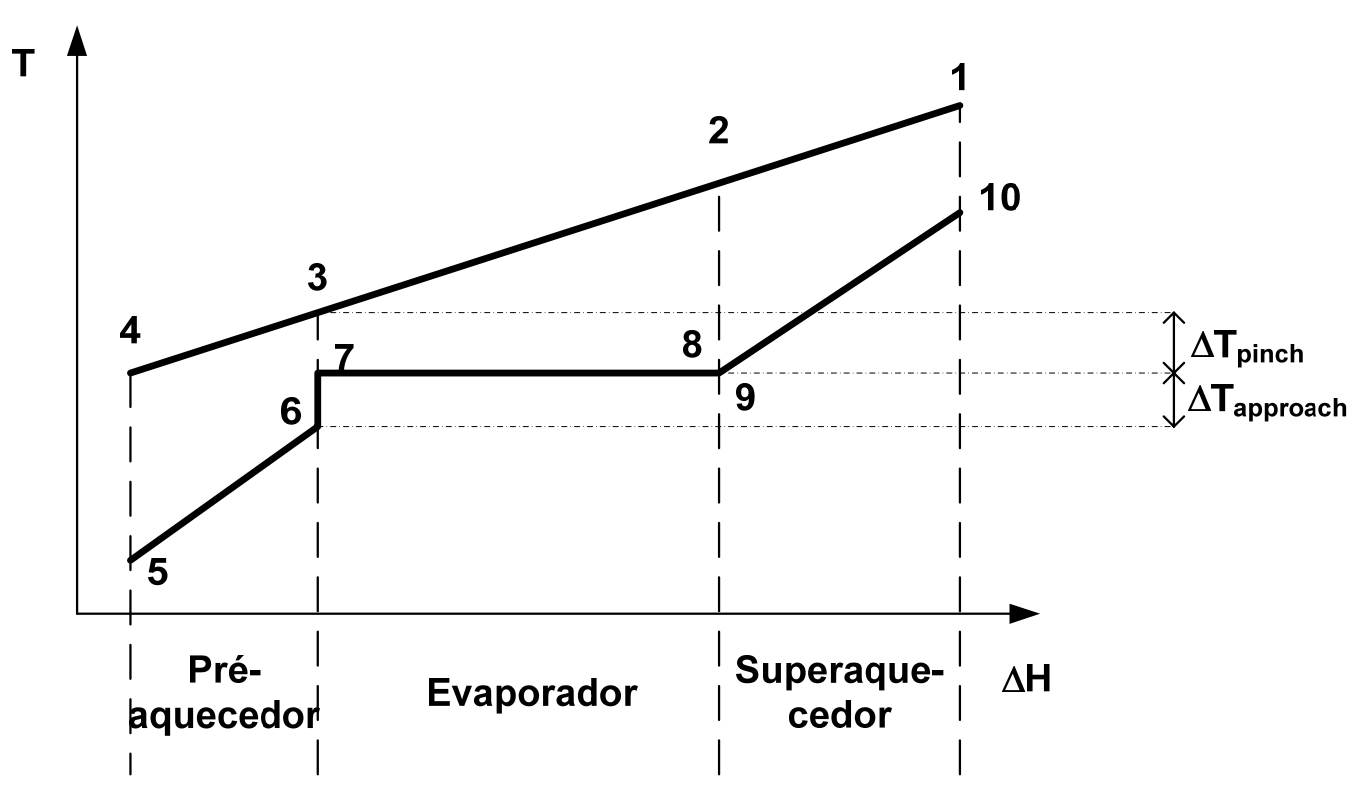

Figura C.3 - Diagrama T vs. $\Delta \mathrm{H}$ para a Caldeira de Recuperação.

As grandezas características de uma caldeira de recuperação são:

$\checkmark$ Approach Point: diferença entre a temperatura da água na saída do pré-aquecedor e a temperatura de saturação do balão de vapor $\left(\mathrm{T}_{7}-\mathrm{T}_{6}\right)$;

$\checkmark$ Pinch Point: diferença entre a temperatura de saturação do balão de vapor e os gases de aquecimento na saída do evaporador $\left(\mathrm{T}_{3}-\mathrm{T}_{7}\right)$.

Dados esses valores, as condições de entrada dos gases de exaustão da turbina a gás (ponto 1), a temperatura da água de alimentação (ponto 5) e as condições de geração de vapor na caldeira (pressão e temperatura) (ponto 10) é possível definir os estados termodinâmicos dos pontos: $1,3,5,6,7,8,9$ e 10. Os balanços de massa e energia definem, portanto, os estados 2 , 4, além da quantidade de vapor a ser produzida a partir da vazão dos gases da turbina.

Balanços de Massa:

$$
\begin{gathered}
\dot{\mathrm{m}}_{1}=\dot{\mathrm{m}}_{2}=\dot{\mathrm{m}}_{3}=\dot{\mathrm{m}}_{4} \\
\dot{\mathrm{m}}_{5}=\dot{\mathrm{m}}_{6}=\dot{\mathrm{m}}_{7}=\dot{\mathrm{m}}_{8}=\dot{\mathrm{m}}_{9}=\dot{\mathrm{m}}_{10}
\end{gathered}
$$

Balanços de Energia: 


$$
\begin{aligned}
& \dot{\mathrm{m}}_{1} \cdot \mathrm{h}_{1}+\dot{\mathrm{m}}_{5} \cdot \mathrm{h}_{5}=\dot{\mathrm{m}}_{4} \cdot \mathrm{h}_{4}+\dot{\mathrm{m}}_{10} \cdot \mathrm{h}_{10} \\
& \dot{\mathrm{m}}_{3} \cdot \mathrm{h}_{3}+\dot{\mathrm{m}}_{5} \cdot \mathrm{h}_{5}=\dot{\mathrm{m}}_{4} \cdot \mathrm{h}_{4}+\dot{\mathrm{m}}_{6} \cdot \mathrm{h}_{6}
\end{aligned}
$$

Balanços de Exergia:

$$
\dot{\mathrm{m}}_{1} \cdot \mathrm{b}_{1}+\dot{\mathrm{m}}_{5} \cdot \mathrm{b}_{5}=\dot{\mathrm{m}}_{4} \cdot \mathrm{b}_{4}+\dot{\mathrm{m}}_{10} \cdot \mathrm{b}_{10}+\dot{\mathrm{I}}_{\text {caldeira }} \text { recuperação }
$$

Balanços de Custos:

$$
\dot{\mathrm{m}}_{1} \cdot \mathrm{b}_{1} \cdot \mathrm{c}_{1}+\dot{\mathrm{m}}_{5} \cdot \mathrm{b}_{5} \cdot \mathrm{c}_{5}=\dot{\mathrm{m}}_{4} \cdot \mathrm{b}_{4} \cdot \mathrm{c}_{4}+\dot{\mathrm{m}}_{10} \cdot \mathrm{b}_{10} \cdot \mathrm{c}_{10}
$$

Os gases de exaustão da caldeira de recuperação são utilizados no secador para diminuir a umidade do bagaço antes do gaseificador. Portanto, como o objetivo da caldeira é gerar vapor, o custo em base exergética dos gases não se altera.

$$
\mathrm{c}_{1}=\mathrm{c}_{4}
$$

\section{C.2.6. Compressores de Ar e Gás Produzido}

Os balanços para o compressores de ar e gás produzido são similares aos balanços desenvolvidos para a turbina a gás. Para esses equipamentos foi utilizada uma efieicnecia isoentrópica igual a $80 \%$.

\section{C.2.7. Secador}

A mesma modelagem feita para o sistema supercrítico foi desenvolvida para os sistemas com gaseificação de biomassa.

\section{C.2.8. Turbinas, Bombas e demais Equipamentos}


Esses equipamentos foram modelados de maneira similar à apresentada no Apêndice A. Os valores das eficiências isoentrópicas são apresentados no corpo da tese. 